\title{
Fundamentação teórica da Quota Ambiental e estudo de caso de seu desenvolvimento em São Paulo
}

Paulo Mantey Domingues Caetano

Tese apresentada ao Programa de Pós-Graduação em Saúde Pública da Faculdade de Saúde Pública da Universidade de São Paulo para obtenção do título de Doutor em Ciências

Área de concentração: Saúde Ambiental

Orientador: Prof. Dr. Leandro Luiz Giatti

Versão Revisada

São Paulo

2016 
Autorizo a reprodução e divulgação total ou parcial deste trabalho, por qualquer meio convencional ou eletrônico, para fins de estudo e pesquisa, desde que citada a fonte.

Catalogaçăo da Publicaçăo

Biblioteca/CIR: Centro de Informação e Referência em Saúde Pública Faculdade de Saúde Pública da Universidade de São Paulo

Dados fornecidos pelo(a) autor(a)

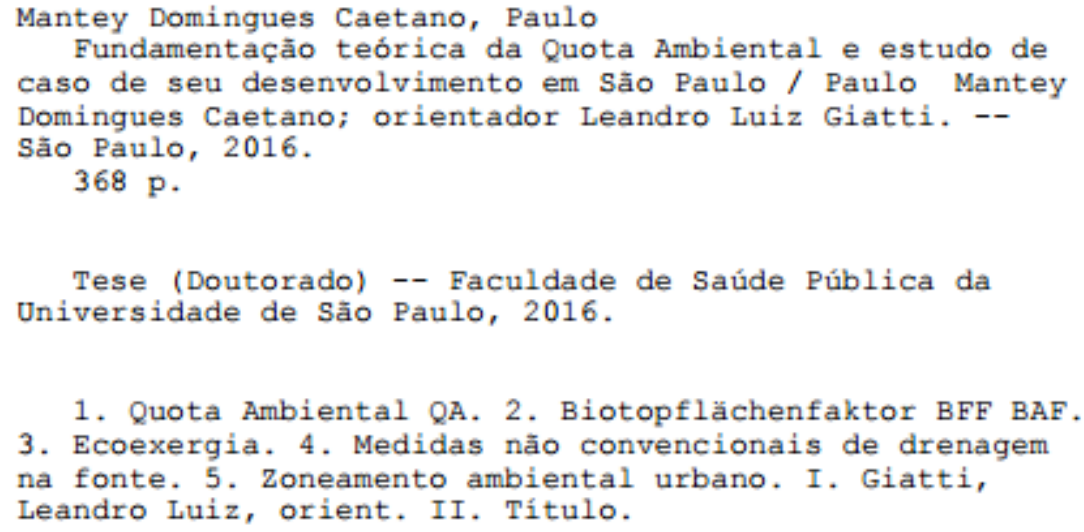


À Rôsi

(eu lhe dei uma costela, ela me deu vértebras

e asas)

e ao Lucas

(eu lhe dei genes, ele me deu raízes

e luz) 


\section{AGRADECIMENTOS}

Agradeço:

- ao meu orientador, que muito admiro, Prof. Dr. Leandro Luiz Giatti, devido ao seu conhecimento, sua generosidade, sua extrema gentileza, sua enorme capacidade de trabalho e sua incomparável paciência;

- a todos quantos (impossível enumerar) auxiliaram fornecendo ideias, cambiando conceitos e reflexões e propiciando condições para que partes do conteúdo desta tese fossem discutidos em seminários, oficinas, reuniões, conversas de corredor e no café;

- a todos os docentes que de alguma forma colaboraram generosamente com o presente trabalho;

- a todos os demais colaboradores da Universidade de São Paulo, em especial os da Faculdade de Saúde Pública, pelo profissionalismo, gentileza e extrema dedicação;

- ao corpo discente da Faculdade de Saúde Pública, pela amizade, encorajamento, discussões, ideias e apoio;

- ao povo do estado de São Paulo, por alocar escassíssimos recursos para a manutenção da Universidade de São Paulo e sua gratuidade no ensino;

- aos colegas e amigos da Secretaria Municipal do Verde e do Meio Ambiente da Prefeitura do Município de São Paulo, de quem muito tenho aprendido, e que, contra tudo e contra muitos, vêm extraindo leite de pedra;

- aos colegas Patrícia, Hélia, Lara, Bruno, Hyun, Marcelo e Daniel, pelos ensinamentos e pela honra a mim concedida de permitirem minha participação nesta empreitada;

- a todas as pessoas e instituições (também impossível enumerar) que colaboraram na e forneceram meios para minha formação acadêmica e profissional;

- em especial, à minha esposa Rôsi e ao meu filho Lucas, pela compreensão, encorajamento e amor. 
A Odisseia não é, no fundo, mais que simplesmente a epopeia mítica da navegação, como vitória sobre os dois perigos essenciais de todo navegar: a destruição (triunfo do oceano, inconsciente) ou o retrocesso (regressão, estancamento). Mas Homero situa o final do périplo odisseico num sublime, mas sentimental "retorno" à esposa, ao lar, à pátria. Esta ideia mítica corresponde analogicamente ao mistério da "queda" da alma no plano material (existência) e à necessidade de seu regresso ao ponto de partida (involução, evolução). (...) Esta origem retornante corresponde a um conceito do universo "fechado" como o do eterno retorno ou o que concebe todos os processos organizados em ciclo. A navegação, numa filosofia do infinito absoluto, negaria ao herói até mesmo a chegada à pátria $\mathrm{e} o$ faria navegador eterno em mares sempre novos, em horizontes intermináveis.

CIRLOT (2005, p.403-4)

O esforço é grande e o homem é pequeno.

$\mathrm{Eu}$, Diogo Cão, navegador, deixei

Este padrão ao pé do areal moreno

E para diante naveguei.

A alma é divina e a obra é imperfeita. Este padrão sinala ao vento e aos céus Que, da obra ousada, é minha a parte feita:

O por-fazer é só com Deus.

E ao imenso e possível oceano

Ensinam estas Quinas, que aqui vês, Que o mar com fim será grego ou romano:

O mar sem fim é português.

E a Cruz ao alto diz que o que me há na alma E faz a febre em mim de navegar Só encontrará de Deus na eterna calma $\mathrm{O}$ porto sempre por achar.

FERNANDO PESSOA 
CAEtAnO, Paulo Mantey Domingues. Fundamentação teórica da Quota Ambiental e estudo de caso de seu desenvolvimento em São Paulo. 2016. 328p. Tese (Doutorado em Ciências) Faculdade de Saúde Pública, Universidade de São Paulo, São Paulo.

\section{Resumo}

É conveniente que as políticas ambientais municipais contem não apenas com os instrumentos previstos na legislação federal, mas também com instrumentos urbanístico-ambientais a serem inseridos na legislação de parcelamento, uso e ocupação do solo. Assim, objetivou-se neste trabalho desenvolver um tal instrumento. Para tanto, estabeleceu-se: a) requisitos do instrumento: simplicidade, flexibilidade e embasamento teórico; b) objetivos ambientais considerados: promoção da qualidade ecossistêmica, melhoria do microclima e promoção do controle de drenagem na fonte; c) desenvolvimento de métricas: para os dois primeiros objetivos ambientais, demonstrou-se teoricamente ser satisfatório como indicador único uma simplificação do conceito de ecoexergia devido a Jørgensen e, para o último objetivo ambiental, o pico da vazão de saída do lote; d) estabelecimento de padrões: para os dois primeiros objetivos, definição de valores mínimos da ecoexergia simplificada para lotes em diferentes locais e com diferentes usos e taxas de ocupação, enquanto para o último objetivo, impacto zero. Coincidentemente, enquanto esse instrumento era desenvolvido a Prefeitura do Município de São Paulo (Brasil) procedia a uma revisão da lei de parcelamento, uso e ocupação do solo, tendo sido aceito que o instrumento teórico acima servisse como base para o desenvolvimento de um novo instrumento denominado Quota Ambiental (QA). A transformação do instrumento teórico acima na Quota Ambiental, que terminou por ser inserida no projeto de lei encaminhado à Câmara Municipal e depois aprovado por ela, foi objeto de um estudo sui generis, visto que o autor participou ativamente do desenvolvimento da QA como servidor público. Tal demandaria um método a meio caminho entre o estudo de caso e a observação participante, tendo-se optado por um método análogo ao fenomenológico. Para o desenvolvimento da QA foi formado um pequeno grupo de trabalho do qual o autor participou. O instrumento teórico recebeu diversas modificações não só para conformação a diretrizes e decisões políticas, como para amadurecimento de conceitos e cálculos, mostrando-se viável como base para o desenvolvimento da QA. Diversos grupos de interesse influenciaram o desenvolvimento da QA em diferentes fases e em diferentes níveis, chegando a ocorrer de eles se manifestarem diretamente junto ao grupo de trabalho. A Superior Administração prestigiou o processo, mas mostrou-se às vezes dividida em relação ao conflito entre aspectos ambientais e sociais. O grupo teve sucesso em potencializar os ganhos decorrentes da complementaridade de expertises decorrentes da heterogeneidade em termos de formação e experiência dos membros do grupo. Ele procurou harmonizar as diferentes pressões, muitas vezes até se antecipando a elas. Para tanto, o grupo de trabalho desenvolveu uma dinâmica para chegar a consensos internos e para prever, internalizar e posicionar-se frente a pressões, frequentemente conflitantes. As pressões mais severas provieram da própria burocracia municipal. Em todos esses processos a simplicidade, como requisito, foi perdendo-se. A Quota Ambiental mostrou-se um instrumento inovador, aparentando dar satisfação aos reclamos de diversos grupos de interesse e, principalmente, representando uma cunha ambiental inserida na legislação de parcelamento, uso e ocupação do solo.

Descritores: Meio ambiente e saúde pública; Política ambiental; Planejamento de cidades; Zoneamento; Inundações; Área urbana; Cidades; Habitação; Especificações para construção; Indicadores; Hidrologia; Escoamento; Ciclo hidrológico; Permeabilidade do solo; Infiltração; Reservatórios; Captação de água de chuva; Hidrodinâmica; Valas de infiltração-percolação; Percolação; Áreas verdes; Ecossistema; Ecologia; Entropia; Informação; Microclima; Mudança climática; Efeito-estufa; Natureza; Setor público; Política; Governo; Governo local; Organização; Organização municipal.

Palavras-chave: Quota ambiental; QA; BFF; BAF; Instrumentos urbanístico-ambientais; Zoneamento urbano ambiental; Legislação de parcelamento, uso e ocupação do solo; Qualidade ecossistêmica; Exergia; Ecoexergia; Impacto zero; Métricas; Indicadores ambientais; Stakeholders; Fenomenologia; Insegurança jurídica; BMP; SuDS; Traffic calming; Verkehrsberuhigung; Saúde ecossistêmica; Integridade ecológica; Zoneamento ambiental. 
CAETANO, Paulo Mantey Domingues. Fundamentação teórica da Quota Ambiental e estudo de caso de seu desenvolvimento em São Paulo/ Theoretical foundations of the Environmental Quota (QA) and case study referring to its development in São Paulo, Brazil. 2016. 328p. Thesis (Doctorate) - Faculty of Public Health, University of Sao Paulo, Sao Paulo.

\begin{abstract}
It is appropriate that municipal environmental policies incorporate not only the instruments provided for in federal legislation, but also the urban-environmental instruments to be inserted in the urban legislation. Thus, it was aimed in this work to develop such an instrument. To do so, it was established the following: a) requirements of the instrument: simplicity, flexibility and theoretical background; b) environmental objectives considered: promotion of ecosystem quality, improvement of microclimate and promotion of drainage control at source; c) development of metrics: a simplification of the concept of eco-exergy due to Jørgensen has been theoretically proven to be satisfactory as a single indicator of the first two environmental objectives; for the last environmental objective, the lot peak output flow; d) establishment of legal standards: for the first two objectives, definition of minimum values of simplified eco-exergy for lots in different locations and with different uses and occupation rates, whereas for the last objective, zero impact. Coincidentally, while this instrument was being developed, the City of São Paulo (Brazil) proceeded to a review of the zoning law, thus being accepted that the above theoretical instrument should serve as the basis for the development of a new instrument called Environmental Quota (Quota Ambiental, QA, in Portuguese). The transformation of the above theoretical instrument into the QA, which ended up being inserted in the bill forwarded to the City Council and later approved by it, was the subject of a sui generis study, as the author participated actively in the development of QA as a public servant. This would require a method halfway between the case study and the participant observation. A method analogous to the phenomenological one was chosen. A small working group in which the author participated was formed for the development of QA. The theoretical instrument received several modifications not only to conform to political guidelines and decisions, but to maturation of concepts and calculations as well, proving feasible as a basis for the development of QA. Several special interest groups influenced the development of QA in different phases and at different levels; it even occurred to interest groups to directly sue the working group. The High Administration supported the process, but it became sometimes divided in relation to the conflict between environmental and social aspects. The group succeeded in enhancing the gains derived from the complementarity of skills resulting from the heterogeneity in terms of training and experience of the working group members. It sought to harmonize the different pressures, often even foreseeing them. To this end, the working group has developed a dynamic to reach internal consensus and to anticipate, internalize and position itself in the face of frequently conflicting pressures. The most severe pressures came from the municipal bureaucracy itself. In all these processes simplicity, as a requirement, was lost. The Environmental Quota proved to be an innovative instrument, appearing to satisfy the demands of various interest groups and, mainly, representing an environmental wedge inserted in the zoning law.
\end{abstract}

Descriptors: Environment and public health; Environmental policy; City planning; Zoning; Floods; Urban area; Cities; Housing; Building specifications; Indicators; Hydrology; Runoff; Water cycle; Soil permeability; Infiltration; Reservoirs; Rainwater catchment; Hydrodynamics; Infiltrationpercolation ditches; Percolation; Green areas; Ecosystem; Ecology; Entropy; Information; Microclimate; Climate change; Greenhouse effect; Nature; Public sector; Politics; Government; Local government; Organizations; Municipal organization.

Keywords: Environmental Quota; QA; BFF; BAF; Urban and environmental instruments; Urban environmental zoning; Land use legislation; Ecosystem quality; Exergy; Eco-exergy; Zero impact; Metrics; Environmental indicators; Stakeholders; Phenomenology; Legal uncertainty; BMP; SuDS; Traffic calming; Verkehrsberuhigung; Ecosystem health; Ecological integrity; Environmental zoning. 


\section{SUMÁRIO}

TOMO I PRELIMINARES

1 INTRODUÇÃO

2 OBJETIVOS

3 MÉTODO 40

3.1 PRIMEIRO OBJETIVO 40

3.2 SEGUNDO OBJETIVO 40

TOMO II PROPOSTA E EMBASAMENTO 46 TEÓRICO DE PARÂMETRO URBANOAMBIENTAL UTILIZADO COMO BASE DE DISCUSSÃO NO DESENVOLVIMENTO DA QUOTA AMBIENTAL

4 O BIOTOPFLÄCHENFAKTOR (BFF) DE BERLIM

4.1.1 Hierarquia de Planejamento na República Federal da 49 Alemanha

4.1.2 Sistema Federativo da República Federal da Alemanha e a situação de Berlim nesse sistema

4.1.3 Influência da Guerra Fria na Conformação das Questões Urbanas de Berlim

4.1.4 Histórico do BFF 
4.2 ETAPAS DE CONSTRUÇÃO DE INSTRUMENTO ANÁLOGO AO BFF

4.3 PROPOSTA DE CRIAÇÃO DE UM PARÂMETRO

URBANÍSTICO-AMBIENTAL INSPIRADO EM ADAPTAÇÃO

DO BFF À CIDADE DE SÃO PAULO

5 PROMOÇÃO DE CONTROLE DE DRENAGEM NA FONTE

5.1 RESERVATÓRIOS DE LOTE

5.2 ALGUMA PALAVRA SOBRE A INFILTRAÇÃO

5.3 CONCLUSÕES PARCIAIS SOBRE O OBJETIVO

AMBIENTAL "PROMOÇÃO DO CONTROLE DE DRENAGEM NA FONTE" NO CONTEXTO DA CRIAÇÃO DE UM BFF PAULISTANO

\section{PROMOÇÃO DA QUALIDADE ECOSSISTÊMICA}

6.1 INTEGRIDADE ECOLÓGICA E SEUS INDICADORES

6.2 SAÚDE ECOSSISTÊMICA

6.3 ECOEXERGIA

6.4 ECOEXERGIA COMO INDICADOR PRIVILEGIADO PARA 103 A SAÚDE ECOSSISTÊMICA

6.5 PROPOSTA DE INDICADOR DA SAÚDE ECOSSISTÊMICA 108 DE BIÓTOPOS PARA FINS DE UTILIZAÇÃO EM INSTRUMENTOS NORMATIVOS

\section{MELHORIA DO MICROCLIMA}

7.1 ESCOLHA DE UMA MÉTRICA PARA O MICROCLIMA

7.2 LIMITAÇÕES DA ABORDAGEM ADOTADA

7.3 UMA ABORDAGEM PROMISSORA: ESTIMATIVAS DA EXERGIA DE ECOSSISTEMAS A PARTIR DE IMAGENS DE SATÉLITE 
7.4 A DRENAGEM REVISITADA À LUZ DAS

CONSIDERAÇÕES ACIMA: UMA RÁPIDA NOTÍCIA SOBRE A

RELAÇÃO ENTRE O CONTROLE DA POLUIÇÃO DIFUSA E A MÉTRICA PROPOSTA

8 CONSOLIDAÇÃO INICIAL DA PROPOSTA

8.1 CONCLUSÕES PRELIMINARES

TOMO III COMENTÁRIOS PRÉVIOS AO ESTUDO DE CASO

9 QUESTÕES DE ORDEM GERAL

9.1 O SIMPLES E O COMPLEXO

9.2 VALOR DA NATUREZA

133

9.3 OBJETIVOS AMBIENTAIS ACESSÓRIOS

143

9.4 MULTIDISCIPLINARIDADE

10 ASPECTOS RELEVANTES DO EXECUTIVO MUNICIPAL PAULISTANO

10.1 ASPECTOS JURÍDICOS

10.2 ASPECTOS DE CULTURA INSTITUCIONAL

10.3 RELACIONAMENTO DO EXECUTIVO COM O

LEGISLATIVO

10.4 DECISÕES DURANTE ELABORAÇÃO DE MINUTA DE 175

PROJETO DE LE 
11.2 DIRETRIZES IMPOSTAS AO DESENVOLVIMENTO DA 189 QA

12 PROMOÇÃO DE CONTROLE DE DRENAGEM NA 194 FONTE

12.1 VOLUME DE RESERVAÇÃO

12.2 COEFICIENTE DE ESCOAMENTO SUPERFICIAL DA SITUAÇÃO DE PROJETO

12.3 QUESTIONAMENTOS INTERNOS 204

12.4 REBAIXAMENTO DO LENÇOL 209

12.5 ESTRUTURAS DE SAÍDA 216

12.6 INFILTRAÇÃO E POLUIÇÃO DIFUSA 223

12.7 QA PARA PARCELAMENTOS 224

12.8 RESERVAÇÃO PARA APROVEITAMENTO DE ÁGUAS 227

PLUVIAIS PROVENIENTES DE COBERTURAS

\section{VEGETAÇÃO}

13.1 INDIVÍDUOS ARBÓREOS EXISTENTES 230

13.2 INDIVÍDUOS ARBÓREOS A SEREM PLANTADOS 235

13.3 ÁREAS AJARDINADAS E COBERTURAS VERDES 237

13.4 PALMEIRAS EXISTENTES E A SEREM PLANTADAS 239

13.5 MACIÇOS ARBÓREOS EXISTENTES 239

13.6 MUROS VERDES E JARDINS VERTICAIS 240

13.7 NORMALIZAÇÃO DO INDICADOR DE ECOEXERGIA 241 SIMPLIFICADA 
13.9 COMPARAÇÃO DA ECOEXERGIA SIMPLIFICADA COM 243 A ÁREA FOLIAR

14.1 DEFINIÇÃO DE PERÍMETROS DE QUALIFICAÇÃO AMBIENTAL

14.2 AVALIAÇÃO DE CADA UM DOS PERÍMETROS EM

14.6 FISCALIZAÇÃO

14.7 INCENTIVOS

14.8 INDUÇÃO A BAIXAS TAXAS DE OCUPAÇÃO 264

14.9 ANOMALIAS NA FUNÇÃO D 265

15 EVENTOS E PARTICIPAÇÃO PÚBLICA 266

15.1 PRIMEIRA OFICINA TÉCNICA PARA DISCUTIR 266 RESULTADOS PRELIMINARES DA QUOTA AMBIENTAL

15.2 SEGUNDA OFICINA TÉCNICA RELATIVA À QUOTA 270 AMBIENTAL

15.3 ENCONTRO “O QUE É A COTA AMBIENTAL?” 
INTERESSES DE ALGUNS STAKEHOLDERS QUE SE

COLOCARAM FRENTE AO PROCESSO?

17 CONCLUSÕES 
A2.1 INTRODUÇÃO

A2.2 EXERGIA E INFORMAÇÃO

A2.3 ECOEXERGIA E INFORMAÇÃO

ANEXO 3 CONTROVÉRSIA JØRGENSEN/ SCHNEIDERKAY

A3.1 INTRODUÇÃO

A3.3 UMA MÍNIMA HISTÓRIA DAS TEORIAS ECOSSISTÊMICAS

A3.4 DEMONSTRAÇÃO SEGUNDO FATH, PATTEN, CHOI E 353 HIGASHI DA COMPLEMENTARIDADE E CONSISTÊNCIA INTERNA DE FUNÇÕES-OBJETIVO ECOLÓGICAS

A3.5 FUNÇÕES-OBJETIVO AO LONGO DO 362 DESENVOLVIMENTO DO ECOSSISTEMA A3.6 UMA MÉTRICA COMUM À ECOEXERGIA E À DEGRADAÇÃO DE EXERGIA 


\section{LISTA DE FIGURAS}

Figura 1 Hidrogramas de segmentos retos relativos a quatro chuvas associadas ao mesmo tempo de retorno, sendo uma delas de duração igual ao tempo de concentração, para bacias pequenas

Figura 2 Obtenção do volume de reservatório de detenção a partir dos 78 hidrogramas de entrada e saída ao reservatório

Figura 3 Cálculo simplificado do volume de reservatório 79

Figura 4 Volumes de reservatórios de detenção calculados segundo diferentes critérios

Figura A3-1 Modelo de quatro caixas de Holling

Figura A3-2 Esquema gráfico dos conceitos da análise de rede

Figura A3-3 Relação entre exergia degradada e exergia armazenada em diversos ecossistemas

Figura A3-4 Relação entre a exergia específica degradada e a exergia armazenada no contexto dos estágios de crescimento dos ecossistemas 


\section{LISTA DE TABELAS}

Tabela 1 Avaliação de indicadores de bens a proteger de tecnologias superficiais verdes de lote realizada no processo de desenvolvimento do BFF

Tabela 2 Fatores de conversão exergia-biomassa de diferentes grupos de organismos

Tabela 3 Exergia armazenada em diversos ecossistemas

Tabela 4 Cálculo do balanço médio de energia superficial de quatro grandes regiões em 50 dias de verão

Tabela 5 Composição percentual dos diferentes grupos de solos em cada um dos litotipos ocorrentes na bacia do Alto Tietê

Tabela 6 Comparação entre estimativas da ecoexergia simplificada e a área foliar para exemplares arbóreos existentes e a plantar de diferentes portes

Tabela 7 Pontuação e ranqueamento dos perímetros de qualificação urbana

Tabela $8 \quad$ QAmin para diferentes perímetros e áreas de lote

Tabela A2-1 Taxas de exergia por unidade de informação para diversos processos de transferência de informação

Tabela A3-1 Representação de partições de fluxos e armazenamentos em cinco modos para cada par $(\mathrm{i}, \mathrm{j})$ em um sistema

Tabela A3-2 Princípios extremos de descrição de ecossistemas associados à representação de partições de fluxos e armazenamentos em cinco modos para todo o sistema 


\section{LISTA DE QUADROS}

Quadro $1 \quad$ Hierarquia de planejamento urbano na cidade de Stuttgart 50

Quadro 2 Comparação dos conceitos de canalização e reservação 65

$\begin{array}{lll}\text { Quadro } 3 & \text { Evolução histórica dos objetivos associados às obras de } & 65\end{array}$ detenção em centros urbanos

Quadro 4 Encadeamento teórico relacionado ao conceito de integridade ecológica de Müller

Quadro 5 Indicadores propostos por Müller (2005) para representar o 90 estado de ecossistemas e paisagens

Quadro 6 Definições de saúde ecossistêmica levantadas por XU e TAO (2000)

Quadro 7 Funções-objetivo propostas para sistemas dinâmicos 95

Quadro $8 \quad$ Alguns indicadores de saúde ecossistêmica 96

Quadro 9 Correspondência entre alguns dos atributos de Odum e formas 105 de crescimento segundo JØRGENSEN et al. (2000)

Quadro 10 Correspondência entre indicadores de saúde ecossistêmica de 105 Constanza e formas de crescimento segundo JØRGENSEN et al. (2000)

Quadro 11 Correlação entre vários indicadores baseados em exergia e outros indicadores de estado ecossistêmico

Quadro 12 Hierarquia de solução de problemas

Quadro 13 Modelo de relacionamento entre o executivo e o legislativo do município de São Paulo 


\section{SIGLAS E SÍMBOLOS UTILIZADOS}

ABNT

ABRH

ADIN

AGU

AMI

B

BAF

$\mathrm{BaGB}$

BASt

$\mathrm{BFF}$

BfLR

BMP

B-Plan

CBCS

CDHU

CEDEC

CET

CETESB
Associação Brasileira de Normas Técnicas

Associação Brasileira de Recursos Hídricos

Ação Direta de Inconstitucionalidade

American Geophysical Union

Average Mutual Information

Biomassa do ecossistema

Biotope Area Factor

Baugesetzbuch (Código de Obras)

Bundesanstalt für Straßenwesen (Instituto Viário Federal)

Biotopflächenfaktor (Fator de Superfície de Biótopo)

Bundesforschungsanstalt für Landeskunde und Raumordnung (Instituto Federal de Pesquisas Geográficas e de Ordenamento Territorial)

Best Management Practices

Bebaungsplan (tradução difícil por não haver equivalente no Brasil: Plano de Desenvolvimento, Plano de Urbanização; optamos por Plano Local de Construções)

Conselho Brasileiro de Construção Sustentável

Companhia de Desenvolvimento Habitacional e Urbano da Secretaria da Habitação do Governo do Estado de São Paulo

Centro de Estudos de Cultura Contemporânea

Companhia de Engenharia de Tráfego (vinculada à Secretaria Municipal de Transportes da Prefeitura do Município de São Paulo)

Companhia Ambiental do Estado de São Paulo (antiga Companhia de Tecnologia de Saneamento Ambiental, antigo Centro Técnico de Saneamento Básico) 
CEUSO Comissão de Edificações e Uso do Solo

CFG Coalização fisiológica de governo

CIRIA Construction Industry Research and Information Association

$\mathrm{CN} \quad$ Curve Number

COE Código de Obras e Edificações

CPG Coalizão pragmática de governo

D Indicador Drenagem, correspondendo ao grau de abatimento do hidrograma de saída em relação à situação pré-desenvolvida

DAEE Departamento de Águas e Energia Elétrica do Governo do Estado de São Paulo

dap Diâmetro do caule à altura do peito (aproximadamente 1,3m)

dapp Diâmetro do caule à altura do peito potencial

DDR Deutsche Demokratische Republik (República Democrática Alemã)

DEPAVE Departamento de Parques e Áreas Verdes da Secretaria Municipal do Verde e do Meio Ambiente da Prefeitura do Município de São Paulo

DEPLAN Departamento de Planejamento Ambiental da Secretaria Municipal do Verde e do Meio Ambiente da Prefeitura do Município de São Paulo

DEPLAN 1 Divisão Técnica de Planejamento do Departamento de Planejamento Ambiental da Secretaria Municipal do Verde e do Meio Ambiente da Prefeitura do Município de São Paulo

DEUSO Departamento do Uso do Solo da Secretaria Municipal de Desenvolvimento Urbano da Prefeitura do Município de São Paulo

EHIS Empreendimento de Habitação de Interesse Social

ELT Ecological Law of Thermodynamics

EMATER-DF Empresa de Assistência Técnica e Extensão Rural do Distrito Federal 
EMBRAPA Empresa Brasileira de Pesquisa Agropecuária

EMPLASA Empresa Paulista de Planejamento Metropolitano

ENVI-met Modelo de simulação microclimática desenvolvido por Bruse

ESALQ Escola Superior de Agricultura "Luiz de Queiroz" da Universidade de São Paulo

Estrategista K População para a qual a capacidade-suporte do meio se constitui em fator limitante; apresentam maior longevidade, menos prole e mais cuidado com ela (K corresponde à população-limite da curva logística)

Estrategista $\mathrm{r}$ População para a qual a capacidade-suporte não se constitui em fator limitante; apresentam menor longevidade, mais prole e menos cuidado com ela ( $\mathrm{r}$ corresponde à taxa de crescimento da curva logística)

ET

Evapotranspiração

$\mathrm{ET}_{0} \quad$ Evapotranspiração potencial

Exs $\quad$ Ecoexergia simplificada

$\mathrm{F}$

Fator de qualificação de indivíduos arbóreos

FAU-USP Faculdade de Arquitetura e Urbanismo da Universidade de São Paulo

FB

Foliar biomass

FCTH Fundação Centro Tecnológico de Hidráulica

FEHIDRO Fundo Estadual de Recursos Hídricos

FNP Flächennutzungsplan (Plano Preparatório de Uso e Ocupação do Solo)

FV Fator de eficácia ambiental do indicador cobertura vegetal

G Fator de qualificação de maciços arbóreos

GOP Grünordnungsplan (tradução literal: Plano de Ordenamento do Verde) 
GPS

GSF

GT

IAHR

IAWPRC

ICLARM

i-d-f

IPCC

IPH

IPTU

IQE

$\mathrm{IQE}_{\min }$

i-Tree

JICA

Kf-Werte

LA

LPUOS

MCQA

MEM

MQU
Green Points System

Green Space Factor

Grupo de Trabalho

International Association for Hydro-Environment Engineering and Research

International Association on Water Pollution Research and Control

The International Center for Living Aquatic Resources

Curva intensidade-duração-frequência (equação que associa a intensidade de precipitações e sua duração com períodos de retorno a partir de tratamento estatístico de medidas de precipitação)

The International Panel on Climate Change

Instituto de Pesquisas Hidráulicas da Universidade Federal do Rio Grande do Sul

Imposto Predial e Territorial Urbano

Indicador de Qualidade Ecossistêmica

Mínimo valor do indicador de qualidade ecossistêmica a ser observado em um lote no caso de haver norma compulsória nesse sentido

Modelo do United States Forest Service de análise de florestas urbanas e de ferramentas de avaliação de benefícios

Japan International Cooperation Agency

Durchlässigskeitsbeiwert (coeficiente de permeabilidade - lei de Darcy)

Leaf area

Legislação de Parcelamento, Uso e Ocupação do Solo

Macroárea de Controle e Qualificação Urbana e Ambiental

Macroárea de Estruturação Metropolitana

Macroárea de Qualificação da Urbanização 
MRV

MRVRA Macroárea de Redução da Vulnerabilidade e Recuperação Ambiental

MUC

NBR

NFPA

NP

observaSP

Macroárea de Urbanização Consolidada

Denominação de norma da Associação Brasileira de Normas Técnicas

National Fire Protection Association

Negociação pontual

Observatório ligado ao projeto de pesquisa "Estratégias e instrumentos de planejamento e regulação urbanística voltados à implementação do direito à moradia e à cidade no Brasil", desenvolvido pelo Laboratório Espaço Público e Direito à Cidade (Lab Cidade), da Faculdade de Arquitetura e Urbanismo da Universidade de São Paulo (informação extraída de seu sítio)

OR Oposição rígida

$\mathrm{P}$

1) Fator de horizonte

2) Taxa de produção do ecossistema

PDE Plano Diretor Estratégico

PL Projeto de lei

PPB Partido Progressista Brasileiro

QA Quota Ambiental

$\mathrm{R}$

Taxa de respiração do ecossistema

REGA Revista de Gestão de Águas da América Latina

RSPB The Royal Society for the Protection of Birds

SCS United States Soil Conservation Service

SCTDE Secretaria de Estado da Ciência, Tecnologia e Desenvolvimento Econômico do Governo do Estado de São Paulo

SGF

Seattle Green Factor 
SEMPLA Secretaria Municipal de Planejamento Urbano da Prefeitura do Município de São Paulo; atualmente essa sigla designa um órgão diferente, a Secretaria Municipal de Planejamento, Orçamento e Gestão da Prefeitura do Município de São Paulo

SISNAMA Sistema Nacional do Meio Ambiente

SIURB Secretaria Municipal de Infraestrutura Urbana e Obras da Prefeitura do Município de São Paulo

SMDU Secretaria Municipal de Desenvolvimento Urbano da Prefeitura do Município de São Paulo

SOHO Self-Organizing Holarchic Open Systems

SUDENE Superintendência de Desenvolvimento do Nordeste

SuDS Sustainable Drainage Systems

SVMA Secretaria Municipal do Verde e do Meio Ambiente da Prefeitura do Município de São Paulo

SVP Secretaria de Vias Públicas da Prefeitura do Município de São Paulo

SWMM United States Environmental Protection Agency Storm Water Management Model

TAC Termo de Ajustamento de Conduta

TCA Termo de Compromisso Ambiental

TID Tramitação Interna de Documentos

TO Taxa de ocupação

UBA Umweltbundesamt (Escritório Federal de Meio Ambiente)

UFORE Urban Forest Effects Model

UFRGS Universidade Federal do Rio Grande do Sul

V Indicador Cobertura Vegetal

valor C Quantidade total de DNA nuclear 
WWT Wildfowl \& Wetland Trust

ZEIS

Zona Especial de Interesse Social

ZEM

Zona Eixo de Estruturação da Transformação Metropolitana

ZEMP

Zona Eixo de Estruturação da Transformação Metropolitana Previsto

ZEPAM

Zona Especial de Proteção Ambiental

ZER

Zona Exclusivamente Residencial

ZEU

Zona Eixo de Estruturação da Transformação Urbana

ZEUP

Zona Eixo de Estruturação da Transformação Urbana Previsto

ZPDS

Zona de Preservação e Desenvolvimento Sustentável

$\mathrm{ZPDSr}$

Zona de Preservação e Desenvolvimento Sustentável da Zona Rural

$\alpha$

Parâmetro da equação de definição da Quota Ambiental

$\beta$

1) fator de conversão ecoexergia-biomassa

2) parâmetro da equação de definição da Quota Ambiental 


\section{LISTA DE SÍMBOLOS EM EQUAÇÕES}

$\mathrm{Na}$ listagem anterior foram apresentadas diversas siglas e símbolos que constavam no texto. No entanto, para a melhor compreensão de parâmetros constantes de equações não basta, a nosso ver, enfileirá-los, sendo necessário apresentá-los no contexto das equações onde eles aparecem. Assim, serão apresentadas diversas equações com a definição de seus parâmetros. Esta listagem deve ser entendida meramente como continuação da listagem anterior, não se prestando como resumo da teoria. Não foram consideradas as equações constantes dos anexos, uma vez que o texto é autônomo em relação a eles.

Equação da conservação de massa para volume de controle com coordenadas eulerianas

$0=\partial / \partial \mathrm{t} \int_{\mathrm{VC}} \rho \mathrm{dU}+\int_{\mathrm{SC}} \rho \mathbf{V} \cdot \mathrm{dA}$

VC: volume de controle; SC: superfície de controle; $\rho$ : massa específica [M.L-3]; U: grandeza do volume de controle $\left[\mathrm{L}^{3}\right]$; dU: diferencial do volume de controle $\left[\mathrm{L}^{3}\right]$; $\mathrm{t}$ : tempo $[\mathrm{t}] ; \mathbf{V}$ : vetor velocidade normal à superfície de controle $[\mathrm{L} / \mathrm{t}] ; \mathrm{dA}$ : diferencial de vetor normal à superfície de controle $\left[\mathrm{L}^{2}\right]$.

Equação da continuidade simplificada para reservatórios

$\mathrm{Q}_{\mathrm{e}}-\mathrm{Q}_{\mathrm{s}}=\mathrm{dU} / \mathrm{dt}$

$\mathrm{Q}_{\mathrm{e}}$ : vazão de entrada no reservatório $\left[\mathrm{L}^{3} . \mathrm{t}^{-1}\right]$; $\mathrm{Q}$ : vazão de saída do reservatório $\left[\mathrm{L}^{3} \cdot \mathrm{t}^{-1}\right]$; volume de reservatório $\left[\mathrm{L}^{3}\right]$.

Pico da vazão de entrada no reservatório para uma bacia pequena totalmente impermeabilizada

$\mathrm{Q}=\mathrm{i} . \mathrm{A}$

Q: vazão $\left[\mathrm{L}^{3} \cdot \mathrm{t}^{-1}\right]$; $\mathrm{i}$ : intensidade da chuva $\left[\mathrm{L} \cdot \mathrm{t}^{-1}\right]$; A: área da bacia $\left[\mathrm{L}^{2}\right]$. 
Pico da vazão de entrada para uma bacia pequena não totalmente impermeabilizada $\mathrm{Q}=$ C.i.A

C: coeficiente de escoamento superficial.

Volume aproximado de reservatório para uma determinada duração de chuva $\mathrm{U}=\left(\mathrm{Q}_{\mathrm{e}}-\mathrm{Q}_{\mathrm{s}}\right) \cdot \mathrm{t}$

U: volume do reservatório necessário para, dada uma determinada vazão de entrada, obter uma determinada vazão de saída $\left[\mathrm{L}^{3}\right]$; Qe: vazão que entra no reservatório $\left[\mathrm{L}^{3} \cdot \mathrm{t}^{-1}\right] ; \mathrm{Q}_{\mathrm{s}}$ : valor imposto para a vazão de saída do reservatório $\left[\mathrm{L}^{3} \cdot \mathrm{t}^{-1}\right]$; t: duração da chuva $[\mathrm{t}]$.

Exergia de um sistema (WALL e GONG, 2001)

$\mathrm{E}=\mathrm{U}+\mathrm{P}_{0} \mathrm{~V}-\mathrm{T}_{0} \mathrm{~S}-\Sigma_{\mathrm{i}} \mu_{\mathrm{i} 0} \mathrm{n}_{\mathrm{i}}$

$\mathrm{E}$ : exergia; U: energia interna do sistema; V: volume do sistema; S: entropia do sistema; $\mathrm{n}_{\mathrm{i}}$ : número de moles das diferentes substâncias i no sistema; $\mathrm{P}_{0}$ : pressão do ambiente; $\mathrm{T}_{0}$ : a temperatura do ambiente; $\mu_{\mathrm{i} 0}$ : potencial químico generalizado da substancia i no ambiente.

Ecoexergia de organismos e ecossistemas (SILOW, MOKRY e JØRGENSEN, 2011a e 2011b)

$\mathrm{Ex} / \mathrm{RT}=\Sigma_{\mathrm{i}=1, \mathrm{n}} \mathrm{c}_{\mathrm{i}} \cdot \beta_{\mathrm{i}} \quad\left[\mathrm{g}\right.$ detritus. $\left.\mathrm{m}^{-3}\right]$

Ex: ecoexergia total do sistema, em J; R: constante dos gases, no valor de 8,31 J.Mol ${ }^{-1} \cdot \mathrm{K}^{-1}$; T: temperatura absoluta do ambiente, em $\mathrm{K}$; $\mathrm{c}_{\mathrm{i}}$ : concentração da biomassa, em g.m ${ }^{-3} ; \beta_{\mathrm{i}}$ : fator de conversão ecoexergia-biomassa, que reflete a quantidade de informação armazenada no organismo. 
Exergia física relacionada à teoria de informação WALL (2009, p.70-8)

$\mathrm{E}=\mathrm{k} \ln 2 \mathrm{~T}_{0} \mathrm{I}$

$\mathrm{k}$ : constante de Boltzmann $\left(1,38054 \cdot 10^{-23} . \mathrm{J} . \mathrm{K}^{-1}\right) ; \mathrm{T}_{0}$ : temperatura absoluta do ambiente (K); I: informação ou capacidade de informação, expressa em binary units (bits).

Volume de first flush SCHUELLER (1987) apud TOMAZ (2006):

$\mathrm{WQv}=\mathrm{P} \cdot \mathrm{R}_{\mathrm{v}} \cdot \mathrm{A}$

$\mathrm{WQ}_{\mathrm{v}}$ : volume do first flush; P: altura de precipitação, sendo maior ou igual a $13 \mathrm{~mm}$;

A: área da bacia; $\mathrm{R}_{\mathrm{v}}$ : coeficiente volumétrico dependente da área impermeável, conforme a equação seguinte: $\mathrm{R}_{V}=0,05+0,009$. AI sendo AI: área impermeável da bacia, em porcentagem.

Critério de BMP de faixa de filtro gramada USSCS apud TOMAZ (2006):

$\mathrm{t}=\left[5,52(\mathrm{n} \cdot \mathrm{L})^{0,8}\right] /\left[\left(\mathrm{P}_{2}\right)^{0,5} \cdot \mathrm{S}^{0,4}\right]$

t: tempo de trânsito do escoamento superficial, em min; n: coeficiente de rugosidade de Manning, em s.m ${ }^{-1 / 3}$; $\mathrm{S}$ : declividade, em m.m ${ }^{-1}$; L: comprimento, em m, $\mathrm{P}_{2}$ : precipitação de $24 \mathrm{~h}$, em mm, com período de retorno de 2 anos.

Definição de Quota Ambiental (QA)

$\mathrm{QA}=\mathrm{V}^{\alpha} \cdot \mathrm{D}^{\beta}$

alfa e beta: fatores de ponderação, V: indicador cobertura vegetal; D: indicador drenagem

Volume do reservatório em função do parâmetro D

$V / A=\left\{C_{d} \cdot i-\left[C_{a} \cdot i+\left(C_{d}-C_{a}\right) \cdot i \cdot(1-D)\right]\right\} \cdot t$

$\mathrm{V}$ : volume de reservação $\left[\mathrm{L}^{3} \cdot \mathrm{t}^{-1}\right] ; \mathrm{A}$ : área do lote $\left[\mathrm{L}^{2}\right]$; i: intensidade da chuva $\left[\mathrm{L}^{\left.-\mathrm{t}^{-1}\right]}\right.$; $\mathrm{C}_{\mathrm{a}}$ : coeficiente de escoamento superficial na situação pré-desenvolvida (adimensional); $\mathrm{C}_{\mathrm{d}}$ : coeficiente de escoamento superficial na situação desenvolvida (adimensional); D: grau de abatimento do hidrograma de saída em relação à situação 
pré-desenvolvida (indicador drenagem, adimensional); t: tempo de duração da chuva $[\mathrm{t}]$.

Equação acima com D isolado

$\mathrm{D}=1-\left[(\mathrm{V} / \mathrm{A})-\right.$ t.i. $\left.\left(\mathrm{C}_{\mathrm{a}}-\mathrm{C}_{\mathrm{d}}\right)\right] /\left[\mathrm{t} \cdot \mathrm{i} \cdot\left(\mathrm{C}_{\mathrm{a}}-\mathrm{C}_{\mathrm{d}}\right)\right]$

\section{Equação acima para unidades em particular}

$\mathrm{D}=1-[0,0105(\mathrm{~V} / \mathrm{A})-\mathrm{C}+0,38)] /(0,38-\mathrm{C})$

C: composição do coeficiente de escoamento superficial da situação de projeto; V em litros; A em metros quadrados.

Equação decorrente da definição dos parâmetros relativos ao método de obtenção do escoamento superficial pelo método do SCS

$\mathrm{S}^{\prime}=\left(\mathrm{R}-\mathrm{I}_{\mathrm{A}}\right)-\mathrm{R}_{\mathrm{e}}$

$\mathrm{R}_{\mathrm{e}}$ : precipitação excedente acumulada desde o início da chuva que se transforma em escoamento superficial [L]; R: precipitação acumulada sobre a bacia [L]; S': infiltração mais interceptação nas depressões mais armazenamento superficial acumulados [L]; S: valor limite de S' para uma dada condição antecedente de umidade do solo [L]; $\mathrm{I}_{\mathrm{A}}$ : extração inicial, que corresponde à precipitação inicial que não tem nenhuma parcela convertida em escoamento superficial [L].

Hipótese fundamental do método do SCS

A cada instante é válido:

$\mathrm{S}^{\prime} / \mathrm{S}=\mathrm{R}_{\mathrm{e}} /\left(\mathrm{R}-\mathrm{I}_{\mathrm{A}}\right)$

Definição de parâmetros conjugada com hipótese básica do método do SCS

$$
\begin{array}{ll}
\mathrm{R}_{\mathrm{e}}=\left(\mathrm{R}-\mathrm{I}_{\mathrm{A}}\right)^{2} /\left(\mathrm{S}+\mathrm{R}-\mathrm{I}_{\mathrm{A}}\right) & \text { para } \mathrm{I}_{\mathrm{A}}<\mathrm{R} \\
\mathrm{R}_{\mathrm{e}}=0 & \text { para } \mathrm{I}_{\mathrm{A}} \geq \mathrm{R}
\end{array}
$$

\section{Definição de CN}

$\mathrm{S}=25400 / \mathrm{CN}-254$

$\mathrm{S}$ em milímetros. 
Conversão de S para diferentes condições antecedentes de umidade do solo

$\mathrm{S}_{\mathrm{I}}=2,38 \mathrm{~S}_{\mathrm{II}}$

$\mathrm{S}_{\mathrm{III}}=0,43 \mathrm{~S}_{\mathrm{II}}$

Equação de determinação da altura de sub-base de pavimentos permeáveis DE VIRGILIS (2009)

h $\geq$ i.t. $\Phi^{-1}$

h: altura da sub-base [L]; i: intensidade da chuva de projeto [L.t $\left.{ }^{-1}\right]$; t: duração da chuva de projeto $[\mathrm{t}] ; \Phi$ : porosidade.

Equação proposta para área da tubulação da estrutura de saída do reservatório

Ats $\leq$ Q.C $C_{\mathrm{v}}{ }^{-1} \cdot(2 \cdot g \cdot h)^{-1 / 2}$

Ats: área da tubulação de saída do reservatório $\left[\mathrm{L}^{2}\right] ; \mathrm{C}_{\mathrm{v}}$ : coeficiente de vazão (admitido como 0,6 no caso de orifícios); g: aceleração da gravidade (admitida como 9,8m.s $\mathrm{s}^{-2}$ ); h: carga hidráulica disponível imediatamente a montante da seção de entrada da tubulação de saída, podendo ser admitida meramente como a altura de água disponível [L]; Q: vazão de saída do reservatório $\left[\mathrm{L}^{3} \cdot \mathrm{t}^{-1}\right]$.

Vazão de saída do reservatório (supondo que, mesmo havendo soluções não convencionais de drenagem no lote, a saída do lote se faria por reservatório de $\underline{\text { detenção) }}$

Qmax = A.i. [0,38+(C-0,38).(1-D)]

Qmax: vazão máxima $\left[\mathrm{L}^{3} \cdot \mathrm{t}^{-1}\right] ; \mathrm{A}$ : área do lote $\left[\mathrm{L}^{2}\right]$; i: intensidade da chuva $[\mathrm{L} / \mathrm{t}] ; \mathrm{C}$ : coeficiente de escoamento superficial do lote, denominado no PL como Dparcial; D: indicador drenagem.

\section{Equação anterior para unidades em particular}

Qmax $=\{$ A.11,3.[0,38+(C-0,38).(1-D)] $\} / 10000$

Qmax: vazão máxima em $\ell . \mathrm{s}^{-1} ; \mathrm{A}$ : área do lote $\mathrm{em} \mathrm{m}^{2}$; C: coeficiente de escoamento superficial do lote, denominado no PL como Dparcial. 
Equação para a obtenção de D, o indicador de drenagem

$\mathrm{D}=1-[0,0105(\mathrm{~V} / \mathrm{A})-\mathrm{C}+0,38)] /(0,38-\mathrm{C})$

$\mathrm{V}$ : volume do reservatório $(\ell)$.

$\underline{\text { Situação crítica de transição do tipo } 3 \text { para o tipo } 2 \text { do canal de saída do reservatório, }}$ admitido como bueiro

Canal de saída do reservatório admitido como bueiro, sendo que para o tipo 3 o controle está na entrada, sendo regido pela equação de orifício, enquanto que para o tipo 2 o controle está na saída, sendo regido pela equação de Bernoulli - ou de Manning, se considerar-se escoamento a seção plena. No limite - situação crítica - as duas equações se igualam. Tem-se, portanto:

$\mathrm{R}_{\mathrm{h}}{ }^{2 / 3} \cdot \mathrm{i}^{1 / 2} \cdot \mathrm{n}^{-1}=\left(2 \cdot \mathrm{g} \cdot \mathrm{H}^{*}\right)^{1 / 2}$

$\mathrm{R}_{\mathrm{h}}$ : raio hidráulico, correspondente à divisão entre a área molhada e o perímetro

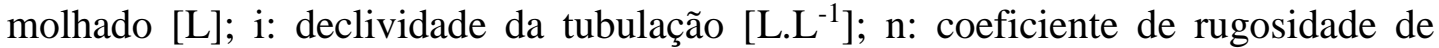
Manning [ $\left[\mathrm{L}^{-1 / 3} . \mathrm{t}\right]$; g: aceleração da gravidade; $\mathrm{H}^{*}$ : altura crítica do reservatório imediatamente a montante da estrutura de saída de transição do tipo 3 para o tipo 2 [L].

Manipulação da equação acima

2.g. $\mathrm{H}^{*} \cdot \mathrm{n}^{2} \cdot \mathrm{R}_{\mathrm{h}}^{-4 / 3} \cdot \mathrm{i}^{-1}=1$

Equação acima na situação crítica, o que implica $\mathrm{R}_{\mathrm{h}}=\pi \mathrm{D} / 4$

2.g.H*. $\mathrm{n}^{2} \cdot(\pi \mathrm{D} / 4)^{-4 / 3} \cdot \mathrm{i}^{-1}=1$

Equação alométrica utilizada para exemplares arbóreos

$\mathrm{Y}=(1 / 0,8) \cdot\left(38,4908-11,7883 \cdot d a p+1,1926 \cdot\right.$ dap $\left.^{2}\right)$

Y: massa do indivíduo arbóreo, incluindo raízes, em kg; dap, em cm.

Ecoexergia simplificada de cada indivíduo arbóreo i existente no lote

$\operatorname{Exs}_{i}($ u.a. $)=Y_{i}(\mathrm{~kg}) \cdot \beta \cdot A^{-1}\left(\mathrm{~m}^{2}\right) \cdot 10^{-3} \cdot P$

Exs $_{\mathrm{i}}$ em u.a. (unidades ambientais); $\mathrm{P}$ : fator de horizonte; $\beta$ : fator de conversão ecoexergia-biomassa. 
Ecoexergia simplificada de todos os $\mathrm{n}$ indivíduos arbóreos existentes no lote

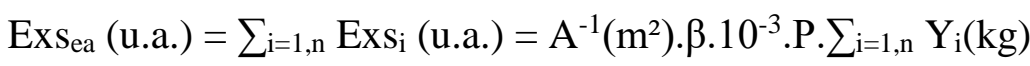

Exsea em u.a.

Ecoexergia simplificada de todos os $\mathrm{n}$ indivíduos arbóreos existentes no lote considerando três classes de indivíduos, a saber, pequenos, médios e grandes (aqui com índices $\mathrm{p}, \mathrm{m}$ e g), com número de exemplares $\mathrm{n}_{\mathrm{p}}, \mathrm{n}_{\mathrm{m}}$ e $\mathrm{n}_{\mathrm{g}}$

$\operatorname{Exs}_{\text {ea }}($ u.a. $)=\left(\mathrm{A}^{-1}\left(\mathrm{~m}^{2}\right) \cdot \beta \cdot 10^{-3} \cdot \mathrm{P}\right) \cdot\left[\sum_{\mathrm{p}=1, \mathrm{np}} \mathrm{Y}_{\mathrm{p}}(\mathrm{kg})+\sum_{\mathrm{m}=1, \mathrm{~nm}} \mathrm{Y}_{\mathrm{m}}(\mathrm{kg})+\sum_{\mathrm{g}=1, \mathrm{ng}} \mathrm{Y}_{\mathrm{g}}(\mathrm{kg})\right]$

$\operatorname{Exs}_{\text {ea }}($ u.a. $)=\left(\mathrm{A}^{-1}\left(\mathrm{~m}^{2}\right) \cdot \beta \cdot 10^{-3} \cdot \mathrm{P}\right) \cdot\left[\mathrm{n}_{\mathrm{p}} \cdot \mathrm{Y}_{\mathrm{p}}(\mathrm{kg})+\mathrm{n}_{\mathrm{m}} \cdot \mathrm{Y}_{\mathrm{m}}(\mathrm{kg})+\mathrm{n}_{\mathrm{g}} \cdot \mathrm{Y}_{\mathrm{g}}(\mathrm{kg})\right]$

$\beta$ : fator de conversão ecoexergia-biomassa, aqui adotado como 268; P: fator de horizonte, aqui adotado como 0,5; $\mathrm{Y}_{\mathrm{i}}$ : massa de cada exemplar arbóreo i, em quilogramas, aqui obtida da equação alométrica acima considerando dap $p_{p}=25 \mathrm{~cm}$, dap $_{\mathrm{m}}=35 \mathrm{~cm}$ e dap $=50 \mathrm{~cm}$.

Obtenção do parâmetro FV constante do quadro 3B do PL, válido para indivíduos arbóreos existentes

$\mathrm{FV}=\beta \cdot 10^{-3} \cdot \mathrm{P} \cdot\left[(1 / 0,8) \cdot\left(38,4908-11,7883 \cdot \mathrm{dap}+1,1926 \cdot \mathrm{dap}^{2}\right]\right.$

Ecoexergia simplificada de áreas ajardinadas para determinada superfície i

$\operatorname{Exs}_{\mathrm{i}}($ u.a. $)=0,6\left(\mathrm{~kg} / \mathrm{m}^{2}\right) \cdot \mathrm{a}_{\mathrm{i}}\left(\mathrm{m}^{2}\right) \cdot \beta \cdot \mathrm{A}^{-1}\left(\mathrm{~m}^{2}\right) \cdot 10^{-3}$

$\beta$ : fator de conversão ecoexergia-biomassa, aqui adotado como 363, a:

superfície ajardinada i (não confundir com a área A do lote).

$\underline{\text { Ecoexergia simplificada de áreas ajardinadas para n superfícies }}$

$\operatorname{Exs}_{\text {ea }}($ u.a. $)=\sum_{\mathrm{i}=1, \mathrm{n}} \operatorname{Exs}_{\mathrm{i}}($ u.a. $)=\mathrm{A}^{-1}\left(\mathrm{~m}^{2}\right) \cdot \beta \cdot 10^{-3} \cdot \sum_{\mathrm{i}=1, \mathrm{n}} 0,6\left(\mathrm{~kg} / \mathrm{m}^{2}\right) \cdot \mathrm{a}_{\mathrm{i}}\left(\mathrm{m}^{2}\right)$

Determinação de FV para A.1. no quadro 3B do PL

$\mathrm{FV}=0,6\left(\mathrm{~kg} / \mathrm{m}^{2}\right) \cdot \beta \cdot 10^{-3} \cdot \sum_{\mathrm{i}=1, \mathrm{n}} \mathrm{a}_{\mathrm{i}}\left(\mathrm{m}^{2}\right)$.

$\beta$ : fator de conversão ecoexergia-biomassa, aqui adotado como 363 
Equação alométrica adotada para palmeiras HIGUCHI et al. (1998) adapt.

$\mathrm{Y}(\mathrm{kg})=(1 / 0,8) \cdot \exp [-1,497+2 \cdot 548 \cdot \ln$ dap $(\mathrm{cm})]$

Correlação entre biomassa foliar FB e dap TOBIN et al. (2006)

$\mathrm{FB}=\exp (-3,07+1,73 . \ell \mathrm{n}$ dap $)$

Equação adotada para obtenção de área foliar NOWAK (1996)

$\mathrm{LA}\left(\mathrm{m}^{2}\right)=\exp (0,3795+0,0586 \cdot \operatorname{dap}(\mathrm{cm})+4,0202 . \mathrm{S}+\mathrm{MSE} / 2)$

LA: área foliar (leaf area), em $\mathrm{m}^{2}$; dap, em cm; S: fator de sombreamento médio para cada espécie individual (porcentagem da intensidade de luz interceptada pelas copas das árvores); MSE: um fator de correção que, dividido por 2, deve ser adicionado para corrigir o viés logarítmico da correlação.

\section{$\underline{\text { Curva logística demográfica }}$}

$\mathrm{P}(\mathrm{t})=\mathrm{P}_{\mathrm{L}} /[1+\mathrm{a} \cdot \exp (-\mathrm{b} . \mathrm{t})]$

$\mathrm{P}(\mathrm{t})$ : população em função do tempo; $\mathrm{P}_{\mathrm{L}}$ : população limite; $\mathrm{a}, \mathrm{b}$ : constantes; t: tempo.

Curva logística adotada como subsídio para obtenção do QAmin

$\mathrm{QAmin}=(\mathrm{QAmin} 10000+1) /[1+1,3 \cdot \exp (-0,0005 . \mathrm{A})]$

QAmin: QA mínimo exigido para um determinado perímetro ambiental e determinada área de lote; QAmin 10000: QAmin atribuído aos lotes com área maior do que $10.000 \mathrm{~m}^{2}$; A: área do lote $\left(\mathrm{m}^{2}\right)$. 
TOMO I:

PRELIMINARES 


\section{INTRODUÇÃO}

O gestor municipal dispõe, para a execução da gestão ambiental municipal, de um leque de sistemas jurídico-institucionais que se interseccionam parcialmente. São eles: sistema de recursos hídricos, sistema de saneamento e, evidentemente, sistema de meio ambiente.

O sistema de recursos hídricos se consolidou no Brasil como gestão integrativa por bacia (modelo francês), sendo precursora a lei paulista $\mathrm{n}^{\circ} 7.663$, de 30 de dezembro de 1991 (SÃO PAULO [ESTADO], 1991). A lei federal $n^{\circ} 9.433$, de 8 de janeiro de 1997 (BRASIL, 1997), tornou esse modelo obrigatório em todo o país, embora tenda mais a uma gestão coordenativa que integrativa por bacia. Embora haja evidentes interfaces entre recursos hídricos e meio ambiente, trata-se de sistema autônomo em relação ao de meio ambiente. De fato, poderíamos fazer uma analogia por meio da qual o sistema de recursos hídricos consiste em um almoxarifado de insumos, enquanto o sistema de meio ambiente se situaria como o controle no uso desses insumos. É importante ressaltar que no sistema de recursos hídricos o município tem um papel relativamente secundário na tomada de decisões, dificilmente servindo como subsídio relevante para a gestão ambiental municipal.

Quanto ao sistema de saneamento, há necessidade de clarificar alguns conceitos. SILVA, GUIMARÃES e CARVALHO (2007) e o eminente engenheiro Prof. Dr. Nelson Nucci ${ }^{1}$ informam que o conceito de saneamento envolve pelo menos os seguintes serviços e estruturas (adaptado): a) coleta, adução, tratamento, reservação e distribuição de água; b) coleta, transporte, tratamento e disposição final de esgotos; c) manejo de águas pluviais; d) coleta, transporte, transbordo, tratamento e destino final de resíduos sólidos urbanos; e) drenagem de zonas alagadiças; f) controle de vetores; g) vigilância sanitária; h) controle da poluição. Acrescentaríamos o serviço funerário. No Brasil, foi introduzido o conceito algo problemático de saneamento básico. Segundo Nucci, diante do quadro de brutal carência de recursos,

\footnotetext{
${ }^{1}$ Notas de aula.
} 
a SUDENE teria feito uma opção por privilegiar, tendo em vista considerações de custo-efetividade, os serviços de água e esgoto em detrimento dos outros serviços de saneamento. Assim, o conceito de saneamento básico referiu-se durante muito tempo apenas a água e esgoto. DA MOTTA (1995), ao avaliar os custos marginais de diminuição de mortes associados à oferta de serviços de saneamento, parece dar respaldo a esse tipo de argumento. Queremos crer, no entanto, que hoje, pela própria evolução sócio-econômica do país, o conceito de saneamento básico não mais faria sentido. Não obstante, a lei federal $n^{\circ}$ 11.445, de 5 de janeiro de 2007 (BRASIL, 2007), consagrou a expressão, porém associando a ela também o manejo de águas pluviais e o de resíduos sólidos. O legislador houve por bem, além disso, criar lei exclusiva para uma Política Nacional de Resíduos Sólidos, a lei federal n ${ }^{\circ} 12.305$, de 2 de agosto de 2010 (BRASIL, 2010).

Os serviços de água e esgoto vinham sendo prejudicados devido a uma enorme controvérsia jurídica em torno da titularidade desses serviços, se do município ou do estado. Apenas em 2013 o Supremo Tribunal Federal, por meio do julgamento da Ação Direta de Inconstitucionalidade ADIN 1842 (BRASIL, 2013) ainda que não tenham sido julgadas ainda as ADINs 1826, 1843 e 1906 - pacificou a questão em favor dos municípios. No entanto, parece que poucos municípios têm condições plenas de exercer a sua titularidade.

O manejo de águas pluviais sempre foi exercido sem controvérsias pelos municípios, talvez por ausência de condições jurídicas para a cobrança por esse serviço (cobrança essa hoje viabilizada pelo inciso IV do art. 22 da lei federal $\mathrm{n}^{\circ}$ 11.445/2007). Porém, a magnitude dos investimentos em medidas estruturais associadas ao manejo de águas pluviais compromete seriamente a capacidade de os municípios realizarem a contento esse serviço, mesmo que estejam disponíveis fontes de financiamento.

Igualmente incontroverso é o exercício por parte dos municípios dos serviços associados a resíduos sólidos. Mas a grande dificuldade reside no tratamento e destinação final deles, dados os enormes custos de investimento e operação.

Contudo, o município está plenamente habilitado juridicamente para atuar como órgão local do Sistema Nacional do Meio Ambiente (SISNAMA), conforme 
lhe faculta a lei federal 6.938, de 31 de agosto de 1981 (BRASIL, 1981) ${ }^{2}$. Assim, o município poderá, por exemplo, realizar licenciamento e fiscalização ambientais. É necessário não perder de vista, no entanto, que a legislação ambiental apresenta altíssimo grau de complexidade técnica e jurídica. Além disso, via de regra o licenciamento é discricionário, e não vinculado, o que tende a causar desconforto aos empreendedores e, dada a enorme insegurança jurídica vigente, aos próprios servidores encarregados do licenciamento.

Esse desconforto é muito diferente da relativa zona de conforto em que opera o município na gestão do uso e ocupação do solo. Aqui temos o domínio por excelência do município. A ideia de restrições ao direito de propriedade em nome do ordenamento territorial há muito está consolidada e aceita. O arsenal legal disponível, consubstanciado principalmente nos códigos de obras e edificações e nas leis de parcelamento, uso e ocupação do solo (conhecidas também como leis de zoneamento), ainda que possa eventualmente demandar dos gestores um conhecimento legal enciclopédico, não levanta as mesmas dificuldades, técnicas e jurídicas, associadas à fiscalização e ao licenciamento de meio ambiente. A instrumentos como taxa de ocupação, coeficiente de aproveitamento, gabarito e taxa de permeabilidade não se opõem usualmente maiores objeções ou dificuldades. Finalmente, a legislação urbanística é eminentemente vinculada.

O desafio que se coloca é: dado que o município opera em zona de relativo conforto no domínio da legislação urbanística, o que não ocorre no âmbito da legislação ambiental, haveria como cravar uma cunha ambiental na legislação urbanística na forma de um instrumento vinculado de caráter ambiental de modo tal que haja progressos ambientais sensíveis sem que se incorra nas agruras associadas à gestão de um órgão local do SISNAMA?

\footnotetext{
${ }^{2}$ A lei complementar $n^{\circ} 140$, de 8 de dezembro de 2011 (BRASIL, 2011), fixa normas para a distribuição das competências constitucionais comuns dos diversos entes federados em matéria ambiental. A deliberação CONSEMA normativa 01/2014, de 23 de abril de 2014 (SÃO PAULO [ESTADO], 2014), fixa, para o estado de São Paulo, a delimitação do exercício da competência municipal em licenciamento ambiental. O decreto municipal no 54.421, de 3 de outubro de 2013 (SÃO PAULO [CIDADE], 2013c), regulamenta a fiscalização ambiental no município de São Paulo. A competência desse município no licenciamento ambiental é objeto da resolução $n^{\circ} 170 / 14$ CADES/SVMA, de 05 de dezembro de 2014 (SÃO PAULO [CIDADE], 2014e).
} 
É evidente que o desafio não implica abrir mão da aplicação da legislação ambiental por parte do município, mas consolidar uma janela de grandes oportunidades garantindo a progressiva aplicação de novos instrumentos de caráter ambiental em processos de licenciamento urbanístico.

Dessa maneira, confere-se também uma resposta razoável às demandas teóricas representadas pela inclusão do zoneamento ambiental como instrumento legal de política urbana definido na lei no 10.257, de 10 de julho de 2001 (BRASIL, 2001), demanda essa a que se dá usualmente como resposta, de forma relativamente insatisfatória, o zoneamento ecológico-econômico.

$$
* * *
$$

Durante nossos trabalhos no programa de doutorado tivemos oportunidade de desenvolver um instrumento que, acreditamos, satisfaz ao desafio exposto acima.

Ocorreu que, por uma feliz coincidência, no momento em que esses trabalhos já se encontravam em fase madura, a Prefeitura do Município de São Paulo (PMSP), por meio de sua Secretaria Municipal de Desenvolvimento Urbano (SMDU), iniciava estudos para elaborar uma proposta de projeto de lei referente à revisão da lei de parcelamento, uso e ocupação do solo. Ora, um dos instrumentos previstos para figurar nessa proposta constava como "Quota Ambiental", definida como "o conjunto de parâmetros de uso, dimensionamento e ocupação dos lotes voltados à melhoria da qualidade ambiental e paisagística, em conformidade com os princípios, objetivos e diretrizes estabelecidos no Plano Diretor Estratégico, a ser atendido nos lotes, glebas e unidades de conservação no momento do licenciamento urbanístico". Entendemos na ocasião que o instrumento por nós desenvolvido se prestava bem como Quota Ambiental (QA). Assim, na qualidade de servidor efetivo da Secretaria Municipal do Verde e do Meio Ambiente (SVMA) da PMSP, apresentamos nossa proposta, que foi aceita como base para o desenvolvimento da Quota Ambiental. Formou-se, em decorrência, um grupo ad hoc que trabalhou duramente para aperfeiçoar o instrumento proposto, adequá-lo aos princípios exarados no Plano Diretor Estratégico, recentemente sancionado, harmonizá-lo com a legislação vigente e viabilizá-lo politicamente por meio da consideração das diretrizes políticas da superior administração, dos interesses dos diferentes stakeholders e do rito da Câmara Municipal. A Quota Ambiental, tal como acima desenvolvida, foi 
incorporada na minuta de projeto de lei (PL) de zoneamento e enviada à Câmara Municipal, onde se encontra presentemente tramitando ${ }^{3}$.

$* * *$

O conteúdo da presente tese é inerente à utilização de teorias de diferentes domínios, o que demanda um tratamento preferivelmente interdisciplinar, ou pelo menos multidisciplinar. Disso decorre um grande desafio em termos de pesquisa e de redação da tese. Em termos de pesquisa, porque o olhar do pesquisador não é o de uma águia, que mira um alvo longínquo, na borda do saber, em seu estado-da-arte, porém com escopo reduzido, e se lança com rapidez para ele, mas um olhar de boi, que observa, parado, ruminante, por todos os lados. Em termos de redação da tese, porque, por seu caráter multi- ou interdisciplinar, seus leitores terão diferentes formações, não podendo certos conhecimentos serem presumidos. Esses desafios demandam soluções que necessariamente destoam dos cânones da pesquisa e da redação científicas, impondo-se a necessidade de soluções de compromisso para dar conta minimamente desses desafios. Uma dessas soluções aqui adotadas foi a utilização de anexos, nos quais partes mais formais das teorias são apresentadas. $\mathrm{O}$ texto foi escrito para poder ser lido sem necessidade de recorrer aos anexos; estes, também, foram redigidos de forma a guardar certa autonomia. Disso decorre que pode eventualmente haver superposição de conteúdos entre o texto principal e os anexos.

Houve também reflexos no tamanho do texto, que sofre o conflito entre a clareza e a concisão em um contexto multidisciplinar. Procuramos fazer com que o texto principal não avançasse muito além de desejáveis 200 páginas, no quê tivemos sucesso relativo. Os anexos e revisões espicharam o texto para bem longe desse referencial.

Entre o falar tudo de nada e o nada de tudo, escolhemos o caminho apresentado a seguir, que pretende ser o do meio. Soluções de compromisso podem agradar a todos ou não agradar a ninguém; esse é o risco inerente a tais situações.

\footnotetext{
${ }^{3}$ No momento em que é feita a última revisão desta tese (29.2.2016), o PL encontra-se aprovado pela Câmara (em 26.2.2016), tendo-nos sido informado que a QA permaneceu no último substitutivo, aguardando-se agora a sanção do prefeito.
} 


\section{OBJETIVOS}

São os seguintes os objetivos a serem perseguidos no estudo:

1) A partir de uma adaptação do parâmetro BFF da cidade de Berlim, construir uma proposta teoricamente embasada de instrumento urbano-ambiental passível de ser inserido na legislação de parcelamento, uso e ocupação do solo.

2) Fazer narrativa do processo de construção em âmbito oficial da Quota Ambiental, no qual foi usada como referencial teórico a proposta acima. O horizonte de tempo descrito pela narrativa vai do início das discussões até a apresentação do substitutivo ao projeto de lei à Câmara Municipal, em dezembro de 2015. 


\section{MÉTODO}

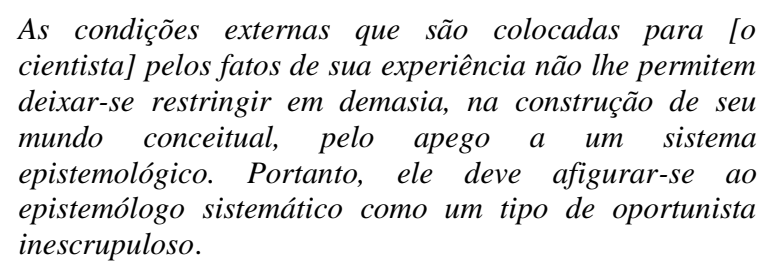

Einstein (1951) apud Feyerabend (2011.p. 33)

\subsection{PRIMEIRO OBJETIVO}

O primeiro objetivo, qual seja, a construção de proposta e embasamento teórico de um instrumento urbano-ambiental passível de ser inserido na legislação de parcelamento, uso e ocupação do solo tem como sua metodologia uma pesquisa exploratória e um desenvolvimento teórico. Evidentemente esse desenvolvimento teórico tem que se ater à viabilidade técnica, política e econômica do futuro instrumento.

\subsection{SEGUNDO OBJETIVO}

O estudo relativo ao segundo objetivo aqui apresentado, algo sui generis, a saber, uma narrativa acadêmica do processo de desenvolvimento em âmbito oficial de um particular instrumento urbano-ambiental, a saber, a Quota Ambiental na Prefeitura do Município de São Paulo, na qual o pesquisador prepara o fundamento teórico a ser seguido no trabalho e participa do desenvolvimento do instrumento, não como pesquisador, mas como profissional atuante, demanda um método que estaria a meio caminho entre o estudo de caso e a observação participativa.

Segundo YIN (2001), o estudo de caso corresponde à estratégia escolhida ao se examinarem assuntos coevos nos quais os comportamentos não podem ser 
manipulados. Além disso, o estudo de caso pressupõe olhar o fenômeno a partir de teorias preexistentes.

A observação participativa, por outro lado, implica atuação no fenômeno examinando.

Propomos aqui um método intermediário entre o estudo de caso e a observação participativa, método esse que vai tentar buscar alguns elementos na fenomenologia.

O conceito da fenomenologia de Husserl é assim explicado por Chauí:

A unidade entre o ato de conhecer e o objeto que é conhecido encontra na fenomenologia, na ciência do fenômeno, isto é, da consciência enquanto manifestação de si mesma e das significações objetivas, a possibilidade de instauração da "filosofia como uma ciência rigorosa". Assim, a descrição do vivido, dos atos intencionais da consciência e das essências que eles visam, isto é, dos correlatos intencionais - enfim, a disciplina que poderá fundamentar a lógica -, é a fenomenologia. Esta não considera, de maneira inseparável, o fato e o objeto que ele visa, mas estabelece sua união mediante a estrutura básica da consciência, a intencionalidade, que revela a impossibilidade de um ato da consciência não ter um objeto, não visar um objeto. Isto não significa, contudo, que a consciência vise seus objetos de uma mesma maneira, nem também que esses objetos se apresentem para a consciência de um mesmo modo. É nesse ponto que a fenomenologia se destaca: cabe a ela distinguir, revelar o que há de essencial na percepção, na recordação, na imaginação. (...) As coisas, segundo Husserl, caracterizam-se pelo seu perspectivismo, pelo seu inacabamento, pela possibilidade de sempre serem visadas por noesis novas que as enriquecem e as modificam. As idéias ou conceitos, ao contrário, caracterizam-se por seu aspecto globalizante, total e acabado. (...) Basicamente, entre a percepção e a ideação encontra-se a diferença entre a transcendência da coisa, que a torna inesgotável, e a imanência da idéia, que a torna completamente definida pela e para a consciência. CHAUÍ (1992, p.X, XII e XIII).

DELBOS $(1911)^{4}$ apud LALANDE (1966, p.372) informa parecer necessário distinguir na fenomenologia um método e um sistema. Como método, consiste em um esforço para apreender, através dos acontecimentos e dos fatos empíricos, "essências", ou seja, significações ideais. Estas são apreendidas diretamente pela intuição (Wesenschau, significando visão ou contemplação das essências) nos casos de exemplos singulares, estudados em pormenor e de maneira muito concreta. Como sistema, toma mais especialmente o nome de "fenomenologia pura" ou de "fenomenologia transcendental". Trata-se de pôr em evidência o princípio último de toda realidade. Uma vez que se coloca sob o ponto de vista da significação, esse princípio será aquele mediante o qual tudo adquire sentido: o "ego transcendental",

\footnotetext{
${ }^{4}$ DELBOS, V. Husserl, sa critique du psychologisme et sa conception d'une logique pure. Revue de Métaphysique et de Morale, p.697, sept. 1911.
} 
exterior ao mundo, mas voltado em direção a ele. Esse sujeito puro não é único, pois pertence à significação do mundo oferecer-se a uma pluralidade de sujeitos. A objetividade do mundo aparece assim como uma "intersubjetividade transcendental".

VARGAS (1985, p.45-6) apresenta o método fenomenológico a ser aplicado às pesquisas científicas. Para ele, o método fenomenológico se baseia na crença de que é possível ao pesquisador intuir a essência da coisa pesquisada quando o fenômeno é examinado atentamente sob vários pontos de vista. O pesquisador deverá fazer uma descrição atenta e detalhada do fenômeno sob diferentes aspectos, do que saltaria a sua essência por uma espécie de intuição do pesquisador. Para tal, seria necessário um procedimento chamado "redução fenomenológica", que se faz em três etapas: a) redução de todo o subjetivo; b) redução de tudo que é teórico a respeito do fenômeno, inclusive toda e qualquer forma de saber prévio sobre o fenômeno; c) redução de tudo que a tradição diz a respeito do fenômeno. Dessa forma, o objeto fundamental da fenomenologia seria a essência, o eidos ${ }^{5}$ das coisas. Porém, só se busca o fenômeno, e não a coisa em si.

Flusser informa ter aplicado o método fenomenológico em sua obra Fenomenologia do brasileiro (FLUSSER, 1998), que trata de um olhar estrangeiro sobre o Brasil. Diz ele que o método consiste em retroceder para imaginar, depois compreender e, finalmente, agir decididamente; tudo depende da distância do afastamento e do ponto de vista; toda tentativa de visão é individual, e a visão que se oferece caracteriza tanto o que vê como a situação vista. Isso não significa que toda tentativa é necessariamente subjetiva e, portanto, nada comunicaria, mas pelo contrário: da soma das situações disponíveis pode-se fazer um mapa que se aproxima assintoticamente da "verdade objetiva". O método consiste em: movido por angústia existencial, distanciar-se da situação, assumir um ponto de vista específico, projetar daí uma imagem da situação com a esperança de que, com outras imagens, se possa

\footnotetext{
5 “Ềdos e Idéa: na linguagem comum dos gregos, significa o aspecto exterior e visível de uma coisa: a forma de um corpo, a fisionomia de uma pessoa. A seguir, na linguagem filosófica (com Platão), passa a significar a forma imaterial de uma coisa, a forma conhecida apenas pelo intelecto e pelo espírito, a idéia ou a essência puramente inteligível de coisa. Significa também a forma própria de uma coisa que a distingue de todas as outras, seus caracteres próprios; por exemplo, a doença é um ềdos, uma forma que o médico reconhece. (...) Eîdos, a forma inteligível, idéa, o conceito, ideîn, ver, e ồda/ eidénai, saber (por ter visto), conhecer, criam a tradição filosófica do conhecimento como visão intelectual ou visão espiritual, e da verdade como visão plena ou evidência." (CHAUÍ, 2002, p.499).
} 
ajudar na orientação da situação e servir como trampolim para sua modificação. Todo preconceito e todo valor devem ser abandonados, devem ser feitos “despreconceituadamente", ou seja, livre de ideologias e de teorias prévias. Não se pretende análise sociológica, econômica, etnológica, etc., mas, pelo contrário, todo possível conhecimento que porventura existir no autor quanto aos métodos e resultados destas disciplinas é posto entre parênteses, a fim de não perturbar o fenômeno mesmo.

O método que aqui propomos e tentaremos aplicar consiste em uma adaptação da metodologia de Flusser acima exposta. Os componentes de nosso tentativo método implicam:

a) estabelecer claramente um ponto de vista: a peculiaridade do objeto da tese implica um ponto de vista privilegiado, no qual um pesquisador tem seu trabalho acadêmico aceito como base para o desenvolvimento de um instrumento urbanísticoambiental em uma situação real, participando ativamente no desenvolvimento desse instrumento visando sua inserção em uma lei municipal;

b) "narrar" esses eventos na forma de um "observador ingênuo". Observador ingênuo porque ele não tentará usar nenhum de seus parcos e vagos conhecimentos em ciências sociais para descrever a dinâmica das inter-relações que ocorrem nos eventos. Obviamente não existe observador que não faça uso de um conhecimento prévio do mundo, de uma ideologia, de uma filosofia, de um conhecimento científico, por mais simples que seja. Aqui, por observador ingênuo entende-se aquele que permite que suas visões prévias sobre o assunto - sempre inadequadas, relativas, arbitrárias, apriorísticas, ideologizadas - estejam abertas o suficiente para dialogar com os elementos que forem aparecendo nos processos - fenômenos observados;

c) dialogar e aprender com a realidade por meio de analogias e contrastes: nossa mente, que opera com frequência de modo binário, aprende muito com analogias e contrastes. O conhecimento só pode ser repassado porque a tinta escura colocada sobre um papel claro cria o contraste que permite a leitura. A analogia corrobora alguns de nossos pressupostos, permitindo algumas proto-generalizações; o mundo humano, o da ação, aquele que foge ao labor e ao trabalho (conforme terminologia de ARENDT, 2005, 1958), é por natureza imprevisível e apenas descritível a posteriori; 
não há situações iguais; porém, algumas generalizações se impõem ou são possíveis, sem as quais não poderia haver convivência em um corpo político.

Concluindo: o estudo de caso e a observação participativa não se prestam em suas formas idealizadas para a presente pesquisa. O estudo de caso, que pode ser exploratório, descritivo ou explanatório, pressupõe a utilização de teorias preexistentes para avaliar, descrever e explicar o fenômeno observado. Tal método não se mostra adequado para a presente pesquisa porque se tomou como norte não avaliar os fenômenos à luz de teorias preexistentes e porque esse método por definição constitui-se em observação sem manipulação dos acontecimentos, o que não é o caso aqui. Porém, o método tentativo aqui sugerido tem muito de descritivo, algo de exploratório e definitivamente nada de explanatório. A observação participativa não pode ser utilizada porque nós participamos do evento não na forma de observador participante pesquisador, mas como servidor da Prefeitura do Município de São Paulo. Daí a necessidade de tentar um método que se constitua em uma mescla dos dois, com algumas eventuais contribuições da fenomenologia.

Ainda com relação à analogia e ao contraste, devemos lembrar que eles não correspondem necessariamente a conceitos e métodos científicos considerados clássicos, tais como:

a) indução a partir de dados "puros" provenientes da observação (empirismo ingênuo);

b) formulação de hipóteses a serem submetidas a "testes de hipóteses" estatísticos (o que chamaríamos de “empirismo estatístico");

c) dedução de uma determinada consequência de teorias pré-estabelecidas e confronto dessa consequência com o observado em teste, de maneira a ratificar a teoria pré-existente ou declará-la nula (o que chamaríamos de "empirismo lógico", que corresponde, obviamente, ao procedimento de verificação de falseabilidade no âmbito do racionalismo crítico de POPPER, 1993, 1934).

Por outro lado, contraste e analogia têm uma vaga afinidade conceitual com o contraindutivismo de FEYERABEND (2011, p.43-7).

Como engenheiro, agrada-nos que analogia e contraste explicitamente não estejam em busca da verdade. Das ciências e demais narrativas interessa-nos 
sobretudo a descrição com vistas à previsão. Não estamos interessados em "critérios de verdade", mas em "força preditiva". "Verdade" é um conceito metacientífico, metafísico. Não pode ser objeto de busca, nem mesmo assintoticamente. Que há separação inconciliável entre metafísica e ciência já fora objeto de argumentação por KANT $(1974,1781)$. Assim, a resposta existencial a este autor poderia ser esta:

Somente nos espíritos mais ativos, que nunca agüentaram permanecer na dúvida, apareceria, no lugar dela, aquele abalo e desespero de toda verdade, que foi vivido, por exemplo, por Heinrich von Kleist, como efeito da filosofia kantiana. "Há pouco", escreve ele, certa vez, a seu modo cativante, "travei conhecimento com a filosofia kantiana, e agora tenho de comunicar-te um pensamento tirado dela, pois não posso temer que ele te abalará tão profunda, tão dolorosamente quanto a mim. - Não podemos decidir se aquilo que denominamos verdade é verdadeiramente verdade ou se apenas nos parece assim. Se é este último, então a verdade que juntamos aqui não é mais nada depois da morte e todo esforço para adquirir um bem que nos siga até mesmo no túmulo é vão. - Se a ponta desse pensamento não atinge teu coração, não sorrias de um outro que se sente profundamente ferido por ele, em seu íntimo mais sagrado. Meu único, meu supremo alvo foi a pique, e não tenho mais nenhum". (NIETZSCHE, 1999, 1874, p. 289-90). 
TOMO II:

PROPOSTA E EMBASAMENTO TEÓRICO DE

PARÂMETRO URBANO-AMBIENTAL UTILIZADO

COMO BASE DE DISCUSSÃO NO

DESENVOLVIMENTO DA QUOTA AMBIENTAL 


\title{
4 O BIOTOPFLÄCHENFAKTOR (BFF) DE BERLIM
}

\author{
A QA foi inicialmente concebida como uma adaptação - uma "tropicalização" \\ - do instrumento urbanístico-ambiental existente em Berlim denominado \\ Biotopflächenfaktor (BFF), ou Fator de Superfície de Biótopo (na bibliografia é \\ nomeado também como BAF, Biotope Area Factor). Assim sendo, é interessante dar \\ uma breve notícia desse instrumento.
}

\subsection{CONTEXTO DE APARECIMENTO DO BFF}

O BFF (Biotopflächenfaktor, Fator de Superfície de Biótopo) constitui-se em uma razão entre a área da superfície ecologicamente eficiente de um lote e a área desse lote. A tipologia ecologicamente eficiente convencionada é área com vegetação não densa em contato com o solo sem estruturas (garagens, máquinas, lajes, porões, etc.) sob esse solo. A essa superfície convencionada é atribuído um fator 1,0. No caso de haver superfícies que não correspondam às propriedades da superfície convencionada, mas que atendam, pelo menos em parte, aos objetivos ambientais colimados previamente, elas também são consideradas, mas com fator menor do que a unidade, constituindo-se, portanto, o BFF como a média aritmética ponderada das diferentes superfícies de interesse do lote por meio dos fatores acima descritos.

Um aspecto positivo de monta do BFF consiste no fato de que tipologias com grau de eficiência ecológica menor do que a convencionada podem ser consideradas no numerador da razão desde que sua área seja multiplicada por um fator de ponderação menor do que a unidade. Isso confere uma flexibilidade aos projetos que tende a agradar os empreendedores e arquitetos.

Temos, portanto:

$$
\mathrm{BFF}=\left(\sum_{\mathrm{i}} \mathrm{a}_{\mathrm{i}} \cdot \mathrm{A}_{\mathrm{i}}\right) / \mathrm{A}_{\mathrm{t}}
$$

sendo $a_{i}$ e $A_{i}$, respectivamente, o fator de ponderação e a área de uma tipologia em particular que atenda os objetivos ambientais considerados; $A_{t} a$ área do lote. 
Para diferentes usos e locais é fixado um valor mínimo do BFF a ser observado pelo empreendedor.

Cumpre agora definir biótopo, para o quê nos socorreremos de NEHRING e ALBRECHT (2000) e OLENIN e DUCROTOY (2006). Há uma grande ambiguidade em diversos conceitos da biologia. O sentido dos termos muda com o tempo ou eles têm significados distintos em diferentes domínios do conhecimento ou, finalmente, são empregados com significados distintos em diferentes países. É o que ocorre com “biótopo". Em 1877, Möbius foi comissionado por administradores de pesca para examinar um banco de ostras que produzia menos que o esperado. Ele nomeou o banco de ostras como uma "biocenose" ou "comunidade social", que corresponde a um complexo nos quais animais e plantas vivem conjuntamente em uma comunidade biológica interdependente. Essa foi a fundação da ecologia. Duas décadas depois, Dahl cunhou um novo termo, "biótopo", definido como um complexo de fatores que determinam as condições físicas da existência de uma biocenose. Posteriormente, Tansley produziu a primeira definição de ecossistema. Finalmente, após avanços teóricos, sugeriu-se que o ecossistema era constituído do biótopo (o ambiente abiótico) e da biocenose (as comunidades bióticas). Definiu-se, assim, a equação: biótopo + biocenose = ecossistema. No domínio linguístico anglo-saxão, "hábitat"6 é frequentemente usado como sinônimo de "biótopo", enquanto no domínio germanístico "hábitat" corresponde a "pequeno biótopo". Essa noção "biótopo + biocenose = ecossistema" foi aceita na literatura ecológica da Alemanha, França, Rússia e de outras nações europeias “continentais". Nos anos 1990, o Comitê Conjunto de Conservação da Natureza do Reino Unido, trabalhando em uma classificação do ambiente costeiro marinho, "redescobriu" o termo "biótopo", produzindo uma nova definição: biótopo $=$ hábitat + comunidade. Assim, a nova definição de biótopo associa a ele o ambiente físico (hábitat) e seu conjunto de espécies. O hábitat foi definido de acordo com a localização geográfica, com os

\footnotetext{
${ }^{6}$ Segundo HOUAISS e VILLAR (2001), habitat corresponde a uma substantivação da terceira pessoa do singular do presente do indicativo do verbo habitare. Eles não registram a forma hábitat. Mantemo-la pelo uso consagrado (embora preferíssemos habitat) e porque não é feita nenhuma menção a ela, assim como também não a superávit e déficit, no Acordo Ortográfico de Língua Portuguesa, promulgado pelo decreto $\mathrm{n}^{\circ} 6.583$, de 29 de setembro de 2008 (BRASIL, 2014b). O Vocabulário Ortográfico da Língua Portuguesa registra habitat, mas esse documento não é legalmente vinculante, nem sequer mencionado no referido acordo.
} 
recursos fisiográficos e com o ambiente físico e químico, enquanto a comunidade foi descrita como um grupo de organismos ocorrentes em um ambiente em particular, presumivelmente interagindo um com o outro e com o ambiente, sendo identificável por meios de pesquisa ecológica. Assim, a comunidade foi interpretada como o elemento biótico de um biótopo. No entanto, o biótopo assim definido não deve ser confundido com o ecossistema, que inclui tanto o ambiente físico como a comunidade.

Na presente tese, o biótopo será entendido no âmbito da equação "biótopo + biocenose = ecossistema".

\subsubsection{Hierarquia de Planejamento na República Federal da Alemanha}

Para a adequada consideração do histórico do BFF em Berlim é necessária uma rápida notícia da hierarquia de planejamento do espaço na Alemanha. Para tanto, utilizaremos, sem perda de generalidade, o exemplo da cidade de Stuttgart, cuja apresentação (STUTTGART [STADT], 2006) é particularmente didática. A hierarquia do planejamento urbano da cidade de Stuttgart é apresentada no quadro 1.

Nos termos do Código Federal de Construções (Baugesetzbuch - BaGB), o Plano Preparatório de Uso e Ocupação do Solo (Flächennutzungsplan - FNP) e o Plano Local de Construções (Bebaungsplan - B-Plan) constituem um complexo denominado Planejamento Diretor de Construções (Bauleitplanung) (DEUTSCHLAND, 2013). O FNP pode ser assistido por um Plano da Paisagem (Landschaftsplan), enquanto o B-Plan pode sê-lo por um Plano de Ordenamento da Paisagem (Grünordnungsplan - GOP). O FNP é legalmente vinculante apenas para os órgãos públicos, enquanto o B-Plan é vinculante também para os particulares. Mal comparando, o FNP aproxima-se do Plano Diretor de nosso meio, ainda que o faça em nível um pouco mais detalhado. Já o B-Plan aproxima-se da Lei de Zoneamento de nosso meio, embora seus ordenamentos se deem em uma área bastante limitada do espaço urbano e em nível de detalhe muito maior. 
Quadro 1 - Hierarquia de planejamento urbano na cidade de Stuttgart.

Plano de Desenvolvimento Estadual
(Landesentwicklungsplan)
Objetivo: estabelecer metas de desenvolvimento espacial do estado;
Território objeto: todo o estado;
Escala: predominantemente 1:900.000;
Intervalo: 10 anos;
Participação pública: indireta.
Plano Regional
(Regionalplan)
Objetivo: adaptar e contextualizar o Plano de Desenvolvimento Estadual; constituir-se em
ponte entre planejamento estadual e local;
Território objeto: cidade sem condado e condados adjacentes;
Escala: $1: 50.000 ;$
Intervalo: $10-15$ anos;
Participação pública: dois estágios:

\section{Programa Setorial de \\ Paisagem \\ (Landschafts- \\ rahmenprogramm)}

\section{Plano Regional Setorial}

de Paisagem

(Landschafts-

rahmenplan)

a) participação informal de entidades públicas e privadas; b) participação pública formal.

\section{Plano de Desenvolvimento Urbano \\ (Stadtentwicklungsplan)}

Objetivo: tratar de processos de longo prazo relativos a análise, informação e coordenação de questões de planejamento municipal e compatibilizar aspectos de construção, econômicos, ecológicos e sociais da cidade; Território objeto: todo o território da cidade;

Escala: 1:2.500 - 1:2.000, principalmente em forma escrita;

Intervalo: 15 a 20 anos;

Participação pública: workshops e conselhos de bairro.

\section{Plano Preparatório de Uso e Ocupação do Solo}

(Flächennutzungsplan FNP)

Objetivo: preparar e guiar o os aspectos construtivos e de uso e ocupação do solo dos

lotes nos termos do Código Federal de Construções;

Território objeto: todo o território da cidade;

Escala: 1:10.000;

Intervalo: $10-15$ anos;

Participação pública: dois estágios: a) participação pública inicial; b) apresentação pública da minuta.

\section{Plano Setorial de Construções Urbanas}

(Städtbaulicher Rahmenplan)

Objetivo: nível não formal de planejamento entre o FNP e o B-Plan;

Território objeto: distritos;

Escala: 1:500 - 1:1000;

Intervalo: de pequeno a longo prazo;

Participação pública: discussão com interessados e os conselhos consultivos distritais.

\section{Plano Local de Construções}

(Bebaungsplan B-Plan)

Objetivo: concretizar o FNP de forma legalmente vinculante;

Território objeto: dependente das exigências de planejamento;

Plano Paisagístico

(Landschaftsplan)

\section{Escala: 1:500 - 1:1000;}

Intervalo: ilimitado;

Participação pública: dois estágios: a) participação pública inicial; b) apresentação pública da minuta em processo participativo e consideração de sugestões.

\begin{tabular}{|c|}
$\begin{array}{c}\text { Plano de Configuração } \\
\text { (Gestaltungsplan) }\end{array}$ \\
\hline $\begin{array}{c}\text { Normas Adicionais } \\
\text { (Sonstige Satzungen) }\end{array}$ \\
\hline Pedido de Alvará de Construção \\
(Baugesuch)
\end{tabular}

Fonte: STADT STUTTGART (2006), adaptado, formatado, traduzido e modificado

Plano de Ordenamento do Verde (Grünordnungsplan GOP) 


\title{
4.1.2 Sistema Federativo da República Federal da Alemanha e a situação de
}

\author{
Berlim nesse sistema
}

A República Federal da Alemanha (Bundesrepublik Deutschland) é até certo ponto sucessora de diversas entidades político-territoriais caracterizadas, devido a condicionantes históricos de diversas ordens, por federações com maior ou menor grau de frouxidão. Ele remonta, como pode ser observado em qualquer manual de história, aos domínios de Otto I, que recebeu do papa João XII o título de Imperador Romano (em 1157, ao título foi adicionado o adjetivo "Sacro" e, em 1512, "Germânico", tornando-se o titular, portanto, soberano do Sacro Império Romano Germânico - Sacrum Imperium Romanum Nationis Germanica - Heiliges Römisches Reich ${ }^{7}$ Deutscher Nation). Em 1816, Napoleão induziu 16 estados do império a formar a Confederação do Reno (Rheinbund), na realidade um protetorado francês. Ainda em 1806, o império foi dissolvido. Em 1815, foi estabelecido pelo Congresso de Viena a Confederação Germânica (Deutscher Bund). Em 1866, a Prússia, após vitória sobre a Áustria, fundou a Confederação Germânica do Norte (Norddeutscher Bund). Em 1871, após a vitória da Prússia sobre a França e aliados, foi formado o Império Alemão (Deutsches Reich), uma confederação de 26 entidades, a maior parte das quais monarquias, o que se constituiu na culminação do chamado processo de unificação alemã, sob a égide da Prússia com exclusão da

\footnotetext{
${ }^{7}$ Reich é palavra sem correspondente no português. Etimologicamente provém do alto alemão arcaico ri(h)i. Como adjetivo, significa: a) rico, abastado; b) substancioso, proveitoso; 3 ) de grande quantidade. Como substantivo (das Reich), significa: 1) um grande país, um grande estado; 2) em sentido próprio, o Reich alemão (BROCKHAUS, 1984, p.552, tradução livre nossa). Não pode ser traduzido como império, a não ser em sentido figurado, por não estar necessariamente ligado ao conceito de monarquia. Mas Keiserreich seguramente o pode. Com certeza tem afinidade etimológica com o inglês rich, supostamente evidenciando uma incapacidade de os antigos povos germânicos diferenciarem o público do privado. Evidentemente isso é simplista. Da feudalidade latina, que apresenta fusão de elementos romanos e germanos, pode ser dito: "Durante toda a era feudal, é muito raro que se fale da propriedade, seja de uma terra, seja de um poder de comando. (...) A palavra propriedade, aplicada a um imóvel, seria um tanto vazia de sentido. (...) Sobre quase toda terra, e sobre muitos homens, pesava, nesses tempos, uma multiplicidade de direitos, diversos por sua natureza, sendo, porém, que cada um, dentro de sua esfera, parecia igualmente respeitável. Nenhum apresentava essa rígida exclusividade, característica da propriedade, do tipo romano." (BLOCH, 1982, 1939, p.173-4).
} 
Áustria (Kleindeutsche Lösung). Em 1918, como condição para aceitação do armistício, o Deutsches Reich converteu-se em uma república federada, conhecida como república de Weimar. De 1933 a 1945, a Alemanha, com o mesmo nome, existiu como a odiosa ditadura nazista (a rigor, entre 1943 a 1945 seu nome oficial foi Großdeutsches Reich). De 1945 a 1949, a Alemanha, como entidade política, deixou de existir. Em 1949, nas zonas de ocupação americana, britânica e francesa foi instalada a República Federal da Alemanha (Bundesrepublik Deutschland), enquanto a zona de ocupação soviética converteu-se na República Democrática Alemã (Deutsche Demokratische Republik - DDR), que se tornou estado unitário. Em 1990, a DDR converteu-se em federação e teve seus estados incorporados à República Federal da Alemanha, o que se constituiu na chamada reunificação alemã.

A República Federal da Alemanha tem, portanto, condicionado pela história um caráter fortemente federativo (mais do que em qualquer outra nação europeia, com a possível exceção da Suíça), ainda que os estados atualmente existentes tenham sido originados de meras divisões administrativas impostas pelas forças de ocupação (estados-hífen). Seu sistema federativo é um tanto complexo, podendo-se, em uma primeira aproximação, falar em quatro níveis. O primeiro corresponde à união (Bund). O segundo são os estados federados (Länder ${ }^{8}$ ou Bundesländer). Há dois tipos de estados federados: estados territoriais (Flächenländer) e cidades-estado $\left(\right.$ Stadtstaaten $\left.^{9}\right)$. Os primeiros dividem-se em condados $\left(\right.$ Kreise $\left.^{10}\right)$, que correspondem ao terceiro nível, dividindo-se eles por sua vez em comunas (Gemeinde), correspondentes ao quarto nível. As comunas têm autonomia administrativa, mas não legislativa, ao contrário dos condados, que possuem também autonomia legislativa. Há comunas que não compõem condados, tendo status de cidade (Kreisfreiestädte),

8 Land, em tradução literal, significa país, embora comumente seja traduzido por estado, especialmente no contexto federativo. Há quem traduza como província, o que não nos agrada porque enfraquece o significado federativo, ainda que federações como a Argentina e o Canadá tenham nominalmente províncias como entes federados

9 Stadt é traduzido como cidade e Staat como estado.

10 Kreis, em tradução literal, significa círculo. Pela tradição anglo-saxã, traduz-se geralmente como condado. O termo mais próximo no Brasil seria comarca, que, no entanto, tem aqui atualmente significado judiciário. (Carlos Magno dividiu seu império em regiões administrativas, entregando as regiões internas a condes (Landgrafen) e as regiões de fronteira a marqueses (Markgrafen), daí a conveniência de traduzir como comarca). 
sendo usualmente as maiores cidades ${ }^{11}$.

Berlim é uma cidade-estado dividida em regiões administrativas (Bezirke). Tais regiões gozam de certa autonomia, sem, porém, possuírem personalidade jurídica $^{12}$. Na falta de palavra melhor, denominaremos aqui tais regiões administrativas como distritos, embora em Portugal o termo "distrito" corresponda a uma unidade administrativa que congrega diversos municípios (concelhos).

Após a incorporação da República Democrática Alemã à República Federal da Alemanha, cogitou-se da incorporação de Berlim ao estado de Brandeburgo, mas, por extrema exaustão com os traumas das mudanças institucionais imediatamente anteriores, desistiu-se da ideia.

\subsubsection{Influência da Guerra Fria na Conformação das Questões Urbanas de}

Berlim

A cidade de Berlim foi em quase sua maior parte destruída na Segunda Guerra Mundial por força dos bombardeios aéreos aliados e da extremamente violenta batalha de Berlim, que culminou no fim da guerra na Europa. A divisão do território do que se denominava Deutsches Reich em suas fronteiras de 1939 em quatro regiões administrativas ${ }^{13}$, o status especial de Berlim nessa divisão, o bloqueio de 1948-1949, a reconstrução da cidade às pressas, a criação de duas novas entidades políticas nas regiões de ocupação, o erguimento do Muro e o estado de extrema tensão ideológica e militar da Guerra Fria, cujo centro de gravidade se dava

\footnotetext{
$11 \mathrm{Na}$ Alemanha já se entende por uma cidade grande aquela com algo em torno de 100.000 habitantes, uma situação, portanto, bastante distinta de nossa realidade.

12 Mal comparando com a situação do município de São Paulo, seria como se às Subprefeituras fosse concedida certa autonomia.

13 A rigor cinco, se contarmos os territórios anexados pela República Popular da Polônia (grosso modo, Prússia Oriental, Pomerânia Posterior e Silésia), hoje República da Polônia. Além disso, se considerarmos a situação de agosto de 1939, resultante das ofensivas do regime nazista, houve a anexação da região de Königsberg (hoje Kaliningrado) pela República Socialista Federativa Soviética Russa, hoje Federação Russa, a restauração da independência, em 1955, da República da Áustria (Republik Österreich), a devolução dos Sudetos à Tchecoslováquia (hoje na República Tcheca), e a entrega do Memel (hoje Condado de Klaipèda e municípios anexos) à República Socialista Soviética da Lituânia, hoje República da Lituânia.
} 
justamente em Berlim, condicionaram nessa cidade uma situação bastante peculiar do ponto de vista urbanístico, com a qual os seus planejadores e administradores tiveram que se haver. Destacamos duas entre as inúmeras consequências desse estado de coisas durante a Guerra Fria: a) a alta densidade e a promiscuidade de usos; b) a extrema necessidade de proteção, do ponto de vista qualitativo e quantitativo, do aquífero subterrâneo destinado ao abastecimento urbano.

\subsubsection{Histórico do BFF}

Uma descrição dos eventos que levaram à criação do BFF tal como hoje existente é feita por POBLOTH (2008). O BFF foi desenvolvido a partir da constatação da necessidade de simplificar, flexibilizar e unificar parâmetros dos Planos de Paisagem em regiões de urbanização consolidada, bem como de compatibilizar suas normas com as de outros textos normativos urbanísticos e facilitar a obtenção de consenso. Em suma, facilitar a viabilização técnica, jurídica e política dos Planos de Paisagem.

O Governo Distrital de Kreuzberg (Bezirksamt Kreuzberg) utilizou o Plano de Paisagem de Tempelhofer Vorstadt como um modelo a partir do qual o conceito de BFF e seus parâmetros foram sendo gradualmente desenvolvidos e testados, de maneira a servir, por sua vez, como modelo para outros Planos de Paisagem. Importante também para o desenvolvimento do BFF foi a preparação do Plano de Paisagem de Stephankiez pelo Governo Distrital de Tiergarten, subsidiado por consultorias contratadas pela Administração Senatorial de Desenvolvimento Urbano e Proteção Ambiental do Estado de Berlim (Senatsverwaltung für Stadtentwicklung und Umweltschutz Berlin). Tais consultorias definiram em grande parte a estrutura normativa do BFF.

O arcabouço legal do BFF encontra-se na Lei Federal de Proteção da Natureza (Bundesnaturschutzgesetz) (DEUTSCHLAND, 2009) e na Lei Berlinense de Proteção da Natureza (Berliner Naturschutzgesetz) (BERLIN, 2013).

A designação "fator de biótopo" foi objeto de discussão. O nome "Fator de 
Superfícies Eficazes do ponto de vista da Preservação do Patrimônio da Natureza" (Faktor für naturhaushalt-wirksame-Flächen) foi abandonado devido às dificuldades associadas aos conceitos envolvidos; por outro lado, os conceitos associados a "Fator de Superfície de Biótopos" alcançaram um alto grau de reconhecimento junto à comunidade de especialistas (LANDSCHAFT... et al., 1990).

Apesar do sucesso alcançado, Giseke lembra que "o BFF foi um filho dos encerrados anos 80, quando a ideia de trabalhar com tais valores padronizados era difundida em toda a Alemanha Ocidental e havia outras abordagens paralelas" (GISEKE, 2004, apud POBLOTH, 2008, p.186). Tais abordagens paralelas, como o Número de Volume Verde (Grünvolumzahl) e o Número de Função do Solo (Bodenfunktionszahl), desenvolvidas em Hamburgo, encontraram grandes dificuldades na sua operacionalização (GISEKE, 2004, apud POBLOTH, 2008).

\subsubsection{BFF em Malmö e Seattle}

Malmö desenvolveu no final dos anos 90 um Fator Espacial Verde (GSF, em inglês) e um Sistema de Pontos Verdes (GPS) (KRUUSE, 2011, e SKÄRBÄCK, 2007), a serem aplicados em um novo bairro construído no âmbito de uma exposição internacional de construção sob o tema "A Cidade Sustentável de Amanhã". O GSF tem formulação análoga à do BFF, consistindo em uma média ponderada, devendo cada lote atingir o valor mínimo de 0,5. Além do GSF foram feitas exigências em termos do GPS, tendo sido fornecida uma lista de ações tendentes a favorecer a biodiversidade em cada condomínio, devendo o empreendedor escolher obrigatoriamente no mínimo dez delas.

A cidade de Seattle inspirou-se no BFF de forma a desenvolver em 2006 o Fator Verde de Seattle (Seattle Green Factor, SGF) (STENNING, 2008; HIRST, MORLEY e BANG, 2008). 


\subsection{ETAPAS DE CONSTRUÇÃO DE INSTRUMENTO ANÁLOGO AO BFF}

De maneira a melhor avaliar a estrutura do BFF e facilitar a sua adaptação a outras realidades, apresentamos as etapas genéricas a ser seguidas na construção de um instrumento análogo ao BFF.

\section{Primeira etapa: escolha do nome}

Segundo veremos adiante, uma das vantagens do BFF está no fato de ele se assemelhar a parâmetros urbanísticos com os quais projetistas, empreendedores e servidores públicos estão habituados, como a taxa de ocupação e o coeficiente de aproveitamento. Cumpre, pois, fornecer um nome ao instrumento análogo ao BFF que seja coerente com o vocabulário da matemática e que não cause estranheza ao público especializado.

Segundo FERREIRA (1999), fator corresponde a cada um dos elementos submetidos à operação de produto; coeficiente pode ser a parte numérica em um produto de fatores numéricos e literais ou o produto de alguns dos fatores escolhidos segundo uma convenção arbitrária no contexto de uma expressão constituída de vários fatores; taxa é a razão entre as variações de duas grandezas das quais a primeira é dependente da segunda; finalmente, razão constitui-se na relação entre grandezas de mesma espécie ou quociente de dois números.

De todos os termos apresentados, o BFF se aproxima mais de "razão". Seguramente não é um fator no sentido estrito da palavra. Porém, razão não é um termo usual em urbanismo, além de poder ocorrer que a forma final de um instrumento análogo ao BFF não assuma necessariamente a forma de uma razão. Sugerimos, então, em um primeiro momento, o uso do termo "indicador". Sendo o indicador uma pálida descrição da realidade, fica claro com a expressão acima que o instrumento análogo ao BFF se constitui tão somente em uma primeira aproximação da descrição do desempenho ambiental efetivo do lote, além de ficar implícito que a agregação dos diferentes elementos considerados no indicador se dê de forma 
arbitrária $^{14}$. Finalmente, tomando a forma de indicador, tal instrumento análogo ao BFF pode servir a outras finalidades além das constantes de normas e regulamentos, como, por exemplo, diversas formas de avaliação.

\section{Segunda etapa: escolha dos objetivos ambientais}

Há que definir agora quais interesses ambientais o instrumento vai proteger por meio da sua normatização. A esses interesses ambientais poderíamos dar o nome de bens a proteger, talvez má tradução do conceito oriundo do direito alemão Schutzgut; preferimos "objetivos ambientais". Com isso, garantiríamos a amplitude do conceito de meio ambiente a ser utilizado no instrumento, que poderia, caso adotássemos as expressões interesses ambientais ou bens a proteger, ficar demasiadamente ligado ao meio físico ou às necessidades estritamente humanas.

Para o BFF foram escolhidos cinco objetivos ambientais: melhoria do microclima, melhoria da higiene do ar (combate à poluição atmosférica), reforço do ciclo da água, reforço das funções do solo (filtração, tamponamento e transformação de substâncias nocivas) e melhoria da disponibilidade de hábitats (Lebensräume) para flora e fauna (LANDSCHAFT... et al., 1990).

\section{Terceira etapa: escolha dos indicadores referentes aos elementos dos objetivos ambientais}

É necessário agora escolher indicadores para cada um dos elementos dos objetivos ambientais. A escolha de indicadores constitui-se em um compromisso entre o rigor científico e a facilidade de uso e de entendimento, além da disponibilidade de dados. Uma discussão a respeito pode ser encontrada, por exemplo, em CAETANO (2013).

No caso do BFF, foram escolhidos os seguintes indicadores: a) para

$14 \mathrm{O}$ indicador que estamos construindo constitui-se em um indicador sintético, que a rigor deveria receber o nome de índice. Assim, o indicador acima referido é um índice que agrega diferentes indicadores segundo um critério arbitrário que reflete os valores de quem construiu o índice. Preferimos aqui não utilizar a palavra índice, que poderia dar margem a confusões desnecessárias. Um excelente apanhado de terminologias, definições, conceituações e classificações de indicadores de desenvolvimento sustentável é apresentado por GALLOPÍN (1997). 
microclima: evapotranspiração; b) para higiene do ar: capacidade de retenção de particulados; c) para ciclo da água: capacidade de infiltração e armazenamento de águas pluviais ${ }^{15}$; d) para funções do solo: baixo grau de impermeabilização, alta porcentagem de húmus e baixa alteração da estrutura natural do solo e de sua inclinação; e) para disponibilidade de hábitats para flora e fauna: solo não compactado aberto.

\section{Quarta etapa: escolha das tecnologias verdes superficiais disponíveis}

Preferimos a expressão "tecnologias verdes" a "cobertura do solo" porque a aplicação de diferentes coberturas verdes no solo deve se dar segundo normas, a experiência acumulada e a boa técnica, o que, a rigor, diferencia-se de uma mera cobertura do solo. Isso é particularmente evidente no caso de medidas de drenagem não convencionais na fonte.

Em Berlim foi utilizado o termo "biótopo", ainda que LANDSCHAFT... et al. (1990) designem as coberturas vegetais como "tipologias superficiais" (Flächentypen). SUKOPP e WEILER (1988), LÖFVENHAFT, BJÖRN e IHSE (2002) e MANSUROGLU, ORTACESME e KARAGUZEL (2006) apresentam e

15 A expressão utilizada por LANDSCHAFT... et al. (1990) foi Versickerungsfähigkeit und Speicherung von Niederschlagwasser, o que em uma tradução literal significa "capacidade de infiltração e armazenamento de águas pluviais". Quanto ao armazenamento da água no solo, em português temos o conceito de retenção específica (quantidade de água que fica no solo por adesão e capilaridade, após a drenagem natural; MARTINS, 1976), capacidade de armazenamento do solo (intensidade de redistribuição da água após cessada a infiltração e sua duração; SILVEIRA, LOUZADA e BELTRAME, 1993) e capacidade de campo (volume máximo de água que um solo bem drenado pode armazenar por longos períodos sem evapotranspiração, determinado pela quantidade de água que um perfil de terreno sem vegetação e evaporação retém contra a ação da gravidade, após plenamente inundado e deixado drenar livremente por uns poucos dias, em condições de campo; FABIAN e OTTONI FILHO, 2000). O alemão dispõe do termo Feldkapazität, que significa precisamente "capacidade de campo". Quanto à capacidade de infiltração, em português há uma nítida distinção entre capacidade de infiltração (quantidade máxima de água que um solo, sob uma dada condição, pode absorver na unidade de tempo por unidade de área horizontal; MARTINS, 1976, grifo nosso), e coeficiente de permeabilidade do solo (a constante da equação de Darcy, que rege o escoamento laminar em meios porosos de fluidos incompressíveis; mais rigorosamente, o tensor de coeficientes de permeabilidade; v FRANCISS, 1980). É possível visualizar uma relação entre infiltração e escoamento em meios porosos na demonstração da equação de Richards, que descreve a infiltração da água considerando o escoamento em meio poroso não saturado e uma função entre coeficiente de permeabilidade e umidade (v. CHOW, MAIDMENT e MAYS, 1988); porém, são conceitos distintos. Em alemão, o coeficiente de permeabilidade do solo tem uma expressão bem definida (Kf-Werte ou Durchlässigkeitsbeiwert), assim como a capacidade de infiltração (Versickerungsfähigkeit), embora às vezes, parece-nos, sejam utilizados como sinônimos. 
discutem casos de mapeamento de biótopos como subsídio para o planejamento urbano. SUKOPP e WEILER (1988) e QIU et al. (2010) discutem alguns aspectos metodológico sobre o assunto.

As tecnologias verdes consideradas no BFF estão apresentadas na primeira coluna da tabela 1 .

Tabela 1 - Avaliação de indicadores de bens a proteger de tecnologias superficiais verdes de lote realizada no processo de desenvolvimento do BFF.

\begin{tabular}{|c|c|c|c|c|c|c|}
\hline & Evaporação & $\begin{array}{c}\text { Infiltração e } \\
\text { armazena- } \\
\text { mento de água }\end{array}$ & $\begin{array}{l}\text { Funções do } \\
\text { solo }\end{array}$ & Hábitat & $\begin{array}{c}\text { Filtração de } \\
\text { poluentes } \\
\text { aéreos }\end{array}$ & $\begin{array}{l}\text { Ponderação } \\
\text { recomendada }\end{array}$ \\
\hline Superfícies impermeáveis & Nada - pouco & Nada & Nada & Nada & Nada & 0,0 \\
\hline $\begin{array}{l}\text { Superfícies impermeáveis, nas quais todas as águas } \\
\text { pluviais são infiltradas na propriedade }\end{array}$ & Nada & $\begin{array}{l}\text { Alto - muito } \\
\text { alto }\end{array}$ & Nada & Nada & Nada & 0,2 \\
\hline Superfícies não vegetadas e semipermeáveis & Pouco & Pouco & Pouco & $\begin{array}{l}\text { Nada - } \\
\text { pouco }\end{array}$ & Nada & 0,3 \\
\hline Pavimento semipermeável com vegetação & Moderado & Moderado & Moderado & Pouco & Pouco & 0,5 \\
\hline Fachadas verdes & $\begin{array}{l}\text { Moderado - } \\
\text { alto }\end{array}$ & Nada & Nada & $\begin{array}{l}\text { Moderado - } \\
\text { alto }\end{array}$ & $\begin{array}{l}\text { Moderado - } \\
\text { alto }\end{array}$ & 0,5 \\
\hline Terrenos vegetados com menos de $80 \mathrm{~cm}$ de solo & $\begin{array}{l}\text { Moderado - } \\
\text { alto }\end{array}$ & Nada & Pouco & Moderado & $\begin{array}{l}\text { Moderado - } \\
\text { alto }\end{array}$ & 0,5 \\
\hline Terrenos vegetados com mais de $80 \mathrm{~cm}$ de solo & Alto & Nada & Moderado & Moderado & Alto & 0,7 \\
\hline Coberturas verdes & $\begin{array}{l}\text { Moderado - } \\
\text { alto }\end{array}$ & Nada - pouco & Pouco & $\begin{array}{l}\text { Moderado - } \\
\text { alto }\end{array}$ & $\begin{array}{l}\text { Moderado - } \\
\text { alto }\end{array}$ & 0,7 \\
\hline Áreas vegetadas & $\begin{array}{l}\text { Alto - muito } \\
\text { alto }\end{array}$ & Moderado & $\begin{array}{l}\text { Alto - muito } \\
\text { alto }\end{array}$ & $\begin{array}{l}\text { Alto - } \\
\text { muito alto }\end{array}$ & Alto & 1,0 \\
\hline
\end{tabular}

Fonte: KEELEY (2011) adapt.

\section{Quinta etapa: escolha de indicadores de desempenho e avaliação das tecnológicas verdes}

A escolha dos indicadores dos elementos dos objetivos ambientais corresponde a um compromisso entre coerência teórica, facilidade de entendimento e disponibilidade. A avaliação de desempenho das tecnologias verdes à luz desses indicadores é eivada de incertezas. No caso do BFF essa avaliação foi feita de modo subjetivo através de uma escala ordinal de cinco valores (nenhum, pequeno, moderado, alto, muito alto), como podemos observar nas colunas 2 a 6 da tabela 1 . 
Sexta etapa: determinação da ponderação de cada tecnologia verde

A partir da avaliação de cada tecnologia verde devem ser estimados os fatores de ponderação associados a cada uma delas. Em Berlim tal foi feito a partir de mesas redondas interdisciplinares (KEELEY, 2011), resultando nos valores constantes da última coluna da tabela 1 .

\section{Oitava etapa: definição de critérios e padrões}

Para cada uso, dimensões do lote ou das edificações e localização no território do município, deve ser definida uma expressão do índice ${ }^{16}$ final e os seus valores-limite. Corresponde a atividade metatécnica. No caso do BFF, foram estabelecidos valoreslimite por uso e localização.

\footnotetext{
${ }^{16}$ De uma maneira geral, critérios e padrões são valores limites, ou limiares, que definem critérios de aceitabilidade de certa grandeza em determinado contexto. As diferenças entre critérios e padrões estão relacionadas a sua origem e finalidade. Os critérios decorrem de considerações científicas, técnicas ou de recomendações de especialistas com finalidades acadêmicas, técnicas, administrativas e/ ou educacionais. Os padrões são valores determinados por instrumento normativo oficial (lei, decreto, portaria, resolução, decisão de diretoria, provimento, etc.) com a finalidade de exercício do poder de polícia do estado, decorrente de seu poder eminente, ou a atividade interna dos órgãos públicos. (Discussões e definições de critérios e padrões podem ser também encontradas em PORTO, 1991). O fato de padrões muitas vezes se mostrarem menos rigorosos do que critérios pode ser justificado pelo jogo político, que arbitra interesses conflitantes, e por uma tomada de decisão frente à incerteza entre critérios de diferentes magnitudes. Coerentemente com essa distinção entre critérios e padrões, a prática alemã reconhece a diferença entre os seguintes conceitos (FÖRSTNER, 1995, p.110): Diskussionswerte ou Orientirungswerte (valores de discussão ou de orientação), sugeridos por especialistas para grêmios, comissões, uniões e órgãos públicos; Richtwerte (critérios), propostos por grêmios, comissões e uniões, dados a conhecer publicamente; Grenzwerte (padrões), estabelecidos administrativa e/ ou legislativamente e com observância compulsória.
} 


\title{
4.3 PROPOSTA DE CRIAÇÃO DE UM PARÂMETRO URBANÍSTICO-
}

\section{AMBIENTAL INSPIRADO EM ADAPTAÇÃO DO BFF À CIDADE DE}

\author{
SÃO PAULO
}

Nos próximos capítulos apresentaremos uma sugestão e sua respectiva fundamentação teórica de um parâmetro urbanístico-ambiental a ser inserido na legislação de parcelamento, uso e ocupação do solo do município de São Paulo. Tal parâmetro teve, pelo menos inicialmente, por norte para o seu desenvolvimento a estratégia de criação de um parâmetro análogo ao BFF de Berlim, embora, como se verá, o resultado acabou por diferir bastante. Posteriormente, tal parâmetro serviu como base de discussão na criação da QA.

Inicialmente devemos definir os requisitos por meio dos quais a proposta será elaborada e a partir dos quais ela deverá ser avaliada. No caso de um BFF paulistano, tendo em mente sua finalidade de servir de parâmetro a textos normativos no âmbito da legislação urbanístico-ambiental, destinada, por sua vez, a disciplinar as edificações em áreas urbanas, eventualmente não consolidadas, parece-nos bastante razoáveis adotar os três requisitos a seguir:

a) simplicidade na compreensão e no uso;

b) flexibilidade, de maneira a fornecer aos empreendedores diversas possibilidades para as inúmeras decisões envolvidas nos empreendimentos;

c) embasamento teórico do ponto de vista técnico-científico.

Podemos imediatamente visualizar contradições e $\operatorname{tradeoff} s^{17}$ : quanto maior a simplicidade, menor a flexibilidade e o embasamento teórico; quanto maior a

\footnotetext{
${ }^{17} \mathrm{Um}$ tradeoff corresponde ao vetor de magnitudes de consecução de diferentes objetivos tal que o aumento da magnitude de um objetivo só possa ocorrer com a diminuição da magnitude de pelo menos um outro objetivo. Em pesquisa operacional a superfície de tradeoff é chamada de conjunto não inferior (BRAGA, 1987, p.460-4). Em microeconomia é chamada de fronteira de possibilidades de produção ou curva de possibilidade de produção; tratando-se de análise multiobjetivo, a eficiência ocorre nos pontos correspondentes a essa fronteira. A fronteira de possibilidades de produção constitui-se em uma das condições para o chamado ótimo de Pareto. Em princípio, as soluções de engenharia devem situar-se em superfícies de tradeoff. Em tais superfícies, é impossível, a priori, determinar qual o ponto a ser escolhido (ou seja, não existe ponto ótimo), a não ser que condições adicionais relativas ao ponto ótimo sejam exogenamente fornecidas. Essas condições, porém, estão necessariamente relacionadas a questões de valor, sendo, portanto, metacientíficas e/ ou metatécnicas.
} 
flexibilidade, menor a simplicidade; quanto maior o embasamento teórico, menor a simplicidade e, eventualmente, menor a flexibilidade.

Uma maneira de conciliar o inconciliável consistiria na adoção, no texto legal, de parâmetros ou soluções default ${ }^{18}$. Assim, empreendedores e avaliadores teriam à disposição, na maior parte dos casos, soluções relativamente simples, fornecidas pela legislação. A definição de parâmetros ou soluções default, ainda que simples em sua apresentação, deve ter bom lastro teórico. A fim de conferir maior flexibilidade aos empreendedores, a legislação abriria possibilidades no sentido de conferir um leque maior de soluções possíveis, desde que o empreendedor comprove que elas contemplem coerência técnico-científica compatível com o embasamento teórico adotado, a ser justificada por meio de memoriais, planilhas e arrazoados teóricos elaborados dentro de parâmetros, tanto quanto possível, definidos legalmente, eventualmente em normas infralegais.

Cumpre agora definir os objetivos ambientais a serem considerados em um BFF paulistano. No estudo preferimos falar de "objetivos ambientais" ao invés de bens a proteger.

Confrontando as demandas ambientais do município com as possibilidades do instrumento proposto, definimos três objetivos ambientais a serem considerados no instrumento urbanístico-ambiental proposto:

a) promoção do controle de drenagem na fonte;

b) promoção da qualidade ecossistêmica;

c) melhoria do microclima.

É evidente que a adoção de tais objetivos ambientais não exclui outros, que podem ser contemplados indiretamente, como é o caso de atendimento a questões relacionadas à emissão de gases de efeito-estufa.

\footnotetext{
${ }^{18}$ Default, segundo HOUAISS e VILLAR (2001), significa literalmente padrão. Porém, sua etimologia está ligada ao latim fallo, que significa faltar, não cumprir. Assim, a palavra tem dois sentidos: padrão e não cumprimento. Podemos dizer que em engenharia, especialmente nos modelos hidrológicos, soluções ou parâmetros default correspondem à adoção, quando da utilização de modelos, de determinadas soluções ou parâmetros ligadas a critérios de engenharia, valores encontrados em outros casos ou soluções usualmente aceitas pela comunidade técnica.
} 


\section{PROMOÇÃO DE CONTROLE DE DRENAGEM NA FONTE}

É necessário definir alguns conceitos antes de tratar diretamente desse objetivo ambiental.

Segundo CAETANO (1999), as atividades relacionadas a gestão de inundações dividem-se em: a) atividades relacionadas a prevenção de inundações, entre as quais se destacam o planejamento, o projeto, a construção e a manutenção de estruturas hidráulicas destinadas a reduzir a probabilidade de ocorrência de inundações, bem como o controle do uso e da ocupação do solo e a criação e aplicação de legislação edilícia relacionada com inundações; b) atividades relacionadas a combate a inundações; c) atividades relacionadas a convivência com inundações.

CAETANO (1999), na esteira de LANNA (1997), que fornece conceituação análoga para um sistema de recursos hídricos, propõe um Sistema de Gestão de Inundações, composto dos seguintes elementos: a) Política de Inundações; b) Sistema de Gerenciamento de Inundações; c) Plano de Inundações.

O complexo de conceitos, atividades e obras relacionadas ao projeto, à construção e à manutenção de estruturas hidráulicas destinadas a reduzir a probabilidade de danos decorrentes de inundações denomina-se drenagem. A drenagem é elemento de saneamento e também urbanístico. Ela pode se dar em diferentes níveis (classificação de CAETANO, 2010, modificada e aumentada a partir de classificação apresentada por GENZ e TUCCI, 1995): a) por meio de reservatórios formados por grandes barramentos com finalidade de usos múltiplos, entre os quais se inclui o controle de cheias; b) controle de grandes bacias (macrodrenagem); c) controle de pequenas bacias (microdrenagem); d) controle na fonte (em nível de lote). A macrodrenagem pode se dar por meio dos seguintes tipos de estruturas hidráulicas: a) canalização; b) endicamento; c) reservação. A estratégia de canalização corresponde a aumentar a velocidade da água de forma a baixar a lâmina d'água. $\mathrm{O}$ endicamento corresponde à construção de diques, de forma a 
proteger áreas ao longo dos cursos d'água situadas em cotas mais baixas que o nível d'água quando de cheias, podendo tal solução envolver ou não bombeamento. A reservação corresponde a temporariamente reter a água de forma a diminuir o pico de vazão a jusante e aumentar o tempo de pico $\left(\operatorname{lag}^{19}\right)$. Ela pode se dar por meio de reservatórios ou da própria calha dos cursos d'água por ocasião da propagação de uma onda de cheia (routing).

É importante ressaltar que existe uma diferença entre as estratégias de canalização e reservação, o que vale inclusive para todos os níveis de drenagem. Essa diferença é detalhada por Canholi (2005) no quadro 2. A estratégia de canalização demanda aumentar a velocidade da água de maneira a diminuir a sua altura, piorando dessa forma as condições de drenagem a jusante; a estratégia de reservação procura o abatimento e o retardamento dos picos de vazão a jusante.

Os reservatórios podem ser do tipo in-line, quando eles se encontram na própria linha do curso d'água, ou off-line, quando a água é temporariamente afastada para os reservatórios. Os reservatórios podem ser de retenção ou de detenção. Nos reservatórios de retenção prevê-se um volume de água permanente, enquanto nos reservatórios de detenção a previsão é que ele fique vazio na ausência de chuvas (exceto com relação à vazão de base, nos reservatórios in-line). A função dos reservatórios pode não corresponder apenas à macrodrenagem, eventualmente envolvendo também recreação (se a qualidade da água ou o tipo de manutenção assim o permitirem), paisagismo, controle da poluição difusa e formação de mananciais urbanos (se possível). Tais funções foram sendo cumulativamente consideradas em diferentes fases ao longo do tempo, conforme se pode observar no quadro 3. Aparentemente nossa triste realidade em termos de saneamento não seria compatível mais do que o primeiro nível ${ }^{20}$.

\footnotetext{
${ }^{19}$ Define-se lag como o intervalo de tempo que vai do "centroide" do hietograma de precipitação efetiva até o pico do hidrograma. Pode ser chamado também de tempo de pico.

${ }^{20}$ No entanto, talvez possamos avançar com calma no sentido da consideração de alguns aspectos de qualidade quando da regulamentação de medidas de drenagem na fonte, que é parte do escopo desta tese. Talvez já estejamos maduros para incorporar aspectos relativos à qualidade nos termos, por exemplo, do conceito de Sustainable Drainage System (SuDS), descrito no item 12.7, e do conceito de Best Management Practices (BMP).
} 
Quadro 2 - Comparação dos conceitos de canalização e reservação.

\begin{tabular}{|c|c|c|}
\hline CARACTERÍSTICA & CANALIZAÇÃO & RESERVAÇÃO \\
\hline Função & Remoção rápida dos escoamentos & $\begin{array}{l}\text { Contenção temporária para } \\
\text { subsequente liberação }\end{array}$ \\
\hline Componentes principais & Canais abertos/galerias & $\begin{array}{l}\text { Reservatórios a superfície livre; } \\
\text { reservatórios subterrâneos; } \\
\text { retenção subsuperficial }\end{array}$ \\
\hline Aplicabilidade & $\begin{array}{l}\text { Instalação em áreas novas; } \\
\text { construção por fases; ampliação da } \\
\text { capacidade pode se tornar difícil } \\
\text { (centros urbanos) }\end{array}$ & $\begin{array}{l}\text { Áreas novas (em implantação); } \\
\text { construção por fases; áreas } \\
\text { existentes (à superfície ou } \\
\text { subterrâneas) }\end{array}$ \\
\hline $\begin{array}{l}\text { Impacto nos trechos de jusante } \\
\text { (quantidade) }\end{array}$ & $\begin{array}{l}\text { Aumenta significativamente os } \\
\text { picos das enchentes em relação à } \\
\text { condição anterior; maiores obras } \\
\text { nos sistemas de jusante }\end{array}$ & $\begin{array}{l}\text { Áreas novas: podem ser } \\
\text { dimensionadas para impacto zero } \\
\text { (legislação EUA); reabilitação dos } \\
\text { sistemas: podem tornar vazões a } \\
\text { jusante compatíveis com a } \\
\text { capacidade disponível }\end{array}$ \\
\hline $\begin{array}{l}\text { Impacto nos trechos de jusante } \\
\text { (qualidade) }\end{array}$ & $\begin{array}{l}\text { Transporta para o corpo receptor } \\
\text { toda a carga poluente afluente }\end{array}$ & $\begin{array}{l}\text { Facilita a remoção de material } \\
\text { flutuante por concentração em } \\
\text { áreas de recirculação dos } \\
\text { reservatórios e dos sólidos em } \\
\text { suspensão pelo processo natural de } \\
\text { decantação }\end{array}$ \\
\hline Manutenção/operação & $\begin{array}{l}\text { Manutenção em geral pouco } \\
\text { frequente (pode ocorrer excesso de } \\
\text { assoreamento e de lixo); } \\
\text { manutenção nas galerias é difícil } \\
\text { (condições de acesso) }\end{array}$ & $\begin{array}{l}\text { Necessária limpeza periódica; } \\
\text { necessária fiscalização; sistemas de } \\
\text { bombeamento requerem operação/ } \\
\text { manutenção; desinfecção eventual } \\
\text { (insetos) }\end{array}$ \\
\hline Estudos hidrológicos/hidráulicos & $\begin{array}{l}\text { Requer definição dos picos de } \\
\text { enchente }\end{array}$ & $\begin{array}{l}\text { Requer definição dos hidrogramas } \\
\text { (volumes das enchentes) }\end{array}$ \\
\hline
\end{tabular}

Fonte: CANHOLI (2005)

Quadro 3 - Evolução histórica dos objetivos associados às obras de detenção em centros urbanos.

\begin{tabular}{|l|l|l|l|}
\hline \multicolumn{1}{|c|}{ Fase 1 } & \multicolumn{1}{|c|}{ Fase 2 } & \multicolumn{1}{c|}{ Fase 3 } & \multicolumn{1}{c|}{ Fase 4 } \\
\hline Controle de enchentes & Controle de enchentes & Controle de enchentes & Controle de enchentes \\
\cline { 2 - 4 } & $\begin{array}{l}\text { Recreação; paisagismo; } \\
\text { outros }\end{array}$ & $\begin{array}{l}\text { Recreação; paisagismo; } \\
\text { outros }\end{array}$ & $\begin{array}{l}\text { Recreação; paisagismo; } \\
\text { outros }\end{array}$ \\
\cline { 2 - 4 } & $\begin{array}{l}\text { Controle da qualidade } \\
\text { da água }\end{array}$ & $\begin{array}{l}\text { Controle da qualidade } \\
\text { da água }\end{array}$ \\
\cline { 3 - 4 } & & $\begin{array}{l}\text { Mananciais urbanos } \\
\text { (water harvesting) }\end{array}$ \\
\hline
\end{tabular}

Fonte: WALESH e USEPA mod. apud CANHOLI (2005) mod.

A construção e operação de piscinões constituem-se não somente em prática antiga, como também em algo correntemente referido nos manuais de drenagem. Uma vez, entretanto, que até certo tempo atrás o paradigma técnico em macrodrenagem era a canalização, a reservação assumiu, quando da construção do 
reservatório do Pacaembu, foros de novidade. A certidão de nascimento dessa novidade foi a criação do neologismo piscinão para referir-se a reservatórios de detenção em âmbito de macrodrenagem. Além disso, na elaboração do Plano Diretor de Macrodrenagem da Região Metropolitana de São Paulo criou-se o conceito de vazão de restrição. Isso deriva do entendimento de não mais ser conveniente aumentar a capacidade do rio Tietê, do que se conclui que qualquer intervenção nas suas bacias contribuintes não pode ultrapassar essa vazão de restrição. Isso na prática limita, em grande parte, à reservação o rol de medidas estruturais disponíveis para atuação nessas bacias. É de se esperar que a existência de piscinões se configure como bastante negativa aos moradores do entorno (embora há quem afirme ser esse entendimento exagerado ou até mesmo equivocado). Isso decorre de infortúnios tais como mau cheiro, dada a enorme carga de poluição dos cursos d'água, proliferação de insetos, aspecto repugnante do lixo retido, estética bastante infeliz dos reservatórios e incômodo provocado pela limpeza deles depois de episódios chuvosos. Além disso, é provável que a escolha da localização dos reservatórios privilegie áreas desocupadas, justamente aquelas muitas vezes utilizadas informalmente como recreação para a população do entorno. Esses incômodos devem ser mais bem considerados por meio de estudos caso a caso por ocasião do licenciamento e/ ou da autorização. Ademais, os recursos financeiros despendidos pelas municipalidades para a sua manutenção, especialmente na forma de desassoreamento, transporte e disposição dos sedimentos, são bastante vultosos. Finalmente, a destinação a reservatórios das escassas áreas desocupadas na Região Metropolitana de São Paulo faz-se à custa da oportunidade de destinação dessas áreas a lazer, equipamentos sociais e áreas verdes.

Não era raro haver quem argumentasse que a adoção de medidas não estruturais e o controle na fonte seriam suficientes para um adequado combate às enchentes, dispensando-se a comunidade dos incômodos associados aos piscinões. Evidentemente a validade dessa asserção depende de um estudo criterioso em cada bacia. Ressalte-se a necessidade de demonstrar quantitativamente tal asserção e a extrema dificuldade de fiscalização e execução de medidas não estruturais e de controle na fonte.

A microdrenagem corresponde às tradicionais guias, sarjetas, bocas de lobo, 
poços de visita, poços de inspeção e galerias de águas pluviais. Cada vez mais, porém, fala-se de estruturas menos convencionais que concernem a obras de reservação referentes a pequenas bacias, a chamada detenção in-situ ${ }^{21}$. CANHOLI (2005) informa que tal detenção é feita para controlar áreas urbanizadas restritas, como condomínios, loteamentos e distritos industriais. Tais áreas de reservação são normalmente incorporadas aos projetos de paisagismo e recreação, propiciando a formação de lagos ou a instalação de quadras de esportes nas partes secas atingidas apenas pelas enchentes maiores (caso as condições sanitárias o permitam). URBONAS (1993) ${ }^{22}$ apud CANHOLI (2005) informa que pode ser desaconselhável a multiplicação de bacias de detenção em virtude das dificuldades e custos de inspeção, operação e manutenção, bem como das próprias incertezas quanto à real influência hidráulica desses sistemas, visto que em certos casos pode ocorrer o resultado inverso ao pretendido, ou seja, a ampliação dos picos de vazão. Isso se daria porque a combinação dos hidrogramas de vazão efluente das diversas bacias, em determinada seção a jusante, pode ser tal que resulte em uma vazão de pico maior do que aquela que ocorreria na situação não desenvolvida devido a um problema de simultaneidade (timing) dos diversos hidrogramas efluentes.

Medidas na fonte, que são as que mais nos interessam aqui, são feitas em lotes ou em áreas muito pequenas. Evidentemente estão aqui incluídas todas as medidas para a drenagem de edificações e lotes. Consideraremos aqui dois gêneros de medidas na fonte, o que nos embasará para a proposta de terminologia adotada: reservação de controle do escoamento superficial (conhecida como piscininhas) e medidas não convencionais de drenagem na fonte ${ }^{23}$.

A teoria para reservatórios de detenção está apresentada em CANHOLI (1995 e 2005). CRUZ, TUCCI e SILVEIRA (1998 e 2000) apresentaram informações e considerações bastante úteis sobre reservatórios de detenção em lotes.

Bons apanhados bibliográficos referentes a medidas na fonte encontram-se em URBONAS e STAHRE (1993), PORTO ALEGRE [CIDADE] (2005) e

\footnotetext{
${ }^{21}$ CANHOLI (2005), bem como a literatura em geral, e ao contrário do aqui apresentado, entende que a detenção in-situ refere-se a medidas na fonte.

${ }^{22}$ Referência não apresentada na fonte.

${ }^{23}$ Essa terminologia não tem consenso na comunidade técnica, mas é a que, parece-nos, melhor se adequa ao presente.
} 
CAETANO (2010). Limitar-nos-emos aqui a apresentar uma visão bastante panorâmica das estruturas possíveis. CANHOLI (2005) mod. apresenta a seguinte classificação das medidas na fonte: a) dispositivos de infiltração, ou seja, estruturas, obras e dispositivos que facilitam a infiltração e a percolação; b) controle de entrada: dispositivos que restringem a entrada na rede de drenagem, como válvulas nos telhados ou o controle nas captações das áreas de estacionamentos e pátios. Quanto aos dispositivos de infiltração, NAKAMURA (1988) ${ }^{24}$ apud CANHOLI (2005) classifica-os em dois grupos principais, denominados métodos dispersivos e métodos em poço. Os primeiros incluem os dispositivos por meio dos quais a água infiltra no solo. Os métodos em poços são aqueles em que há recarga do nível subterrâneo pelas águas de superfície. Quanto aos dispositivos de controle na entrada, CANHOLI (2005) $\operatorname{cita}^{25}$ : a) controle nos telhados: pode ser obtido com a adoção de um sistema de calhas e condutores com capacidade de armazenamento, que é controlado mediante válvulas especiais; b) controle em áreas impermeabilizadas: instaladas em grandes áreas impermeabilizadas, como estacionamentos, pátios de manobras, subestações, cemitérios, praças públicas e centros esportivos, trata-se de estruturas que reservam a água precipitada tanto por meio de inundação controlada como por implantação de reservatórios. Para obter o retardamento do acesso das águas à rede de drenagem é possível instalar obstruções especialmente projetadas nas caixas de coleta, de forma que, nas proximidades das captações, mantenha-se um alagamento controlado, podendo ser previstos elementos para facilitar a infiltração. Mediante a previsão de depressões nas praças públicas, estacionamentos e outros locais, é possível também obter um retardamento de forma ainda mais controlada, podendo conter tais locais um espelho d'água permanente, além de um volume de espera.

Alguns instrumentos normativos sugerem que o reservatório de detenção seja tal que obrigatoriamente proporcione infiltração no solo do fundo do reservatório. Julgamos problemática tal obrigatoriedade pelos seguintes motivos: a) enquanto a água lentamente se infiltra no solo, pode ocorrer outra precipitação (de não necessariamente o mesmo período de retorno), ficando comprometido o desempenho

\footnotetext{
${ }^{24}$ NAKAMURA, E. Regulating loads to receiving waters: control practices for combined sewer overflows in Japan. In: IAWPRC/ IAHR SEMINAR URBAN DISCHARGES AND RECEIVER WATER QUALITY IMPACTS, 1988, Brighton, UK.

$25 \mathrm{~V}$. penúltima nota.
} 
do reservatório caso a água esteja ainda infiltrando; b) nem todos os solos se prestam bem à infiltração; c) em reservatórios de lote com infiltração sempre existe o risco de colmatação, além de a limpeza ficar dificultada. De fato, Tucci é de opinião que "o uso de superfície permeável no fundo [de reservatório de lote] não contribui de forma significativa e muitas vezes dificulta a limpeza. Com a entrada de água com algum material, em pouco tempo o fundo se colmata tirando a capacidade de infiltração. As paredes podem ser filtrantes, mas geralmente os tempos de infiltração são muito altos para apresentar grande eficiência no armazenamento" (TUCCI, s.d.). Preferimos, portanto, situar os reservatórios de detenção de lote com infiltração como um caso possível, embora não generalizável. Entram, portanto, na categoria de medidas não convencionais de drenagem na fonte.

\subsection{RESERVATÓRIOS DE LOTE}

A função de um reservatório é compatibilizar fluxos de entrada e de saída de diferentes magnitudes. Por exemplo, um porto exige armazenamento porque a taxa com que o trem ou os caminhões trazem a mercadoria ao porto não é igual à taxa com que a mercadoria é embarcada no navio.

Entenderemos o lote como uma bacia na qual um determinado hidrograma atinja o sistema de reservação de controle de escoamento superficial, sendo o objetivo que o hidrograma de saída do lote esteja amortecido e retardado em relação ao pico do hidrograma de entrada no reservatório.

A literatura e a comunidade técnica usualmente propõem um critério de dimensionamento do reservatório de lote segundo o qual as condições de saída do reservatório não podem ser piores do que o lote teria na condição "natural" ou "não desenvolvida" do lote, ou seja, antes da urbanização ${ }^{26}$. Trata-se do princípio de dimensionamento conhecido como "impacto zero" (v., p.ex., SÃO PAULO $[C I D A D E], 2012 \mathrm{a}$, p. 57). Há quem proponha que o lote suporte também proporcionalmente o impacto da cota do lote referente a vias - leito carroçável e

\footnotetext{
${ }^{26}$ Evidentemente o conceito de "antes da urbanização" é bastante problemático.
} 
passeio - e áreas e equipamentos públicos. Três são as condições a ser atingidas segundo o critério do impacto zero: a) o pico do hidrograma de saída do reservatório não deve ser maior do que o pico do hidrograma de saída do lote nas condições "naturais"; b) o lag, ou seja, o intervalo de tempo que vai do centro de gravidade do hietograma (distribuição temporal da chuva) e o pico do hidrograma de saída do reservatório, não deve ser menor do que o lag do lote nas condições "naturais"; c) o volume escoado após o reservatório deve ser igual ou menor à quantidade de água precipitada Temos, portanto, que dimensionar o reservatório de lote, especialmente nos aspectos relativos ao volume e dispositivos de saída, de forma tal que as três condições acima sejam satisfeitas. Para tanto, todas as durações de chuva associadas ao período de retorno escolhido devem ser examinadas de forma a encontrar a mais crítica em termos de dimensionamento.

$$
* * *
$$

O dimensionamento de reservatórios faz-se por meio da equação da conservação de massa para volume de controle com variáveis eulerianas (v., p.ex., FOX e McDONALD, 1981, p.98-106):

$$
0=\partial / \partial \mathrm{t} \int_{\mathrm{VC}} \rho \mathrm{dU}+\int_{\mathrm{SC}} \rho \mathbf{V} \cdot \mathrm{d} \mathbf{A}
$$

sendo VC: volume de controle; SC: superfície de controle; $\rho$ : massa específica [M.L $\left.{ }^{-3}\right]$; U: grandeza do volume de controle [L $\left.\mathrm{L}^{3}\right]$; dU: diferencial do volume de controle $\left[\mathrm{L}^{3}\right]$; t: tempo $[\mathrm{t}] ; \mathbf{V}$ : vetor velocidade normal à superfície de controle $[\mathrm{L} / \mathrm{t}]$; dA: diferencial de vetor normal à superfície de controle $\left[\mathrm{L}^{2}\right]$.

Para a aplicação dessa equação no dimensionamento de reservatórios o volume de controle é associado ao próprio reservatório. Nessas condições, a equação acima pode ser assim simplificada

$$
\mathrm{Q}_{\mathrm{e}}-\mathrm{Q}_{\mathrm{s}}=\mathrm{dU} / \mathrm{dt}
$$

sendo $\mathrm{Q}_{\mathrm{e}}$ : vazão de entrada no reservatório $\left[\mathrm{L}^{3} . \mathrm{t}^{-1}\right]$; $\mathrm{Q}_{\mathrm{s}}$ : vazão de saída do reservatório $\left[\mathrm{L}^{3} \cdot \mathrm{t}^{-1}\right]$. Ou seja, a vazão que entra menos a vazão que sai é igual à derivada do volume em relação ao tempo.

Quase todos os métodos de dimensionamento de reservatórios consistem em integração da equação acima. No caso de lotes, devemos escolher um período de retorno, obter por meio de equações i-d-f os pares intensidade-duração de chuva associados a esse período de retorno, proceder ao cálculo do volume para diversos 
pares e obter a duração de chuva crítica, que é aquela a partir da qual se obtém o maior volume.

Adotaremos 10 anos como período de retorno porque parece ser um consenso na comunidade técnica (v., p.ex., SÃO PAULO [CIDADE], 2012a, p.57; PORTO ALEGRE [CIDADE], 2005, p.45 e 62; cf. TOMAZ, 2002, p.142; URBONAS e STAHRE, 1993, p.36, 50, 116 e 214; PORTO et al., 1993, p.815).

Quanto à vazão de entrada, temos que nos valer dos diversos métodos disponíveis para estimá-la. De todos eles, o mais simples é o chamado "método racional". O eminente Prof. Dr. Eng ${ }^{\circ}$ Kokei Uehara recomenda que esse método possa ser aplicado sem fatores corretivos para bacias da ordem de até $0,5 \mathrm{~km}^{2}$, o que o torna a melhor opção para dimensionamentos em lotes urbanos ${ }^{27}$ (TOMAZ, 2002, p.141, apresenta compilação de diversos autores a respeito do tamanho máximo das bacias segundo os quais é considerada adequada a aplicação do método racional ${ }^{28}$.

${ }^{27}$ Informação verbal em 1992.

${ }^{28}$ A partir de notas de aula do Prof. Dr. Kokei Uehara, das práticas correntes em nosso meio, da contribuição de colegas, da bibliografia em geral e de observações nossas, apresentamos a sistematização seguinte para métodos de estimativa de vazões: 1) para bacias menores do que $0,5 \mathrm{~km}^{2}$ : método racional; 2) para bacias entre $0,5 \mathrm{~km}^{2}$ e $2,0 \mathrm{~km}^{2}:$ método racional com fator corretivo; 3) para bacias entre $2 \mathrm{~km}^{2}$ e $25 \mathrm{~km}^{2}$ : métodos derivados de hidrogramas unitários sintéticos, como o método de Ven Te Chow, adaptado a bacias urbanas por CAETANO (1995); 4) para bacias entre $25 \mathrm{~km}^{2} \mathrm{e}$ 200km²: hidrogramas unitários sintéticos aplicados às sub-bacias e propagação de ondas de cheia pelo método de Muskingum ou pela integração das equações de Saint-Venant; 5) para bacias maiores do que $200 \mathrm{~km}^{2}$ : hidrograma unitário analítico, simulação hidrológica ou análise estatística de séries históricas de vazões disponíveis. Para as bacias maiores do que $2 \mathrm{~km}^{2}$ há necessidade de obter a precipitação efetiva a partir da precipitação total, sendo em nosso meio muito comum a aplicação do método do Soil Conservation Service. Para bacias maiores do que $25 \mathrm{~km}^{2}$ há necessidade de consideração das variações espaciais e temporais da chuva e suas consequências na avaliação do período de retorno (para bacias menores do que $25 \mathrm{~km}^{2}$, usualmente se considera, erroneamente, que o período de retorno da chuva crítica coincida com a período de retorno da vazão). Em nosso meio, é usual avaliar a variação temporal da chuva pelo método de Huff. A variação espacial pode ser avaliada por dados pluviométricos disponíveis ou por equações e gráficos constantes da bibliografia. As simulações podem se dar de forma discreta, contínua ou pseudocontínua (CANHOLI, 2005, p.84-6 e observações nossas). A forma discreta corresponde à simulação de eventos discretos definidos através da adoção de determinados percentis de variáveis aleatórias que se constituem nos parâmetros da simulação; assume-se que o período de retorno da vazão coincida com o período de retorno da chuva adotada; v. nota de rodapé adiante. A forma contínua, que se constitui no método ideal, corresponde à análise estatística dos resultados de simulação da bacia através de dados históricos contínuos e de séries históricas geradas, variando os parâmetros conforme a marcha da simulação; dificilmente seria disponível tamanha quantidade de informação; postula-se que a variação do uso do solo da bacia não provoque variação no padrão das chuvas; a simulação da situação atual e de cenários futuros utilizando as séries históricas disponíveis e geradas de forma a permitir análise estatística das vazões produz um valor associado a determinada probabilidade e determinado padrão do uso do solo, raciocínio adequado somente tendo como válido o postulado acima. A forma pseudocontínua corresponde a definir hietogramas para eventos extremos ocorridos na bacia, procedendo-se à sua 
Para melhor justificação do método racional, devemos nos reportar à figura 1 . O conceito-chave é o chamado tempo de concentração $\left(t_{c}\right)$, que consistiria no maior intervalo de tempo que uma partícula de chuva levaria para ir dos pontos extremos da bacia até a seção considerada. Supõe-se que ele seja constante para cada bacia.

Se supusermos também que a chuva não tem variação temporal e espacial ${ }^{29}$, que a duração da chuva total é igual à da chuva efetiva, que os hidrogramas constituem-se em segmentos retos, formando apenas trapézios e triângulos, e, principalmente, que a chuva escoa pela bacia em blocos translacionais, não havendo acumulação nela, então o raciocínio seguinte é válido (observe-se que tais hipóteses são tanto mais verdadeiras quanto menor o tamanho da bacia e quanto mais impermeável for ela). Quando o tempo, contado a partir do início da precipitação, chegar ao instante igual ao tempo de concentração da bacia, então toda ela estará contribuindo e, dadas as hipóteses acima, a vazão será a máxima, constituindo-se no patamar dos trapézios dos hidrogramas ou no ápice do triângulo (neste último caso, quando a chuva tiver duração igual ao tempo de concentração). Terminando a chuva, o hidrograma passa a diminuir (à mesma taxa com que subiu), até que chegue a zero. Observe-se na figura que quanto mais longas as chuvas menores são os picos; isso decorre do princípio de que quanto mais longas as chuvas, menos intensas são elas (quando associadas ao mesmo período de retorno), princípio esse materializado no formato das curvas i-d-f. O pico da vazão, para uma bacia totalmente impermeabilizada, seria dado então por:

$$
\mathrm{Q}=\mathrm{i} . \mathrm{A}
$$

sendo Q: vazão $\left[\mathrm{L}^{3} \cdot \mathrm{t}^{-1}\right]$; i: intensidade da chuva $\left[\mathrm{L} \cdot \mathrm{t}^{-1}\right]$; A: área da bacia $\left[\mathrm{L}^{2}\right]$.

simulação e selecionando-se os picos máximos anuais, o que permite realizar uma análise estatística de vazões. SÃO PAULO (CIDADE) (2012a, p.31-4) informa que ainda não existe metodologia amplamente aceita para considerar as variações espaciais e temporais das tormentas de projeto, podendo ser utilizado, quando se dispõe de dados em quantidade suficiente, o conceito de "concepção de cenários de tormentas de projeto". Sua aplicação não permite avaliar a recorrência das tormentas críticas analisadas, sendo possível, no entanto, mediante abordagens empíricas e aproximadas, associar períodos de retorno às diversas tormentas analisadas.

${ }^{29}$ Ou seja, utiliza-se o método de bloco de tormenta (block rainstorm), que se constitui no método mais simples de desagregação da tormenta de projeto (CANHOLI, 2005, p.75). 
Figura 1 - Hidrogramas de segmentos retos relativos a quatro chuvas associadas ao mesmo tempo de retorno, sendo uma delas de duração igual ao tempo de concentração, para bacias pequenas.

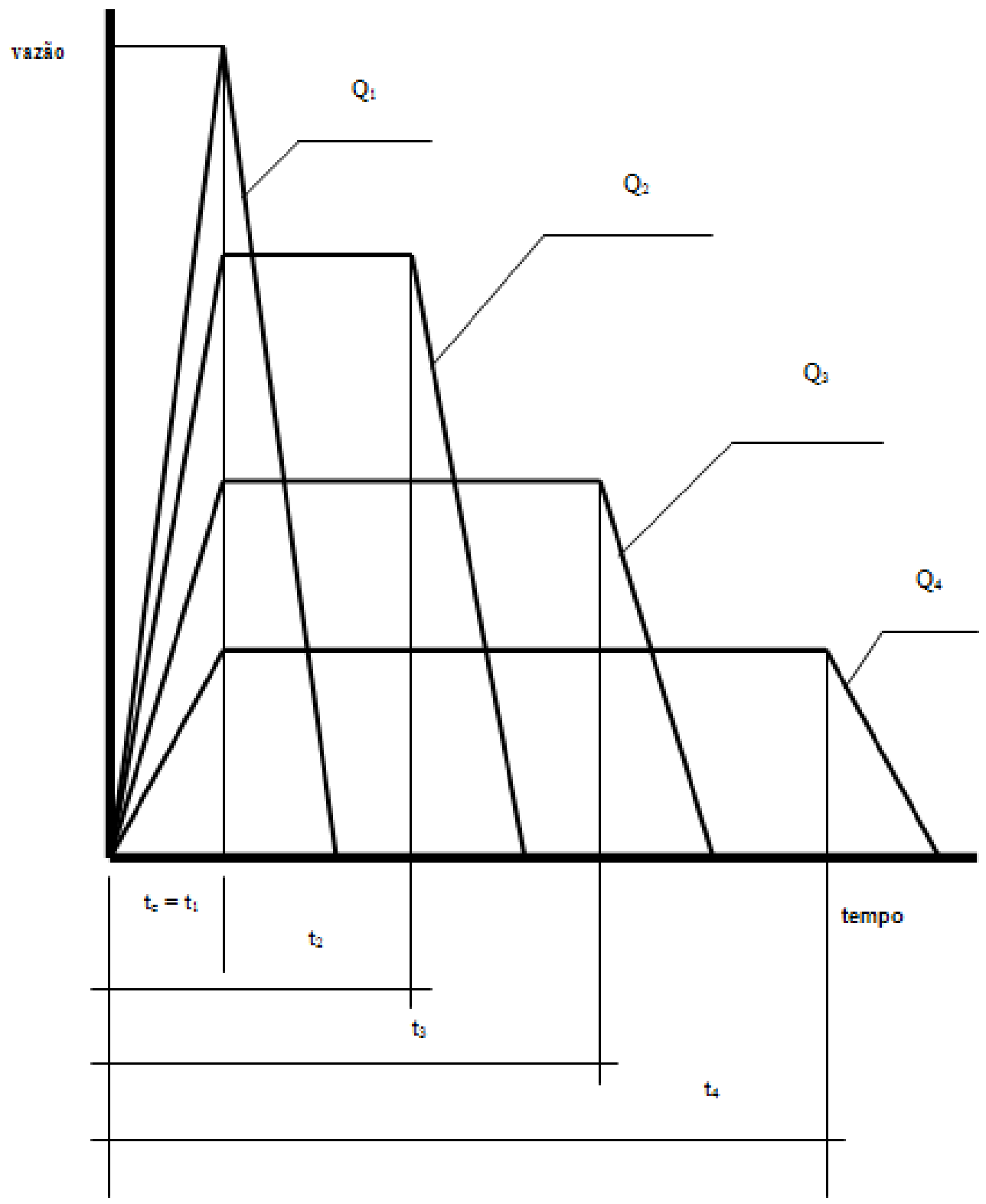

Fonte: produção própria

Notas:

a) as chuvas 1, 2, 3 e 4 são associadas ao mesmo período de retorno (assim, quanto mais longa a chuva, menor sua intensidade);

b) a chuva 1 tem duração igual ao tempo de concentração da bacia, motivo pelo qual sua vazão máxima é maior do que qualquer outra vazão máxima associada ao mesmo período de retorno (hipótese básica do método racional);

c) válido apenas para bacias pequenas, de forma a se poder justificar hidrogramas não curvos; 
Ocorre que nenhuma bacia é absolutamente impermeabilizada, daí a necessidade de um fator de correção $\mathrm{C}$, denominado coeficiente de escoamento superficial, que, em uma primeira aproximação, bem grosseira, pode ser considerado constante para a bacia (observe-se que quanto mais impermeabilizada e menor a bacia, mais $\mathrm{C}$ se aproxima de um valor constante, para um determinado período de retorno). Admite-se que, sendo o uso do solo da bacia heterogêneo, se pondere $\mathrm{C}$ pela área. A máxima vazão corresponde, portanto, a:

$$
\mathrm{Q}=\text { C.i.A }
$$

Quando o objetivo é determinar, para todos os pares intensidade-duração, a maior vazão, basta igualar a duração da chuva ao tempo de concentração da bacia. Caso se deseje o dimensionamento de uma estrutura de reservação, todas as durações devem ser avaliadas, de maneira a determinar a mais crítica.

O método racional recebe esse nome porque em seu memorável relatório KUICHLING (1889) verificou que a razão entre Q (vazão que sai) e i. ("vazão" que entra) era aproximadamente constante e igual à área impermeabilizada da bacia (C.A), considerando-se C como a proporção de impermeabilização da bacia. C.A foi denominado valor racional, decorrendo daí o nome do método (v. tb. CANHOLI, 2005, p.88).

É justo observar que o método racional não se constitui tanto em um modelo chuva-vazão, mas mais em um critério de cálculo. Não se pode perder de vista todas as hipóteses simplificadoras embutidas, a partir das quais se infere o campo de validade de sua aplicação.

$\mathrm{Na}$ realidade $\mathrm{C}$ depende de diversos fatores além do uso do solo da bacia, entre os quais podemos citar o período de retorno considerado, a duração da chuva, o tipo de solo e as condições antecedentes de umidade. Vimos que Kuichling associa C à fração de área impermeabilizada da bacia. Muitos assumem C como numericamente igual à razão entre a chuva escoada e a chuva total precipitada. Em nossa opinião, C, na realidade, é apenas um fator de ajuste entre um modelo teórico válido para uma situação ideal e os valores observados. Mesmo assim, terminaremos no trabalho por adotar a segunda conceituação do coeficiente de escoamento superficial, a saber, $\mathrm{C}$ numericamente igual à razão entre a chuva escoada e a chuva total precipitada. 
TOMAZ (2002, p.157) realizou uma avaliação da incerteza dos parâmetros que compõem o método racional e propagou os erros, tendo concluído que o erro de estimativas de aplicação do método racional é de 38\%. Esse alto valor de incerteza deve ser levado em conta para que não se proceda a análises demasiadamente precisas e se adotem preciosismos que pouco acrescentam ao cálculo em termos de precisão.

É costume associar à vazão assim obtida pelo método racional um período de retorno igual ao período de retorno da chuva. Isso é conceitualmente errado, motivo pelo qual C varia (ou deveria ser posto a variar) com o período de retorno. $\mathrm{Na}$ realidade, cada vez mais se evita em modelos chuva-vazão associar a vazão a uma determinada probabilidade, mas sim reconhecer que os inúmeros parâmetros do modelo são geralmente variáveis aleatórias, muitas vezes independentes umas das outras, sendo que a cada uma dessas variáveis aleatórias individualmente é associada uma probabilidade nos cálculos ${ }^{30}$. Assim operando, não se obtém, a rigor, um período de retorno associado à vazão.

Obtida a vazão de entrada no reservatório, estamos aptos a integrar a equação da continuidade de maneira a obter o volume do reservatório.

A integração numérica da equação da conservação de massa pode se mostrar ainda relativamente trabalhosa, motivo pelo qual se costuma apelar para procedimentos simplificados. Um deles é o método de Baker, que examina apenas a chuva com duração igual ao tempo de concentração da bacia, o que não pode ser considerado adequado. Mesmo assim, TUCCI (2000b), utilizando o método de Baker, dimensionou o volume de detenção de reservatórios para diversas cidades brasileiras para períodos de retorno de 2 e 5 anos, obtendo valores da ordem de 5 a $7 \ell / \mathrm{m}^{2}$ de área impermeável do terreno. Como comparação, o Código de Obras e Edificações do município de São Paulo (SÃO PAULO [CIDADE], 1992a) impõe

\footnotetext{
${ }^{30}$ Podemos fazer uma comparação das considerações relativas à busca do período de retorno "verdadeiro" com os métodos probabilísticos de verificação de segurança das estruturas (FUSCO, 1976, p.163-8). Estes podem ser feitos em três níveis. O nível III corresponde ao processo exato e lógico da verdadeira probabilidade de ruína. O nível II corresponde ao processo dos extremos funcionais. O nível I, finalmente, corresponde à verificação determinística da segurança a partir de certos percentis de parâmetros correspondentes a variáveis aleatórias. Os níveis II e I, a despeito de uma aparente precisão formal, acarretam, na verdade, a perda do significado lógico da medida de segurança. A avaliação do período de retorno na prática faz-se no nível I; assim, o período de retorno dessa forma avaliado deve ser entendido com cautela.
} 
volumes mínimos de reservatório de $9 \ell / \mathrm{m}^{2}$ de área impermeável do lote. A lei municipal no 13.276, de 4 de janeiro de 2002 (SÃO PAULO [CIDADE], 2002a) ("lei das piscininhas"), e a lei estadual $n^{\circ} 12.526$, de 2 de junho de 2007 (SÃO PAULO [ESTADO], 2007) ("lei estadual das piscininhas"), também impõem volumes mínimos de reservatório de $9 \ell / \mathrm{m}^{2}$ de área impermeável do lote. TOMAZ (2001) realizou estudos, também utilizando o método de Baker, visando subsidiar a redação do Código de Obras de Guarulhos, lei 5.617, de 9 de novembro de 2000, atualmente revogada (GUARULHOS [CIDADE], 2000), tendo obtido valores da ordem de $6 \ell / \mathrm{m}^{2}$. CAETANO (2001b), ainda utilizando o método de Baker, propôs a regressão seguinte para o cálculo do volume mínimo de reservatórios, válida para períodos de retorno de 10 anos: $\mathrm{V}=6,365 \cdot 10^{-4} \cdot \mathrm{A}_{\mathrm{i}}{ }^{1,352}$, sendo $\mathrm{V}$ o volume mínimo do reservatório, em $\mathrm{m}^{3}$, e $\mathrm{A}_{\mathrm{i}}$ a área do lote, em $\mathrm{m}^{2}$, para áreas de até $15.000 \mathrm{~m}^{2}$ (em todos os seus estudos, Caetano supôs que todo o lote estivesse impermeabilizado, dada a dificuldade de fiscalizar a sua taxa de impermeabilização). Tal equação corresponde a volumes mínimos da ordem de 5 a $17 \ell / \mathrm{m}^{2}$.

Como observado, o método de Baker não é adequado porque considera apenas uma chuva com duração igual ao tempo de concentração da bacia, ao invés de considerar todas as durações associadas a um determinado período de retorno de forma a determinar a chuva crítica, que é a que fornece o maior volume mínimo. Isso sugere a conveniência da utilização do método de DONAHUE, McCUEN e BONDELID (1981) apud CHOW, MAIDMENT e MAYS (1988). Tal método, ao contrário do de Baker, examina chuvas de diversas durações e adota hidrogramas com segmentos retos na forma de triângulos e trapézios. Tem como vantagem uma formulação suficientemente simples de maneira a evitar dificuldades maiores associadas à integração numérica direta. Esse método não consta da relação de métodos de dimensionamento de volumes de reservatórios de detenção apresentada por CANHOLI (1995 e 2005). O método verifica qual dos hidrogramas demandaria o maior volume de detenção. O volume corresponde à área destacada na figura 2 . No entanto, cálculos preliminares realizados por nós mostraram que as durações de chuvas críticas são bastante grandes, do que decorre a viabilidade de desconsiderar as fases inicial e final dos hidrogramas de entrada e saída. Dessa forma, o volume, para uma determinada chuva, pode ser visualizado na figura 3 e corresponde 
numericamente a:

$$
\mathrm{U}=\left(\mathrm{Q}_{\mathrm{e}}-\mathrm{Q}_{\mathrm{s}}\right) \cdot \mathrm{t}
$$

sendo U: volume do reservatório necessário para, dada uma determinada vazão de entrada, obter a correspondente vazão de saída [L33]; Q: vazão que entra no reservatório $\left[\mathrm{L}^{3} \cdot \mathrm{t}^{-1}\right] ; \mathrm{Q}_{\mathrm{s}}$ : valor imposto para a vazão de saída do reservatório $\left[\mathrm{L}^{3} \cdot \mathrm{t}^{-1}\right]$; t: duração da chuva [t].

Isso, por sua vez, justifica a determinação do volume mínimo de reservatório por meio de método simplificado correspondente à obtenção da condição necessária de mínimo da função volume de reservatório, facilmente obtenível por meio da equação de chuva e da equação de saída do reservatório.

O dimensionamento do reservatório deve considerar não só o volume, mas também as condições de saída.

Propomos como solução default o seguinte critério: considera-se que, quando da integração da equação da continuidade, no momento em que a altura da água imediatamente a montante da estrutura de saída é a maior, a estrutura de saída estará descarregando segundo sua lei de descarga para regime permanente. Caso a estrutura de saída seja constituída de orifícios, podemos adotar como coeficiente de vazão o valor de 0,6. O critério torna-se tanto mais inválido quanto menor a altura da água imediatamente a montante da estrutura de saída. 
Figura 2 - Obtenção do volume de reservatório de detenção a partir dos hidrogramas de entrada e saída ao reservatório.

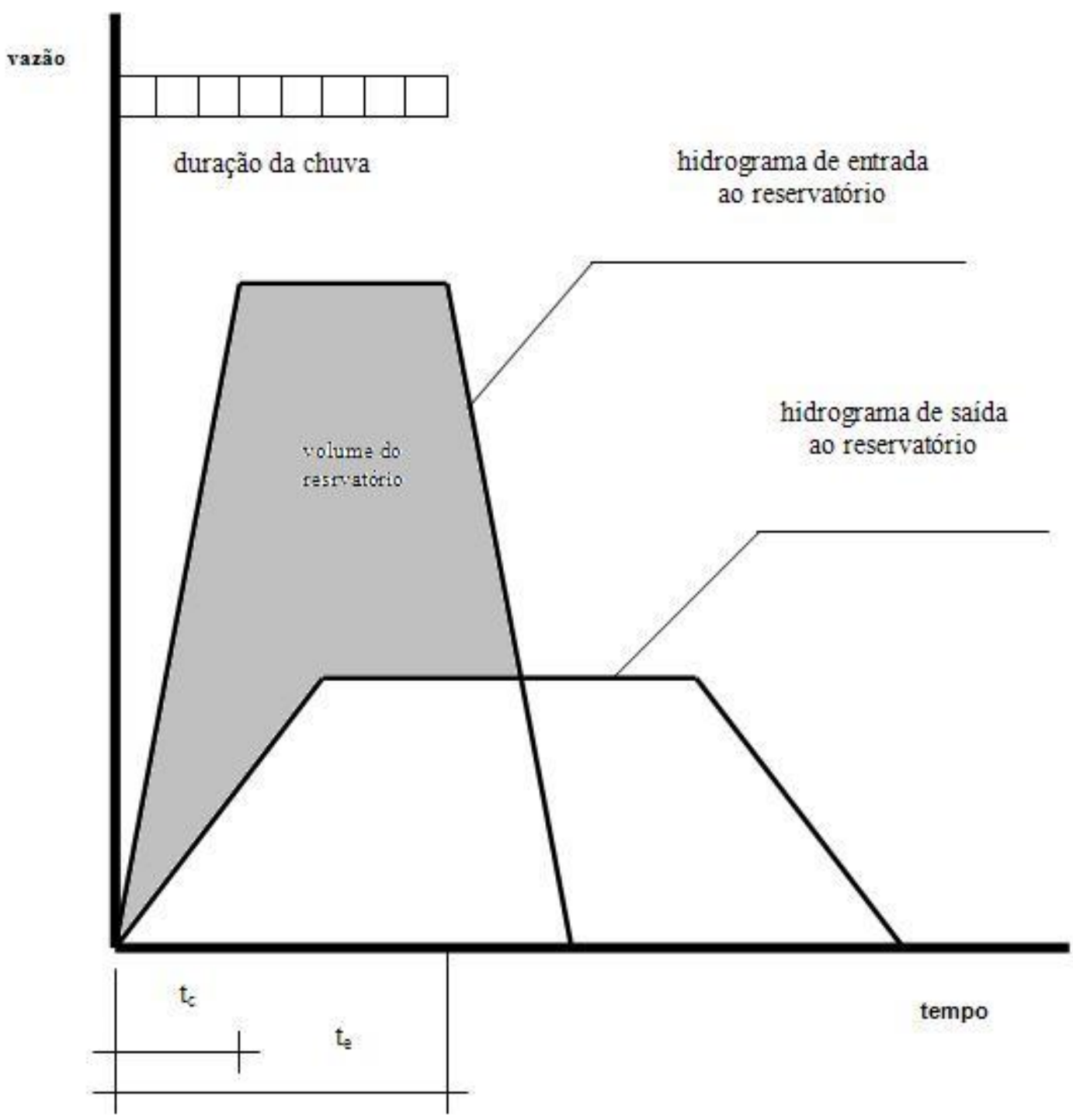

Fonte: produção própria

Notas:

a) $t_{c}$ : tempo de concentração da bacia;

b) $t_{\mathrm{e}}$ : duração da chuva efetiva associada ao hidrograma de entrada ao reservatório;

c) válido apenas para bacias pequenas. 
Figura 3 - Cálculo simplificado do volume de reservatório.

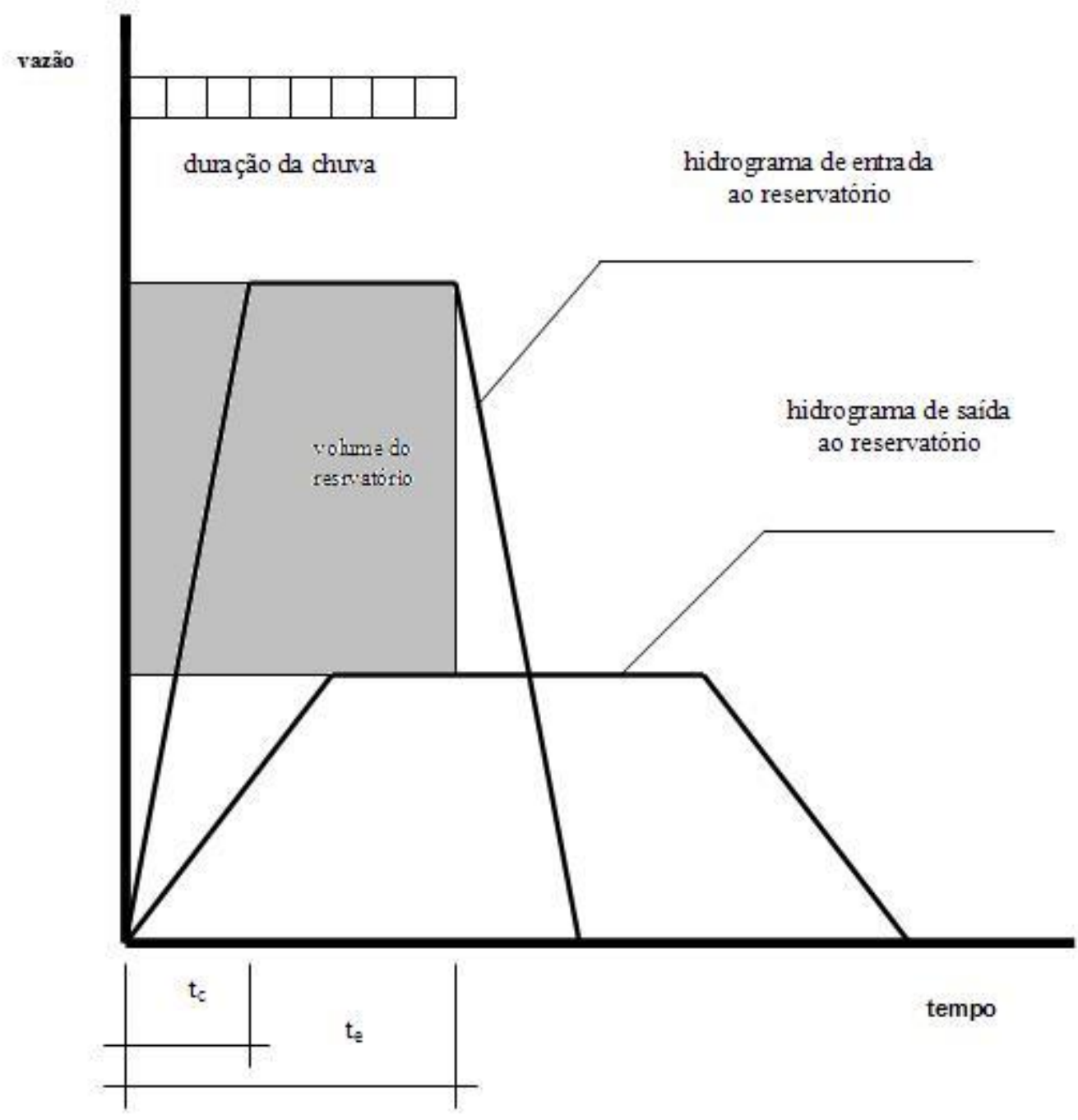

Fonte: produção própria

Notas:

a) comparar com figura 2 ;

b) $t_{c}$ : tempo de concentração da bacia;

c) te: duração da chuva efetiva relacionada com o hidrograma de entrada ao reservatório;

d) comparando o volume de reservatório aqui obtido por método simplificado com o volume de reservatório a que se refere a figura 2, a simplificação aqui apresentada é razoável uma vez que a duração crítica de chuva (aquela que, dentre os pares intensidade-duração associados a um mesmo período de retorno (curva i-d-f) está associada ao maior volume de reservatório) é muito maior do que o tempo de concentração da bacia, o tempo de ascensão do hidrograma e o lag da bacia. 


\subsection{ALGUMA PALAVRA SOBRE A INFILTRAÇÃO}

Em Berlim, o abastecimento de água é feito a partir de águas subterrâneas, fazendo o BFF parte de um complexo de medidas destinados a elevar o nível freático e garantir a qualidade da água bruta para abastecimento.

Em uma primeira aproximação, extremamente simplificada, o mesmo não se daria em São Paulo. Muito do solo do território do município de São Paulo constituise em depósitos sedimentares nos quais se intercalam camadas de areia e argila, ocorrendo diversos aquíferos suspensos, com água cuja qualidade é no mínimo duvidosa. É muito improvável que a água desses aquíferos suspensos venha a provocar recarga do aquífero do embasamento cristalino, este sim com água de boa qualidade, mas que vem sofrendo forte processo de depleção nos últimos anos (v. HIRATA e FERREIRA, 2001). Assim, ainda em primeira aproximação, o que importa em São Paulo é abater e atrasar o pico das vazões que saem do lote, de maneira a atenuar o risco de inundações. Dessa maneira, a promoção da infiltração não seria um objetivo ambiental prioritário.

É claro que a situação não se põe assim de maneira tão simples. Conforme veremos com mais detalhes, as escavações destinadas à construção da parte subterrânea das edificações provocam recalques na vizinhança que em alguns casos são bastante dramáticos. O fato de boa parte de território da área edificada do município constituir-se em aterros sobre argilas orgânicas moles, ou até mesmo turfas, piora em muito a situação. Porém, isso corresponde a problemas "localizados", que não deveriam interferir, pelo menos ainda em uma primeira aproximação, na escolha da infiltração como objetivo ambiental.

Porém, essa primeira aproximação foge do elemento óbvio: as plantas necessitam da água e dos nutrientes do solo trazidos pela chuva, disponíveis basicamente pela infiltração. PEREIRA-SILVA, JOLY e AIDAR (2007) e PEREIRASILVA et al. (2012), por exemplo, informam que em ecossistemas naturais terrestres o nitrogênio é o elemento que mais limita o desenvolvimento vegetal. As estratégias adotadas pelas plantas para obterem o nitrogênio podem ser: via sistema radicular 
(nitrato, amônio, ureia e aminoácidos); via cavidade subestomática foliar (nitrito e óxido nítrico) e fixação biológica do $\mathrm{N}_{2}$. Os autores constataram que em floresta ombrófila densa submontana ${ }^{31}$, em Mata Atlântica ao sul do estado de São Paulo, eventos de chuva são essenciais para a disponibilização de nitrogênio no solo e para a sua aquisição pelas plantas, as quais se mostram adaptadas à condição sazonal dos processos de mineralização e de nitrificação do solo. Em floresta estadual subdecídua, em Mata Atlântica no interior do estado, constataram que características do solo e estacionalidade da precipitação são fatores limitantes do processo de nitrificação do solo. Foi verificada correlação positiva substancial e significativa entre a concentração de nitrato no solo e a precipitação. Assim, existe essencialidade da água para a demanda de nitrogênio das espécies, permitindo o metabolismo primário do nitrogênio a organização das espécies em grupo funcionais de sucessão ecológica. Espécies pioneiras têm preferência pelo íon nitrato como fonte de nitrogênio e possuem níveis relativamente altos de atividade de redutase do nitrato, enquanto espécies secundárias tardias têm preferência pelo amônio como fonte primária e apresentam níveis relativamente baixos de redutase do nitrato. ROSADO et al. (2011), estudando florestas ombrófilas densas de terras baixas e florestas ombrófilas densas montana, na Mata Atlântica, endossam o uso do metabolismo primário do nitrogênio para a organização das espécies em grupos funcionais da sucessão ecológica. Além disso, informam que raízes finas com menos de $2 \mathrm{~mm}$ de diâmetro são as principais responsáveis pela absorção da água e nutrientes e, portanto, têm um papel central nos ciclos de carbono, água e nutrientes, desde o nível da planta até o ecossistêmico. Informam também que a disponibilidade de água pode estimular a produção de raízes finas.

Como veremos no item 12.6, julgamos que seria interessante agregar ao indicador drenagem aspectos referentes a infiltração e poluição difusa, de maneira a compor um índice mais abrangente. Mas o grupo decidiu por não considerar essa agregação.

\footnotetext{
${ }^{31}$ Para a terminologia do sistema de classificação fitogeográfico, v. BRASIL (1992).
} 


\subsection{CONCLUSÕES PARCIAIS SOBRE O OBJETIVO AMBIENTAL "PROMOÇÃO DE CONTROLE DE DRENAGEM NA FONTE" NO CONTEXTO DA CRIAÇÃO DE UM BFF PAULISTANO}

1) Cotejando o exposto acima com o BFF de Berlim, podemos observar que as tecnologias, superficiais ou não, já disponíveis para as medidas de drenagem na fonte são suficientemente mais complexas do que as singelas superfícies de biótopos, às quais são atribuídos simples fatores de ponderação tais como os constantes do BFF de Berlim, que tem como um de seus objetivos proporcionar maior infiltração das águas.

2) Em um BFF paulistano, o reservatório não deve ser a única medida a ser considerada, mas todo o elenco de medidas não convencionais disponíveis na bibliografia e na prática. O volume mínimo de reservatório e as condições de saída devem consistir simplesmente em medidas default a constarem na legislação, não podendo elas impedir que a legislação explicite ou o empreendedor apresente e justifique medidas não convencionais, associadas ou não à reservação.

Do exposto, concluímos que uma tabela de biótopos, ou de tecnologias verdes, não seria satisfatória para promover o objetivo ambiental "promoção do controle de drenagem na fonte" no território do município de São Paulo. O resultado nesse caso é infelizmente negativo. $\mathrm{O}$ que propomos, portanto, em termos de regulamentação, é que em um eventual BFF paulistano haja exigências em termos de medidas na fonte destinadas a garantir o abatimento e o retardamento do pico do hidrograma de saída do lote, quiçá de forma a garantir um resultado no mínimo equivalente à situação "natural" do lote (critério de impacto zero) (v. CAETANO et al., 2001). 


\section{PROMOÇÃO DA QUALIDADE ECOSSISTÊMICA}

Trataremos da qualidade ecossistêmica por meio de dois conceitos: integridade ecológica e saúde ecossistêmica.

Em nome da autonomia do texto principal e dos anexos, apresentamos tanto no anexo 3, item A3.1, como a seguir definições e diferenciação de conceitos que podem eventualmente ser objeto de confusão ${ }^{32}{ }^{33}$. Assim, temos que regime permanente, segundo KAY (2002), significa que certas variáveis de estado do sistema não se alteram com o tempo ${ }^{34}$. Na maior parte do tempo isso corresponde à igualdade entre insumos e respostas ao sistema. Esse conceito é interessante porque usualmente se postula que os ecossistemas tendam a certos estados nos quais, atingidos, o ecossistema opera em regime permanente ${ }^{35}$. O equilíbrio (interno) de um sistema, também segundo KAY (2002), está relacionado a variações espaciais de variáveis intensivas do sistema ${ }^{36}$; existindo tal variação, um gradiente existe e o

\footnotetext{
32 De fato, JAYNES (1980) assevera que "as principais dificuldades que retardaram o progresso em um século [em termos de desenvolvimento de teorias relacionadas a princípios variacionais em dissipação de energia] não são de ordem matemática, mas conceitual; e estas, por sua vez, constituemse principalmente em artefatos da semântica. As palavras 'irreversível', 'entropia', 'probabilidade' são usadas indiscriminadamente com sentidos muito diversos, e o fato de a mesma palavra ser usada dificulta a muitos ver que os significados são diferentes. Assim, uma frase comum tal como 'o paradoxo de como reconciliar a irreversibilidade da segunda lei com a reversibilidade das equações de movimento' registra não um paradoxo, mas um abuso de linguagem. É impossível pensar em e comunicar racionalmente esses problemas a menos que usemos diferentes palavras e símbolos para transmitir ideias diferentes. De longe, a palavra que mais sofre abuso é 'entropia'. Confusões a respeito dos diferentes significados da palavra, já sérios há 35 anos atrás, atingiram proporções desastrosas com o advento da teoria da informação de Shannon em 1948, que não só se apropriou da mesma palavra para um novo conjunto de significados, mas, ainda pior, provou ser altamente relevante para a mecânica estatística" (JAYNES, 1980, p.583).

${ }^{33}$ V. tb. BRANCO (1999, p.72-6).

${ }^{34}$ Estritamente falando, isso implica que qualquer derivada, parcial ou total, em relação ao tempo nas equações que regem o funcionamento de um sistema ou de um volume de controle é necessariamente nula.

${ }^{35} \mathrm{~A}$ respeito das consequências teóricas da hipótese segundo a qual os sistemas passam a regime permanente quando o tempo tende ao infinito v. BRUERS (2007).

${ }^{36}$ As variáveis macroscópicas que descrevem o estado de um sistema termodinâmico, segundo VAN WYLEN e SONNTAG (1976, p.16), podem ser intensivas (aquelas que independem da massa; p.ex.: temperatura, pressão e densidade) ou extensivas (p.ex.: massa e volume). Se uma quantidade de matéria é dividida em duas porções iguais, o valor numérico de suas propriedades intensivas permanece o mesmo e o das propriedades extensivas é dividido por dois.
} 
sistema não está em equilíbrio. O equilíbrio de um sistema com o meio ocorre, segundo VAN WYLEN e SONNTAG (1876, p.206), quando não há variações espaciais de variáveis intensivas do sistema com o meio (em especial, sistema com a mesma pressão e temperatura do meio; o sistema também deve ter velocidade zero e energia potencial mínima, além de estar em equilíbrio químico com o meio, o que implica não ocorrer nenhuma reação). É necessário ainda distinguir irreversibilidades e dissipação. KAY (2002) observa que os dois conceitos são muitas vezes usados como equivalentes. Segundo VAN WYLEN e SONNTAG (1976, p.132), a irreversibilidade de um ciclo termodinâmico está relacionada à impossibilidade de realizar tal ciclo sem que uma parcela de calor seja transmitida ao meio. Já a dissipação corresponde a fluxos de saída do ecossistema ${ }^{37}$. Sistema corresponde a uma quantidade limitada de matéria. É uma contradição em termos falar em fluxos de matéria através da fronteira de sistemas, ainda que tal seja comum em trabalhos de ecologia e físico-química (v., p.ex., CASTELLAN, 1983, p.109). Volume de controle corresponde a uma região espacialmente delimitada. As leis que governam sistemas inerciais (leis zero, primeira, segunda e terceira da termodinâmica, princípio de conservação da massa, segunda e terceira leis de Newton) são válidas também para volumes de controle inerciais, mas a formulação é diferente, sendo necessário recorrer ao teorema de transporte de Reynolds para sair da formulação relativa a sistemas para chegar a formulações válidas para volumes de controle. A termodinâmica clássica é em grande parte uma ciência de sistemas em equilíbrio (interno). Assim, os conceitos termodinâmicos definidos para sistemas em equilíbrio em princípio não fazem sentido para sistemas que não se encontrem em equilíbrio.

Posteriormente trataremos da exergia com mais profundidade. Por ora, definiremos exergia como o máximo trabalho reversível que pode ser realizado por um sistema para passar do estado em que se encontra até o estado de equilíbrio com o meio (VAN WYLLEN e SONNTAG, 1976, p.205).

\footnotetext{
${ }^{37}$ SCHNEIDER e KAY (1994, p.34) fornecem uma diferenciação entre dissipação e degradação. Para eles, dissipação de energia significa mover energia através do sistema, o que pode ou não destruir gradientes. Degradação de energia significa destruir a habilidade de a energia estabelecer gradientes. Assim, degradação de energia significa destruição de exergia, ou seja, a degradação da habilidade de a energia produzir gradientes capazes de realizar trabalho. Estruturas dissipativas são dissipadores de gradientes e degradadores de exergia.
} 


\subsection{INTEGRIDADE ECOLÓGICA E SEUS INDICADORES}

A integridade ecológica será aqui vista à luz de Kay e Müller.

Em um resumo muito apertado, podemos dizer que SCHNEIDER e KAY (1994) e KAY (2000) postularam um princípio de degradação de exergia abaixo descrito. Um sistema exposto a um fluxo de exergia de origem externa será deslocado do equilíbrio. A resposta do sistema consistirá em se organizar de forma a dissipar a exergia tão minuciosamente quanto as circunstâncias permitirem, assim limitando o grau a que o sistema é movido do equilíbrio com o meio. Além disso, quanto mais o sistema é afastado do equilíbrio, maior o número de oportunidades dissipativas que se tornarão acessíveis a ele e, consequentemente, mais efetivo ele se tornará na degradação de exergia. A vida (organismos e ecossistemas) se constitui em uma forma particular de estrutura dissipativa, sendo a fonte de exergia a radiação solar.

KAY (2000) definiu, no âmbito de sua teoria de ecossistemas, holarquia como uma versão generalizada da hierarquia tradicional, com relações de poder recíprocas entre níveis, ao invés de uma preponderância de poder exercida de cima para baixo. Um tipo particular desse sistema é chamado de hólon porque ele ocorre em uma realidade holárquica com interações recíprocas conduzidas pela causalidade múltipla entre um hólon e os hólons próximos ou contíguos de diferentes escalas. O autor recorre ao conceito de propensividade, devido a ULANOWICZ (1996) ${ }^{38}$ apud KAY (2000), segundo o qual uma espécie de autocatálise mútuo-causal exerce um papel auto-organizante, talvez gerando coesão dinâmica por meio de forças que agem assimetricamente. $\mathrm{O}$ autor lembra também que diversos autores defendem a tese segundo a qual ecossistemas comportam-se, utilizando uma classificação e terminologia criadas por MARUYAMA (1980), como sistemas abertos holárquicos auto-organizantes (self-organizing holarchic open systems, SOHO). A dinâmica

38 ULANOWICZ, R.E. The propensities of evolving systems. In: KHALIL, E.L.; BOULDING, K.E. (ed.). Evolution, order and complexity. London: Routledge, 1996. p.217-33. 
desses sistemas é descrita por narrativas. Uma questão central na narrativa de um sistema SOHO consiste em uma elaboração de suas propensividades. A elaboração delineia a causalidade mútua dos loops de retroalimentação e processos autocatalíticos que dão ao sistema sua coerência como uma entidade. Esse conjunto de propensividades, que define um hólon, consiste em seu cânon.

Dessa teoria de ecossistemas, KAY (1991) deriva o seu conceito de integridade. O desenvolvimento de sistemas SOHO é caracterizado por fases de rápida organização em direção a um estado permanente seguidas por um período durante o qual o sistema se mantém nesse novo estado permanente. A organização do sistema não é um processo suave, mas se dá aos saltos. Esses saltos consistem em uma aceleração súbita na mudança de estado do sistema. Tal mudança de estado pode ser contínua ou catastrófica e é acompanhada da adição de novas estruturas dissipativas ao sistema. Tais estruturas podem consistir em novos caminhos para o fluxo de energia, que conecta velhos componentes, ou de novos caminhos e seus caminhos associados. Cada salto resulta em o sistema mover-se para mais longe do equilíbrio com o meio, dissipando mais energia e tornando-se mais organizado. Cada salto ocorre quando condições aleatórias do ambiente excedem um limiar de catástrofe para o sistema. À medida que os sistemas se distanciam do equilíbrio eles se tornam mais eficientes na dissipação da energia solar. Ao mesmo tempo em que esse processo auto-organizante está ocorrendo nos sistemas, flutuações ambientais externas tendem a desorganizar o sistema. $\mathrm{O}$ ponto em que as forças desorganizantes do ambiente externo e as forças termodinâmicas organizantes estão equilibradas corresponde ao ponto ótimo de operação. Um ponto em particular só será ótimo temporariamente porque o ambiente externo está em mudança e a evolução do sistema estará em progresso, dessa forma alterando o equilíbrio entre as forças organizantes e as desorganizantes. No entanto, é útil tratar o ponto ótimo de operação em curtos períodos de tempo como se ele fosse estacionário. A integridade está relacionada à habilidade de o ecossistema manter sua organização e continuar seu processo de auto-organização. Porém, fora do curto prazo não é possível identificar um estado organizacional em particular que corresponda à integridade. Pelo contrário, há uma gama de estados organizacionais nos quais o ecossistema é considerado como íntegro. 
MÜLLER, HOFFMANN-KROLL e WIGGERING (2000) e MÜLLER (2005) apresentaram sua própria conceituação referente à integridade ecológica, da qual derivaram indicadores.

O princípio básico da integridade de Müller repousa na sustentabilidade. O quadro 4 evidencia alguns aspectos da integridade decorrentes dessa base conceitual na sustentabilidade. A manutenção da capacidade de os ecossistemas prestarem serviços ambientais ao longo do tempo recebe, nessa perspectiva, grande importância. Daí decorre que a auto-organização dos sistemas desempenha um papel importante no conceito de integridade de Müller. Os elementos teóricos que orientam esse conceito estão lastreados no princípio dos orientadores (orientor principle), embasado, por sua vez, nas ideias da termodinâmica afastada do equilíbrio aplicada a ecossistemas de JØRGENSEN (1992) e de SCHNEIDER e KAY (1994), bem como na teoria do desenvolvimento de rede de FATH e PATTEN (1999) e na teoria de sucessão e clímax de ODUM (1983). Em linhas muito gerais, temos que há certas características ecossistêmicas que crescem permanente e vagarosamente. Essas características correspondem a um desenvolvimento em direção a certo estado atrator determinado pelas características do local e se constitui em resultado de condições ecológicas prevalecentes. Uma vez que o desenvolvimento parece ser regularmente orientado em direção a um atrator, as respectivas variáveis de estado são chamadas de orientadores. Em geral, pode ser postulado que por meio de um desenvolvimento sem perturbações, a complexidade de um ecossistema aumentará assintoticamente a um estado chamado por Odum de maturidade. Durante esse processo, aumentam o armazenamento de exergia, a diversidade de fluxos, a ascendência e certas características da rede. Portanto, a exergia armazenada e a degradada constituem-se em orientadores típicos. MÜLLER (2005) ressalta, no entanto, que altos valores dos orientadores não garantem uma alta estabilidade ou uma grande capacidade-tampão ao sistema. De fato, ocorre decrescente adaptabilidade dos ecossistemas à medida que se aproximam do clímax. 
Quadro 4 - Encadeamento teórico relacionado ao conceito de integridade ecológica de Müller.

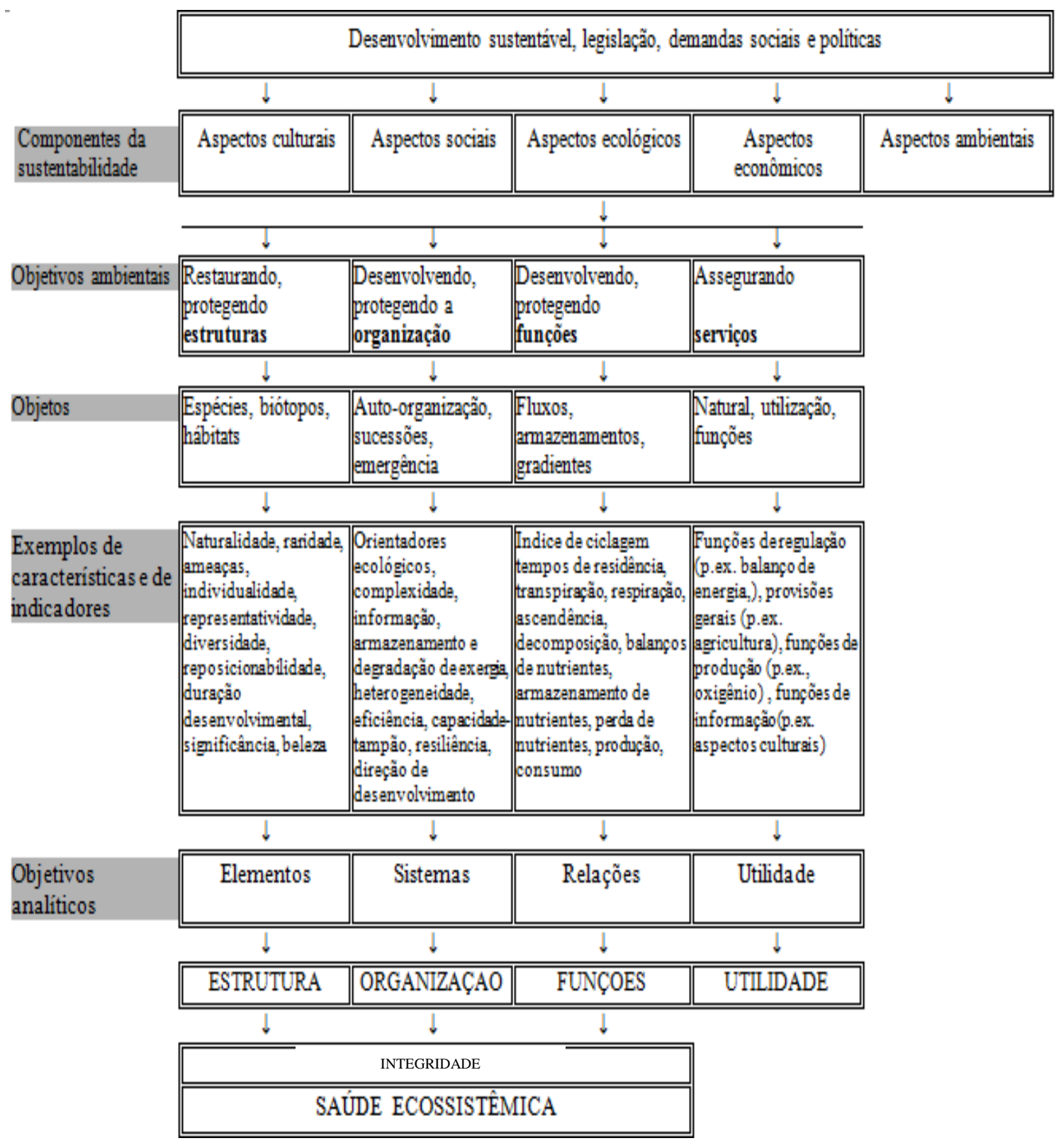

Fonte: MÜLLER, HOFFMANN-KROLL e WIGGERING (2000) adapt. 
O sistema de indicadores propostos deriva da seleção de alguns orientadores, que necessitam ser descritos por variáveis, que por sua vez são acessíveis por meio de métodos tradicionais de quantificação na ecologia. São os subsistemas gerais seguintes que devem ser levados em conta para representar a organização ecossistêmica, sendo apresentadas também as consequências do encaminhamento do sistema em direção à maturidade: a) estruturas: alto grau de informação, heterogeneidade e complexidade; específicas formas de vida (simbiose) e específicos tipos de organismos (estrategistas K, organismos com crescentes tempos de vida e massas corporais) tornam-se predominantes; b) funções: o armazenamento torna-se mais significativo, o tempo de residência aumenta, a ciclagem é otimizada e perdas de matéria são reduzidas. As seguintes funções são usualmente investigadas: b1) equilíbrio energético: tendência de maximização de algumas funções, como exergia e ascendência; b2) equilíbrio da água: mais e mais elementos devem ser proporcionados através da água, o que significa que os fluxos de água através dos compartimentos de vegetação mostra um típico comportamento voltado a um orientor; b3) equilíbrio de matéria: nutrientes importados são transferidos para dentro da comunidade biótica; as frações biológicas de nutrientes, a taxa de ciclagem e a eficiência aumentam, do que resulta que a perda de nutrientes é reduzida. Do exposto, Müller derivou um conjunto geral de indicadores para descrever ecossistemas ou paisagens terrestres, apresentado no quadro 5. Tal conjunto de indicadores não contempla os serviços ambientais prestados pelos ecossistemas. No entanto, DE GROOT (1992) $)^{39}$ apud MÜLLER (2005) entende que os serviços ambientais de regulação estão representados no conjunto apresentado e que há alta correlação entre eles.

39 DE GROOT, R.S. Functions of nature: evaluation of nature in environmental planning, management and decision-making. Groningen: Wolters Noorhoff, 1992. 
Quadro 5 - Indicadores propostos por Müller (2005) para representar o estado de ecossistemas e paisagens.

\begin{tabular}{|l|l|l|}
\hline \multicolumn{1}{|c|}{$\begin{array}{c}\text { Grupo de } \\
\text { orientadores }\end{array}$} & \multicolumn{1}{|c|}{ Indicando } & \multicolumn{1}{c|}{ Variáveis-chave potenciais } \\
\hline Estruturas bióticas & Biodiversidade & Número de espécies \\
\hline Estruturas abióticas & Heterogeneidade de biótopos & Índice de heterogeneidade \\
\hline Equilíbrio energético & $\begin{array}{l}\text { Captura de exergia, produção de } \\
\text { entropia segundo Svirezhev e } \\
\text { Steinborn, produtos de } \\
\text { evapotranspiração e respiração }\end{array}$ & $\begin{array}{l}\text { Produção primária de entropia bruta ou } \\
\text { líquida } \\
\text { Produção segundo Aoki }\end{array}$ \\
\cline { 2 - 4 } & Eficiência metabólica & Respiração por biomassa \\
\hline Equilíbrio de água & Fluxos bióticos de água & Transpiração \\
\hline Equilíbrio de matéria & $\begin{array}{l}\text { Capacidade de armazenamento } \\
\text { frente a perda de nutrientes }\end{array}$ & $\begin{array}{l}\text { Lixiviação de nitratos, nitrogênio } \\
\text { intrabiótico, carbono orgânico no solo }\end{array}$ \\
\hline
\end{tabular}

Fonte: MÜLLER (2005) mod.

Nota: As variáveis-chave apresentadas podem ser entendidas como um conjunto ótimo de indicadores.

Caso esses parâmetros não estejam disponíveis, outras variáveis podem ser escolhidas para refletir os indicandos. Ao fazê-lo, deve-se atentar para o fato de a qualidade das relações indicador-indicando poder ser prejudicada.

Os indicadores podem ser apresentados em um gráfico de "ameba", devendo, no entanto, ser antes normalizados. Para tanto, as combinações de parâmetros de um sistema (por exemplo, ecossistema próximo das condições "naturais") podem ser tomadas como estado de referência. É possível também usar o estado relativo a um objetivo de gestão ou a um ponto específico no tempo.

\subsection{SAÚDE ECOSSISTÊMICA}

XU e TAO (2000) selecionaram algumas definições de saúde ecossistêmica, apresentadas no quadro 6. Os autores ressaltam que alguns ecólogos preferem a expressão "integridade ecológica" a "saúde ecológica" e que nos documentos dos Estados Unidos da América referentes a políticas de longo prazo tais expressões são utilizadas onipresentemente associadas a objetivos de proteção. Ressaltamos que há debate em ecologia referente à equivalência entre saúde e integridade, não se podendo assumir a priori a igualdade entre os dois conceitos. CAMPBELL (2000), por exemplo, utiliza a Teoria de Sistemas para diferenciar integridade ecológica de 
Quadro 6 - Definições de saúde ecossistêmica levantadas por XU e TAO (2000).

\begin{tabular}{|c|c|}
\hline Fonte & Definição \\
\hline $\begin{array}{l}\text { Karr et al. } \\
(1986)^{40}\end{array}$ & $\begin{array}{l}\text { Um sistema biológico, seja individual ou ecológico, pode ser considerado saudável quando seu } \\
\text { potencial inerente é realizado, sua condição é estável, sua capacidade para autorreparo diante de } \\
\text { uma perturbação é preservada e é necessário apenas mínimo suporte externo para manejo. }\end{array}$ \\
\hline $\begin{array}{l}\text { Schaeffer et al. } \\
(1988)^{41}\end{array}$ & $\begin{array}{l}\text { A saúde [de um ecossistema] não deveria depender de critérios baseados na presença, ausência } \\
\text { ou condição de espécies individuais e em um censo ou mesmo inventário de grande número de } \\
\text { espécies; a saúde deveria refletir nosso conhecimento da sucessão normal ou mudanças } \\
\text { sequenciais esperadas que ocorram naturalmente em ecossistemas. }\end{array}$ \\
\hline $\begin{array}{l}\text { Rapport } \\
(1989)^{42}\end{array}$ & $\begin{array}{l}\text { O conceito de saúde ecossistêmica deveria ser derivado por analogia a conceitos relacionados à } \\
\text { saúde humana. A saúde ecossistêmica exibe certas propriedades fundamentais de sistemas } \\
\text { complexos auto-organizáveis, incluindo os quatro atributos de Bertalanffy relacionados à } \\
\text { evolução de sistemas complexos, a saber, integração progressiva, diferenciação progressiva, } \\
\text { mecanização progressiva e centralização progressiva. }\end{array}$ \\
\hline Norton $(1992)^{43}$ & $\begin{array}{l}\text { O autor sugere um quadro definitório de saúde ecossistêmica incluindo o axioma de dinamismo, } \\
\text { relacionabilidade, hierarquia, criatividade e fragilidade diferencial. }\end{array}$ \\
\hline $\begin{array}{l}\text { Haskell et al. } \\
(1992)^{44}\end{array}$ & $\begin{array}{l}\text { Um sistema ecológico é saudável e livre de "síndrome de tribulação" se ele é estável e } \\
\text { sustentável, ou seja, se ele é ativo e mantém sua autonomia e organização ao longo do tempo e é } \\
\text { resiliente a estresse. }\end{array}$ \\
\hline Page $(1992)^{45}$ & $\begin{array}{l}\text { Saúde é considerada uma relação harmoniosa entre as partes do corpo e entre o corpo e o mundo } \\
\text { ao redor; o conceito de homeostase, pensado em escolas médicas como um conceito normativo, } \\
\text { tem um paralelo direto com a noção de estabilidade nos ecossistemas. }\end{array}$ \\
\hline $\begin{array}{l}\text { Ulanowicz } \\
(1992)^{46}\end{array}$ & $\begin{array}{l}\text { Um sistema saudável é aquele cuja trajetória em direção ao clímax é relativamente desimpedida } \\
\text { e cuja configuração é homeostática de forma a influenciar o que o trouxer de volta a estágios } \\
\text { anteriores de sucessão. }\end{array}$ \\
\hline $\begin{array}{l}\text { Constanza } \\
(1992)^{47}\end{array}$ & $\begin{array}{l}\text { O autor ressalta que todos os conceitos acima representam peças de um quebra-cabeça, mas } \\
\text { nenhum é abrangente o suficiente para servir como uma definição operacional. Ele sumarizou o } \\
\text { conceito de saúde ecossistêmica como: a) saúde como homeostase; b) saúde como ausência de } \\
\text { doença; c) saúde como diversidade ou complexidade; d) saúde como estabilidade ou resiliência; } \\
\text { e) saúde como vigor ou âmbito para o crescimento; f) saúde como equilíbrio entre componentes } \\
\text { do sistema. Ele enfatizou que uma definição adequada de saúde deve integrar os conceitos de } \\
\text { saúde mencionados acima, ou seja, ela deveria ser uma medida combinada de resiliência, } \\
\text { equilíbrio, organização (diversidade) e vigor (metabolismo). }\end{array}$ \\
\hline
\end{tabular}

Fonte: XU e TAO (2000) mod.

${ }^{40}$ KARR, J.R. et al. Assessing biological integrity in running waters: a method and its rationale. Champaign: Illinois Natural History Survey, 1986. (Special publication 5).

${ }^{41}$ SCHAEFFER, D.J.; HERRICKS, E.E.; KERSTER, H.W. Environmental Management, n.12, p.445-55, 1988.

${ }^{42}$ RAPPORT, D.J. Perspectives in Bio. and Med., n.33, p.120-32, 1989.

${ }^{43}$ NORTON, B.C. In: CONSTANZA, R. et al. (ed.). Ecosystem health: new goals for environmental management. Washington D.C.: Island Press, 1992. p.23-41.

${ }^{44}$ HASKELL, B.D.; NORTON, B.G.; CONSTANZA, R. In: CONSTANZA, R. et al. (ed.).

Ecosystem health: new goals for environmental management. Washington D.C.: Island Press, 1992. p.3-20.

${ }^{45}$ PAGE, T. In: CONSTANZA, R. et al. (ed.). Ecosystem health: new goals for environmental management. Washington D.C.: Island Press, 1992. p. 97-123.

${ }^{46}$ ULANOWICZ, R.E. In: CONSTANZA, R. et al. (ed.). Ecosystem health: new goals for environmental management. Washington D.C.: Island Press, 1992. p.190-206.

${ }^{47}$ CONSTANZA, R. Toward an operational definition of health. In: CONSTANZA, R. et al. (ed.).

Ecosystem health: new goals for environmental management. Washington D.C.: Island Press, 1992. 
saúde ecossistêmica. Assim, integridade ecológica corresponde a uma propriedade emergente de ecossistemas operando à máxima potência, enquanto saúde está relacionada à sua resiliência.

HEARNSHAW, CULLEN e HUGHEY (s.d.) têm uma visão bastante crítica em relação ao conceito de saúde ecossistêmica (v. anexo A.3, mais completo). Eles argumentam que existem discursos ideológico-científicos no âmbito da ecologia usados para embasar o conceito de sanidade ecossistêmica que são altamente passíveis de críticas. São eles: a) modelo naturalista árcade, segundo o qual um ecossistema é tanto melhor e, portanto, mais saudável quanto menos tocado pela mão humana. A credibilidade desse modelo é duvidosa na medida em que há numerosas dificuldades de ordem filosófica e pragmática na conceituação de tal naturalidade, até porque humanos e, portanto, a ação humana que altera os sistemas "naturais", devem ser considerados também "naturais"; b) modelo reducionista, que postula ser o reducionismo na forma da ciência molecular a melhor abordagem para desvelar as leis da natureza. Segue daí que qualquer tipo de formato biológico ou ecológico é possível, dentro de certos limites mecânicos básicos. Assim, ele se constitui em um modelo neodarwinista que postula um processo de seleção natural conduzido por forças naturais cegas, cumulativas e não direcionais, do que decorre a importância da diversidade genética, uma vez que um ecossistema é tanto mais capaz de sobreviver nos ambientes presentes e futuros quanto maior sua biodiversidade. A fraqueza do modelo, segundo os autores, passa pela presunção de serem a natureza e os ecossistemas mecanísticos, bastando, para entender seu funcionamento, quebrá-los em seus componentes; c) abordagem de sistemas clássica referente aos modelos de sucessão e clímax, do que decorreria que um ecossistema é tanto mais saudável quanto mais próximo de seu clímax. Segundo os autores, essa abordagem erradamente insinua que os ecossistemas se desenvolvem de modo linear em direção a um único estado permanente autoperpetuado, ao invés de assumir a existência de múltiplos estados de equilíbrio e de uma dinâmica não linear; d) modelo que postula um aumento da estabilidade em função do aumento da diversidade, de forma que um ecossistema é tanto mais saudável quanto maior diversidade apresentar. Para os 
autores, há pouca evidência empírica que suporte tal modelo ${ }^{48}$. A teoria de sistemas mostrou que sistemas auto-organizados complexos são sistemas dinâmicos não lineares que apresentam múltiplos estados permanentes e propriedades emergentes e caóticas. Daí decorre não haver meios teóricos de prever o comportamento dos ecossistemas ou precisar quais de seus múltiplos estados são preferíveis. Os autores concluem, então, que não há possibilidade de usar objetividade científica para determinar a sanidade de um ecossistema, devendo a questão ser entendida como associada a juízos de valor.

Indicadores de saúde ecossistêmica podem ser sugeridos a partir de postulados de diversos autores sobre o comportamento dos ecossistemas que tenderiam, segundo tais postulados, à maximização ou minimização de certos conceitos (funções-objetivo, goal functions). ${ }^{49} \mathrm{~A}$ medida desses conceitos poderia

\footnotetext{
${ }^{48}$ Não se deve inferir a partir desse resumo sumaríssimo que os autores desprezem o valor da biodiversidade. Para melhor entender a posição dos autores, recomenda-se a leitura do original. ${ }^{49}$ Descrever o comportamento de ecossistemas como maximizadores de determinada função corresponde a uma maneira bastante interessante de simplificar o seu tratamento analítico. Consideremos, por exemplo, um gradiente de temperatura ocorrendo entre um solo aquecido e nuvens mais frias. O método de análise-síntese nos sugere atacar o problema procurando desenvolver e resolver equações diferenciais obtidas da dinâmica, o que pode eventualmente se mostrar extremamente trabalhoso. Uma maneira alternativa e mais elegante de atacar o problema consiste em interpretar o gradiente de temperatura como um desequilíbrio que vai ensejar no sistema soloatmosfera-nuvens uma estrutura auto-organizante destinada a dissipar esse desequilíbrio. Em certas condições essa estrutura se manifestará na forma de tornados. Ou seja, foi postulado um princípio de auto-organização e de dissipação capaz de descrever o fenômeno de forma mais simples, eficaz e elegante que a sugerida pelo método de análise-síntese. Outro exemplo são as famosas células de Bénard, tão estimadas por Prigogine.

BRAGA (1987) apresenta um resumo de técnicas de maximização. Para funções contínuas, deriváveis e de domínio abarcando todos os reais, a condição necessária e suficiente para máximos locais ou global corresponde à negatividade da primeira derivada não nula de ordem par nos pontos considerados; caso o domínio da função seja limitado, os pontos na(s) fronteira(s) do domínio devem ser averiguados e cotejados com os máximos locais de forma a obter o máximo global. Para funções de mais de uma variável, a condição necessária para que um ponto seja estacionário corresponde a que todas as derivadas parciais da função nesse ponto sejam nulas; a condição suficiente para que um ponto estacionário de uma função de mais de uma variável seja um máximo é que a forma quadrática associada ao hessiano da função seja negativa. Máximos de funções de mais de uma variável podem ser obtidos numericamente através de métodos de busca direta. Funções de mais de uma variável condicionadas por igualdades têm como condição necessária para que um ponto seja estacionário as derivadas parciais do lagrangiano serem todas nulas. Se a função de mais de uma variável a ser maximizada for condicionada por desigualdades e ambas essas funções forem lineares, podem ser utilizados métodos de programação linear. As condições necessárias para ótimo no caso de função de mais de uma variável não necessariamente linear condicionada por desigualdades também não necessariamente lineares são as denominadas condições de Kuhn-Tucker.

Obviamente o entendimento de os ecossistemas caminharem em direção a um clímax não deixa de ser uma hipótese eivada de ideologia. Assim se exprime Spirn: "A ciência não foi imune a noções normativas derivadas da natureza. Quando os ecólogos descrevem a 'harmonia' da natureza e a sucessão das 'comunidades' de plantas até o clímax estável de florestas, eles estão também
} 
ser, assim, um indicador do grau de saúde ecossistêmica. O quadro 7, extraído de BENDORICCHIO e JØRGENSEN (1997) com adições de FATH, PATEN e CHOI (2001) organizadas por SILOW e MOKRY (2010), apresenta uma relação de funções-objetivo. Faz sentido, portanto, que XU e THAO (2000) mencionem máxima potência, diversidade, biomassa, emergia, exergia e ascendência como indicadores de saúde ecossistêmica. XU e THAO (2000) selecionaram alguns outros indicadores de saúde ecossistêmica, apresentados no quadro 8. CONSTANZA e MAGEAU (1999) afirmam que um ecossistema saudável é aquele que pode desenvolver uma eficiente diversidade de componentes e caminhos de trocas (exchange pathways) (alta organização) enquanto mantém alguma redundância ou resiliência como proteção contra estresse, bem como substancial vigor para rapidamente utilizar o estresse de maneira positiva. Assim, vigor (função), estrutura (organização) e resiliência passam a ser considerados três componentes da saúde ecossistêmica que embasam indicadores fundamentais para a saúde. $\mathrm{O}$ vigor pode ser medido direta e facilmente por métodos consagrados como, por exemplo, a produção primária bruta. Os autores sugerem o conceito de Informação Mútua Média (Average Mutual Information, AMI), criado por Ulanowicz, como uma boa medida da estrutura. Finalmente, os autores sugerem que a resiliência seja medida pela máxima magnitude de um estressor a que um ecossistema é submetido de forma a ser capaz de retornar a um prévio estado permanente, ou pelo tempo de recuperação, que corresponde ao tempo para o ecossistema voltar a um prévio estado permanente quando submetido a um determinado estressor.

\footnotetext{
descrevendo um modelo de sociedade humana. A ideia da Queda - da comunidade expulsa do Paraíso, um estado anterior de graça inserido na natureza - exerceu uma influência poderosa na imaginação das culturas ocidentais" (SPIRN, 1997, p.252). De Moura, analisando Nietzsche, assim escreve: 'Saudemos Kant por ter introduzido, na Alemanha, esta 'evidência' a mais: se existe uma 'história universal', ela só testemunha a tendência da humanidade a caminhar em direção ao Bem. Afinal, para ele, a razão que se exibe na natureza não pode estar ausente da saga humana, e é uma hipótese altamente racional considerar que o gênero humano progride 'em direção ao melhor no que concerne ao fim moral de sua existência'. Uma hipótese tão racional que Kant nem se preocupa em prová-la. Já nos acostumamos às filosofias do 'melhoramento' do homem, a essa ideia de que a história será a realização da moral. (...) Em nossa época 'antiidealista', é a política que vai permitir a realização do 'reino dos fins', no interior da história universal. Através dela, o homem 'bom' finalmente se tornará real e a humanidade ganhará nova face” (DE MOURA, 2005, p.88).
} 
Quadro 7 - Funções-objetivo propostas para sistemas dinâmicos.

\begin{tabular}{|c|c|}
\hline Autor & Função-objetivo \\
\hline \multicolumn{2}{|c|}{ Múltiplos sistemas } \\
\hline Lotka $(1922)^{50}$ e Odum e Pinkerton $(1955)^{51}$ & Máxima potência útil ou fluxo de energia \\
\hline Onsager $(1931)^{52}$ e Prigogine $(1945)^{53}$ & Mínima dissipação específica \\
\hline Glansdorff e Prigogine $(1971)^{54}$ & Mínima entropia \\
\hline Cheslak e Lamarra $(1981)^{55}$ & Máximo tempo de retenção \\
\hline \multicolumn{2}{|c|}{ Sistemas ecológicos } \\
\hline Ulanowicz $(1986)^{56}$ & Máxima ascendência \\
\hline Morowitz $(1968)^{57}$ & Máxima ciclagem \\
\hline Margalef $(1968)^{58}$ & Máxima biomassa \\
\hline Whitaker e Woodwell (1971) $)^{59}$ e O'Neill et al. $(1975)^{60}$ & Máxima matéria orgânica persistente \\
\hline Odum $(1983)^{61}$ & Máxima emergia \\
\hline Mejer e Jørgensen (1979) $)^{62}$ & Máxima exergia armazenada \\
\hline Schneider e Kay $(1994)^{63}$ & Máxima dissipação de exergia \\
\hline Bastianoni e Marchettini (1997) ${ }^{64}$ & Máximos efeitos indiretos \\
\hline Wall $(1993)^{65}$ & Máximo empoderamento para razão de exergia \\
\hline $\begin{array}{l}\text { Ludovisi (2006) }{ }^{66} \text { e Ludovisi, Pandolfi e Taticchi } \\
(2005)^{67}\end{array}$ & $\begin{array}{l}\text { Máxima dissipação específica (ou mínima produção de } \\
\text { entropia específica) }\end{array}$ \\
\hline Svirezhev $(2000)^{68}$ e Patten $(1995)^{69}$ & Máxima informação estrutural \\
\hline \multicolumn{2}{|c|}{ Sistemas econômicos } \\
\hline Diversos autores & Máximo lucro \\
\hline
\end{tabular}

Fonte: BENDORICCHIO e JØRGENSEN (1997) com adições de FATH, PATEN e CHOI (2001) organizadas por SILOW e MOKRY (2010)

${ }^{50}$ LOTKA, A.J. Contribution to the energetics of evolution. PNAS 6, n.8, p.147-51, 1922

${ }^{51}$ ODUM, H.T.; PINKERTON. R.C. Time's speed regulator: the optimum efficiency for maximum power output in physical and biological systems. Am. Sci., n.43, p.331-43, 1955 .

52 ONSAGER (1931)

${ }^{53}$ PRIGOGINE, I. Moderation et transformations irreversibles des systemes ouvertes. Bulletin de la Classe de Sciences, n.31, p.600-6, 1945.

${ }^{54}$ GLANSDORFF, P.; PRIGOGINE, I. Thermodynamic theory of structure, stability and fluctuations. New York: Wiley, 1971.

${ }^{55}$ CHESLAK, E.F.; LAMARRA, V.A. The residence time of energy as a measure of ecological organization. In: BOSSERMANN, R.W.; KLOPATEK, J.M. (ed.).

Energy and ecological modelling. Amsterdam: Elsevier, 1981. p.591-600.

${ }^{56}$ ULANOWICZ, R.E. Growth and development: ecosystems phenomenology. New York: Springer, 1986

${ }^{57}$ MOROWITZ, H.J. Energy flows in Biology. New York: Academic Press, 1968.

${ }^{58}$ MARGALEF, R. Perspectives in ecological theory. Chicago: University Press, 1968.

${ }^{59}$ WHITAKER, R.H.; WOODWELL, G.M. Evolution of natural communities. In: WIENS, J.A. (ed.). Ecosystem structure and function. Corvallis: Oregon State University Press, 1971. p.137-59.

${ }^{60}$ O'NEILL, R.V. et al. A theoretical basis for ecosystem analysis with particular reference to element cycling. In: HOWELL, F.G.; GENTRY, J.B.; SMITH, M.H. (ed.). Mineral cycling in south-eastern ecosystems. Athens, GA: Athens University Press, 1975. p.28-40.

${ }^{61}$ ODUM, H.T. System Ecology. New York: Wiley, 1983

${ }^{62}$ MEJER, H.F.; JøRGENSEN, S.E. Energy and ecological buffer capacity. In: JøRGENSEN, S.E. (ed.). State of the art of ecol. modell.: environmental sciences and applications. Copenhagen: International Society for Ecological Modelling, 1979. p.829-46.

${ }_{63}^{63}$ SCHNEIDER E KAY (1994).

${ }^{64}$ BASTIANONI, S.; MARCHETTINI, N. Emergy/ exergy ratio as a measure of the level of organization of systems. Ecological Modelling, n.99, p.33-40, 1994.

${ }^{65}$ WALL, G. Exergy, ecology and democracy. In: INTERNATIONAL CONFERENCE ON ENERGY SYSTEMS AND ECOLOGY, 1993, Krakow.

Proceedings...Krakow, 1993. p.111-21.

${ }^{66}$ LUDOVISI, A. Use of thermodynamic indices as ecological indicators of the development state of lake ecosystems. Ecological Indicators, n.6, p.30-42, 2006. ${ }^{67}$ LUDOVISI, A.; PANDOLFI, P.; TATICCHI, M.I. The strategy of ecosystem development: specific dissipation as an indicator of ecosystem maturity. J. Theor. Biol., n. 235, p. $33-43,2005$.

${ }^{68}$ SVIREZHEV (2000)

${ }^{69}$ Acrescentada por BENDORICCHIO e JøRGENSEN (1997). PATTEN, B.C. Network integration of ecological external principles: exergy, emergy, power, ascendency

and indirect effects. Ecological Modelling, v.79, p.75-84, 1995. 
Quadro 8 - Alguns indicadores de saúde ecossistêmica.

\begin{tabular}{|l|l|}
\hline \multicolumn{1}{|c|}{ Autor } & \multicolumn{1}{|c|}{ Indicador de saúde ecossistêmica } \\
\hline $\begin{array}{l}\text { Karr }(1991)^{70} \text { e Karr et } \\
\text { al. }(1986)^{71}\end{array}$ & $\begin{array}{l}\text { Os autores desenvolveram o Índice de Integridade Biológica (IBI, em inglês) } \\
\text { para a avaliação da qualidade de recursos hídricos, sendo bastante utilizado } \\
\text { nos Estados Unidos e na Europa. Constitui-se na integração de doze atributos } \\
\text { da biota (peixes) de um curso d'água. }\end{array}$ \\
\hline Hannon (1985) & $\begin{array}{l}\text { O autor desenvolveu o produto ecossistêmico bruto (GEP, em inglês), análogo } \\
\text { ao PIB. }\end{array}$ \\
\hline Rapport et al. (1985) & $\begin{array}{l}\text { Propuseram cinco indicadores de estresse ecossistêmicos: combinação de } \\
\text { nutrientes, produtividade primária, distribuição do tamanho, diversidade de } \\
\text { espécies e regressão do sistema (em direção a estágios anteriores). }\end{array}$ \\
\hline Constanza (1992) & $\begin{array}{l}\text { Propôs um índice sintético de saúde do sistema: HI=V.O.R, sendo HI: índice } \\
\text { de saúde; V: índice de vigor do sistema, expresso por uma medida cardinal } \\
\text { abrangendo atividade, metabolismo ou produtividade primária; O: índice de } \\
\text { organização do sistema, com valor de zero a um, fornecendo o grau relativo } \\
\text { de organização do sistema, incluindo sua diversidade e conectividade; R: } \\
\text { indice de resiliência do sistema, com valor de zero a um, fornecendo um grau } \\
\text { relativo de resiliência do sistema. }\end{array}$ \\
\hline $\begin{array}{l}\text { Dalsgaard }(1995)^{75} \text { e } \\
\text { ealsgaard }(1996)^{76}\end{array}$ & $\begin{array}{l}\text { O autor aplicou uma série de indicadores, incluindo biomassa (B), colheita } \\
\text { (H), ingresso de N (E), P/B, H/E, eficiência, índice de Shinn, índice de Finn, } \\
\text { ascendência, exergia, exergia estrutural e capacidade-tampão para } \\
\text { comparações quantitativas de maturidade ou sustentabilidade de quatro } \\
\text { agroecossistemas com diferentes graus de complexidade. }\end{array}$ \\
\hline
\end{tabular}

Fonte: XU e TAO (2000) mod.

\subsection{ECOEXERGIA}

Indicadores de saúde ecossistêmica bastante citados na literatura são os relacionados ao conceito de exergia.

A exergia é definida como "o máximo trabalho teórico útil obtido quando um sistema $S$ é trazido ao equilíbrio termodinâmico com o ambiente por meio de processos nos quais $\mathrm{S}$ interage somente com seu ambiente" (SCIUBBA e WALL, 2007, p.3). Um sinônimo de exergia é disponibilidade. O conceito de exergia ou

\footnotetext{
${ }^{70}$ KARR, J.R. Assessment of biotic integrity using fish communities. Fisheries, n.6, p.21-27.

${ }^{71}$ KARR, J.R. et al. Assessing biological integrity in running waters: a method and its rationale. Champaign: Illinois Natural History Survey, 1986. (Special publication 5).

${ }^{72}$ Referência não fornecida pelos autores

${ }^{73}$ RAPORT, D.J.; REGIER, H.A.; HUTCHINSON, T.C. Ecosystem behavior under stress. American Naturalist, n.125, p.617-40.

${ }^{74}$ CONSTANZA, R. Toward an operational definition of health. In: CONSTANZA, R. et al. (ed.). Ecosystem health: new goals for environmental management. Washington D.C.: Island Press, 1992.

${ }^{75}$ DALSGAARD, J.P.T. Applying systems ecology to the analysis of integrated agriculture aquaculture farms.

The ICLARM Quarterly, v.18, n.2, p.15-9, 1995.

${ }^{76}$ DALSGAARD, J.P.T. An ecological modelling approach towards the determination of sustainability in farming system. Royal Agriculture \& Veterinary, 1996.
} 
disponibilidade encontra-se formalizado, por exemplo, em VAN WYLLEN e SONNTAG (1976), WALL e GONG (2001) e WALL (2009). DEWULF et al. (2008a e 2008b) apresentam uma síntese do conceito. A exergia E de um sistema pode ser assim expressa (WALL e GONG, 2001):

$$
\mathrm{E}=\mathrm{U}+\mathrm{P}_{0} \mathrm{~V}-\mathrm{T}_{0} \mathrm{~S}-\Sigma_{\mathrm{i}} \mu_{\mathrm{i}} \mathrm{n}_{\mathrm{i}}
$$

sendo U: energia interna do sistema $\left[\mathrm{M} \cdot \mathrm{L}^{2} . \mathrm{t}^{-2}\right]$; V: volume do sistema $\left[\mathrm{L}^{3}\right]$; S: entropia do sistema $\left[\mathrm{M} . \mathrm{L}^{2} \cdot \mathrm{t}^{-3} \cdot \mathrm{T}^{-1}\right] ; \mathrm{n}_{\mathrm{i}}$ : número de moles das diferentes substâncias i no sistema; $\mathrm{P}_{0}$ : pressão do ambiente $\left[\mathrm{M} . \mathrm{L}^{-1} \cdot \mathrm{t}^{-2}\right] ; \mathrm{T}_{0}$ : a temperatura absoluta do ambiente $[\mathrm{T}] ; \mu_{\mathrm{i} 0}$ : potencial químico generalizado da substancia i no ambiente. Da expressão acima podem ser derivados, como casos especiais da exergia, todos os outros potenciais termodinâmicos, como a energia livre de Gibbs, a energia livre de Helmholz e a entalpia (WALL e GONG, 2001).

Como já dito, exergia é sinônimo de disponibilidade. O esloveno RANT (1956) apresenta os motivos de ordem conceitual e linguística para propor o termo Exergie no lugar de technische Arbeitsfähigkeit (literalmente, capacidade técnica de trabalho). SCIUBBA e WALL (2007) informam que a expressão “energia disponível” é devida a Gibbs e que o croata Bošnjakovic usava o termo Arbeitsfähigkeit como sinônimo da disponibilidade de Gibbs. Eles informam também que na prática levou 50 anos para a denominação proposta por Rant tornar-se de aceitação mundial e que alguns autores americanos ainda usavam o termo disponibilidade (availability). A argumentação utilizada por Rant é bastante interessante, constituindo-se apenas um dos elementos dela a etimologia proposta: segundo DIAZ e DOUGLAS (1993),

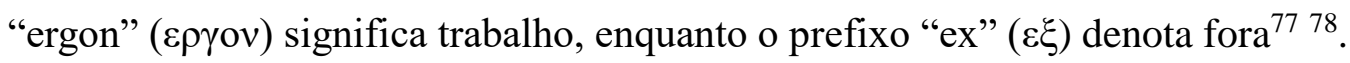

\footnotetext{
${ }^{77}$ Isso talvez solucione a questão, a nós frequentemente indagada, da pronúncia de exergia em português, se exssergia /cs/, ezergia /z/ ou egzergia /gz/. Em princípio, a pronúnica seria exsergia /cs/, porque $\xi$ tem, fora de dúvida, pronúncia "cs", não havendo, segundo DIAZ e DOUGLAS (1993), contradições entre a pronúnica helênica e a pronúnica erásmica. No entanto, HOUAISS e VILLAR (2001) informam haver em português duas preposições (que, obviamente, converteram-se em prefixos; v. CEGALLA (1971, p.89), uma de origem latina, ex/e, significando "movimento para fora, tirado de, acabamento", e outra de origem grega, exo, significando "fora, de fora, por fora, afora". Eles informam que o Vocabulário Ortográfico da Língua Portuguesa da Academia Brasileira de Letras registra 300 palavras com esses prefixos, sendo que delas 270 correspondem ao prefixo de origem grega. O Vocabulário Ortográfico registra tanto a pronúnica /z/ como /cs/ para o prefixo de origem grega, rejeitando a pronúncia /gz/, por considerá-la anglicismo ou francesismo. Uma vez que a palavra exergia não se encontra registrada em HOUAISS e VILLAR (2001), o mais completo dicionário da língua portuguesa, não saberíamos o que os eruditos propõem como pronúncia adequada. Considerando, porém, que todas as palavras constantes da referida obra com prefixo de origem grega
} 
Jørgensen postulou uma lei para ecossistemas: "Se um sistema tiver um fluxo de exergia por suas fronteiras, ele procurará utilizar tal fluxo de forma a aumentar sua exergia, isto é, mover-se para uma posição distante do equilíbrio termodinâmico; se mais combinações e processos forem oferecidos para utilizar o fluxo de exergia, a organização que for capaz de dar ao sistema a mais alta exergia, sob as condições e perturbações prevalecentes, será a selecionada" (JØRGENSEN, 1992, p.186). O que essa lei informa é que os ecossistemas se mantêm fora do equilíbrio termodinâmico com o meio, com um alto grau de organização e de informação em relação a esse meio, e que o fazem de tal forma que sua exergia seja máxima.

BENDORICCHIO e JØRGENSEN apud DEWULF et al. (2008, p.2223-4) propuseram calcular o conteúdo de exergia de um componente de ecossistema como a probabilidade de produzir o componente considerado no equilíbrio termodinâmico. Para os componentes biológicos de um ecossistema, ela consiste na probabilidade de produzir a matéria orgânica (termo clássico da exergia) e na probabilidade de encontrar o código genético, isto é, a sequência correta de nucleotídeos do DNA (termo da exergia informacional), sendo obtida uma expressão relacionando ambos

têm pronúncia recomendada /z/ (com exceção de uma, de pronúncia facultativa), parece-nos bastante razoável propor que exergia em português tenha pronúncia /z/.

${ }^{78}$ Bastante interessante é a origem da palavra entropia. JAYNES (1980) informa que sua passagem pela Universidade de Tübingen tornou possível desenredar o mistério da origem histórica da palavra "entropia", dando a entender que o crédito a isso deva ser dado ao Professor W. Güttinger. De acordo com Prigogine, ela veio do grego $\varepsilon v \tau \rho o \pi \eta$, significando "evolução". De acordo com Clausius (o propositor da palavra), ela vem de $\tau \rho \circ \pi \eta$, significando "volta", "ponto de inflexão", sendo que a mesma raiz aparece em isotrópico, fototrópico, troposfera, etc. Clausius afirma que ele adicionou o prefixo en- apenas para fazer a palavra parecer e soar como "energia", embora ele devesse ter notado que en- em grego, assim como em alemão e em inglês, é um prefixo padrão de modificação, e $\varepsilon v \tau \rho o \pi \eta$ (de acordo, segundo o autor, com três dicionários de grego e com dois "bons amigos" dele) significa "virar a cabeça de lado", ao invés de expressar o aspecto unilateral de S que ele descobriu. Uma vez que todo substantivo em alemão tem um gênero, ele também determinou, por motivos inexplicados, que die Entropie fosse uma palavra feminina. Apenas a título de comparação, DIAZ e DOUGLAS (1993) informam que o prefixo en- constitui-se na verdade no advérbio $\varepsilon v$, significando "em" (que é uma preposição), "dentro"; além disso, informam que $\tau \rho o \pi \circ \varsigma$ significa "direção", "particularidade". HOUAISS e VILLAR (2001) informam que a palavra foi criada por Clausius em 1865, significando "volta sobre si mesmo", ocorrendo no inglês em 1868 e 1875, difundindo-se pelo francês entropie a partir de 1877; segundo os autores, provém do grego entrope,es, significando "ação de voltar (-se), mudança de disposição ou de sentimento, ensimesmar-se". Ainda segundo esses autores, a raiz entropsignifica "ensimesmar-se (por medo ou por pudor)"; ocorre em cultismos da terminologia médica, com a acepção de "dobra, volta sobre si mesmo". Finalmente, esses autores informam que o prefixo en-, quando de origem grega, corresponde a um prefixo e um advérbio "em, dentro", sendo que 1) como prevérbio pode significar a) "em": "ver em ou sobre, observar em ou sobre, fixar os olhos sobre", "ligar em ou a"; b) "diante": "mostrar diante, designar, explicar, expor"; 2) associado a um adjetivo pode significar: a) "um pouco", com sentido de atenuação; b) "nos limites de, na medida de, de acordo com". 
os termos. A essência dessa teoria consiste justamente no fato de que a exergia do organismo e do ecossistema corresponde não somente a uma parcela referente a sua exergia física tal como definida na termodinâmica, mas também a uma parcela que considera a informação contida no organismo ou no ecossistema; toda a virtude e todas as possíveis críticas a essa teoria centram-se nisso. A exergia de organismos e de ecossistemas - que denominaremos a partir de agora como ecoexergia, como justificado abaixo - pode ser estimada por (SILOW, MOKRY e JØRGENSEN, 2011a e 2011b):

$$
\mathrm{Ex} / \mathrm{RT}=\Sigma_{\mathrm{i}=1, \mathrm{n}} \mathrm{c}_{\mathrm{i}} \cdot \beta_{\mathrm{i}} \quad\left[\mathrm{g} \text { detritus }{ }^{79} \cdot \mathrm{m}^{-3}\right]
$$

sendo Ex: ecoexergia total do sistema, em J; R: constante universal dos gases, no valor de 8,31 $\mathrm{J} \cdot \mathrm{Mol}^{-1} \cdot \mathrm{K}^{-1}$; T: temperatura absoluta do ambiente, em $\mathrm{K}$; $\mathrm{c}_{\mathrm{i}}$ : concentração da biomassa, em g.m ${ }^{-3} ; \beta_{\mathrm{i}}$ : fator de conversão ecoexergia-biomassa.

No anexo 1 é apresentada a justificativa da expressão acima. Embora ela esteja disponível nas referências apresentadas, sua discussão no anexo proporcionará a explicitação de pressupostos e o aclaramento de pontos. Além disso, esforçamo-nos por integrar distintas referências bibliográficas e, na medida do possível, torná-las mais palatáveis.

Fica claro, a partir das considerações do anexo, que a estimativa da ecoexergia é feita tomando como estado de referência não o ambiente, como no caso da exergia termodinâmica, mas detritus. Fica evidenciado também que se trata apenas de uma primeira aproximação, grosseira, até mesmo porque não foi considerada a informação constante das redes ecossistêmicas. Finalmente, a demonstração esclarece o motivo pelo qual é mais cômodo descrever a exergia em

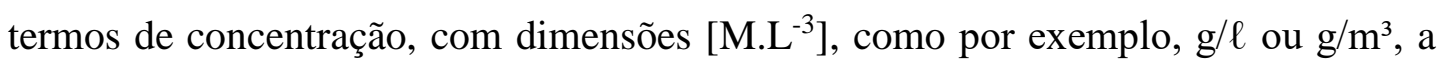

\footnotetext{
${ }^{79}$ Detritus, neste contexto, corresponde a elementos orgânicos abióticos de um ecossistema, na forma, por exemplo, de carboidratos, lipídios e protídeos. Uma vez que no nosso idioma a palavra detrito dá ideia de resto, sobra, rejeito, ou, mais explicitamente, o resultado de um processo de desintegração, sendo proveniente do latim detritus, a, um "retirado, suprimido, rejeitado", particípio passado do verbo latino detere "tirar esfregando, gastar, enfraquecer", sendo etimologicamente associado a trépano, tritura, atrito, tribulação, trigo (porque triturado), detrimento, contrição, deterioração (HOUAISS e VILLAR, 2001), não havendo, ao que parece, algo que se aproxime do sentido de "matéria orgânica sem vida" ou "partículas de matéria orgânica", a não ser eventualmente por estrangeirismo, pareceunos mais adequado ao longo desta tese manter a forma do latim, que é a que comparece em inglês, sendo por isso necessário manter a palavra em itálico. Não é esse o entendimento, por exemplo, de GOMES e VARRIALE (2004, p.172) que, mesmo no âmbito da teoria da ecoexergia de Jørgensen, usam simplesmente a palavra "detrito".
} 
descrevê-la em dimensões [M.L $\left.{ }^{2} \cdot \mathrm{t}^{-2}\right]$, como por exemplo J.

Uma vez que a expressão acima tem como estado de referência uma sopa de detritus e que sintetiza não exatamente a disponibilidade termodinâmica do ecossistema, mas também a probabilidade de ser selecionada sua correspondente informação genética, houve-se por bem denominar o conceito assim expresso como ecoexergia.

SCIUBBA e WALL (2004) e DE WIT (2005) apresentaram críticas a essa abordagem. Assim, os dois primeiros assim se manifestaram, com bastante severidade:

Seus trabalhos [de Jørgensen e outros autores que desenvolveram diversas aplicações de uma análise aproximada de exergia de sistemas biológicos] são, em nossa opinião, caracterizados por um alto grau de originalidade e insight biológico, mas também por uma ausência de rigor termodinâmico: a maioria de suas aplicações baseia-se em princípios de equilíbrio e são aplicadas a seres vivos, que, por definição, são sistemas distantes do equilíbrio. Os trabalhos originais nos quais tais linhas de pesquisa se enraízam são aqueles de Knizia (1986) e, é claro, o famoso livro de Schrödinger (1944), ambos os quais são muito mais rigorosos e não lançaram mão de recursos algo arbitrários de "princípios adicionais da termodinâmica". Outra linha de pesquisas foi direcionada para a definição de modos e métodos de análise energética de estruturas complexas, sempre consideradas como sistemas interagindo com a biosfera: Nielsen (1995, 1997), Bendoricchio e Joergensen (1997), Bianciardi e Ulgiati (1998), Svirezhev (1997, 2000), Szargut (2003) publicaram trabalhos relevantes nesse campo. (...) Em algumas análises de sistemas de seres vivos, o uso de uma "exergia de informação" é proposto. A exergia é considerada como o correspondente à "informação" genética contida no DNA. Nós devemos observar que: a) não há ligação provada entre exergia e informação, exceto em um senso estritamente físico especificado [abaixo]; b) "termodinâmica da vida" - se um tal objeto existe! - vai bem além da "transmissão da informação". (SCIUBBA e WALL, 2007, p.22 e 25).

De Wit é um pouco mais amistoso, valendo a pena transcrever o trecho seguinte:

Eu acredito que esta abordagem [cálculo de um índice de exergia] corresponde a uma aproximação muito boa da distância de ecossistemas do equilíbrio termodinâmico, mas eu entendo ser muito difícil fazer a ligação entre esse índice e a definição original de exergia no sentido de uma medida da capacidade de trabalho de um sistema. Eu não vejo como a amplificação exergética decorrente do armazenamento de energia possa ser liberada na forma de trabalho. Simplesmente de um ponto de vista prático, quando predadores se alimentam de uma presa eles usam o conteúdo de energia livre da biomassa da presa, mas eles não podem extrair energia livre da informação energética incorporada nos genes. A informação genética é simplesmente destruída nessas interações; felizmente, isso não é tão dramático como parece, porque enquanto os predadores não provocarem a extinção da presa, a informação redundante persistente propiciará o restabelecimento das populações de presas (Margalef, 1968). Eu reconheço que os cálculos do "índice de exergia" ou de "exergia" são consistentes com uma aplicação formal do potencial químico, o que inclui a ponderação de probabilidades extremamente pequenas de encontrar organismos complexos quando comparadas com o 
ambiente abiótico de referência. Não obstante, esse índice é absolutamente inútil para cálculos bioenergéticos e infelizmente é muito diferente do que é intencionado quando se sugere que os ecossistemas são dependentes de fluxos de exergia. (DE WIT, 2005, p.432).

Para o uso da ecoexergia em modelagem, âmbito no qual se admite uma função de maximização dessa grandeza, e nas avaliações da qualidade dos ecossistemas (como veremos mais adiante), cumpre estimar os fatores de correlação entre concentração e ecoexergia (JØRGENSEN et al., 2005; FONSECA et al., 2002). As primeiras estimativas dos fatores de correlação baseavam-se no dogma central da genética: DNA produz RNA, RNA produz proteínas, entre as quais se situam as enzimas, catalisadoras de todas as reações bioquímicas. Para tal, era necessário o conhecimento do número de genes de cada espécie. No entanto, a disponibilidade de tais informações é bastante limitada. A fim de facilitar a operacionalização do conceito, propôs-se que os $\beta$ s fossem correlacionados à quantidade total de DNA nuclear (valor C), muito mais fácil de ser medida. No entanto, empiricamente não se observa uma correlação entre a complexidade estrutural dos organismos e os valores C (o que é chamado de paradoxo do valor C) ${ }^{80}$, dada a existência dos assim chamados junk genes. Por outro lado, o dogma central da genética passou a ser contestado (EDDY, 2001; MATTICK, 2003), constatando-se que muitos genes escondidos trabalham por meio do RNA e que alguns deles desempenham um importante papel no controle, manutenção e desenvolvimento dos organismos. Disso decorreu a necessidade de enriquecer, ajustar e corrigir a tabela de fatores de correlação, o que foi feito levando em conta o número de tipos de células de cada organismo, a razão entre o non-coding DNA e a quantidade total de DNA, a mínima quantidade de DNA em uma unidade taxonômica (procedimento de segurança decorrente do paradoxo do valor $\mathrm{C}$ ), a idade evolutiva das espécies e a quantidade de

\footnotetext{
80 "Nos estudos iniciais da complexidade associada ao DNA, assumia-se que os organismos mais "avançados" (tais como os humanos) eram mais complexos, em algum sentido não especificado, e a expectativa era que a geração de maiores complexidades requereria mais genes e genomas maiores (Britten e Davidson, 1969; Sparrow et al., 1972). Na maior parte das vezes, essas expectativas foram frustradas. Baseados em dados limitados (Cavalier-Smith, 1985; Szathmáry e Maynard Smith, 1995), a correlação entre ‘avanço' e tamanho do genoma (também chamado de valor C) é fraca. A correlação com número de genes é melhor, mas as estimativas disponíveis colocam humanos na mesma posição de peixes pulmonados (Szathmáry e Maynard Smith, 1995). O comportamento rebelde dessas variáveis foi chamado de 'paradoxo do valor C', mas para a complexidade tal paradoxo não existe. De fato, a ausência de uma correlação entre estrutura e mecanismo de geração não é surpreendente, especialmente ao longo da enorme diferença de escala que separa moléculas de DNA e a morfologia do organismo inteiro.” (McSHEA, 1996, p.482).
} 
DNA nuclear. Finalmente, elaborou-se uma tabela de fatores de correlação considerando as árvores evolutivas. Os valores obtidos devem ser considerados apenas como uma primeira aproximação da informação genética e não levam em conta a informação contida nas redes biológicas dos ecossistemas. A tabela 2, constante de SILOW e MOKRY (2010), apresenta uma versão na qual são consideradas as correções acima. Selecionamos: a) monocotiledôneas: $\beta=393$; b) eucotiledôneas: $\beta=268$; c) gimnospermas: $\beta=314$; d) pteridófitas: $\beta=146$; e) briófitas: $\beta=173$ (mas para arroz e mostarda silvestre, ambas angiospermas, fornecem-se os valores 275 e 143 , respectivamente).

WALL (2009, p.70-8) relaciona a exergia física à informação por meio da seguinte expressão:

$$
\mathrm{E}=\mathrm{k} \ell \mathrm{n} 2 \mathrm{~T}_{0} \mathrm{I}
$$

sendo E: exergia (J); k: constante de Boltzmann $\left(1,38054.10^{-23} \mathrm{~J}^{-\mathrm{K}^{-1}}\right)$; $\mathrm{T}_{0}$ : temperatura absoluta do ambiente (K); I: informação ou capacidade de informação, expressa em binary units (bits). Assim, à temperatura ambiente, a quantidade de exergia relacionada a 1 bit de informação é aproximadamente $2,9.10^{-21} \mathrm{~J}$.

Analogamente, SVIREZHEV (2000) desenvolveu aplicações da medida de Kullback, situada no âmbito da Teoria da Informação, correspondente à medida da informação adicional a uma distribuição previamente conhecida, à expressão da ecoexergia.

No anexo 1 encontra-se o detalhamento formal da obtenção das expressões de ecoexergia. No anexo 2 estão apresentadas relações entre exergia física, ecoexergia e informação. 
Tabela 2 - Fatores de conversão exergia-biomassa de diferentes grupos de organismos.

\begin{tabular}{|c|c|c|c|c|c|}
\hline Grupo & & $\boldsymbol{\beta}$ & Grupo & & $\boldsymbol{\beta}$ \\
\hline Células mínimas & & 5,8 & Brachiopoda & & 109 \\
\hline Bactérias & & $8,5-12$ & $\begin{array}{l}\text { Plantas vasculares } \\
\text { sem sementes }\end{array}$ & & 158 \\
\hline Archaea & & 13,8 & Rotifera & & 163 \\
\hline Levedura & & 18 & Insecta & & $\begin{array}{c}167- \\
446 \\
\end{array}$ \\
\hline \multirow[t]{7}{*}{ Algas } & & $15-298$ & & Chironomida & 300 \\
\hline & $\begin{array}{l}\text { Ciano- } \\
\text { bactérias }\end{array}$ & 15 & Musgos & & 174 \\
\hline & Dinófitas & 18 & Crustáceos & & $\begin{array}{c}230- \\
300\end{array}$ \\
\hline & $\begin{array}{l}\text { Microalgas } \\
\text { verdes }\end{array}$ & 20 & & Cladocera & 232 \\
\hline & Diatomáceas & 66 & & Copepoda & 240 \\
\hline & $\begin{array}{l}\text { Macrófitas } \\
\text { (algas) }\end{array}$ & $67-298$ & & Amphipoda & 290 \\
\hline & Rodófitas & 92 & Moluscos & & $\begin{array}{c}297- \\
450 \\
\end{array}$ \\
\hline \multirow[t]{3}{*}{ Protozoários } & & $31-97$ & & Bivalves & 297 \\
\hline & Amebas & 38 & & Gastropoda & $\begin{array}{c}312- \\
450\end{array}$ \\
\hline & Gastrotricha & 97 & Gimnospermas & & 314 \\
\hline Fungos & & 61 & Macrófitas (fanerógamas) & & $\begin{array}{c}356- \\
520\end{array}$ \\
\hline Nemertina & & 76 & Plantas com flores & & $\begin{array}{l}393- \\
543 \\
\end{array}$ \\
\hline \multirow[t]{5}{*}{ Vermes } & & $91-133$ & Peixes & & $\begin{array}{l}499- \\
800 \\
\end{array}$ \\
\hline & Cnidaria & 91 & Anfíbios & & 688 \\
\hline & Platelmintos & 120 & Répteis & & 833 \\
\hline & Oligoquetas & 130 & Aves & & 980 \\
\hline & Nematoda & 133 & Mamíferos & & 2127 \\
\hline Esponjas & & 98 & Homo sapiens & & 2173 \\
\hline
\end{tabular}

Fonte: SILOW e MOKRY (2010)

Nota:

Recomendamos consulta às referências originais antes do uso de qualquer informação.

\subsection{ECOEXERGIA COMO INDICADOR PRIVILEGIADO PARA A SAÚDE}

\section{ECOSSISTÊMICA}

JØRGENSEN (2006) apresenta a argumentação seguinte para justificar o lugar privilegiado ocupado por indicadores relacionados ao conceito de ecoexergia na avaliação da saúde de ecossistemas:

a) JØRGENSEN, PATTEN e STRAŠKRABA (2000) ${ }^{81}$ apud JØRGENSEN (2006) propuseram que o crescimento e o desenvolvimento de um ecossistema podem ser

${ }^{81}$ JØRGENSEN, S.E.; PATTEN, B.C.M.; STRAŠKRABA, M. Ecosystem emerging: 4. Growth. Ecol. Model., v.126, p.249$84,2000$. 
descritos por três formas de crescimento: i) crescimento da biomassa ou da estrutura físico-biológica; ii) crescimento da rede - cada vez mais componentes são ligados em uma rede permanentemente em crescimento; iii) crescimento da informação cada vez mais organismos complexos estrategistas do tipo $\mathrm{K}$ ao invés do tipo $\mathrm{r}$ tornam-se crescentemente dominantes;

b) VON BERTALLANFFY (1952) ${ }^{82}$ apud JØRGENSEN (2006) caracterizou a evolução de sistemas complexos em termos de quatro maiores atributos: i) integração progressiva (desenvolvimento de ligações); b) diferenciação progressiva (aumento da diversidade); iii) mecanização progressiva (aumento de mecanismos de retroalimentação e regulação); iv) centralização progressiva (maior cooperação entre os organismos). Jørgensen argumenta que os quatro maiores atributos de Bertallanffy estão relacionados às três formas de crescimento: i) integração progressiva corresponde ao crescimento da rede; ii) diferenciação progressiva corresponde ao crescimento da informação e parcialmente ao da rede; iii) mecanização progressiva corresponde principalmente ao crescimento da rede pelo fato de retroalimentações e regulações conectarem componentes, aumentando o número de retroalimentações com a complexidade dos organismos; iv) a centralização progressiva é coberta pelo crescimento da informação;

c) JØRGENSEN (2006) mostra que as três formas de crescimento claramente cobrem os mais importantes dos atributos de Odum (ODUM, 1969, ${ }^{83}$ apud JØRGENSEN, 2006), conforme apresentado no quadro 9;

d) JØRGENSEN (2006) mostra que os seis elementos propostos por Constanza para caracterizar a saúde ecossistêmica (v. penúltima linha do quadro 8) podem ser traduzidos nas três formas de crescimento, conforme apresentado no quadro 10;

e) JØRGENSEN, PATTEN e STRAŠKRABA (2000) apud JØRGENSEN (2006) argumentaram que ocorre um aumento da exergia com as três formas de crescimento: i) o aumento da biomassa está em concordância com a definição de exergia e com a equação proposta para estimar exergia; ii) quando a rede cresce, mais retroalimentações ocorrem e a exergia capturada pelo ecossistemas é mais bem utilizada; consequentemente, a exergia também cresce, principalmente devido ao

${ }^{82}$ VON BERTALLANFFY, L. Problems of life: an evaluation of modern biological thought. New York: Wiley, 1952.

${ }^{83}$ ODUM, E.P. The strategy of ecosystem development. Science, v.164, p.262-70, 1969. 
aumento de biomassa porque o ecossistema pode sustentar mais biomassa quando a exergia capturada é melhor utilizada; iii) o aumento da informação significa que o fator $\beta$ da equação de ecoexergia aumenta, o que implica aumento da exergia. Jørgensen conclui que "a ecoexergia aumenta com as três formas de crescimento e as três formas de crescimento são consistentes com a percepção usual de desenvolvimento do ecossistema. A ecoexergia pode, portanto, ser usada como um indicador holístico da saúde e do desenvolvimento ecossistêmicos" (JØRGENSEN, 2006, p.28).

Quadro 9 - Correspondência entre alguns dos atributos de Odum e formas de crescimento segundo JØRGENSEN et al. (2000).

\begin{tabular}{|l|l|c|}
\hline \multicolumn{1}{|c|}{ Sistema em estágio inicial } & \multicolumn{1}{c|}{ Sistema maduro } & Forma de crescimento \\
\hline P/B alto (B é baixo) & P/B alto (B é alto) & I \\
\hline R/B alto & R/B baixo & I \\
\hline Poucas retroalimentações & Muitas retroalimentações & II \\
\hline Baixa biodiversidade & Alta biodiversidade & III \\
\hline Rede simples & Rede complexa & II \\
\hline Baixa capacidade-tampão & Alta capacidade-tampão & II + III \\
\hline Poucos nichos ecológicos & Muitos nichos ecológicos & III \\
\hline Estrategistas r & Estrategistas K & III \\
\hline
\end{tabular}

Fonte: JØRGENSEN (2006)

Nota:

P: produção; B: biomassa; R: respiração.

Quadro 10 - Correspondência entre indicadores de saúde ecossistêmica de Constanza e formas de crescimento segundo JØRGENSEN et al. (2000).

\begin{tabular}{|l|c|}
\hline \multicolumn{1}{|c|}{ Indicadores de saúde ecossistêmica de Constanza } & Correspondente forma de crescimento \\
\hline Homeostase & II + III \\
\hline Ausência de doença & I \\
\hline Diversidade ou complexidade & II III \\
\hline Estabilidade ou resiliência & Capacidade-tampão é proporcional à exergia \\
\hline Vigor ou escopo para crescimento & \multicolumn{1}{|c|}{ I + II + III } \\
\hline Equilíbrio entre componentes do ecossistema & Exergia específica \\
\hline
\end{tabular}

Fonte: JØRGENSEN (2006) 
Segundo JØRGENSEN (2006), os aspectos ecossistêmicos cobertos pelo indicador de ecoexergia são: a) distância do equilíbrio termodinâmico, ou seja, uma medida geral da complexidade ecossistêmica; b) estrutura (tamanho da biomassa e da rede) e função (informação); c) sobrevivência expressa como biomassa e informação. Os aspectos ecossistêmicos cobertos pelo indicador de ecoexergia específica (ecoexergia por unidade de biomassa) são: a) tamanho da rede e eficiência na utilização exergética, na medida em que mais organismos podem ser suportados pelo ecossistema; b) informação carregada pelos organismos e os efeitos de melhores regulações e sinergia entre organismos ou grupo de organismos.

SILOW e MOKRY (2010), a partir de revisão bibliográfica, compilaram uma correlação entre indicadores ecossistêmicos baseados em exergia e outros indicadores de estado ecossistêmico (quadro 11).

Tivemos oportunidade de realizar pesquisa bibliográfica sobre a utilização do conceito de ecoexergia em ecossistemas e na avaliação da saúde ecossistêmica em particular, tendo encontrado os seguintes trabalhos: JØRGENSEN (2006), SILOW e MOKRY (2010) - ambos já mencionados -, AUSTONI et al. (2007), FABIANO et al. (2004), FONSECA et al. (2002), JØRGENSEN (2000), JØRGENSEN, MARQUES e NIELSEN (2002), LIBRALATO, TORRICELLI e PRANOVI (2006), LU et al. (2011), LUDOVISI e POLETTI (2003), MARCHI et al. (2011), MARQUES et al. (1997), MOLOZZI et al. (2013), PUSCEDDU e DANOVARO (2009), SALAS et al. (2003), SILOW, MOKRY e JØRGENSEN (2011a), SILOW (2012), SILOW et al. (2011c), VASSALLO et al. (2006), XU et al. (1999), XU, JØRGENSEN e TAO (1999), XU et al. (2004), XU et al. (2005), XU, CHEN e ZHAO (2011), XU et al. (2011), XU et al. (2012), e ZHANG, YANG e YANG (2013).

MUYS e QUIJANO (2002) estruturaram um sistema de indicadores ecológicos destinados à avaliação de impactos de uso da terra a partir de considerações de maximização de ecoexergia, por meio das quais postularam que para qualquer local a vegetação potencial natural, isto é, o clímax, constitui-se no ecossistema com o mais alto controle energético possível para o local, sendo por isso considerado como referencial no método proposto pelos autores. Dessa forma, eles definiram 19 indicadores, agrupados em 4 temas (solo, água, vegetação e biodiversidade). 
A exergia armazenada em diversos ecossistemas é apresentada na tabela 3 , obtida de FATH et al. (2004).

Quadro 11- Correlação entre vários indicadores baseados em exergia e outros indicadores de estado ecossistêmico.

\begin{tabular}{|c|c|c|}
\hline Parâmetro & $\begin{array}{l}\text { Exergia, ecoexergia, } \\
\text { índice de exergia }\end{array}$ & $\begin{array}{c}\text { Exergia estrutural, } \\
\text { ecoexergia específica, } \\
\text { índice de exergia } \\
\text { específica }\end{array}$ \\
\hline Biomassa total & Positiva & - \\
\hline Biomassa de fitoplâncton & Negativa & Negativa \\
\hline Biomassa de zooplâncton & Positiva & Positiva \\
\hline Transparência pelo disco de Secchi & Positiva & Positiva \\
\hline Biomassa bacteriana & Positiva & Negativa \\
\hline Biomassa de peixes & - & Positiva \\
\hline Biomassa bêntica & Positiva & - \\
\hline Biodiversidade como riqueza de espécies & Positiva & Positiva \\
\hline Biodiversidade como heterogeneidade & Positiva & - \\
\hline Índice de Shannon-Wiener & Positiva & Positiva \\
\hline Índice de Margalef & Positiva & Positiva \\
\hline Raridade de Pielou & Positiva & Positiva \\
\hline $\begin{array}{l}\text { Razão entre biomassa de zooplâncton e biomassa } \\
\text { de fitoplâncton }\end{array}$ & Positiva & Positiva \\
\hline Estado trófico & Positiva & Negativa \\
\hline Índice de estado trófico de Carlson & Negativa & Negativa \\
\hline Capacidade-tampão do zooplâncton & Positiva & - \\
\hline Índice de Avaliação Ecológica & Positiva & Positiva \\
\hline Informação de Fisher & Negativa & - \\
\hline Emergia & Positiva & Positiva \\
\hline Ascendência & Positiva & Positiva \\
\hline
\end{tabular}

Fonte: SILOW e MOKRY (2010)

Para estimativas grosseiras da ecoexergia armazenada em diferentes locais, pode ser interessante conhecer o valor numérico da biomassa de florestas secundárias em zonas tropicais, informação essa apresentada por LIMA (2010). Uma vez que tal tabela informa apenas a respeito da biomassa acima do solo, é útil o trabalho de FORSTER e MELO (2007), que estudaram a distribuição proporcional da biomassa, pelos compartimentos, de 120 árvores de 44 espécies plantadas em reflorestamentos 
ciliares no Médio Vale do Paranapanema, SP. Eles concluíram que o percentual de biomassa das raízes representa em média algo como $20 \%$.

Tabela 3 - Exergia armazenada em diversos ecossistemas.

\begin{tabular}{lc}
\hline \multicolumn{1}{c}{ Ecossistema } & Exergia armazenada $\left(\mathbf{M J} / \mathbf{m}^{2}\right)$ \\
\hline Área de caça (querry) & 0 \\
\hline Semiárido & 0,07 \\
\hline Área aberta (clear-cut) & 0,59 \\
\hline Gramado (grassland) & 0,94 \\
\hline Douglas fir plantation de 25 anos & 12,70 \\
\hline Floresta natural (growing forest) de 23 anos & 26,00 \\
\hline Fir forest de 400 anos & 38,00 \\
\hline Floresta tropical & 64,00 \\
\hline
\end{tabular}

Fonte: FATH et al. (2004)

Nota:

Recomendamos consulta às referências originais antes do uso de qualquer informação.

\subsection{PROPOSTA DE INDICADOR DA SAÚDE ECOSSISTÊMICA DE BIÓTOPOS PARA FINS DE UTILIZAÇÃO EM INSTRUMENTOS NORMATIVOS}

O conceito de integridade ecossistêmica de Kay não se presta à criação de indicadores. Isso porque a dinâmica de sistemas do tipo SOHO é descrita por narrativas, sendo questão central na descrição narrativa desses sistemas uma elaboração de suas propensividades. O conceito de integridade ecossistêmica de Müller é operacionalizado por diversos indicadores, o que se afasta de nossa proposta de uma norma simples. Porém, o conceito de saúde ecossistêmica de Jørgensen é bastante promissor.

$\mathrm{Na}$ norma urbanístico-ambiental, entenderemos o lote como uma bacia, no que se referir a aspectos hidráulico-hidrológicos, e como um conjunto de biótopos superficiais, no que se referir a questões ecossistêmicas. Propomos aqui uma supersimplificação do conceito de ecoexergia de maneira a obtermos um indicador 
da qualidade ecossistêmica para cada biótopo. Assim, propomos que seja considerada a concentração superficial (em unidade quilograma de detritus equivalente por metro quadrado), e não a volumétrica (quilograma de detritus equivalente por metro cúbico), de forma que a exergia seja calculada nas unidades dessa concentração, e que sejam consideradas apenas as espécies mais visíveis dos biótopos, ou, caso se prefira, das tecnologias verdes superficiais. Tal indicador se prestaria bem a textos legais porque aos empreendedores que queiram obter maior flexibilidade, afastandose assim dos valores e soluções default aceitos, seria facultado propor soluções paisagísticas diferentes, justificáveis por meio da apresentação de um memorial de cálculo no qual seria estimado o indicador de ecoexergia do lote como um todo associado à solução apresentada.

Seria necessário estabelecer padrões legais para a ecoexergia superficial total do lote, padrões esses que variariam segundo a área do lote, seu uso e sua localização na cidade. Em uma primeira versão, apresentamos a sugestão seguinte, que foi refutada ao longo das discussões da QA. Assim, temos que o Código de Obras e Edificações (COE) do Município de São Paulo (SÃO PAULO [CIDADE], 1993) estabelece a exigência de $15 \%$ da área do lote livre de pavimentação ou impermeabilização ${ }^{84}$ ou a construção de reservatório de detenção. CAETANO et al. (2001) apresentaram uma crítica a tais exigências. Parece, ou pelo menos parecia, haver certo consenso em termos de ampliar a área livre de pavimentação e construção para $30 \%$ da área do lote (no entanto, essa providência não substitui a construção de estruturas hidráulicas de lote destinadas a abater o hidrograma de saída do lote e aumentar o lag). Tal corresponderia, no caso de se utilizar grama batatais (6t/ha, segundo PEREIRA, 2008), a um valor numérico da ecoexergia superficial da ordem de 70 quilogramas de detritus equivalente por metro quadrado de terreno (chamaremos provisoriamente essa unidade de $\mathrm{kgde} / \mathrm{m}^{2} \mathrm{t}$ ). Assim, esse poderia ser o valor mínimo a constar no texto do Código de Obras e Edificações, podendo a legislação de zoneamento estabelecer valores mais rigorosos para diferentes usos e localizações. O código deveria também estabelecer $15 \%$ da área do lote como constituída necessariamente por área vegetada, não se permitindo a existência de existência de estruturas, e, se permitida, qual a espessura máxima do solo. 
estruturas sob essa área, por mais profundas que fossem.

$* * *$

Caso esse indicador seja utilizado em sistemas normativos, é importante ter em mente algumas simplificações que foram admitidas, conforme apresentado ao longo desta tese:

a) a ecoexergia não corresponde exatamente à disponibilidade termodinâmica do ecossistema porque os referenciais adotados são diferentes;

b) as estimativas dos fatores de correlação entre a ecoexergia e a concentração são bastante grosseiros;

c) o cálculo da ecoexergia não leva em consideração a informação contida na estrutura dos ecossistemas;

d) o indicador aqui adotado corresponde a uma simplificação do cálculo da ecoexergia. 


\section{MELHORIA DO MICROCLIMA}

\subsection{ESCOLHA DE UMA MÉTRICA PARA O MICROCLIMA}

Cumpre-nos escolher uma métrica para o microclima que se mostre adequada para o instrumento urbanístico-ambiental que temos em vista. Na prática, procuraremos fazer com que essa métrica para microclima seja de alguma maneira ligada à métrica de qualidade ecossistêmica. A justificativa de um tal resultado se fará por meio de algumas etapas encadeadas.

\section{A evapotranspiração como métrica do microclima}

Desejamos correlacionar microclima a qualidade ecossistêmica, ou microclima a vegetação. Temos, portanto, que procurar uma métrica adequada a partir da fisiologia das plantas. Esta, no entanto, é extremamente complexa, como podemos aquilatar, por exemplo, em NOBEL (2005) ou DE PURY e FARQUHAR $(1997)^{85}$. Mesmo modelos da fisiologia de folhas revelam-se relativamente complexos, ou pelo menos trabalhosos (v., p.ex., modelo de fotossíntese, transpiração e condutância de FRIEND, 1995, ${ }^{86}$ apud GOMES e VARRIALE, 2004, p. 234-46; para a big-leaf theory, v. FRIEND, 2001). Em sendo assim, há necessidade de buscar métricas simplificadas.

DUARTE (2010), por exemplo, obteve para a cidade de São Paulo algumas correlações entre atributos do microclima e da vegetação, uma das quais foi:

$$
\operatorname{tar}=25,9488+0,8769 . \mathrm{CA}-0,0362 \cdot \mathrm{TO}-0,0616 \text {.verde }-0,0031 \text {.água } \quad \mathrm{r}^{2}=0,985
$$

sendo tar: temperatura do ar em dezembro de 2003 (verão) às $18 \mathrm{~h}\left({ }^{\circ} \mathrm{C}\right)$; $\mathrm{CA}$ : coeficiente de aproveitamento urbano (inclui vazios urbanos e vias); TO: taxa de

\footnotetext{
${ }^{85}$ Um apanhado (antigo) de bioclimatologia vegetal pode ser encontrado em OMETTO (1981).

${ }^{86}$ FRIEND, A.D. Integrated model for photosynthesis of leaves, transpiration and conductance. Ecological Modelling, v.75, p.123-34, 1994.
} 
ocupação urbana (inclui vazios urbanos e vias) (não informado se razão ou porcentagem); verde: projeção de área das copas de árvores (unidade não informada; aparentemente se trata de porcentagem de área na superfície homogênea escolhida); água: área de espelhos d'água (unidade não informada; aparentemente se trata de porcentagem de área na superfície escolhida). Correlações como essa poupam-nos, em nível de planejamento, do ônus de lidar com modelos microclimáticos complexos ou de considerações relacionadas a aspectos aprofundados da fisiologia botânica.

TAKÁCS, KISS e GULYÁS (2014) realizaram pesquisa bibliográfica a partir da qual concluíram que os melhores indicadores de microclima segundo a vegetação são sombreamento, evapotranspiração e efeito local de espaços verdes. McPHERSON, KREMER e HAMSTEAD (2012) utilizaram como indicador de microclima as trocas de calor latente da vegetação com a atmosfera. LANDSCHAFT... et al. (1990, p.6) propõem a evapotranspiração como indicador de melhoria do microclima e da higiene do ar.

Do exposto, parece que estamos autorizados a utilizar a evapotranspiração e o sombreamento (projeção das copas de árvores) como métricas adequadas ao fim a que nos propusemos. Superfícies vegetadas não arbóreas obviamente contribuem para a evapotranspiração. No caso de árvores, um indicador da evapotranspiração pode ser a área de folhagem ou a biomassa de folhas. GSPALTL e STERBA (2011) informam existir correlações entre a projeção das copas e a área foliar. Interessa-nos saber a função utilizada para as correlações. Assim, se ocorrer de a área foliar (LA) ou a biomassa foliar (FB) serem diretamente proporcionais à projeção da copa (CA), então poderemos dispensar a área sombreada como parte de um índice agregado para microclima urbano (a menos, evidentemente, da contribuição de áreas vegetadas não arbóreas). Em outros termos, desejamos que a função entre LA ou FB em função de CA sejam do tipo LA $\alpha \mathrm{CA}$ ou FB $\alpha \mathrm{CA}$

BARTELINK (1997) obteve para faias relação alométrica entre LA e CA na forma de função de potência. Ocorre que o expoente a que a variável é elevada é quase igual à unidade nas equações alométricas obtidas. Postulamos que esse resultado é válido para outras espécies. Assim, é razoável usar a evapotranspiração como métrica de microclima. 
A evapotranspiração como métrica da degradação de exergia

Como verificamos, SCHNEIDER e KAY (1994) postularam um princípio de maximização de degradação de exergia. A degradação de exergia em ecossistemas está estreitamente relacionada à transpiração e à respiração. A evaporação está relacionada à energia que já foi dissipada e que não mais causará desequilíbrio, enquanto a radiação de onda longa reirradiada e o fluxo de calor sensível representam energia que não foi degradada. Daí temos que quanto maior o desenvolvimento do ecossistema, maior a evapotranspiração, menor a reirradiação de onda longa, menor o fluxo de calor sensível e menor a temperatura. A tabela 4 mostra que o argumento acima tem amparo empírico.

Verificamos, portanto, que evapotranspiração e degradação de exergia estão relacionados.

Máxima degradação de exergia e máximo armazenamento de exergia: condições para que a ecoexergia sirva como métrica da degradação de exergia

O princípio da máxima degradação de exergia de Kay e Schneider não se confunde com o princípio de máximo armazenamento de Jørgensen. Um trata de fluxos, outro de quantidade armazenada.

Cumpre observar, porém, que as teorias de Jørgensen e de Kay não são tão incompatíveis como pareceria à primeira vista. KAY et al. (1999) fizeram uma leitura de trabalho de HOLLING (1986, 1992), expresso em seu modelo de quatro caixas, que compatibiliza os dois conceitos. Hearnshaw, Cullen e Huguey (s.d.) entendem que Holling, com esse trabalho, foi "o primeiro que desenvolveu um meio de modelar especificamente o desenvolvimento de ecossistemas, com os princípios de emergência, complexidade, evolução e integridade de auto-organização sendo intuitivamente incorporados" (HEARNSHAW, CULLEN e HUGUEY, s.d., p.18). JØRGENSEN, NIELSEN e MEJER (1995) já haviam observado grandes afinidades conceituais entre os conceitos de ecoexergia e ascendência. ULANOWICZ, JØRGENSEN e FATH (2006) demonstraram complementaridades entre os conceitos de ascendência, ecoexergia acumulada, dissipação de ecoexergia e aggradation. 
FATH, PATTEN e CHOI (2001) lograram demonstrar formalmente a complementaridade e a consistência mútua entre dez indicadores ecológicos: máxima potência (Lotka), máximo armazenamento (Jørgensen-Mejer), máximo empoderamento e emergia (Odum), máxima ascendência (Ulanowitz), máximo tempo de residência (Cheslak-Lamarra), máxima dissipação (Schneider-Kay), máxima ciclagem (Morowitz), mínima dissipação específica (Onsager, Prigogine) e mínima razão entre empoderamento e exergia (Bastianoni-Marchettini). Esse notável resultado sugere um padrão comum e consistente para o desenvolvimento de ecossistemas. FATH et al. (2004), a partir de considerações teóricas e simulações, propuseram que alguns princípios de maximização são válidos pelo menos em algumas fases da sucessão ecológica, mas que somente os princípios de maximização da potência e da maximização do armazenamento de exergia são válidos em todas as fases da sucessão ecológica ${ }^{87}$. Um detalhamento dos argumentos acima está apresentado no anexo 3. Nesse anexo, argumentamos também que nas condições válidas para aplicação do instrumento urbanístico-ambiental aqui proposto existe uma relação de proporcionalidade entre o máximo armazenamento de exergia e a máxima dissipação de exergia. Ou seja, a métrica desenvolvida por Jørgensen para a quantificação da exergia, a saber, a ecoexergia, serve, nos domínios apontados, como métrica para a dissipação de exergia.

\footnotetext{
${ }^{87}$ Os resultados apresentados acima são bastante surpreendentes. A física apresenta-nos outros exemplos de fenômenos distintos que podem ser descritos por modelos e/ ou conceitos semelhantes. Assim, existe nela um conceito bastante profícuo, o de entropia, que se insere em várias teorias (v. anexo 3). Além disso, é notável que uma quantidade grande de fenômenos possa ser modelada pelas equações de Fourier, Laplace e Poisson, bastante semelhantes. Assim, são modeláveis pela equação de Fourier os fenômenos seguintes: campo eletrodinâmico (lei de Ohm mais lei de conservação de carga elétrica); escoamento laminar em meio poroso e homogêneo (lei de Darcy mais lei de conservação de massa); escoamento irrotacional em fluido perfeito (definição de potencial de velocidade e lei de conservação de massa); condução de calor sem sorvedouros ou fontes de energia (lei de Fourier mais lei de conservação de energia); difusão molecular (lei de Fick mais lei de conservação de massa); adensamento de argilas saturadas profundas (lei de Darcy mais lei de conservação de massa considerando o conceito de tensão efetiva); escoamento unidirecional em meio poroso não saturado - infiltração - equação de Richards (lei de Darcy estendida considerando tensões capilares e lei de conservação de massa). Caso esses fenômenos ocorram em regime permanente, são todos regidos pela equação de Laplace. São modeláveis pela equação de Poisson os fenômenos seguintes: campo eletrostático (definição de potencial elétrico e lei de Gauss ou de Coulomb); campo gravitacional (definição de potencial gravitacional e lei de gravitação de Newton). Caso esses fenômenos ocorram em pontos com ausência de carga elétrica ou de massa, respectivamente, eles são também regidos pela equação de Laplace. Muito da ciência, assim como do humor e da arte, consiste em visualizar relações entre elementos sobre os quais até então não se cogitava nenhuma relação.
} 
Tabela 4 - Cálculo do balanço médio de energia superficial de quatro grandes regiões em 50 dias de verão.

\begin{tabular}{|c|c|c|c|c|}
\hline Área & $\begin{array}{l}\text { Energia } \\
\text { absorvida } \\
\text { na } \\
\text { superfície } \\
\text { W.m } \\
\text { W.dia } \\
\end{array}$ & $\begin{array}{l}\text { Energia de } \\
\text { onda longa } \\
\text { reirradiada }\end{array}$ & $\begin{array}{l}\text { Fluxo de } \\
\text { calor } \\
\text { sensível }\end{array}$ & Evapotranspiração \\
\hline Amazônia & 185 & $17 \%$ & $15 \%$ & $70 \%$ \\
\hline Estados Unidos & 220 & $18 \%$ & $19 \%$ & $61 \%$ \\
\hline Ásia & 223 & $24 \%$ & $26 \%$ & $50 \%$ \\
\hline Saara & 202 & $41 \%$ & $56 \%$ & $2 \%$ \\
\hline Floresta tropical & 204 & $16 \%$ & $22 \%$ & $63 \%$ \\
\hline Pradarias & 186 & $22 \%$ & $30 \%$ & $48 \%$ \\
\hline \multicolumn{5}{|c|}{$\begin{array}{l}\text { Fonte: SATO et al. (1989) }{ }^{88} \text { apud SCHNEIDER e KAY (1994) } \\
\text { Nota: } \\
\text { Dados de satélite obtidos do Earth Radiation Budget Experiment e cálculos } \\
\text { realizados segundo o modelo climático de biosfera SiB de SELLERS e MINTZ } \\
(1986)^{89} \text {. }\end{array}$} \\
\hline
\end{tabular}

\section{Ecoexergia como métrica da melhoria do microclima}

Inicialmente argumentamos pela evapotranspiração como métrica da melhoria do microclima. A seguir, mostramos que ela poderia servir como indicadora da dissipação de exergia. Depois, verificamos que, em certas condições nas quais a aplicação do instrumento aqui proposto se dá, a dissipação de ecoexergia poderia ter como métrica a ecoexergia. Desse encadeamento podemos concluir ser válido que a melhoria do microclima tenha como métrica a ecoexergia.

Essas conclusões são notáveis e lograram algo que, em um primeiro momento, parecia improvável: conciliar, de forma teórica rigorosa, dois objetivos ambientais (promoção da qualidade ecossistêmica e melhoria do microclima) por meio de uma equação simples, que produz um indicador único de rápido e fácil cálculo.

\footnotetext{
88 SATO, N. et al. Effects of implementing the simple biosphere model in a general circulation model. Journal of the Atmospheric Science, v.46, n.18, p.2757-82, Sept. 1989.

89 SELLERS, P.J.; MINTZ, Y. A simple biospheric model (SiB) for use within general circulation models. Journal of the Atmospheric Science, v.43, p.505-31, 1986.
} 


\subsection{LIMITAÇÕES DA ABORDAGEM ADOTADA}

O microclima é um fenômeno extremamente complexo. Isso pode ser bem avaliado a partir da consideração da extrema dificuldade para modelar o microclima, sendo um exemplo o programa ENVI-met ${ }^{90}$. Assim, é muita pretensão que uma métrica relativamente simples, como a ecoexergia, possa dar conta de um fenômeno tão complexo como o microclima. Estamos, porém, no domínio das políticas públicas. Ainda não chegamos a uma situação (e talvez nunca cheguemos) em que uma norma geral coercitiva no âmbito da legislação municipal de parcelamento, uso e ocupação do solo se faça senão nos termos da simplicidade ${ }^{91}$. Oportunamente, nesta tese, discutiremos com mais detalhe as questões referentes a norma geral versus estudo caso a caso, simplicidade versus complexidade e aspectos da administração do município.

Do ponto de vista normativo, há uma importante restrição ao raciocínio acima, relacionada ao fato de que medidas de melhoria do microclima podem ser logradas a partir das chamadas coberturas frias, que dispensariam o uso de vegetação (GARTLAND, 2010). O legislador deverá observar essa possibilidade.

Finalmente, esse indicador não se presta para avaliar o combate a inundações. Isso porque o estado atual da técnica de utilização de medidas de controle de drenagem na fonte conduz a um nível de detalhamento das superfícies aptas a promover um bom controle na fonte muito mais refinado do que o passível de ser descrito por um indicador de biótopos superficiais. Isso decorre essencialmente do fato de que para a viabilização do objetivo ambiental "promoção de controle de

\footnotetext{
${ }^{90}$ Uma apresentação do ENVI-met e algumas aplicações e discussões podem ser encontradas em BRUSE (1999a e 1999b), BRUSE (2000), BRUSE e SCHUSTER (2008), BRUSE e SKINNER (1999), DOSTAL (2009), HUTTNER et al. (2009), HUTTNER, BRUSE e DOSTAL (2008) e HUTTNER e BRUSE (2009), além, é claro, da página do modelo (BRUSE, s.d.). Uma aplicação do modelo em São Paulo aparece em SPANGENBERG (2008 e 2010) e em João Pessoa, em SOARES et al. (2011). Uma característica marcante do modelo é que ele se presta a estudos em diferentes escalas de análise climática urbana, tendo sido usado com sucesso até mesmo em dispersão de metais pesados particulados em ruas (BRUSE, THÖNNESSEN e RADKE, 1999). BRUSE (1999a), HUTTNER (2012) e TUNICK (2005) fornecem as equações que embasam o ENVI-met.

${ }^{91}$ Por exemplo, sabe-se que plantas $\mathrm{C}_{4}$ são mais energeticamente eficientes do que plantas $\mathrm{C}_{3}$ (v., p.ex., GOMES e VARRIALE, 2004, p.221-34 e 299-307, SLACK e HATCH, 1967, OSBORNE e BEERLING, 2006, EDWARDS e SMITH, 2010, WILLIAMS et al., 2013). No entanto, levar isso em conta em uma legislação como a que aqui se pretende sugerir seria impraticável.
} 
drenagem na fonte" cuida-se não diretamente das condições das superfícies do lote, mas da eficácia das medidas destinadas a obter a meta de impacto zero, ou qualquer outra meta de ordem hidráulico-hidrológica. Por isso, uma possível adaptação do BFF a São Paulo incluiria dois níveis de exigências: a) uso de medidas, não necessariamente relacionadas a tecnologias verdes superficiais, destinadas a promover impacto zero; b) obtenção no projeto de um valor mínimo de um indicador de biótopo superficial a ser definido no texto normativo. Nisso, esse BFF paulistano se diferencia essencialmente do de Berlim. Nesta cidade, a recarga do lençol se constitui em demanda importante, uma vez que o abastecimento de água se dá por águas subterrâneas. Em São Paulo, a geologia é complexa e não garante que a infiltração provocará melhoria da disponibilidade de água destinada ao abastecimento; preferível, em São Paulo, do ponto de vista ambiental e sanitário, é o combate a inundações. Evidentemente isso deve ser entendido à luz dos comentários ao item 5.2 relativos à infiltração.

\subsection{UMA ABORDAGEM PROMISSORA: ESTIMATIVA DA EXERGIA DE ECOSSISTEMAS A PARTIR DE IMAGENS DE SATÉLITE}

Usualmente a avaliação de um ecossistema implica a consideração de diversas variáveis, cuja obtenção demanda vultosos recursos.

Uma vez que se demonstrou, com bom lastro teórico, ser a ecoexergia uma medida razoável da qualidade ecossistêmica e do microclima, parece-nos interessante, pelo menos numa primeira aproximação, usar esse indicador único para

a avaliação de ecossistemas. É preciso, no entanto, ter em mente que ecossistemas se constituem em fenômeno extremamente complexo, sendo sua modelagem difícil e demandando um número grande de indicadores para sua caracterização. Mesmo a mera obtenção do valor numérico da exergia em um ecossistema demandaria por si só enormes recursos.

Assim sendo, seria interessante usar imagens de satélite para avaliação da exergia. De fato, "a análise de fluxos de energia reirradiada parece ser uma 
ferramenta única e valiosa na medida do balanço e das transformações de energia em ecossistemas terrestres. (...) A temperatura do ecossistema ou a razão $R_{n} / K^{*}\left[R_{n}\right.$ corresponde ao fluxo líquido de radiação absorvido na superfície e $K^{*}$, o fluxo líquido de radiação solar incidente] podem ser excelentes indicadores da integridade ecológica (...) É necessário [no entanto] muito mais pesquisa em transformação de energia em ecossistemas, bem como o desenvolvimento de métodos para corrigir processos energéticos dependentes da localização específica do sistema, isto é, precipitação e altitude" (SCHNEIDER e KAY, 1994, p.42). WAGENDORP et al. (2006) fizeram uso dessas ideias. SVIREZHEV e STEINBORN (2001) desenvolveram método para estimar a ecoexergia a partir de imagens de satélite. Vale a pena testar essas promissoras abordagens em projetos tais como os que a PMSP está envolvida no momento, como o pagamento por serviços ambientais.

\subsection{A DRENAGEM REVISITADA À LUZ DAS CONSIDERAÇÕES}

\section{ACIMA: UMA RÁPIDA NOTÍCIA SOBRE A RELAÇÃO ENTRE O CONTROLE DA POLUIÇÃO DIFUSA E A MÉTRICA PROPOSTA}

Uma questão que se coloca corresponde ao controle da poluição difusa. As medidas não convencionais de lote foram apresentadas apenas sob o ponto de vista da quantidade de água, ou seja, sob a capacidade de essas estruturas promoverem abatimento e retardamento do hidrograma do lote. Ocorre que algumas exigências ao empreendedor aqui propostas poderiam eventualmente ser capazes de, por si só, promover também uma diminuição da poluição difusa na saída do lote.

Uma boa referência é TOMAZ (2006). A prática de dimensionamento de estruturas de lote destinadas à atenuação da poluição difusa pode ser feita por meio das chamadas melhores práticas de gestão (best management practices, BMP). Um critério de BMP consiste no tratamento do first flush, que, por corresponder a uma primeira lavagem das superfícies, carreando assim a maior parte da poluição difusa, seria suficiente em termos de BMP. O volume de first flush pode ser estimado por 
meio das equações seguintes, devidas a SCHUELLER (1987) ${ }^{92}$ apud TOMAZ (2006):

$$
\mathrm{WQ}_{\mathrm{v}}=\mathrm{P} \cdot \mathrm{R}_{\mathrm{v}} \cdot \mathrm{A}
$$

sendo $\mathrm{WQ}_{\mathrm{v}}$ : volume do first flush; $\mathrm{P}$ : altura de precipitação, sendo maior ou igual a 13mm; A: área da bacia; e $\mathrm{R}_{\mathrm{v}}$ : coeficiente volumétrico dependente da área impermeável, conforme a equação seguinte:

$$
\mathrm{R}_{\mathrm{V}}=0,05+0,009 . \mathrm{AI}
$$

sendo AI: área impermeável da bacia, em porcentagem.

Para que P se refira ao first flush, é sugerido que ele corresponda a $90 \%$ das precipitações que produzam escoamento superficial. TOMAZ (2006), estudando os registros de precipitação da cidade de Mairiporã, São Paulo, chegou ao valor de 25mm, que ele recomenda para toda a superfície da Região Metropolitana de São Paulo.

Por que restringimos aqui as medidas de drenagem de lote apenas a aspectos quantitativos, desconsiderando os relativos à qualidade da água? Inicialmente poderíamos argumentar que a realidade brasileira estaria tão atrasada na questão da drenagem que não seria o caso de promovermos tal refinamento nesse momento. Escorar-nos-íamos nessa argumentação no quadro 3, extraído de WALESH e USEPA (mod.) apud CANHOLI (2005), no qual podemos verificar que mesmo municípios grandes como São Paulo se encontrariam na fase 1. Isso seria corroborado no excelente plano diretor de drenagem de Porto Alegre (PORTO ALEGRE [CIDADE], 2005), que segue uma orientação quantitativa. No entanto, uma longa jornada começa com o primeiro passo.

Em segundo lugar, argumentamos que a consideração de aspectos qualitativos não estaria em conformidade com a estrutura da regulamentação proposta no presente. De fato, não faria sentido deixar ao empreendedor a opção entre reservatório de detenção (solução default) ou outras medidas se a primeira se constitui em medida essencialmente quantitativa.

A reflexão sobre essa questão levou-nos a considerar a possibilidade de que a

92 SCHUELLER, T. Controlling urban runoff: a practical manual for planning and designing urban BMPs. Washington, DC: Metropolitan Washington Council of Governments, 1987. 
determinação de parâmetros considere não apenas a biodiversidade e o microclima, mas também a diminuição da poluição difusa. Isso poderia ser feito pela regulamentação proposta determinando que metade da composição do BFF (15\% da área do lote) se dê por meio de área gramada em contato com o solo. Tais áreas gramadas poderiam ser testadas em relação a sua capacidade de diminuir a poluição difusa.

Como critério de BMP de faixa de filtro gramada, pode ser usada a equação seguinte, proposta pelo USSCS apud TOMAZ (2006):

$$
\mathrm{t}=\left[5,52(\mathrm{n} . \mathrm{L})^{0,8}\right] /\left[\left(\mathrm{P}_{2}\right)^{0,5} \cdot \mathrm{S}^{0,4}\right]
$$

sendo t: tempo de trânsito do escoamento superficial, em min; n: coeficiente de rugosidade de Manning, em s.m ${ }^{-1 / 3}$; S: declividade, em m.m ${ }^{-1}$, L: comprimento, em m; $\mathrm{P}_{2}$ a precipitação de $24 \mathrm{~h}$, em mm, com período de retorno de 2 anos.

Avaliações preliminares, considerando determinados arranjos de forma do lote e de implantação da edificação, autorizam uma conclusão provisória no sentido de que muitas vezes as referidas faixas gramadas seriam capazes de proporcionar tratamento satisfatório às águas de chuva que saem do lote.

Temos, portanto, três possibilidades: a) admitir como garantido sempre o tratamento da poluição difusa quando atendidas as normas anteriores propostas; b) propor soluções default, que, imaginamos, seriam faixas gramadas, ao mesmo tempo em que permitimos aos empreendedores usar outras soluções; c) considerar a impossibilidade de existirem soluções default e obrigar todos os empreendedores a verificar o atendimento do tratamento da poluição difusa. A segunda opção parece melhor, restando determinar tais soluções default que, com certo grau de probabilidade, necessariamente alto, garantam que na saída do lote as águas de chuva tenham sido objeto de adequado abatimento da poluição difusa. 


\section{CONSOLIDAÇÃO INICIAL DA PROPOSTA}

Cumpre agora consolidar e detalhar a proposta de modo a conformá-la como instrumento urbanístico-ambiental apto a constar em textos legais. Neste capítulo, o indicador de qualidade ecossistêmica será abreviado como IQE.

1) Pela dificuldade de associar as tipologias do lote às técnicas bastante mais específicas de detenção, amortecimento, retardamento e infiltração de águas pluviais, a exigência de um valor mínimo do IQE deve ser acompanhada de exigências em termos de obtenção de impacto zero no lote através de estruturas hidráulicas.

2) A aplicação conjunta do IQE mínimo e de medidas de impacto zero garantem razoável solidez teórica à normatização, mas tornam o atendimento a tais exigências algo complexo. A fim de alcançar o requisito de simplicidade na aplicação da legislação, o texto legal deve prever medidas e parâmetros default para o IQE (na forma de porcentagem de área gramada no lote) e reservatório de detenção de águas pluviais (volume mínimo e estruturas de saída). A flexibilidade é proporcionada pela possibilidade legal de o empreendedor buscar soluções alternativas propiciadas pelo instrumental técnico disponível.

3) Ficam assim garantidos os requisitos de simplicidade, flexibilidade e solidez teórica na normatização.

4) Os valores mínimos do IQE, que sugerimos como sendo $70 \mathrm{kgde} / \mathrm{m}^{2} \mathrm{t}$, devem ser acompanhados de algumas restrições e exigências adicionais.

5) Assim, sugerimos que $50 \%$ da composição do IQE deva ser obtido na forma de área vegetada não densa em contato com o solo, sem estruturas sob a área vegetada, como por exemplo garagens e lajes. Isso corresponde, segundo nossa sugestão, a no mínimo $15 \%$ da área do lote sendo vegetada. Tal sugestão decorre de duas ordens de considerações:

a) a exigência da existência de áreas vegetadas no lote é vista como uma conquista política, não se devendo esperar que seja aceita a compensação integral de áreas vegetadas por outras tipologias, como coberturas verdes ou paredes vegetadas; 
b) LANDSCHAFT... et al. (1990, p.7) entendem que hábitats (Lebensräume) para flora e fauna em regra são mais bem proporcionados por solos abertos, não adensados.

6) A nossa sugestão de valor mínimo de $70 \mathrm{kgde} / \mathrm{m}^{2} \mathrm{t}$ não levou em consideração a existência de estruturas sob a área vegetada. Se o cálculo simplificado de ecoexergia levasse em consideração a ecoexergia do solo, seria possível considerar as diferenças entre superfícies vegetadas sem ou com estruturas sob elas. Porém, levar o cálculo da ecoexergia a esse nível de complexidade desbalancearia o frágil equilíbrio que acreditamos lograr entre simplicidade, flexibilidade e embasamento teórico. Uma saída consiste em utilizar os seguintes fatores de ponderação do BFF: 0,5 para solos de até $80 \mathrm{~cm}$ de profundidade e 0,7 para solos com mais de $80 \mathrm{~cm}$ de profundidade (esse limiar de $80 \mathrm{~cm}$ parece ter sido estabelecido considerando a capacidade de o solo poder suportar raízes de árvores; v. LANDSCHAFT... et al., 1990, p.8). Assim, qualquer quantidade de ecoexergia estimada para tipologias sobre solos com profundidade menor do que $80 \mathrm{~cm}$ deveria ser multiplicada por 0,5 (p.ex., para superfície gramada teríamos $0,5 \times 70 \mathrm{kgde} / \mathrm{m}^{2} \mathrm{t}=35 \mathrm{kgde} / \mathrm{m}^{2} \mathrm{t}$ ), e para tipologias sobre solos com profundidade maior do que $80 \mathrm{~cm}$, por 0,7 (p.ex., para superfícies gramadas teríamos $0,7 \times 70 \mathrm{kgde} / \mathrm{m}^{2} \mathrm{t}=49 \mathrm{kgde} / \mathrm{m}^{2} \mathrm{t}$ ).

8) O BFF não aceita a consideração de paredes vegetadas dotadas de vãos. LANDSCHAFT... et al. (1990) recomendam que a vegetação dessas paredes seja considerada até uma altura de $10 \mathrm{~m}$. Os motivos não ficaram suficientemente claros. Não ficou claro também se haveria restrições também para muros de divisa vegetados, tanto em suas faces internas como externas.

9) Nossa proposta de IQE ignora determinadas características especiais de certos exemplares arbóreos: espécies arbóreas nativas (SÃO PAULO [CIDADE], 2011; SÃO PAULO [ESTADO], 1989); vegetação situadas em áreas de preservação permanente (BRASIL, 2007; SÃO PAULO [CIDADE], 1987) ${ }^{93}$; flora ameaçada de extinção (BRASIL, 1992); patrimônio ambiental (SÃO PAULO [ESTADO], 1989); vegetação imune ao corte (SÃO PAULO [CIDADE], 1987); exemplares da Lista Oficial de Espécies da Flora Brasileira Ameaçadas de Extinção (BRASIL, 2014a);

\footnotetext{
${ }^{93}$ Devem ser observadas também faixas não edificantes previstas em SÃO PAULO [CIDADE] (1992a e 1992b).
} 
sítios de excepcional valor paisagístico (SÃO PAULO [CIDADE], 1987) ${ }^{94}$. Há necessidade de considerá-las, podendo os textos legais que regulamentam a matéria servir de ponto de partida para a determinação de coeficientes.

10) Propusemos um valor mínimo de $70 \mathrm{kgde} / \mathrm{m}^{2} \mathrm{t}$ para todos os empreendimentos em todo o território do município, valor esse capacitado a constar em um Código de Obras e Edificações. Nada impediria exigências maiores para determinados usos e determinadas regiões da cidade, o que seria objeto, a par de parâmetros tais como taxa de ocupação, coeficiente de aproveitamento e gabarito, da lei de zoneamento. Propomos que quaisquer usos não residenciais mantenham o valor mínimo apresentado acima. Para usos residenciais, seria razoável adotar valores mínimos mais rigorosos. A questão reside em grande parte na factibilidade e na razoabilidade dessas exigências. Em Berlim, foram estudadas edificações existentes, concluindo-se ser razoável aumentar o BFF mínimo exigido em função da taxa de ocupação (TO) segundo a função (adapt.): para $\mathrm{TO}<0,37, \mathrm{BFF}_{\min }=0,60$; para $0,37 \leq \mathrm{TO}<0,50$, $\mathrm{BFF}_{\min }=0,45$; para $\mathrm{TO} \geq 0,50, \mathrm{BFF}_{\min }=0,30$. Em que pesem as óbvias diferenças entre as tipologias de edificações em São Paulo e Berlim, parece razoável, pelo menos em primeira aproximação, aproveitar o resultado dos estudos conduzidos na antiga Berlim Ocidental. Assim, teríamos: para $\mathrm{TO}<0,37, \mathrm{IQE}_{\min }=(0,60 / 0,30) .70 \mathrm{kgde} / \mathrm{m}^{2} \mathrm{t}$ $=140 \mathrm{kgd} / \mathrm{m}^{2} \mathrm{t}$; para $0,37 \leq \mathrm{TO}<0,50, \mathrm{IQE}_{\min }=(0,45 / 0,30) .70 \mathrm{kgde} / \mathrm{m}^{2} \mathrm{t}=105 \mathrm{kgde} / \mathrm{m}^{2} \mathrm{t}$; para $\mathrm{TO} \geq 0,50, \mathrm{IQE}_{\min }=70 \mathrm{kgde} / \mathrm{m}^{2} \mathrm{t}$.

11) Há a questão bastante delicada referente às edificações existentes. Propomos que para edificações novas e para reformas de certa magnitude se aplique o IQE $\mathrm{E}_{\min }$. Julgamos inviável administrativa e politicamente (e em muitos casos tecnicamente) fazer tal exigência para edificações já existentes. ${ }^{95}$

12) A legislação do BFF não faz menção à possibilidade de transferir as exigências para outros lotes. Julgamos razoável que na impossibilidade, em termos do princípio da razoabilidade, de obter o $\mathrm{IQE}_{\min }$ no lote, a fração faltante do $\mathrm{IQE}_{\min }$ (multiplicada por um fator maior do que a unidade) seja compensada em outro lote, desde que

\footnotetext{
${ }^{94}$ A lista de normas legais aqui apresentadas não pode, evidentemente, ser considerada exaustiva. ${ }^{95}$ É possível, porém, fazer algumas exigências nesse sentido quando das chamadas anistias de edificações irregulares. Assim, por exemplo, a lei do município de São Paulo n ${ }^{\circ} 13.558$, de 14 de abril de 2003 (SÃO PAULO [CIDADE], 2003b), em seu artigo $5^{\circ}$ estabelece algumas exigências de ordem urbano-ambiental para que ocorra a regularização da edificação.
} 
próximo e em via de circulação com volume de automóveis e pedestres aproximadamente igual, ou pelo menos próximo (isso se destina a garantir a igualdade da fruição dos efeitos, inclusive estéticos, resultantes da normatização do IQE, e para que não se aproveite essa brecha para descumpri-la em áreas mais valorizadas). Nesse caso, dever-se-ia examinar a viabilidade jurídica de essa exigência administrativa constar na matrícula do imóvel usado para a compensação.

13) O BFF foi pensado em Berlim para áreas urbanas densamente ocupadas. É necessário avaliar criteriosamente tendências de urbanização e déficits de áreas verdes de maneira a definir o perímetro de aplicação de uma normatização lastreada no IQE.

\subsection{CONCLUSÕES PRELIMINARES}

O uso de soluções default proporcionou a superação das contradições associadas à facilidade, flexibilidade e embasamento teórico rigoroso, desde o início estabelecidas como requisitos para a construção de parâmetros urbanísticoambientais análogos ao BFF.

Houve grande fortuna em obter rigor teórico para qualidade ecossistêmica por meio de uma equação bastante simples, que garante o atendimento a requisitos de saúde e integridade ecossistêmica, e mais ainda ao mostrar que tal equação se mostrava coerente para garantir o atendimento às exigências de microclima.

Poderíamos avançar na normatização de maneira a incluir também a água de chuva que não sai do lote? Entramos aqui no campo do tratamento e uso de águas meteóricas, que não se prestariam a um parâmetro análogo ao BFF. O mesmo vale para o reúso de águas. A legislação municipal, à semelhança da regulação de medidas de drenagem na fonte, poderia impor exigências nesse sentido ao empreendedor, podendo eventualmente fornecer soluções default.

Algumas questões remanescentes merecem cuidado:

a) aprofundamento do estudo das tecnologias superficiais verdes disponíveis, principalmente nos aspectos referentes à adaptação aos trópicos de soluções originalmente desenvolvidas para regiões temperadas; 
b) verificação da viabilidade administrativa das soluções propostas, especialmente nos aspectos relativos ao licenciamento e à fiscalização;

c) pesquisa dos custos das soluções envolvidas (no caso de reservatórios de detenção de lote, CRUZ, TUCCI e DA SILVEIRA, 2000, fornecem avaliação para diversas soluções);

d) verificação com mais profundidade da factibilidade das soluções propostas em termos arquitetônicos e de implantação no lote;

e) realização de estudos aprofundados da viabilidade política das soluções propostas. 


\section{TOMO III:}

\section{COMENTÁRIOS PRÉVIOS}

\section{AO ESTUDO DE CASO}




\section{QUESTÕES DE ORDEM GERAL}

Neste capítulo serão tratadas algumas questões de ordem geral, sob nosso ponto de vista. Pela natureza extremamente complexa delas, o tratamento dado aqui a essas questões terá caráter ensaístico. Porém, não podemos nos furtar a elas, nem que seja na forma de uma rápida vista panorâmica, contaminada com nosso viés pessoal, sob pena de haver subtração de elemento importante para o bom entendimento da apresentação do estudo de caso e de sua posterior discussão.

\subsection{O SIMPLES E O COMPLEXO}

Em oficina e em um evento relativos à Quota Ambiental, a questão da oposição entre simplicidade e complexidade foi objeto de discussão, justificando-se aqui algum comentário sobre isso.

Há muito a ser dito sobre a conclusão de Kay sobre a impossibilidade de descrever ecossistemas complexos senão por meio de narrativas. Apresentaremos aqui algumas reflexões imediatas, sem pretender, obviamente, esgotar o assunto. McSHEA (1996, p.479-82), por exemplo, discute de maneira sistemática o conceito de complexidade.

Essa impossibilidade apontada por Kay estaria evidenciando um fracasso da ciência tradicional quanto a sua aplicabilidade e poder explicativo em relação a sistemas complexos. Parece-nos que esse fracasso da ciência tradicional seja uma crise de maturidade, não de infância. Essa ciência tradicional avançou tanto que encontrou não seu esgotamento, mas uma evidenciação de certos limites intrínsecos à sua abordagem.

Havendo impossibilidade de descrever exaustivamente um sistema complexo, o descritor deve, então, escolher determinados aspectos que mais lhe chamam a atenção, que mais lhe parecem fazer sentido e que, por isso, merecem ser descritos. Essas narrativas o mais das vezes usam o vocabulário da ciência tradicional. 
Dois aspectos ficam evidenciados. O primeiro diz respeito às relações entre sujeito e objeto do conhecimento. O segundo, ao reducionismo e, em última instância, ao método de análise-síntese.

Que o sujeito do conhecimento condiciona de alguma forma o objeto não é assunto novo. Muito da filosofia tratou dessa questão.

Hoje se apela a um resultado da física quântica, a saber, o princípio da incerteza de Heisenberg, para "provar" que o mero olhar do sujeito já altera o objeto. $\mathrm{O}$ argumento talvez seja um tanto exagerado. Em primeiro lugar, essa é apenas uma das interpretações do referido princípio - a chamada Interpretação de Copenhague (v., p.ex., LEITE e SIMON, 2010, e BUNGE, 1980). Em segundo lugar, o referido princípio só vale no domínio quântico, não fazendo nenhum sentido no domínio newtoniano. Aliás, invocar o princípio de incerteza como evidência definitiva da influência do sujeito sobre o objeto da observação trai um reducionismo, que, ironicamente, é uma faceta da ciência tradicional. Em terceiro lugar, as relações entre sujeito e objeto do conhecimento constituem-se em assunto tratado sobejamente pela filosofia muito antes da elaboração do princípio da incerteza. No limite, temos Kant (KANT, 1983, 1781), segundo o qual a ciência só é possível em relação ao fenômeno, e não à coisa em si, estando o fenômeno condicionado pelas formas de nossa percepção (tempo e espaço) e pelas categorias de nosso pensamento.

Tratemos agora da questão do método da análise-síntese. Uma similaridade entre esse método e as narrativas de Kay reside no fato de que a faca com a qual arbitrariamente cortamos o fenômeno de modo a expor alguns de seus aspectos que irão merecer nossa atenção pode fazê-lo em qualquer superfície do fenômeno pesquisado. Não obstante, Kay parece tratar de limites da análise-síntese.

Muito se falou sobre esses limites. Porém, parece que se falou muito sobre as limitações da análise-síntese, especialmente frente à complexidade, mas não tanto no motivo de seu extraordinário sucesso, especialmente na física. A física newtoniana é, por excelência, o discurso sobre o ponto material (a termodinâmica clássica trata de sistemas, que, contudo, são agregados de pontos materiais). Ora, esse discurso se faz a partir da decomposição da realidade em pedaços até reduzi-la ao ponto material e da verificação do comportamento desse ponto material diante de diversos contextos causais (sob esse ponto de vista, a segunda lei de Newton compor-se-ia, na verdade, 
de catálogo de leis que regem o comportamento do ponto material diante de circunstâncias que ocorrem em universos nos quais só existiriam o ponto material e a circunstância objeto de investigação, do que resulta uma lei causal que trata do movimento do ponto material nessa circunstância ${ }^{96}$ ). A seguir, todos os aspectos que influenciam o movimento do ponto material são reconstruídos de maneira conceitualmente controlada de forma a descrever situações de maior complexidade e/ ou conjuntos complexos de pontos materiais. Assim, a possibilidade da física faz-se por meio de discursos a respeito de pontos materiais, inicialmente isolados para seu estudo e posteriormente reconstruídos em modelo que se aproximaria da situação "real". Existe grande analogia entre o processo acima descrito e as operações matemáticas de derivação e integração; aliás, as expressões que descrevem os efeitos causais a que um ponto material é submetido usualmente se fazem por meio de equações diferenciais, construídas a partir do pinçamento adequado das leis disponíveis no catálogo de relações causais e do enquadramento delas em uma única equação diferencial, que, integrada, descreve o comportamento mecânico do ponto material. Porém, o que é esse ponto material?

Ele consiste em um ponto (conceito matemático primitivo), portanto desprovido de dimensão, no qual está concentrada uma quantidade finita de massa (conceito físico primitivo). No laboratório, em que se faz a transição de teorias matemáticas idealizadas para a visualização fenomênica, o ponto material pode ser associado a um objeto suficientemente pequeno no contexto das dimensões envolvidas no fenômeno a ser observado, e que não rotaciona. Em casos especiais, objetos considerados corpos rígidos podem ser tratados como pontos materiais desde que não ocorram rotações desses corpos rígidos.

\footnotetext{
${ }^{96}$ A existência da segunda lei de Newton enquanto tal faz sentido somente quando se admitem quatro grandezas fundamentais, a saber, as relativas a espaço, tempo, massa e força. Assim, à derivada do momento linear em relação ao tempo seria multiplicada uma constante, sendo essa a expressão da segunda lei de Newton. Admitindo-se, no entanto, três grandezas fundamentais (as relativas a espaço, tempo e massa), a segunda lei passa de uma proposição universal a uma definição de força. Onde estaria então o conteúdo do sistema newtoniano representado pela sua segunda lei? Queremos crer que em um catálogo genérico de leis, catálogo esse a que damos, em abuso de linguagem, o nome de segunda lei de Newton. Esse catálogo de leis constitui-se em diversas narrativas do comportamento do ponto material sob diferentes circunstâncias. Cada conjunto de circunstâncias, nesse caso, constitui-se em condição suficiente para descrever o comportamento do ponto material, mas não em condição necessária.
} 
O ponto material por si informa sobre a existência de um limite para a massa quando as dimensões tendem a zero. A existência desse limite é contraintuitiva e motivo de espanto. Como é possível que em um ponto sem dimensões possa existir massa? Isso porque qualquer quantidade de matéria pode ser dividida o quanto se queira. Nesse processo, como é possível que exista um valor limite para a massa? Existe esse limite? Como ele se encaixa no discurso newtoniano?

Para entender a existência desse limite, temos que nos socorrer de um teorema que assegura que a somatória de todas as forças externas que atuam sobre todos os pontos materiais de um sistema se iguala à somatória das massas de todos os pontos materiais do sistema multiplicada pela aceleração do centro de massa do sistema (desde, é óbvio, que estejamos utilizando referenciais inerciais) ${ }^{97} 98$. Esse teorema garante a possibilidade de existência de um ponto material, uma vez que se a soma das forças externas atuantes sobre qualquer sistema se iguala à aceleração do centro de massa do sistema multiplicada pela somatória das massas de todos os pontos materiais que compõem o sistema, então qualquer corpo pequeno e que não rotaciona pode ser assimilado a um ponto material porque todas as forças internas de interações entre as abstrações de pontos materiais que o compõe simplesmente não têm importância. Acontece que na dedução desse teorema desempenha papel essencial a terceira lei de Newton. Ora, não estivesse inscrita no universo fenomênico a terceira lei, não haveria como associar o ponto material (conceito matemático-físico primitivo) com as observações laboratoriais. Foi assim que a mecânica newtoniana (mecânica do domínio das grandes massas e das velocidades pequenas) conseguiu lidar com a complexidade. Talvez esse seja o motivo do relativo fracasso da aplicação do método de análise-síntese em fenômenos nos quais não vale a terceira lei, como, por exemplo, em sistemas sociais. Eis a questão que talvez dê origem a muito dos problemas da complexidade: é possível aplicar o método da análise-síntese a sistema cujas menores partículas constituam-se na

\footnotetext{
${ }^{97}$ Uma vez que os postulados básicos da física newtoniana só valem para referenciais inerciais, como identificar referenciais inerciais em nosso universo, uma vez que, dada a relatividade galileana, ou seja, a inexistência de pontos fixos no universo, sempre pairariam dúvidas sobre o caráter inercial de qualquer referencial? Uma resposta algo escolástica de um professor de física nos tranquilizou: procure-se um referencial no qual as leis de Newton sejam verificadas; então qualquer referencial que esteja em repouso ou em velocidade constante em relação a ele constitui-se em referencial inercial. ${ }^{98}$ Uma demonstração desse teorema pode ser encontrada, por exemplo, em KAPLAN (1972, p.75).
} 
verdade em sistemas extremamente complexos sem que haja uma terceira lei que garanta que as interações entre cada uma dessas partículas se deem sem que tais interações de alguma forma se anulem $?^{99}$

A impossibilidade de descrever ecossistemas complexos (sob o ponto de vista de Kay) evidencia diversas outras questões. Uma delas relaciona-se à aparente impossibilidade de utilizar funções-objetivo para as quais tenderiam os ecossistemas, funções essas que permitiriam boa descrição do comportamento dos ecossistemas na direção de uma dada função-objetivo. De fato, Kay não endossa postulado segundo o qual ecossistemas tenderiam ao clímax (KAY, 1991).

As funções-objetivo facilitam sobremaneira o tratamento matemático de ecossistemas por meio de funções de maximização (v. BRAGA JR., 1987). Porém, a ideia que perpassa a existência de funções-objetivo é bastante cara e confortável ao pensamento científico tradicional. Em diversas ciências, principalmente na economia, busca-se descrever estados para os quais tenderiam sistemas complexos. Negar, a priori, a viabilidade desse procedimento, como parece fazer Kay, é frustrante e vai contra algumas concepções enraizadas. Como sobreviver nesse caos conceitual? Como obter um cosmos? Só a empiria pode arbitrar essa questão.

Concluindo: o motivo de fazer essas considerações sobre o problema da complexidade relaciona-se ao fato de a QA pretender ter uma fundamentação teórica, ao contrário do BFF de Berlim, que é calcado na utilização do método Delphi. Ora, nas apresentações que tivemos oportunidade de fazer junto a meios acadêmicos, sempre nos era cobrada a não consideração de detalhes conceituais e factuais que

\footnotetext{
${ }^{99}$ É bem conhecida a expressão do ex-ministro Delfim Netto a respeito de dificuldades epistemológicas da economia enquanto ciência segundo as quais nela os átomos pensam, tomam decisões e aprendem em função de experiências anteriores. É claro que o eminente ministro da Fazenda e do Planejamento na ditadura tratava da ausência de determinismo dos integrantes de um sistema econômico, pelo menos até certo ponto; nós, porém, acrescentamos uma interpretação adicional: além do fato de esses indivíduos serem, em princípio, dotados de liberdade, os indivíduos por si sós se constituem em sistemas extremamente complexos e a interação entre eles é igualmente complexa. Da complexidade da interação de sistemas já complexos e do caráter ao mesmo tempo determinístico e livre de seu comportamento decorre a complexidade e eventualmente a indeterminação do sistema. Mesmo assim, economistas conseguiram elaborar teorias que parecem ter fumos de universalidade. Por exemplo, podemos citar Bacha: "O conceito de demanda efetiva foi proposto simultaneamente por Kalecki e Keynes, no princípio dos anos 30. Uma das poucas esperanças de que a economia seja realmente uma ciência reside nesse fato singular de que Keynes, vindo de Marshall, e Kalecki, vindo de Marx, ambos preocupados com o mesmo problema, embora sob óticas ideológicas distintas, tenham chegado a formulações teóricas extremamente parecidas com relação ao princípio da demanda efetiva" (BACHA, 1989, p.23).
} 
questionariam o status pretensamente científico dos parâmetros da QA. A minha resposta a esse tipo de questionamento baseava-se em dois eixos: a) os parâmetros de um sistema definido por legislação são necessariamente políticos. Assim, se houvesse necessidade de sacrificar a pureza conceitual em troca da viabilidade política, não hesitaria em fazê-lo, em nome de um princípio de flexibilidade, realismo e viabilidade política; b) discorri, apoiando-me às vezes em descrições do método de análise-síntese, sobre aspectos da ciência, enfatizando que muito da arte de fazer ciência ou de fazer técnica estava em procurar a simplicidade no complexo. Fiquei feliz que em uma apresentação na Faculdade de Arquitetura e Urbanismo da Universidade de São Paulo (FAU-USP) um dos docentes comentou que o nosso resultado se constituía em um bom compromisso entre a complexidade dos objetos tratados no projeto de lei e a necessidade de simplicidade do instrumento legal. Aliás, foi um dos temas tratados em uma publicação do observaSP, cujo título, por sinal, é: Quota Ambiental: o desafio de ser simples em território complexo (NOBRE, MARTIN e LIMA, 2015).

$* * *$

Discutimos algo sobre as relações entre a ciência e a complexidade. Não podemos nos esquecer também do caráter problemático e precário da verdade científica. Uma vez que isso está muito além dos meios e da proposta do presente trabalho, limitamo-nos a citar dois autores consagrados.

$\mathrm{Na}$ ciência as convicções não têm nenhum direito de cidadania, assim se diz com bom fundamento: somente quando elas resolvem a rebaixar à modéstia de uma hipótese, de um ponto de vista provisório de ensaio, de uma ficção regulativa, pode ser-lhes concedida a entrada e até mesmo um certo valor dentro do reino do conhecimento - sempre com a condição de permanecerem sob vigilância policial, sob a polícia da desconfiança. Mas isso, visto com mais precisão, não quer dizer: somente quando a convicção deixa de ser convicção, ela pode ter acesso à ciência? A disciplina do espírito científico não começa com o não mais se permitir convicções? (NIETZSCHE, 1999, 1886, p. 196).

O conhecimento não é uma série de teorias autoconsistentes que converge para uma concepção ideal. É, antes, um sempre crescente oceano de alternativas mutuamente incompatíveis, no qual cada teoria, cada conto de fadas e cada mito que faz parte da coleção força os outros a uma articulação maior, todos contribuindo, mediante esse processo de competição, para o desenvolvimento de nossa consciência. (...) Teorias são abandonadas e substituídas por explicações que estão mais de acordo com a moda muito antes de terem tido a oportunidade de mostrar suas virtudes. (...) $\mathrm{O}$ procedimento usual é esquecer as dificuldades, jamais falar sobre elas e proceder como se a teoria não tivesse falhas. (...) $\mathrm{Na}$ maioria dos casos, a ciência moderna é mais opaca e muito mais enganosa do que jamais 
foram suas ancestrais dos séculos XVI e XVII. (...) A ciência é tão só um dos muitos instrumentos que as pessoas inventaram para lidar com seu ambiente. Não é o único, não é infalível e tornou-se poderosa demais, atrevida demais e perigosa demais para ser deixada por sua própria conta. (...) Recomendo colocar a ciência em seu lugar como uma forma de conhecimento interessante, mas de modo algum exclusivo, que tem muitas vantagens, mas também muitos inconvenientes. (FEYERABEND, 2011, p. 44, 62, 74, 78, 211 e 213). ${ }^{100}$

\subsection{VALOR DA NATUREZA}

\section{A curta vida dos nossos antepassados}

Não eram muitos os que passavam dos trinta.

A velhice era privilégio das pedras e das árvores.

A infância durava tanto quanto a dos filhotes dos lobos.

Era preciso se apressar, dar conta da vida antes que o sol se pusesse, antes que a primeira neve caísse. (...)

De todo modo, não contavam os anos.

Contavam as redes, os tachos, os ranchos, os machados. O tempo, tão generoso para qualquer estrela no céu, estendia-lhes a mão quase vazia e a retirava rápido, como se tivesse pena. (...)

Não havia nem um instante a perder, perguntas a postergar e iluminações tardias a não ser as que tivessem sido antes experimentadas. A sabedoria não podia esperar os cabelos brancos. Tinha que ver claro, antes que a claridade chegasse, e ouvir toda voz, antes que ela se propagasse.

O bem e o mal -

dele sabiam pouco, porém tudo: quando o mal triunfa, o bem se esconde; quando o bem aparece, o mal fica de tocaia. Nem um nem outro se pode vencer nem colocar a uma distância sem volta. Por isso, se há alegria, é com um misto de aflição, se há desespero, nunca é sem um fio de esperança. A vida, mesmo se longa, sempre será curta. Curta demais para se acrescentar algo.

Wisława Szymborska (1923-2012), 1987 Trad. Regina Przybycien

${ }^{100}$ Como engenheiro, não posso aceitar que a finalidade da ciência se resuma apenas ao desenvolvimento de nossa consciência (muito menos adotar uma posição essencialista). Aliás, o meu entendimento é de que a ciência de nada serve para isso, uma vez que cuida dos fenômenos e não da coisa em si. Conforme já tive oportunidade de me manifestar, o valor, ou a utilidade, da ciência, pelo menos para um engenheiro, está em sua capacidade descritiva e preditiva. 
Muitas vezes profissionais de instituições de meio ambiente são taxados de radicais, de darem à natureza um valor desproporcional. O Prof. Dr. Silvio Soares Macedo, da Faculdade de Arquitetura e Urbanismo da USP, fez, em entrevista ao observaSP (OBSERVASP, 2015), algumas considerações sobre a Quota Ambiental, sendo possível extrair dessas suas considerações alguns elementos que trazem à tona a questão das relações entre homem e natureza ${ }^{101}$. Por serem altamente questionáveis, como de resto a maior parte da entrevista, somos obrigados a inserir na presente tese nosso entendimento personalíssimo sobre o valor da natureza e suas relações com o ser humano ${ }^{102}$.

O conceito de natureza é problemático. Para LALANDE (1966, p.675) não é possível ordenar os sentidos da palavra natureza, do ponto de vista semântico, em uma série linear. Parecem ter-se formado por irradiações em várias direções em torno de uma ideia primitiva, que, segundo o autor, seria a do desenvolvimento espontâneo dos seres vivos segundo um tipo determinado: $\Phi v \rho \imath \varsigma$ (natureza) ${ }^{103}, \varphi v \omega$ (produzir), a mesma raiz em fetus (fértil, no sentido de fêmea), fecundus (fecundo); natura (natureza), nasci (nascer), natural (no sentido de autóctone) ${ }^{104}$. O autor observa ainda que desde a antiguidade essa palavra apresenta toda a variedade de significações que conservou nos tempos modernos, sendo que a maior parte dos

\footnotetext{
101 "Isso tudo [a QA], desculpe, é coisa de ecologista, não tem que ver com gente, gente tem que ter espaço, dimensão, insolação, ventilação. (...) O que acontece é que essa proposta não vem a partir de critérios de projeto de paisagismo. Ela vem a partir de critérios de ecologistas ou de pseudoambientalistas, que não estão nem aí para as pessoas. (...) Eles [o DEPAVE] trabalhavam com áreas maiores, com arborização, gramados, tinham padrões de equipamentos, padrão de plantio, e tinha gente boa projetando, não ecólogo. Ecólogo não pode projetar. (...) Gente muito boa que começou, as equipes iniciais eram fantásticas. Mas depois de toda a dominação pelo pessoal da mobilidade e da ecologia... (...) A quota [ambiental] poderia ser (sic) em função de projeto aprovado. Você aprova o projeto do prédio, mas com o projeto do paisagismo. Talvez fosse uma coisa importante, mas não pode ser aprovado por ecólogo e por certos arquitetos que eu conheço, também não dá." (OBSERVASP, 2015).

${ }^{102} \mathrm{O}$ conceito de natureza e seu valor é algo que mereceria um tratamento estonteantemente vasto. Um mero delineamento da questão demandaria suporte de vastíssima bibliografia e ampla erudição, o que não é evidentemente nosso caso nem nossa intenção. Daí o caráter de ensaio. Limitamo-nos a alguns aspectos mínimos da questão que entendemos ser de interesse para a tese, e mesmo assim em nível superficialíssimo. Talvez uma discussão adequada do tema da natureza no âmbito do saneamento ambiental possa ser encontrada em BRANCO (1999, p.163-78), embora nós não possamos fazer coro à sua opinião sobre a ética em relação a seres sencientes. Fica essa citação como uma homenagem ao ilustre professor do Departamento de Saneamento Ambiental da Faculdade de Saúde Pública da Universidade de São Paulo, a casa em que esta tese foi gestada.

${ }^{103} \mathrm{~V}$. significado de physis apresentada adiante.

${ }^{104}$ Segundo HOUAISS e VILLAR (2001), natureza está etimologicamente ligada à raiz nasc-, do latim nascor,eris,natus, sum,nasci "nascer, ser posto no mundo".
} 
autores a empregam em todas as suas acepções. LOVEJOY (1935) ${ }^{105}$ apud SPIRN (1997, p.251) identificou sessenta e seis diferentes sentidos das palavras natureza e natural (nature e natural) usadas na literatura e na filosofia desde os antigos gregos até o século dezoito. "Parece que devamos reconhecer pelo menos dois sentidos principais na palavra Natureza. No primeiro sentido, significa todos os domínios existentes tanto no mundo interior como no exterior e tudo que tem lugar por meios decorrentes desses poderes. No segundo, significa não tudo o que acontece, mas somente o que toma lugar sem o concurso humano ou pelo menos sem o concurso voluntário e intencional do homem. Essa distinção está longe de exaurir as ambiguidades da palavra; mas é a chave para a maioria daquelas das quais importantes consequências decorrem" (MILL, 1874, p.8-9). SPIRN (1997, p.251-2) entende que natureza se constitui em uma abstração, um conjunto de ideias para as quais muitas culturas não possuem nenhuma palavra equivalente; a natureza é um espelho da e para a cultura.

Entenderemos aqui, com certeza muito simploriamente, a natureza como um dos extremos, supostamente determinístico, da problemática dicotomia entre natureza e homem, este supostamente livre.

A QA trata, de alguma forma, de uma relação institucional entre homem e natureza. À natureza diferentes pessoas conferem diferentes valores. Os valores usualmente conferidos à natureza podem ser estritamente utilitários, estéticos, científicos, espirituais, culturais, religiosos. Muitas vezes, quando se fala em valor da natureza, pensa-se em quantificá-la monetariamente, em princípio considerando todos os esses valores. Não é o nosso intuito nem vemos sentido nele. A precificação de bens ou serviços é feita no âmbito da Economia do Bem-Estar, que por sua vez está ancorada em teoria de valor, necessariamente metafísica e arbitrária (por menos que queiram aceitá-lo os cultores desse dogma), segundo a qual o valor de um bem ou serviço corresponderia ao preço que esse bem ou serviço possuiria em um mercado de competição perfeita.

O enfoque que daremos aqui, tão arbitrário como qualquer outro, corresponde ao sofrimento do homem frente ao estado de natureza. O estado de natureza 
corresponde não somente à natureza propriamente dita, mas também e sobretudo à carência do homem em sua condição de mamífero, tratando-se nesse caso de carência de comida, água, abrigo, amizade, afeição, sexo, status no grupo, relação com o sagrado; corresponde também à luta travada contra outros homens na apropriação dos bens naturais e artificiais; finalmente, corresponde à compaixão e à angústia da ética em relação ao clã, à tribo, depois à humanidade como um todo, e finalmente a qualquer ser senciente. Aqui a natureza não é mãe, mas uma madrasta severa, da qual todos os seres provêm, com a qual se definem, de que dependem inteiramente e que, por isso, exige ser tratada com respeito, cuidado e, talvez, até veneração. Certamente Cesar e Cidade, numa abordagem marxista, discordariam:

\footnotetext{
Embora as relações materiais estabeleçam as linhas mestras do desenvolvimento social, o relacionamento entre a sociedade e a natureza parece revelar muito mais das relações sociais do que das relações de necessidade. Um pressuposto básico é que, à medida que a sociedade evolui, modificam-se as ideologias hegemônicas de acordo com as transformações sociais, políticas e econômicas. Por sua vez, as ideologias condicionam visões de mundo e essas informam práticas relativas à natureza, em particular o paisagismo. Diferentes visões de mundo propiciaram, ao longo dos séculos, posturas que se refletem em distintas maneiras de intervir na natureza. (CESAR e CIDADE, 2003, p.132-3).
}

FLUSSER (1998, p.117-21) descreve três relações culturais ideais frente ao sofrimento provocado pelo estado de natureza: a) a miséria mamífera é tomada como um dado. Aceito o dado, é imposta sobre o ambiente e sobre o comportamento humano uma estrutura rígida e exata que transforma o ambiente de natureza em mundo vital, e o homem de mamífero em existência humana. Tal estrutura dá sentido preciso a todo ato e a todo sofrimento humano, e isso significa que os impulsos mamíferos, embora não satisfeitos, são subordinados a impulsos de espécie diferente (ética e religiosa); b) a miséria mamífera do homem é inaceitável, já que degrada a dignidade humana. Por isso, é preciso transformar carência em abundância, e assim acabar com a miséria humana. Tendo tal meta em mira, é preciso modificar o ambiente natural e forçá-lo a satisfazer os impulsos mamíferos do homem para que esses impulsos possam ser sublimados em níveis superiores; c) a miséria mamífera do homem não é dado objetivo porque o homem não é apenas mamífero, e, portanto, se vê de fora. Miserável é apenas aquele que se assume miserável. Isso não implica 
que os impulsos mamíferos não existam, mas implica que no homem tais impulsos são controláveis e assim deve ocorrer ${ }^{106}$.

Flusser distingue miséria e carência. Assim, um índio de uma comunidade que não tenha tido ainda contato com culturas europeias, ou o tenha muito superficialmente, mas cuja cultura se inscreve no primeiro grupo ideal de Flusser, é carente, mas não miserável, porque sua cultura dá sentido à sua miséria. Por outro lado, um proletário que vive na periferia de uma metrópole de um país subdesenvolvido é carente e também miserável, porque sua saída do campo rouboulhe o acervo cultural com o qual ele poderia dar sentido à sua miséria.

A civilização ocidental é mais clara e fortemente descrita pelo segundo tipo ideal apresentado acima. E uma vez que, querendo-se ou não, para o bem ou para o mal, nossa civilização ainda é eminentemente cristã ${ }^{107}$, por mais que os atos e fatos pareçam desmenti-lo, daremos um expeditíssimo passeio sobre a resposta cristã ao sofrimento decorrente do estado de natureza.

Usualmente argumenta-se que o utilitarismo egoísta de nossa civilização em relação à natureza encontra justificação nas palavras de Deus no Gênesis: “[Deus] disse [ao homem e à mulher]: 'Sede fecundos, multiplicai-vos, enchei a terra e submetei-a; dominai todos os peixes do mar, as aves do céu e todos os animais que rastejam sobre a terra"”. (Gn 1,28) ${ }^{108}$. Esse é um argumento de peso. Mas o importante a observar aqui é que o Éden se constitui em um mundo no qual o homem não se encontra no estado de natureza (expressão anacrônica), e que pela Queda ele é empurrado para o sofrimento do estado de natureza. Não entendemos aqui o Éden como o espaço de uma natureza idílica, mas justamente o oposto, ou seja, o Éden

\footnotetext{
106 Talvez nós estejamos a faltar com o respeito às mulheres ao adotar linguagem presumivelmente incorreta do ponto de vista de gênero ao usar a palavra "homem" no sentido de humanidade. No entanto, sentimo-nos tranquilos em relação a isso porque originalmente o termo latino para homem no sentido de ser masculino era vir. Homo referia-se tanto a mulheres como a homens. Por evolução semântica, em nosso idioma e em outros, "homem" tem esse duplo significado (ser humano e ser masculino), o que representa um empobrecimento dessas línguas frente a outras, o que certamente causa desconforto (v. ROUCHE, 2009, p.518).

107 "Como uma vitória final, e duramente conquistada, da consciência européia, como o ato mais rico de consequiências de dois milênios para a verdade... Vê-se o que propriamente triunfou sobre o Deus cristão: a própria moralidade cristã, o conceito de veracidade, tomado cada vez mais rigorosamente, o refinamento de confessores da consciência cristã, traduzido e sublimado em consciência científica, em asseio intelectual a qualquer preço." (NIETZSCHE, 1999, 1886, p.205). V. tb. DE MOURA (2005, p.15-21).

108 Todas as citações aqui feitas referentes à Bíblia cristã foram extraídas da monumental obra de GORGULHO, STORNIOLO e ANDERSON (1985).
} 
como ausência de natureza. Delineia-se então uma questão que assombrou o pensamento judaico e principalmente o cristão: se Deus é bom, de onde vem o mal do mundo?

O pensamento judaico sonha com a perspectiva escatológica messiânica correspondente a um retorno do homem ao estado edênico (GORGULHO, STORNIOLO e ANDERSON, 1985, p.1337-8). Em Isaías, por exemplo, esse sonho de retorno está poeticamente descrito: "Estes [muitos povos] quebrarão as suas espadas, transformado-as em relhas [arados], e as suas lanças, a fim de fazerem podadeiras. Uma nação não levantará a espada contra a outra, e nem se aprenderá a fazer guerra. (...) Então o lobo morará com o cordeiro, e o leopardo se deitará com o cabrito. (...) O leão se alimentará de forragem como o boi. (...) Ninguém fará o mal nem destruição nenhuma" (Is 2,4 e 11, 6-9). O processo histórico de construção da figura de Jesus Cristo (EHRMAN, 2014) pouco a pouco define seu papel na escatologia.

Os gnósticos também enfrentaram a questão referente à origem do mal. A gnose marciana (SIMON e BENOIT, 1987, p.155-6), por exemplo, trata das relações entre a criação do mundo por um deus justo (daí o sofrimento do homem frente à natureza) e do apiedar-se desse sofrimento por parte de um Deus bom, que envia, então, seu filho para salvar a humanidade do estado de natureza. Ele, no entanto, falha porque o deus justo o perseguiu e o fez morrer na cruz. O retorno ao estado edênico se dará, portanto, escatologicamente.

Mircea Eliade faz uma interessante comparação entre as sociedades antigamente denominadas "primitivas"109, composta por "selvagens", e o cristianismo no tocante à queda que teria ocorrido em épocas muito remotas:

Poder-se-ia dizer que os selvagens (sic) consideravam-se, não mais nem menos do que os cristãos ocidentais, seres "decaídos" com respeito a uma situação anterior fabulosamente feliz. Sua condição atual não era original, senão o resultado de uma catástrofe ocorrida in illo tempore. Antes desse desastre, o homem desfrutava de uma vida não muito diferente da de Adão antes do pecado. Os mitos do paraíso diferem, evidentemente, de uma cultura a outra, mas há alguns traços comuns: nessa época, o homem era imortal e podia falar com Deus face a face; era feliz e não tinha que trabalhar para se alimentar pois uma árvore se ocupava de sua subsistência ou os utensílios agrícolas trabalhavam por si sós. (...) Não obstante, havia uma diferença fundamental: o selvagem (sic) esforçava-se em não se esquecer do sucedido in illo

${ }^{109}$ V., p.ex., LÉVI-STRAUSS (1980, 1950, p.45-87). 
tempore. Remontava-se periodicamente aos acontecimentos essenciais que o tinham levado à condição de homem "decaído". (...) Repetia-se assim a cosmogonia, os gestos tornados exemplares dos deuses, os atos que fundamentavam civilizações. A verdadeira "nostalgia do paraíso" pode ser encontrada nos místicos das sociedades primitivas (sic): durante seus êxtases, reintegram a condição paradisíaca do antepassado mítico antes da "queda". (...) Para muitos povos, sobretudo os mais antigos cultivadores de tubérculos, as tradições relativas à origem da condição humana atual estão revestidas de uma expressão ainda mais dramática. Segundo seus mitos, o homem se converteu no que é hoje - mortal, sexuado e condenado ao trabalho devido a um assassinato primordial: in illo tempore, um ser divino, frequentemente uma mulher ou um jovem, às vezes um menino ou um homem, deixou-se imolar para que os tubérculos ou as árvores frutíferas pudessem crescer a partir de seu corpo. (...) A imolação do ser divino inaugurou tanto a necessidade de alimentar-se como a fatalidade da morte e, em consequência, da sexualidade, o único meio de assegurar a continuidade da vida. (...) Para que o mundo vegetal possa continuar existindo, o homem deve matar e ser morto; além disso, deve assumir a sexualidade. (...) A experiência mística por excelência das sociedades arcaicas (sic), o xamanismo, revela a nostalgia do paraíso, o desejo de liberdade e de beatitude de antes da "queda", a vontade de restaurar a comunicação entre a terra e o céu. Em poucas palavras: abolir tudo que foi modificado na estrutura própria do cosmos e no modo de ser do homem como consequência da ruptura primordial. $\mathrm{O}$ êxtase do xamã recupera em grande parte a condição paradisíaca: recupera a amizade dos animais; através de seu voo, o xamã volta a unir terra e céu; lá acima, volta a encontrar-se, cara a cara, com o deus celestial com o qual fala diretamente, como ocorria in illo tempore. (...) O cristianismo é dominado pela nostalgia do paraíso. (...) Também se poderia fazer uma revisão do simbolismo paradisíaco das igrejas e dos jardins dos monastérios. A paisagem que rodeia o monge reflete o paraíso terrestre, em certo sentido antecipa-o. (...) A experiência mística cristã exemplar é a ascensão espiritual de são Paulo. (...) Ainda que o cristianismo esteja dominado pela nostalgia do paraíso, somente os místicos obtém, em parte, a restauração paradisíaca: amizade com os animais, ascensão aos céus e reencontro com Deus. (ELIADE, 2001, 1957, p.42-6 e 81-5).

Uma vez que a filosofia grega pré-socrática e clássica influenciou decisivamente a escolástica, convém passar uma vista panorâmica sobre a questão (GILSON, 2006, p.446). A filosofia pré-socrática teve como problema central a determinação da substância estável de que tudo nasce e a que tudo retorna,

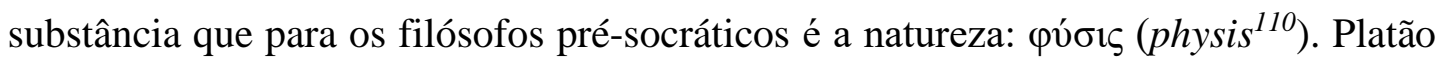
apenas substituiu a necessidade dessa substância material pela da ordem inteligível. Para Aristóteles, a existência de certa regularidade nos acontecimentos atesta a presença de uma essência. Platão não deixou nenhuma solução sistemática para o problema do mal. Aristóteles interpretou o ponto de vista platônico como o princípio do mal estando na matéria (GILSON, 2006, p.150).

\footnotetext{
110 "Phýsis: Natureza. Possui três sentidos principais: 1) processo de nascimento, surgimento, crescimento (sentido derivado do verbo phýomai); 2) disposição espontânea e natureza própria de um ser; características naturais e essenciais de um ser; aquilo que constitui a natureza de um ser; 3) força originária criadora de todos os seres, responsável pelo surgimento, transformação e perecimento deles. A phýsis é o fundo inesgotável de onde vem o kósmos; e é o fundo perene para onde regressam todas as coisas, a realidade primeira e última de todas as coisas. Opõe-se a nómos." (CHAUÍ, 2002, p.509).
} 
Para a questão da natureza e a origem do mal e do sofrimento humano na escolástica, valer-nos-emos de GILSON (2006, p.146-74). Ao contrário do asseverado pelo senso comum, a escolástica tinha a natureza por boa. Gilson fala de um otimismo cristão (GILSON, 2006, p.155). Porém, são Tomás fornece uma explicação mais interessante sobre a Queda, que teria contaminado a natureza ${ }^{111}$. A natureza, mesmo decaída, ainda reflete a glória de Deus, e por isso há o que admirar nela. A Renascença apenas afirmou que o homem (ocidental) se declara satisfeito com o estado de natureza decaída. À solução sofisticada da escolástica opôs-se a concepção popular segundo a qual a natureza é corrompida pelo pecado, concepção essa que deve muito a Lutero ${ }^{112}$ e a Calvino. A esse respeito, assim De Moura apresenta um comentário sobre a natureza (obviamente no âmbito do sistema nietzschiano):

\begin{abstract}
Afinal, quem é esse homem "bom" da Revolução Francesa e de Rousseau, que é herdado pelo imaginário do socialismo? Ninguém mais senão o homem cristão. Por mais que se pense o contrário, aquele homem natural não passa de uma idealização cristã. $O$ que não é surpreendente, se formos fiéis ao preceito nietzschiano de procurar o cristianismo mesmo ali onde ele não se reveste mais de sua forma dogmática. Afinal, qual era o procedimento de Rousseau? Para melhor enraizar a humanidade sonhada pela moral cristã, ele pensa em extraíla da Natureza. E, para isso, ele forja o conceito de uma Natureza que seria liberdade, bondade, inocência, justiça, idílio. No fundo, essa Natureza imaginária já é o culto da moral cristã. O restante da operação já se conhece: após conceber como boa a Natureza de antes da queda, a "instituição" entra no lugar do pecado original, como origem da corrupção. E por isso a Revolução Francesa, promovendo o homem bom de Rousseau, foi mais uma vitória insidiosa do cristianismo. (DE MOURA, 2005, p.91-2).
\end{abstract}

Assim, sob essa argumentação, estado de natureza corresponderia a um estado de necessidade que provoca sofrimento no homem e em todos demais seres sencientes. Ironicamente, homem e demais seres sencientes só existem e se definem

111 "Feito por Deus, o homem preferiu-se a Deus e, fazendo isso, introduziu o mal moral no mundo. (...) O mal moral induzido por uma vontade livre, num universo criado, põe diretamente em jogo a relação fundamental de dependência que une a criatura a Deus. A interdição tão leve e, por assim dizer, gratuita, com que Deus havia punido o uso perfeitamente inútil ao homem de um só dos bens postos à sua disposição era o indício sensível dessa dependência radical da criatura. Aceitar a interdição era reconhecer essa dependência; infringir a interdição era negar essa dependência e proclamar que o que era bom para a criatura é melhor do que o próprio bem divino. Ora, cada vez que peca, o homem renova esse ato de revolta e se prefere a Deus; preferindo a si, ele se separa; separando-se, ele se priva do único fim em que se encontra sua beatitude e se condena por isso mesmo à miséria. (...) O que é para o problema da origem do mal, também é para o valor do mundo, depois que o mal nele se introduziu com a falta original." (GILSON, 2006, p.162 e 168).

${ }^{112} \mathrm{Um}$ bom apanhado de alguns aspectos da complexa teologia de Lutero pode ser encontrado em FORTE (2005, p.113-80). 
enquanto tais no âmbito da natureza ${ }^{113}$. Seu estado de necessidade não impede que na natureza sejam encontrados pelo homem outros valores. Mais do que nunca, estamos na contingência de proteger a natureza porque ela, no seu estado atual, é que propicia as condições de vida ao homem. Mais ainda: a concepção da natureza como algo de mau e nossa condição de mamíferos impõem-nos aliança automática e deveres éticos para com todos os seres sencientes e entre todos os homens na luta comum pela diminuição do sofrimento provocado pelo estado de natureza.

Concluindo: o homem (húmus) é natureza. Por ser natureza, vive no estado de necessidade, e sofre por isso. Para satisfazer suas necessidades, vitais ou não, necessita da natureza. Daí decorre que ela não se relaciona ao arquétipo de mãe, mas é mais bem descrita e sentida como madrasta. Para tentar se tornar independente dessa severa madrasta, o ser humano, suprema ironia, toma elementos da natureza e constrói o mundo (no sentido dado por ARENDT, 2005, 1958). Existe, portanto, uma contradição dialética entre natureza e mundo. O ser humano (pelo menos o ocidental) odeia a natureza porque ela o colocou no estado de necessidade, mas necessita de seus serviços ambientais. Além disso, o homem sente-se comprometido com a natureza por motivos estéticos, emocionais, culturais, espirituais e por compaixão com e solidariedade aos demais seres sencientes.

$$
* * *
$$

A QA trata de dar mais natureza à gestão urbana. Mas nem sempre mais natureza é desejável na cidade, pelo menos não para todos e nem em todas as situações. Aqui viceja o princípio not in my backyard. Por exemplo, CÁNOVAS (1988) informa que as raízes de certas árvores podem produzir alterações, especialmente em estruturas pouco ou medianamente importantes. Algumas árvores possuem raízes que se desenvolvem horizontalmente e com grande rapidez, alcançando grandes distâncias, podendo criar efeitos de cunha entre as fundações e o terreno, e produzindo recalques importantes. Pode ocorrer que o indivíduo arbóreo tenha raízes de desenvolvimento vertical, mas, por existirem camadas inferiores

\footnotetext{
113 “Quando se fala em humanidade, a noção fundamental é a de algo que separa e distingue o homem da natureza. Mas uma tal separação não existe na realidade: as qualidades 'naturais' e as propriamente chamadas 'humanas' cresceram conjuntamente. O ser humano, em suas mais elevadas e nobres capacidades, é totalmente natureza, carregando consigo todo seu inquietante caráter." (NIETZSCHE, 1996, 1872).
} 
secas ou rochosas, as raízes sejam obrigadas a correr horizontalmente. Por outro lado, como lembra também THOMAZ (1989), as árvores podem modificar as condições de umidade de alguns terrenos, especialmente no caso de argilas expansivas, situação em que a poda delas, cujas raízes podem penetrar bastante sob o edifício, tem a eventual possibilidade de dar lugar a um aumento da umidade com consequentes efeitos expansivos. Segundo o BUILDING RESEARCH ESTABLISHMENT (1977) ${ }^{114}$ apud THOMAZ (1989), pode ocorrer a absorção de água por vegetação localizada próxima à edificação, provocando ressecamento do solo e fissuras relacionadas a esse ressecamento. CÁNOVAS (1988) lembra a possibilidade de ocorrer penetração das raízes e seu desenvolvimento nas tubulações de concreto de esgoto, provocando o entupimento e a ruptura delas. Esse autor informa a respeito do grau de periculosidade de algumas espécies arbóreas na Espanha, classificando-as como muito perigosas (choupo, amieiro, acácia, salgueiro, olmo), perigosas (bordo, bétula, freixo, faia, carvalho) e pouco perigosas (lariço, cedro, abeto). Finalmente, esse autor recomenda não plantar árvores a uma distância do edifício menor do que a sua altura, ou, quando plantadas em fileira paralela aos edifícios, do que uma vez e meia essa altura. MILITITSKY, CONSOLI e SCHNAID (2008) entendem que tal recomendação é inaceitável por motivos ecológicos e práticos. Eles informam ainda que nas várias referências sobre o assunto os resultados mostram uma diferença marcante para cada espécie vegetal. De fato, a capacidade de a vegetação causar aumento ou redução volumétrica no solo e, por conseguinte, danos às estruturas depende de tipo de vegetação, solo, nível d'água, clima, tipo de fundação e distância da vegetação, sendo complexa a interação entre esses fatores. CUTLER e RICHRDSON (1981) ${ }^{115}$ apud MILITITSKY, CONSOLI e SCHNAID (2008) fornecem algumas indicações práticas. Outras indicações são fornecidas pelo Manual técnico de arborização urbana (SÃO PAULO [CIDADE], 2015d), em especial em sua página 38, pela portaria 130/SVMA-G/2013 (SÃO PAULO [CIDADE], 2013b), em especial em sua tabela IV, e pela portaria 1/14 DECONT-SVMA (SÃO PAULO [CIDADE], 2014d), em especial em sua tabela II.

114 BUILDING RESEARCH ESTABILISHMENT. Soils and foundations. Darston, 1977. (Digest n. 63, Part 1).

115 CUTLER, D.F.; RICHARDSON, I.B.K. Tree routs and buildings. London: Construction Press, 1981. p.94. 
Além disso, exemplares arbóreos constituem-se em grave responsabilidade do ponto vista jurídico para os detentores dos domínios nos quais eles se situam.

A ação do Poder Público é paradoxal. Reconhecendo que a natureza é um bem escasso e precioso, ele tende, às vezes, a tutelá-la exageradamente. Porém, quanto mais ele a tutela, mais podem os efeitos ser contraditórios, porque a legislação impõe graves ônus, por exemplo, a quem possui exemplares arbóreos em seu terreno. Assim, o proprietário de um terreno com árvores arca pesadamente com ônus que se transformarão em bônus para toda a coletividade. Daí o desejo dele tanto maior de se livrar de exemplares arbóreos ou evitá-los quanto maior a tutela sobre eles.

A QA é um instrumento, como veremos, que inverte essa lógica ao dar benefícios a quem possui exemplares arbóreos em seu terreno. Assim, com a QA árvores frequentemente não causarão desvalorização, mas poderão, ao contrário, valorizar monetariamente o imóvel.

\subsection{OBJETIVOS AMBIENTAIS ACESSÓRIOS}

A QA contempla três objetivos ambientais. Frequentemente fomos indagados a respeito do motivo de não incluir outros. Minha resposta tem sido calcada em dois argumentos.

O primeiro relaciona-se ao fato de que se três objetivos ambientais implicaram certa complexidade, sendo essa relativa complexidade objeto de críticas, a consideração de mais objetivos implicaria em muito mais complexidade, provavelmente de maneira mais do que proporcional.

O segundo argumento relaciona-se a que, estando adequado o tratamento aos três objetivos ambientais, outros seriam indiretamente atendidos. É o caso da emissão de gases de efeito-estufa. O município de São Paulo dispõe de uma Política de Mudança do Clima, a lei $\mathrm{n}^{\circ}$ 14.933, de 5 de junho de 2005 (SÃO PAULO [CIDADE], 2005c), que fixa, aliás, uma meta de redução de emissões antrópicas medidas por meio de dióxido de carbono equivalente de 30\% até 2012. Quer-nos 
parecer, no entanto, que os municípios são pouco dotados de instrumentos para promover reduções significativas de gases de efeito-estufa. Os municípios devem ficar atentos, isso sim, às alterações climáticas decorrentes dos fenômenos associados às cidades, como as ilhas de calor.

É nosso entendimento que nas negociações internacionais envolvendo a questão do aquecimento global não tem sido permitido, em virtude da pressão das nações ricas, nenhum questionamento em relação ao status quo. Há nações ricas que se empenham mais na questão, outras, menos. Porém, não acreditamos que mesmo as que têm se empenhado mais estejam dispostas a uma mudança significativa no seu estilo de vida. Para prová-lo, basta imaginar se seria viável estabelecer uma cota de emissão de gases de efeito-estufa em uma base per capita das populações de cada país em 1990, sendo os emissores obrigados a pagar a esses detentores de cotas uma quantia, definida em um mercado de quotas de emissão, relativa a cada tonelada de $\mathrm{CO}_{2}$ equivalente ${ }^{116}$.

\subsection{MULTIDISCIPLINARIDADE}

Uma característica marcante da QA é o seu caráter multi-, talvez interdisciplinar. Esse caráter perpassou as fases de delineamento e de desenvolvimento do instrumento. Entendemos que tal se trata de um dos aspectos mais positivos do trabalho. Isso justifica uma discussão a respeito do nosso ponto de vista a respeito da multi- e da interdisciplinaridade.

O trabalho em equipe multidisciplinar corresponde a uma oportunidade ímpar de aprimorar conhecimentos e adquirir visões de mundo, bem como produz sentimentos de humildade e admiração ${ }^{117}$.

\footnotetext{
${ }^{116}$ Do ponto de vista teórico, um mercado de quotas de emissão considerado de competição perfeita induziria um estado final equivalente independentemente da alocação inicial das quotas, ou seja, tais mercados têm eficiência de segunda ordem. Porém, essa alocação final condiciona fortemente os ganhos e perdas dos participantes do mercado. A esse respeito, v. CAETANO (1999).

${ }^{117} \mathrm{Nem}$ sempre os sentimentos produzidos em grupos se afiguram tão nobres assim. Consideremos o caso da ambição. Segundo HOUAISS e VILLAR (2001), ambição vem do latim ambitio,onis, que significa "ação de rodear, cercar, solicitação, manejo, lisonja, adulação, fausto, ostentação, elevada condição". A raiz ambi(e) está relacionada a ir em volta de, fazer a ronda de, estando especializada na
} 
linguagem política em candidatos que disputavam uma magistratura e faziam a corte dos eleitores. Assim, ambição é cognata de ambiência e ambiente. O românico ambitare resultou no português e espanhol "andar". ZIMERMAN (2012) enxerga na ambição um sentimento positivo, relacionado ao desejo de crescer na vida de forma adequada, e um negativo, associado a um movimento de intensa inveja, à desmedida. HOUAISS e VILLAR (2001) entendem a palavra inveja como proveniente do latim invidia,ae, de invidus,a,um, significando "que tem ou lança mau-olhado, que tem inveja, invejoso", e de invidere, "olhar de modo malévolo, lançar mau-olhado", donde invejar. Consideremos agora a inveja. ZIMERMAN (2008, p.224-7) fornece uma etimologia aparentemente influenciada pela psicanálise, na medida em que enxerga duas origens da palavra inveja, uma segundo a qual ela provém de in (dentro) + videre (olhar), significando, portanto, um olhar mau que entra dentro do outro; e outra, oposta, associada a alguém fortemente fixado na posição narcisista, recusando-se a ver, a reconhecer a diferença entre ele e o outro. ARISTÓTELES (Retórica) apud FIGUEIREDO e FERREIRA (2008) define de maneira particularmente feliz a inveja como o "pesar pelo sucesso evidente de que gozam os demais". ZIMERMAN (2008) e FIGUEIREDO e FERREIRA (2008) apresentam sucintamente a inveja à luz de teorias psicanalíticas de autores diversos. Assim, Freud fala da inveja como afeto presente no desenvolvimento sexual feminino, isto é, a inveja seria o "sentimento particular da falta" e que se dá a partir do momento em que a menina sente falta do pênis e percebe que o sexo oposto o possui. Melanie Klein postula a inveja primária como um derivado direto da pulsão de morte, presente desde o início da vida sob a forma de ataques invejosos e sádicodestrutivos contra o seio da mãe. Postula ela ainda que a inveja não é querer ter o que o outro tem, mas não querer que o outro tenha o que tem. Finalmente, para Lacan a inveja está relacionada ao desfazimento do "paraíso simbiótico" (período em que a criança se sente fundida com a mãe) e, consequentemente, da necessidade de se depender de pessoas do ambiente exterior.

Hesíodo trata das duas deusas da discórdia, as Eris ("E Lutas [Eris], mas sobre a terra existem duas. Quando alguém observa uma delas, considera louvável; a outra é digna de censura: elas têm ânimos diversos. Pois uma promove a guerra má e a disputa, é a cruel. Nenhum mortal a ama, mas por necessidade, pela vontade dos deuses, têm de honrar a Luta pesada. A outra, a primeira, gerou-a a Noite escura, e o filho de Crono, Zeus sentado em alto trono, habitante do éter, colocou-a nas raízes da terra; é bem melhor para os homens: ela leva ao trabalho mesmo a pessoa sem meios. Pois um homem sente falta de trabalho ao olhar para outro que, rico, apressa-se a arar, plantar e administrar bem sua casa, e um vizinho procura igualar o outro que se apressa em alcançar a fartura. Essa Luta é boa para os mortais. O oleiro irrita-se com o oleiro, o carpinteiro com o carpinteiro; o mendigo inveja ao mendigo, o poeta ao poeta" (HESÍODO, 2012, 750-650A.C., p.61-3). Nietzsche usa as duas Eris, uma relacionada à disputa mortal, e outra associada à inveja, sendo a primeira má e a segunda, boa, como um exemplo de contraposição à moral cristã. A Eris associada à inveja, ao ensejar a competição entre os homens, seria boa à cidade. "Para nossos estudiosos, os dois últimos versos [da citação acima] parecem inconcebíveis. Segundo seu parecer, os predicativos 'rancor' e 'inveja' só convém par ao modo de ser da má Eris. (...) A Antigüidade grega em geral pensa diferente de nosso rancor e inveja, julgando como Hesíodo, que apontou uma Eris como má, a saber, aquela que conduz os homens à luta aniquiladora e hostil entre si, e depois enaltece uma outra como boa, aquela que como ciúme, rancor, inveja, estimula os homens para a ação, mas não para a luta aniquiladora, e sim para a ação da disputa. O grego é invejoso e percebe essa qualidade, não como uma falha, mas como a atuação de uma divindade benéfica: que abismo existe entre esse julgamento ético e o nosso! (...) Quanto maior e mais sublime um homem grego, maior a claridade com que emana dele a chama da ambição, construindo todos os que seguem pelo mesmo caminho. (...) Quanto ao sentimento da necessidade de disputa quando se deve preservar a saúde da cidade-estado, pensemos no sentido original do ostracismo: 'Entre nós ninguém deve ser o melhor; se alguém for, todavia, então que seja em outra parte e na companhia de outros'. (...) Para os antigos, entretanto, o objetivo da educação 'agônica" era o bem do todo, da sociedade citadina. (...) Não se tratava de nenhuma ambição do desmedido [hybris] e do incalculável” (NIETZSCHE, 1996, 1872). Felizmente o cristianismo nos livrou da boa Eris. Não percebi, nas atividades do grupo, sentimentos, mesmo em baixa magnitude, de inveja ou ambição. Sem nenhum exagero, os trabalhos desenvolveram-se de maneira respeitosa às aptidões e conhecimentos uns dos outros, que serviram para que se atuasse de forma complementar e não competitiva. 
Não há necessidade de argumentos a favor da multidisciplinaridade em questões ambientais. Isso é assunto pacificado e irreversível. Porém, há algumas situações em que a multidisciplinaridade não funciona tão bem como esperado ou chega até a comprometer em algum nível os trabalhos realizados. Ou seja, há necessidade de um planejamento da multi- e da interdisciplinaridade em instituições e projetos relacionados ao meio ambiente de maneira que o trabalho não saia prejudicado e que sejam exploradas todas as vantagens e potencialidades que a situação pode trazer. Nesta seção, discutiremos algumas dificuldades. HOBBS (1997) e MOSS (2000) apresentam interessantes discussões sobre problemas e dilemas relacionados à interdisciplinaridade no âmbito da ecologia da paisagem.

De maneira muito simples e esquemática, com valor apenas para os limitados propósitos deste texto, podemos classificar as interações entre disciplinas em pesquisa e trabalho em três: a) situações nas quais haja concurso de mais de uma disciplina, funcionando elas apenas como um apoio em relação à disciplina principal; b) situações nas quais o objeto de estudo ou de trabalho seja tal que somente uma abordagem nas quais concorram simultaneamente diferentes disciplinas dê conta da consecução dos objetivos colimados. Essa situação implica que as diferentes disciplinas sejam utilizadas com "certa reciprocidade dentro das trocas [entre as disciplinas], de maneira que aí haja um enriquecimento mútuo" (DE ALVARENGA et al., 2011) ou uma fertilização cruzada; c) situações em que abordagens com mais de uma disciplina impliquem a emergência de novas questões de ordem epistemológica. Se quisermos, nada nos impediria de, talvez um tanto descuidadamente, atribuir às definições acima os adjetivos multidisciplinar, interdisciplinar e transdisciplinar, respectivamente. ${ }^{118}$

Um primeiro aspecto de problemas que podem ser suscitados pela utilização de equipes multidisciplinares em instituições refere-se às relações entre ciência e

\footnotetext{
${ }^{118}$ Uma divisão interessante proposta por MOSS (2000) consiste no seguinte: multidisciplinaridade (quando diversas disciplinas estão envolvidas, mas sem interação); pluridisciplinaridade (quando há uma interação descoordenada entre as disciplinas); interdisciplinaridade unidirecional (quando a interação e a coordenação são impostas por uma única disciplina); interdisciplinaridade orientada $a$ objetivos (quando a interação e a coordenação são determinadas pela natureza de um problema identificado); transdisciplinaridade (quando a interação envolve não somente as disciplinas científicas e tecnológicas relacionadas a objetivos estabelecidos, mas também quando planejadores e administradores estão envolvidos no processo).
} 
técnica. Para que a discussão desta seção possua terminologia um pouco mais rigorosa, socorrer-nos-emos do físico e filósofo argentino Mário BUNGE (1980) ${ }^{119}$. Ele apresenta definições para quadro teórico, doutrina, teoria e teoria científica. Delas, concluímos haver diversos gêneros de teoria que não podem ser considerados científicos nos termos das definições apresentadas acima, como por exemplo as teorias referentes à matemática e à filosofia (esta, em todos os seus ramos consagrados, como ontologia, metafísica, epistemologia, ética, lógica, estética), as teorias referentes ao direito e à contabilidade e todas as técnicas, tais como engenharia, medicina e administração.

Bunge vê a tecnologia como um domínio no qual podem ser observadas uma gnosiologia, uma ontologia e uma axiologia. Poderíamos acrescentar que, uma vez que todo ato humano se faz segundo um valor (objeto da axiologia) e que eventualmente pode estar relacionado com um dever (objeto da deontologia), existiria um campo de interesse dos mais importantes na prática tecnológica relacionado à sua deontologia. Não há como, no quadro apresentado por Bunge, hierarquizar atividades afirmando serem as teorias científicas superiores às tecnológicas.

Bunge faz uma distinção entre técnica e tecnologia. Para ele, um corpo de conhecimentos constitui-se em uma tecnologia se, e somente se: a) é compatível com a ciência contemporânea e controlável pelo método científico; b) é empregado para transformar ou criar coisas ou processos, naturais ou sociais. A tecnologia seria, portanto, a técnica que emprega conhecimento científico ${ }^{120}$. No entender de Bunge, a

\footnotetext{
${ }^{119}$ Ele se notabilizou como epistemólogo, podendo ser considerado adepto da escola do racionalismo científico. Entre diversos princípios normativos e reguladores dessa doutrina elencados por Bunge, WESTPHALEN E PINHEIRO (2004) destacam: a) o mundo existe em si (por si mesmo), ou seja, havendo ou não sujeitos cognoscentes; b) podemos chegar a conhecer o mundo, mesmo que somente em parte, imperfeitamente e aos poucos. Ele sempre refutou ser um positivista lógico, embora haja inegáveis pontos de contato entre as duas doutrinas.

${ }^{120}$ No nosso entendimento, tal definição é problemática. Em primeiro lugar porque só se preocupa com o corpo de conhecimentos, enquanto a tecnologia se refere a um corpo de conhecimentos $e$ de práticas. (A língua alemã encontrou um bom meio para escapar dessa armadilha: o nome do profissional, o exercício de uma atividade e o corpo de conhecimento associados a ela podem ser diferenciados por um processo de formação de palavras por composição. O nome da atividade pode ser obtido pelo acréscimo de Wesen (que significa ser, ente) ao nome do profissional, e o conhecimento associado a ela pode ser obtido pelo acréscimo de Wissenschaft (que é traduzida às vezes como ciência, mas pode ser entendida como um corpo de conhecimento; wissen significa saber). Assim, Ingenieur: engenheiro; Ingenierwesen: engenharia; Ingenieurwissenschaft: corpo de conhecimentos associados à engenharia). Em segundo lugar porque tal diferenciação tem pouca força
} 
gnosiologia da tecnologia tem uma forte inclinação pragmática, sendo por isso mais tosca que a gnosiologia da investigação científica; ao contrário, a axiologia e a ética da tecnologia são mais ricas que as da ciência.

$\mathrm{Na}$ Grécia clássica, a filosofia não tinha finalidade prática, como bem atesta Aristóteles $^{121}$. Não é o que se sucedeu na Europa. Desde a idade moderna estava claro que, embora a ciência pudesse se revestir de uma linguagem formal independente de aplicações, o móvel dela estava no domínio da natureza.

Para que os preconceitos ainda hoje infelizmente existentes sejam mais bem compreendidos, temos que remontar à classificação das ciências realizada por Aristóteles. Essa classificação foi a base para a definição de currículos nas universidades medievais e, pode-se dizer, valia ainda, de certa maneira, até o século XVIII. Para melhor compreendê-la, talvez seja interessante lembrar de duas características do pensamento grego: a) os gregos tinham horror a serem considerados como escravos ou escravizar-se ao que quer que seja; muito das virtudes que os gregos delineavam relacionava-se à não escravidão do homem aos seus sentidos e às suas paixões ${ }^{122}$; b) para os gregos, e para o pensamento europeu de um modo geral até Hobbes, os homens se diferenciam entre si, e por extensão, as coisas, demais seres e conceitos, por natureza. Assim, para eles nitidamente havia conhecimentos superiores e inferiores. Um resumo da hierarquia dos conhecimentos é fornecido por CHAUí (2002, p.346-51). Deter-nos-emos um pouco longamente

heurística. Em terceiro lugar porque subentende que a tecnologia se constitui meramente em um conhecimento científico aplicado; nada mais distante da realidade: a engenharia está muito longe de se constituir meramente em física aplicada, ainda que a engenharia preste um tributo (às vezes exagerado) à física; a medicina definitivamente não é bioquímica aplicada; seria risível dizer que a administração é psicologia aplicada. A distinção feita por Bunge explica-se por alguns entendimentos seus apresentados sobre a relação entre a metodologia da ciência e a metodologia da técnica. Explicase também pelo viés de sua formação em física; é irônico que Bunge, que sempre criticava o exercício da filosofia da ciência por parte de pessoas que não tiveram a oportunidade de ter uma formação em ciência, tenha caído em uma situação na qual trata de filosofia da tecnologia sem que ele próprio tivesse formação em tecnologia.

121 "[A filosofia] deve ser, com efeito, a [ciência] teorética dos primeiros princípios e das causas, porque o bem e o "porquê" são uma das causas. Que não é uma [ciência] prática resulta [da própria história] dos que primeiro filosofaram. Foi, com efeito, pela admiração que os homens, assim hoje como no começo, foram levados a filosofar. (...) Ora, quem duvida e se admira julga ignorar: por isso, também quem ama os mitos é, de certa maneira, filósofo, porque o mito resulta do maravilhoso. Pelo que, se foi para fugir à ignorância que filosofaram, claro está que procuraram a ciência pelo desejo de conhecer, e não em vista de qualquer utilidade." (ARISTÓTELES, 1973, p.214, destaque nosso).

122 "Quando somos autossuficientes e nos bastamos a nós mesmos, conseguimos um bem inestimável: a liberdade.” (EPICURO apud CHAUÍ, 2010, p.108). 
sobre essa divisão porque ela, além do seu interesse implícito pela formatação inculcada no pensamento ocidental e sua elegância teórica, demonstra claramente as raízes de certos pré-juízos ainda hoje existentes. A divisão do conhecimento proporcionada por Aristóteles é: a) ciências produtivas: referem-se à ação fabricadora humana (poíesis ${ }^{123}$ ), sendo o agente, a ação e o produto termos diferentes e separados. Incluem a serralheria, a marcenaria e a agricultura, mas também a medicina, a engenharia, a arquitetura, a estratégia, a poesia e o drama; b) ciências práticas: são aquelas cujo princípio ou causa é o homem como agente da ação e cuja finalidade é o próprio homem; o agente, a ação e a finalidade são uma só coisa; seu objeto não é necessário, mas possível, e não é universal, mas particular. A ação envolvida nas ciências práticas é a práxis ${ }^{124}$. Há algo nelas que lhes confere certa necessidade e certa universalidade. As ações verdadeiramente racionais e refletidas são aquelas que se realizam para alcançar um fim, o Bem, que é a medida da independência e da autossuficiência de alguém. Dividem-se em: b 1) ética: estuda a ação do homem enquanto alguém que deve ser preparado para viver na Cidade (corpo político); b 2) política: estuda a ação dos homens enquanto seres comunitários ou sociais; c) ciências teoréticas: são aquelas que investigam os princípios e as causas de seres ou coisas que existem independentemente da vontade e da ação humanas e cujo curso se desenvolve naturalmente e por si mesmo. Os seus princípios são universais e necessários. O princípio-guia para verificar se uma ciência é teorética está no movimento (kínesis ${ }^{125}$ ). Dividem-se elas em: c 1) fúsica: ciência dos

\footnotetext{
123 "Poíesis: Ação de fabricar, fabricação. Confecção de um objeto artesanal. Composição de uma obra poética. O verbo poiéo significa: fabricar, executar, confeccionar (obras manuais), compor (obras intelectuais, como um poema), construir, produzir (no trabalho agrícola), provocar (riso, vergonha, pobreza, lágrimas, riqueza), fazer (sacrifícios aos deuses, a guerra, o bem ou o mal a alguém); agir com eficácia produzindo um resultado (um remédio, uma arma, um artefato). Aristóteles explicita o sentido principal da poíesis como uma prática na qual o agente e o resultado da ação estão separados ou são de natureza diferente. A poíesis liga-se à idéia de trabalho como fabricação, construção, composição e à idéia da tékhne." (CHAUÍ, 2002, p.509).

124 “Práxis: Ação, ato (por oposição a fabricação, poíesis); atividade (por oposição a paixão, passividade, páthos); realização, maneira de agir e maneira de ser. O verbo prátto (no infinitivo: práttein) significa: percorrer um caminho até o fim, chegar ao fim, alcançar o objetivo, executar, cumprir, realizar, agir, conseguir, fazer acontecer alguma coisa, fazer por si mesmo. Aristóteles explicita o sentido de práxis afirmando tratar-se daquela prática na qual o agente, o ato ou ação e o resultado são inseparáveis. Trata-se da ação no campo ético e político. A práxis difere da poíesis e se opõe ao páthos." (CHAUÍ, 2002, p.510).

125 "Kínesis: Movimento; ação de mover ou de mover-se; agitação da alma; movimento da dança; movimentos da alma. (...) A palavra movimento, em grego, indica toda modalidade de alteração ou de mudança: mudança de qualidade, de quantidade, de lugar, de tempo, de ânimo; é o devir como
} 
seres que possuem em si mesmos o princípio do movimento e do repouso. Esta se divide em: c 1 1) ciência da natureza; c 12 2) psicologia (pois a psykhé $e^{126}$ é um tipo de repouso e movimento); c 2) matemática: ciência das coisas ou seres que, embora tenham existência nas coisas físicas, podem ser estudados em si mesmos, sem relação com a materialidade do movimento. Esta, por sua vez, divide-se em: c 2 1) aritmética: estuda números e operações; c 2 2) geometria: estuda pontos, linhas, superfícies e figuras; c 2 3) música: estuda ritmos e proporções dos sons; c 2 4) astronomia: estuda os astros imperecíveis; c 3) filosofia primeira, teologia $e$ metafísica: c 3 1) filosofia primeira: estudo do ser enquanto tal sem nenhuma determinação particular; c 3 2) teologia: estudo do ser imutável que é princípio do mundo; c 3 3) metafísica: fornece os primeiros princípios dos quais dependem os princípios da matemática e da física, sendo a mais universal de todas, e também a mais nobre e mais importante das ciências teoréticas.

Na Baixa Idade Média, o ensino em universidades era dividido em quatro campos (NUNES, 1979; JAMDADE, 2012): a) o Trivium (lógica, gramática e retórica); b) Quadrivium (aritmética, harmonia, geometria e astronomia); c) um terceiro grupo (teologia, metafísica e ética); d) após o estudo do Trivium e do Quadrivium, o aluno podia seguir estudos em direito romano, direito canônico e medicina ${ }^{127}$. Disso resultou que, até hoje, há certo desprezo dos praticantes de ciências, formais ou empíricas, pelos praticantes de técnicas. Ainda nos dias atuais, o fato de uma disciplina receber a chancela de ciência confere-lhe status.

Isso não acarretaria maiores problemas, constituindo-se apenas em um problema de semântica e de preconceitos de ordem de prestígio social, se não houvesse uma distinção radical no ensino e na prática de ciências experimentais e de técnicas. Tomemos como exemplo a distinção entre física e engenharia. Já nos referimos à questão do método de análise-síntese, sendo a física a ciência

\footnotetext{
nascimento, desenvolvimento e perecimento de um ser e todas as mudanças sofridas por ele ou causadas por ele. A locomoção é um tipo de kínesis, mas não é todo o movimento. Envelhecer, rejuvenescer, amarelecer, diminuir, aumentar, alegrar-se, entristecer-se etc. são kinéseis (movimentos)." (CHAUÍ, 2002, p.503).

126 "Psykhé: Alma, psique; sopro de vida; princípio da vida; o vivente; caráter, temperamento; sede dos desejos, sentimentos e pensamentos. Personificada, Psyché simboliza a imortalidade e é atormentada por Eros." (CHAUÍ, 2002, p.510).

${ }^{127}$ Aliás, houve momentos em que a medicina, a par da tecelagem, do trabalho com ferro, da guerra, da navegação, da agricultura e da caça, era incluída nas sete artes mecânicas (v. NUNES, 1979).
} 
paradigmática na utilização desse método. O objetivo da engenharia é obter soluções, seja no âmbito do simples ou do complexo, e que podem basear-se ou não em reconstruções da realidade modeladas pela física. Esta, se adotarmos um ponto de vista popperiano, tem como preocupação principal derivar situações-limite a partir de suas hipóteses e teorias de forma tal que permitam pô-las à prova em experimentos. Ou seja, a engenharia preocupa-se com o geral; a física, em que pese sua propensão a um reducionismo radical do Universo, preocupa-se com o particular. A engenharia procura poder descritivo, e, portanto, preditivo; a física, obter descrições do mundo com forte caráter reducionista. Algumas estratégias da engenharia para lidar com as limitações do método de análise-síntese decorrentes da complexidade da natureza (com um viés da engenharia civil, nossa formação) são: a) ver o simples no complexo; b) muito da engenharia é intuição; é o frequentemente denominado feeling; c) muitas vezes não se sabe onde exatamente está a solução do problema, mas se é capaz de determinar, com certa probabilidade de acerto, envoltórias de solução que satisfaçam os requisitos de projeto; d) a engenharia não procura descrever com exatidão a realidade, mas procura trabalhar com critérios de projeto, frequentemente, mas nem sempre, consubstanciados em normas técnicas ${ }^{128}$; e) a fim de compatibilizar modelos analíticos com a realidade, às vezes é muito útil estabelecer coeficientes corretivos; f) o teorema de Buckingham, ou dos $\prod$, assevera que, para um fenômeno cuja descrição não é conhecida, mas do qual se saiba ser influenciado por $n$ variáveis, existe uma função de n-m variáveis adimensionais, sendo m o número de dimensões associadas (espaço, tempo, massa, etc.) (v., p. ex., FOX e McDONALD, 1981, p.251-61; STREETER e WYLIE, 1982, p.166-82), capaz de descrever adequadamente o fenômeno, o que facilita brutalmente os procedimentos experimentais ${ }^{129} ; \mathrm{g}$ ) modelos em escala reduzida, lastreados em teoria de adimensionais; h) analogias: muitos fenômenos físicos distintos são descritos por equações de Fourier, de Young e de Ampère (v. PISKUNOV, 1969, p.365-6); i) analogias, com interesse meramente histórico e, eventualmente, didático (v., por exemplo, FRANCISS, 1980, p.111-60), já que hoje em dia abundam pacotes

\footnotetext{
${ }^{128}$ Esse é um dos motivos pelos quais é tão equivocada a concepção corrente segundo a qual a engenharia não é mais do que Física aplicada.

${ }^{129}$ Ainda há quem torça o nariz pelo fato de esse procedimento evidenciar certo caráter de caixa-preta de certas teorias de engenharia.
} 
computacionais capazes de integrar equações diferenciais relativamente complexas; j) muito do avanço técnico corresponde a processos de tentativa e erro, mais do que a avanços analíticos. Em grande parte, esse é o motivo pelo qual a engenharia não pode ser plenamente ensinada somente em escolas e por meio de livros: apenas a convivência com profissionais mais experientes pode trazer a confiança e a maturidade profissional.

Uma frequente fonte de mal-entendidos no trabalho interdisciplinar em instituições está em que a engenharia, assim como outras técnicas, se dá no âmbito de trabalhos em grupo nos quais estão presentes especialistas diversos, equipamentos, softwares, fornecedores, terceirizados. A expertise não está na mente das pessoas, mas na cultura do grupo; dissolvido o grupo, a expertise desaparece; se não houver um modo de os profissionais mais experientes transmitirem $o$ conhecimento aos mais novos, a expertise também desaparece. Em instituições públicas, mormente aquelas em que o saber-poder do jurídico é mais manifesto, há uma tendência de predomínio da cultura do processo administrativo, na qual os problemas são resolvidos à medida que chegam solicitações inscritas em processos ou outros expedientes. Nada poderia ser mais diferente do que a prática da engenharia e de algumas outras técnicas. Porém, nem sempre isso é compreendido por alguns profissionais provenientes de outras formações, especialmente as que tratam de demandas profissionais que possam ser satisfeitas por meio de atividades individuais.

Outro mal-entendido está no fato de os profissionais de formações técnicas poderem se constituir em especialistas ou em generalistas. O exercício profissional na Administração Pública condiciona fortemente um desenvolvimento de profissionais generalistas, porém frequentemente profissionais de outras formações, especialmente aqueles cujas formações tratam de demandas profissionais que possam ser satisfeitas por meio de atividades individuais, a que já nos referimos, têm a expectativa de que os generalistas estejam à disposição para exercer seu trabalho como especialistas, o que é impossível ${ }^{130}$.

\footnotetext{
${ }^{130}$ Parece haver, em alguns profissionais provenientes de outras áreas, dificuldade em entender as diferentes especializações e as diferenciadas atividades de profissionais de engenharia. OUZOONIAN e ZELAZNY (2000), por exemplo, distinguem claramente engenheiros calculistas e engenheiros
} 
Outra situação em que a multidisciplinaridade pode vir a redundar em problemas é a questão do qualitativo e do quantitativo. Algumas disciplinas e formações estão calcadas, em maior ou menor grau, em modelos e métodos quantitativos, assim como em outras ocorre o contrário ${ }^{131}$. O que poderia se constituir em excelente oportunidade de visualização de complementaridades, na prática muitas vezes resulta em dissensões. $\mathrm{O}$ antigo preconceito em relações às artes mecânicas frente às artes liberais às vezes toma a forma de uma pretensa superioridade de uma formação "humanística" frente à formação técnica. Ademais, em algumas formações os futuros profissionais são convencidos de que estão sendo treinados para o comando de equipes ou então a se constituir em ponto de vista privilegiado de interpretação e atuação na realidade. De fato, chegamos a ouvir de uma arquiteta que durante seus estudos de graduação um professor seu teria dito, metaforicamente, que eles não estavam sendo preparados para tocar um instrumento, mas para reger orquestras ${ }^{132}$.

Queremos crer que essa questão resulta de uma má compreensão do relacionamento entre modelos qualitativos e modelos quantitativos. O quadro 12 sintetiza bem tal relacionamento. É óbvio que são modelos qualitativos que predominam na fase inicial de tomada de decisão em relação a qualquer empreendimento. Disso, aliás, decorre um paradoxo: as decisões mais importantes

\footnotetext{
"forenses" (má tradução nossa do inglês): "Um engenheiro estrutural é um engenheiro com conhecimento especializado, treinamento e experiência em matemática relacionada à análise e projeto de sistemas resistivos a forças direcionados a edifícios e outras estruturas" (COUNCIL OF AMERICAN STRUCTURAL ENGINEERS, CASE, apud OUZOONIAN e ZELAZNY, 2000, p.2 do capítulo 1). Já um engenheiro forense é "um engenheiro estrutural que, por meio de treinamento, educação, experiência e conhecimento, tem reconhecimento de seus pares na posse de informações especializadas em um determinado ramo estrutural e que é experiente e versado na prática ética da engenharia forense e geralmente tem conhecimentos e experiência com o processo de resolução de conflitos". (COUNCIL OF AMERICAN STRUCTURAL ENGINEERS, CASE, apud OUZOONIAN e ZELAZNY, 2000, p.2 do capítulo 1). Parece-nos haver um certo viés no sentido de alguns agentes de direito no Brasil não reconhecerem tal distinção.

${ }^{131}$ Ficamos por vezes surpreendidos pelo fato de excelentes profissionais de arquitetura, com formação igualmente excelente, terem dificuldades com operações matemáticas tais como a potenciação.

${ }^{132}$ Curiosamente, veja-se a seguinte citação: "No caso de edificações, o arquiteto é o criador da estrutura com a finalidade de seu uso e de sua estética e tem a responsabilidade de coordenar o projeto produzido por especialistas. $\mathrm{O}$ arquiteto é similar a um regente de orquestra conduzindo musicistas em direção a um evento que dê satisfação ao público. [Mas:] o arquiteto revê e implementa o programa do proprietário para a alocação de espaços" (OUZOONIAN e ZELAZNY, 2000, p.3-4 do capítulo 1). Ou seja, o arquiteto é o regente generalista, mas também, paradoxalmente, é o musicista especialista em alocação de espaços.
} 
tomadas em um projeto ocorrem quando menos se dispõe de informações em relação à situação específica em que se dará o empreendimento. Uma vez que a função da técnica não é descrever, mas tomar decisões, e que modelos, principalmente matemáticos, servem apenas de ferramenta para simular a realidade, verificando as decisões tomadas, ou procedendo a otimizações, é óbvio que o determinante nessa hierarquia entre modelos qualitativos e modelos quantitativos no processo de tomada de decisões não corresponde a uma privilegiada formação do profissional, mas à experiência e à expertise desse profissional que propõe e decide em uma fase inicial do processo de tomada de decisão.

Quadro 12 - Hierarquia de solução de problemas.

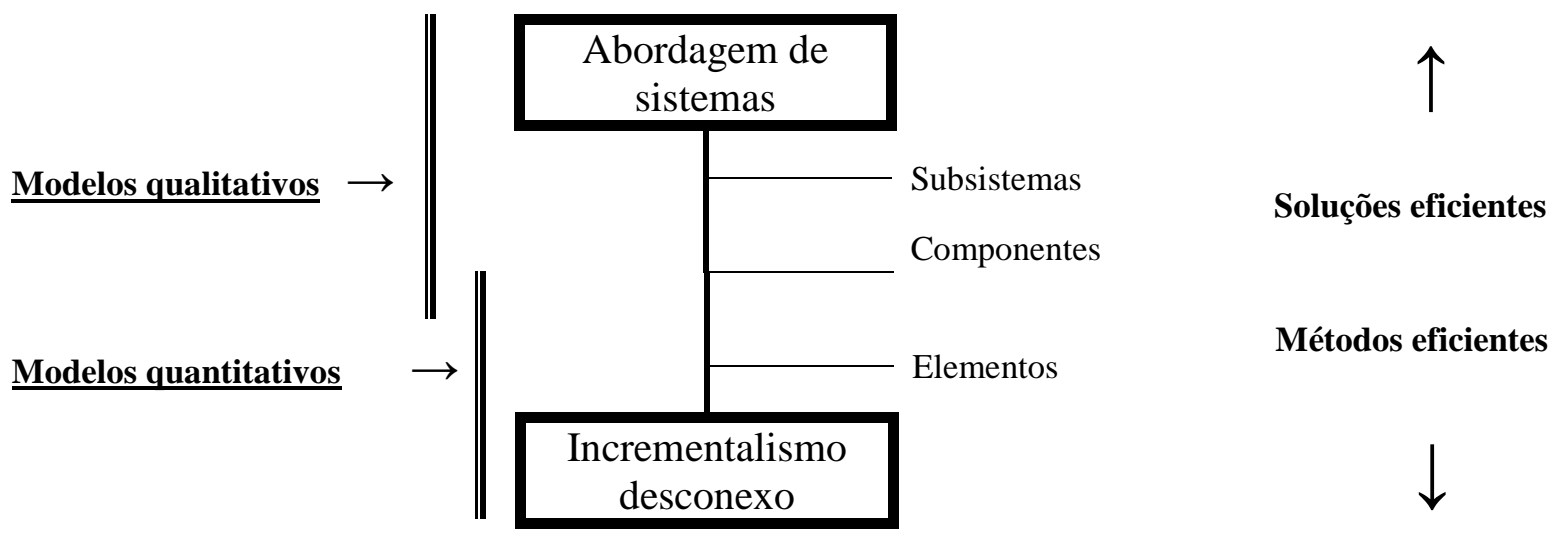

Fonte: WATTS JR. (1997, p.36 da primeira seção)

Cada formação incute, de uma forma ou de outra, na falta de uma expressão melhor, uma concepção de mundo (que não corresponde exatamente à Weltanschauung), que consiste em um construto ideológico que aponta para determinada maneira com que a realidade deva ser vista a partir de seus próprios marcos conceituais; seus problemas, identificados; e suas soluções, implementadas. Muito dessa concepção de mundo corresponde, no caso de ciências empíricas, ao conceito de paradigma na obra de Kuhn (KUHN, 2003, 1969). O conceito de paradigma de Kuhn não pode ser utilizado, sem maiores alterações, a ciências formais ou à técnica, embora às vezes isso seja feito. Para a técnica, na falta de melhor expressão, chamamos aqui de "paradigma técnico" uma tendência de, em determinada comunidade técnica, adotar soluções estereotipadas. Generalizações, 
sonhos e interesses, extremamente condicionados a determinada realidade, sem necessariamente haver adequação a outra realidade, geram os princípios do paradigma técnico; esses princípios condicionam a visualização de determinados problemas e respectivas determinadas soluções e práticas; eventualmente essas soluções e práticas transformam-se em dogmas. A existência de diferentes concepções de mundo e seus respectivos marcos conceituais associados é natural e a existência de paradigmas técnicos às vezes se torna um mal com o qual somos obrigados a conviver. Deve ser observado também que diferentes ciências frequentemente constroem, ancoradas em paradigmas próprios, teorias diferentes para os mesmos fenômenos. Diferentes concepções de mundo, paradigmas técnicos e soluções teóricas divergentes podem vir a se constituir em uma oportunidade de grande enriquecimento, redundando em melhor qualidade dos produtos, atendimento ao interesse público e à qualidade de vida das pessoas. Nem sempre, porém, tal acontece, o que dependerá da maturidade e do interesse do grupo.

Não é o menor dos problemas que a multidisciplinaridade pode acarretar que haja, em instituições em que profissionais de diferentes formações interajam, uma tendência para que o tratamento das questões se dê segundo um denominador comum criado a partir dos aspectos mais elementares dos conhecimentos envolvidos, um risco que deve ser evitado a todo custo. Determinadas carreiras, em decorrência da formação da chefia, ou do número de integrantes no grupo, ou ainda devido à liderança que um de seus membros exerce ou carisma que possui, podem criar uma sensação de privilégio. Às vezes pode ocorrer corporativismo.

Em suma, em instituições de meio ambiente é da mais alta conveniência a formação de equipes multi- ou interdisciplinares. Porém, não basta alocar profissionais de diferentes formações em uma determinada seção para que as equipes desenvolvam todo o potencial que a multidisciplinaridade, quiçá a interdisciplinaridade, possa trazer. Há necessidade de que essa questão seja visualizada e acompanhada com muita atenção, demandando um projeto especial de atuação frente à multidisciplinaridade. Há necessidade de que as diferenças de status e de rendimentos (que em nosso meio frequentemente caminham unidas) não sejam grandes a ponto de criar animosidades (estamos utilizando como equivalentes os termos salários, rendimentos, vencimentos, subsídios e proventos, o que é 
tecnicamente incorreto, mas que se justifica no presente contexto) ${ }^{133}$. Há necessidade de que seja formada uma cultura da casa; que a expertise do grupo não seja morta a cada mudança de chefia; que nesse processo seja formada uma hierarquia; que haja renovação do quadro de servidores; e que os servidores mais antigos se conscientizem de seu papel de correia transmissora de conhecimentos específicos e da cultura da casa. A Prefeitura do Município de São Paulo parece ter certa dificuldade em enfrentar esses desafios.

Na equipe ad hoc encarregada de propor a QA, não ocorreram os problemas acima. Pelo contrário, foram visualizadas e aproveitadas complementaridades. Isso decorreu da maturidade profissional e pessoal dos participantes do grupo e do respeito profissional entre eles. Além disso, os integrantes do grupo eram todos dotados de visão generalista, o que permitiu estabelecer um campo de diálogo, um vocabulário comum e sensibilização para os problemas sem que fosse estabelecida uma base comum elementar. Todos os integrantes do grupo eram provenientes de classe média. Finalmente, pelo menos três dos integrantes conheciam-se já havia pelo menos quinze anos e já haviam trabalhado juntos.

\footnotetext{
${ }^{133}$ Essa é uma questão bastante delicada, como quaisquer outras que envolvam diferenças relativas entre rendimentos, e têm reflexos bastante profundos em equipes multidisciplinares. Em princípio, no serviço público o conjunto seguinte de fatores corresponde às condições legítimas para que haja diferenças entre rendimentos: a) competências profissionais; b) responsabilidade envolvida; c) desgaste e riscos envolvidos nas tarefas; d) escassez de profissionais. Prestígio e lobbies não deveriam ter lugar aqui. Muitas carreiras são beneficiadas porque o seu poder é tamanho que os governantes ou as temem, e seus altos rendimentos são expressão disso, ou desejam cooptar essas carreiras, efeitos esses que entram em uma espiral quase infinita. O corporativismo campeia solto nessa questão. Autoridades com afinidades com uma determinada formação às vezes, mas nem sempre, cumulam de privilégios a carreira associada. A extrema necessidade de recursos financeiros por parte das administrações faz com que se privilegiem as áreas ligadas à tributação. Fatores culturais são importantes: profissionais de nível médio e operacional tendem a ser tratados, por motivos de classe e sociais, de maneira bastante depreciativa; no estado de São Paulo, existe um desprezo generalizado por servidores públicos, especialmente em épocas de recessão, o que se reflete em disposições negativas para fixar seus vencimentos. Respeitado apenas o conjunto de fatores legitimadores acima, necessariamente haveria diferenças de rendimentos. Assim, uma carreira que tem entre suas atribuições o exercício de grandes responsabilidades receberia mais proventos, o que por si só já causa desconforto. $\mathrm{O}$ fato de alguns integrantes dessas carreiras que exigem mais responsabilidade encontrarem nichos nos quais não incorram em tantas responsabilidades aumenta esse desconforto; o fato de alguns servidores se empenharem mais e trazerem junto a si mais responsabilidades o aumenta mais ainda. Finalmente, o fato de diversos profissionais em carreiras de nível médio, mas cuja formação e habilidades são de nível superior, serem integrados em equipes e tarefas atribuídas às carreiras de nível superior, mas sem paridade de rendimentos, torna esse desconforto quase insuportável.
} 


\section{ASPECTOS RELEVANTES DO EXECUTIVO MUNICIPAL PAULISTANO}

A devida apreciação do estudo de caso demanda o entendimento de alguns condicionantes de ordem administrativa (e política) do executivo municipal paulistano. É fundamental entender que são muitas as Prefeituras de São Paulo, cada uma com características distintas. Assim, é possível indicar, um tanto arbitrariamente, macrossetores diversos nela, alertando que há, obviamente, superposições: Saúde, Assistência Social e Moradias Populares, Infraestrutura e Zeladoria Urbana, Educação, Segurança Urbana, Cultura, Esportes, Promoção de Minorias, Promoção de Turismo e Desenvolvimento Econômico, Jurídico e Controladoria, Finanças, Assessoria Administrativa e Política ao Prefeito, Urbanismo e Meio Ambiente. Não é exagero dizer que cada uma delas possui cultura administrativa e processos de trabalho próprios, sendo o caso de perguntar se alguém conhece com profundidade todos esses macrossetores. Trataremos aqui de algumas questões de ordem administrativa referentes a Urbanismo e Meio Ambiente. Alertamos que por abuso de linguagem frequentemente denominaremos esse setor de executivo municipal ou de prefeitura.

Houve um esforço para calcar o texto em bibliografia e dar-lhe rigor acadêmico. No entanto, conforme descrito e frisado no capítulo referente à metodologia, não deve fazer parte do escopo do presente capítulo demonstrar e utilizar conhecimentos prévios no estado da arte.

Aqui é um bom lugar para fazer uma advertência que vale para todo o trabalho. É um fato haver sérias restrições legais em nível criminal, cível e administrativo relativas à liberdade de expressão no Brasil, mesmo em âmbito acadêmico. Na prática, a liberdade de expressão é tanto maior quanto maior a capacidade de contar continuamente com os serviços de um bom advogado (ou com a sorte). Para quem, como nós, não tão pobres a ponto de nos habilitarmos aos préstimos da justiça gratuita, mas não possuindo recursos para contratar advogados, é frequentemente mais prudente se calar. Além disso, ocupamos cargo efetivo na 
Prefeitura do Município de São Paulo. Muito da legislação que disciplina a atividade de servidores municipais é anterior à Constituição Federal de 1988, em especial o Estatuto dos Funcionários Públicos do Município de São Paulo, lei no 8.989, de 29 de outubro de 1979 (SÃO PAULO [CIDADE], 1979), e suas numerosas alterações, não havendo clareza sobre o que foi ou não recepcionado pela nova constituição. Além disso, essa legislação é frequentemente vazada em linguagem vaga. Averiguações e processos, não importa se administrativos, cíveis ou criminais, constituem-se sempre em fonte de enorme estresse e grandes despesas, mesmo na hipótese de resultado favorável. De fato, averiguar e processar constituem-se por si próprios em severíssima punição, independentemente do resultado; a mera ameaça de averiguar é (ou potencialmente pode ser) muitas vezes utilizado oficiosamente como um instrumento de exercício de poder não tão micro, como aquele a que se refere Foucault. Em assim sendo, alguns assuntos não serão tratados, outros terão que ser lidos nas entrelinhas, outros serão suavizados. Esso é o tributo que a academia paga ao ordenamento legal, processo que se realiza de maneira muito diferente da inocente homenagem que o vício presta à virtude através da hipocrisia.

\subsection{ASPECTOS JURÍDICOS}

Para tratar convenientemente de alguns aspectos do desenvolvimento da QA no que diz respeito à sua viabilidade política e funcional, é impossível esquivar-nos a uma consideração, expeditíssima, de algumas contradições históricas que envolvem e contritam o direito. Essa viabilidade correlaciona-se estreitamente com aspectos jurídicos que afetam a eficiência e a eficácia dos processos administrativos e a situação do servidor frente à legislação e aos órgãos de controle. Pensamos inicialmente que seria conveniente utilizar conceitos e métodos da chamada antropologia jurídica, com o instrumental teórico, por exemplo, de DE LIMA (2001 e 2010), ainda que não necessariamente nos atrelemos a seu pensamento e endossemos suas conclusões. Porém, faltar-nos-ia fôlego para tal, além de se constituir em um desvio do caminho. Assim, optamos aqui por simplesmente tecer considerações 
relativas a aspectos jurídicos que tiveram forte influência na concepção e no desenvolvimento da QA e na atuação de grupos de interesse e pressão. Em especial, temos intenção aqui de tratar dos funestos efeitos da insegurança jurídica sobre a atuação de servidores públicos, em especial no que diz respeito à QA. Alertamos que os conceitos de filosofia aqui expressos correspondem a uma brutal simplificação, como não poderia deixar de ser, tendo em vista as finalidades deste texto. Por esse motivo, recorremos de preferência a manuais, ao invés dos próprios textos primários ou de comentadores mais sofisticados.

Iniciemos esse voo panorâmico citando de passagem as controvérsias entre sofistas, de um lado, e socráticos, platônicos e aristotélicos, de outro. Os primeiros, segundo CHAUÍ (2002, p.161), correspondem àqueles que usam uma arte especial, a retórica, que permite obter a atenção e a benevolência do interlocutor ou do ouvinte, persuadindo-o a aceitar o que lhe é dito. Trata-se da arte do convencimento, necessária para os atenienses em instâncias judiciais e políticas, algo que poderia depois ser comparado à ars disputandi dos romanos. Sócrates opõe-se a isso porque faz distinção entre a opinião ( doxa $^{134}$ ) e a verdade, ou o desvelamento (aleteia ${ }^{135}$ ); assim, por exemplo, antes de indagar se certa forma de conduta é ou não virtuosa é preciso indagar o que é a própria virtude $\left(\right.$ aretét $^{136}$ ) (CHAUÍ, 2002, p.201). A

134 “Dóxa: Opinião, crença, reputação (isto é, boa ou má opinião), suposição, conjetura. Esta palavra possui dois sentidos diferentes por ser usada em dois contextos diferentes: o contexto político, no qual foi usada inicialmente, e o contexto filosófico, a partir de Parmênides e Platão. Deriva-se do verbo dokéo, que significa: 1) tomar partido que se julga mais adequado para uma situação; 2) conformar-se a uma norma estabelecida pelo grupo; 3 ) escolher, decidir, deliberar e julgar segundo os dados oferecidos pela situação e segundo a regra ou norma estabelecida pelo grupo. Era este o seu sentido na assembléia política, na democracia. Como a escolha e decisão se davam a partir do que era percebido, dito e convencionado pelo grupo, dóxa ganha também o sentido de uma modalidade do conhecimento e, agora, articula-se ao verbo doxázo, que significa: ter uma opinião sobre algumas coisas, crer, conjeturar, supor, imaginar, adotar opiniões comumente admitidas. É neste segundo sentido que dóxa pode ter o sentido pejorativo de conhecimento falso, preconceito, conjetura sem fundamento, sem convenção, arbitrária." (CHAUÍ, 2002, p.498-9).

135 "Alétheia: Verdade, realidade. Palavra composta pelo prefixo negativo a- e pelo substantivo léthe (esquecimento). É o não-esquecido, não-perdido, não-oculto; é o lembrado, encontrado, visto, visível, manifesto aos olhos do corpo e aos olhos do espírito. É ver a realidade. É uma vidência e uma evidência, na qual a própria realidade se revela, se mostra ou se manifesta a quem conhece. A palavra grega difere de duas outras que vieram, com ela, a formar a idéia ocidental da verdade: a palavra veritas, que se refere à veracidade de um fato; e a palavra hebraica emunah, que significa confiança numa palavra divina. Aléthes, o verdadeiro, significa: o não-esquecido, o não-escondido, donde: sincero, veraz, justo, eqüitável, verídico, franco ou não-dissimulado.” (CHAUÍ, 2002, p.494).

136 "Areté: Mérito ou qualidade nos quais alguém é mais excelente; excelência do corpo; excelência da alma e da inteligência. Virtude é a sua tradução costumeira porque foi traduzida para o latim por virtus, que significa, inicialmente, força e coragem e, só depois, excelência e mérito moral e 
contradição, que ainda parece persistir, é se a justiça é uma verdade que possa ser alcançada racionalmente, tornando-a necessária, ou apenas se constitui em uma convenção ou até mesmo em mera disputa argumentativa.

Na Idade Média estabeleceu-se um grande debate entre os realistas e os nominalistas. Em brutal síntese, os realistas creem na existência de universais, havendo, assim, por exemplo, o Bem, o Belo, o Justo. Por outro lado, os nominalistas rejeitam ontologicamente a existência de universais. "Uma das maiores questões filosóficas [da Escolástica] foi o problema dos universais, que dividiu o mundo filosófico em dois campos opostos. Os realistas garantiam que os universais eram coisas, baseando-se em Platão e na teoria das idéias. Os nominalistas, ao contrário, sustentavam que os universais eram meros nomes ${ }^{137}$, invocando a autoridade de Aristóteles" (RUSSELL, 2013, p.231-2). CULLETON (2011) apresenta a questão de uma maneira um pouco mais aprofundada através de considerações sobre os sistemas de Tomás de Aquino e de Guilherme de Ockham.

As tensões entre realistas e nominalistas tiveram enormes consequências para a filosofia moderna, especialmente no campo da filosofia política.

Thomas Hobbes foi um filósofo político que influenciou profundamente o pensamento político ocidental e era, por sua vez, profundamente influenciado pelo nominalismo. Ele, desejando estudar o funcionamento do Estado, realizou um procedimento analítico vagamente análogo a algo que poderíamos denominar hoje de Gedankenexperiment: se se quer estudar o Estado, necessariamente imerso em uma sociedade, imagine-se uma sociedade sem Estado. Como Hobbes visualizou o homem sem o Estado, ou seja, o homem no que seria o estado de natureza ${ }^{138}$ ? Ele postulou que nesse estado o homem se sente com direito a tudo (direito subjetivo). Se

\footnotetext{
intelectual. A areté indica um conjunto de valores (físicos, psíquicos, morais, éticos, políticos) que forma um ideal de excelência de valor humano para os membros da sociedade, orientando o modo como devem ser educados e as instituições sociais nos quais esses valores se realizam. A areté se refere à formação do áristos: o melhor, o mais nobre, o homem excelente.” (CHAUÍ, 2002, p.495). ${ }^{137}$ Quanto do pensamento europeu estava obcecado na época de Hobbes, de quem trataremos logo a seguir, por línguas históricas, consideradas originária ou misticamente perfeitas; pela reconstrução de línguas pretensamente originárias ou línguas-mãe mais ou menos fantásticas; por línguas mágicas em grau maior ou menor, tanto redescobertas como reconstruídas e que aspiram a uma perfeição, seja por efabilidade mística ou por segredo iniciático; pode ser verificado em ECO (1994). A expressão "meros nomes" precisa ser considerada à luz disso.

${ }^{138}$ Essa expressão, "estado de natureza", tem aqui sentido diferente do que adotamos no item referente à natureza. Lá, estado de natureza relaciona-se à condição mamífera do ser humano. Aqui, define-se por uma sociedade sem Estado.
} 
todos se sentirem com direito a tudo e não houver um critério e um poder para alocar os benefícios da natureza, as posses de outrem ou seus serviços, então o estado de natureza é necessariamente um estado de guerra de todos contra todos ${ }^{139}$. A ausência desse critério decorre essencialmente do nominalismo.

\begin{abstract}
Tudo aquilo que é válido para um tempo de guerra, em que todo homem é inimigo de todo homem, o mesmo é válido também para o tempo durante o qual os homens vivem sem outra segurança, senão a que pode lhes ser oferecida por sua própria força e sua própria invenção. Numa tal situação não há lugar para a indústria, pois seu fruto é incerto; conseqüentemente não há cultivo da terra, nem navegação, nem uso das mercadorias que podem ser importadas pelo mar; não há construções confortáveis, nem instrumentos para mover ou remover as coisas que precisam de grande força; não há conhecimento da face da Terra, nem cômputo do tempo, nem artes, nem letras; não há sociedade; e o que é pior do que tudo, um constante temor e perigo de morte violenta. E a vida do homem é solitária, pobre, sórdida, embrutecida e curta. (...) É dado que a condição do homem é uma condição de guerra de todos contra todos, sendo neste caso cada um governado por sua própria razão, e não havendo nada, de que possa lançar mão, que não possa servir-lhe de ajuda para a preservação de sua vida contra seus inimigos, segue-se daqui que numa tal condição todo homem tem direito a todas as coisas, incluindo os corpos dos outros. Portanto enquanto perdurar este direito de cada homem a todas as coisas, não poderá haver para nenhum homem (por mais forte e sábio que seja) a segurança de viver todo o tempo que geralmente a natureza permite aos homens viver. (HOBBES, 1988, 1651, p.76 e78).
\end{abstract}

Daí a necessidade de um soberano, que decide sobre o justo e o injusto. Porém, ele o faz não baseado em critérios de justiça ou equidade, porque Justiça e Equidade enquanto universais não existem no nominalismo. O soberano decide o que é justo e o que é injusto apenas com base em sua opinião, sua doxa, sempre de maneira arbitrária. E nada o impede de mudar a opinião ao longo do tempo. Não é o reinado do Rei-Filósofo. Alguém poderia argumentar que a antropologia de Hobbes é pobre; veja-se, para ficar apenas em alguns exemplos, o altruísmo sob o ponto de

\footnotetext{
${ }^{139}$ Uma problematização possível (e ingênua) a respeito desse aspecto fundamental da filosofia hobbesiana está no caráter necessário dessa situação no estado de natureza. Decorreria ela de um cálculo que cada um faz racionalmente considerando seus desejos e necessidades, sendo postulado que cada um procure maximizar seu prazer? Ou seria uma busca de prazer e satisfação decorrente de nossas disposições frente às quais o ser humano não consegue opor-se de maneira a realizar um cálculo racional? Ou seria, finalmente, um comportamento meramente condicionado por instintos? A resposta a essa problematização não é, pelo menos para mim, leigo, tão óbvia. Tendo a interpretar a problematização segundo a primeira possibilidade. No entanto, uma discussão minimamente consistente deveria considerar a antropologia hobbesiana e uma teoria de instintos e paixões. Pareceme particularmente pertinente nessa discussão o conceito freudiano denominado Trieb, usualmente traduzido em português como pulsão, sendo especialmente focadas as pulsões tanatológicas (FREUD, 1976). Freud menciona que Trieb é uma palavra pela qual muitas línguas modernas invejam o alemão. Etimologia, conotações, conceituação e comparação de Trieb com outros conceitos estão apresentadas em HANNS (1996, p.338-54). Como mera curiosidade, os termos ingleses drive e drift têm longínquo parentesco etimológico com Trieb. É muito interessante uma inspeção do vocábulo Trieb no monumental dicionário dos irmãos Grimm (GRIMM e GRIMM, 1971, 1854).
} 
vista evolutivo (DE MORAES, 2013), ou a empatia sob um ponto de vista filosófico (SILVEIRA e BRITO, 2014), ou, finalmente, a construção de poderes deônticos em instituições (SEARLE, 2005). Seja como for, o único remédio que Hobbes vê contra o estado de guerra de todos contra todos é a pacificação realizada pela força, sendo a submissão forjada por esse contrato social. Se no estado de natureza todos se sentem com direito a tudo, do que resulta que ninguém usufrui nenhum direito, em benefício do soberano abre-se mão de direitos de maneira a tornar possível a fruição da segurança.

A ideia de Hobbes de um estado escorado no poder absolutista do soberano pode parecer antipática. No entanto, Hobbes trouxe uma série de inovações (ou melhor, consolidações) conceituais na filosofia política ocidental. Assim, ele consagrou o conceito de direito subjetivo em comparação ao direito objetivo, ou positivo; com ele foi introduzida a noção de igualdade; ele inovou ao traduzir os conceitos envolvidos no nominalismo em filosofia política, conceitos esses que se mostraram de certa maneira vitoriosos no pensamento político ocidental ${ }^{140}$; ele consagrou o contratualismo na fundação do Estado; finalmente, abriu caminho para que outros filósofos argumentassem sobre filosofia política a partir da consideração de um estado de natureza ${ }^{141}$.

Locke foi um desses. Ao contrário de Hobbes, o estado de natureza de Locke não é um estado de guerra de todos contra todos e há critérios para a alocação dos direitos de cada um. Assim, o direito natural de Locke preconiza o direito de cada um dispor de si mesmo e, curiosamente, de seus bens. Qual seria então o critério para definir a cada um os seus direitos de propriedade? Locke apresenta uma interessante resposta, que teve grandes repercussões na economia, inclusive no pensamento de Ricardo e de Marx:

\footnotetext{
140 Tanto quanto um conceito filosófico possa ser "vitorioso" em uma cultura. ${ }^{141}$ Muito do aqui discutido a respeito de Hobbes e Locke decorre de curso proferido pelo Prof. Dr. Carlos Alberto Ribeiro de Moura, da Faculdade de Filosofia, Letras e Ciências Humanas da Universidade de São Paulo. Esse insigne professor não pode, obviamente, ser responsabilizado por minhas observações e conceituações leigas e ingênuas.
} 
Ainda que a terra e todas as criaturas inferiores pertençam em comum a todos os homens, cada uma guarda a propriedade de sua própria pessoa; sobre esta, ninguém tem qualquer direito, somente ela. Podemos dizer que o trabalho de seu corpo e a obra produzida por suas mãos são propriedade sua. Sempre que ele tira um objeto do estado em que a natureza o colocou e deixou, mistura nisso o seu trabalho e a isso acrescenta algo que lhe pertence, por isso o tornando sua propriedade. Ao remover este objeto do estado comum dos outros em que a natureza o colocou, através do seu trabalho adiciona-lhe algo que exclui o direito comum dos outros homens. Sendo este trabalho uma propriedade inquestionável do trabalhador, nenhum homem, exceto ele, pode ter o direito ao que o trabalho lhe acrescentou, pelo menos quando o que resta é suficiente aos outros, em qualidade e quantidade. (LOCKE, 1963, 1689).

Hobbes, portanto, alinha-se ao nominalismo e Locke, ao realismo. O modo como essas duas correntes evoluíram na história e no pensamento político produziu uma contradição insolúvel na teoria política ocidental, da qual ainda nos ressentimos. Trata-se da contradição entre o direito da maioria (o soberano nominalista) e os direitos mínimos das minorias (o direito "natural” realista).

Se a política ocidental se ressente dessa contradição, seria justo dizer que, tanto quanto que se possa fazer esse tipo de afirmação em filosofia, o nominalismo nessa mesma cultura ocidental parece ter se consolidado como ideologia e visão de mundo. Ainda hoje, o direito natural soa-nos como algo extravagante e arbitrário. Talvez porque a força do nominalismo não está no que ele afirma, mas no que ele não permite que se afirme. Hoje, parece que poucos juristas abraçam o direito natural. Mas ainda podemos, talvez, vê-lo recôndito, obscuro, clandestino na fundamentação jurídica, problemática, dos julgamentos, justos, de crimes contra a humanidade, na crença da existência de uma categoria tal como direitos humanos com os quais nasceríamos e que seriam inalienáveis, na Declaração de Independência Americana de 1776, na Declaração dos Direitos do Homem e dos Cidadãos (v. BILLIER e MARYIOLI, 2005, p.166-81). Queremos crer que aparece também em sistemas normativos decorrentes de teorias de valor na Economia. Sempre que questionados sobre a arbitrariedade em que se alicerçam esses sistemas de direitos apriorísticos, naturais, seus defensores invariavelmente se espantam e replicam: se não houver uma medida, um padrão, como poderíamos trabalhar, viver em sociedade, decidir? Parece que o instinto de justiça (qualquer um) está inscrito em nossa herança primata, ou que simplesmente o platonismo é mais forte em nossa 
cultura do que imaginamos. ${ }^{142}$ Aliás, um belo momento do direito natural do tomismo em oposição ao nominalismo aparece por ocasião dos grandes debates teológico-jurídicos ocorridos na Espanha do século XVI em torno dos direitos dos índios, em especial nos escritos do grande teólogo tomista Francisco de Vitoria (v. CHAUNU, 1984, p.414-20, e D’OCA, 2012).

Como essa contradição se reflete no Direito? Há uma profusão enorme de sistemas de filosofia do direito. BILLIER e MARYOLI (2005) apresentam, por exemplo, uma fantástica coleção desses sistemas na qual é possível discernir, entre muitos aspectos, a constante contradição entre a positividade convencional da lei produzida pelo legislador e o grau de liberdade do intérprete na aplicação da lei a casos concretos.

O direito administrativo brasileiro distinguia claramente atos discricionários de atos vinculados (v., p.ex., MEIRELLES, 1995). Os atos discricionários se relacionavam a uma margem que o legislador legou ao administrador na tomada de decisão. A contestação judicial de um ato administrativo discricionário precisava demonstrar desvios no tocante à competência, à finalidade e à forma, além, é claro, da não aderência do ato aos princípios constitucionais e aos que regem a administração pública ${ }^{143}$, ficando vedado ao juiz, idealmente, ater-se ao mérito da questão. Após a promulgação da Constituição Federal de 1988 (BRASIL, 1988), houve um entendimento generalizado de que o Judiciário podia, sim, tratar do mérito da questão, especialmente se na consideração desse mérito se questionava a

\footnotetext{
${ }^{142}$ Talvez o personagem Riobaldo, de Grande sertão: veredas, esse Fausto do sertão em busca do conhecimento de si e do bem e do mal sinta essa mesma angústia: "Sempre sei, realmente. Só o que eu quis, o que eu pelejei para achar, era uma só coisa - a inteira - cujo significado e vislumbrado dela eu vejo que sempre tive. A que era: que existe uma receita, a norma dum caminho certo, estreito, de cada uma pessoa viver - e essa pauta cada um tem - mas a gente mesmo, no comum, não sabe encontrar; como é que, sozinho, por si, alguém ia poder encontrar e saber? Mas, esse norteado, tem. Tem que ter. Se não, a vida de todos ficava sempre o confuso dessa doideira que é. E que: para cada dia, e cada hora, só uma ação possível da gente é que consegue ser a certa. Aquilo está encoberto: mas, fora dessa consequência, tudo o que eu fizer, o que o senhor fizer, o que o beltrano fizer, o que todo-o-mundo fizer, ou deixar de fazer, fica sendo falso, e é o errado" (ROSA, G., 2001, 1967, p.500).

143 Os princípios constitucionais que regem a administração pública são: legalidade, moralidade, impessoalidade e publicidade. Segundo MUKAI (1994), os princípios de direito público a serem observados são: primazia do interesse público, legalidade, liberdade dos cidadãos e proporcionalidade entre meios e fins. Ainda segundo MUKAI (1994), os princípios de direito administrativo a serem observados são: indisponibilidade do interesse público, especialidade administrativa, poder-dever do administrador público, finalidade, impessoalidade, moralidade administrativa e publicidade.
} 
aderência aos princípios constitucionais ${ }^{144}$. Ora, tais princípios são tão vagos e polissêmicos que quase qualquer conclusão quanto ao mérito é possível ${ }^{145}$. Dessa forma, a discricionariedade do Administrador enfraquece-se bastante. Se o Judiciário pode se ater ao mérito da questão, igualmente todos os órgãos de controle da administração também o podem. Alguém talvez pudesse ver aí certa anomalia decisória tendo em vista a inexistência de legitimidade democrática dessas instâncias ${ }^{146}$; trata-se da contradição acima exposta entre a positividade da lei e o grau de liberdade do intérprete. Além disso, uma vez que esses questionamentos se dão frequentemente a posteriori dos atos administrativos e de todos os seus efeitos legais e materiais; que na prática não há critério seguro para o administrador saber como o Judiciário e as instâncias de controle decidirão; que a mera abertura de inquérito significa grande prejuízo ao servidor em termos de tensão nervosa, dinheiro e saúde, o que pode se arrastar por anos; e que as penalizações para os servidores públicos podem ser desproporcionalmente graves em relação às faltas cometidas (punições administrativas podendo culminar na exoneração a bem do serviço público, obrigações de restituir os gastos ou reparar os efeitos com seu próprio patrimônio, sem prejuízo de multas impostas e a possibilidade de figurar no polo passivo de uma ação de improbidade administrativa), tudo isso conduz a um estado de insegurança jurídica extremamente opressivo no servidor público. Sem exagero, essa insegurança jurídica tende a produzir, dependendo de uma série de circunstâncias, certo estado mental análogo a terror e paranoia na administração, especialmente entre os que devem atuar em fiscalização, licenciamento e compras governamentais. Servidores de órgãos muito formalistas, como a Prefeitura do Município de São Paulo, são mais vulneráveis a esse problema. Constrói-se uma cultura de trabalho com a cabeça voltada por sobre o ombro, em que há mais

\footnotetext{
${ }^{144}$ A esse respeito, v. EMERIQUE (2011), obra, a nosso ver, passível de críticas.

145 A um leigo parece às vezes que o uso que se faz da Constituição Federal de 1988 se assemelha à leitura do Livro de Areia de Borges (BORGES, 2011).

${ }^{146}$ Essas instâncias são legítimas. O que elas não possuem é legitimidade democrática na medida em que seus decisores não são eleitos, nem demissíveis ad nutum por alguém eleito, nem escolhidos por sorteio (como se fazia em Atenas e como se faz ainda na composição do corpo de jurados) e nem seu exercício corresponde à participação direta dessa abstração denominada "povo". O que lhe confere fumos de legitimidade democrática e limitado controle social em nível federal é que os escolhidos para o Supremo Tribunal Federal e para a Procuradoria-Geral da República devem ser indicados pelo Presidente da República (eleito) e aprovados pelo Senado Federal (representantes dos estados que compõem a União escolhidos pelo voto) após arguição pública.
} 
preocupação com a possibilidade de ser punido do que com a qualidade, eficácia e eficiência do trabalho ${ }^{147}$; uma cultura de recibos, carimbos, assinaturas, arquivos; uma cultura em que todos evitam decidir, aconselhar ou participar. Implica ainda que a zona de conforto do servidor está no indeferimento e na procrastinação e que se corre muito menos risco não fazendo do que fazendo. Algum dia será devidamente avaliado o prejuízo em termos de eficácia, eficiência e qualidade decorrente desse tipo de controle.

O servidor sofre ainda com todas as contradições sociais e políticas que explodem em suas mãos, às quais as leis e o direito, de uma maneira geral, não dão conta. Sofre também com a incompatibilidade entre as cobranças decorrentes de suas atribuições e deveres e a grave e generalizada escassez de recursos, argumento muitas vezes não considerado pelos órgãos de controle; nisso, os municípios sofrem muito mais porque, devido a sua capilaridade, é a eles que a população recorre em sua legítima busca de direitos, sendo uma contradição que seja o município justamente o ente federado que menos dispõe de recursos e que conte com servidores mais mal remunerados ${ }^{148}$. Sofre com o fato de estarem à mercê dos membros dos órgãos de controle, frequentemente constituídos de jovens brilhantes, aprovados em concursos extremamente concorridos, bem-intencionados, mas algumas vezes imaturos e até às vezes arrogantes. Sofre com os poderes exorbitantes, oficiais e oficiosos, de que esses órgãos dispõem, a ponto de colocar em risco a harmonia e a independência de poderes. Sofrem com a inaplicabilidade da legislação frente ao enorme gap entre as situações fáticas e jurídicas. Sofre porque o servidor não tem segurança para saber se o que faz e decide será considerado lícito ou ilícito. Sofre porque os conceitos com os quais trabalha e deve decidir (por exemplo, a decisão multiobjetivo e/ ou envolvendo risco) normalmente são de difícil entendimento para quem o fiscalizará e para quem o julgará. Sofre por ser obrigado em cada caso a reexpor os rudimentos dos elementos conceituais através dos quais decide. Sofre com a frustração de pouco poder fazer e pouco decidir, de se sentir, portanto, inútil. Sofre,

\footnotetext{
${ }^{147}$ Obviamente toda instituição tem que ser submetida a mecanismos de controle. Não é disso que se cuida aqui. A questão está em aspectos relativos ao controle a que se procede.

${ }^{148}$ Servidores municipais que trabalham em fiscalização ou licenciamento têm também a grave desvantagem de ter que considerar e, portanto, dominar a legislação federal, estadual e municipal.
} 
finalmente, com o aviltamento de seus valores morais que essa situação provoca, tornando-o às vezes cínico ${ }^{149}$.

Tudo isso vai desvelando que um dos estamentos internos à Administração Pública - em relação ao qual o servidor de níveis hierárquicos baixos que não faz parte desse estamento, ou não participa de grupos de pressão que o protejam dele, se encontra inteiramente à mercê - fortificou-se a partir da promulgação da Constituição Federal de 1988. Trata-se das instâncias jurídicas do Estado. É um estamento poderoso, unido, bem remunerado e escorado no mérito ${ }^{150}$. Um dos grandes problemas associados a esse estamento é que ele, por força das regras que normalmente asseguram altíssima autonomia a seus membros de maneira a diminuir a probabilidade de ingerências indevidas, não atua de forma unificada, havendo muitas vezes conflito, o que desnorteia, desorienta e sobrecarrega a Administração.

Esse estamento não nasceu da Constituição de 1988, mas de um fenômeno social denominado bacharelismo. Uma rápida pesquisa em dicionários respeitados (FERREIRA, 1986 e 1999; MICHAELIS, 1998; HOUAISS e VILLAR, 2001) destaca dois aspectos do bacharelismo, um positivo e outro negativo. Assim, o bacharelismo se refere a uma conjuntura sócio-político-cultural em que é muito valorizado o bacharel ("advogado"). Por outro lado, o bacharelismo recebe a acepção de palavreado pretensioso, afetado, fastidioso, impertinente, com pouco ou nenhum nexo, ou irrelevante. A origem do bacharelismo em nossa cultura está relacionada à necessidade, quando da Independência, de formar e fornecer quadros ao Estado, dos quais se esperava que exercessem quaisquer cargos, com formação supostamente

\footnotetext{
149 Podem ser aventadas várias hipóteses para a existência desse tipo de controle: variação pendular em oposição à falta de controle e transparência da ditadura; eventual atuação irresponsável das oposições para inviabilizar as situações; justo reclamo da sociedade em relação à corrupção, a partir do quê os setores mais vulneráveis da administração (normalmente os servidores de carreira) são expostos a saraivadas dispersas de metralhas de fogo amigo, destinadas a, na sorte, derrubar o verdadeiro alvo. Há quem avente até a possibilidade de eventual atuação proposital para inviabilizar o Estado com vistas à privatização e à terceirização

${ }^{150}$ Não há dúvida que da atuação desse estamento, bastante competente, ocorreram consequências bastante positivas, não sendo a menor delas a conscientização geral de que as leis existem e que todos os agentes do estado têm de prestar contas de seus atos. Daí resultou maior rigor na proteção ao meio ambiente, ao consumidor, às minorias, aos portadores de deficiências físicas, aos setores mais fragilizados e marginalizados da população. Não tratamos desses inúmeros pontos positivos porque o que se cuida aqui é a influência da insegurança jurídica sobre o funcionamento da máquina pública, especialmente nos procedimentos de licenciamento e fiscalização, de interesse direto na concepção e no desenvolvimento da QA e na atuação de grupos de pressão internos à Administração.
} 
humanista, recrutados nas oligarquias e capazes de harmonizar elementos eventualmente conflitantes nessas oligarquias (ARAÚJO, 2010; DE MENEZES, 2009; SANTOS e CASIMIRO, 2012; DE FREITAS, 2010). Já durante a Colônia, a figura do "bacharel" era vista com certo melindre, como verificado por FREYRE (2007, 1933). Esse fenômeno não agradou certo olhar estrangeiro, como, por exemplo, LÉVI-STRAUSS (1996, 1955) e FLUSSER (1998). Cremos que "mandarinato" é um termo que bem se adequa a esse estamento, visto que os mandarins eram recrutados nas classes dirigentes do Império do Meio, eram alçados à carreira por mérito através de concorridos concursos e recebiam enormes poderes, vantagens e prestígio social.

Há um ramo da medicina dedicado a doenças laborais de servidores públicos. É evidente que o foco recai em categorias tais como policiais, bombeiros, professores e profissionais da saúde. Porém, profissionais de colarinho branco também são objeto desses estudos por serem vítimas de doenças específicas (BAZZO, 1997; CUNHA, 2007; CAMPOS, 2006; NUNES e LINS, 2009; SCHLINDWEIN e MORAIS, 2014). Tais servidores são vulneráveis à síndrome de burnout, relacionada a prolongados níveis de estresse no trabalho e compreendendo exaustão emocional, distanciamento das relações pessoais e diminuição do sentimento de realização pessoal (TRIGO, TENG e HALLAK, 2007; MALLMANN et al., 2009; PALAZZO, CARLOTTO e DE CASTRO, 2012). Toda a bibliografia citada neste parágrafo é brasileira. Não queremos, por óbvio, afirmar que o estresse provocado nos servidores públicos pela insegurança jurídica seja causa única das doenças laborais desses trabalhadores. Sugerimos, no entanto, que não se pode descartar precipitadamente hipótese segundo a qual esse fator teria um peso significativo na saúde deles.

Qual a relação de todas essas considerações com a criação de um instrumento como a QA? É que o seu propositor não pode nunca perder de vista que o servidor público municipal encarregado de aprovar empreendimentos imobiliários, ao fazê-lo, incorre em pesada responsabilidade. Por isso, constitui grupos de interesse para já na fase do desenvolvimento da QA se posicionar contra algo que lhe parecerá envolver dificuldades mais sérias, de ordem técnica e/ ou especialmente legal. Muitas das pressões a que o grupo esteve sujeito no desenvolvimento da QA veio de setores de licenciamento, especialmente vulneráveis à insegurança jurídica. Esse servidor 
preferirá sempre instrumentos vinculados, simples, de fácil entendimento para si e para o estamento jurídico e com exigências facilmente verificáveis. Rejeitará qualquer coisa nova e pela qual ele não se sinta absolutamente confortável em relação a seus aspectos técnicos ou que venha a lhe proporcionar insegurança jurídica. A QA não é complexa, mas não é trivial, embora a planilha fornecida tornea prontamente digerível e manuseável, até certo ponto. A QA, tal como consta no PL, é vinculada se o empreendedor aceitar apenas o cardápio de opções expressas no texto da lei, mas é discricionária caso venha a propor soluções inovadoras. Esse servidor se sentirá pouco confortável com essa possibilidade. Nas discussões do grupo, sempre se debateu essa questão: quem avaliará as propostas dos empreendedores se eles optarem por soluções novas? Aparentemente a resposta foi dada no PL: não se aventou a possibilidade de soluções paisagísticas novas (contra a nossa opinião), e as possibilidades em drenagem ficaram estritamente na dependência de regulamentação ${ }^{151}$. Propostas nossas no sentido de que argumentações dos empreendedores fossem aceitas de boa-fé pela Administração foram descartadas do texto final da minuta.

\subsection{ASPECTOS DE CULTURA INSTITUCIONAL}

O desenvolvimento da QA e sua aceitação pela Administração foram fortemente influenciados pela cultura organizacional do executivo municipal.

Cultura organizacional costuma ser definida como um conjunto de pressupostos, criados e validados ao longo do tempo, que definem a forma como as pessoas se comportam, as decisões são tomadas e as ações são conduzidas em uma determinada instituição (WOOD JR., 2015).

Há uma classificação de culturas organizacionais proposta por HANDY (1987) e resenhada por MOTTA (1991) extremamente simplificada, mas que se presta bem a uma primeira avaliação de culturas de uma determinada instituição.

\footnotetext{
${ }^{151}$ Entendemos que, além da regulamentação dos instrumentos não convencionais de drenagem na fonte e de novas soluções paisagísticas, haveria necessidade de regulamentar as próprias soluções paisagísticas e de drenagem já constantes do PL.
} 
Handy classifica as culturas organizacionais em quatro: apolíneas (em que a regra é preponderante), de Zeus (centrada em pessoas dominantes), atenienses (centradas na coletividade da decisão) e dionisíacas (centradas na expertise individual).

O executivo paulistano relacionado a desenvolvimento urbano é excessivamente eivado de regras e hierarquia, mas isso não o torna apolíneo. Ele é, na realidade, extremamente centrado em pessoas, no qual o poder de um servidor não decorre de sua posição no organograma, mas de sua proximidade pessoal a determinadas pessoas que se constituem em centros de poder, encaixando-se com mais propriedade a uma cultura Zeus. Essa contradição é extremamente estressante para os servidores.

O excessivo grau de formalização do executivo paulistano condiciona um estilo de administração em que os funcionários são levados a trabalhar eminentemente com processos e outros expedientes, ou seja, o ponto do servidor recebe processos ou outros expedientes (para os quais existe grande controle, principalmente em termos de prazos), havendo esforço para que esses processos e expedientes saiam rapidamente do ponto ${ }^{152}$. Ora, isso pode ser extremamente danoso na condução de políticas públicas porque o mero passeio dos processos e expedientes de ponto em ponto não garante a consecução delas ${ }^{153}$. Pior. Uma vez que muitas vezes eles versam sobre solicitações pontuais, os funcionários gastam quase todo o seu tempo e estrutura emocional em questões secundárias e para as quais frequentemente o município não tem como dar solução, seja pelos condicionantes jurídicos envolvidos, seja pela extrema escassez de recursos frente a amplas demandas. Não há, portanto, como fazer uma alocação racional do tempo porque são justamente os processos e expedientes que tratam de situações juridicamente mais difíceis, para os quais as soluções seriam pouco prováveis, de pouca eficácia e parco interesse público, que mais mobilizam os recursos humanos. Não é exagero dizer que só se "trabalha" de fato nos horários livres, após esses processos e expedientes terem

\footnotetext{
${ }^{152}$ Isso deve ser entendido não só como relacionado aos prazos, como também aos conteúdos. A PMSP é bastante eficaz em localizar processos e expedientes, mesmo que arquivados. Qualquer palavra ou omissão pode redundar em responsabilização funcional.

${ }^{153}$ Obviamente isso vale para profissionais envolvidos em delineamento de políticas públicas e em planejamento. Muitos profissionais, como, por exemplo, os envolvidos em fiscalização e licenciamento, têm a essência do seu trabalho no atendimento a processos.
} 
tido o encaminhamento devido. Nesse sentido, trabalhos como o de desenvolvimento da QA se mostram bastante gratificantes do ponto de vista profissional e pessoal.

A QA, quando aplicada por meio de planilha, não gerará, cremos, maiores apreensões nas decisões. Porém, possivelmente haverá necessidade de constituir sistema formado por corpo técnico treinado para as especificidades da QA, prestigiado pela Superior Administração, assessorado pelo jurídico e com decisões referendadas por colegiados dotados de poderes deliberativos ou sacramentadas por decreto (para o caso de o empreendedor apresentar soluções inovativas), tudo de forma a produzir segurança técnica e jurídica nas decisões.

\subsection{RELACIONAMENTO DO EXECUTIVO COM O LEGISLATIVO}

Para existir efetivamente, a QA precisa ser exposta a duas poderosas instâncias de decisão: a superior administração e o legislativo municipal. Isso justifica algumas considerações sobre o relacionamento do executivo com o legislativo.

O Centro de Estudos de Cultura Contemporânea (CEDEC) realizou trabalho de quatro anos no âmbito do projeto Estruturas e Práticas do Processo Decisório no Legislativo, com ênfase no município e no estado de São Paulo. O objeto do trabalho é um pouco antigo (no caso do município, trata-se das gestões Erundina e Maluf), mas apresenta modelos, dados, observações e conclusões bastante interessantes, sendo usado abundantemente nesta seção como referência ${ }^{154}$. O município de São Paulo, especificadamente, foi tratado em ANDRADE (1998), COUTO (1998) e PRALON e FERREIRA (1998).

Andrade postula, na criação de modelo para explicar a relação entre executivo e legislativo, que

${ }^{154}$ Para a mesma temática em nível federal, um trabalho bastante interessante é BEZERRA (2012). 
entre os diversos interesses perseguidos pelos parlamentares, o da própria reeleição, por hipótese, é o principal. Num sentido amplo, isso significa que, independentemente de suas motivações últimas, os parlamentares preferem reeleger-se a tomar qualquer outro rumo profissional ou político no final de seus mandatos. São, ou procuram ser, políticos profissionais, e não profissionais de outros setores de passagem pela política. (...) Não há por que deduzir daí uma completa ausência de convicções éticas ou políticas entre os parlamentares; a hipótese sugere apenas que eles tendem a avaliar com liberdade e flexibilidade estratégica o campo de oportunidades em que atuam. (ANDRADE, 1998, p.17).

Os autores não tratam da questão seguinte: os parlamentares representam interesses de classe ou constituem-se em mero estamento que pode ou não se pôr a serviço desses interesses? Tendemos a tomar partido da segunda hipótese, mas uma resposta a isso demandaria, obviamente, um estudo específico.

COUTO (1998) propôs o modelo apresentado no quadro 13.

A questão é saber onde o governo Haddad se enquadra no modelo apresentado acima. Não encontramos bibliografia que nos auxiliasse nessa tarefa. Assim, temos que nos valer de nosso ponto de observação muito pouco privilegiado na administração para lançar conjeturas, meras hipóteses, a respeito.

Quadro 13 - Modelo de relacionamento entre o executivo e o legislativo do município de São Paulo.

\begin{tabular}{|c|c|c|}
\cline { 3 - 3 } \multicolumn{1}{c|}{} & \multicolumn{2}{c|}{ Caráter de interação } \\
\cline { 3 - 3 } \multicolumn{1}{c|}{} & Programática/ de Conteúdo & $\begin{array}{c}\text { Barganha Alocativa (log rolling) } \\
\text { e Fisiológica }\end{array}$ \\
\hline Padrão Interativo & & $\begin{array}{c}\text { Coalizão Fisiológica de Governo } \\
\text { (CFG) }\end{array}$ \\
\hline Coalizões & Coalização Pragmática de Governo \\
& (CPG) & $\begin{array}{c}\text { Negociação Pontual Alocativa/ } \\
\text { Fisiológica }\end{array}$ \\
\hline Negociação Pontual (NP) & Negociação Pontual s/ Conteúdos & $\begin{array}{c}\text { Ausência Reiterada de Barganha } \\
\text { Alocativa/ Fisiológica }\end{array}$ \\
\hline Oposição Rígida (OR) & $\begin{array}{c}\text { Diferenças Programáticas } \\
\text { Irredutíveis }\end{array}$ & . \\
\hline
\end{tabular}

Fonte: COUTO (1998, p.46), com colaboração de Régis de Castro Andrade, adapt.

Notas:

Coalizão Programática de Governo (CPG): consiste na formação de uma bancada de sustentação do executivo no legislativo com base na costura de um programa comumente aceito, de cuja conformação os parlamentares participam.

Negociação Pontual (NP): consiste na negociação entre executivo e legislativo para cada projeto de lei na qual o parlamentar vota a favor do executivo em troca da liberação de recursos orçamentários, abstenção de veto por parte do executivo e outras vantagens.

Barganha Alocativa: consiste em uma troca em que o parlamentar presta seu apoio a iniciativas do executivo tendo como contrapartida ações governamentais em benefício de setores e/ ou regiões consideradas prioritárias pelo legislador.

Coalizão Fisiológica de Governo (CFG): consiste em os parlamentares absterem-se de utilizar sistematicamente seus poderes de veto, obstrução e controle em troca da distribuição de cargos na administração e na administração indireta a pessoas indicadas pelos partidos coligados.

Oposição Rígida (OR): consiste na indisposição completa ao estabelecimento de negociações por divergências fundamentais (oposição ideológica). 
No entender de PRALON e FERREIRA (1998), é no início de cada gestão que a opção do prefeito quanto à forma de relacionamento com o parlamento vai determinar o grau de dependência ou autonomia do legislativo frente ao executivo. Ora, no início da gestão Haddad era de conhecimento geral que o prefeito tinha formado uma coalizão extremamente ampla, o que lhe daria folga na aprovação dos projetos de lei de seu interesse. O prefeito chegou a nomear "técnicos" (devendo-se entender nesse contexto por "técnico" uma pessoa nomeada para o cargo não em decorrência de negociações políticas, mas por sua aptidão técnica para o cargo, de preferência um servidor efetivo) para cargos de grande importância, como o de subprefeito. É claro que isso deve ser entendido em um quadro de estrita tutela desses "técnicos" por um servidor comissionado de confiança do prefeito. A resposta à questão da posição em que a gestão Haddad no início de sua gestão se encontrava no modelo acima depende de um estudo próprio. Ele logrou montar uma ampla coalização, de amplo espectro entre direita e esquerda. Tendemos a acreditar que no início a administração realizava uma coalização programática de governo simultaneamente a barganhas alocativas e negociações pontuais ${ }^{155}$.

Pudemos perceber, no entanto, ter havido um momento crítico na administração em que o secretariado foi reformado, tendo havido a exoneração dos "técnicos". Isso sugere um fortalecimento do legislativo frente ao executivo. Parece que o prefeito foi levado a se focar mais em realizar negociações pontuais ou até mesmo montar uma coalizão fisiológica de governo.

Não obstante, independentemente da estratégia e das táticas de negociação, sempre tivemos a impressão de que o executivo via o legislativo de maneira confortável. Obviamente não havia apoio incondicional ao prefeito, mas aparentemente as negociações eram costuradas de maneira tal que o executivo vislumbrava ampla possibilidade de aprovar o que quisesse, desde que estivesse disposto, é claro, a utilizar o seu capital político em uma determinada iniciativa. Do nosso limitadíssimo ponto de vista, parecia-nos que o executivo estava tranquilo em relação à aprovação de uma lei de zoneamento. Parece-nos que esse foi o motivo pelo qual havia uma pressão grande sobre o grupo para que a QA fosse autoaplicável,

${ }^{155}$ No momento em que revisamos o presente (dezembro de 2015), tudo indica que o PMDB se retirará da coalização do prefeito Haddad. 
ficando a impressão de que o partido não queria correr o risco de essa situação não ocorrer em futuro próximo, querendo, portanto, a administração deixar marcas indeléveis na forma de lei, e não de decretos facilmente revogáveis em governos posteriores. Ressaltamos que o aparente conforto do executivo frente ao legislativo não implica que situações como a aprovação de novas leis e a aposição de vetos, por exemplo, não cobrassem custos políticos ao capital político do governo, e que muitas vezes não valeria a pena, do ponto de vista do executivo, empenhá-lo em certas situações. O grau de conforto do executivo dependeria também da relação entre os movimentos sociais e o executivo. Não temos como avaliar isso. Certas tensões vazaram para a imprensa, especialmente no início da gestão; talvez se tratasse apenas de uma acomodação inicial, em que cada lado avalia a correlação de forças.

$* * *$

É absolutamente fundamental acrescentar que historicamente as coalizões fisiológicas de governo contribuíram para o enfraquecimento da capacidade administrativa do executivo. Uma vez que quase todos os cargos, mesmo os de chefia de seção, correspondem a cargos de livre provimento do prefeito, sendo os requisitos para o exercício dos cargos bastante frouxos (normalmente posse de diploma de curso superior ou de curso de especialização na área), não tem sido possível consolidar a cultura da casa e a expertise acumulada. Isso não quer dizer que muitos desses servidores comissionados não tenham contribuído muito e não tenham sido dotados de grande capacidade gerencial e de conhecimentos técnicos. Associado a isso, passou-se muito tempo sem a realização de concursos, e, havendo-os, os novos servidores logo abandonavam o serviço em virtude dos baixos vencimentos (decorrentes de uma política de mais de uma década de não realização de qualquer reposição inflacionária), incompatíveis com a ausência de proteção jurídica frente à enorme responsabilidade associada aos cargos. Assim sendo, a morte ou a aposentadoria de servidores tem impossibilitado a transmissão dos conhecimentos ainda incorporados nos grupos.

O Plano Diretor Estratégico (PDE) (SÃO PAULO [CIDADE], 2014b) e a minuta de projeto de lei de parcelamento, uso e ocupação do solo (LPUOS), que chamaremos aqui de maneira simplificada como minuta da lei de zoneamento (SÃO PAULO [CIDADE], 2015), foram gestados na Secretaria Municipal de 
Desenvolvimento Urbano (SMDU). Fomos testemunhas de que, não obstante todos os problemas apresentados acima, essa secretaria apresentava alto padrão de desempenho, com os altos cargos sendo ocupados por servidores comissionados com excelente capacidade técnica e gerencial. Tudo isso conspirou para a qualidade do PDE e da minuta da LPUOS e permitiu grande grau de confiança técnica e conforto administrativo ao grupo da QA.

\subsection{DECISÕES DURANTE ELABORAÇÃO DE MINUTA DE PROJETO}

\section{DE LEI}

Em uma situação ideal, existe um Estado e governos que detêm legitimidade para governar. Em nosso sistema, trata-se de legitimidade democrática, do que decorre que se espera que os governos se sucedam mantendo-se a estrutura do Estado. Em sistema presidencialista, o governo (executivo), dotado de legitimidade democrática por via de eleição, é independente do parlamento (legislativo), que representaria o próprio povo exercendo o poder por meio de seus representantes. Há assim dois poderes dotados de legitimidade democrática, mas autônomos um em relação ao outro. A fim de assegurar a manutenção da estrutura do Estado e a continuidade administrativa e oferecer suporte para os novos governos, o executivo conta com uma burocracia permanente a serviço do Estado e que mantém com o governo uma relação hierárquica, embora conserve certa autonomia porque é obrigada a se recusar a realizar tarefas ilegais. O governo nomeia pessoas de sua confiança para os cargos-chave da administração. Uma vez que essas pessoas podem ser demitidas ad nutum, elas representam o governo e têm para si transferida a legitimidade democrática desse governo.

Obviamente esse quadro ideal difere bastante da realidade corrente. Uma das diferenças reside no fato de que, embora a decisão no âmbito do executivo caiba ao seu titular ou a seus prepostos, muitas vezes a decisão é tomada a partir de 
alternativas propostas pela burocracia ${ }^{156}$. No caso do município de São Paulo, como vimos, isso é relativizado na medida em que quase todos os cargos são de livre provimento, o que distorce bastante a ideia de uma burocracia permanente destinada a prover suporte administrativo e conhecimentos administrativos e técnicos para os novos governos, desobrigados eles que estão de deter conhecimentos técnicos, cabendo-lhes, em princípio, apenas as decisões políticas.

No núcleo do pequeno grupo ad hoc formado para desenvolver a QA havia apenas servidores efetivos, o que em princípio os colocava como membros da burocracia permanente. No entanto, alguns membros desse pequeno núcleo ocupavam cargos em comissão, o que os tornava representantes do governo. Mesmo isso precisa ser relativizado porque, sendo quase todos os cargos de livre provimento, os servidores efetivos aceitam, para fins de carreira, cargos em comissão mesmo que não possuam nenhum compromisso ideológico com o governo. Porém, precisam ter clareza de que mesmo que ocupem os cargos nesse contexto, ao aceitá-los tornam-se, em diferentes graus, e até certo ponto, representantes do governo.

Os servidores efetivos podem, se quiserem, submeter à superior administração as propostas a serem decididas sem se preocupar com os aspectos políticos. Não é uma boa estratégia. Um servidor estável não tem obrigação de se curvar às diretrizes ideológicas do governo, mas trabalhar sem considerar aspectos políticos relacionados às preferências da superior administração, do legislativo e dos diferentes grupos de interesse e de pressão implica um trabalho de baixa qualidade. É essencial, portanto, que o servidor estatutário tenha sensibilidade a essas questões já na fase de elaboração de alternativas que serão submetidas à superior administração. Isso pode se mostrar de grande complexidade porque ele tem que se antecipar a essas questões políticas e considerar os interesses dos diferentes stakeholders envolvidos de maneira a garantir a viabilidade da sua proposta; ora, essas pressões são

\footnotetext{
${ }^{156}$ No entender de NIJKAMP (1980), a função de um técnico na análise de políticas ambientais limita-se a: a) provisão de informação a decisores; b) o cálculo de todos os sacrifícios e benefícios marginais associados a certa decisão ou problema político, de forma que o decisor conheça precisamente as repercussões de qualquer escolha que ele queira fazer; esta análise de tradeoffé extremamente importante em qualquer análise operacional de política ambiental; c) a construção de um apropriado procedimento de política ou avaliação que trate toda a informação necessária de uma maneira compreensível; desse modo, o decisor pode julgar todas as escolhas, alternativas e critérios de uma maneira sistemática, tal que no final ele faça uma escolha de melhor compromisso.
} 
conflitantes entre si, devendo a decisão final resultar de embates e convergências políticas. Muitas dessas pressões de grupos de interesse já ocorrem na própria fase de elaboração da minuta de projeto de lei e às vezes se dirigem diretamente a membros do governo em cargos de nível hierárquico baixo ou até mesmo a servidores efetivos. A superior administração também não é homogênea e nem sempre tem claro a si exatamente o que quer; assim, diretrizes contraditórias ou vazias podem ser passadas durante os trabalhos.

Nesta seção, discutiremos a respeito de algumas dificuldades que servidores efetivos enfrentam ao redigir minutas de projetos de lei (PLs), principalmente, mas não só, levando em conta as dificuldades objeto de discussão no início deste item.

\section{Normas específicas ou estudos caso a caso}

Na minuta de um PL, há necessidade de decidir quais elementos serão tratados por meio de normas específicas ou de estudo caso a caso.

FISCHHOFF (1985) enumera condições tendentes a favorecer normas específicas ou estudos caso a caso.

Convém não fetichizar normas específicas na forma de padrões. Estes correspondem a um acordo social envolvendo dano ou risco aceitável e avaliação de oportunidades perdidas na aplicação de recursos destinados a atingir determinado padrão; frequentemente os que arcam com os ônus do estabelecimento de padrões não são os beneficiados com os bônus. Esse acordo social é feito tomando como base critérios, cujo estabelecimento é frequentemente eivado de incertezas, da tácita ou expressa assunção de um risco, das tecnologias disponíveis e de uma consideração sobre a razoabilidade dos custos incorridos. Não se pode entender, como muitas vezes ocorre, que desde que os padrões sejam obedecidos a situação é necessariamente aceitável ou vice-versa ${ }^{157}$. Muitos padrões são estabelecidos a partir da consideração de diversos cenários entre cujos parâmetros encontram-se outros parâmetros mais gerais. Idealmente seria interessante proceder nos processos de licenciamento a estudos caso a caso. Isso, no entanto, implica frequentemente em

\footnotetext{
${ }^{157}$ Obviamente no caso de sistemas homeostáticos há certos valores de referência que, alterados, indicam problemas, como é o caso da temperatura dos seres homeotérmicos.
} 
uma mobilização exagerada de recursos. Apela-se, então, a padrões; nesse caso, estes devem ser entendidos como um sucedâneo imperfeito ao estudo caso a caso.

Obviamente normas específicas tendem a implicar atos vinculados, enquanto estudos caso a caso, atos discricionários. Estes, principalmente no âmbito de uso e ocupação do solo, tendem a causar desconfiança por parte dos empreendedores e desconforto (como já tivemos oportunidade de discutir) aos servidores. Já no âmbito ambiental estudos caso a caso estão mais assimilados pelos empreendedores, servidores e até operadores de direito. Independentemente do âmbito, atos discricionários são necessários em casos de grande especificidade e/ou complexidade.

É possível, porém, a opção de eivar o texto legal das chamadas normas em branco. Trata-se de normas vagas, imprecisas, polissêmicas. Em textos legais destinados a operadores técnicos é importante evitar ao máximo normas em branco porque costumam trazer diversos problemas de interpretação e de insegurança jurídica. Há a quem agrade inserir normas em branco na forma de princípios programáticos. Acreditam, dessa forma, que todos os aspectos da questão por eles defendidos serão cobertos. Às vezes elas são necessárias porque o nível de complexidade com que os legisladores estão dispostos a tratar da questão não alcança as minúcias necessárias para aplicação imediata das normas. Pode acontecer também que a própria administração opte por propor PLs com normas em branco porque não conseguiu chegar a soluções precisas, ou, tendo chegado, não houve consenso. Nesse caso, o ideal é remeter a decretos regulamentadores.

\section{Simples ou complexo}

É desejo de todos os leigos que se envolvem com leis que elas sejam de fácil entendimento. Porém, há um tradeoff entre simplicidade e rigor teórico. A decisão se inscreverá em algum ponto da curva de tradeoff. Navega-se, portanto, entre a conotação e a denotação.

Às vezes, como foi o caso da QA, houve diretriz segundo a qual o PL deveria ser simples e autoaplicável. Também aqui existe um tradeoff. Se se deseja um texto 
simples, ele tende a não ser autoaplicável, demandando regulamentação na forma de legislação infralegal, ou até mesmo de outra lei.

\section{Prazo versus qualidade}

Todo trabalho administrativo tem associado a si um prazo. Às vezes prazos excessivamente longos implicam desleixo porque fazem o grupo perder o foco e a dedicação. Porém, na maioria das vezes existe também um tradeoff entre o prazo concedido e a qualidade do trabalho. É na fase final do trabalho que a questão objeto de estudo é mais bem conhecida, do que decorre que o grupo almeje uma retroalimentação no sentido de começar novamente, desta vez com o conhecimento adquirido; porém, frequentemente o prazo não o permite, do que decorre que o grupo fica insatisfeito com alguns aspectos de seu próprio trabalho e, pior, sujeito a críticas com as quais tem que concordar, ainda que explicando aos críticos a impossibilidade de resolver o problema.

O prazo concedido ao grupo era extremamente exíguo (seis meses). Porém, esse prazo foi sendo dilatado por motivos técnicos e políticos, não claramente expostos a nós.

\section{Facilidade de fiscalização e licenciamento e qualidade}

A legislação de uso e ocupação do município de São Paulo é notoriamente complexa, frequentemente difícil de interpretar (sendo que os técnicos não poderiam ser obrigados a conhecer e praticar hermenêutica e nem ser responsabilizados $a$ posteriori por interpretações divergentes, embora seja esta a realidade do serviço público e em particular da PMSP), e dispersa por uma infinidade de atos infralegais. Além disso, o servidor municipal deve velar não só pela legalidade em nível municipal, mas considerar e observar a legislação federal e estadual, a jurisprudência, a doutrina, conteúdo de Termos de Ajustamento de Conduta fixados anteriormente com o Ministério Público e recomendações emanadas deste órgão, além de estar atento às posições do Tribunal de Contas. Muitas vezes, a posição do próprio Ministério Público é discrepante; tal ocorre, por exemplo, entre a área de 
meio ambiente e a de habitação de baixa renda. Muitas vezes a questão é remetida a vagos princípios constitucionais, sendo os servidores obrigados a se responsabilizar por decisões tomadas com base nesses princípios, ou, pior, suportar críticas $a$ posteriori por uma suposta não adesão a esses princípios, às vezes mesmo que o direito positivo e as regulamentações digam o contrário. Não é nenhum exagero afirmar que para um engenheiro ou arquiteto estar apto a licenciar ou fiscalizar com relativa segurança e autonomia aspectos relacionados a parcelamento, uso e ocupação do solo é necessária uma experiência mínima de alguns anos, além de, idealmente, treinamento formal. Isso é ignorado porque sempre se parte do pressuposto que, estando uma pessoa legalmente habilitada a exercer determinada profissão, ela está capacitada a exercer qualquer atividade que conste em suas atribuições definidas na legislação e pelo órgão de fiscalização do exercício da atividade profissional.

Além disso, o grupo que elabora uma minuta de PL precisa ter em mente que a lei não é capaz, por si só, de criar uma realidade nova, e pode ter consequências não previstas na boa vontade de que seus membros são dotados.

Assim sendo, os setores do executivo encarregados de licenciamento não veem novidades com bons olhos, podendo pressionar fortemente no sentido de a minuta não ser aceita pela superior administração ${ }^{158}$.

\footnotetext{
${ }^{158}$ Muitas vezes o setor de licenciamento se queixa de que se a lei tiver certa complexidade e demandar grande especialização, não haverá como dispor de servidores com conhecimento necessário para avaliar o projeto submetido à administração; isso procede porque o serviço público tende a produzir generalistas. Queixa-se também da falta de recursos. As duas queixas são absolutamente pertinentes. Por uma série de motivos, a PMSP é extremamente depauperada em termos de recursos na área de parcelamento, uso e ocupação do solo. O setor privado argumenta que o empreendedor pode apresentar laudos assinados por profissional competente na área, com emissão de ART, o que viabilizaria o licenciamento. O setor de licenciamento contra-argumenta no sentido de que o servidor é solidariamente responsável pelo que aprova, de maneira que um laudo ou uma mera declaração não seriam suficientes. Por outro lado, o Código de Obras e Edificações (SÃO PAULO [CIDADE], 1992a) determina que os projetos submetidos à PMSP devam obedecer a todas as normas técnicas oficiais - o que confere, aliás, poderes legislativos a uma entidade privada (a Associação Brasileira de Norma Técnicas, ABNT), sem que ao menos as normas sejam publicadas em Diário Oficial. Além de o conhecimento aprofundado de todas as normas técnicas implicar em conhecimento enciclopédico virtualmente inalcançável, especialmente para um generalista, o setor de licenciamento costumeiramente não verifica, por exemplo, o cálculo de estruturas, o de fundações e as planilhas de elétrica e hidráulica. Por outro lado, há quem no licenciamento entenda que uma mera declaração por parte do responsável técnico pelo empreendimento é suficiente para isentar o servidor de responsabilidade solidária; essas mesmas pessoas, no entanto, argumentam não ser possível inserir claramente no texto legal os limites da responsabilidade técnica do servidor. Por outro lado, elas entendem que nesse caso o empreendedor fica obrigado à declaração e eventualmente à apresentação
} 
Acrescente-se a isso que, por uma série de motivos que não cabe aqui aprofundar, a fiscalização de parcelamento, uso e ocupação do solo sofre de dificuldades sérias. Dessa forma, sempre há o legítimo questionamento a respeito da viabilidade de fiscalização, questionamento esse com o qual os membros do grupo precisam estar preparados para considerar, alterando a minuta, se for o caso, ou dar uma resposta adequada.

\section{Complexidade dos métodos a serem empregados}

Durante a redação da minuta de PL alguns métodos e modelos técnicocientíficos são utilizados. Além disso, o texto pode remeter à obrigatoriedade de o empreendedor demonstrar o atendimento a certas situações que demandem um modelo. Ora, na técnica não existe modelo certo ou errado; existem, sim, modelos que dão ou não respostas satisfatórias no contexto em que são aplicados e para a finalidade a que se destinam. Muitas vezes, modelos mais simples podem dar respostas mais satisfatórias que modelos complexos, estes muitas vezes sedentos de conceituações mais sofisticadas e de parâmetros ${ }^{159}$ a respeito dos quais se dispõe de pouca informação.

\section{Parâmetros numéricos a serem utilizados no corpo da minuta de PL ou de sua regulamentação}

A mesma dificuldade apontada acima ocorre na definição dos parâmetros numéricos usados no texto legal. Caso se determinem estudos caso a caso, o

\footnotetext{
da solução associada ao projeto; porém, se algum cálculo ou alguma justificativa for anexada ao processo, isso criaria insegurança jurídica porque sentem que teriam que avaliar a pertinência técnica do cálculo e responsabilizar-se por ela; assim, não aceitam que qualquer cálculo ou justificativa anexem-se ao processo sem que haja necessidade de apreciação por parte do servidor, sendo guardado apenas para emergências ou investigações futuras ou para controle social. É uma situação muito difícil que se perpetua e para a qual parece haver poucas possibilidades de pacificação.

${ }^{159}$ Em consonância com o PL 272/2015 (SÃO PAULO [CIDADE], 2015a), no qual a QA é enquadrada no gênero "parâmetros", a par da taxa de ocupação e do coeficiente de aproveitamento, por exemplo, temos utilizado o termo com esse sentido. A palavra "parâmetro" é semanticamente ampla o suficiente para aceitar esse uso. Nós, porém, preferiríamos que esse gênero fosse denominado "instrumentos". Até porque nos parece mais adequado nominar parâmetros a dados numéricos de entrada de modelos. Usaremos o termo com esse sentido, também, o que poderá causar certa confusão. Acreditamos, porém que o contexto esclarecerá o significado.
} 
problema não é tão sério. Mas na norma geral adotam-se, implicitamente, modelos, mais ou menos precisos, que são carregados com parâmetros com um grau maior ou menor de conhecimento e risco. Caso os parâmetros sejam bem conhecidos, adotamse médias, ou medianas, ou modas, ou percentis (a que probabilidade?). Frequentemente a distribuição dos parâmetros não é bem conhecida; às vezes, o máximo que se consegue é um parâmetro meramente verossímil.

\section{Estrutura e conteúdo}

Pode acontecer de que o texto de uma minuta de PL esteja bem estruturado, conciso, claro e coerente. Porém, a entrada de novos interesses e grupos de pressão pode ter o condão de obrigar a incluir elementos novos, desfazendo, em maior ou menor grau, a estrutura, concisão, clareza e coerência do texto.

\section{Todos os "tradeoffs"}

Em textos normativos, quase todas as decisões tomadas implicam determinada escolha dentro de uma curva de tradeoff. Não existe o mais correto ou o mais adequado, a menos que a priori nos sujeitemos a uma deontologia ou a uma axiologia específica ${ }^{160}$. Cada passo, cada discussão, são eivados da angústia da decisão.

Porém, no final, os tradeoffs, os compromissos e as antinomias serão resolvidos pelas instâncias de decisão (superior administração, legislativo e eventualmente judiciário). Do entrechoque e da colaboração de dezenas, centenas, milhares de vontades sairá o texto legal e sua interpretação, pelo qual somos todos um pouco responsáveis.

\footnotetext{
${ }^{160}$ A rigor, a Constituição e elementos programáticos de outras leis, bem como os valores vigentes na média na sociedade, teriam esse papel.
} 


\section{TOMO IV:}

ESTUDO DE CASO 


\section{CONTEXTO}

A partir desse momento será necessário, pelo fato de termos pessoalmente participado dos fatos narrados, abandonar o plural majestático e o uso da partícula "se" como índice de indeterminação do sujeito ou de partícula apassivadora, o que poderia gerar confusões. Mais do que uma simples mudança de regra, há uma alteração de estilo decorrente dela. Faço-o por entender que a metodologia aplicada demanda uma observação de caráter mais parcial. Fujo assim das regras acadêmicas convencionadas porque essa metodologia não permite o distanciamento linguístico que exprime supostas neutralidades e objetividades. Não há como embasar tudo; muitos dos comentários, reflexões e conclusões decorrem de uma observação direta, que se autofundamenta no próprio testemunho e na participação. Embora sejam máscaras diferentes, a do pesquisador e a do participante, não há como separar o discurso de ambos. Assim, no presente tomo, o tom de linguagem necessariamente se aproximará do coloquial e as pessoas serão designadas com a mesma familiaridade com que se trataram (pelo prenome precedido de artigo definido). As questões serão colocadas nos termos familiares com que se deram as discussões, porque traduzi-las para outra linguagem falsearia a percepção das questões e - por que não - dos sentimentos envolvidos. Além disso, há que atribuir a cada participante, interno ou externo ao grupo, o seu papel e delimitar suas contribuições. As situações serão descritas não com distanciamento, porque este não houve, mas com linguagem e estilo que evidenciam a participação. Se este tomo fosse pautado por rígidas regras acadêmicas não haveria como praticar a metodologia desenvolvida nem como atingir os objetivos propostos.

O Plano Diretor Estratégico (PDE) do município de São Paulo foi aprovado pela lei municipal 16.050, de 31 de julho de 2014 (SÃO PAULO [CIDADE], 2014a). Embora esse plano tenha caráter multissetorial, na prática a sua tônica é de parcelamento, uso e ocupação do solo. Isso confere grande importância à revisão da 
lei de parcelamento, uso e ocupação do solo (lei de zoneamento), a qual se procede usualmente logo após a aprovação do PDE.

A Secretaria Municipal de Desenvolvimento Urbano (SMDU) e a Secretaria Municipal do Verde e do Meio Ambiente (SVMA) formaram diversos grupos e subgrupos para subsidiar a elaboração da lei de zoneamento ${ }^{161}$. Encarregado de coordenar todos os trabalhos ficou o arquiteto Daniel Todtmann Montandon, diretor do Departamento do Uso do Solo (DEUSO) da SMDU.

Ele idealizou como um dos parâmetros da lei de zoneamento a Quota Ambiental (QA), definida como "o conjunto de parâmetros de uso, dimensionamento e ocupação dos lotes voltados à melhoria da qualidade ambiental e paisagística, em conformidade com os princípios, objetivos e diretrizes estabelecidos no Plano Diretor Estratégico, a ser atendido nos lotes, glebas e unidades de conservação no momento do licenciamento urbanístico“. O conceito estava razoavelmente claro, mas o meio de materializá-lo era algo a ser buscado.

A tropicalização que eu idealizei do BFF, apresentada no tomo II da presente tese, no meu entender encaixava-se como base teórica para o desenvolvimento da QA. Tive, então, oportunidade de conversar a respeito com a arquiteta Hélia Maria Santa Bárbara Pereira, diretora da Divisão Técnica de Planejamento (DEPLAN 1) do Departamento de Planejamento Ambiental (DEPLAN) da SVMA, tendo ela concordado. Assim, ela o informou à geóloga Dra. Patrícia Marra Sepe, coordenadora executiva da QA, que por sua vez me chamou para uma reunião.

Antes de descrever essa reunião, é necessário informar que dessa reunião resultou a formação de um grupo de trabalho informal, ad hoc, destinado a desenvolver a QA, e igualmente necessário fazer uma rápida apresentação das pessoas mais fortemente envolvidas nos primeiros trabalhos relacionados à QA. Eu obtive autorização verbal de todas elas para que seus nomes constassem aqui, o que, a rigor, seria desnecessário porque não há nada que ocorra em uma instalação pública, a menos que se refira a aspectos pessoais, que seja confidencial ou que a legislação assim o estabeleça, o que não é o caso.

\footnotetext{
${ }^{161}$ Verificou-se posteriormente, no entanto, que nem todos os servidores da SVMA, alguns extremamente qualificados, tomaram ciência da possibilidade de contribuir para a elaboração da minuta do projeto de lei.
} 


\subsection{PARTICIPANTES}

Em um primeiro momento, as pessoas com quem eu trabalhei com maior proximidade foram, além da Patrícia e da Hélia (como informado acima, permitirme-ei chamar as pessoas pelo prenome e com artigo), a arquiteta Lara Cavalcanti Ribeiro de Figueiredo, que na época se encontrava lotada no DEUSO.

Patrícia Marra Sepe é geóloga, mestre em geologia e meio ambiente e doutora em geografia urbana. É servidora efetiva da PMSP há 24 anos, atuando na consolidação da atuação do profissional de geociências nas políticas públicas de meio ambiente e planejamento urbano. Integrou a equipe de geólogos da Prefeitura de São Paulo que, em 1993, elaborou a Carta Geotécnica do Município de São Paulo (SÃO PAULO [CIDADE], 1992c e 1992d), na escala 1:10.000, com a consultoria do Instituto de Pesquisas Tecnológicas do Estado de São Paulo (IPT). Por mais de 20 anos trabalhando na Secretaria Municipal do Verde e do Meio Ambiente, coordenou diversos projetos de destaque na área de planejamento ambiental, entre os quais: a) Atlas Ambiental de São Paulo (SÃO PAULO [CIDADE], 2002c); b) elaboração de um Sistema de Indicadores Ambientais, resultando nas publicações GEO Cidade de São Paulo (SÃO PAULO [CIDADE], 2004) e Indicadores Ambientais e Gestão Urbana (SÃO PAULO [CIDADE], 2008b), ambos em parceria com o Programa das Nações Unidas para o Meio Ambiente (PNUMA); c) revitalização de brownfields, a partir da utilização de instrumentos urbanísticos. Participou da elaboração dos Planos Diretores Estratégicos do Município de São Paulo (SÃO PAULO [CIDADE], 2002b e 2014b), quando utilizou a Carta Geotécnica como subsídio para a definição do macrozoneamento da cidade. Há dois anos trabalha na Assessoria Técnica da Secretaria Municipal de Desenvolvimento Urbano, onde integrou equipe responsável pela revisão da LPUOS, coordenando a temática ambiental. Nessa temática foi proposta a incorporação de parâmetros e critérios ambientais para novas edificações, por meio do instrumento da QA. Exerceu diversos cargos de direção, entre os quais as Chefias de Gabinete da SVMA e da Subprefeitura de Itaquera. Possui dezenas de 
artigos publicados em congressos e é autora de capítulos de livros na área de planejamento ambiental.

Hélia Maria Santa Bárbara Pereira é arquiteta e urbanista, especializada em gestão ambiental e em geoprocessamento. É servidora efetiva da PMSP há mais de 20 anos, sendo atualmente diretora da Divisão Técnica de Planejamento (DEPLAN1) do Departamento de Planejamento Ambiental (DEPLAN) da Secretaria Municipal do Verde e Meio Ambiente (SVMA) da PMSP. Destacam-se entre as atividades desenvolvidas no âmbito do planejamento ambiental: estudos técnicos para a aplicação de instrumentos de gestão ambiental; formulação e implementação de diretrizes e estratégias ambientais integrantes do PDE; coordenação das propostas formuladas pela SVMA para a revisão da Lei de Parcelamento, Uso e Ocupação do Solo; formulação dos planos municipais referentes a áreas verdes; e participação no Plano Municipal da Mata Atlântica, no Plano Municipal de Conservação e Recuperação de Áreas Prestadoras de Serviços Ambientais e no Plano de Áreas Protegidas, Áreas Verdes e Espaços Livres. Possui artigos publicados como autora ou coautora em simpósios, seminários e encontros sobre sensoriamento remoto e geoprocessamento, planejamento urbano e planejamento ambiental. É representante titular da SVMA no Conselho Gestor da Operação Urbana Água Branca e representante suplente da SVMA no Conselho Municipal de Política Urbana (CMPU).

Lara Cavalcanti Ribeiro de Figueiredo é arquiteta e urbanista com especialização técnica em paisagismo em Toronto, Canadá. Trabalhou por 2 anos na SVMA como arquiteta paisagista e foi Coordenadora do Núcleo de Projetos e Obras da Região Centro-Oeste do Departamento de Parques e Áreas Verdes - DEPAVE 1. Transferiu-se em 2013 para a SMDU, onde foi Assessora do Gabinete do Departamento de Uso e Ocupação do Solo (DEUSO), participando ativamente do processo de revisão da Lei de Parcelamento, Uso e Ocupação do Solo, sendo também secretária executiva da Comissão de Proteção da Paisagem Urbana (CPPU). Atualmente ocupa o cargo de Gerente de Planejamento da Paisagem Urbana na SP Urbanismo e é vice-presidente da CPPU.

Conheço a Patrícia e a Hélia desde 1994 e 1998, respectivamente. Posso atestar que são profissionais extremamente dedicadas e competentes. Ambas têm 
profundo conhecimento da legislação ambiental e da de parcelamento, uso e ocupação do solo, bastante complexas. Da sua grande experiência na PMSP e por participarem e/ ou liderarem projetos de grande envergadura, detêm grande conhecimento das características da cidade e de estatísticas e informações associadas. São proativas na defesa dos interesses ambiental e urbano da cidade. A Patrícia tem grande senso de liderança. É importante ressaltar que ela, na qualidade de assessora técnica do gabinete da SMDU, representou o governo na dinâmica de desenvolvimento da QA, ainda que seja servidora efetiva da PMSP.

Tenho pouco conhecimento pessoal da Lara. Pude observar que ela é bastante competente do ponto de vista técnico, conhece bem, apesar do pouco tempo na PMSP, a legislação de parcelamento, uso e ocupação do solo, e é extremamente dedicada.

Daniel Todtmann Montandon é arquiteto e urbanista e mestre em planejamento urbano e regional. Participou de curso de desenvolvimento urbano pela Agência de Cooperação Internacional do Japão (JICA) e de curso de desenvolvimento profissional sobre a recuperação de mais-valia pelo Lincoln Institute of Land Policy. Trabalhou como planejador urbano na então Secretaria Municipal de Planejamento Urbano (SEMPLA) da PMSP (2002-2008); como diretor de planejamento urbano no Ministério das Cidades (2008-2011); e como coordenador-geral de controle de utilização do patrimônio no Ministério do Planejamento, Orçamento e Gestão (2012-2013). Desde 2013 é diretor de uso do solo da SMDU.

Tenho pouco conhecimento pessoal do Daniel. A ele foi confiada a ingrata tarefa de coordenar a elaboração da minuta de PL da LPUOS, o que, pode-se aquilatar, envolveu monstruosas pressões. Pude observar que ele tem grande qualificação técnica e qualidades de gestão e liderança. Pude observar também que, de maneira geral, os servidores comissionados da SMDU possuem grande capacitação técnica. 


\subsection{DIRETRIZES IMPOSTAS AO DESENVOLVIMENTO DA QA}

Na longa reunião inicial que eu tive com a Patrícia e a Hélia, apresentei o método desenvolvido, tendo um retorno bastante favorável.

No entanto, a Patrícia solicitou que não houvesse a conformação de um indicador de qualidade ecossistêmica e microclima mais a condição de impacto zero, mas um único indicador que avaliasse o desempenho ambiental do lote, agregando os três objetivos ambientais.

Em assim sendo, sugeri o seguinte à Patrícia:

- se a ideia era fazer uma composição entre um indicador de vegetação e um de drenagem, era importante que houvesse uma normalização dos indicadores, a fim de tornar possível compará-los. O indicador de vegetação, que posteriormente teve consolidada a notação "V", seria calculado a partir da normalização da estimativa da ecoexergia simplificada de diferentes tipologias de cobertura do solo. A normalização que eu acabei por propor consistia em simplesmente dividir essa avaliação por um valor de referência;

- dada a necessidade de criar um indicador de drenagem, que veio a ter consolidada a notação "D”, propus que ele se constituísse na porcentagem de abatimento do pico do hidrograma de saída do lote quando comparado à situação não desenvolvida. Assim, se o pico da saída fosse igual ao pico do hidrograma na condição não desenvolvida, o indicador D seria 1,0. Caso o abatimento fosse de $80 \%$, o indicador D seria 0,8. Definido dessa maneira, não haveria necessidade de normalização. Dessa forma se estaria comparando apenas os picos dos hidrogramas, mas não o lag nem a proporção de precipitação infiltrada;

- propus que na composição do índice, ou do indicador agregado se usasse uma ponderação por produtória, e não por somatória. Assim, ficaria muito mais difícil a um empreendedor que apresentasse projeto com baixo desempenho em drenagem ou em vegetação que ele pudesse compensar um pelo outro. De fato, ele precisaria de uma pontuação boa nos dois indicadores. Assim, a agregação se faria por:

$$
\mathrm{QA}=\mathrm{V}^{\alpha} \cdot \mathrm{D}^{\beta}
$$


sendo alfa e beta fatores de ponderação. Curiosamente, a notação que eu usei nessa primeira reunião foi a que acabou por constar na minuta do PL;

- alfa e beta deveriam representar as condições ambientais prevalecentes na região em que se encontrasse o lote (a SMDU tem consolidado o termo perímetro para regiões homogêneas);

- ao propor a notação acima, eu tinha em mente o resultado matemático segundo o qual se $\alpha+\beta=1,0 \leq \mathrm{V} \leq 1,0$ e $0 \leq \mathrm{D} \leq 1,0$, então $0 \leq \mathrm{QA} \leq 1,0$. Posteriormente os indicadores teimaram muitas vezes por ser maiores do que a unidade ${ }^{162}$, do que resultou que a QA passou a ter também valores maiores do que a unidade;

- propus também que para cada uso do empreendimento, cada perímetro e cada área do lote fosse definido um QA mínimo obrigatório. Posteriormente, o uso foi desconsiderado.

A partir dessa reunião, foi formado o pequeno grupo de trabalho ad hoc composto por mim, a Patrícia, a Hélia e a Lara. Para mim foi uma grande honra ser convidado a fazer parte desse grupo, ter meu trabalho servindo de base teórica para o desenvolvimento da QA, ser ouvido nas reuniões e serem-me delegadas tarefas na forma de desenvolvimento de estudos específicos para aspectos de cujo detalhamento tenha sido exigido ao longo dos trabalhos.

Com a formação do grupo de trabalho, tomei conhecimento das diretrizes impostas pela superior administração.

Foi imposto um prazo de seis meses para a minuta de PL de zoneamento, o que se constitui em tempo extremamente curto. Nesse período as equipes de SMDU e de SVMA deveriam desenvolver seus trabalhos, consolidá-los, compatibilizá-los entre si, tê-los aprovados pela superior administração e o resultado ser submetido a revisão e atuação de grupos de interesse internos e externos. Não pude deixar de sentir certa satisfação ao constatar que, de todos os grupos formados para a elaboração da minuta de PL de zoneamento, o nosso era o que, via de regra, se encontrava mais adiantado.

Gostaria de propor um conceito, ao qual já me referi anteriormente, que pode se mostrar útil ao estudo. Trata-se de conceito por mim denominado "paradigma

\footnotetext{
${ }^{162}$ D > 1,0 implicaria que o pico do hidrograma de saída do lote seria menor do que o pico na situação não desenvolvida.
} 
técnico". Talvez a palavra paradigma não seja das mais felizes porque o conceito de paradigma de KUHN (2003) foi desenvolvido para ciências empíricas.

O paradigma técnico ocorre por consenso técnico, ideologias, interesses consolidados ou até mesmo utopias e sonhos. Há uma natural tendência de ele ser aplicado de maneira generalizada, mesmo que as condições em que ele foi concebido e desenvolvido tenham-se sensivelmente alterado. Quem ousa desafiá-lo sofre severas pressões. Há uma tendência de que ele se transforme em dogma. Por exemplo, antigamente entendia-se que a melhor solução para a macrodrenagem estava no aumento da velocidade do escoamento a fim de que nas cheias a lâmina d'água estivesse mais baixa. É evidente que bons profissionais souberam na prática avaliar com critério as situações, não apelando necessariamente ao paradigma técnico vigente.

A construção da minuta de PL de zoneamento supunha a aderência a alguns paradigmas técnicos. Talvez o de maior repercussão seja o referente à cidade compacta. Há muita bibliografia sobre ele, na maioria a favor, mas também com questionamentos. Dela destacamos DEVECCHI (2014), MIANA (2010), RUEDA et al. (2006), HIGUERAS GARCIA et al. (2009), MASCARÓ e MASCARÓ (2001), MOUHEBATI (2012), NUCCI (2008), ROGERS et al. (2005) e THADANI (2010, p.209-15). Não é um princípio que tenha minha adesão irrestrita, mas é forçoso destacar que, pelo art. 18 da lei municipal 14.993, de 5 de junho de 2009 (SÃO PAULO [CIDADE], 2009), a sustentabilidade da aglomeração urbana deverá ser norteada pelo princípio da cidade compacta. Meu pouco entusiasmo incondicionado por ela decorre dos problemas ambientais gerados, referentes a iluminação, ventilação, ruídos e incômodos. Por outro lado, a cidade compacta propicia um dinamismo maior nas interações urbanas e economias na instalação, operação e manutenção das infraestruturas urbanas, bem como evita grandes deslocamentos. Cada sociedade terá que ponderar ônus e bônus para decidir a respeito da compacidade desejada. 
Desse paradigma de cidade compacta decorrem mistura de usos e altas taxas de ocupação. Significativo que tenha sido abandonado o conceito de estoques ${ }^{163}$. Parece ter havido certa insensibilidade em relação a aspectos ambientais decorrentes do adensamento (lembrando que a SMDU é um domínio de arquitetos, não necessariamente ambientalistas). Talvez se tenha acreditado que os chamados parâmetros de incomodidade pudessem dar conta desses aspectos ambientais. Parece que se vislumbra um sonho, uma utopia de uma cidade vibrante, cosmopolita, atrativa, movimentada e que propicie muitas interações. Muitas vezes tive a impressão de que o modelo mental era o do Conjunto Nacional, na avenida Paulista. Às vezes, Paris, com blocos de quatro andares ocupando uma quadra inteira e pátio interno central, solução generalizada também em Berlim, era explicitamente citada. Eu não sou urbanista, mas a minha utopia de cidade, pelo menos da parte formal dela, consiste em muita luz, muita ventilação e muito céu, o que demandaria taxas de ocupação pequenas, anátema para o novo PDE.

Há naturalmente um tradeoff entre meio ambiente e moradia popular. A esse respeito se podia observar as hesitações e as contradições da alta administração em relação a esse tradeoff. Do choque frequentemente resultava uma tendência de preferir a moradia popular em detrimento do meio ambiente. Nem sempre tal ocorria, porém, sendo a prova a QA ter sido prestigiada pela superior administração e, por isso, incluída na minuta do PL de zoneamento.

Em outras demandas da alta administração também ocorria um tradeoff. Assim, ao mesmo tempo em que se exigia simplicidade nas normas a serem desenvolvidas, pedia-se que elas fossem autoaplicáveis, ou seja, independessem de legislação infralegal para sua regulamentação. Talvez isso tenha decorrido, como já tive oportunidade de me referir, de uma percepção da superior administração de haver então uma situação bastante confortável na Câmara, querendo esse governo usar-se desse fato para perenizar seus princípios e ideologias na forma de lei. $\mathrm{O}$ fato é que em assuntos dessa complexidade, como os tratados por uma lei de zoneamento, parece-me ser impossível prescindir de regulamentações posteriores.

\footnotetext{
${ }^{163} \mathrm{OH}$ et al. (s.d.) e LEE, OH e JUNG (s.d.) propuseram método para estimar a capacidade-suporte ambiental urbana.
} 
A participação pública é princípio da administração pública, decorrendo, inclusive, de disposições da Lei Orgânica do Município de São Paulo (SÃO PAULO [CIDADE], 1990). A administração não se furtou a isso. Porém, o PL tratava de tantos assuntos que a participação popular tendia naturalmente nas audiências públicas, por exemplo, a se fixar nos parâmetros urbanos mais tradicionais e nos usos permitidos.

Depois de muitas reuniões, debates, revisões, encaminhamento à superior administração, mais revisões e aprovação do prefeito, foi encaminhado à Câmara um PL tratando da revisão da lei de parcelamento, uso e ocupação do solo, que recebeu a denominação de PL 272/2015 (SÃO PAULO [CIDADE], 2015a) e que teve como relator o vereador Paulo Frange (PPB). Dentro do prazo final para apresentação de propostas ao substitutivo ao PL, o grupo se reuniu, sendo acordadas algumas alterações, parte das quais incluídas no substitutivo. No momento em que esta tese está sendo revisada, o PL foi aprovado pela Câmara há 3 dias. 


\section{PROMOÇÃO DE CONTROLE DE DRENAGEM NA FONTE}

Segundo a terminologia adotada no presente texto, as medidas de controle de drenagem na fonte compõem-se de sistema de reservação de detenção (aqui denominado mais genericamente "reservação de controle de escoamento superficial") e medidas não convencionais.

Desde o início, a ideia era que a QA estimulasse a adoção de medidas não convencionais, porém o texto final dá a impressão, para quem o considera rapidamente em uma primeira vez, que foi dada preferência ao sistema de reservação. Isso decorreu do seguinte: a) a reservação de controle de escoamento superficial foi considerada medida default; b) as medidas não convencionais demandam necessariamente regulamentação; c) usou-se como pressuposto que o empreendedor teria liberdade para utilizar as medidas não convencionais que desejasse, mesmo que elas não constassem em regulamentação, bastando para tal que demonstrasse o atendimento a critérios de desempenho hidrológico-hidráulico; d) existem leis municipais (SÃO PAULO [CIDADE], 1992a e 2002a) que exigem a utilização de reservação de detenção. Assim, revogar tais leis e permitir que medidas não convencionais compensassem sistemas de reservação, embora se constituam em medidas razoáveis, poderiam resultar em uma percepção errônea de retrocesso. Além disso, existe legislação estadual (SÃO PAULO [ESTADO], 2007) com as mesmas disposições, sendo obrigatória sua observância independentemente da revogação da legislação municipal supracitada. Portanto, manteve-se a exigência do sistema de reservação constante dessas leis como um requisito mínimo obrigatório independentemente da adoção de outras medidas não convencionais (o que se mostrou viável, já que tais exigências não são tão rigorosas ${ }^{164}$ ). Dessa forma, qualquer imóvel sujeito às normas da QA necessariamente deverá apresentar sistema

\footnotetext{
${ }^{164}$ As referidas leis fazem exigência de volume mínimo de reservatório de $9 \ell / \mathrm{m}^{2}$ de área impermeável. Para que esse parâmetro se referisse à área total considerou-se uma taxa de ocupação (TO) considerada representativa no valor de 0,7 , de modo a se obter um volume mínimo de reservação de $6,3 \ell / \mathrm{m}^{2}$ de área total do lote. Imóveis com baixa taxa de ocupação tenderão, assim, a ter exigências maiores em termos de reservação. Em futuras edições da QA, se houver, poder-se-á, talvez, estabelecer como volume mínimo de reservação TO. $9 \ell /\left(\mathrm{m}^{2}\right.$ de área impermeável).
} 
de reservação, mesmo que o empreendedor apele também para medidas não convencionais.

\subsection{VOLUME DE RESERVAÇÃO}

Em capítulo anterior, verificamos que os tempos de ascensão e descenso dos hidrogramas de entrada e saída do reservatório são pequenos em relação à duração da chuva crítica.

Eu já havia feito algumas simulações prévias de volume de reservação por meio do método de DONAHUE, MCCUEN e BONDELID (1981) ${ }^{165}$ apud CHOW, MAIDMENT e MAYS (1988). Fiz também algumas simulações prévias por meio do método de ARON e KIBLER (1990) ${ }^{166}$ apud TOMAZ (2002, p.255-8). Por meio delas verifiquei que não era possível determinar a chuva crítica porque mesmo em chuvas de duração maior do que 24 h não ocorre otimização. Era necessário fixar arbitrariamente uma chuva crítica. Em reunião decidiu-se que ela teria duração de $24 \mathrm{~h}$.

Se o volume do reservatório for colocado em função do parâmetro $\mathrm{D}$, que se refere ao grau de sucesso no abatimento do pico do hidrograma de saída do reservatório em relação à situação pré-desenvolvida, terei:

$$
\mathrm{V} / \mathrm{A}=\left\{\mathrm{C}_{\mathrm{d}} \cdot \mathrm{i}-\left[\mathrm{C}_{\mathrm{a}} \cdot \mathrm{i}+\left(\mathrm{C}_{\mathrm{d}-} \mathrm{C}_{\mathrm{a}}\right) \cdot \mathrm{i} \cdot(1-\mathrm{D})\right]\right\} \cdot \mathrm{t}
$$

sendo $\mathrm{V}$ : volume de reservação $\left[\mathrm{L}^{3}\right]$; $\mathrm{A}$ : área do lote $\left[\mathrm{L}^{2}\right]$; i: intensidade da chuva [L.t $\left.{ }^{-1}\right] ; C_{a}$ : coeficiente de escoamento superficial na situação pré-desenvolvida (adimensional); $\mathrm{C}_{\mathrm{d}}$ : coeficiente de escoamento superficial na situação desenvolvida (adimensional); D: grau de abatimento do hidrograma de saída em relação à situação pré-desenvolvida (adimensional); t: tempo de duração da chuva [t].

É preciso ressaltar que o volume de reservação é calculado para a vazão originada da chuva cuja duração é a crítica em termos de reservação e não da vazão

${ }^{165}$ DONAHUE, J.R.; McCUEN, R.H.; BONDELID, T.R. Comparision of detention basin planning and design models. J. Water Res., Planning and Management Division, Am. Soc. Civ. Eng., v.107, n.WR2, p.385-400, Oct. 1981.

${ }^{166}$ Referência não fornecida pelo autor; provavelmente ARON, G.; KIBLER, D.F. Pond sizing for rational formula hydrographs. Water Resources Bulletin, v.26, n.2, p.255-8. 
máxima, ou seja, aquela originada de chuva cuja duração seja igual ao tempo de concentração da bacia (chuva crítica em termos de vazão), uma vez que não há sentido em comparar situações com chuvas de diferentes durações. Eu evitei comentar esse aspecto durante os trabalhos de desenvolvimento da QA porque poderia suscitar questionamentos indevidos por pessoas fora do grupo.

$\mathrm{D}$ não necessita de normalização. $\mathrm{O}$ que se deseja é obter $\mathrm{D}$ e não $\mathrm{V}$, já que o volume de reservação é dado de entrada para o cálculo de $\mathrm{D}$, uma vez que o empreendedor é livre para usar qualquer volume de reservação, desde que respeitado o valor mínimo. Assim, isolando D na equação acima, obtenho:

$$
\mathrm{D}=1-\left[(\mathrm{V} / \mathrm{A})-\text { t.i. }\left(\mathrm{C}_{\mathrm{a}}-\mathrm{C}_{\mathrm{d}}\right)\right] /\left[\mathrm{t} \cdot \mathrm{i} \cdot\left(\mathrm{C}_{\mathrm{a}}-\mathrm{C}_{\mathrm{d}}\right)\right]
$$

É necessário determinar agora os parâmetros a constarem no texto de lei.

O período de retorno escolhido foi o de 10 anos, que parece ser um consenso na área técnica.

A equação de chuva (equação intensidade-duração-frequência, i-d-f) utilizada foi a devida a Paulo Sampaio Wilken. Poderá causar espécie que tal equação seja usada, uma vez que: a) é antiga; b) foi obtida a partir de um único posto pluviográfico; c) não leva em conta mudanças devido a tendências temporais. Uma discussão sobre equações de chuva para São Paulo, inclusive a respeito de sua variação espacial, pode ser encontrada em SÃO PAULO [CIDADE] (1999a):

Essas equações [de Ochipintti e Santos e de Paulo Sampaio Wilken] são consideradas aceitáveis pela Prefeitura do Município de São Paulo nos seguintes casos: • nos Estudos de Viabilidade; • nos Projetos Básicos, desde que esteja prevista uma reavaliação dos estudos na etapa do Projeto Executivo; com exceção dos projetos específicos de drenagem, como, por exemplo, canalização de córregos; • nos projetos classificados como de baixo impacto; • nos projetos de microdrenagem em via pública com escoamento superficial livre e vazão de projeto inferior a $10 \mathrm{~m}^{3} / \mathrm{s}$ (não inclui casos de obras especiais, como travessia sob via férrea, por exemplo). (SÃO PAULO [CIDADE], 1999a, p. 22-3).

Ainda neste documento se informa:

A região do Município de São Paulo abrange uma extensa área, pouco inferior a $2.000 \mathrm{~km}^{2}$, até hoje não muito bem compreendida em termos da variação espacial das chuvas intensas, mesmo porque os dados pluviográficos na região são escassos. Por isso têm sido adotados, nos estudos de drenagem do Município, valores de chuvas intensas referidos a um único posto pluviográfico, denominado de Posto do IAG (Instituto Astronômico e Geofísico da Universidade de São Paulo), situado no bairro da Água Funda e incorporado à rede do DAEE 
com o prefixo E3-035. (SÃO PAULO [CIDADE], 1999a, p. 26, reforçado por SÃO PAULO [CIDADE], 2012a, p.17).

SÃO PAULO [CIDADE] (1999b, p.45-54) fornece dados para estimar diferentes relações i-d-f em qualquer coordenada geográfica do território do município de São Paulo. Sobre mudanças nos padrões temporais das chuvas, um estudo particularmente interessante é DIAS (2018). Nele se informa que tendências significativas foram encontradas na evolução dos extremos de precipitação diária de 1933 a 2010 em São Paulo. Concluiu-se que índices climáticos e a temperatura da superfície do mar na costa próxima a São Paulo explicam 85\% do aumento da frequência de extremos durante a estação seca, mas para a estação úmida eles explicam uma fração menor da variância total quando comparada à estação seca, indicando que outros fatores tais como o crescimento da ilha de calor urbana e o papel da poluição do ar na microfísica de nuvens precisam ser levados em conta para explicar as tendências detectadas. Quanto à variação da distribuição de probabilidade devido a tendências, parece não haver recomendação consolidada. COELHO (2014) realizou análise estatística em seis postos pluviométricos em São Paulo, tendo concluído que a precipitação total anual possui comportamento não estacionário em três deles. Ao analisar a precipitação máxima diária anual, verificou que dois postos apresentaram aumentos significativos entre os anos de 1997 e 2012. Embora tenham sido constatadas e quantificadas algumas tendências de aumento de precipitação, não foi possível afirmar, a partir dos resultados obtidos, que esse fenômeno possui um comportamento não estacionário em toda a área de influência dos postos estudados tendo em vista que houve um maior número de casos em que as tendências não foram confirmadas. De nossa parte, entendemos que as incertezas envolvidas nos cálculos são suficientemente grandes para justificar o uso de formulações mais simples, com o quê parece concordar Plínio Tomaz ${ }^{167}$. Para uma chuva de $24 \mathrm{~h}$ e período de retorno de 10 anos a intensidade é de $11 \ell \cdot \mathrm{s}^{-1} \cdot \mathrm{ha}^{-1}$.

O coeficiente de escoamento superficial da situação pré-desenvolvida foi objeto de muitos debates no grupo. A tabela de AUSTIN [CIDADE] apud CHOW, MAIDMENT e MAYS (1988, p.498) dá respaldo tanto ao valor de 0,38 como o de

${ }^{167}$ Comunicação pessoal. 
0,43. Os dois são bastante favoráveis aos empreendedores, não se tendo desejado onerá-los em demasia. Depois de muitas simulações e debates, o grupo decidiu adotar o valor de 0,38 .

Com essas informações e sendo compatibilizadas as unidades, a equação anterior transforma-se em:

$$
\mathrm{D}=1-[0,0105(\mathrm{~V} / \mathrm{A})-\mathrm{C}+0,38)] /(0,38-\mathrm{C})
$$

sendo $\mathrm{C}$ a composição do coeficiente de escoamento superficial da situação de projeto. As unidades de entrada são: V em litros; A em metros quadrados.

No caso de $\mathrm{C}$ ser menor ou igual ao coeficiente de escoamento superficial na situação pré-desenvolvida, já se está numa situação de impacto zero, sendo bastante razoável que D seja considerado igual a 1,0, ou até mesmo um valor maior. Mesmo nesse caso o empreendedor não estaria dispensado do volume de reservação mínima. No entanto, o PL encaminhado à Câmara pelo executivo não previu a possibilidade de $\mathrm{D}>1$ se $\mathrm{C} \leq 0,38$.

A questão de atribuir valores de $\mathrm{D}$ maiores do que a unidade no caso de $\mathrm{C} \leq 0,38$ foi objeto de debates no grupo. Eu argumentei que, uma vez que o empreendedor tenha se esforçado em alterar a superfície do lote construído a ponto de $\mathrm{C}$ ser menor ou igual a 0,38 , seria razoável que lhe fosse dado $\mathrm{D}>1$, embora a solução anterior seja também defensável. No final, o grupo deliberou no sentido de manter $\mathrm{D}=1,0$.

Nada impede que, abaixando suficientemente $\mathrm{C}$ e aumentando suficientemente V, sejam obtidos valores de D maiores do que 1,0. Quero crer que seria interessante colocar um limite a V.

\subsection{COEFICIENTE DE ESCOAMENTO SUPERFICIAL DA SITUAÇÃO DE PROJETO}

Diversos manuais, como, por exemplo, RIGHETTO (1998), WILKEN (1978) e FUJITA (1986), fornecem valores de coeficiente de escoamento superficial, mas deixavam em mim muitas dúvidas. Procurei me socorrer de maior bibliografia: 
FABIAN e OTTONI FILHO (2000), ACIOLI (2005), ARAÚJO, TUCCI e GOLDENFUM (2000), ALESSI, KOKOT e GOMES (2006), MOURA (2005), TUCCI (2000a), LORENZINI NETO et al. (1995), HORN et al. (2011), SANDERS (1986) e STEENHUIS et al. (1995), além, é claro, de AUSTIN [CIDADE] apud CHOW, MAIDMENT e MAYS (1988, p.498). Uma vez que os valores provenientes de todos esses estudos que eu ia sugerindo ao grupo começaram a se mostrar incoerentes, resolvi padronizar os valores calculando-os por meio da razão entre volume escoado superficialmente e volume total precipitado. Para tanto, utilizei o método preconizado pelo Soil Conservation Service (SCS).

A rigor, a fórmula do SCS, muito popular em nosso meio técnico, é utilizada para estimar a precipitação efetiva. No entanto, nos casos em que hipóteses robustas sobre outros elementos do ciclo hidrológico puderem ser feitas, ela pode ser utilizada para a estimativa da infiltração ao longo do tempo.

Assim, seja $R_{e}$ a precipitação excedente acumulada desde o início da chuva que se transforma em escoamento superficial [L]; $\mathrm{R}$ a precipitação acumulada sobre a bacia [L]; S' a infiltração mais interceptação nas depressões e mais armazenamento superficial acumulados [L]; S o valor limite de $\mathrm{S}$ ' para uma dada condição antecedente de umidade do solo $[\mathrm{L}] ; \mathrm{I}_{\mathrm{A}}$ a extração inicial, que corresponde à precipitação inicial que não tem nenhuma parcela convertida em escoamento superficial $^{168}[\mathrm{~L}]$.

Por definição

$$
\mathrm{S}^{\prime}=\left(\mathrm{R}-\mathrm{I}_{\mathrm{A}}\right)-\mathrm{R}_{\mathrm{e}}
$$

O SCS admite que a cada instante é válida a seguinte relação:

$$
S^{\prime} / \mathrm{S}=\mathrm{R}_{\mathrm{e}} /\left(\mathrm{R}-\mathrm{I}_{\mathrm{A}}\right)
$$

de onde se conclui que

$$
\begin{array}{ll}
\mathrm{R}_{\mathrm{e}}=\left(\mathrm{R}-\mathrm{I}_{\mathrm{A}}\right)^{2} /\left(\mathrm{S}+\mathrm{R}-\mathrm{I}_{\mathrm{A}}\right) & \text { para } \mathrm{I}_{\mathrm{A}}<\mathrm{R} \\
\mathrm{R}_{\mathrm{e}}=0 & \text { para } \mathrm{I}_{\mathrm{A}} \geq \mathrm{R}
\end{array}
$$

As duas equações acima valem, em princípio, em cada instante de tempo.

\footnotetext{
${ }^{168} \mathrm{I}_{\mathrm{A}}$ usualmente é designado em nosso meio "abstração inicial", o que talvez corresponda a uma tradução demasiado literal do termo inglês abstraction. Assim, proponho a expressão "extração inicial", talvez tão ruim quanto a tradução usual.
} 
Como assinala KIBLER (1982), nem sempre se dá a devida atenção para o fato de os parâmetros do modelo terem sido obtidos empiricamente a partir de medidas diárias, o que é frequentemente esquecido nas tentativas de analisar os runoffs incrementais ao longo de uma chuva.

Do estudo de diversas bacias pequenas, o SCS sugeriu que $\mathrm{I}_{\mathrm{A}}$ pode ser estimado como $20 \%$ de S. ARON (1982), entretanto, informa parecer questionável que $\mathrm{I}_{\mathrm{A}}$ seja correlacionável a $\mathrm{S}$ e mesmo que tal correlação seja da ordem de $20 \%$, sugerindo que talvez se esteja superestimando um pouco o valor de $\mathrm{I}_{\mathrm{A}}$. ARON et al. apud ARON (1982) propõem que $\mathrm{I}_{\mathrm{A}}$ seja estimado como algo entre 5 e $10 \%$ de $\mathrm{S}$. MAYS (2001) ${ }^{169}$ apud CANHOLI (2005, p.93) informa que alguns autores sugerem para bacias urbanas com porcentagem substancial de áreas impermeáveis $\mathrm{I}_{\mathrm{A}}=0,1$.S.

Quanto a S, o SCS admite que ele é uma característica de cada solo para uma dada condição antecedente de umidade. Como estas condições antecedentes podem ser infinitas, o SCS definiu, para fins de tabelamento, três condições: a) condição I: os solos estão secos; b) condição II: condição intermediária mais comum entre a I e a III; c) condição III: os solos estão quase saturados. Quanto aos solos, o SCS os tipificou todos em quatro categorias: solos com baixo potencial de escoamento superficial (solos A); solos com potencial de escoamento superficial abaixo da média ( solos B); solos com potencial de escoamento superficial acima da média (solos C); solos com elevado potencial de escoamento superficial (solos D).

O SCS fornece tabelas para o parâmetro S, usualmente relativo à condição II, em áreas urbanas, que podem ser encontradas, por exemplo, em KIBLER (1982), SHEAFFER et al. (1982), LENCASTRE e FRANCO (1984), CHOW, MAIDMENT e MAYS (1988), TUCCI (1993) e especialmente HOGGAN (1989). Na realidade, não é S o parâmetro apresentado nestas tabelas, mas outro, chamado número de curva, $\mathrm{CN}$, definido por:

$$
\mathrm{S}=25400 / \mathrm{CN}-254
$$

sendo S em milímetros ${ }^{170}$.

\footnotetext{
${ }^{169}$ MAYS, L.W. (ed.). Stormwater drainage systems design handbook. [S.l.]: McGraw-Hill, 2001.

${ }^{170}$ Essa equação parece menos arbitrária ao utilizar-se polegadas, ao invés de milímetros: $\mathrm{S}=1000 / \mathrm{CN}-10$.
} 
Quer parecer-me que esse número de curva foi proposto para facilitar a aplicação da equação referente a $\mathrm{R}_{\mathrm{e}}$ quando o uso de calculadoras de bolso não era difundido, perdendo hoje, segundo o meu entendimento, a razão de ser. Ocorre que o SCS, talvez para simplificar os cálculos, sugere que a obtenção de $\mathrm{S}$ em áreas heterogêneas seja feita por ponderação de áreas por meio do parâmetro $\mathrm{CN}$. CAETANO (1992) é de opinião que seria mais interessante ponderar por meio de $\mathrm{S}$ porque este último tem, em princípio, correspondência física com as características do solo. CANHOLI (2005, p.93) apresenta ábacos para a ponderação de CN a partir das porcentagens de área impermeabilizada conectadas ou não diretamente à rede de drenagem e do $\mathrm{CN}$ da porção permeável.

Para obter S relativo às condições I e III, o SCS, citado por CHOW, MAIDMENT e MAYS (1988), propõe fórmulas relativas a CN, que adaptei para que se referissem a $\mathrm{S}$, obtendo dessa forma equações bem mais simples:

$$
\begin{aligned}
\mathrm{S}_{\mathrm{I}} & =2,3 \mathrm{~S}_{\mathrm{II}} \\
\mathrm{S}_{\mathrm{III}} & =0,43 \mathrm{~S}_{\mathrm{II}}
\end{aligned}
$$

Os cálculos para a QA foram padronizados com os seguintes parâmetros: período de retorno de 10 anos; condição II antecedente de umidade; S obtido por meio de CN, extraído por sua vez de SANDERS (1986), UTAH COOPERATIVE EXTENSION SERVICE (1985), SOIL CONSERVATION SERVICE (1975) e LORMAND (1988); solo tipo B; extração inicial correspondendo a 0,2.S.

KUTNER (1998) apresenta na tabela 5 a composição percentual dos diferentes grupos de solos em cada um dos litotipos ocorrentes na bacia do Alto Tietê. Daí se inferiria que o tipo de solo predominante nessa bacia é do tipo C. Porém, ao utilizar essa premissa nos cálculos, obtive valores do coeficiente de escoamento superficial um tanto discrepantes com os constantes das tabelas usuais na bibliografia. Importa, nessa situação, buscar a razoabilidade e não ser excessivamente purista. Daí a opção de considerar solo do tipo B. 
Tabela 5 - Composição percentual dos diferentes grupos de solos em cada um dos litotipos ocorrentes na bacia do Alto Tietê.

\begin{tabular}{lcccc}
\hline \multicolumn{1}{c}{ Litotipo } & A & B & C & D \\
\hline Sedimentos aluvionares quaternários & 15 & 25 & 30 & 30 \\
\hline Sedimentos terciários da bacia de São Paulo & 10 & 15 & 40 & 35 \\
\hline Grupo das intrusões graníticas e granodioríticas & 15 & 45 & 15 & 25 \\
\hline Grupo dos micaxistos & 5 & 10 & 35 & 50 \\
\hline Grupo dos filitos & - & - & 50 & 50 \\
\hline Gnaisses e migmatitos & 15 & 35 & 25 & 25 \\
\hline Fonte: KUTNER (1998) & & &
\end{tabular}

Copas de árvores possuem valores de CN tabelados (SANDERS, 1986, SOIL CONSERVATION SERVICE, 1975). Infelizmente, ao considerar as copas das árvores na composição do $\mathrm{C}$ do terreno, é necessário descontar as áreas sob uma copa padrão. Além disso, parte das copas pode estar nos terrenos vizinhos ou na via. Devido a isso, a Lara encontrou grandes dificuldades em confeccionar uma planilha de cálculo na qual as entradas em vegetação fossem automaticamente lançadas em drenagem, motivo pelo qual o grupo optou, em favor da simplicidade, por excluir as copas das árvores da planilha.

Nos cálculos, determinei $\mathrm{C}$ para paralelepípedos e blocos de concreto. O grupo optou por atribuir esses valores para pavimento semipermeável com vegetação e pavimento semipermeável sem vegetação, respectivamente. Confesso que esse encaminhamento não me agradou de todo, mas fui voto vencido.

No caso de solo com profundidade limitada por superfície impermeável subterrânea, não era possível utilizar valores tabelados de CN para obter C. Utilizei, então, um artifício por meio do qual $\mathrm{I}_{\mathrm{A}}$ foi equiparado à diferença entre a porosidade total e a umidade retida após a drenagem, diferença essa designada por porosidade drenável. Utilizei o valor de 0,04 para a porosidade drenável, correspondendo tal número ao limite inferior de valores típicos de solo bem estruturado. Esse é um exemplo da dificuldade de decidir por parâmetros e métodos que conformem a norma geral.

No caso de pavimento permeável, C poderia ser considerado como próximo de zero, desde que em seu projeto fosse adotado um volume de chuva capaz de armazenar e drenar o volume aqui considerado. Por segurança, adotei para essa situação $\mathrm{C}$ como 0,1 . De fato, a capacidade de o pavimento reter toda a chuva de 
projeto é garantida, conforme a excelente dissertação de DE VIRGILIS (2009), por meio de uma expressão bem simples: $\mathrm{h} \geq \mathrm{i} . \mathrm{t} . \Phi^{-1}$, sendo $\mathrm{h}$ : altura da sub-base [L]; i: intensidade da chuva de projeto $\left[{\left.\mathrm{L} . \mathrm{t}^{-1}\right]}^{1}\right.$; t: duração da chuva de projeto $[\mathrm{t}] ; \Phi$ : porosidade. A prefeitura dispõe da especificação técnica ETS-03/2013 para pavimentos porosos (SÃO PAULO [CIDADE], 2013). Isso proporciona uma reflexão bastante interessante a respeito da redação de normas legais. No início, propus um valor que julguei razoável para $\Phi$ e inseri h como nota associada ao item “pavimentos porosos" da tabela de obtenção de D. Depois, pareceu-me essa postura um pouco temerária, já que $\Phi$ tem uma faixa de variação razoável. Assim, propus que na referida nota fosse colocada a expressão acima. Isso gerou alguns problemas, porque um membro da administração entendeu que a expressão acima era suficiente como norma de projeto, não adiantando argumentar que a engenharia demanda muito mais do que isso. Por fim, chegou-se no PL a uma solução que foi capaz de desagradar a todos: o pavimento poroso constava da tabela de cálculo de $\mathrm{D}$, acompanhado de uma pequena definição. Hoje me é evidente que o pavimento poroso deveria ter sido considerado como uma medida não convencional; porém, era tão grande o entusiasmo, especialmente na Secretaria de Infraestrutura Urbana (SIURB), onde o autor da referida dissertação trabalhava, e um vídeo no qual aparecia um esguicho de água de uma mangueira sendo completamente infiltrado instantaneamente provocava uma impressão tão forte, que não houve como resistir à ideia de incluir desde o início tal pavimento na $\mathrm{QA}^{171}$. Na última reunião destinada a fazer propostas para o substitutivo, foi decidido que se usasse a ETS-03/2013 para a definição do que poderia ser considerado pavimento permeável.

$\mathrm{Na}$ redação final do PL, o coeficiente de escoamento superficial foi denominado Dparcial. Essa denominação não me agradou porque sinalizava, indevidamente, que se estaria compondo D por meio de uma ponderação de área dos Dparcial. Assim, havia dificuldade, entre outras, em entender por que motivo áreas ambientalmente mais eficazes tinham Dparcial menor do que áreas menos eficazes. Esse questionamento ocorreu até mesmo para profissionais gabaritados, como se pode ver em CBCS (2015). A denominação que terminou por prevalecer teve lugar

\footnotetext{
${ }^{171}$ No mínimo, deveria ter sido feita uma distinção entre os pavimentos permeáveis que drenam determinada área e os que drenam apenas a sua própria área.
} 
porque urgia o tempo para o responsável pela minuta, sendo ele obrigado a tomar diversas decisões sem possibilidade de consultar o grupo.

Eu entendo que a regulamentação da lei deverá prover parâmetros para medidas não convencionais, critérios de aceitação de novas medidas não convencionais propostas pelos empreendedores e hipóteses simplificadoras para a consideração das medidas não convencionais no cálculo de $\mathrm{D}^{172}$. Caso eu seja chamado a colaborar nessa regulamentação, proporei uma hipótese simplificadora segundo a qual, em função do desempenho de determinada medida não convencional, toda a área do lote drenada por um dispositivo não convencional receba um valor de $\mathrm{C}$, segundo metodologia prevista na própria regulamentação. É uma simplificação extrema, mas não de todo desarrazoada, e simplificará bastante os cálculos, além de torná-los de mais fácil entendimento. É minha intenção também que se eu for convidado a colaborar nesse mister que sejam levados também em consideração elementos relacionados à qualidade da água.

\subsection{QUESTIONAMENTOS INTERNOS}

Durante os trabalhos do grupo ad hoc, outro grupo desenvolvia atividades no sentido de preparar uma minuta de PL tratando de revisão do Código de Obras e Edificações (COE). Fomos procurados por representantes desse grupo, destacando-se entre eles Marco Antonio Palermo, engenheiro bastante respeitado no meio técnico, para conhecer melhor nosso trabalho, verificar eventuais discrepâncias entre o nosso trabalho e o deles e propor alterações. Foram três as questões levantadas.

\footnotetext{
${ }^{172}$ Uma crítica usualmente feita com relação às medidas não convencionais está no fato de supostamente não se considerar a capacidade de infiltração (definida como a máxima quantidade de água na unidade de tempo e de área que um solo, em uma dada condição de umidade, é capaz de absorver, conforme MARTINS, 1976, p.45, adapt., grifo meu) do solo no local do empreendimento. Uma resposta que eu costumo dar, que muitas vezes encontra ouvidos moucos, é que o empreendedor que se dispuser a propor medida não convencional no mínimo deveria fazer um teste de infiltração in loco. Na realidade, muitos outros critérios precisam ser considerados para verificar a viabilidade de uma dada medida não convencional em um dado lote, como apresentado em PORTO ALEGRE $[C I D A D E]$ (2005) e adaptado por CAETANO (2010), bem como SÃO PAULO [CIDADE] (2012b).
} 


\section{Impacto zero}

Mais uma vez voltou o questionamento relativo a essa questão. A Patrícia argumentou que adotar o impacto zero como exigência demoliria todo o edifício da QA, vez que não mais se poderia compor uma métrica única para ela.

\section{Regionalização do CN}

Foi proposto que nos cálculos que integravam a QA fosse considerada uma regionalização do CN, nos moldes apresentados em KUTNER (1998).

Eu argumentei que o método racional é tão simplificado e impreciso que tal consideração pouco faria por aumentar a precisão do método. Dessa forma, uma enorme complicação do texto da QA seria trazida sem que se ganhasse um benefício compatível com esse enorme esforço. De qualquer forma, terminei por adotar critério segundo o qual C é obtido a partir do método do SCS, do que resultou a necessidade de definir um solo e uma condição antecedente de umidade "padrões". Assim, não foi realizada uma regionalização do $\mathrm{CN}$, mas a consideração de um valor considerado representativo do território do município de São Paulo.

\section{Coerência com Manual de drenagem e manejo de águas pluviais}

Foi solicitado que adotássemos uma metodologia coerente com a preconizada com o Manual de drenagem e manejo de águas pluviais (SÃO PAULO [CIDADE], 2012b, 2012d e especialmente 2012a, p.57-8). Trata-se do conceito de vazão específica, também defendido por TUCCI (s.d.).

A ideia é obter uma razão, denominada vazão específica, entre vazão e área do terreno válida para todo o território do município, de maneira que o empreendedor não tenha que conduzir cálculos hidrológicos a cada empreendimento. Para obter essa vazão, apela-se para um procedimento curioso. Inicialmente admite-se um lote de 100ha, retangular na razão 1:2, formando bacia com tempo de concentração com ordem de grandeza de 1 h. É adotado tempo de retorno de 10 anos. Considera-se C como 0,15 , sendo um valor padrão único para toda a cidade. Impõe-se o critério de 
impacto zero. Aplicando-se o método racional tem-se $25 \ell \cdot \mathrm{s}^{-1} \cdot \mathrm{ha}^{-1}$. Parece um valor razoável, muito próximo do obtido por TUCCI (s.d.) para Porto Alegre $\left(20,8 \ell \cdot \mathrm{s}^{-1} \cdot \mathrm{ha}^{-1}\right) \mathrm{e}$ dos coletados por URBONAS (1999) apud TUCCI (s.d.) para Seattle $\left(14 \ell . \mathrm{s}^{-1} \cdot \mathrm{ha}^{-1}\right) \mathrm{e}$ Denver $\left(16,7 \ell \cdot \mathrm{s}^{-1} \cdot \mathrm{ha}^{-1}\right)$.

Em engenharia não há o certo ou o errado. O que existem são diferentes critérios. Em hidrologia conta muito o feeling do engenheiro. O fato dos valores apresentados da vazão específica para diversas cidades serem da mesma ordem de grandeza conspira por sua adequabilidade. Além disso, são valores cuja respeitabilidade decorre da dos profissionais e acadêmicos que conduziram esses estudos. Isso posto, cabe dizer que essas considerações não são absolutamente coerentes do ponto de vista hidrológico (em hidrologia, quantos métodos podem ser arrogados coerentes?). Esse é um dos motivos pelos quais não julguei necessário alterar os cálculos relacionados à QA, uma vez que não poderia avalizá-los do ponto de vista teórico. Além disso, o argumento segundo o qual todos os documentos de planejamento tornam-se vinculantes, conforme preconiza a Lei Orgânica do Município (SÃO PAULO [CIDADE], 1990), não poderia ser invocado porque nenhum ato administrativo tornou o referido manual instrumento de planejamento oficial da prefeitura; trata-se de um documento muito interessante e bem feito, mas que, por uma série de motivos, não recebeu esse status. Ademais, os trabalhos da QA estavam avançados demais para que o muito trabalho de alterar fosse compensado com uma melhoria duvidosa do ponto de vista de precisão conceitual e de qualidade dos cálculos. Acrescente-se que a QA foi idealizada de maneira tal que não demanda ao empreendedor que opte pela solução default realizar cálculos hidrológicos. Finalmente, o que é mais importante, eu realizei um estudo mostrando que os volumes calculados pelos dois métodos não se mostram tão díspares assim (CAETANO, 2015). É justo que se diga que o Palermo não se preocupou muito com a questão da vazão específica, acredito que por ter entendimento semelhante ao meu segundo o qual a prática de engenharia se faz por critérios. A única vantagem da vazão específica consistia em que na determinação da chuva crítica evidenciava-se facilmente um ponto de máximo. A figura 4 sintetiza o resultado dos cálculos por mim efetuados. 
Figura 4 - Volumes de reservatórios de detenção calculados segundo diferentes critérios.

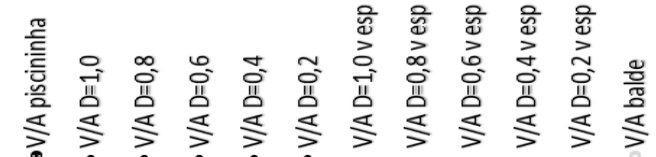

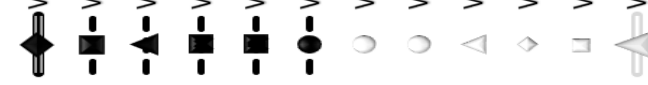

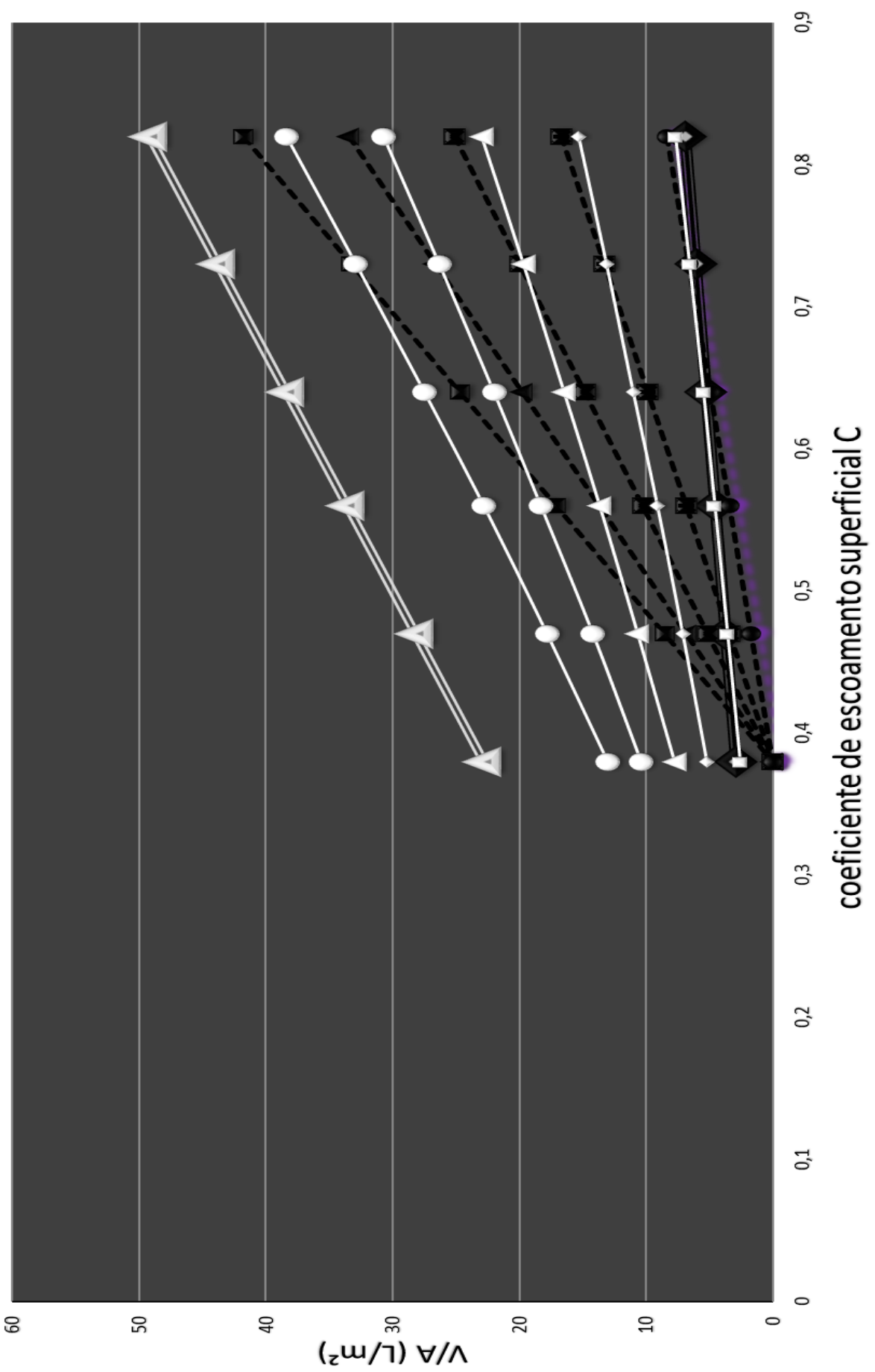

Fonte: CAETANO (2015) 
Notas:

a) V corresponde ao volume de reservatório (L);

b) A corresponde à área do lote $\left(\mathrm{m}^{2}\right)$;

c) D corresponde ao grau de abatimento do hidrograma de saída do lote em relação à situação pré-desenvolvida (adimensional);

d) "V/A piscininha" significa volume mínimo de reservatório calculado segundo legislação municipal e estadual referentes a reservatórios de detenção;

e) "V/A D=x" significa volume de reservatório calculado segundo metodologia da QA;

c) "V/A D=x v esp" significa volume de reservatório calculado segundo metodologia da vazão específica;

d) "balde" significa volume de reservatório calculado considerando reservatório de infiltração sem saída por conduto.

Interpretando a figura, posso concluir que:

a) o volume requerido pela atual legislação (piscininhas) corresponde a um valor bem baixo, quase coincidente com $\mathrm{D}=0,2$ para cálculo do volume de reservatório segundo metodologia da vazão específica;

b) dimensionar um reservatório capaz de absorver toda a chuva de projeto com saída apenas por infiltração corresponderia a um volume muito alto (v. "balde");

c) volumes calculados segundo método constante da QA e da vazão específica são bastante próximos. Só não o são mais porque a QA foi generosa com os empreendedores ao atribuir à condição pré-desenvolvida um $\mathrm{C}=0,38$. O resultado é interessante porque as chuvas utilizadas para os dois métodos são bastante diferentes.

Concluí-se não haver necessidade de alterar os parâmetros da QA em virtude de utilização em algumas cidades do conceito de vazão específica.

Esse exemplo foi interessante por ilustrar pressões provenientes não de grupos de interesse, mas de técnicos internos que pouco teriam a ganhar, do ponto financeiro e ideológico, com a mudança de métodos embutidos na QA. O que os levou a isso? Um sentimento apolíneo de ordem e uniformidade? Um desejo de interferir no trabalho de outrem no sentido de um prazer decorrente do exercício de um micropoder? Pressões da alta administração divergentes? Ou, finalmente, uma crença de que o método seguido na QA estava errado, desejando-se a alteração por amor à correção? 


\subsection{REBAIXAMENTO DO LENÇOL}

Os reservatórios de detenção de lote, pelas suas características de saída, podem ser classificados em três:

a) por gravidade;

b) por bombeamento;

c) por infiltração.

Nas reuniões eu chamava os reservatórios por gravidade de pia, e os por infiltração, de balde, por analogia a seus comportamentos hidráulicos.

Os reservatórios por infiltração já foram objeto de comentário, tendo-se concluído por sua inviabilidade.

Os reservatórios por gravidade têm que ter sua altura limitada a algo como 1m de altura, de maneira a viabilizar seu despejo na rede de microdrenagem. Daí decorre que, em lotes com área grande, a área do reservatório ocuparia parte significativa da área do lote, sendo necessário, então, o bombeamento. Um reservatório profundo sempre inquietou a Patrícia porque nele é difícil evitar que haja entrada de água subterrânea, que terá que ser bombeada enquanto durar a vida útil do edifício, sob pena de os pavimentos inferiores, usualmente ocupados por garagem, serem inundados. Isso remete à bastante delicada questão do rebaixamento de água do lençol.

O que tentei argumentar foi: a) na maior parte das vezes, já é realizada escavação para pavimentos inferiores, não tendo o reservatório de detenção de águas pluviais o condão de piorar a situação, a menos que ele induza pavimentos mais profundos para compensar a perda de área para estacionamento; b) não há como viabilizar reservatórios de detenção de lote sem bombeamento.

A questão do bombeamento de águas subterrâneas por parte de edifícios com pavimentos abaixo do nível da água sempre foi motivo de inquietação na prefeitura. Várias vezes foi cogitada a edição de norma proibindo-o.

Os problemas do rebaixamento da água subterrânea são de duas espécies: a) rebaixamento do lençol e "perda" de água, à qual se poderia dar um uso; b) possíveis recalques diferenciais na vizinhança. 
O uso que poderia ser dado à água bombeada constitui-se em delicada questão, na qual se teria que levar em conta a viabilidade desse uso e aspectos de ordem geológica. Aqui não é o lugar de tratar integralmente desses aspectos da questão. O único que podemos disso comentar está no fato de que, com enorme simplificação, a geologia do território do município de São Paulo é dividido em bacia sedimentar e cristalino. A primeira, de maior interesse, é muitas vezes formada por intercalações de camadas de argila e areia, sob as quais está uma rocha fraturada de onde se pode extrair água de boa qualidade ${ }^{173}$. Tem sido constatada enorme depleção do nível da última, o que é motivo de enorme preocupação. Quanto ao solo onde ocorre intercalação entre camadas de argila e areia existem diversos aquíferos denominados suspensos, porque limitados pelas camadas impermeáveis. É essa água que é objeto de rebaixamento. A sua qualidade, e, portanto, as possibilidades de seu uso, é questionável. Isso não esgota a questão, mas a torna mais complexa.

Temos que fazer um pequeno parêntesis na argumentação para tratar do fenômeno de recalques, especialmente em argilas saturadas profundas e em solos moles, notadamente as turfas. O estudo dos recalques constitui-se em parte fundamental de Mecânica dos Solos, de Obras de Terra e de Fundações. As causas de recalques são inúmeras, sendo apresentadas aqui as mais importantes:

a) recalques elásticos (BADILLO e RODRÍGUEZ, 1974, p.60-3);

b) recalques por adensamento de camadas de argilas profundas saturadas. $\mathrm{O}$ seu estudo, conduzido pelo eminente engenheiro Karl Terzaghi, deu à Mecânica dos Solos o status de ciência. Para tanto, fundamental foi a consideração do princípio da tensão efetiva ${ }^{174}$. O aumento da tensão efetiva pode dar-se por carregamentos

\footnotetext{
${ }^{173}$ Evidentemente esse é um modelo conceitual excessivamente simplificado. V., p.ex., HIRATA e FERREIRA (2001).

${ }^{174}$ A tensão efetiva é definida como a diferença entre a tensão total a que o solo se encontra submetido e a pressão neutra (da água). Seria a tensão efetiva, e não a total, que comandaria o comportamento dos solos. Postula-se que as argilas, em sendo carregadas, de imediato têm a tensão total e a pressão neutra aumentadas, do que decorreria não haver alteração de imediato da tensão total; porém, a lenta percolação da água teria o condão de gradativamente diminuir a pressão neutra, do que decorreria o correspondentemente gradativo aumento da tensão efetiva; aumentando a tensão efetiva, aumentaria então, paulatinamente, o recalque (aconteceria processo análogo no caso do rebaixamento do lençol, motivo pelo qual este provoca recalques quando da existência de camadas de argilas profundas saturadas). Esse processo não ocorreria com as areias porque nelas, em sendo carregadas, a pressão neutra seria imediatamente dissipada, do que decorreria que a tensão efetiva variaria da mesma quantidade da variação de tensão total provocada pelo carregamento.
} 
aplicados sobre o solo ou por drenagem com rebaixamento do nível d'água (BADILLO e RODRÍGUEZ, 1975, p.245-349);

c) deslocamentos e deformações provocados por solos expansíveis (PINTO, 1998, p.114-5);

d) recalques provocados por solos colapsíveis (PINTO, 1998, p.112-4; MILITITSKY, CONSOLI e SCHNAID, 2008, p.38-44);

e) recalques provocados por influência da vegetação. Podem se dar, fundamentalmente, por dois modos: a vegetação resseca a terra, provocando recalque; ou após o corte de árvore, o solo se umidifica, sofrendo expansão (MILITITSKY, CONSOLI e SCHNAID, 2008, p.33-8);

f) deformações e deslocamentos provocados pela construção de estruturas de arrimo (MILITITSKY, CONSOLI e SCHNAID, 2008, p.38-44, p.134-42).

A drenagem e o rebaixamento do nível de água subterrânea encontram-se desenvolvidos, por exemplo, em TERZAGUI e PECK (1958, p.139-59), TSCHEBOTARIOFF (1973, p.349-64), CAPUTO (1983), GRANDIS (1998, p.58195) e DE MELLO (1998, p.596-602).

Um capítulo especial de Obras de Terra refere-se aos solos moles, principalmente os que sofreram aterramento, em especial as turfas. Embora o assunto pudesse ser tratado, em princípio, pela teoria de adensamento de Terzaghi, considerações adicionais de ordem teórica e prática fazem-se necessárias, como as encontradas, por exemplo, em MARCELLI (2007) e DOMINONI (2011). Uma relação de medidas para o aterramento de solos moles pode ser encontrada em LEROUEIL (1997) apud ALMEIDA e MARQUES (2010) e BRASIL (1998).

Um caso extremo de solos moles refere-se às turfas. Sabe-se que no território do município de São Paulo os depósitos aluviais dos sedimentos quaternários, entre os quais se encontram as turfas e as argilas orgânicas, sofreram um processo de aterramento para que os cursos d'água fossem retificados, tendo na parte aterrada da várzea ocorrido processo de urbanização. TAKIYA (1997) estudou detalhadamente a sedimentação quaternária do território do município de São Paulo. Informa que os depósitos aluviais ocupam grande parte do território do município de São Paulo, principalmente as extensas planícies aluviais dos rios Tietê, Pinheiros, Tamanduateí, Aricanduva e seus principais tributários. Informa também que sobre os depósitos 
aluviais é bastante frequente a presença de camada de aterro, podendo ela alcançar até $15 \mathrm{~m}$ de espessura.

Dentre os solos moles, as turfas merecem atenção por se constituir em caso extremo de solo mole. KAZEMIAN et al. (2011) definem turfa como um tipo de solo mole composto por grandes conteúdos de matéria orgânica fibrosa, sendo produzida pela decomposição e desintegração parcial de musgos, carriços, árvores e outras plantas que crescem em pântanos e outras áreas úmidas em condição de ausência de oxigênio. Esses solos, ainda segundo os autores, são geotecnicamente problemáticos na medida em que apresentam alta compressibilidade e baixa resistência à tensão de cisalhamento. A produção de gases de efeito-estufa por parte de turfas é tratada por IPCC (2006). Modelos teóricos de comportamento das turfas podem ser encontrados, por exemplo, em KOGURE (1993), no qual ele informa que seu comportamento não pode ser explicado pela teoria de adensamento de Terzaghi, propondo outro tratamento teórico, e em BARDEN (1968). Aspectos empíricos do comportamento de turfas são tratados por BIN MASAWI (s.d.), que informa que turfas e solos orgânicos são sujeitos a instabilidade e grande adensamento primário e secundário quando sujeitos mesmo a carregamentos moderados. MORARESKUL e BRONIN (1974) conduziram experimentos em laboratório para estudar em turfas o papel da água nos poros e a estrutura do solo. MARCELLI (2007) relata sinistros devido a aterro com presença de turfa ou argila em camadas inferiores. Os mecanismos biológicos de degradação da matéria orgânica não são tratados por esses autores. Esses aspectos são tratados, por exemplo, por JAUHIAINEN et al. (2014) e DREXLER, DE FONTAINE e DEVEREL (2009). Estes últimos relatam os processos envolvidos na drenagem de turfas; assim, primeiramente ocorre subsidência devido à perda de flutuação da turfa; a seguir, ocorre subsidência secundária devido à redução de volume da turfa provocada pela secagem, erosão eólica, decomposição anaeróbica, dissolução de matéria orgânica, redução dos níveis das valas de drenagem e oxidação do carbono orgânico da turfa, provocando emissão de $\mathrm{CO}_{2}$. É justo dizer que as mudanças do nível d'água na turfa provocam alteração no regime de degradação da matéria orgânica, passando por condições aeróbias, anóxidas e anaeróbias. Um colega afirmou que, sendo a degradação aeróbia muito mais eficiente que a anaeróbia, o ritmo de produção de gases é maior, sendo mais 
rápidos os recalques. Assim, a exposição de turfas por escavações ou a variação do nível d'água por drenagem seguramente conduziriam a um recalque muito mais rápido.

Em resumo, o aterramento das várzeas em amplas extensões do território do município de São Paulo com a retificação dos cursos d'água e a subsequente ocupação urbana desses territórios "reclamados" aos rios expõe até hoje a população moradora dessas áreas a condições hidrológicas e geotécnicas bastante preocupantes.

O que tem chamado mais a atenção da população do ponto de vista geotécnico são os recalques diferenciais gerados pelas obras, sejam por recalques decorrentes da própria escavação e escoramento, seja por ressecamento dos solos, seja, finalmente, pelo fenômeno de adensamento de argilas profundas saturadas. Particularmente perverso para as edificações é que o fenômeno de adensamento em solos moles de argilas orgânicas ou turfas ocorre por diversos anos, sendo em alguns bairros da cidade o problema especialmente severo.

Esse problema sensibilizou diversas administrações da prefeitura e membros do legislativo. Por exemplo, tramita na Câmara o PL 01-822/2003 do Vereador Goulart (SÃO PAULO [CIDADE], 2003a), que dispõe sobre a proibição de rebaixamento do lençol freático, da lavagem da via pública por particulares e da proibição do uso do subsolo para ancoragens. O executivo constituiu grupo de trabalho (GT) visando propor minuta de PL tratando do assunto (SÃO PAULO [CIDADE], 2012e). Desse grupo, a portaria de sua criação cita como membros engenheiros do gabarito de Roberto Kochen, Milton Golombek, Frederico Falconi e Pedro Algodoal, para citar apenas os de meu conhecimento. A criação do GT decorreu do tratado no processo administrativo 2006-0.160.942-1, servindo ele próprio como processo documental dos trabalhos do referido GT. Segundo informação prestada pelo engenheiro Cyro Chinellato ${ }^{175}$, o GT teve andamento regular e, após vários estudos e reuniões, foi elaborado um relatório final prevendo a obrigatoriedade de subsolos estanques, tendo havido aval das entidades do setor imobiliário e da construção civil participantes. Ele informa ainda que, quando os

\footnotetext{
${ }^{175}$ Informação prestada pelo engenheiro Cyro Chinellato em 6 de março de 2015 por mensagem eletrônica à geóloga Patrícia Marra Sepe. Ele teve também a gentileza de prestar informações em reunião com parte do grupo.
} 
trabalhos já estavam praticamente finalizados, o processo documental foi avocado pela Comissão de Edificações e Uso do Solo (CEUSO), permanecendo lá desde o final de 2013, não tendo sido possível, dessa forma, encaminhar o relatório final para apreciação por parte do prefeito. A proposta de minuta de PL feita pelo grupo prevê a proibição do rebaixamento permanente em obras residenciais e não residenciais.

Por outro lado, o Fundo Estadual de Recursos Hídricos (FEHIDRO) forneceu suporte e recursos para estudo cujos objetivos correspondem à proposição de práticas para a utilização não potável de água bombeada e de formas alternativas viáveis técnica e economicamente para a execução de obras enterradas para evitar o rebaixamento do lençol freático (empreendimento FEHIDRO 2009 - AT-500). O tomador desse projeto é a Fundação Centro Tecnológico de Hidráulica (FCTH), sendo beneficiário o Ministério Público do Estado de São Paulo, através das promotorias de justiça do meio ambiente e de habitação e urbanismo da capital (SÃO PAULO [ESTADO], 2012). Do relatório final interessa-nos particularmente o anexo 2 do módulo 2, de autoria dos eminentes engenheiros Waldemar Hachich e Marco Antonio Palermo, o que lhe confere bastante credibilidade e autoridade. Eles são de opinião que a eliminação completa do fluxo é uma meta pouco realista. Eles afirmam existir duas técnicas de construção civil destinadas a reduzir o bombeamento de águas do lençol após a conclusão das obras. A primeira consiste na estanqueidade das paredes e do piso dos pavimentos subterrâneos abaixo do lençol. Isso teria como consequência que esses elementos estruturais ficariam sujeitos a elevadíssimos esforços solicitantes, além de haver riscos de falha dessa estanqueidade, do que decorreriam também reparos de manutenção bastante complexos e onerosos. Outra técnica construtiva possível destinada a reduzir o fluxo de água subterrânea seria a utilização de parede-diafragma com ficha de diferentes dimensões enterrada inteiramente na camada permeável responsável pela entrada de água dentro da edificação. No estudo, eles examinam essa solução para duas situações-paradigma, tendo analisado a custo-efetividade de reduções significativas do fluxo de água. 
Todas essas informações levaram-me a escrever uma longa mensagem eletrônica a todos os membros do grupo ${ }^{176}$. É impossível aqui mencionar todos os elementos da mensagem, limitando-me aqui a informar apenas alguns. Sugeri que, dada a enorme complexidade técnica e política envolvida, não seria interessante tratar do assunto na minuta de PL de zoneamento, mas em um PL próprio. O objeto desse PL deveria contemplar não somente o bombeamento de água e do rebaixamento, mas de diversas externalidades provocadas por obras de construção civil. Discuti aspectos administrativos e jurídicos das autorizações e/ ou licenciamentos ${ }^{177}$. Sugeri uma solução de compromisso por meio da qual seriam focadas determinadas áreas da cidade onde a questão se mostra de forma mais dramática. Eu percebi que a Patrícia nunca ficou satisfeita com a ideia de retirar da minuta do PL qualquer consideração sobre o rebaixamento do lençol. Aliás, essa era uma preocupação sua antiga. Pareceu-me que talvez ela lamentasse que uma oportunidade como essa de consolidar de maneira quase permanente a questão, em que o executivo detém situação confortável no legislativo, fosse perdida. Em outra mensagem ${ }^{178}$, propus, como mera solução de emergência e paliativa, a redação de um artigo a constar na minuta de PL de zoneamento, com uma redação bastante genérica e meramente proteladora, segundo a qual "o executivo regulamentará e consolidará exigências administrativas relacionadas à gestão dos riscos ambientais associados à construção de edificações, em especial os referentes a (...)". Esse tipo de solução se mostra adequado se não houver consenso sobre o assunto ou não haja tempo ou ocasião de chegar a esse consenso.

O fato é que o PL de zoneamento encaminhado à Câmara não considera a questão.

\footnotetext{
${ }^{176}$ Mensagem eletrônica minha datada de 10 de março de 2015 destinada a Patrícia Marra Sepe, Hélia Maria Santa Bárbara Pereira e Lara Cavalcanti Ribeiro de Figueiredo.

177 Segundo a doutrina, autorizações correspondem a atos administrativos discricionários precários, enquanto licenças correspondem a atos administrativos permanentes vinculados decorrentes de exercício de direito subjetivo.

${ }^{178}$ Mensagem eletrônica minha datada de 12 de março de 2015 destinada a Patrícia Marra Sepe, com cópia a Hélia Maria Santa Bárbara Pereira e Lara Cavalcanti Ribeiro de Figueiredo.
} 


\subsection{ESTRUTURAS DE SAÍDA}

Sempre nos causou espécie que algumas legislações referentes a reservatórios de detenção de lote fizessem exigências apenas em relação ao volume mínimo de reservação, mas nada determinassem sobre a estrutura de saída ou mesmo a estrutura de extravasão. Ora, de nada adianta um grande volume de reservatório se à sua existência não estiver associada uma conveniente estrutura de saída. Em um caso extremo, se a as estruturas de entrada e saída do reservatório se fizerem na forma de tubos circulares de mesmo diâmetro, tudo se passaria como se, do ponto de vista hidráulico, simplesmente não existisse o reservatório (a menos que eventualmente se considerasse o volume de retenção). Deve-se, portanto, dar também uma boa atenção, na norma, à estrutura de saída.

Uma vez que o empreendedor pode optar por uma solução de mais de um reservatório, associado ou não a medidas não convencionais, e, como se verá adiante, tendo havido demanda no sentido de que se obrigasse a construção de reservatório para aproveitamento de águas pluviais provenientes da cobertura, eu propus, tendo sido aceito, que se falasse de "reservação de controle de escoamento superficial" e de "reservação para aproveitamento de águas pluviais", nomenclatura que constou no texto do PL de zoneamento.

Eu sempre tive tranquilidade no sentido de que, face às dimensões, objetivos e incertezas associadas às circunstâncias, uma solução razoável para o dimensionamento da estrutura de saída de reservatórios por gravidade consistiria em adotar a área da tubulação de saída como a decorrente da lei de um orifício, tendo proposto o valor numérico do coeficiente de vazão como 0,6 . Uma vez que a equação de orifício foi deduzida considerando regime permanente, seu uso se justificava uma vez que a duração da chuva crítica é tal que se pode admitir hipótese de regime permanente em quase toda a duração da chuva. Mesmo que isso não ocorresse, a hipótese de movimento permanente ainda poderia ser considerada uma hipótese razoável para o dimensionamento.

Quando da redação da norma referente a estruturas de saída da reservação de controle de escoamento superficial (uma das inúmeras versões de minuta de PL), eu 
propus simplesmente que a área da tubulação da estrutura de saída fosse determinada a partir da teoria de orifícios, que é materializada em uma expressão bastante simples:

$$
\text { Ats } \leq \text { Q.C. }{ }_{v}^{-1} \cdot(2 \cdot g \cdot h)^{-1 / 2}
$$

sendo Ats: área da tubulação de saída do reservatório [ $\left[\mathrm{L}^{2}\right] ; \mathrm{C}_{\mathrm{v}}$ : coeficiente de vazão (admitido como 0,6); g: aceleração da gravidade (admitida como 9,8m.s ${ }^{-2}$ ); h: carga hidráulica disponível imediatamente a montante da seção de entrada da tubulação de saída, podendo ser admitida meramente como a altura de água disponível decorrente do dimensionamento do reservatório [L]; Q: vazão de saída do reservatório $\left[\mathrm{L}^{3} \cdot \mathrm{t}^{-1}\right]$, determinada pela equação seguinte (supondo que, mesmo havendo soluções não convencionais de drenagem no lote, a saída do lote se faria por reservatório de detenção):

$$
\text { Qmax = A.i.[0,38+(C-0,38).(1-D)] }
$$

sendo Qmax: vazão máxima $\left[\mathrm{L}^{3} \cdot \mathrm{t}^{-1}\right]$; A: área do lote $\left[\mathrm{L}^{2}\right]$; $\mathrm{C}$ : coeficiente de escoamento superficial do lote, denominado no PL como Dparcial (adimensional); D: indicador de drenagem. Passando Qmax para $\ell . \mathrm{s}^{-1}$ e A para $\mathrm{m}^{2}$, fica-se com:

$$
\mathrm{Qmax}=\{\mathrm{A} \cdot 11,3 \cdot[0,38+(\mathrm{C}-0,38) \cdot(1-\mathrm{D})]\} / 10000
$$

Como já visto, D, o indicador de drenagem, é obtido por sua vez por meio da equação seguinte:

$$
\mathrm{D}=1-[0,0105(\mathrm{~V} / \mathrm{A})-\mathrm{C}+0,38)] /(0,38-\mathrm{C})
$$

sendo V: volume do reservatório (em $\ell$ ).

Está implícito que o cálculo deve ser iterativo.

A obtenção desses parâmetros não é difícil, dada a estrutura das tabelas constante do PL e da planilha disponível. Porém, a Lara me informou que a inequação de obtenção da área do conduto de saída seria inviável pela existência da raiz quadrada, o que poderia causar confusão aos profissionais encarregados do dimensionamento. Propus, então, eu elaborar uma tabela relacionando Ats a C, D e A (admitindo $\mathrm{h}=0,9 \mathrm{~m}$ ).

Pus, então, mãos à obra, obtive as equações e passei aos cálculos. Foi quando constatei que os valores de Ats eram baixos. Revi todas as equações, realizei cálculos em diversas situações, porém sempre ocorria de Ats corresponder a valores baixos. Tinha, então, que novamente revisar a bibliografia. 
O Plano Diretor de Drenagem Urbana de Porto Alegre (PORTO ALEGRE [CIDADE], 2005), elaborado pelo conceituadíssimo Instituto de Pesquisas Hidráulicas (IPH) da Universidade Federal do Rio Grande do Sul, apresenta equações para as estruturas de saída que, manipuladas, mostram-se como equações de orifício (coeficiente de vazão 0,6) ou de bocal (mesma equação, mas com coeficiente de vazão 0,5). TUCCI (s.d.), eminente professor do IPH, por outro lado, propõe o diâmetro das estruturas de saída como uma tubulação operando em regime permanente uniforme à seção plena, sendo o diâmetro obtido por meio da equação de Manning. O documento SÃO PAULO [CIDADE] (2014a), elaborado pela também prestigiada Fundação Centro Tecnológico de Hidráulica (FCTH), propõe cálculo semelhante ao de Tucci. O Manual de Drenagem Urbana da Região Metropolitana de Curitiba (PARANÁ [ESTADO], 2002) silencia a respeito do cálculo da tubulação de saída.

Como sair do impasse entre consideração de orifício ou bocal e tubulação operando à seção plena? Uma maneira é apelar para a teoria de bueiros. Ela está muito bem descrita por CHOW (1959, p.496-7). Complemento a exposição daqui com ajuda de CANHOLI (2005, p.148-57). Chow classificou o escoamento de bueiros em seis tipos, de acordo com o controle do escoamento (observar que a teoria vale para escoamentos permanentes, o que pode ser admitido em reservatório de detenção de lote). Modifiquei a apresentação de Chow na forma de um algoritmo, tendo resultado o seguinte:

se saída afogada então tipo 1

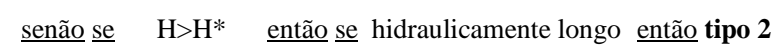

senão tipo 3

$\underline{\text { senão }} \underline{\text { se }}$ carga a jusante $>y_{c}$ então tipo 4

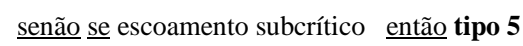

senão tipo 6

sendo $\mathrm{H}$ : carga hidráulica imediatamente a montante da entrada do bueiro [L]; H*: H considerado crítico (pode-se considerar que $\mathrm{H}^{*}=1,2 \mathrm{D}$, sendo $\mathrm{D}$ a altura da galeria) [L]; yc: altura crítica da galeria (para uma dada vazão) [L]. Para o restante do item, considerar yt: altura d'água imediatamente a jusante da galeria [L]; y: altura do escoamento [L].

Se a galeria estiver trabalhando afogada, ou seja, se o nível d'água imediatamente a jusante da galeria for maior que a altura da galeria $\left(\mathrm{y}_{\mathrm{t}}>\mathrm{D}\right)$, o 
escoamento ocorre forçado, sendo o controle na saída (tipo 1). O cálculo deve ser feito considerando as perdas de carga na entrada e na saída, outras perdas de carga localizadas e perda de carga distribuída ao longo da galeria. Considere-se agora a situação em que a galeria não estiver forçada e $\mathrm{H}>\mathrm{H}^{*}$. Duas coisas podem acontecer. Se o conduto for considerado hidraulicamente longo, o escoamento ocorre forçado e o controle está na saída (tipo 2). O cálculo é semelhante ao do tipo 1. Porém, se o conduto for considerado hidraulicamente curto, o escoamento se dá livre ao longo da galeria, sendo o controle realizado na entrada (tipo 3). Canholi não fala de condutos hidraulicamente longos ou curtos, mas da existência de um canto vivo ou reentrância que promova o descolamento do fluxo na entrada da galeria. O cálculo pode ser realizado por meio da equação de orifícios. Segundo Chow, o coeficiente de vazão varia de 0,45 a 0,75, enquanto Canholi apresenta tabela válida para tubulação de saída retangular segundo a qual o coeficiente de vazão varia em função da relação $\mathrm{H} / \mathrm{D}$ de 0,48 a 0,59 . Se $\mathrm{H}<\mathrm{H}^{*}$, a carga a jusante for maior do que a carga crítica, mas menor do que a altura da galeria $\left(\mathrm{y}_{\mathrm{c}}<\mathrm{y}_{\mathrm{t}}<\mathrm{D}\right)$, e o escoamento for fluvial (ou subcrítico, ou seja, $\mathrm{y}>\mathrm{y}_{\mathrm{c}}$ ), ocorre escoamento livre com controle na saída (tipo 4). O cálculo pode ser realizado considerando escoamento fluvial gradualmente variado, sendo, portanto, os cálculos realizados de jusante para montante. $\mathrm{Se} \mathrm{H}<\mathrm{H}^{*}$, a carga a jusante for maior do que a carga crítica da galeria $\left(\mathrm{y}_{\mathrm{t}}>\mathrm{y}_{\mathrm{c}}\right)$ e o escoamento também for fluvial (ou subcrítico, ou seja, y>yc), ocorre escoamento livre com controle na saída (tipo 5). $\mathrm{O}$ cálculo é realizado de maneira análoga ao do tipo 4 . Se, porém, $\mathrm{H}<\mathrm{H}^{*}$, a carga a jusante for menor do que a carga crítica, mas menor do que a altura da galeria $\left(y_{c}<y_{t}<D\right)$ e o escoamento for torrencial (ou supercrítico, ou seja, $y<y_{c}$ ), ocorre escoamento livre com controle na entrada (tipo 6). Entendo que o cálculo possa ser realizado considerando escoamento torrencial gradualmente variado, sendo, portanto, os cálculos realizados de montante para jusante.

O meu entendimento é que o a tubulação de saída do reservatório de detenção de lote possa ser aproximada a um escoamento de bueiro do tipo 2 ou 3. No caso de tipo 3, o controle é na entrada, e o cálculo se faz por meio da equação de orifício; o escoamento é livre. No caso de tipo 2, o controle é na saída, o escoamento é forçado, e o cálculo se faz por meio da equação de Bernoulli, nada impedindo que se opte também pela equação de Manning supondo o escoamento pleno. Portanto, tudo se 
resume ao conduto ser hidraulicamente longo ou curto. CHOW (1959, p.494) informa que o caráter longo ou curto de um bueiro não pode ser determinado apenas pelo comprimento do tubo, dependendo de outras características, como declividade, tamanho, geometria de entrada, carga a montante, entrada, condições de saída e outras.

Eu proporei aqui um critério bastante simplificado para decidir se se trata de galeria hidraulicamente curta ou longa, ou seja, escoamento pelo tipo 3 ou 2.

Para o tipo 3 o controle está na entrada, sendo regido pela equação de orifício, enquanto que para o tipo 2 o controle está na saída, sendo regido pela equação de Bernoulli - ou de Manning, se se considerar escoamento a seção plena. No limite situação crítica - as duas equações se igualam. Tem-se, portanto:

$$
\mathrm{R}_{\mathrm{h}}^{2 / 3} \cdot 1^{1 / 2} \cdot \mathrm{n}^{-1}=\left(2 \cdot \mathrm{g} \cdot \mathrm{H}^{*}\right)^{1 / 2}
$$

sendo $\mathrm{R}_{\mathrm{h}}$ : raio hidráulico, correspondente à divisão entre a área molhada e o perímetro molhado [L]; i: declividade da tubulação [L.L $\left.{ }^{-1}\right]$; n: coeficiente de rugosidade de Manning [ $\left.\mathrm{L}^{-1 / 3} . \mathrm{t}\right] ; \mathrm{g}$ : aceleração da gravidade.

Manipulando a equação acima, chega-se a:

$$
\text { 2.g. } H^{*} \cdot n^{2} \cdot R_{h}^{-4 / 3} \cdot i^{-1}=1
$$

Tem-se, portanto, que a situação crítica, ou seja, de transição entre o tipo 3 e o tipo 2, o adimensional acima, que denominaremos $\mathrm{B}$ (de bueiro), seja igual à unidade $^{179}$. A questão que se coloca agora é: se B>1, tenho tipo 3 ou tipo 2? Farei

\footnotetext{
$179 \mathrm{O}$ fato de ser útil construir um adimensional no qual conste n mostra o quão importante é que ele seja apresentado com suas unidades, o que usualmente não ocorre em nosso meio. KHOURY (2005) nos informa que a primeira fórmula de Manning era a seguinte: $v=32$. $\left[R_{h} \cdot i \cdot\left(1+R_{h}{ }^{1 / 3}\right)\right]^{1 / 2}$. Ele então a simplificou para: $v=C \cdot R_{h}{ }^{x} \cdot i^{1 / 2}$. Segundo CHOW (1959), para a obtenção do expoente de $R_{h}$ Manning usou dados experimentais de Bazin em canais artificiais. Para diferentes formas e rugosidades, obteve o valor médio desse expoente entre 0,6499 a 0,8395. Considerando estas variações, Manning adotou um valor aproximado de $2 / 3$ como expoente. Com base em estudos posteriores, alguns autores sugeriram um valor de $3 / 4$, e outros sugeriram uma variável dependente de $\mathrm{R}_{\mathrm{h}}$ e $\mathrm{n}$. KHOURY (2005) conta que, em uma carta para Flamant, Manning escreveu: "A recíproca de C corresponde de perto ao valor de n, tal como determinado por Ganguillet e Kutter; tanto C como n são constantes para o mesmo canal". Manning não gostava de sua própria equação por dois motivos. Em primeiro lugar, era difícil naquele tempo determinar a raiz cúbica de um número e então obter seu quadrado de forma a chegar à potência de $2 / 3$. Além disso, a equação era dimensionalmente incorreta. Assim, para obter correção dimensional ele desenvolveu a seguinte equação:

$\mathrm{v}=\mathrm{C} \cdot(\mathrm{g} \cdot \mathrm{i})^{1 / 2} \cdot\left[\mathrm{R}_{\mathrm{h}}{ }^{1 / 2}+\left(0,22 / \mathrm{m}^{1 / 2}\right) \cdot\left(\mathrm{R}_{\mathrm{h}}-0,15 \cdot \mathrm{m}\right)\right]$, sendo $\mathrm{m}$ : altura da coluna de mercúrio que equilibra a atmosfera; C: adimensional que varia com a natureza da superfície (KHOURY, 2005). Segundo CHOW (1959), a fórmula foi simplificada para $v=C \cdot R_{h}{ }^{2 / 3} \cdot j^{1 / 2}$ sendo: $v$ : velocidade média; $C$ : um fator de resistência; $j$ : declividade. Posteriormente ela foi modificada por outros e expressa em unidades métricas como $\mathrm{v}=(1 / \mathrm{n}) \cdot \mathrm{R}_{\mathrm{h}}{ }^{2 / 3} \cdot \mathrm{j}^{1 / 2}$. Mais tarde ela foi convertida de volta para as unidades inglesas, resultando em $v=(1,486 / \mathrm{n}) \cdot \mathrm{R}_{\mathrm{h}}{ }^{2 / 3} \cdot \mathrm{j}^{1 / 2}$. Na conversão, assim como na conversão da fórmula de Ganguillet e Kutter, o valor numérico de $\mathrm{n}$ permaneceu inalterado. Consequentemente, o mesmo valor de $\mathrm{n}$ é usado em ambos os sistemas de unidades. Segundo KHOURY (2005), King, por meio de seu Manual de Hidráulica de 1918, levou ao uso generalizado da fórmula de Manning tal como é hoje conhecida, bem como à aceitação de que o coeficiente n de Manning deveria ser a recíproca do coeficiente C de Kutter. Nos EUA, n é chamado de constante de Manning. Na Europa, o fator k de Strickler corresponde ao C de Manning, isto é, a recíproca de n. CHOW (1959) observa que na visão da Mecânica dos Fluidos presta-se muita atenção em dimensões. Assim, as dimensões de $\mathrm{n}$ foram objeto de considerações diversas. Diretamente da fórmula de Manning, as dimensões de $\mathrm{n}$ devem ser vistas como [t. $\left.\mathrm{L}^{-1 / 3}\right]$. Uma vez que não é razoável que o coeficiente de rugosidade mantenha a dimensão [t], alguns autores assumem que o numerador contenha $\mathrm{g}^{1 / 2}$, levando assim à dimensão [ $\mathrm{L}^{1 / 6}$ ]. Isso é bastante razoável
} 
uma hipótese segundo a qual se $\mathrm{B}>1$, o que controla $\mathrm{B}$ é $\mathrm{H}^{*}$; aumentando $\mathrm{H}$, tem-se tipo 3. Portanto, admitirei que se $\mathrm{B}>1$, tenho tipo 3 e se $\mathrm{B}<1$, tenho tipo 2.

Lembro que na situação crítica, $\mathrm{R}_{\mathrm{h}}=\pi \mathrm{D} / 4$, do que decorre que a equação acima se converta em:

$$
\text { 2.g. } H^{*} \cdot n^{2} \cdot(\pi \mathrm{D} / 4)^{-4 / 3} \cdot \mathrm{i}^{-1}=1
$$

Posso sofisticar mais um pouco aplicando o teorema de Buckingham. Esse teorema assevera, grosso modo, que se um fenômeno for descrito por n variáveis envolvendo $m$ dimensões, então ele pode ser integralmente descrito por (n-m) adimensionais. Em uma primeira aproximação, posso dizer que o escoamento de bueiros nas situações 2 e 3 são descritos pelas variáveis $g, H^{*}, n, D$ e i ( $R_{h}$ não é uma variável porque em regime livre à plena carga ele é função apenas de D). Tenho, portanto, $n=5$ e $m=3$; assim, sendo $n-m=2$, são necessários dois adimensionais. Parece razoável que L (comprimento da canalização) também influa no fenômeno. Tenho, assim, $\mathrm{n}=6$, podendo o fenômeno ser descrito por 3 adimensionais. Dois outros adimensionais poderiam ser L/D e i. Assim:

$$
\mathrm{f}_{1}=\mathrm{f}_{1}(\mathrm{~B}, \mathrm{~L} / \mathrm{D}, \mathrm{i})=0
$$

Somente experiências laboratoriais poderão mostrar como a função acima se comporta. Porém, antecipando-me a essas experiências, tenho uma razoável esperança de que se $\mathrm{B}<1$, tem-se escoamento tipo 2, se $\mathrm{B}>1$, tem-se escoamento tipo 3 , e se $B=1$ está-se na transição crítica.

CARTER (1957) ${ }^{180}$ apud CHOW (1959, p.494-5) preparou gráficos que descrevem o fenômeno e informam a respeito da transição crítica. Vê-se claramente que ele apelou para o teorema de Buckingham, tendo além disso acrescentado outra variável, r, o raio da reentrância superior do emboque da tubulação. Tem-se agora $\mathrm{n}=7$, sendo, portanto, necessários 4 adimensionais (ele adotou como adimensional adicional r/D). Usando a notação aqui apresentada, ter-se-ia:

$$
\mathrm{f}_{2}=\mathrm{f}_{2}\left(\mathrm{~B} \cdot \mathrm{i}^{1 / 2}, \mathrm{~L} / \mathrm{D}, \mathrm{i}, \mathrm{r} / \mathrm{D}\right)=0
$$

Para Carter, a separação entre o escoamento tipo 2 e tipo 3 faz-se quando a função $29 \cdot n^{2} \cdot H^{*} \cdot R_{h}^{-4 / 3}$ (unidades não mencionadas, presumindo-se que sejam pés, $\mathrm{ft}$ )

\footnotetext{
porque há fundamento teórico e empírico para que a rugosidade seja elevada a 1/6 nas considerações de perda de carga, como por exemplo pode ser deduzido da fórmula universal de perda de carga e obtido em diversas observações.

${ }^{180}$ CARTER, R.W. Computation of peak discharge at culverts. [S.1.]: U.S. Geological Survey, 1957. (Circular 376).
} 
atinge certo valor crítico que depende de L/D, i e r/D. Em conformidade com minha esperança, acima desse valor crítico o escoamento se faz pelo tipo 3; abaixo, pelo tipo 2.

Informações a respeito de dimensionamentos de bueiros estão disponíveis, por exemplo, em FUGITA et al. (1986), SÃO PAULO [CIDADE] $(1999,2012 \mathrm{~b}$ e 2012c), CANHOLI (2005), MARTINS, GUKOVAS e SALEMI FILHO (1978) e ARMCO (1950). Informações adicionais sobre dimensionamento de reservatórios podem ser encontradas em PORTO ALEGRE [CIDADE] (2005) e CRUZ, TUCCI e DA SILVEIRA (2000).

$$
* * *
$$

As dificuldades com as estruturas de saída não pararam aí. Em reunião com o eng. Pedro Algodoal, que chegou a fazer alguns dimensionamentos para estruturas de saída de águas pluviais, a água lançada na sarjeta não pode ter velocidade alta, devendo de preferência o escoamento do tubo ser feito em regime livre ${ }^{181}$.

Não ficou claro para o grupo se seria viável fazer a ligação física direta entre a tubulação de saída do reservatório e a tubulação de microdrenagem (PORTO ALEGRE [CIDADE], 2005, informa que quando o reservatório é fechado e existe um vertedor de emergência, em geral é construída uma câmara de inspeção e limpeza imediatamente a jusante do reservatório). Haveria necessidade de um poço de inspeção público? O que fazer se não existir no local uma tubulação de microdrenagem? (Quando a vazão da chuva pode ser escoada pelo canal formado por guia e sarjeta, não há necessidade de galeria de microdrenagem.) Parece que não seria viável encaminhar essa água através de uma galeria na via pública até encontrar uma boca de lobo.

Encaminhei um questionamento a esse respeito a um eminente engenheiro da FCTH, que me informou estar no momento sem tempo, mas que depois verificaria a questão. Nesse meio tempo, ele se afastou da FCTH.

\footnotetext{
${ }^{181} \mathrm{O}$ eng. Pedro Algodoal informou também que, na sua opinião, exigir impacto zero é uma meta um tanto irrealista. Não sei se ele o fez em função da extrema cortesia que caracteriza sua pessoa, ou por convicção.
} 
Essas questões ficaram todas pendentes. Por isso propus uma redação para a minuta de PL que eu reputo elegante, precisa, sintética, talvez um pouco covarde, mas a única possível:

\footnotetext{
Nos lotes com área superior a $500 \mathrm{~m}^{2}$, as condições de dimensionamento, construção, operação e manutenção do lote, em especial das suas estruturas hidráulicas, deverão ser tais que, em ocorrendo chuvas de qualquer duração associadas ao período de retorno de 10 anos, a vazão de saída do lote em nenhum momento supere a vazão determinada pela seguinte equação:

$\mathrm{Qmax}=\{\mathrm{A} \cdot 11,3 \cdot[0,38+(\mathrm{Dp}-0,38) \cdot(1-\mathrm{D})]\} / 10000^{182}$. (SÃO PAULO [CIDADE], 2015, p.21).
}

Nesse caso não se trata de não se haver chegado a um consenso técnico ou político, interno ou externo, mas simplesmente de incapacidade de dar uma resposta adequada à questão nos termos em que ela foi colocada. Ou melhor, ela foi dada, mas reservatórios por gravidade ficaram praticamente inviáveis, devendo, pelo espírito da lei, a maior parte se dar por bombeamento. O que, aliás, não se constitui em grande dificuldade de projeto.

\subsection{INFILTRAÇÃO E POLUIÇÃO DIFUSA}

$\mathrm{Eu}$ julguei que seria interessante agregar ao indicador de drenagem aspectos referentes a infiltração e poluição difusa, de maneira a compor um índice mais abrangente.

Gastei um número razoável de horas procurando e processando informações, tendo-as obtido em TOMAZ (2006), SÃO PAULO [CIDADE] (2012c), PREVEDELLO (1999), TUCCI (1993), TUCCI e BELTRAME (1993), MOURA et al. (2013), SAMMIS, WANG e MILLER (2011) e EMBRAPA e ESALQ (s.d.).

O grupo, porém, julgou por não ser conveniente agregar à métrica de drenagem considerações de infiltração e poluição difusa.

\footnotetext{
${ }^{182} \mathrm{Na}$ realidade, houve um erro na equação, sendo que o grupo deliberou, na última reunião antes de fornecimento de propostas para o substitutivo, pela retificação da equação.
} 


\subsection{QA PARA PARCELAMENTOS}

A administração fez chegar ao conhecimento do grupo que desejava que, à semelhança dos lotes, se idealizasse uma QA para parcelamentos.

Fui encarregado de realizar um estudo e já elaborar minuta de texto em formato legaloide.

O texto que eu apresentei, em síntese muito apertada, dispunha: a) durante qualquer fase da implantação do empreendimento, a erosão não poderia apresentar taxas superiores às que a área do empreendimento apresentaria se em situação de prédesenvolvimento com cobertura equivalente a pastos em boas condições hidrológicas (a regulamentação poderia encontrar subsídios na versão da equação universal de perda de solo apresentada por RIGHETTO, 1998, p.749-54); b) estabeleci faixas não edificantes e protegidas tais que a vegetação ripária promovesse uma diminuição da poluição difusa em quantidade maior ou igual à equivalente do first flush. Foi calculado um valor numérico para superfícies gramadas conforme metodologia de SCHUELLER (1987) ${ }^{183}$ citada, adaptada e aprimorada por TOMAZ (2006), do que resultou um valor muito alto. Estabeleci que, para dirimir controvérsias levantadas pela linha a partir da qual é contada a faixa protegida, ela o fosse a partir da estimativa da margem do curso d'água corrente estimada para uma vazão de período de 2 anos, que, crê-se, corresponda às condições referentes ao leito menor do corpo d'água; c) o parcelamento deveria compor um valor mínimo de ecoexergia simplificada (com exclusão da área dos lotes e dos cursos d'água) em valor igual ou superior a 0,36u.a.; d) o parcelamento deveria compor um valor máximo de coeficiente de escoamento superficial para a área total de certas superfícies do parcelamento (exclusão da superfície dos lotes e dos cursos d'água) em valor igual ou inferior a 0,6. Na redação estabeleci o princípio de que tais verificações deveriam ser feitas segundo laudo apresentado pelo empreendedor, a ser aceito de boa-fé pelo Executivo.

183 SCHUELLER, T. Controlling urban runoff: a practical manual for planning and designing urban BMS. Washington: Council of Government, 1987. 
As minhas propostas foram escorraçadas durante a reunião do grupo. Houve grande discussão, mas não se chegou a uma proposta, quanto mais a um consenso.

Pesquisando mais a bibliografia, observei que existe um conceito estabelecido no Reino Unido denominado Sustainable Drainage Systems (SuDS, Sistemas Sustentáveis de Drenagem) (UNITED KINGDOM OF GREAT BRITAIN AND NORTHERN IRELAND, 2006, 2010 e 2011, GRAHAM et al., 2012, e CIRIA, 2013a e 2013b). Essa bibliografia é composta também do monumental manual CIRIA (2015), de quase 1000 páginas.

Entre muitas conceituações de SuDS, escolhi a seguinte

\begin{abstract}
Sistemas de Drenagem Superficial (Sustainable Drainage Systems, SuDS) é o nome genérico para uma gama de técnicas que visam lidar de forma integrada com as questões da quantidade de água, qualidade da água e lazer. Elas objetivam fazer a gestão das águas de chuva tão próxima quanto suas fontes, desacelerar o escoamento superficial e lançar água de boa qualidade para os cursos d'água superficiais e subterrâneos. Os recursos utilizados pelos SuDS mimetizam sistemas de wetlands. (...) Os SuDS escapam da dependência de abordagens tradicionais de sistemas de tubulações subterrâneas e se posicionam em direção a soluções de engenharia que repliquem processos naturais de drenagem. Há uma grande gama de técnicas de drenagem sustentáveis que podem ser aplicadas individualmente ou combinadas de forma a satisfazer as necessidades particulares de drenagem de um determinado arranjo. Elas incluem: técnicas de controle na fonte que procuram se contrapor ao aumento de descargas decorrentes de locais pós-desenvolvidos, tratando do escoamento superficial de forma tão próxima às condições da fonte como possível e minimizando a quantidade descarregada nos cursos d'água; técnicas de condução através de meios permeáveis que reduzem a velocidade do escoamento superficial em direção ao corpo d'água receptor, permitindo a reservação, filtração e alguma perda de água por meio de evaporação e infiltração antes da descarga. (UNITED KINGDOM OF GREAT BRITAIN AND NORTHERN IRELAND, 2011, p.6) ${ }^{184}$.
\end{abstract}

Se as técnicas de SuDS fossem combinadas com as de traffic calming (ou Verkehrsberuhigung) ${ }^{185}$ (BUNDESREPUBLIK DEUTSCHLAND, 1992,

\footnotetext{
${ }^{184}$ A redação que eu sugeri foi: Drenagem sustentável corresponde ao conjunto de princípios, parâmetros, critérios e soluções destinados a aprimorar o desempenho do sistema de drenagem em aspectos qualitativos e quantitativos (por exemplo, promovendo infiltração, intercepção, controle de saída e aspectos paisagísticos, de lazer e ecológicos), a serem adotados no âmbito do controle de escoamento superficial na fonte (a ser considerado no lote por meio da QA) e no âmbito da microdrenagem (a ser considerada nos novos parcelamentos).

${ }^{185}$ Segundo o INSTITUTE OF TRANSPORTATION ENGINEERS apud FEHR e PEERS (2005), traffic calming envolve mudanças no alinhamento das vias, a instalação de barreiras e outras medidas físicas destinadas a reduzir as velocidades associadas ao tráfego e/ ou reduzir volumes, no interesse da segurança da via, das condições de vida e de outros propósitos públicos. Uma definição minha de traffic calming está relacionada à superação das soluções físicas das vias tradicionalmente restritas a passeio e leito carroçável de forma a, em determinadas vias, fazer com que o domínio do automóvel seja defenestrado, de maneira a permitir a apropriação da via em favor de pedestres, permitindo, entre outros objetivos, redução da velocidade dos veículos, o que redunda em menor poluição, ruído e
} 
CAETANO, 2005, e FEHR e PEERS, 2005) quando possível, teríamos uma situação bastante favorável ao meio ambiente e à qualidade de vida da população.

A ideia era incluir pelo menos o primeiro conceito, que deveria presidir, entre outros, a concepção de novos parcelamentos, desde que cabíveis, sendo necessária, evidentemente, uma regulamentação. Infelizmente a expressão "drenagem sustentável" foi retirada da redação do PL encaminhada à Câmara. O grupo, mesmo na última reunião de propostas para o substitutivo, insistiu que não faria sentido alterar a redação dada no PL.

$* * *$

A Patrícia continuou muito interessada na questão do rebaixamento do lençol, inclusive pela possibilidade de construção de reservatórios de águas pluviais operando por bombeamento.

Em uma reunião entre mim, ela e o engenheiro Marco Antonio Palermo, tratamos da questão. Apresentei as seguintes propostas para discussão: a) deixar como está: bombeamento permanente; b) proibição total do bombeamento: impermeabilização total com eventual uso de tirantes na laje de fundo (dependeria de laudo do engenheiro de fundações, a ser aceito de boa-fé pela administração); c) permissão de algum bombeamento: construção de barreira consistindo em paredediafragma de maneira a reduzir a carga hidráulica da água subterrânea e assim diminuir a entrada de água na estrutura (dependeria de laudo do engenheiro de fundações, a ser aceito de boa-fé pela administração); d) idem aos dois anteriores, mas apenas nas regiões onde o problema se mostrasse mais relevante (dependeria de estudo do executivo para definição dessas áreas mais problemáticas); e) idem ao segundo, com proibição de construção de subsolo em localidades mais problemáticas; f) idem ao terceiro, mas com permissão de construção de subsolo apenas em localidades não problemáticas; g) idem ao terceiro, com permissão de construção em localidades problemáticas sem pavimentos enterrados; h) no máximo apenas um subsolo em todos os empreendimentos. Lembrei que isso corresponde a parte de um problema maior, referente à gestão de riscos e impactos de construções leves; que a perda de água talvez não seja tão relevante, mas que os recalques 
diferenciais em prédios vizinhos com certeza é; que seriam possíveis duas soluções de compromisso, a quarta e a quinta, sendo ambas jurídica, técnica, política e institucionalmente mais fáceis, a quarta implicando em maiores dispêndios financeiros, podendo tal ocorrer na quinta ou não. Na minha opinião, a solução parecia convergir para a quinta. A delimitação das áreas mais problemáticas poderia envolver o conhecimento acumulado de décadas por parte de profissionais da prefeitura e outros auxílios, como SÃO PAULO [ESTADO] (1990) e SÃO PAULO [CIDADE] (1992c e 1992d).

O PL encaminhado à Câmara não contemplou essa questão.

\subsection{RESERVAÇÃO PARA APROVEITAMENTO DE ÁGUAS PLUVIAS PROVENIENTES DE COBERTURAS}

Como se verá adiante, a SP Urbanismo foi chamada a colaborar no desenvolvimento da QA no tocante aos incentivos aos empreendedores, tendo alocado dois de seus técnicos, o economista Hyun In $\mathrm{Ra}$ e o administrador de empresas Bruno de Lima Borges. Os dois se mostraram profissionais extremamente competentes e laboriosos.

Estando a questão da crise de água no auge, eles informaram que foram instados a incluir na QA a reservação para aproveitamento de águas pluviais.

Fui convocado a determinar um volume mínimo para essa reservação. Pesquisei TOMAZ (2003), DE AMORIM e PEREIRA (2008), CARVALHO, DE OLIVEIRA e MORUZZI (2007), MAY (2004), MIERZWA et al. (2007), ANNECCHINI (2005) e a NBR 15527 (ASSOCIAÇÃO BRASILEIRA DE NORMAS TÉCNICAS, 2007). Depois procurei fazer uma estimativa razoável do que a lei poderia incluir como uso não potável (tendo feito várias hipóteses) e finalmente determinei um volume mínimo, tendo escolhido para esse mister o método de Rippl com médias de precipitações mensais (é claro que esses cálculos, como quase tudo o mais na engenharia, e especialmente nos trabalhos relativos à QA, foram feitos de forma iterativa e com cotejo de outros métodos). Nos cálculos 
considerei, conforme orientação de KHAN (2001) ${ }^{186}$ apud TOMAZ (2003), C do telhado verde como 0,27 e $\mathrm{C}$ de cobertura comum como 0,80. Esses valores não diferenciam a inclinação do solo e a umidade antecedente; a esse respeito, v. MORUZZI (2014).

Disso resultaram volumes muito grandes, não tendo sido aceitos pelo grupo. A Patrícia pediu que na própria reunião eu estimasse o volume por meio do mês de maior consumo, e esse acabou sendo o volume mínimo de reservação de aproveitamento de águas pluviais proveniente de coberturas. Essa solução está absolutamente de acordo com a norma. Valeria a pena propor estudos estatísticos mais avançados e aprofundados? Queremos crer que não, porque os dados de entrada já eram bastante imprecisos. Fica a gosto de quem quiser tratar da questão no futuro.

Houve a seguir uma reunião do grupo com o Bruno e o Hyun para tratar, entre outros assuntos, dos detalhes dessa questão. Como sempre ocorre nesse tipo de reunião, princípios foram aventados, orientações da superior administração foram lembradas, e decisões foram tomadas e posteriormente abandonadas em função da continuidade das discussões. Como nem sempre ocorre nesse tipo de reunião, pouco a pouco os conceitos foram sendo clarificados e a decisão tendeu para um consenso, não sem inevitáveis concessões. Ou seja, a reunião não foi tempo perdido. Aliás, algo extremamente positivo em todo o trabalho de desenvolvimento da QA é que as reuniões eram produtivas porque se se sentava à mesa para efetivamente tomar decisões, ou pelo menos para concluir que ainda não havia elementos para tomar as decisões desejadas, sendo feitos os encaminhamentos devidos. De qualquer maneira sempre havia a sensação de que o trabalho avançava e, não importava quantas horas as reuniões durassem, não se havia perdido tempo. Pelo contrário, havia quase sempre uma sensação de realização profissional, não obstante as frustrações e outras pedras no caminho.

Alguns pontos de consenso que foram emergindo:

- não se tratava de água de reúso, uma vez que a água a ser armazenada seria apenas a proveniente da cobertura (o que garantia que a cota dos reservatórios para

\footnotetext{
${ }^{186}$ KHAN. Domestic roof criates harvesting technology in the desert. In: NATIONAL SEMINAR ON GROUNDWATER MANAGEMENT STRATEGIES IN ARID AND SEMI ARID REGIONS, 2001, Jaipur. Proceedings... Jaipur: Groundwater Department, Government of Rajasthan, 2001.
} 
aproveitamento de águas pluviais fosse mais alta do que as cotas dos reservatórios de controle de escoamento superficial), destinada a usos não potáveis, desde que garantidas as exigências sanitárias. Caso o empreendedor quisesse operar um sistema de reúso, ele ficaria, é claro, livre, mas isso não seria obrigatório;

- o empreendedor não seria obrigado a executar um sistema hidráulico separado para aproveitamento de águas meteóricas e/ ou de reúso, até mesmo porque a QA seria obrigatória para reformas com alteração de certa porcentagem da área construída;

- a água proveniente da extravasão da reservação para aproveitamento de águas pluviais seria encaminhada à reservação de controle de escoamento superficial, e não diretamente ao sistema de microdrenagem público;

- se o empreendedor optasse pelo bombeamento da água da extravasão da reservação para aproveitamento de águas pluviais, isso não lhe facultaria a diminuição dos volumes mínimos a que ele estava obrigado;

- o volume de reservação para aproveitamento de águas pluviais não poderia ser utilizado no abatimento do volume de reservação de controle de escoamento superficial;

- água proveniente de telhado verde não poderia ser conduzida diretamente à rede pública de microdrenagem;

- uma vez que existia uma questão sempre relembrada no sentido de considerar superfícies frias na cobertura no cálculo de $\mathrm{V}$, a existência de reservação para aproveitamento de águas pluviais em nada alteraria o entendimento do grupo no sentido de não pontuar superfícies frias.

Na última reunião destinada à formulação de propostas para o substitutivo, propus que se explicitasse nele a necessidade de atender à NBR 15527 (ASSOCIAÇÃO BRASILEIRA DE NORMAS TÉCNICAS, 2007) no sentido de o dispositivo de descarte do first flush, quando utilizado, ser dimensionado pelo projetista, sendo recomendado, na falta de dados, o descarte de $2 \mathrm{~mm}$ da precipitação inicial (como visto, no caso de superfícies, TOMAZ, 2006, recomenda 25mm para a Região Metropolitana de São Paulo). 


\section{VEGETAÇÃO}

Em capítulo anterior, argumentei que uma boa métrica para a integridade ecossistêmica e o microclima corresponderia à simplificação do conceito de ecoexergia devido a Jørgensen. A métrica seria estimada em quilogramas de detritus equivalente por metro quadrado de área de terreno. Posteriormente o grupo verificou que os valores numéricos eram muito altos, motivo pelo qual se optou, sem nenhuma perda conceitual, por dividir os valores obtidos por mil. A essa nova unidade denominei u.a. (unidades ambientais) ${ }^{187}$.

A métrica de vegetação em u.a. não corresponde ao indicador $\mathrm{V}$, uma vez que é necessário normalizar a métrica. Isso foi feito por meio da divisão da ecoexergia em u.a. por um valor de referência. Nas seções seguintes, farei comentários a respeito do meio pelo qual estimei a ecoexergia simplificada em u.a. para diferentes tipologias paisagísticas no lote.

O engenheiro agrônomo Marcello Coco gentilmente ofereceu importantes informações em reunião realizada com o grupo.

É importante ressaltar que o PL não faz referência à possibilidade de o empreendedor propor à municipalidade alguma nova solução construtiva ou paisagística. Eu preferiria que o fizesse, mas na última reunião para definição de propostas ao substitutivo fui voto vencido.

\subsection{INDIVÍDUOS ARBÓREOS EXISTENTES}

Para a determinação das ecoexergias simplificadas de indivíduos arbóreos ${ }^{188}$ existentes foi necessário definir características para indivíduos pequenos, médios e

\footnotetext{
${ }^{187}$ Uma discussão mais detalhada sobre unidades está apresentada no anexo 1. 188 Árvore, segundo HOUAISS e VILLAR (2001), é proveniente do latim arboris e corresponde, em botânica, a um vegetal lenhoso, de porte muito variável, que apresenta um caule principal ereto e indiviso, o tronco, e que emite ramificações a uma altura também variável, sempre distantes do solo, e formadoras da copa, havendo espécies que apresentam ramos, geralmente esparsos, abaixo da ramada que compõe a copa.
} 
grandes. Nesse ponto, é necessário esclarecer que, depois de muita discussão, o grupo concluiu que arbustos ${ }^{189}$ não seriam considerados.

Uma opção razoável para a diferenciação de um indivíduo arbóreo como pequeno, médio ou grande seria sua altura. Ocorre que a maior parte das equações alométricas usam como variável o diâmetro à altura do peito (dap). Além disso, é muito mais fácil medir dap do que a altura. Assim, para desespero dos biólogos e dos engenheiros agrônomos e florestais, eu defini uma tabela classificando os indivíduos arbóreos segundo o dap potencial (dapp).

A partir da consideração das informações constantes de SÃO PAULO [CIDADE] (2005a), estabeleci:

- indivíduos arbóreos pequenos: $25 \mathrm{~cm} \leq \mathrm{dapp}<35 \mathrm{~cm}$;

- indivíduos arbóreos médios: $35 \mathrm{~cm} \leq \mathrm{dapp}<40 \mathrm{~cm}$;

- indivíduos arbóreos grandes: dapp $\geq 40 \mathrm{~cm}$.

No caso de indivíduos arbóreos com dapp menor do que $25 \mathrm{~cm}$, o grupo decidiu que, para efeito da composição da tabela de vegetação, eles seriam considerados indivíduos a serem plantados (o que, como se verá, implica pontuação consideravelmente menor).

A partir dos intervalos acima, extremamente questionáveis, foi estabelecido um dapp a ser considerado nos cálculos alométricos:

- indivíduos arbóreos pequenos: dapp=25cm;

- indivíduos arbóreos médios: dapp=35cm;

- indivíduos arbóreos grandes: dapp=60 $\mathrm{cm}$ (posteriormente foi alterado para $50 \mathrm{~cm}$, por sugestão minha, porque o grupo notou que usando $60 \mathrm{~cm}$ os valores da ecoexergia simplificada ficavam muito grandes; teria prazer em dizer que isso correspondeu a um exemplo de não dogmatismo de nosso trabalho, com disposição a fazer concessões em nome da maior conveniência do texto legal; não posso fazê-lo, no entanto, porque os erros incorridos são tão grandes que nem se pode falar em dogmatismo).

\footnotetext{
${ }^{189}$ Arbusto, segundo SÃO PAULO [CIDADE] ([2008a], p.101), proveniente do latim arbustu, corresponde a uma plante de caule lenhoso, com ramificações desde a base do caule, ou próximas a ela, com porte de até $6 \mathrm{~m}$ de altura. Diferencia-se de subarbusto, que possui lenho só na base, sendo a maior parte da ramagem herbácea, e de arvoreta (palavra não registrada por HOUAISS e VILLAR, 2001), que corresponde a uma pequena árvore, em geral não ultrapassando $3 \mathrm{~m}$ de altura.
} 
O passo seguinte consistiu em procurar na bibliografia elementos para estimar a massa desses indivíduos arbóreos. Uma vez que as equações alométricas usualmente disponíveis na literatura não informam a respeito da massa de raízes, recorri a FORSTER e MELLO (2007) para estimar fatores de correção para a participação das raízes nas biomassas. Esses autores concluíram que um fator razoável seria 20\%. A pesquisa de equações alométricas consumiu mais trabalho, tendo sido levantados e consultados os trabalhos seguintes: BROWN, GILLESPIE e LUGO (1989), SILVEIRA et al. (2008), UHL, BUSCHBACHER e SERRÃO (1988), NELSON et al. (1999), BURGER e DELITTI (2008) e LIMA (2010). MURRAY e JACOBSON (1982) tratavam de arbustos, mas a informação fornecida por eles não pôde ser aproveitada.

Das considerações acima, defini a seguinte equação alométrica a ser utilizada nos cálculos:

$$
\mathrm{Y}=(1 / 0,8) \cdot\left(38,4908-11,7883 \cdot d a p+1,1926 \cdot \text { dap }^{2}\right)
$$

sendo: Y: massa do indivíduo arbóreo, incluindo raízes, em kg; dap, em cm.

É evidente que essa não foi a única equação testada.

O beta de Jørgensen adotado foi 268.

Faltava, finalmente, um parâmetro, que aqui denominarei $\mathrm{P}$, fator de horizonte, relativo à probabilidade de que o exemplar arbóreo sobreviva em um espaço de tempo suficientemente longo para ser de interesse aos objetivos associados à legislação. Na absoluta falta de informações, arbitrei que esse parâmetro seria numericamente igual a 0,5 .

A ecoexergia simplificada Exs, em u.a., de cada exemplar arbóreo existente ${ }^{190}$ no lote pode, portanto, ser assim expressa:

\footnotetext{
${ }^{190}$ Essa equação considera o dap dos exemplares arbóreos quando do seu levantamento, e não seu dap potencial. O ideal seria fazer uma avaliação da idade do exemplar arbóreo existente e estimar a possível evolução do dap. (Sobre modelos de crescimento das árvores, v. IMAÑA-ENCINAS, DA SILVA e PINTO, 2005.) Isso não foi considerado porque traria complicações consideradas inadequadas. Essa posição poderá ser eventualmente revista no futuro. Além disso, o eng. agr. Ricardo Fonseca Reis Iunes Elias (Divisão Técnica de Proteção e Avaliação Ambiental, DPAA, do DEPAVE) (comunicação pessoal) entende que, uma vez que indivíduos arbóreos com dap maior do que $5 \mathrm{~cm}$ já são protegidos por lei, seria interessante que os indivíduos com dap menor do que o limite inferior considerado e maior do que $5 \mathrm{~cm}$ devessem ser enquadrados através do porte de sua espécie. Alguém poderia entender ser algo inadequado que o glossário do PL, no que se referiu a indivíduos arbóreos e palmeiras existentes, remeta não apenas ao Manual Técnico de Arborização Urbana do
} 


$$
\operatorname{Exs}_{i}(\text { u.a. })=Y_{i}(k g) \cdot \beta \cdot A^{-1}\left(m^{2}\right) \cdot 10^{-3} \cdot P
$$

A ecoexergia simplificada de todos os $\mathrm{n}$ exemplares arbóreos existentes Exs ea é dada por:

$$
\operatorname{Exs}_{\text {ea }}(\text { u.a. })=\sum_{\mathrm{i}=1, \mathrm{n}} \operatorname{Exs}_{\mathrm{i}}(\text { u.a. })=\mathrm{A}^{-1}\left(\mathrm{~m}^{2}\right) \cdot \beta \cdot 10^{-3} \cdot \mathrm{P} \cdot \sum_{\mathrm{i}=1, \mathrm{n}} \mathrm{Y}_{\mathrm{i}}(\mathrm{kg})
$$

Considerando terem sido consideradas apenas três classes de exemplares arbóreos, a saber, pequeno, médio e grande (denominados aqui p, m e g), com número de exemplares $\mathrm{n}_{\mathrm{p}}, \mathrm{n}_{\mathrm{m}}$ e $\mathrm{n}_{\mathrm{g}}$, tenho:

$$
\begin{aligned}
& \operatorname{Exs}_{\text {ea }}(\text { u.a. })=\left(\mathrm{A}^{-1}\left(\mathrm{~m}^{2}\right) \cdot \beta \cdot 10^{-3} \cdot \mathrm{P}\right) \cdot\left[\sum_{\mathrm{p}=1, \mathrm{np}} \mathrm{Y}_{\mathrm{p}}(\mathrm{kg})+\sum_{\mathrm{m}=1, \mathrm{~nm}} \mathrm{Y}_{\mathrm{m}}(\mathrm{kg})+\sum_{\mathrm{g}=1, \mathrm{ng}} \mathrm{Y}_{\mathrm{g}}(\mathrm{kg})\right] \\
& \operatorname{Exs}_{\mathrm{ea}}(\text { u.a. })=\left(\mathrm{A}^{-1}\left(\mathrm{~m}^{2}\right) \cdot \beta \cdot 10^{-3} \cdot \mathrm{P}\right) \cdot\left[\mathrm{n}_{\mathrm{p}} \cdot \mathrm{Y}_{\mathrm{p}}(\mathrm{kg})+\mathrm{n}_{\mathrm{m}} \cdot \mathrm{Y}_{\mathrm{m}}(\mathrm{kg})+\mathrm{n}_{\mathrm{g}} \cdot \mathrm{Y}_{\mathrm{g}}(\mathrm{kg})\right]
\end{aligned}
$$

sendo $\beta$ : beta de Jørgensen, adotado como 268; P: fator de horizonte, adotado como 0,5; $\mathrm{Y}_{\mathrm{i}}$ : massa de cada exemplar arbóreo i, em quilogramas, obtido da equação alométrica acima considerando dap $\mathrm{p}_{\mathrm{p}}=25 \mathrm{~cm}$, dap $\mathrm{m}=35 \mathrm{~cm}$, dap $_{\mathrm{g}}=50 \mathrm{~cm}$.

Os valores constantes no quadro 3B do PL como FV de exemplares arbóreos existentes são dados por:

$$
\mathrm{FV}=\beta \cdot 10^{-3} \cdot \mathrm{P} \cdot\left[(1 / 0,8) \cdot\left(38,4908-11,7883 \cdot \mathrm{dap}+1,1926 \cdot \mathrm{dap}^{2}\right)\right]
$$

sendo dap para exemplares arbóreos pequenos, médios e grandes $25 \mathrm{~cm}, 35 \mathrm{~cm}$ e $50 \mathrm{~cm}$, respectivamente.

$$
* * *
$$

Um questionamento, pertinente, indaga por que motivo não usar o dap real dos exemplares arbóreos que já existem no lote ao invés de os inserir em classes "pequeno", "médio" ou "grande" definidas em intervalos do próprio dap.

Posso dar duas respostas para esse questionamento. Já tive oportunidade aqui de manifestar meu espanto e incompreensão pelo fato de não poucos excelentes profissionais de arquitetura, com formação igualmente excelente, sentirem-se incomodados com equações que envolvam mais do que as quatro operações principais. Utilizando o dap real das árvores existentes, o cálculo da ecoexergia simplificada demandaria a utilização da equação alométrica citada no presente item. No processo de redação da minuta, fui mais de uma vez advertido que equações tão ou mais simples do que essa não seriam aceitas. Uma alternativa seria utilizar as palmeiras existentes deveriam satisfazer os dois critérios. 
tabelas; não é uma boa solução porque elas tiram da redação da minuta aquele caráter de ordem, simplicidade e concisão que se deseja conferir a elas.

Outro motivo está relacionado ao processo de escolha dos parâmetros. É evidente que não extraí uma equação da literatura e a apliquei a valores previamente determinados de dap de maneira a obter os parâmetros a constarem na minuta de PL. O que aconteceu foi um processo iterativo, não necessariamente convergente.

Outro questionamento, igualmente pertinente, está relacionado ao motivo de eu ter proposto uma classificação do tamanho das árvores em função de determinados intervalos do dap e não dos intervalos apresentados em legislação existente. Assim, por exemplo, a lei n ${ }^{\circ}$ 10.365/87 (SÃO PAULO [CIDADE], 1987), em seu artigo 20, estabelece três classes de dap para fins de multa por corte de vegetação: menos que $10 \mathrm{~cm}$, entre 10 e $30 \mathrm{~cm}$, mais que $30 \mathrm{~cm}$. Para ser honesto, a hipótese não chegou a ser considerada pelo grupo. O que posso dizer agora é que tais intervalos praticamente unificam as classes média e grande no intervalo superior, o que não era meu objetivo. Desconheço os critérios segundo os quais foram estabelecidos tais intervalos; o que posso dizer é que sua finalidade (fiscal) diverge da dos nossos objetivos. O anexo VII da portaria 130/SVMA-G/2013 (SÃO PAULO [CIDADE], 2013b) estabelece, para fins de determinação de um fator multiplicador para o cálculo de exemplares a serem compensados quando do corte, três classes: 0 a $10 \mathrm{~cm}, 10$ a $30 \mathrm{~cm}, 30$ a $60 \mathrm{~cm}$. Tais intervalos são praticamente iguais aos citados acima, valendo as mesmas considerações. Na mesma portaria, são apresentados nas tabelas VI e VII intervalos relacionados a fatores de compensação para transplantes e cortes: 5 a 10cm, 10 a 30cm, 30 a 60cm, 60 a 90cm, 90 a $120 \mathrm{~cm}, 120$ a $150 \mathrm{~cm}$, mais do que $150 \mathrm{~cm}$. Essa divisão em intervalos têm a vantagem de melhor distinguir exemplares grandes. Há, porém, uma desvantagem: o número grande de intervalos é contrário aos critérios impostos para a redação da minuta. Pelas vantagens apresentadas, seria o caso de considerá-lo se houver uma revisão da QA. Durante a redação da minuta, propus que os parâmetros de cálculo da ecoexergia pudessem ser alterados por decreto, justamente prevendo uma situação como essa. Uma vez que isso afrontava o critério de autoaplicabilidade da minuta, não foi aceito. 


\subsection{INDIVÍDUOS ARBÓREOS A SEREM PLANTADOS}

Para os cálculos de indivíduos arbóreos a serem plantados valem exatamente as considerações do item anterior, exceto que aqui o fator de horizonte $\mathrm{P}$ não se refere somente à probabilidade de que o exemplar arbóreo sobreviva em um espaço de tempo suficientemente longo para ser de interesse dos objetivos associados à legislação, mas também ao tempo até que o exemplar tenha porte considerado interessante aos objetivos da QA e à probabilidade de o exemplar "pegar". Aqui a incerteza é muitíssimo maior, e na falta mais do que absoluta de dados adotei $\mathrm{P}=0,1$ 191 192. É por esse motivo que exemplares existentes pontuam muito mais do que exemplares a serem plantados. Disso decorreu uma consequência bastante interessante da QA no sentido de que exemplares existentes tenderem a deixar de desvalorizar o imóvel e a terem a possibilidade de eventualmente o valorizarem em função do aumento da QA.

A minuta do PL estabelece em relação às árvores a serem plantadas apenas a sua descrição em função do tamanho e não em função do dap potencial, como chegou a constar nas primeiras versões da tabela. Evidentemente que está implícita aí a necessidade de regulamentação e que essa regulamentação tenha que passar pelo DEPAVE. Este departamento já dispõe de excelente material técnico (por exemplo, SÃO PAULO [CIDADE], 2005a, 2012f, 2012g e 2015d). Além disso, a legislação sobre vegetação é abundante. Só em nível municipal, há pelo menos 13 leis, 17 decretos, 9 portarias e 1 resolução (v., p.ex., SÃO PAULO [CIDADE], 2015d, p.58$9^{193}$ ), sem falar na legislação estadual e federal. No entanto, o mais provável é que o DEPAVE tenha que baixar regulamentação adicional para estabelecer os critérios segundo os quais serão aceitos os exemplares arbóreos a serem plantados como

\footnotetext{
${ }^{191}$ Não foi considerado o transplante para a QA. URTADO (2008) estudou 1040 transplantes de indivíduos arbóreos no município de São Paulo realizados no âmbito de Termos de Compromisso Ambiental firmados com a SVMA atendendo em parte os procedimentos estabelecidos pelo DEPAVE para transplante. Foi possível determinar taxas de sobrevivência segundo a espécie bem como estabelecer uma relação entre o dap da árvore transplantada e essa taxa.

$192 \mathrm{O}$ eng. agron. Ricardo Elias (comunicação pessoal) defende que esse fator deveria levar em consideração o dap da muda.

${ }^{193}$ Por um pequeno lapso, duas das portarias citadas na referência foram aparentemente grafadas incorretamente.
} 
pontuação para a QA. Se ele vai ser chamado a exercer esse papel fundamental, vem aqui uma indagação pertinente: por que motivo ele não foi chamado a participar da elaboração da minuta do PL? A rigor, a SVMA montou um grande grupo para tratar de sua contribuição à redação da minuta, tendo sido ele dividido em vários subgrupos, um dos quais recebeu como responsabilidade a QA. Esse subgrupo, que tinha membros do DEPAVE, reuniu-se algumas vezes, tendo o DEPAVE se manifestado, principalmente, em não haver divergência entre a legislação existente e a nova que estava sendo proposta. É justo dizer que profissionais competentíssimos da SVMA nem foram informados da existência desse grupo; isso aconteceu porque foi imposto um caráter de extrema urgência aos trabalhos da SVMA, urgência essa que estaria relacionada ao prazo que foi imposto à própria SMDU. Passado algum tempo, os trabalhos relativos à QA foram na prática confiados ao grupo ad hoc. Como se pulou de uma situação à outra? Honestamente, não saberia precisar. Posso no máximo aventar hipóteses. Uma hipótese consiste em que a Hélia e a Patrícia tradicionalmente eram o canal de comunicação entre a SVMA e a SMDU; quero crer, sendo perfeitamente possível que esteja enganado, que isso se deva mais o empenho pessoal delas do que a uma política de integração das duas secretarias. Quando a Patrícia se transferiu para a SMDU, esse caráter de concentração das questões relativas ao PDE e à LPUOS nas mãos da Hélia no âmbito da SVMA se acentuou; de fato, até onde me lembro, foi a Hélia quem coordenou a montagem do grupo e dos diversos subgrupos na SVMA, isso tudo em um cenário de extrema pressão por prazos e resultados. Daí talvez, e ressalto o talvez, ter parecido natural, e provavelmente mais conveniente, dada a pressão pelos prazos, que as questões relativas à QA ficassem centralizadas no pequeno grupo ad hoc, que contava com a participação da Hélia e da Patrícia. É nesse contexto que a questão se coloca: se o DEPAVE vai ser chamado a trabalhar, por que ele não participou, ou não lhe foi deixado participar, de todo o trabalho? O grupo poderia se defender dizendo que recorreu a especialistas, que organizou duas oficinas técnicas e que pelo menos uma reunião devolutiva ao subgrupo da SVMA foi realizada. Mesmo assim, visto de retrospecto, parece-me (e aqui externo apenas minha opinião) que faltou no grupo alguém que conhecesse em profundidade a legislação referente a vegetação no município de São Paulo. Por outro lado, se a cada assunto tratado pelo grupo ad hoc 
fosse chamado um membro permanente, o grupo perderia um de seus elementos que compõem, para utilizar o jargão de planejamento estratégico, o fator-chave para o sucesso, qual seja, o pequeno número de membros e a afinidade entre eles. Seja como for, teremos que lidar com essa questão delicada se o PL for aprovado aproximadamente como encaminhado à Câmara.

A portaria 130/SVMA.G/2013 (v. SÃO PAULO [CIDADE], 2013b) regulamenta as mudas para compensação ao corte, estabelecendo como um dos critérios o seu dap. Daí veio outro questionamento: por que a minuta não contemplou o critério de dap das mudas para a vegetação a ser plantada? Na verdade, isso tem que ser objeto da regulamentação, para a qual contamos com a inestimável colaboração do DEPAVE ${ }^{194}$.

\section{3 ÁREAS AJARDINADAS E COBERTURAS VERDES}

Adotei como padrão para área ajardinada sobre solo natural (ou seja, sem qualquer forma de laje sob essa área ajardinada) ${ }^{195}$ a grama batatais, aliás a gramínea que serve de referência, pelo menos no estado de São Paulo, para a determinação da evapotranspiração potencial (v., p. ex., DE CAMARGO e DE CAMARGO, 2000, e MEDEIROS, 2002, p.6-7).

PEREIRA (2008) informa que grama batatais tem uma biomassa de $6 \mathrm{t} / \mathrm{ha}$, o que corresponde a $0,6 \mathrm{~kg} / \mathrm{m}^{2}$. Uma vez que não se está tratando de indivíduos, mas de

\footnotetext{
${ }^{194}$ Em princípio haveria três dimensões de dap para as mudas no plantio: $3 \mathrm{~cm}, 5 \mathrm{~cm}$ e $7 \mathrm{~cm}$. O eng. agr. Ricardo Elias (comunicação pessoal) defende que as de $3 \mathrm{~cm}$ são mais adequadas porque têm mais chances de "pegar", o que estaria relacionado ao fato de haver para essa dimensão uma relação mais favorável entre a massa do torrão e a massa da muda.

${ }^{195}$ Gramíneas, segundo SÃO PAULO [CIDADE] ([2008a], p.111), correspondem a espécies com raízes profusas e muito ramificadas, tipo cabeleira, que penetram fundo no solo, formando um grande emaranhado, bem mais denso e volumoso que o das raízes das outras plantas; são muito empregadas para controlar erosões e para estruturar e proteger o solo em taludes e áreas muito expostas às adversidades climáticas. Muitas espécies hoje utilizadas nos gramados são provenientes de pastagens naturais e originalmente serviam como alimento para os animais, sobrevivendo apenas as espécies muito vigorosas que conseguiram refazer-se rapidamente das constantes "podas" feitas pelos animais; os descendentes dessas gramíneas, de porte mais baixo, adaptaram-se bem às cidades, sendo utilizadas em praças, campos e jardins. Forração, segundo SÃO PAULO [CIDADE] ([2008a], p.77), designa um grupo de plantas com crescimento horizontal sensivelmente maior do que o vertical, tendo caule herbáceo e geralmente não ultrapassando a altura de $30 \mathrm{~cm}$; não toleram o pisoteio e são usadas em locais onde não há presença de pedestres.
} 
uma área, e a taxonomia é diferente, as equações acima necessitam de pequenos ajustes. Assim, o beta de Jørgensen passa a 363, P não faz sentido nessa formulação e é introduzida a área "a" da superfície plantada (não confundir com a área A do lote). Tenho, assim, para uma determinada superfície i:

$$
\operatorname{Exs}_{\mathrm{i}}(\text { u.a. })=0,6\left(\mathrm{~kg} / \mathrm{m}^{2}\right) \cdot \mathrm{a}_{\mathrm{i}}\left(\mathrm{m}^{2}\right) \cdot \beta \cdot \mathrm{A}^{-1}\left(\mathrm{~m}^{2}\right) \cdot 10^{-3}
$$

Para n superfícies tenho:

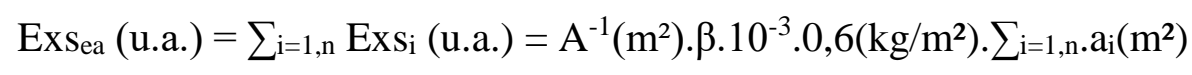

No quadro 3B do PL, a entrada é dada por $\sum \mathrm{i}=1, \mathrm{n} \mathrm{a}_{\mathrm{i}}\left(\mathrm{m}^{2}\right)$, ou seja, somatória das superfícies que podem ser consideradas ajardinadas sobre solo natural. $\mathrm{O}$ valor constante no quadro 3B como FV de área ajardinada sobre solo natural (A.1.) é fornecido pela equação seguinte:

$$
\mathrm{FV}=0,6\left(\mathrm{~kg} / \mathrm{m}^{2}\right) \cdot \beta \cdot 10^{-3} \cdot \sum_{\mathrm{i}=1, \mathrm{n}} \mathrm{a}_{\mathrm{i}}\left(\mathrm{m}^{2}\right) .
$$

sendo neste caso $\beta=363$.

O grupo, em especial a Lara, deliberou pela inclusão no quadro 3B de "A.2. área ajardinada sobre laje com espessura de solo maior do que $40 \mathrm{~cm}$ " e "A3. pavimento semipermeável com vegetação sobre solo natural". Nesses dois casos a análise através de ecoexergia simplificada não se prestaria à obtenção de uma solução porque ela só se refere à biomassa de vegetação sobre o terreno, ainda que suas raízes tenham que ser consideradas. Nesse sentido, talvez FV para A.2 não necessitasse ser muito menor que a unidade, embora A.3 demandasse uma redução um pouco maior. $\mathrm{O}$ grupo decidiu que para $\mathrm{FV}$ de A.2 se multiplicaria o FV de A1 por 0,8 , e para o de A.3, por 0,4, sendo, como em todo o trabalho, arredondados os resultados, para que não se passasse uma falsa impressão de exatidão nos cálculos e nos conceitos.

No caso de cobertura verde, constando na tabela duas soluções paisagísticas, a saber, cobertura verde com substrato superior a $40 \mathrm{~cm}$ (C1) e inferior a $40 \mathrm{~cm}$ (C.2), vale o mesmo raciocínio, exceto que em C.2 se justificaria um fator um pouco maior. Assim, para a obtenção do FV de C1 multiplicou-se o FV de A1 por 0,8 e para o de FV de C.2, por 0,6. Tendo em vista a enorme gama de soluções paisagísticas disponíveis para cobertura verde, talvez os valores a serem multiplicados devessem ser um pouco menores. 


\subsection{PALMEIRAS EXISTENTES E A SEREM PLANTADAS}

O tratamento a ser dado a palmeiras existentes e a serem plantadas é semelhante ao dado para indivíduos arbóreos.

Para as palmeiras, socorri-me da seguinte bibliografia: NOGUEIRA et al. (2008), BRIANEZ et al. (2013), SANTOS, DOS SANTOS e FERREIRA (2013), BOLFE et al. (2009) e HIGUCHI et al. (1998).

Do último extraí uma equação alométrica, que, adaptada, foi usada da seguinte forma nos cálculos:

$$
\mathrm{Y}(\mathrm{kg})=(1 / 0,8) \cdot \exp [-1,497+2 \cdot 548 \cdot \ln \text { dap }(\mathrm{cm})]
$$

Da penúltima referência extraí elementos que me levaram a concluir ser o dap $=12,5 \mathrm{~cm}$ uma estimativa razoável a ser utilizada no texto legal. Os fatores de horizonte $\mathrm{P}$ para palmeiras existentes e a serem plantadas foram adotados como iguais aos de indivíduos arbóreos. Nesse caso, $\beta=393$.

Disso resultou FV para palmeira a ser plantada o valor de 20, e para palmeira existente, 90 (valores arredondados) ${ }^{196}$.

\subsection{MACIÇOS ARBÓREOS EXISTENTES}

A avaliação da ecoexergia simplificada de maciços arbóreos existentes fez-se por definição segundo a qual um maciço arbóreo constitui-se em um agrupamento com no mínimo 15 árvores de espécies nativas ou exóticas, que vivem em determinada área e que guardam relação entre si e as demais espécies vegetais do local, tendo uma área mínima de $500 \mathrm{~m}^{2}$ de projeção contínua de copa.

\footnotetext{
${ }^{196}$ Foi-me observado que a bibliografia usada para obter equação alométrica e valores de dap de palmeiras referia-se à Amazônia, sendo que em São Paulo as palmeiras tendem a ter porte maior. Além disso, o eng. agrônomo Ricardo Elias (comunicação pessoal) entende que palmeiras trazem ganhos ambientais menores do que árvores de pequeno porte, sendo, portanto, incoerente que das equações acima tenha resultado uma pontuação maior para palmeiras do que para árvores de pequeno porte.
} 
Assim, foi estimada a biomassa mínima de um maciço arbóreo (15 indivíduos arbóreos por $500 \mathrm{~m}^{2}$ ), atribuindo-se uma certa proporção entre indivíduos pequenos, médios e grandes e mantendo o mesmo fator de horizonte relativo a indivíduos arbóreos existentes.

\subsection{MUROS VERDES E JARDINS VERTICAIS}

Socorri-me, para muros verdes e jardins verticais, de MORELLI (2009), DA COSTA (2009), PEREIRA (2008), VALESAN (2009) e DA VEIGA et al. (2013) ${ }^{197}$.

A abordagem utilizada é análoga à apresentada para áreas ajardinadas, com algumas diferenças.

Muros verdes e jardins verticais exibem uma quantidade tão extraordinariamente grande de possíveis soluções paisagísticas, com reflexos tão grandes no cálculo de ecoexergia simplificada, que os parâmetros aqui apresentados são, quando muito, apenas verossímeis.

No caso de muros verdes, foi escolhida como representativa a unha de gato, cuja biomassa, segundo PEREIRA (2008), é de 18t/ha. P não foi considerado e o $\beta$ adotado foi 268. No entanto, tendo em vista as enormes possibilidades paisagísticas, a biomassa estimada foi dividida por 4. Disso resultou um FV de 0,10.

No caso de jardins verticais, foram verificadas diferentes biomassas, concluindo-se que 30t/ha seria um bom valor representativo. $\mathrm{P}$ aqui também não foi considerado e o $\beta$ adotado foi 268. Tendo em vista as enormes possibilidades paisagísticas, a biomassa estimada foi dividida por 4. Disso resultou um FV de $0,15^{198}$.

\footnotetext{
${ }^{197}$ Trepadeiras, segundo SÃO PAULO [CIDADE] ([2008a], p.105), são plantas que têm o caule longo, flexível e que não se sustentam verticalmente, a não ser que apoiadas em suportes ou tutores; a maior parte da raiz é superficial. Evidente que as soluções paisagísticas tratadas neste item não se limitam às trepadeiras.

${ }^{198}$ Há queixa no sentido de que para jardins verticais esses valores são pequenos. De fato, muros verdes e jardins verticais, apresentam diferenças de magnitude, estrutura e custo apreciáveis. No entanto, a enormidade de soluções disponíveis obrigou-me a ser conservador. Entendo que o realmente necessário é obter normas de desempenho de jardins verticais com valores de referência de tal maneira que apenas as soluções que demonstrarem desempenho mínimo seriam aceitas. Dispondo,
} 


\subsection{NORMALIZAÇÃO DO INDICADOR DE ECOEXERGIA}

\section{SIMPLIFICADA}

Para que a ecoexergia simplificada possa ser utilizada na composição de um índice, como a QA, é necessário que ela seja normalizada. Tal não foi necessário quando da definição do indicador de drenagem porque este, por sua própria definição, já se encontrava normalizado.

A normalização adotada correspondeu a simplesmente dividir a ecoexergia simplificada por um valor de referência.

A escolha desse fator de referência não se constituiu em uma tarefa trivial. Depois de algumas hesitações, terminou-se por adotar um valor de referência de 0,38 . Talvez esse valor tenha sido situado algo baixo, mas não muito ${ }^{199}$. Isso corresponde a um exemplo do paradoxo de ser obrigado a tomar as decisões mais importantes quando menos se dispõe de informações. Quando eu me apercebi de que talvez valesse a pena testar outros valores, não havia mais como voltar atrás, uma vez que já haviam sido realizadas diversas simulações e várias avaliações de custo por computador utilizando programação linear.

\subsection{PREOCUPAÇÕES DO DEPAVE}

Desde o início, durante os trabalhos da comissão interna da SVMA para discutir a QA, representantes do DEPAVE manifestaram pelo menos duas preocupações.

então, de um leque de soluções aceitáveis seria possível fazer uma melhor avaliação de um valor razoável para o FV de jardins verticais.

1990,38 u.a. correspondem à exergia de $7,1 \mathrm{GJ} / \mathrm{m}^{2}$. Se eu supuser o valor médio de $\beta$ para o bioma Mata Atlântica como algo entre 370 e 380 (v. JØRGENSEN, 2010, p.313, em que $\beta$ para temperate rain forest é 380 e para tropical rain forest, 370), terei que 0,38u.a. corresponderiam a uma biomassa de aproximadamente $1 \mathrm{~kg} / \mathrm{m}^{2}$, o que, segundo PEREIRA (2008), pode ser considerada a massa de puerária. 
A primeira estava relacionada à manutenção da legislação que disciplina a vegetação no município de São Paulo, em especial, mas não somente, a lei n ${ }^{\circ} 10.365$, de 22 de setembro de 1987 (SÃO PAULO [CIDADE], 1987), e a portaria 130/13 SVMA (SÃO PAULO [CIDADE], 2013b), que tratam em parte dos Termos de Compromisso Ambiental (TCAs), que são contratos administrativos a serem celebrados com empreendedores que desejam retirar vegetação dos lotes (manejo arbóreo). Diga-se de passagem, esse é um questionamento muito comum em eventos e reuniões. O entendimento do grupo e da superior administração sempre foi o de que a legislação sobre a QA em nada alteraria o restante da legislação sobre vegetação, em especial sobre os TCAs.

Algo que sempre incomodava o resto do grupo, mas, confesso, não tanto a mim, estava relacionado ao fato de poder acontecer de um empreendedor possuir uma quantidade enorme de árvores em seu terreno e, tendo ele acordado com o DEPAVE um Termo de Compromisso Ambiental (TCA), ser-lhe facultado o corte de diversos exemplares, não se encontrando na QA nada que o barre. O motivo de essa possibilidade não me incomodar tanto (na realidade incomodava um pouco) estava no possível efeito paradoxal de leis de proteção a que tive oportunidade de aludir. Se a vegetação for excessivamente tutelada, a tendência é que a lei não a proteja, mas, na realidade, piore a situação, já que não haverá a menor boa vontade em preservar árvores e haverá muito desejo de suprimi-las. Além disso, parecia-me que essas leis demasiado rigorosas violavam certo princípio de equidade na medida em que os proprietários têm enorme ônus para bônus alheio sem serem recompensados por isso ${ }^{200}$; talvez isso não importasse tanto porque o interesse público se superpõe ao interesse privado e principalmente porque a propriedade é concebida não como um direito absoluto, mas como uma matriz geradora de deveres e direitos.

Tal não incomodava apenas ao restante do grupo, mas se constituía em inquietação que frequentemente era posta diante dele. Porém, a Hélia e a Lara deram uma solução excelente ao problema: nas propostas provisórias para o substitutivo

\footnotetext{
${ }^{200}$ É justo que se diga que o artigo 17 da lei no 10.365, de 22 de setembro de 1987 (SÃO PAULO [CIDADE], 1987) prevê que imóveis revestidos de vegetação arbórea, declarada de preservação permanente ou perpetuada, terão direito a um desconto de até 50\% no seu imposto territorial segundo a relação entre a área protegida e a área do imóvel, sendo o benefício condicionado a um requerimento anual.
} 
consta um fator que diminui, drasticamente, o valor atribuído a exemplares arbóreos a serem plantados em decorrência da celebração de um TCA com o poder público. Com isso, deu-se, pelo menos em parte, uma resposta a todas as inquietações manifestadas. Solução desse gênero consta no substitutivo.

A segunda se relacionava à demanda do DEPAVE no sentido de que houvesse, na medida do possível, harmonização da QA com a legislação municipal relacionada à vegetação. Um representante do DEPAVE foi bastante explícito com relação ao anexo VII da portaria 130/13 - SVMA (SÃO PAULO [CIDADE], 2013b), que trata de pontuação maior para compensação ao corte para a vegetação qualificada por algum tipo de proteção legal. O grupo decidiu que na tabela de vegetação a constar na minuta referente à QA seriam incluídos dois fatores, F e G, que qualificariam a vegetação de exemplares arbóreos e de maciços arbóreos, respectivamente, conferindo-lhes mais pontos, o que seria feito preferivelmente com os mesmos pesos indicados no referido anexo VII. Uma vez que sempre havia pendências mais urgentes no trabalho do grupo, a redação referente aos fatores $F$ e $G$ sempre foi postergada para oportuno detalhamento. No final, em nome da simplicidade, foi deliberado, provavelmente pela superior administração, a retirada de qualquer qualificação da vegetação na forma de fatores como esses.

\subsection{COMPARAÇÃO DA ECOEXERGIA SIMPLIFICADA COM A ÁREA}

\section{FOLIAR}

Biólogos e paisagistas, quando apresentados à ecoexergia simplificada, têm dois tipos de reação: ou um indicador único é insuficiente para caracterizar um ecossistema, sendo necessários muitos deles, ou existem disponíveis indicadores melhores.

Não haveria sentido utilizar aqui modelos sofisticados como o UFORE (NOWAK et al., 2008) ou o i-Tree (I-TREE, s.d.), que fazem avaliações dos serviços ambientais prestados por florestas urbanas. BOTEQUILHA-LEITÃO e AHERN (2002, p.68 e 74) informam que métricas paisagísticas foram usadas largamente em 
pesquisa, mas que é rara sua aplicação no planejamento. Os autores creditam isso provavelmente à grande quantidade de métricas disponíveis e da resultante confusão acerca de qual métrica usar e de como interpretar os resultados. De fato, informam eles, há literalmente centenas de métricas desenvolvidas para analisar a estrutura da paisagem. Citam que métricas paisagísticas são fortemente correlacionadas e podem ser confundidas, e que estudos foram conduzidos no sentido de classificar grupos independentes de métricas.

NOWAK (1994) entende que, uma vez que muitas funções ambientais estão relacionadas à área foliar (por exemplo, redução da temperatura do ar, remoção de poluentes aéreos, sequestro de $\mathrm{CO}_{2}$ ), a compreensão da contribuição da área foliar de várias espécies de árvores é importante para pesquisadores, gestores e planejadores de florestas urbanas. A medida da dominância de espécies de árvores reflete a contribuição relativa de cada espécie para a área foliar total da floresta. Espécies com maior proporção de área foliar são provavelmente as que mais influenciam o ambiente local.

Tendo isso em vista, conduzi um pequeno estudo visando comparar a métrica área foliar (ou eventualmente massa foliar) com a métrica ecoexergia simplificada. Para tanto, necessitava de correlações entre dap e a área foliar (ou, eventualmente, massa foliar).

TOBIN et al. (2006), por exemplo, propõe uma singela equação correlacionando biomassa foliar (FB) e dap:

$$
\mathrm{FB}=\exp (-3,07+1,73 . \ell \mathrm{n} \text { dap })
$$

NOWAK (1996) propõe diversas correlações derivadas de dados extraídos de árvores a céu aberto saudáveis e com a copa completa. Assim, as equações estimam a área foliar próxima ao máximo. Ele próprio informa que as equações tendem a superestimar a área foliar das árvores, não considerando as perdas de folhas ocasionadas por envelhecimento da árvore, desfoliação devido a insetos, podas, etc. De fato, SPANGENBERG (2010), comentando a respeito de uma equação obtida por NOWAK (1994), diz que a aplicação dela para árvores de rua típicas de São Paulo superestima a área foliar quando comparada com resultados de outros modelos, mas que tal abordagem, associada a modelos de taxas de crescimento, é promissora no sentido de predizer aumento de tamanho e benefícios em cenários futuros. 
De NOWAK (1996) selecionamos a equação seguinte para estimar a área foliar:

$$
\mathrm{LA}\left(\mathrm{m}^{2}\right)=\exp (0,3795+0,0586 \cdot \operatorname{dap}(\mathrm{cm})+4,0202 . \mathrm{S}+\mathrm{MSE} / 2)
$$

sendo LA: área foliar (leaf area), em $\mathrm{m}^{2}$; dap, em $\mathrm{cm}$; $\mathrm{S}$ : fator de sombreamento médio para cada espécie individual (porcentagem da intensidade de luz interceptada pelas copas das árvores); MSE: fator de correção que, dividido por 2, deve ser adicionado para corrigir o viés logarítmico da correlação.

$\mathrm{O}$ fator $\mathrm{S}$ corresponde à atenuação definida na lei de Beer-Lambert (ONG, 2003, NOWAK et al., 2008). Por essa lei, a luz é atenuada exponencialmente à medida que ela atravessa a copa de acordo com um coeficiente de extinção k:

$$
\mathrm{Q}_{\mathrm{i}}=\mathrm{Q}_{0} \cdot \mathrm{e}^{-\mathrm{k} \cdot \mathrm{LAI}}
$$

sendo $\mathrm{Q}_{\mathrm{i}}$ : radiação de onda curta sob a copa; $\mathrm{Q}_{0}$ : radiação de onda curta incidente sobre a copa; LAI: índice de área foliar (leaf area index), definido como a razão entre a área foliar e a projeção da árvore sobre o solo.

A fim de ficar de posse de uma estimativa de $S$ (fator de sombreamento, conforme indicado acima) para o estudo, obtive, a partir de uma listagem compilada por SPANGENBERG (2010) referente a diversos dados de árvores brasileiras, um sombreamento de verão que se afigurou razoável $(0,258)$. Nos cálculos, foram considerados os mesmos fatores de horizonte $\mathrm{P}$ utilizados na estimativa da ecoexergia simplificada de exemplares arbóreos. Os resultados estão apresentados na tabela 6 .

Para que se avalie com justiça a comparação acima, é preciso que se diga que eu não fiz uma conta iterativa nem de chegada. Que as razões entre ecoexergia simplificada e área foliar sejam mais ou menos constantes é um resultado impressionante por si só, sugerindo, talvez, ou pelo menos servindo para corroborar, que há realmente algo de privilegiado no conceito de ecoexergia simplificada como métrica da qualidade ecossistêmica e do microclima. Porém, a quase igualdade numérica entre as duas métricas corresponde apenas e tão somente a uma curiosa coincidência. 
Tabela 6 - Comparação entre estimativas da ecoexergia simplificada e a área foliar para exemplares arbóreos existentes e a plantar de diferentes portes.

\begin{tabular}{|c|c|c|c|}
\hline $\begin{array}{c}\text { Porte e situação da } \\
\text { árvore }\end{array}$ & $\begin{array}{l}\text { Exs.P } \\
\text { (u.a.) }\end{array}$ & $\begin{array}{c}\text { LA.P } \\
\left(\mathbf{m}^{2}\right)\end{array}$ & $\mathbf{E x} x_{s} / L A$ \\
\hline $\begin{array}{l}\text { - Indivíduo arbóreo } \\
\text { pequeno a plantar }\end{array}$ & 20 & 15 & 1,3 \\
\hline $\begin{array}{l}\text { - Indivíduo arbóreo } \\
\text { médio a plantar }\end{array}$ & 35 & 35 & 1,0 \\
\hline $\begin{array}{l}\text { - Indivíduo arbóreo } \\
\text { grande a plantar }\end{array}$ & 85 & 80 & 1,1 \\
\hline $\begin{array}{l}\text { - Indivíduo arbóreo } \\
\text { pequeno existente }\end{array}$ & 100 & 80 & 1,3 \\
\hline $\begin{array}{l}\text { - Indivíduo arbóreo } \\
\text { médio existente }\end{array}$ & 180 & 180 & 1,0 \\
\hline $\begin{array}{l}\text { - Indivíduo arbóreo } \\
\text { grande existente }\end{array}$ & 430 & 400 & 1,1 \\
\hline
\end{tabular}

Fonte: produção própria

Notas:

$\mathrm{Ex}_{\mathrm{s}}$ : ecoexergia simplificada (u.a.);

LA: área foliar $\left(\mathrm{m}^{2}\right)$;

$\mathrm{P}$ : fator de horizonte. 


\section{DEFINIÇÃO DE PADRÕES}

O que foi feito até o momento poderia ser um tanto artificialmente chamado de pesquisa. Em princípio não houve ainda apresentação de juízos de valor, embora essa afirmativa seja obviamente um tanto ilusória ${ }^{201}$. A partir de agora tratarei da decisão, ou seja, os parâmetros mínimos a que o empreendedor deve obedecer. Se até agora o trabalho poderia ser denominado "técnico", ou "científico", agora se entra na senda das decisões que as instâncias políticas tomarão. Porém, o profissional de carreira, em princípio "neutro", embora não deva se comprometer com uma posição, tem obrigação de fornecer alternativas (que se situem em uma superfície de tradeoff) às instâncias políticas. Até porque essas instâncias muitas vezes gostam de se resguardar em suas decisões, às vezes optando por afirmar que apenas seguiram recomendações "técnicas", o que, obviamente, ainda que não faça sentido, é um argumento de peso. Pelo contrário, a diversos críticos agrada procurar decisões políticas que não tenham decorrido de orientação técnica, o que também não faz sentido. Afinal, fosse assim, não haveria necessidade de eleições para conferir legitimidade democrática às decisões.

Conforme apresentado no item 4.2, é como se estivéssemos saindo de uma forma de "critérios" (a rigor não, porque os valores sugeridos pelo grupo não correspondem a consenso da comunidade acadêmica e/ ou técnica, às vezes até se opondo a elas) e adentrando em "padrões". Ao definir um índice agregando dois indicadores de forma a definir o valor numérico da QA, de certa maneira já adentráramos nesse domínio dos padrões, porque a definição de qualquer indicador ou índice, ainda que meramente descritivos, já implica parcialmente um juízo.

De uma maneira geral, à exceção do exposto mais à frente, a QA, pelo PL, é obrigatória para construção de imóveis novos em terrenos com área maior do que

\footnotetext{
${ }^{201}$ É claro que os protestos em favor da neutralidade científica do realizado até agora são no mínimo relativos. Não precisamos nos escorar em um Marx, em um Foucault ou em um Nietzsche (v., p.ex., DE MOURA, 2005, p.73-7) para afirmar que a ciência, como a técnica, não é neutra, sendo, porém, sua não neutralidade mais sutil. No nosso caso, até este momento não tenho sido neutro porque o que tenho afirmado até agora, direta ou indiretamente, é que uma situação paisagística, e até ecossistêmica, é tanto melhor quanto maior sua ecoexergia. Uma tal asserção é, a rigor, metacientífica e metatécnica.
} 
$500 \mathrm{~m}^{2}$ ou para reformas com aumento ou diminuição da área construída. A expressão "ou diminuição" foi acordada na última reunião do grupo destinada a fornecer propostas para a redação do substitutivo, sendo acatada no substitutivo na forma de "alteração".

\subsection{DEFINIÇÃO DE PERÍMETROS DE QUALIFICAÇÃO AMBIENTAL}

A ideia inicial era que o valor numérico da quota ambiental mínima (QAmin) a ser observado pelos empreendedores seria função da área do lote, do uso do empreendimento e de sua localização no território do município. Por simplificação, essa função passou a depender de apenas duas variáveis, a saber, localização e tamanho do lote, retirando-se o uso.

Porém, a localização do lote dentro da área urbana demandou um segundo mapa de zoneamento, paralelo ao primeiro, referente ao zoneamento propriamente dito. A hercúlea tarefa de fazer esse segundo zoneamento em prazo estreitíssimo, com poucos recursos, principalmente humanos, e com enorme pressão da administração e dos interessados (porque isso iria influir no preço da terra), coube à Hélia, à Lara e à Patrícia. Eu tive participação quase zero nisso; limitei-me, quando muito, a sugerir dois mapas disponíveis e propor uma escala de um a quatro como meio de avaliar o desempenho da região nos quesitos drenagem e vegetação.

O que elas fizeram foi, nos termos de SÃO PAULO [CIDADE] (2014b), procurar homogeneidades no tocante a problemas de inundação, de microclima e de qualidade ecossistêmica, de maneira a definir perímetros. Tal se deu em consonância com os princípios do Plano Diretor Estratégico (PDE) no sentido de que as macroáreas definidas nesse diploma legal seriam consideradas como base para os estudos, tendo ocorrido dessa forma com os perímetros de qualificação ambiental. Inicialmente foram delimitados 24 perímetros de qualificação ambiental ${ }^{202}$, sendo 8 perímetros na Macroárea de Estruturação Metropolitana (MEM), 2 na Macroárea de

\footnotetext{
${ }^{202}$ Contrariando a opinião majoritária de toda a SMDU e da Hélia, esse nome "perímetros de qualificação ambiental" nunca me agradou. Trata-se aqui de superfícies, zonas, se quiserem, envolvidas por esses perímetros fechados, mas obviamente não os perímetros.
} 
Urbanização Consolidada (MUC), 4 na Macroárea de Qualificação da Urbanização (MQU), 3 na Macroárea de Redução da Vulnerabilidade Urbana (MRVU), 3 na Macroárea de Redução da Vulnerabilidade e Recuperação Ambiental (MRVRA) e 4 na Macroárea de Controle e Qualificação Urbana e Ambiental (MCQA). Elas utilizaram as seguintes bases cartográficas: Mapa de Temperatura Aparente da Superfície ${ }^{203}$, do Atlas Ambiental; Mapa de Uso do Solo, da EMPLASA (classes de vegetação); Mapa de Pontos de Inundação e Alagamentos, da Secretaria Municipal de Coordenação das Subprefeituras e da Companhia de Engenharia de Tráfego (CET); Mapa de Bacias Hidrográficas, do Manual de Drenagem do Município de São Paulo; e imagens do Google Earth, além de, e principalmente, seu apuro técnico.

Houve críticas pelo que foi considerado por alguns, de um lado, como um número excessivo de perímetros e por outros, de outro lado, como não consideração de especificidades locais. Posteriormente se decidiu pela redução do número de perímetros para 12 .

O PL encaminhado para a Câmara previa que os imóveis inseridos na Operação Urbana Centro cuja taxa de ocupação existente e regular fosse superior a 0,7 ficariam dispensados da aplicação da QA. Mesmo assim, se eles tivessem área total superior a $500 \mathrm{~m}^{2}$, não ficariam isentos de exigências relativas a estruturas hidráulicas de drenagem no lote, sejam reservatórios, sejam estruturas alternativas. Aparentemente se aplicam a eles também as exigências relativas à reservação para o aproveitamento de águas pluviais.

A QA, pelo PL encaminhado, não se aplica nas 2 macroáreas que integram a zona rural (Macroárea de Contenção Urbana e Uso Sustentável e Macroárea de Preservação dos Ecossistemas Naturais).

Além disso, o PL estabeleceu que em EHIS e nas áreas inseridas nos planos de urbanização e de regularização fundiária de interesse social em ZEIS-1, localizados em qualquer perímetro de qualificação ambiental, os parâmetros da QA seriam regulamentados em decreto. Isso reflete as divisões na superior administração no que se refere a aspectos sociais e ambientais.

\footnotetext{
${ }^{203}$ Foi-me advertido que tal mapa, que aliás se refere à situação em um instante específico no tempo, encontra-se muito defasado, tendo a bolha de calor já se deslocado do centro para o leste da cidade.
} 


\subsection{AVALIAÇÃO DE CADA UM DOS PERÍMETROS EM TERMOS DE VEGETAÇÃO E DRENAGEM}

A cada um dos perímetros elas atribuíram para drenagem e vegetação notas (de 1 a 4, sendo 4 péssimo, 3 ruim, 2 médio e 1 bom) com base em seu conhecimento da cidade, resultado de largo período na prefeitura e do feeling desenvolvido ao longo desses anos.

Usualmente tarefas como essa podem ser feitas recorrendo a técnicas de superposição de mapas (v., p.ex., McHARG, 1969, e ORTOLANO, 1984). De fato, parece que em manuais de planejamento paisagístico-ecológico, como por exemplo HINZEN et al. (1995), DOS SANTOS (2004) e BASTIAN e SCHREIBER (1994), admite-se que os processos ecológicos e sociais têm tamanha complexidade, como de fato evidentemente têm, que estudar analiticamente esses processos demandaria muitos recursos e que então uma saída viável consistiria em estabelecer indicadores (espacialmente atribuídos) que simplifiquem toda essa complexidade e que se tomem decisões a partir deles. No entanto, a experiência e o conhecimento que a Hélia, a Patrícia e mesmo a Lara (esta ainda com relativamente pouco tempo de prefeitura) têm da cidade dispensa o uso de indicadores (cuja formulação é, aliás, sempre arbitrária) na definição de perímetros homogêneos. Assim, fica mais do que justificado que elas tenham trabalhado usando seu apurado feeling sobre as coisas da cidade.

O estudo empreendido implicitamente análogo à técnica de superposição de mapas torna, de certa maneira, híbrido o modelo de trabalho de desenvolvimento da QA. Isso porque na fase de desenvolvimento das métricas procurei embasar teoricamente os resultados, por mais simplificada do ponto de vista teórico que tenham sido as métricas resultantes. De fato, seria impraticável utilizar grandes pacotes computacionais como, por exemplo, para microclima o ENVI-met (BRUSE, 1999a, 1999b e 2000, BRUSE e SCHUSTER, 2008 e BRUSE e SKINNER, 1999), e para vegetação o i-Tree (I-TREE, s.d.) ou ainda o UFORE (NOWAK et al., 2008). $\mathrm{Na}$ fase de definição do zoneamento da QA ocorreu outra abordagem, ligada ao uso 
de indicadores simplificados destinados a dividir a cidade em zonas homogêneas e avaliar cada uma em relação a aspectos de interesse.

Assim, vale a pena discutir sumariamente o método de superposição de mapas com utilização de indicadores. Inicio com um rápido apanhado teórico da questão dos indicadores e sua agregação. A seguir, situo o paisagismo ambiental dentro das vertentes teóricas do paisagismo surgidas a partir da década de setenta do século passado, entre as quais se situa o paisagismo ambiental, no qual se destaca o trabalho de McHarg. Este é então objeto de crítica. Finalmente, é feito uma consolidação de minha autoria a respeito de possíveis críticas ao método de superposição de mapas e uma avaliação de seu uso nos trabalhos relativos à QA.

$$
* * *
$$

Indicadores, em princípio, ajudam muito simplificadamente a descrever (indicadores descritivos) ou a constatar até que ponto o descrito se submeteu aos desígnios do responsável pelos indicadores (indicadores prescritivos). Ambos devem ser, idealmente, de fácil entendimento e demandar fácil obtenção de dados.

Indicadores descritivos não podem ser entendidos como mais do que uma brutal simplificação da realidade, mostrando apenas tendências ou sugerindo algumas prioridades. Nesse mister, estudos mais aprofundados, quando disponíveis, apresentam geralmente mais informação do que meros indicadores descritivos.

Embora o delineamento de ambos os tipos de indicadores envolva questões de ordem metatécnica e/ou metacientífica, a questão se coloca de forma mais acentuada nos indicadores prescritivos. Aqui desempenha papel importante o teorema da impossibilidade de Arrow. Esse teorema, na forma apresentada por GEANAKOPLOS $(2005)^{204}$, pode ser assim enunciado: seja $\mathbf{A}=\{\mathrm{A}, \mathrm{B}, \ldots, \mathrm{C}\}$ um conjunto finito de pelo menos três alternativas. Uma preferência transitiva sobre A é um ranking de alternativas em $\mathbf{A}$ no sentido do mais preferível ao menos preferível. Consideremos uma sociedade composta por $\mathrm{N}$ indivíduos, cada um dois quais tem uma preferência transitiva (potencialmente diferente). Uma constituição é uma função que associa a cada $\mathrm{N}$-upla de preferências transitivas uma preferência

${ }^{204}$ GEANAKOPLOS (2005), FISHBURN (1970) e WIEDIJK (2007), por exemplo, apresentam formalizações e demonstrações do teorema. Discussões sobre consequências do teorema são apresentadas, por exemplo, por MASKIN (2009) e ULLEN (2004). Uma contestação das interpretações usuais do teorema é feita por TULLOCK (1967). 
transitiva chamada de preferência social. Uma constituição respeita a unanimidade se a sociedade puser a alternativa $\alpha$ estritamente acima da $\beta$ sempre que cada indivíduo puser $\alpha$ estritamente acima de $\beta$. A constituição respeita a independência de alternativas irrelevantes se o ranking relativo social (mais alto, mais baixo ou indiferente) de duas alternativas $\alpha$ e $\beta$ depender somente do ranking relativo de cada indivíduo. A constituição é uma ditadura do indivíduo $n$ se para cada par $\alpha$ e $\beta$ a sociedade preferir estritamente $\alpha$ a $\beta$ sempre que $n$ estritamente preferir $\alpha$ a $\beta$. Isso posto, o teorema é assim enunciado: "qualquer constituição que respeita a transitividade, a independência de alternativas relevantes e a unanimidade é uma ditadura”. Um exemplo das dificuldades daí decorrentes, ainda que não faça menção ao teorema da impossibilidade de Arrow, pode ser encontrado em BRAYBROOKE e LINDBLOM (1972).

A redução do número de indicadores usualmente implica perda de informação, o que se constitui em problema. PELE (2009) informa haver dois métodos para reduzir o número de indicadores: seleção e agregação. A seleção reduz o número de indicadores usando métodos e técnicas estatísticas que eliminam informação redundante. Uma dessas técnicas é a análise fatorial; no entanto, nem sempre é possível que a redução de variáveis se faça de forma a manter a perda da quantidade de informação em nível satisfatório. A seleção pode ser feita ainda por elementos da teoria da classificação. A agregação implica a construção de um indicador agregado, ou índice, que se constitui em uma função dos indicadores iniciais.

Pele informa ainda a respeito do teorema de impossibilidade de Paun. Tal teorema assevera que um indicador agregado sensível (ou seja, um aumento no valor de um indicador inicial não implica a diminuição do valor do indicador agregado) e não explosivo (ou seja, um pequeno aumento no valor de um indicador inicial não implica um aumento grande no valor do indicador agregado) é necessariamente compensatório (ou seja, para que o valor do indicador agregado permaneça constante com a variação de valor de um indicador inicial é necessário que o valor de outro indicador inicial se altere, do que resulta que valores iguais do indicador agregado possam se referir a situações distintas). O caráter compensatório de um indicador agregado corresponde a uma séria deficiência. 
As considerações acima implicam o abandono de qualquer tentativa, por falta de lastro teórico, de embasar e justificar decisões de um ponto de vista tecnocrático, em especial se essa justificativa ocorrer na forma de definição e agregação de indicadores. O que não significa que a definição e a agregação de indicadores não prestem serviços inestimáveis na tomada de decisão.

\section{$* * *$}

Passo agora a um rápido panorama do método de superposição de mapas. A literatura consagra diversos nomes a técnicas que, em última análise, correspondem ao mesmo processo ou que se mostram análogas. Assim, tem-se suitability analysis, McHarg's method, overlay analysis, Empfindlichkeitsanalyse, landscape ecology, planification écologique, cartographie écologique.

CESAR e CIDADE (2003) visualizam a partir da década de setenta do século passado o aparecimento de novas vertentes do paisagismo, revelando seus desdobramentos teóricos e práticos visões de mundo distintas, ainda que "dentro da matriz ideológica da acumulação capitalista contemporânea”. São essas vertentes: a) paisagismo com ênfase na arquitetura da paisagem; b) paisagismo com ênfase na percepção; c) paisagismo ambiental.

O paisagismo com ênfase na arquitetura da paisagem baseia-se em visões de mundo que valorizam a organização do espaço. Embora a vegetação constitua elemento fundamental de composição, essa linha tende a ver todos os espaços como arquitetura, adotando várias escalas de intervenção, desde a rural até a urbana Distancia-se da tradicional visão do paisagismo como jardinagem ou como campo complementar do desenho urbano, trabalhando tanto com elementos construídos como com vegetais e buscando dotar o jardim de arquétipos da arquitetura (como paredes, pisos e tetos), que podem ser configurados pela própria vegetação. Busca o belo e o estético, adotando elementos simbólicos. Utiliza parâmetros de composição como a simetria, o ritmo, a harmonia e o equilíbrio, que salientam a representação do objeto. Por outro lado, salienta também a questão da funcionalidade. O paisagismo com ênfase na arquitetura da paisagem englobou duas tendências que repercutem na organização do espaço: o paisagismo ligado ao desenho urbano, tendo como exemplo Gordon Cullen, e o paisagismo ligado à expressão artística, ao qual está associado Burle Marx. 
O paisagismo com ênfase na percepção apoia-se em visões de mundo que valorizam as relações de espaço com o atendimento de expectativas sociais. Valoriza aspectos sensoriais e psicológicos. A psicologia ambiental teve especial participação no entendimento de expectativas sociais, consideradas inicialmente como necessidade dos usuários. Na perspectiva do urbanismo, os avanços mais específicos na compreensão das relações entre ambiente e comportamento foram reflexos de pesquisas desenvolvidas no campo da percepção urbana, destacando-se Kevin Lynch.

O paisagismo ambiental guarda relações com visões de mundo que valorizam a relação sociedade-natureza e aspectos ecossistêmicos. A evolução da temática ambiental nas práticas de paisagismo constitui uma espécie de rebatimento do desenvolvimento da abordagem ambiental no urbanismo. Esta remonta às preocupações sanitaristas, sob uma perspectiva que tangenciava a ideia de um maior contato com a natureza, agregando sistemas de parques e áreas verdes como complementos dos sistemas urbanos. Hodiernamente tem-se procurado construir consenso em torno do conceito de cidades sustentáveis. Uma abordagem específica da temática ambiental é a que guarda relações estreitas com o desenvolvimento da ecologia, difundidas principalmente através da ecologia profunda, de Arne Naess, que reconhece o valor inerente de seres vivos e concebe os seres humanos apenas como um fio particular na teia da vida. Os termos ecologia e ambiente, ainda que distintos, tendem para uma compreensão única, a da consolidação de práticas comprometidas não apenas com seu significado social, mas também com a natureza, identificadas como paisagismo ambiental. Destaca-se no paisagismo ambiental o nome de Ian McHarg.

DOMON, GARIÉPY e BOUCHARD (1987) identificam uma planificação dita ecológica, na qual eles situam, entre outros, McHarg, e na qual eles visualizam três componentes essenciais:

a) a planificação ecológica leva em conta uma categoria de objetos, ditos biofísicos, sendo a tomada de decisão informada por um conjunto de características biofísicas;

b) para o estudo dessas características lança-se mão de métodos que poderiam ser agrupados em uma denominação de "cartografia ecológica". Inventários e cartas ecológicas são percebidos como um meio privilegiado de análise e de 
representação dos componentes biofísicos, permitindo avaliar as restrições, as aptidões ou os potenciais do meio para as ocupações mais comuns e/ou intervenções particulares;

c) utiliza-se implícita ou explicitamente o conceito de "determinismo ecológico" quando da elaboração de propostas de intervenção. Tal como apresentado por McHarg, esse conceito pressupõe que a intervenção ótima para um dado espaço é aquela que, precedida por um inventário e por uma análise das características biofísicas do território, se destaca como sendo a mais conforme com os "processos naturais" do meio. Na prática, componentes sociais, econômicos ou culturais serão também habitualmente levados em consideração. Contudo, são as características biofísicas as percebidas como determinantes primeiros em matéria de gestão e que definem o campo de intervenções possíveis. Serão elas que os autores que privilegiam a planificação ecológica procurarão prioritariamente conhecer.

HERRINGTON (2010) apresenta algumas críticas a McHarg. Ela informa que McHarg não é o inventor do método da superposição de mapas, que se constitui na chave de seu modelo ecológico, mas que certamente foi protagonista dele como ninguém antes. Ela entende que certamente seu trabalho merece o máximo reconhecimento, mas que, sem uma crítica de suas ideias, perde-se a oportunidade de entender o lugar de McHarg na história.

Para McHarg, o mapa trabalhado era o espaço onde a verdade se revelava. Seu método consistia tanto em um diagnóstico como em uma prescrição. Embora ela ressalte que $\mathrm{McHarg}$ não tenha tido nenhum treinamento formal como cientista e que alguns aspectos de sua ciência não sejam corretos, ele desenvolveu uma teoria científica chamada de adaptação criativa (creative fitting) que tanto explica como valida o projeto com a natureza. O método se diz ecológico não apenas porque usa dados ecológicos, mas porque os resultados que ele produz estão de acordo com os processos de adaptação e evolução. Como ela acentua: 
Criatividade, para McHarg, não era um ato exclusivo de artistas, mas mais um processo em direção a níveis mais altos de ordem, que ele entendia ocorrer nas leis tanto da termodinâmica como da evolução em sistemas bióticos ou abióticos. McHarg definiu adaptação (fit) como uma mistura de duas proposições científicas: a concepção de Charles Darwin segundo a qual "o organismo sobrevivente é adaptado ao ambiente" e a teoria de Lawrence Henderson pela qual "o ambiente real, o mundo real, constitui-se na morada mais adaptada para a vida... essa adaptação, então, é essencial para a sobrevivência, segundo Darwin, e há sempre o ambiente mais adaptado para cada sistema que procure um ambiente". (...) Em 1997, ele se referiu mais uma vez a sua teoria de adaptação criativa em uma definição de projeto ecológico: "O projeto ecológico segue-se ao planejamento e introduz o assunto da forma. Deve haver uma locação, processos com materiais apropriados e formas intrinsicamente adequados. O projeto requer um projetista informado com uma imaginação visual, bem como habilidades gráficas e criativas. Ele se dirige a uma seleção revelada em uma forma intrínseca e expressiva". Ele concluiu: "E, graças a Charles Darwin e Lawrence Henderson, nós temos uma teoria". (HERRINGTON, 2010, p.5).

A autora lembra que McHarg era filho de um pastor. Deus, segundo ela, tinha uma presença espectral no pensamento de McHarg acerca da natureza e da ciência. "Seus escritos estão enredados com conotações de heresia, bem, mal e uma perpétua culpa por nossos cérebros terem tornado os humanos uma doença planetária. Ficava implícito que McHarg entendia que Deus prezava o projetista ecológico sobre todos os outros“ (HERRINGTON, 2010, p.13).

Sua interpretação dos trabalhos de Darwin e Henderson não era, segundo a autora, inteiramente correta. Ele, como outros leitores de Henderson, entendia que suas teorias validariam a ideia segundo a qual haveria um projeto para a Terra, que a fez adequada para toda forma de vida que existiu e que existe.

As ideias de McHarg com relação a Darwin podem ter sido ainda mais influenciadas por suas ideias religiosas. A evolução, em algumas mentes, substituiu a teologia natural.

Ainda segundo a autora, para McHarg outro critério para a adaptação criativa consiste no ecossistema estável. A autora lembra ser bastante contestável que a estabilidade possa ser entendida como um critério de descrição de sistemas saudáveis, ideias essas que podem ser buscadas na filosofia natural dos séculos XVIII e XIX. ${ }^{205}$

205 O arquiteto Luiz Augusto Pereira Leitão (comunicação pessoal), ex-aluno de McHarg, informoume que ele não era dogmático. Aliás, ele muito prezava o trabalho de Burle Marx, com quem mantinha relações de amizade. 
Independentemente das ideias subjacentes ao pensamento de McHarg, a superposição de mapas enquanto processo de tomada de decisão apresenta alguns inconvenientes. Esse método realiza uma descrição supersimplificada da realidade através de indicadores simples e arbitrariamente escolhidos, que já dirigem uma solução; a realidade é descrita estaticamente, e as relações espaciais entre as partes são omitidas; a atribuição de pesos a cada indicador é igualmente arbitrária; finalmente, a superposição de mapas, um método descritivo em sua essência, é utilizado como critério de decisão.

Apesar de todas as restrições apontadas acima, a superposição de mapas tem prestado um auxílio ímpar na consideração de diversos fatores que devem impactar em decisões. Em particular, o uso da superposição de mapas, tal como conduzida nos trabalhos da quota ambiental, pareceu-me bastante adequada e bem conduzida.

\subsection{DEFINIÇÃO DE EXIGÊNCIAS DE PERMEABILIDADE MÍNIMA EM CADA UM DOS PERÍMETROS DE QUALIFICAÇÃO URBANA}

Pelo mesmo processo de conhecimento aprofundado da cidade através do qual foram definidos os perímetros de qualificação urbana, foram estabelecidas taxas mínimas de permeabilidade para cada perímetro, sendo que todos os lotes ficariam obrigados ao atendimento dessas taxas mínimas de permeabilidade, independentemente da área do lote.

Nos lotes inseridos em ZEPAM, ZPDSr, ZPDS, ZCOR, ZPR e ZER deveriam, segundo o PL, ser aplicadas taxas de permeabilidade mínima de 0,90, $0,70,0,50,0,30,0,30$ e 0,30 , respectivamente, independentemente do tamanho do lote.

Nos lotes com área superior a $500 \mathrm{~m}^{2}$, exceto os situados em ZEPAM, ZPDS ou ZER, a taxa de permeabilidade poderia ser reduzida em até 50\% desde que a pontuação da QA fosse majorada na mesma proporção em que a taxa de 
permeabilidade fosse reduzida ${ }^{206}$. No caso dos lotes com área menor do que $500 \mathrm{~m}^{2}$, não obrigados, mas não impedidos da aplicação da QA (com vistas à obtenção de incentivos), e que não estejam localizados em ZEPAM ou ZPDS, a redução da taxa de permeabilidade descrita acima poderia ser aplicada, desde que fosse atendida a pontuação mínima de $\mathrm{QA}=0,15$.

Estipulou-se também que caso a somatória entre a taxa de permeabilidade e a taxa de ocupação fosse superior a 1,00, a taxa de permeabilidade mínima deveria ser respeitada e a taxa de ocupação máxima reduzida proporcionalmente.

\subsection{DEFINIÇÃO DOS ALFAS E BETAS DE CADA PERÍMETRO A SEREM CONSIDERADOS NA EQUAÇÃO DEFINIDORA DA QA}

A definição dos alfas e betas $^{207}$ de cada perímetro considerados na equação definidora da QA foi realizada numa fase inicial, quando ainda se tinha como certo que os indicadores $\mathrm{D}$ e $\mathrm{V}$ fossem menores ou iguais a 1,0. Com isso em mente, propus uma equação bem simples para a definição dos alfas e betas a partir das estimativas da situação de drenagem e vegetação de cada perímetro:

alfa $=($ pontuação atribuída a vegetação)/(somatória das pontuações de drenagem e vegetação)

beta $=($ pontuação atribuída a drenagem $) /($ somatória das pontuações de drenagem e vegetação $)$

Dessa forma, de alguma maneira a situação ambiental existente em cada perímetro no tocante à qualidade ecossistêmica, microclima e drenagem condicionou as exigências em termos da QA.

\subsection{DEFINIÇÃO DA QA MÍNIMA}

A definição da QA mínima passou por alguns passos, apresentados a seguir.

\footnotetext{
${ }^{206}$ Alguém poderia dizer que se trataria de uma compensação entre QA e a Taxa de Ocupação (TO). No entanto, as áreas do lote que não se encaixam como de área edificada a que se refere a TO não coincidem necessariamente com áreas permeáveis.

${ }^{207}$ Não confundir este beta com o fator de conversão ecoexergia-biomassa.
} 


\section{Ranqueamento dos perímetros}

$\mathrm{O}$ ranqueamento dos perímetros correspondeu a uma brilhante ideia trazida pela Lara à discussão.

Cada perímetro possui uma nota relativa à vegetação e outra à drenagem, sendo tanto maior quanto pior a situação existente do perímetro em relação a esses atributos. A Lara propôs que os perímetros também recebessem uma nota relacionada ao seu potencial de transformação em relação à vegetação e à drenagem; no entanto, a escala atribuída foi inversa, ou seja, a nota era tanto menor quanto menor seu potencial de transformação, variando também de 1 a 4 . A seguir, procedeu-se à soma das notas de vegetação, drenagem e potencial de transformação (sem ponderação), variando dessa forma a pontuação de cada perímetro de 3 a 12 . Assim, perímetros com baixo desempenho ambiental e alto potencial de transformação teriam exigências maiores em termos de QA; por outro lado, perímetros com alto desempenho ambiental e baixo potencial de transformação teriam exigências menores em termos de QA.

Os resultados estão apresentados na tabela 7.

Tabela 7 - Pontuação e ranqueamento dos perímetros de qualificação urbana.

\begin{tabular}{lccccc}
\hline Perímetros de origem & $\begin{array}{c}\text { Perímetros de } \\
\text { Qualificação } \\
\text { Ambiental }\end{array}$ & $\begin{array}{c}\text { Microclima+ } \\
\text { Biodiv }\end{array}$ & Drenagem & $\begin{array}{c}\text { Potencial de } \\
\text { transfor- } \\
\text { mação }\end{array}$ & $\begin{array}{c}\text { Somatória/ } \\
\text { ranking }\end{array}$ \\
\hline MEM1, MEM2 & PA 1 & 4 & 4 & 4 & 12 \\
MEM3, MEM5, MEM6 & PA 2 & 3 & 3 & 4 & 10 \\
MEM7, MEM8 & PA 3 & 3 & 3 & 3 & 9 \\
MEM4, MUC2 & PA 4 & 3 & 3 & 3 & 9 \\
MUC1, MRV2 & PA 5 & 1 & 2 & 3 & 6 \\
MQU1 (sudeste) & PA 6 & 3 & 3 & 2 & 8 \\
MQU2, MQU3 & PA 7 & 2 & 3 & 2 & 7 \\
MQU1, MQU3, MQU4 (norte) & PA 8 & 3 & 3 & 3 & 9 \\
MRV1, MRV3 & PA 9 & 4 & 4 & 1 & 9 \\
MRVRA1, MRVRA2 & PA 10 & 2 & 1 & 1 & 4 \\
MRVRA3 & PA 11 & 2 & 1 & 2 & 5 \\
MCQA1 ao 4 & PA 12 & 2 & 2 & 1 & 5 \\
\hline
\end{tabular}

Fonte: composição do grupo, com ênfase na Lara 


\section{Utilização de curvas logísticas}

Eu sugeri que, para cada perímetro, na definição da QAmin em função da área do lote fosse utilizada uma curva logística.

A curva logística era muito utilizada em estudos demográficos, sendo definida por:

$$
\mathrm{P}(\mathrm{t})=\mathrm{P}_{\mathrm{L}} /[1+\mathrm{a} \cdot \exp (-\mathrm{b} . \mathrm{t})]
$$

sendo: $\mathrm{P}(\mathrm{t})$ : população em função do tempo; $\mathrm{P}_{\mathrm{L}}$ : população limite; $\mathrm{a}$, b: constantes; $\mathrm{t}$ : tempo.

Uma característica marcante da curva logística é que ela apresenta valores baixos da ordenada quando a abscissa é baixa, aumentando lentamente, depois mais acentuadamente, até sua derivada segunda anular-se, quando ela muda de concavidade, repetindo o mesmo processo inversamente e tendendo assintoticamente a um valor limite. Essas características tornaram-na atrativa para o grupo.

A Lara, a partir de simulações, propôs que para lotes de $10.000 \mathrm{~m}^{2}$ e para o perímetro ranqueado em primeiro lugar (12 pontos) seria razoável que o valor da QAmin fosse algo como 0,85 ; que para o perímetro ranqueado em último lugar (3 pontos) o valor da QAmin fosse algo como 0,35; e que para a pontuação intermediária o QAmin para lotes com área de $10.000 \mathrm{~m}^{2}$ variasse linearmente entre esses dois pontos.

Coube-me, então, a tarefa de, com base nisso, propor as curvas.

LEMME (1967) 208 apud NOVAES (1981, p.40-1) apresenta um resultado notável das curvas logísticas, que eu pensei em aproveitar: quando se dispõe do valor da função em três pontos equiespaçados em suas abscissas, há uma solução analítica para obter os parâmetros da curva logística.

No entanto, a utilização desse resultado não se apresentou assim tão útil como eu previra. Na prática, tive que fazer uma quantidade muito grande de variações de parâmetros de forma a obter um resultado que eu considerasse satisfatório:

$$
\mathrm{QAmin}=(\mathrm{QAmin} 10000+1) /[1+1,3 . \exp (-0,0005 . \mathrm{A})]
$$

${ }^{208}$ LEMME, R.A.S. Curso de estatística. Rio de Janeiro: Ao Livro Técnico, 1967. 
sendo: QAmin: QA para um determinado perímetro ambiental e determinada área de lote; QAmin 10000: QAmin atribuído aos lotes com área maior do que $10.000 \mathrm{~m}^{2}$; A: área do lote $\left(\mathrm{m}^{2}\right)$.

A expressão acima, com algumas poucas alterações, resultou na tabela 8.

Imóveis situados em lotes cuja área seja menor ou igual a $500 \mathrm{~m}^{2}$ ficariam dispensados do atendimento à QA, mas se a atendessem poderiam vir a usufruir dos incentivos previstos. Porém, se os lotes com área menor ou igual a $500 \mathrm{~m}^{2}$ forem originados de desmembramento ou desdobro realizados após a eventual entrada em vigor da lei nos quais o lote original tinha área maior do que $500 \mathrm{~m}^{2}$, ficarem obrigados ao atendimento da QA.

Como já aqui informado, estabeleceu-se que os imóveis inseridos na Operação Urbana Centro cuja taxa de ocupação existente e regular fosse superior a 0,7 ficariam dispensados da QA, mas não da aplicação de dispositivos destinados ao controle do escoamento superficial quando a área do lote for superior a $500 \mathrm{~m}^{2}$, e que na Macroárea de Contenção Urbana e Uso Sustentável e na Macroárea de Preservação dos Ecossistemas Naturais, agrupadas no Perímetro de Qualificação Ambiental PA13, não se aplicariam as disposições relativas à QA.

Finalmente, propôs-se que no período de 2 anos após a eventual entrada em vigor da lei poderia ser concedido desconto de $25 \%$ na pontuação mínima da QA, sendo vedados nesse caso a concessão dos incentivos previstos.

Tabela 8 - QAmin para diferentes perímetros e áreas de lote.

\begin{tabular}{ccccccccccc}
\hline pontuação & $\mathbf{1 2}$ & $\mathbf{1 1}$ & $\mathbf{1 0}$ & $\mathbf{9}$ & $\mathbf{8}$ & $\mathbf{7}$ & $\mathbf{6}$ & $\mathbf{5}$ & $\mathbf{4}$ & $\mathbf{3}$ \\
\cline { 1 - 6 } $\mathbf{A}\left(\mathbf{m}^{2}\right)$ & & & & & & & & & & \\
\hline 500 & 0,20 & 0,20 & 0,20 & 0,20 & 0,20 & 0,20 & 0,20 & 0,20 & 0,20 & 0,20 \\
600 & 0,43 & 0,40 & 0,37 & 0,35 & 0,32 & 0,30 & 0,27 & 0,24 & 0,22 & 0,20 \\
700 & 0,45 & 0,42 & 0,40 & 0,37 & 0,34 & 0,31 & 0,29 & 0,26 & 0,23 & 0,20 \\
800 & 0,60 & 0,55 & 0,52 & 0,48 & 0,44 & 0,41 & 0,37 & 0,34 & 0,30 & 0,26 \\
900 & 0,70 & 0,69 & 0,64 & 0,60 & 0,55 & 0,51 & 0,46 & 0,42 & 0,37 & 0,33 \\
1.000 & 0,80 & 0,75 & 0,70 & 0,65 & 0,60 & 0,55 & 0,50 & 0,45 & 0,40 & 0,35 \\
\hline
\end{tabular}

Fonte: produção própria 


\subsection{FISCALIZAÇÃO}

Uma questão recorrente levantada foi a dificuldade de garantir, depois da aprovação, o cumprimento de medidas relativamente complexas como as associadas com a QA.

Manifesto a minha estranheza com o fato de esse tipo de questionamento não se dar de maneira tão enfática quando outros instrumentos urbanístico-ambientais são propostos, embora eu seja o primeiro a admitir que a questão procede.

Por esse motivo, elaborei a minuta de diversos artigos tratando da fiscalização da QA. Dela foram aproveitados algumas poucas ideias no PL encaminhado à Câmara: a) a fiscalização e eventuais penalizações de violações à QA far-se-iam tanto nos termos da legislação urbanística como da legislação ambiental: tenho satisfação em dizer que foi uma proposta minha e que eu me bati por ela; isso porque a legislação ambiental é, em diversos aspectos, muito mais rigorosa que a urbanística na aplicação da lei e que apresenta diferenciais que tornam mais provável que ela seja eficaz; b) apresentação de relatórios periódicos dando conta do atendimento à lei; c) verificação desses relatórios por amostragem: algo que eu sugeri para não colocar os órgãos de fiscalização em situação difícil, dadas as carências em termos de recursos materiais e humanos. Na reunião final destinada a definir propostas a serem incluídas no substitutivo, eu propus, e o grupo aceitou, que os recursos financeiros decorrentes de multas aplicadas nos termos da legislação ambiental seriam depositados no Fundo Especial do Meio Ambiente e Desenvolvimento Sustentável (FEMA), e não destinadas ao tesouro municipal ou a qualquer outro fundo. É importante lembrar que a penalização administrativa nos termos da legislação ambiental prevê a possibilidade de descontos significativos na multa caso seja celebrado com o executivo um Termo de Ajustamento de Conduta (TAC) e que em nenhuma hipótese o responsabilizado estará dispensado de medidas de remediação no sentido de repor o ambiente ao estado original, embora haja uma tendência de aceitar, quando a volta do ambiente ao estado anterior se mostrar impraticável, não a remediação, mas um estado ambiental controlado aceitável. 
Nas minutas submetidas ao grupo e ao Daniel, sempre incluí itens que, no meu entendimento, dariam segurança jurídica ao município e aos servidores encarregados da aprovação e da fiscalização, sem o quê suas atividades estariam, como de fato estão, seriamente ameaçadas em função do risco jurídico que tende a paralisar a administração. Com exceção da verificação dos relatórios por amostragem, todas as minhas sugestões nesse sentido de minorar a insegurança jurídica foram recusadas.

\subsection{INCENTIVOS}

A questão dos incentivos foi tratada mais diretamente entre o Daniel e a SP Urbanismo. O grupo tratou-a em grau menor, e eu quase me abstive de qualquer participação mais ativa. Por esse motivo, também me absterei aqui de maiores comentários.

O Bruno e o Hyun criaram uma base de dados de custos de construção e, a partir dela, fizeram diversas simulações para verificar em quanto os empreendedores seriam financeiramente onerados com a QA. Para tanto, utilizaram programação linear de forma a tentar prever as decisões dos empreendedores à vista do cardápio de opções disponibilizados pela QA. A partir dessas simulações, foi discutido o Incentivo da Quota Ambiental, que consiste em um "prêmio", sendo beneficiário o empreendedor que atingir pontuação da QA em certa proporção maior do que a mínima exigida, na forma de desconto na contrapartida financeira de outorga onerosa do direito de construir ou, no caso de terrenos com área menor ou igual a $5.000 \mathrm{~m}^{2}$, na possibilidade de opção por receber na forma de área não computável incentivada.

O segundo incentivo discutido corresponde ao Incentivo de Certificação, não cumulativo com o primeiro e válido apenas para empreendimentos com uso residencial ou não residencial associado a residencial. Tal incentivo seria obtido mediante desconto a ser efetuado no pagamento de contrapartida financeira de outorga onerosa, conforme o grau de certificação de sustentabilidade que o empreendedor venha a obter para o imóvel. Esse incentivo poupa a prefeitura de 
críticas recorrentes no sentido de que apenas três objetivos ambientais tenham sido considerados na QA, ficando outros ausentes. Nossa resposta tem caminhado invariavelmente no sentido de que com apenas três objetivos ambientais já há tamanha controvérsia e relativa dificuldade que a consideração de mais objetivos ambientais complicaria mais do que proporcionalmente a tarefa. Assim, o incentivo de certificação forneceu uma defesa a mais para esses argumentos. Evidentemente que o assunto despertou muitas polêmicas com o setor imobiliário.

Foi pensado um terceiro incentivo, o chamado IPTU verde. A Secretaria Municipal de Finanças costuma se opor fortemente a qualquer nova forma de subsídio ou incentivo tributário. Foi com espanto, portanto, que vi as negociações com ela caminharem. Porém, parece que não caminharam o suficiente porque se optou por retirar a questão do PL. Por outro lado, há sinais de que já se chegou a um acordo. É importante ressaltar que já existe um benefício dessa espécie, ao qual já me referi, previsto na lei 10.365, de 22 de setembro de 1987 (SÃO PAULO [CIDADE], 1987).

No momento que escrevo o presente, há reuniões agendadas com o Conselho Brasileiro de Construção Sustentável (CBCS) para discutir a questão do incentivo de certificação e da QAmin. A respeito desse último, a Patrícia tem sido assertiva no sentido de que o grupo tem muita convicção nas métricas, aceitando discutir apenas os valores numéricos de QAmin.

\subsection{INDUÇÃO A BAIXAS TAXAS DE OCUPAÇÃO}

O Bruno, da SP Urbanismo, ao realizar diversas simulações, queixou-se de que a QA tenderia a fazer os empreendedores decidir por baixas taxas de ocupação, o que contrariaria os princípios do PDE. Os arquitetos da SMDU, e a Hélia, da SVMA, desejavam a todo custo evitar que se recaísse em exigências que produzissem efeitos análogos à fórmula de Adiron (v. DE CARVALHO, 2008, inclusive com entrevista com o urbanista Adiron). 
Para tanto, o Bruno propôs que a pontuação dada às coberturas verdes fosse aumentada, de maneira a estimular coberturas maiores.

Depois de infindáveis discussões, o PL determinou o seguinte: em ZEU, ZEUa, ZEUP, ZEUPa, ZEM e ZEMP, quando o interessado utilizar taxa de ocupação maior ou igual a $50 \%$, com no mínimo $20 \%$ de cobertura verde, com fachada ativa no térreo e com gabarito máximo de $28 \mathrm{~m}$, o desconto concedido em outorga ou a área não computável concedida seria equivalente ao dobro da pontuação exigida no projeto, até o limite máximo de incentivo.

\subsection{ANOMALIAS NA FUNÇÃO D}

O economista Hyun notou que a função D apresenta algumas anomalias no entorno do ponto $\mathrm{D}=0,38$. Assim, a função tenderia a $+\infty$ à direita e a $-\infty$ à esquerda.

Ele verificou que, mantidas outras condições da função (que impediam a possibilidade de que DP se iguale a 0,38 ), a função D poderia ser mantida em valores numéricos aceitáveis e razoáveis na maior parte das vezes impondo simplesmente que DP fosse arredondada no máximo em duas casas depois da vírgula. 


\section{EVENTOS E PARTICIPAÇÃO PÚBLICA}

Além dos processos de participação pública para todo o texto e disposições do PL, houve discussões específicas a respeito da QA. Além disso, embora a QA não tenha ainda sido aprovada e sancionada, já há manifestações a respeito dela na imprensa e na academia. Tudo isso será tratado neste capítulo.

Três foram os eventos que trataram especificamente da QA.

\subsection{PRIMEIRA OFICINA TÉCNICA PARA DISCUTIR RESULTADOS PRELIMINARES DA QUOTA AMBIENTAL}

Numa fase relativamente preliminar do desenvolvimento dos trabalhos da QA, o grupo inclinou-se no sentido de convidar acadêmicos, consultores, membros de institutos de pesquisa e colegas para discutir os resultados alcançados até esse momento. O objetivo era não apenas obter subsídios para o desenvolvimento dos trabalhos, mas também alguma legitimação do ponto de vista teórico adotado. A Patrícia era a mais entusiasta da ideia, mas eu, talvez por covardia, temia muito dar a cara para bater de maneira tão óbvia e tão prematura.

Discutiu-se uma lista de pessoas a serem convidadas e deliberou-se pela necessidade de um texto pequeno, introdutório, para orientar os participantes. Eu criei uma minuta (CAETANO, 2014a), que, depois de substanciais modificações, transformou-se no texto distribuído aos participantes (SÃO PAULO [CIDADE], 2014c).

A oficina teve lugar no dia 30 de outubro de 2014, no edifício Martinelli, onde se encontram os escritórios da SMDU. A oficina foi dividida em duas partes: na parte da manhã, seriam discutidos aspectos de drenagem; na parte da tarde, aspectos de vegetação. Assim, não haveria necessidade de os diferentes especialistas participarem da oficina durante o dia inteiro. 
A parte da manhã foi a mais tranquila. Embora tenham sido feitos diversos questionamentos, tal ocorreu dentro de espírito de urbanidade e respeito.

Após a oficina, eu redigi um documento de consolidação dos questionamentos e sugestões (CAETANO, 2014b). É um documento relativamente extenso, de maneira que vou me fixar apenas em alguns aspectos, e mesmo assim de maneira bastante reduzida, iniciando pelas discussões da parte da manhã.

Foram tratados, entre outros assuntos: regionalização do $\mathrm{CN}$, impacto zero, vazão específica, terminologia, compatibilidade com COE, regionalização por bacia hidrográfica, não utilização da Carta Geotécnica, não consideração da infiltração, fiscalização, avaliação prévia da QA, consideração das estruturas hidráulicas alternativas nos cálculos, reúso e aproveitamento de águas de chuva, simulações, incentivo a aumento do passeio e aterramento dos cabos.

Quase todos esses assuntos já foram objeto de comentários na presente tese. Chamo atenção apenas para a terminologia e incentivos a aumento do passeio e aterramento dos cabos subterrâneos.

Com relação à terminologia, um membro da FCTH, que participou da elaboração do Manual de Drenagem e Manejo de Águas Pluviais, queixou-se, de maneira talvez um pouco veemente, que a terminologia adotada para as medidas de controle do escoamento na fonte não tenha coincidido com a do referido manual. É preciso lembrar que de fato a Lei Orgânica do Município torna vinculantes para a administração os planos setoriais aprovados. Ocorre que, até onde eu sei, tal plano não foi aprovado por nenhum ato administrativo, não sendo, portanto, vinculante. Tenho convicção de que a terminologia que eu propus, e que foi acatada, presta-se melhor aos objetivos específicos da QA.

Com relação ao aumento do passeio, ele já é previsto na legislação do município. Quanto ao aterramento de cabos, tem-se que um dos elementos mais chocantes da paisagem urbana e que mais a depreciam consiste na exposição dos cabos aéreos. A prefeitura tentou normatizar a questão por meio da lei $n^{\circ} 14.023$, de 8 de julho de 2005 (SÃO PAULO [CIDADE], 2005b), regulamentada pelo decreto $\mathrm{n}^{\circ}$ 47.817, de 26 de outubro de 2006 (SÃO PAULO [CIDADE], 2006), mas a resistência tem sido tamanha que esses diplomas legais pouca eficácia surtiram até o momento. 
$\mathrm{Na}$ parte da tarde, o ambiente não foi tão cordial. Interferiram nisso as antinomias decorrentes da multidisciplinaridade, da confusão entre ciência e técnica e da confusão entre academia e aplicações. Do relatório de consolidação constou o seguinte: áreas gramadas geram pouca biodiversidade, consomem muita água e estão fadadas a serem cimentadas; baixo desempenho ambiental das palmeiras; dificuldades em fazer distinção entre palmeiras e arbustos; espessura das coberturas verdes; BFF sem relação com a cultura brasileira e proposto para climas temperados; texto muito ambicioso e sem contribuição efetiva; ecoexergia não é indicador de biodiversidade, nem de microclima; relação com gabaritos; não consideração da densidade foliar; consolidação apenas do dap e não da altura; espécies exóticas; lista de espécies ameaçadas; proposta de eliminação de diferenças entre árvores pequenas, médias e grandes; proposta de não bonificação de árvores existentes; regiões mais vulneráveis menos exigidas em termos de QA; e ausência de políticas públicas relacionadas à QA. Posteriormente o biólogo Dr. Ricardo Francischetti Garcia gentilmente encaminhou contribuições por escrito (GARCIA, 2014), que foram consideradas e aproveitadas.

Dos comentários acima, alguns não fazem sentido. Dos que fazem, muitos foram úteis para o aperfeiçoamento da QA, enquanto outros não puderam ser aproveitados por motivos diversos.

Acredito que muitas das críticas teriam sido esclarecidas, ou pelo menos minimizadas, se o grupo não tivesse deliberado por retirar minha fala da parte da tarde, na qual os aspectos teóricos seriam discutidos.

Coube a mim fazer a última fala da oficina. Eu argumentei que as decisões a respeito de valores-limite são essencialmente políticas, não necessariamente havendo justificativas teóricas para elas, vez que remetem a valores e conveniências dos que detêm legitimidade democrática para decidir, e que o farão considerando a multiplicidade de fatores intervenientes. Porém, o cerne da minha argumentação foi relacionado à complexidade. Eu informei que não haveria como considerar a complexidade envolvida na QA em um texto legal. Argumentei que o método que se impôs na física e, de certa maneira, em outras ciências, foi o da análise-síntese. Ou seja, o fenômeno em estudo é decomposto em fenômenos mais simples, são estabelecidas as leis relativas a esses fenômenos mais simples, e então reconstruída a 
descrição da realidade por meio da consideração conjunta desses fenômenos mais simples. Discorri que em fenômenos complexos a reconstrução da realidade constitui-se em tarefa muito difícil, decorrendo dificuldades em a ciência tratar segundo seus métodos tradicionais da questão, emergindo aí a complexidade. Assim sendo, muito da dificuldade da QA está em tratar de fenômenos complexos por meios simples, não havendo como considerar a complexidade dos fenômenos envolvidos em algo tão singelo como um texto legal. Ou seja, procurou-se um compromisso entre a simplicidade e a complexidade. Eu terminei minha fala com um recurso um tanto perigoso, semelhante ao "pagar para ver". Disse que à vista das críticas talvez a QA realmente não tivesse sentido e seria melhor abandoná-la, ao que os participantes se manifestaram pela continuidade, o que conferiu certa legitimidade da comunidade técnica e científica para a $\mathrm{QA}^{209}$.

A realização da reunião de consolidação da oficina ocorreu imediatamente após o término dela, não obstante o extremo cansaço.

$* * *$

A oficina trouxe diversas contribuições teóricas e, até certo ponto, legitimou o trabalho que vinha sendo realizado até então. Mas nem tudo correu bem, e chegou a haver momentos desagradáveis.

Por certo que qualquer oficina precisa ser detalhadamente preparada, tendo sido isso que efetivamente ocorreu. $\mathrm{O}$ que poderia ser melhorado no projeto da oficina?

Algumas facilidades demandadas por oficinas estão absolutamente fora da realidade orçamentária e alocativa da PMSP.

Parece-nos que o principal desafio corresponda a estabelecer uma base comum de discussão em vista da pluralidade de formações dos envolvidos. Elaborar uma cartilha prévia, como foi tentado, não funcionou ou não foi suficiente. Talvez uma explanação inicial que ressalte a dificuldade intrínseca associada à circunstância tivesse o condão de estimular nos participantes uma atitude mais aberta à contribuição de outras disciplinas.

\footnotetext{
${ }^{209}$ Isso soa algo ridiculamente dramático porque em nenhum momento eu ou os participantes da oficina detivemos poderes de decisão no que se refere à QA.
} 
Uma peculiaridade bastante marcante da cultura brasileira, da qual estrangeiros sempre se queixam, é a extrema sensibilidade a críticas, especialmente em público, em que pese (ou por isso mesmo) o passado escravocrata que ainda perpassa as relações pessoais (e profissionais). Como lidar com isso é uma questão em aberto. Ninguém na nossa cultura está imune a isso. Não obstante, um mínimo de cordialidade é condição essencial, devendo-se coibir, na medida do possível, agressões injustificadas e excentricidades demasiado ofensivas.

\subsection{SEGUNDA OFICINA TÉCNICA RELATIVA À QUOTA}

\section{AMBIENTAL}

Em 7 de agosto de 2015, realizou-se uma segunda oficina relativa à QA. Dessa vez, estavam presentes o secretário de SMDU e o relator do PL na Câmara, o vereador Paulo Frange. Estavam presentes também diversos membros do Conselho Brasileiro de Construção Sustentável (CBCS).

$\mathrm{Na}$ realidade, o evento, diferentemente de uma oficina, constituiu-se mais em uma apresentação do grupo ao gabinete da SMDU, ao relator e ao CBCS.

Passados alguns meses, o CBCS nos procurou com duas demandas. Incomodava ao CBCS que os aspectos de sustentabilidade das edificações além dos objetivos ambientais explícitos na QA fossem considerados apenas no Incentivo de Certificação. Além disso, eles entendiam, a partir de algumas simulações feitas, que alguns valores da QAmin seriam difíceis de serem obtidos.

Com relação à primeira demanda, foi realizada reunião especificamente para tratar dela, não se tendo chegado a nenhuma solução ou conclusão satisfatória.

Com relação à segunda demanda, foi marcada reunião, desmarcada e remarcada para o dia 4 de dezembro de 2015; posteriormente essa reunião foi cancelada e remarcada. Essa data configura-se como absolutamente intempestiva, sendo impossível incluir quaisquer contribuições advindas da reunião no substitutivo ao PL, cuja data final foi estabelecida justamente no dia 4.12.2015. 


\subsection{ENCONTRO “O QUE É A COTA ${ }^{210}$ AMBIENTAL?”}

A Prof. Dra. Paula Freire Santoro, da Faculdade de Arquitetura e Urbanismo da Universidade de São Paulo, gentilmente convidou o grupo para um encontro destinado a debater a QA. Ela concebeu esse encontro para "compreender esse instrumento, suas origens e matrizes históricas, conceitos envolvidos, os insumos para as fórmulas elaboradas e sua evolução durante o processo de discussão no âmbito de processo participativo de debates do zoneamento" 211 .

Pareceu-me uma pauta ampla demais, tendo eu encaminhado mensagem ao grupo argumentando que há muito vínhamos conversando sobre a necessidade de um relatório de consolidação. Assim, julgava eu que seria interessante aproveitar a oportunidade para elaborar tal material e proceder a um pequeno curso. Isso teria o condão de evitar alguns mal-entendidos e ruídos que sempre sobram como resíduos desses pequenos encontros. $\mathrm{O}$ grupo entendeu que não era o caso.

A Lara e a Patrícia aprimoraram uma excelente apresentação em slides, já exibida na segunda oficina.

A apresentação deu-se em 15.9.2015 na sede da FAU-USP, na Cidade Universitária, das $17 \mathrm{~h} 30 \mathrm{~min}$ às $20 \mathrm{~h} 30 \mathrm{~min}$. A maior parte do público era composto de alunos de graduação, estando presentes também professores. $\mathrm{O}$ encontro se deu em clima bastante ameno e agradável. Dessa vez eu pude apresentar a parte teórica a respeito de vegetação.

Foi motivo de grande satisfação para mim que um dos professores, que havia criticado um tanto asperamente a QA na primeira oficina, tenha dito que havíamos encontrado um bom compromisso entre a complexidade e a aplicabilidade do instrumento. Aliás, um belo artigo resultante do encontro, escrito por três estudantes de graduação, foi justamente intitulado "Quota Ambiental: o desafio de ser simples em território complexo" (NOBRE, MARTIN e LIMA, 2015). Algumas das críticas

\footnotetext{
${ }^{210}$ Eu sugeri que a expressão "Cota Ambiental” fosse alterada porque CA seria confundida com Coeficiente de Aproveitamento. Isso se mostrou absolutamente viável porque a língua portuguesa admite as duas formas.

${ }^{211}$ Mensagem eletrônica encaminhada pela Prof. Dra. Paula Freire Santoro ao secretário municipal de desenvolvimento urbano, a Weber Sutti e a Patrícia Marra Sepe em 21.8.2015.
} 
apresentadas nesse artigo são as seguintes: a QA não apresenta propostas de diálogo com as estratégias de articulação entre espaços públicos e privados que são apresentadas na própria revisão do zoneamento: fruição pública no interior do lote, limites de cercamento e permeabilidade visual, doação de recuo para aumento da calçada, etc., enfim, entender que espaços livres podem cumprir outras funções urbanas além da prestação de serviços ambientais; dificuldades de fiscalização; e dispensa de aplicação da QA justamente nas regiões da cidade e nos empreendimentos nos quais ela se mostra mais necessária.

\subsection{A QUOTA AMBIENTAL NA GRANDE IMPRENSA}

Na grande imprensa, o único artigo de que tenho conhecimento a respeito da QA é GERAQUE (2015), publicado na Folha de S. Paulo. Ele cita dois urbanistas: Kazuo Nakano e Renato Cymbalista. O primeiro falou da complexidade da regra e da dificuldade de fisscalização, concluindo ser "muita ginástica para pouco resultado". O segundo ressalvou que os princípios são interessantes, mas que a QA (“cota verde", no artigo) exige fiscalização sofisticada. A reportagem cita ainda o secretário municipal de desenvolvimento urbano, Fernando de Mello Franco, para quem "é algo inédito no país".

\subsection{A QUOTA AMBIENTAL NOS PROCESSOS DE PARTICIPAÇÃO PÚBLICA}

Nos processos de participação pública que presenciei ou de que tomei conhecimento, a QA não foi objeto de discussão. A aparente complexidade do instrumento talvez tenha inibido comentários. A preocupação maior eram as mudanças que as alterações do zoneamento tradicional iriam trazer para o bairro ou até mesmo para a vizinhança dos participantes. 


\subsection{LEGISLAÇÃO DESARMÔNICA COM A QA}

Durante as discussões relativas à QA apareceram dois instrumentos legais que mostravam pontos de contato que provocavam certo atrito com ela.

A lei 16.277, de 5 de outubro de 2015 (SÃO PAULO [CIDADE], 2015b), previa que os projetos de condomínios edificados, residenciais ou não, com mais de 3 unidades agrupadas verticalmente, deveriam prever a construção de telhado verde e que a área correspondente ao telhado verde seria considerada reservatório de retenção e acumulação das águas pluviais para garantir as condições naturais de absorção das águas pluviais no lote, nos termos do Código de Obras e Edificações. Uma vez, no entanto, que o assunto já estava sendo tratado pela QA e que a lei aprovada não fazia menção a habitações de interesse social, o prefeito vetou os trechos do PL que tratavam do ressaltado no presente parágrafo. Disso resultou uma lei absolutamente desconjuntada. $\mathrm{O}$ ideal seria que toda a lei fosse vetada, mas isso implicaria ônus político ao prefeito. Há que ver como a Câmara se comportará na apreciação do veto do prefeito.

O decreto $\mathrm{n}^{\circ}$ 55.994, de 10 de março de 2015 (SÃO PAULO [CIDADE], 2015c), previu a possibilidade de jardins verticais e coberturas verdes serem aceitas em TCAs. Em princípio, isso não torna impossível a aplicação da QA, mas o assunto deveria ter sido discutido de forma integrada. Tal mostra como a vontade política do executivo municipal, especialmente o de um município tão grande como São Paulo, está longe de ser unitária, e que grupos de pressão internos atuam uns contra os outros, às vezes sem terem até conhecimento uns dos outros. 
TOMO V: FINALIZAÇÕES 


\section{SUMÁRIO DOS RESULTADOS DO PROCESSO}

Neste capítulo trataremos de questões que foram surgindo no processo de desenvolvimento da QA. As respostas a essas questões procuram sumarizar parte do já discutido ao longo do texto. Como veremos, é um tanto artificial separar as respostas, vez que elas frequentemente se superpõem. Fazemo-lo por motivo de simplicidade.

\section{1 É POSSÍVEL CONSTRUIR UM INTRUMENTO AMBIENTAL A SER INSERIDO NA LEGISLAÇÃO URBANÍSTICA?}

A rigor, tomando toda a amplidão do conceito de meio ambiente, virtualmente nenhuma legislação urbanística se faz sem que de alguma forma o tema seja tratado. A pergunta cuidou mais precisamente de um instrumento urbanísticoambiental. Essa pergunta é pertinente na medida em que "urbano" e "ambiental" constituem-se em domínios separados legal, institucional, profissional e academicamente. Daí uma certa tendência a instrumentos legais urbanísticos serem assunto de arquitetos urbanistas, enquanto questões ambientais são assunto de quase todas as disciplinas. Porém, é institucional e legalmente que se dão grandes diferenças. Questões urbanísticas são tratadas tradicionalmente em prefeituras por órgãos tais como secretarias de habitação, havendo amplo consenso de que se trata de assunto de interesse local (em que pese haver o Estatuto da Cidade, uma lei federal, mas relativamente recente), e, portanto, da alçada dos municípios. Questões ambientais, por outro lado, tendem a ser tratadas por órgãos do Sistema Nacional de Meio Ambiente (SISNAMA). Os processos de fiscalização, licenciamento e imposição de penalidades variam muito entre esses dois domínios, tendo o domínio ambiental muito mais riqueza e complexidade em, por exemplo, imposição de penalidades. Como vimos, propusemos pessoalmente um dispositivo no PL por meio do qual a fiscalização da QA se daria tanto urbanística como ambientalmente. 
O fato de a elaboração da QA e seus resultados terem sido reiteradamente prestigiados pela superior administração, culminando no envio à Câmara de um PL tratando da lei de parcelamento, uso e ocupação do solo no qual a QA se constitui em parte importante, havendo, portanto, aval político do executivo municipal, demonstra que, sim, é possível, viável e desejável construir um instrumento ambiental inserido na legislação urbanística.

\subsection{QUAIS AS ALTERAÇÕES ENTRE O ESTUDO PRÉVIO E O TEXTO FINAL ENCAMINHADO À CÂMARA?}

A pergunta pode ser respondida de duas maneiras: o conteúdo alterado ao longo do processo de desenvolvimento da QA e os móveis que determinaram as alterações do conteúdo.

Entre o conteúdo alterado ao longo do desenvolvimento, temos:

a) criação de um único índice englobando vegetação e drenagem, ao invés de um indicador para qualidade ecossistêmica e microclima mais a determinação no sentido de impacto zero;

b) adaptação às peculiaridades do novo PDE;

c) consideração de solicitações, determinações, princípios e diretrizes da superior administração;

d) enriquecimento por meio da consideração de perímetros de qualificação urbana, QAmin em função da área e do perímetro, etc.;

e) problemas não detectados anteriormente (por exemplo, dificuldades no dimensionamento de estruturas de saída dos reservatórios de controle do escoamento superficial);

f) possibilidades não consideradas anteriormente (por exemplo, incentivos);

g) novas solicitações (por exemplo, reservatórios para aproveitamento de águas pluviais);

h) preocupação permanente com a viabilidade técnica, urbanística, legal e, sobretudo, política. 
Entre os móveis que determinaram as alterações do conteúdo, temos:

a) interação entre o grupo, propiciando amadurecimento, concorrência de outras expertises, simulações, desafios propostos e impostos e maior autoconfiança;

b) negociação com outras instâncias da prefeitura;

c) contato e negociação com interessados externos já na fase de elaboração;

d) sugestão e, às vezes, imposição de vieses multidisciplinares;

e) pureza conceitual abandonada em função de pragmatismo;

f) críticas externas pertinentes (oriundas, por exemplo, de oficinas);

Em suma, a base teórica comprometeu-se com um instrumento simples, flexível e de base teórica sólida. As múltiplas solicitações dos móveis acima implicaram alteração do conteúdo, com prejuízo em especial da simplicidade.

\subsection{QUAIS AS INTERAÇÕES QUE SE DERAM ENTRE O ÂMBITO ‘TÉCNICO’ E O ÂMBITO ‘POLÍTICO’?}

A rigor, a decisão final não pode se dar no âmbito técnico. A tarefa do técnico é apresentar alternativas que se encontrem em uma curva de tradeoff. Mais ele não pode, ou não poderia, avançar.

Diversas demandas, surgidas da interação com a superior administração ou com interessados internos e externos, solicitaram o grupo. Às vezes, as demandas surgiam em reação ao que o próprio grupo propunha. O grupo, aliás, introjetou e antecipou mudanças tendo em vista a viabilidade política. A superior administração e os interesses políticos a que ela servia não eram homogêneos, tendo de o grupo levar isso em conta, preparar-se e antecipar-se. Às vezes, a própria administração, em sua heterogeneidade, não tinha exatamente claro o que desejava, fazendo opções à medida que o grupo ia propondo sugestões devido ao amadurecimento das discussões. Às vezes, as pressões da superior administração eam discrepantes como resultado da heterogeneidade dos interesses representados no governo. O próprio grupo aumentou o leque de atores e de demandas ao promover, por exemplo, oficinas. O grupo frequentemente era instado, ou se via na posição de, negociar 
diretamente com os atores que iam surgindo. Atores adormecidos, que tinham demandas esquecidas por não terem sido aproveitadas, vislumbraram janelas de oportunidades e vinham procurar o grupo, tratar com a administração ou até fazer pressões políticas. O grupo se deparou com oposições inesperadas, como as provenientes do grupo que elaborava a minuta do COE. Por outro lado, contou com a solidariedade de muitos colegas que anonimamente contribuíram de forma significativa.

A atuação de alguns atores chamou atenção: a SVMA (a sua participação deu-se a partir de iniciativa dos próprios servidores, ou pelo menos assim nos pareceu $^{212}$ ), a academia (no início), movimentos populares (parecia que só os empreendedores tomavam ciência das implicações da QA, ou então a pressão desses movimentos se fazia em instâncias de poder mais altas), e os colegiados municipais.

Do ponto de vista político, o grupo desfrutava de vantagens: o nível técnico da superior administração da SMDU era muito alto; a administração tinha genuíno interesse nos trabalhos; a administração sempre prestigiou o grupo; a Patrícia representava um elo entre o grupo e a administração, elo esse indispensável, pela sua excelência técnica, para o rápido encaminhamento de questões e a devolutiva na forma de decisões.

\subsection{QUAIS OS MECANISMOS POR MEIO DOS QUAIS SE DAVAM 'CONSENSOS TÉCNICOS'?}

É necessário antes esclarecer o que entendemos aqui por consenso técnico.

Os membros do grupo não realizavam barganhas, não formavam coalizões, não realizavam manobras, não havia facções nem enfrentamentos. Tudo era resolvido na mesa de trabalho e todas as mensagens eletrônicas eram "copiadas" a todos os membros. Nenhum membro representava interesses de terceiros,

\footnotetext{
${ }^{212}$ Embora tenhamos nos inteirado de que servidores da SVMA, alguns extremamente qualificados, não tenham tomado conhecimento da possibilidade de contribuir para a elaboração do PL da lei de parcelamento, uso e ocupação do solo.
} 
especialmente interesses antagônicos à administração. Eram quatro servidores estatutários, ainda que pelo menos um deles se pudesse considerar como representando o governo. O grupo se sabia como instância meramente técnica e tinha entendimento claro em não se constituir em instância de decisão (a não ser nos estreitos limites a que nos referimos alhures). Não tinha motivos para estar contra ou a favor do governo, estando seus membros cientes de seus deveres legais relativos à hierarquia. Assim, se tinham valores, princípios, ideologias ou interesses divergentes, isso não se mostrava tão operacionalmente óbvio no processo de decisão interno ao grupo. Seus empregos não dependiam disso. A verdade é que para servidores mais experientes não mais existe ardor juvenil no sentido de procurar atuar de maneira a impactar significativamente o mundo. Servidores mais experientes conhecem o processo de tomada de decisão, sabem a quem é conferida a legitimidade das decisões e se posicionam de maneira coerente em relação a isso, sem adesões irrestritas nem sabotagens. Eles sabem que correspondem apenas ao elemento permanente do estado que deveria dar aos detentores de legitimidade democrática a infraestrutura administrativa e técnica para trabalhar. Por outro lado, não se viu no grupo uma submissão humilhante a imposições oficiais ou oficiosas da administração, como às vezes o império das circunstâncias impõe.

Se é assim, como eram tomadas decisões dentro do grupo? Verdade que os membros do grupo tinham quase a mesma origem e posição social, do que decorre que, mesmo que inconscientemente, compartilhavam ideologias, valores e até interesses. Verdade que todos provinham da SVMA. Verdade que, com exceção da Lara, todos tinham aproximadamente a mesma idade. Verdade, finalmente, que, ainda com exceção da Lara, os membros mantinham relações profissionais e de amizade havia décadas, forjando ao longo desses anos sentimentos mútuos de respeito. Por outro lado, possuíam formações diferentes, com diferentes vieses e, principalmente, diferentes "paradigmas técnicos". Além disso, não havia um processo formal de decisão, tão pequeno era o grupo; ele nem mesmo tinha existência legal, uma vez que não foi criado por meio de portaria publicada em Diário Oficial.

Havia uma consciência ética comum: o grupo tinha claro que qualquer erro seu poderia implicar graves consequências na medida em que era o instrumento para 
a formação de subsídios para a tomada de decisões que teriam impacto razoável. Por outro lado, o grupo tinha consciência de que trabalhava em algo novo e interessante, e que dispunha da confiança da administração, o que impedia seus membros de procrastinarem ou se permitirem chegar a impasse.

Outro elemento em comum era a confiança mútua na complementaridade de suas expertises e no compromisso com o trabalho. Além disso, todos os membros do grupo tinham real interesse na consideração dos mais variados pontos de vista, viessem de onde viessem.

Isso posto, como se dava o processo de formação de consenso (se ele ocorria) ou de tomada de decisão?

Muitos impasses e dificuldades eram tratados através de uma redação vaga e de remissão à regulamentação. Muitas questões eram levadas à superior administração. Muitas vezes a questão era submetida ao membro do grupo que detinha mais conhecimento técnico no aspecto que estava sendo decidido.

Acima de tudo, grupos têm uma interação social complexa que segue certos padrões estudados sobretudo na psicologia comportamental, à qual muitos torcem o nariz, com certa razão, porque seus pressupostos paradigmáticos usualmente não são aceitos por nossa formação ou tradição intelectual. Porém, em nível estritamente de descrição e previsão do comportamento, ela pode se mostar muitas vezes útil.

Não é o caso aqui de procurar teorias que descrevam com maior ou menor precisão os fenômenos relacionados à interação do grupo. O que podemos dizer com certa segurança é que a Patrícia era a líder natural do grupo, seja por seu carisma, seja por representar a administração. Considerando, por exemplo, que a dinâmica de alguns aspectos das relações de grupos sociais é análoga à ordem social de animais de bando, o conceito de alfa pode eventualmente se aplicar a relações humanas, havendo bibliografia em administração de empresas nesse sentido (por exemplo, HAWLEY, LITTLE e CARD, 2008, e LUDEMAN e ERLANDSON, 2004). Nesse aspecto, eventualmente se poderia dizer que em alguns aspectos a Patrícia era o alfa do grupo. É claro que isso é simplificar demais a questão, aparecendo aqui apenas a título de exemplo.

Porém, mais do que a aspectos comportamentais do grupo, talvez ganhássemos mais nos referindo a aspectos existenciais dos membros do grupo. 
Assim, deveríamos nos dedicar a tratar de instintos, pulsões, projeções, arquétipos, mitos vivenciados. Aqui nós paramos. A Patrícia, a Hélia e a Lara me deram permissão para tratar de suas atividades concernentes à QA nesta tese; nem precisariam, porque, como já ressaltamos, nada do que se passa em uma repartição pública que diga respeito ao trabalho desenvolvido pode ser objeto de segredo. No entanto, conhecemos a Patrícia e a Hélia há muitos anos e temos algumas ideias a respeito de suas motivações existenciais, mas não nos sentimos à vontade de expor essa intimidade delas.

\subsection{COMO INTERAGIRAM E SE MOBILIZARAM INTERESSES DE}

\section{ALGUNS STAKEHOLDERS QUE SE COLOCARAM FRENTE AO} PROCESSO?

Como dito, o grupo introjetava, pressupunha e se adiantava a interesses que sabia que seriam necessários à viabilidade política da empreitada. Porém, dentro do grupo não ocorriam barganhas, coalizões ou manobras, dando-se o processo de decisão conforme exposto no item anterior.

Alguns grupos atuavam diretamente junto ao grupo. Outros talvez atuassem em níveis mais elevados, vindo o resultado de suas pressões na forma de decisões políticas da superior administração.

Como já informado, o próprio grupo chamou a si stakeholders ao tomar a iniciativa de propor e promover oficinas e chamar profissionais da área. Disso resultaram diversas contribuições que foram espontaneamente acatadas pelo grupo.

Todas essas pressões eram sempre devidamente comunicadas à superior administração, mas de forma ordenada, justificada e filtrada.

Usualmente interesses se interpõem junto à administração e esta os repassa de maneira quase subliminar, cabendo ao técnico ter a devida compreensão do processo de maneira a incorporar essas decisões já tomadas e não explicitamente expostas. Não foi o que usualmente ocorreu. A SMDU tendeu a ser transparente. Porém, algumas imposições da superior administração nunca foram explicadas, como por 
exemplo o calendário das decisões. Tivessem sido, talvez muitas coisas teriam corrido melhor.

A fase de participação pública nada trouxe para enriquecer o processo. A grande imprensa foi quase que ausente em relação à questão.

Um dado fundamental que tornou mais tranquilo todo o processo: a maioria confortável de que dispunha a administração junto à Câmara. 


\section{CONCLUSÕES}

\subsection{CONCLUSÕES PROPRIAMENTE DITAS}

Parafraseando um grande escritor, podemos dizer que ao fim de uma longa pesquisa sentimos naturalmente o desejo de nos voltarmos para ela a fim de contemplar seus resultados e extrair suas conclusões. Não para tentar uma derradeira vez justificá-los - é tarde demais -, mas sim para revisá-los e, talvez, para dizer tudo o que eles não podiam ser, logo o que também não são, bem como para dizer o que podem ser.

O primeiro objetivo da pesquisa relacionava-se à construção de uma fundamentação teórica para um parâmetro urbanístico-ambiental para o município de São Paulo com base no BFF de Berlim. Três critérios foram impostos para avaliar propostas de adaptação do BFF à cidade de São Paulo: a) simplicidade: o marco legal proposto tem que ser suficientemente simples para o projetista e para as instâncias administrativas de aprovação e fiscalização; b) flexibilidade: o marco legal deve permitir ao projetista e ao empreendedor a adoção de opções técnicas disponíveis que confiram maior valor e qualidade ao projeto; c) embasamento teórico: o marco legal tem que apresentar suficiente embasamento teórico de forma que seus aspectos técnicos possam ser cientificamente defendidos.

O modelo aqui proposto de adaptação do BFF a uma metrópole tropical satisfaz os três critérios acima. A simplicidade aparece na possibilidade de confecção de uma planilha de cálculo, facilmente preenchida pelo projetista, podendo ele recorrer também aos valores padrões default. A flexibilidade advém da possibilidade de escolha de numerosas combinações de cobertura do lote que satisfaçam os padrões legais. O embasamento teórico foi demonstrado no presente. Verificou-se que dois objetivos ambientais, promoção da qualidade ecossistêmica e melhoria do microclima, podem ser descritos pelo mesmo indicador, o que se constitui em um resultado notável, e que o terceiro objetivo ambiental, promoção de medidas de 
controle de drenagem na fonte, não se enquadraria no modelo do BFF, devendo as exigências legais serem feitas à parte, porém considerando as soluções paisagísticas adotadas para os outros dois objetivos ambientais.

Conclui-se que esse modelo pode servir de partida para processos decisórios no sentido de construir um padrão urbanístico-ambiental calcado no BFF, bem como acompanhar o processo de tomada de decisão de maneira a fornecer justificativa para as diversas decisões adotadas nessa construção.

O segundo objetivo estava relacionado a narrar a construção de um instrumento em situação real, oficial, usando como base conceitual a fundamentação teórica construída. Dado o caráter sui generis do objetivo, foi proposto um método no item 3.2, o qual consistia nos seguintes elementos:

a) estabelecer claramente um ponto de vista: o nosso ponto de vista era privilegiado, consistindo em um pesquisador que propõe um referencial teórico para o desenvolvimento de um instrumento urbanístico-ambiental a constar em legislação municipal, que tem esse referencial aprovado para o efetivo desenvolvimento desse instrumento em caráter oficial, e que participa ativamente no desenvolvimento do dispositivo, não como pesquisador, mas como profissional. É claro que esse ponto de vista, no processo, é único, e vai vincular a percepção do fenômeno e o relacionamento que esse observador estabelece com o grupo que desenvolve o instrumento, com as instâncias políticas que atuarão, direta ou indiretamente, do processo e com as responsabilidades do pesquisador perante a comunidade acadêmica, que é para quem o estudo é dirigido.

b) "narrar" os eventos na forma de um "observador ingênuo". É óbvio que esse observador não pode ser inteiramente ingênuo, dado o seu ponto de vista privilegiado, suas responsabilidades profissionais e acadêmicas e o conhecimento técnico necessário para propor o arcabouço teórico e para a participação no desenvolvimento. Por outro lado, ele é ingênuo na medida em que se coloca no processo como um simples técnico que assessora as instâncias políticas de tomada de decisão, não tendo nenhum poder de decisão, porém tendo certo poder de influenciar as atividades do grupo e as opções que serão colocadas para as instâncias políticas de tomada de decisão. É ingênuo também porque ele não domina o arsenal teórico que poderia dar conta de todos os aspectos sociológicos, de psicologia social e políticos 
aptos a lhe fornecer um quadro teórico a partir do qual os eventos seriam descritos, examinados e discutidos. Porém, se ele o dominasse, tenderia a fingir colocar-se fora da relação sujeito-objeto do conhecimento ${ }^{213}$, perdendo a pesquisa as pequenas contribuições da fenomenologia que pretendeu ter. Por outro lado, esse observador tentou manter-se aberto para dialogar com o fenômeno através de suas visões prévias (que podem ser intelectuais, ideológicas, metafísicas) sobre o assunto - sempre inadequadas, relativas, arbitrárias, apriorísticas, ideologizadas. Mesmo assim o observador ingênuo tem consciência desse diálogo e faz uso de suas percepções, seja por qual motivo for, para intervir, às vezes de maneira um pouco mais decisiva, no processo sem que essa intervenção se dê na forma de um experimento ou na confirmação de uma hipótese prévia. Enfim, esse observador ingênuo é único e sua percepção, igualmente única. Todo o seu entendimento sobre o fenômeno é condicionado por sua visão prévia sobre o mundo e por seu papel nesse mundo, por sua dinâmica psicológica e política no grupo e perante as instâncias de decisão, por sua capacidade de percepção dessa dinâmica e por seu desígnio de estabelecer um nível de influência em todo o processo. Além disso, talvez o observador ingênuo possa não ter consciência dos processos inconscientes que rondam sua percepção do fenômeno, sem falar nos constrangimentos de ordem legal e social para falar a "verdade". Nessa pesquisa partiu-se do pressuposto de que, independentemente de qualquer ponto de vista filosófico segundo o qual a "verdade" não exista ou seja inalcançável, essa "verdade" não poderia ser um objeto perseguido na narração;

c) dialogar e aprender com o processo: desde o início o pesquisador tinha consciência que o processo lhe forneceria, quando muito, "proto-generalizações". Se não há, do ponto de vista epistemológico, nenhuma garantia que generalizações obtidas em processos indutivos produzidos no âmbito da comunidade científica tenham sua validade como inquestionável, quaisquer generalizações aqui percebidas são necessariamente grosseiras, para não dizer fruto de preconceitos. Porém, não poderíamos viver sem proto-generalizações: elas são como escadas que utilizamos para subir de patamar para então ser dispensadas; o importante não é garantir que a percepção seja isenta de preconceitos ou de que o resultado seja questionável: o

\footnotetext{
${ }^{213}$ Se ele se pretendesse neutro e despido de valores e de uma visão prévia do mundo, aí então ele seria extrema e tolamente ingênuo.
} 
importante é ter consciência das limitações dos processos através dos quais vamos formando, pelo menos em parte, nossa visão de mundo. Não se pode nunca perder de vista que as faculdades que nos permitem ter uma visão um pouco mais crítica demandam enorme investimento em termos de concentração, do que decorre que na maior parte das vezes nossa percepção é condicionada por faculdades mais simples, que tendem a produzir ações e percepções binárias (bom ou mau). O que acreditamos ter aprendido ou corroborado está, até certo ponto, apresentado ao longo desta tese.

Lembramos que muitas argumentações apresentadas, em especial as do capítulo 9, foram feitas usando o formato de ensaio (talvez mais adequado ao objeto da pesquisa e de sua comunicação). Fugimos propositalmente, nesses casos, do rigor da redação científica.

É bastante conhecida a frase atribuída ao cínico chanceler Bismarck segundo a qual "leis são como salsichas; é melhor não ver como elas são feitas" ou "as pessoas não poderiam dormir tranquilas se soubessem como as salsichas e as leis são feitas”. Essa parece ser uma percepção geral. A partir de qualquer percepção subjetiva do leitor obtida a partir da presente tese, que cobre apenas uma parte de um processo seguramente muito mais amplo, ele poderá ratificar ou retificar quaisquer "proto-generalizações" que possua a respeito do assunto.

\subsection{UM PEQUENO ENSAIO}

Uma última palavra sobre a multi- e interdisciplinaridade. Ela se dará por meio de um pequeno, algo pretensioso e seguramente medíocre mini-ensaio a respeito dos caminhos e narrativas percorridos por uma pesquisa multi- ou interdisciplinar. Isso se justifica porque na introdução tivemos oportunidade de apresentar alguns desafios e dificuldades que a pesquisa e a redação em âmbito multi- ou interdisciplinar envolve.

A academia convencionou que os discursos científicos têm que ter objetivos, claros, sem muitos adjetivos e sem metáforas, de maneira a denotar e conotar imparcialidade na condução da pesquisa e impessoalidade, quase anonimato, na 
contribuição do autor à ciência, que progride por meio de pequenos acúmulos. $\mathrm{O}$ leitor poderá aquilatar certa dificuldade nossa em manter a redação dentro desses padrões. Seja-nos permitido uma metáfora para tratar da multi- ou interdisciplinaridade. Afinal, muito de nosso vocabulário é construído a partir de metáforas. Nietzsche, que, antes de ser filósofo, teve formação intelectual de filólogo, tem algo a nos dizer sobre isso:

a coisa em si é para o formador da linguagem inteiramente incaptável e nem sequer algo que valha a pena. Ele designa apenas as relações das coisas aos homens e toma em auxílio para exprimi-las as mais audaciosas metáforas. Um estímulo nervoso, primeiramente transposto em uma imagem! Primeira metáfora. A imagem, por sua vez, modelada em um som! Segunda metáfora. (NIETZSCHE, 1999, 1873, p.55).

Rousseau também nos diz algo sobre as origens da linguagem:

Como os primeiros motivos que fizeram o homem falar foram paixões, suas primeiras expressões foram tropos. A primeira a nascer foi a linguagem figurada e o sentido próprio foi encontrado por último. Só se chamaram as coisas pelos verdadeiros nomes quando foram vistas sob sua forma verdadeira. A princípio só se falou pela poesia, só muito tempo depois é que se tratou de raciocinar. (ROUSSEAU, 1973, 1762?, p.164).

Assim, talvez uma metáfora naval nos auxilie a tratar da questão da multidisciplinaridade.

Todo estudo multi- ou interdisciplinar começa com uma pergunta. Segundo PERISSÉ $(2006)^{214}$, esta palavra teria origem ${ }^{215}$ no latim vulgar praecuntare, por sua vez proveniente do latim clássico percontare. Esta última está etimologicamente relacionada a contus, que se constituía em uma vara, bastão ou lança com inúmeras utilidades, como arma de caça ou instrumento naval. O contus era usado pelo mestre de qualquer tipo de embarcação para ir tocando o fundo do rio a fim de evitar o encalhe, o que sugere uma metáfora naval. O prefixo per indica movimento para todos os lados, como em perquirir (buscar com cuidado, procurar por toda parte).

\footnotetext{
214 Todas as outras etimologias aqui apresentadas foram extraídas de HOUAISS e VILLAR (2001). ${ }^{215}$ Não seguiremos aqui as convenções usuais da etimologia. As palavras latinas, gregas ou de outras línguas que foram transliteradas para o alfabeto latino não serão apresentadas com os acentos convencionados para elas. As palavras latinas e gregas tiveram apenas as suas formas do nominativo apresentadas. Embora as citações estejam calcadas em referências rigorosas no âmbito da etimologia, houve certa liberdade na forma e no conteúdo da apresentação. Isso se justifica tendo em vista os fins colimados e por ser apenas parte de um ensaio.
} 
Assim, perguntar não só nos conduz etimologicamente à origem da pesquisa multiou interdisciplinar como vai indicando o método: pesquisar sempre com cuidado o substrato teórico ou fenomênico em várias direções e por toda a parte antes de qualquer pequeno avanço, tudo para evitar um desastre; mudar o curso se as condições não forem as esperadas; eventualmente retroceder.

Nessa metáfora naval os conhecimentos científicos especializados constituem-se em ilhas ou continentes. A palavra ilha provém do latim insula, que pode significar um quarteirão cercado de ruas que o isolam do resto da cidade, assim como o mar isola a ilha do resto da terra; isolar provém do francês isoler (obviamente também relacionada a insula), que significa tomar a forma de uma ilha, afastar-se da multidão. Assim, ciências-ilhas são aquelas menos desenvolvidas, ainda nos estágios iniciais de casulo protegido; podem também ser as ciências fossilizadas, que não mais se relacionam. Diferentemente de ciências-continente, que já cresceram muito e estão em pleno vigor. Continente está etimologicamente relacionado ao verbo latino tendo e à raiz latina ten-, que remetem a ocupar, deter, reter na memória, conservar na mente, meter-se em uma direção; em suma, talvez um comportamento algo descuidadamente "contente".

Na pesquisa multi- ou interdisciplinar iremos navegar, necessitando, portanto, de uma nave. Escolhemos o navio que conduziu Jasão, o "Argo". Este nome remete ao filho de Arestor e um dos argonautas, do qual se dizia que tinha cem olhos, o que conota uma pessoa olhando para todos os lados, perspicaz, sagaz, vigilante, observadora (tal como o nosso piloto se conduzindo com o contus). (Infelizmente as palavras "arguto", "argúcia" e "argumento" não têm a mesma origem etimológica, o que tornaria esta metáfora em particular perfeita; elas provêm do latim arguo, que significa tornar brilhante, claro, esclarecer; por outro lado, o grego argos remete a brilhante, resplandecente, ágil, ligeiro).

O nosso Argo, ao alcançar portos nessas ilhas e continentes, vai trazer a si para carregar os seus porões o que julga mais valioso e proveitoso nelas, ou seja, o mais "importante". Ele não vai importar tudo dessas ciências-ilha e continente, mas selecionará para sua pesquisa o que essas ciências dispõem para o seu interesse.

Assim procedendo, o nosso Argo estará realizando uma "costura", ou, melhor, uma "sutura", ambas aparentadas ao sânscrito sutra, que significa linha, fio, 
mas também regra, aforismo; sutra tem significado de uma coletânea de breves aforismos que contêm as regras do rito, da moral, da vida cotidiana, da gramática. $\mathrm{O}$ Argo costura com linho (latim lineus), ou com qualquer linha (latim linea), fio (do latim filum), cordão. Ou seja, o Argo percorre uma trajetória definida por uma "linha", e ao fazê-lo, faz uma "costura" com essa "linha".

Mais do que uma percorrer uma linha unifilar, com o processo ele entrelaça, "tece", do latim texo, que significa fazer tecido, entrelaçar. Ou seja, a matéria "importada" não é simplesmente lançada no porão e lá disposta separada das outras mercadorias, mas entrelaçadas umas com as outras. Além disso, texo está relacionada também à palavra "texto", por meio do latim textos, que denota narrativa, exposição. Essa narrativa constitui-se tanto na apresentação final de toda essa viagem como também o meio pelo qual essa viagem se deu, ou seja, sempre "perguntando". Ulisses viaja não apenas para retornar para casa, mas também para narrar sua viagem.

Tivemos oportunidade de ver o valor que Kay dava às narrativas, talvez a única maneira de descrever os ecossistemas, face à sua complexidade. Narrar consiste em parte fundamental desse nosso método para o qual temerariamente solicitamos contribuições do método fenomenológico.

Indo um pouco mais longe, e lembrando que estamos ainda no domínio de um ensaio, podemos nos perguntar a respeito das implicações, não diríamos epistemológicas, mas até ontológicas, relacionadas ao narrar. Um interessante romance denominado "Dicionário kazar" (PAVIĆ, 1989) trata da conversão do povo cazar ao judaísmo. O que chama a atenção no romance, além de a história ser contada por meio de verbetes de um suposto dicionário enciclopédico, estando eles em ordem alfabética (tendo tido nas traduções, portanto, a sua ordem alterada), é ser essa história contada sob três pontos de vista, um cristão, um muçulmano e um judaico. Uma das muitas interpretações possíveis são aquelas mais óbvias: as diferentes narrativas constroem diferentes passados. Um pouco mais além, poderíamos dizer que diferentes narrativas constroem diferentes realidades pretéritas. Poderíamos ir um pouco mais longe e dizer que qualquer realidade é construída a partir de narrativas. Mais que isso: a narrativa é o único elemento ontológico da realidade (lembramos estar em um ensaio, apenas). Se, indo além, adotarmos um 
ponto de vista heraclitiano, a nossa própria identidade é forjada a partir do fluxo de narrações em nossa consciência. Um poema de Daniel Stein diz: "Matei a minha alma/ Mas não tive coragem de matar o meu corpo./ E acho que eu só existo/ porque converso comigo mesmo".

\subsection{EPÍLOGO}

No início, a QA pretendia-se uma adaptação, uma tropicalização do BFF de Berlim. Sob um ponto de vista, ela é menos do que isso, já que seria apenas uma aplicação de um método cujos delineamentos mais gerais são induzidos do BFF. Por outro ponto de vista, ela é mais. Muito mais para os membros do grupo, que a gestaram. Mais para a administração e para alguns que viram algo de positivo nela, em especial o que ela pretendeu de fato ser: uma cunha ambiental inserida dentro da legislação de uso e ocupação do solo. Por isso ela não se vê acabada, definitiva, completa. Se tiver algum mérito, o tempo solicitará alterações, correções e ampliações. Se não tiver, vai constrangedoramente para o museu das ideias.

Uma questão que sempre se impôs ao trabalho do grupo foi: qual a real eficácia da aplicação da QA? Desde a primeira reunião, a nossa impressão, tendo em vista a previsão do número de novas construções e reformas no território do município, foi de que a eficácia seria relativamente pequena, sob um critério de comparação "antes-depois". Por outro lado, sob um critério “com-sem", não estamos agora tão certos disso. Ficamos pessoalmente devendo ao restante do grupo uma avaliação demandada nesse sentido, que poderia ratificar ou retificar a impressão inicial; chegamos até a delinear uma metodologia para esse mister. Independemente do resultado da avaliação, a QA é uma lembrança de que simplesmente não podemos mais tolerar que as coisas em São Paulo caminhem no rumo e na velocidade em que ocorrem. Se alguém quiser extrair daí que ela se constitua em apenas um instrumento de conscientização ambiental, que seja, embora creiamos que ela seja muito mais. Assim, se ela se mostrar inadequada, que se pense em substituto melhor, ou que se pense em aplicar um instrumento análogo em municípios que ainda não erraram 
tanto como São Paulo, mas que não se a legue ao esquecimento, pelo menos não o ímpeto que motivou sua idealização e desenvolvimento.

NOTA: Quase no momento em que finalizávamos a revisão desta tese (29.2.2016), a Câmara Municipal de São Paulo aprovou, em 26.2.2016, o PL 272/2015. O texto aprovado ainda não está disponível no sítio da Câmara. Fomos informados de que a Quota Ambiental está incluída no texto aprovado, mas não sabemos com quais alterações. Tudo indica que o prefeito sancionará o texto tal como aprovado na Câmara. A sorte está lançada. 


\section{REFERÊNCIAS}

ACADEMIA BRASILEIRA DE LETRAS. Vocabulário Ortográfico da Língua Portuguesa. 5.ed. [Rio de Janeiro]: 2009. Versão on-line. Disponível em: <http://www.academia.org.br/nossa-lingua/busca-no-vocabulario>.

ACIOLLI, L.A. Estudo experimental de pavimentos permeáveis para o controle de escoamento superficial na fonte. 2005. Dissertação (Mestrado) - Programa de Pós-Graduação em Recursos Hídricos e Saneamento Ambiental, Universidade Federal do Rio Grande do Sul, Porto Alegre.

ALESSI, F.; KOKOT, P.J.; GOMES, J. Comparação do escoamento superficial gerado por pavimentos permeáveis em blocos de concreto e asfalto poroso. Da Vinci, Curitiba, v.3, n.1, p.139-56, 2006.

ANDRADE, R.C. Processos decisórios na Câmara dos Vereadores e na Assembléia Legislativa de São Paulo. In: (org.). Processo de governo no município e no estado: uma análise a partir de São Paulo. São Paulo: Edusp, 1998.

ANNECCHINI, K.P.V. Aproveitamento de água de chuva para fins não potáveis na cidade de Vitória (ES). 2005. Dissertação (Mestrado) - Programa de Pós-Graduação em Engenharia Ambiental, Universidade Federal do Espírito Santo, Vitória.

ARAÚJO, L.H.B. Bacharelismo e retórica na construção do Estado Brasileiro. Mnemosine Revista, v.1, n.1, p.227-50, jan./jun 2010 .

ARAÚJO, P.R.; TUCCI, C.E.M.; GOLDENFUM, J.A. Avaliação da eficiência de pavimentos permeáveis na redução do escoamento superficial. Revista Brasileira de Recursos Hídricos, v.5, n.3, p.21-9, jul./set. 2000.

ARENDT, H. A condição humana. 10.ed. Rio de Janeiro: Forense Universitária, 2005.

ARISTÓTELES. Metafísica. Trad. Vincenzo Cocco. São Paulo: Abril Cultural, 1973. (Os pensadores).

ARMCO. Handbook of culvert and drainage practice: for the solution of surface and subsurface drainage problems. Middleton, Ohio: ARMCO, 1950.

ARON,G. Rainfall abstractions. In: KIBLER, D.F. (ed.). Urban stormwater hydrology. Washington: AGU, 1982.

ASSOCIAÇÃO BRASILEIRA DE NORMAS TÉCNICAS. NBR 15527: Água de chuva - aproveitamento de coberturas em áreas urbanas para fins não potáveis - requisitos. Rio de Janeiro, 2007. 8p.

AUSTONI, M. et al. Application of specific exergy to macrophytes as an integrated index of environmental quality for coastal lagoons. Ecological Indicators, n.7, p.229-38, 2007

BADILLO, E.J.; RODRÍGUEZ, A.R. Mecánica de suelos, 2: teoría y aplicaciones de la macánica de suelos. México, D.F.: Limusa, 1974.

Mecánica de suelos, 1: fundamentos de la mecánica de suelos. 3.ed. México, D.F.: Limusa, 1975.

BACHA, E. Introdução à macroeconomia: uma perspectiva brasileira. 5.ed. Rio de Janeiro: Campus, 1989.

BARDEN, L. Primary and secondary consolidation of clay and peat. Géotechnique, n.18, p.1-24, 1968.

BARTELINK, H.H. Allometric relationships for biomass and leaf area of beech (Fagus sylvatica). Ann. Sci. For., v.54, p.39$50,1997$.

BASTIAN; SCHREIBER. Analyse und ökologische Bewertung der Landschaft. 2., überarb. Aufl. Heidelberg: Spektrum, 1994.

BAZZO, E.F. Algumas considerações sobre a saúde mental dos funcionários públicos. Psicologia Ciência e Profissão, v.17, n.1, p.41-4, 1997.

BENDORICCHIO, G; JØRGENSEN, S.E. Exergy as goal function of ecosystem dynamic. Ecological Modelling, n.102, p.5$15,1997$.

BERLIN (STADT). Senatsverwaltung für Stadtentwicklung. Grüne Innenstadt: Biotopflächenfaktor: Ziele und Inhalte. Disponível em: <http://www.stadtentwicklung.berlin.de/umwelt/landschaftsplanung/bff/ >. Acesso em: 2 mar. 2016. 
BEZERRA, G.M.L. A oposição nos governos FHC e Lula: um balanço da atuação parlamentar na Câmara dos Deputados. 2012. Dissertação (mestrado) - Programa de Pós-Graduação em Ciência Política da Universidade Federal do Rio Grande do Sol, Porto Alegre.

BILLIER, J.-C.; MARYIOLI, A. História da Filosofia do Direito. Barueri: Manole, 2005.

BIN MASAWI, A.W. Effects of organic content of consolidation parameters of peat soil. [S.1.]: [S.n.], [S.d.].

BLOCH, M. La societé féodale. ?.ed. Paris: Editions Albin Michel, 1982. (Collection 'L'évolution de l'Humanité', tomes XXXIV et XXXIVbis).

BOLFE, E.L. et al. Estimativa de biomassa epígea e estoque de carbono de sistemas agroflorestais em Tomé-Açu, Pará. In: CONGRESSO BRASILEIRO DE SISTEMAS AGROFLORESTAIS, 7., 2009, Luziânia. Anais... Luziânia: EMATER-DF, 2009.

BORGES, J.L. O livro de areia. In: O livro de areia. São Paulo: Companhia das Letras, 2011, p.100-5.

BORTOLETO, S. et al. Composição e distribuição da arborização viária da estância de Águas de São Pedro - SP. Revista da Sociedade Brasileira de Arborização Urbana, v.2, n.3, p.32-46, 2007.

BOTEQUILHA-LEITÃO, A.; AHERN, J. Applying landscape ecological concepts and metrics in sustainable landscape planning. Landscape and Urban Planning, v.59, p.65-93, 2002.

BRAGA JR. Técnicas de otimização e simulação aplicadas em recursos hídricos. In: BARTH, F.T. et al. Modelos para gerenciamento de recursos hídricos. São Paulo: Nobel/ ABRH, 1987, p.425-518. (Coleção ABRH de recursos hídricos, 1).

BRANCO, S.M. Ecossistêmica: uma abordagem integrada dos problemas do Meio Ambiente. 2.ed. São Paulo: Edgard Blücher, 1999.

BRASIL. Lei $\mathrm{n}^{\circ}$ 6.938, de 31 de agosto de 1981. Dispõe sobre a Política Nacional do Meio Ambiente, seus fins e mecanismos de formulação e aplicação, e dá outras providências. Disponível em: 〈http://www.planalto.gov.br/ccivil_03/Leis/L6938.htm〉. Acesso em: 8 set. 2015 .

Constituição da República Federativa do Brasil de 1988. Disponível em:

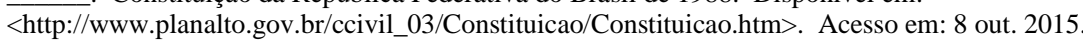

Secretaria de Planejamento, Orçamento e Coordenação. Fundação Instituto Brasileiro de Geografia e Estatística. Diretoria de Geociências. Departamento de Recursos Naturais e Estudos Ambientais. Manual técnico da vegetação brasileira. Rio de Janeiro, 1992. (Manuais técnicos de geociências n.1).

Lei ${ }^{\circ}$ 9.433, de 8 de janeiro de 1997. Institui a Política Nacional de Recursos Hídricos, cria o Sistema Nacional de Gerenciamento de Recursos Hídricos, regulamenta o inciso XIX do art. 21 da Constituição Federal, e altera o art. $1^{\circ}$ da Lei ${ }^{\circ}$ 8.001, de 13 de março de 1990, que modificou a Lei $\mathrm{n}^{\circ}$ 7.990, de 28 de dezembro de 1989. Disponível em: <http://www.planalto.gov.br/ccivil_03/LEIS/L9433.htm〉. Acesso em: 8 set. 2015.

Lei ${ }^{\circ} 10.257$, de 10 de julho de 2001. Regulamenta os arts. 182 e 183 da Constituição Federal, estabelece diretrizes gerais da política urbana e dá outras providências. Disponível em:

<http://www.planalto.gov.br/ccivil_03/leis/LEIS_2001/L10257.htm〉. Acesso em: 8 ago. 2015.

Lei $\mathrm{n}^{\circ}$ 11.428, de 27 de dezembro de 2006. Dispõe sobre a utilização e proteção da vegetação nativa do Bioma Mata Atlântica, e dá outras providências. Disponível em: <http://www.planalto.gov.br/ccivil_03/_ato2004-

2006/2006/lei/111428.htm>. Acesso em: 5 nov. 2015.

Lei $\mathrm{n}^{\circ} 11.445$, de 5 de janeiro de 2007. Estabelece diretrizes nacionais para o saneamento básico; altera as Leis 6.766, de 19 de dezembro de $1979,8.036$, de 11 de maio de 1990, 8.666, de 21 de junho de 1993, 8.987, de 13 de fevereiro de 1995; revoga a Lei no 6.528 , de 11 de maio de 1978; e dá outras providências. Disponível em: <http://www.planalto.gov.br/ccivil_03/_ato2007-2010/2007/lei/111445.htm>. Acesso em: 8 set. 2015.

Ministério do Transportes. Departamento Nacional de Estradas de Rodagem. Diretoria de Desenvolvimento Tecnológico. Divisão de Capacitação Tecnológica. DNER-PRO/98: Projeto de aterros sobre solos moles para obras viárias. Rio de Janeiro, 1998.

Lei $\mathrm{n}^{\circ}$ 12.305, de 2 de agosto de 2010. Institui a Política Nacional de Resíduos Sólidos; altera a Lei $\mathrm{n}^{\circ}$ 9.605, de 12 de fevereiro de 1998, e dá outras providências. Disponível em: <http://www.planalto.gov.br/ccivil_03/_ato20072010/2010/lei/112305.htm>. Acesso em: 8 set. 2015.

. Lei Complementar $\mathrm{n}^{\circ}$ 140, de 8 de dezembro de 2011. Fixa normas, nos termos dos incisos III, VI e VII do caput e do parágrafo único do art. 23 da Constituição Federal, para a cooperação entre a União, os Estados, o Distrito Federal e os Municípios nas ações administrativas decorrentes do exercício da competência comum relativas à proteção das paisagens naturais notáveis, à proteção do meio ambiente, ao combate à poluição em qualquer de suas formas e à preservação das 
florestas, da fauna e da flora; e altera a Lei n ${ }^{\circ} 6.938$, de 31 de agosto de 1981. Disponível em: < http://www.planalto.gov.br/ccivil_03/leis/LCP/Lcp140.htm>.

Ação Direta de Inconstitucionalidade 1842. 2013. Disponível em:

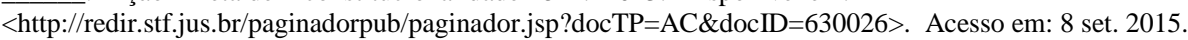

Ministério do Meio Ambiente. Portaria no 443, de 17 de dezembro de 2014a. Disponível em:

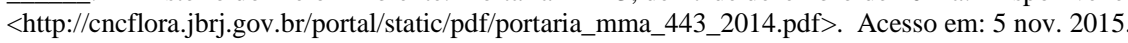

Senado Federal. Coordenação de Edições Técnicas. Acordo ortográfico da língua portuguesa: atos internacionais e normas correlatas. 2.ed. Brasília: 2014.

BRAYBROOKE, D.; LINDBLOM, C.E. Uma estratégia de decisão social: escolha entre políticas alternativas. Rio de Janeiro: zahar, 1972. (Biblioteca Zahar de Ciências Sociais).

BRIANEZ, D. et al. Equações alométricas para estimativa de carbono em árvores de uma área urbana em Viçosa - MG. Revista Árvore, v.35, n.6, p.1073-81, nov./ dez. 2013.

BROCKHAUS: deutsches Bildwörterbuch von A bis Z. 9., neu bearb. u. ern. Aufl. Wiesbaden: Brockhaus, 1984.

BROWN, S.; GILLESPIE, A.J.R.; LUGO, A. Biomass estimation methods for tropical forests with applications to forest inventory data. Forest Science, Lawrence, v.35, p.881-902, 1989.

BRUERS, S. A discussion on maximum entropy production and information theory. Journal of Physics A: Mathematical and Theoretical, v.40, n.27, 2007.

BRUSE, M. Die auswirkungen kleinskaliger Umweltgestaltung auf das Mikroklima: Entwicklung des prognostischen numerischen Modells ENVI-met zur Simulation der Wind-, Temperatur- und Feuchteverteilung in städtischen Strukturen. 1999a. Dissertation (Doktorate Naturwissenschaft) - Fakultät für Geowissenschaft, Ruhr-Universität Bochum, Bochum.

Modelling and strategies for improved urban climate. INTERNATIONAL CONFERENCE ON URBAN CLIMATOLOGY; INTERNATIONAL CONGRESS OF BIOMETEOROLOGY, 1999b, Sydney. Proceedings...

Anwendung von mikroskaligen Simulationsmodellen in der Stadtplanung. In: BERNHARD, L.; KÜGER T. (Hrsg.) Simulation raumbezogener Prozesse: Methoden und Anwendung. [S.1.], IfGIprints 9 Inst. für Geoinformatik, Univ. Münster, Münster, 2000. 21p.

; SCHUSTER, H. Mikroklimasimulation ergänzend zur Gebäudesimulation. BAUSIM, 2008, Kassel. Akte...

; SKINNER, C.J. Rooftop greening and local climate: a case study in Melbourne. INTERNATIONAL CONFERENCE ON URBAN CLIMATOLOGY; INTERNATIONAL CONGRESS OF BIOMETEOROLOGY, 1999, Sydney. Proceedings...

BRUSE, M.; THÖNNESSEN, M.; RADTKE, U. Practical and theoretical investigation of the influence of façade greening on the distribution of heavy metals in urban streets. INTERNATIONAL CONFERENCE ON URBAN CLIMATOLOGY; INTERNATIONAL CONGRESS OF BIOMETEOROLOGY, 1999, Sydney. Proceedings...

BRUSE, M. ENVI-met 3.0: updated model overview. Disponível em:

〈http://envimet.net/documents/papers/overview30.pdf〉. Acesso em: 22 fev. 2013.

BRUTON, M.J. Introdução ao planejamento dos transportes. Rio de Janeiro: Interciência; São Paulo: Edusp, 1979.

BUNGE, M. Epistemologia: curso de atualização. São Paulo: Queiroz/ Edusp, 1980. (Biblioteca de ciências naturais vol.4).

BURGER, D.M.; DELITTI, W.B.C. Allometric models for estimating the phytomass of a secondary Atlantic Forest area of southeastern. Brazil Biota Neotropica, v.8, n.4, out./ dez. 2008.

CAETANO, P.M.D. Adaptação do método de Ven Te Chow a bacias urbanas. SIMPÓSIO BRASILEIRO DE RECURSOS HÍDRICOS, 11., 1995, Recife; SIMPÓSIO DE HIDRÁULICA DOS PAÍSES DE LÍNGUA OFICIAL PORTUGUESA, 2., 1995, Recife. Anais... Recife: ABRH, 1995.

Gestão da qualidade da água e mercados de quaotas de poluição. 1999. Dissertação (mestrado em engenharia civil), Departamento de Engenharia Hidráulica e Sanitária, Escola Politécnica, Universidade de São Paulo, São Paulo.

Relatório Final da Comissão Especial de Elaboração de Estudo de Políticas Públicas para o Aumento da Permeabilidade do Solo Urbano no Município de São Paulo. Diário Oficial do Município, São Paulo, ano 46, n.243, p.28-30, 29 dez. 2001. Disponível (sem os anexos) em:

<http://portal.prefeitura.sp.gov.br/secretarias/meio_ambiente/cades/resolucoes/0068>. Acesso em: 9 dez. 2015.

. Avaliação da eficácia hidrológica de reserva de $30 \%$ de área do lote livre de pavimentação ou construção: relatório técnico. São Paulo: SMMA, 2001a. 
. Avaliação da eficácia hidrológica de reserva de 30\% de área do lote livre de pavimentação ou construção: relatório técnico. São Paulo: SMMA, 2001b.

Proposta de método de dimensionamento de reservatório de detenção de lote baseado no princípio de "impacto zero": relatório técnico. São Paulo: SMMA, 2001c.

Sugestão de procedimento simplificado para o cálculo de volume mínimo de reservatório: relatório técnico. São Paulo: SVMA, 2001d.

. Avaliação do potencial de redução de danos provocados por inundações através da imposição de medidas de impacto zero. São Paulo, 2002.

Proposta de diretrizes para a condução de estudos de zoneamento ambiental em áreas urbanas consolidadas: relatório técnico. São Paulo, 2005.

Avaliação de serviços ambientais prestados por áreas verdes. São Paulo, 2007.

2010.

Medidas não convencionais para o controle de enchentes através de infiltração e percolação. São Paulo: SVMA,

Em busca do Graal do indicador sintético único: contribuições da Termodinâmica e da Teoria da Informação. Revista Brasileira de Ciências Ambientais, n.30, p.11-9, dez. 2013.

Minuta de texto de referência para a oficina de 30.10.2014 sobre a Quota Ambiental. São Paulo, 2014a.

Consolidação da oficina de 30.10.2014: comentários em relação a críticas e sugestões de melhorias: relatório técnico. São Paulo, 2014b.

. Volumes mínimos de reservatórios de detenção de lote segundo diferentes critérios, relatório técnico. rev.2. São

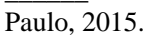

.; DEVECCHI, A.M. Áreas de preservação permanente e o pagamento por serviços ambientais. In: SEMINÁRIO NACIONAL SOBRE O TRATAMENTO DE ÁREAS DE PRESERVAÇÃO PERMANENTE EM MEIO URBANO E RESTRIÇÕES AMBIENTAIS AO PARCELAMENTO DO SOLO, 2007, São Paulo. Anais...São Paulo: FAUUSP, 2007.

CAMPBELL, D.E. Using Energy Systems Theory to define, measure, and interpret ecological integrity and ecosystem health. Ecosystem Health, v.6, n.3, p.181-204, Sept. 2000.

CAMPOS, I.C.M. Diagnóstico de transtornos mentais e comportamentais e relação com o trabalho de servidores públicos estaduais. 2006. Dissertação (Mestrado em Psicologia) - Programa de Pós-Graduação em Psicologia, Curso de Mestrado, Centro de Filosofia e Ciências Humanas, Universidade Federal de Santa Catarina, Florianópolis.

CANHOLI, A.P. Soluções estruturais não convencionais em drenagem urbana. 1995. Tese (Doutorado) - Departamento de Engenharia Hidráulica e Sanitária, Escola Politécnica, Universidade de São Paulo, São Paulo.

Drenagem urbana e controle de enchentes. São Paulo: Oficina de Textos, 2005.

CAPUTO, H.P. Mecânica dos solos e suas aplicações, 2. 5.ed. Rio de Janeiro: LTC, 1983.

CARDOSO, O.R.; TASSI, R.; PICCILLI, D.G.A. Volumes de reservatórios de detenção: influência do uso de diferentes metodologias. In: SIMPÓSIO BRASILEIRO DE RECURSOS HÍDRICOS, 20., 2013, Bento Gonçalves. Anais...Porto Alegre: ABRH, 2013.

CARVALHO, G.S.; DE OLIVEIRA, S.C.; MORUZZI, R.B. Cálculo do volume do reservatório de sistemas de aproveitamento de água de chuva: comparação entre métodos para aplicação em residência unifamiliar. In: SIMPÓSIO NACIONAL DE SISTEMAS PREDIAIS, 10., 2007, São Carlos. Anais...

CASTELLAN, G.W. Físico-Química, 1. Rio de Janeiro: LTC, 1983.

CEGALLA, D.P. Novíssima gramática da língua portuguesa. São Paulo: Companhia Editora Nacional, 1971.

CESAR, L.P.M.; CIDADE, L.C.F. Ideologia, visões de mundo e práticas socioambientais no paisagismo. Sociedade e Estado, Brasília, v. 18, n.1/2, p.115-36, jan./dez. 2003.

CHAUÍ, M. Husserl: vida e obra. In: HUSSERL, E. Investigações lógicas; Sexta investigação; Elementos de uma elucidação fenomenológica do conhecimento. 5.ed. São Paulo: Nova Cultural, 1992. (Os pensadores).

Introdução à história da filosofia: dos pré-socráticos a Aristóteles, 1. 2.ed. São Paulo: Companhia das Letras, 2002.

Introdução à história da filosofia: as escolas helenísticas, 2. São Paulo: Companhia das Letras, 2010. 
CHAUNU, P. Conquista e exploração de novos mundos: século XVI. São Paulo: Pioneira; Edusp, 1984. (Biblioteca Pioneira de ciências sociais: História: Nova Clio).

CHOW, V.T. Open-channel hydraulics. Auckland: McGraw-Hill, 1959.

; MAIDMENT, D.R.; MAYS, L.W. Applied Hydrology. New York: McGraw-Hill, 1988.

CIRIA. Demonstrating the multiple benefits of SuDS: a business case: a literature review. London: CIRIA, 2013a.

Demonstrating the multiple benefits of SuDS: demonstrating ideas: review of sources. London: CIRIA, 2013b

The SuDS Manual. London, 2015. (CIRIA C753). 968p. Ballard, B.W. et al.

CIRLOT, J.-E. Dicionário de símbolos. São Paulo: Centauro, 2005.

COELHO, G.A. Análise de não estacionariedade da precipitação em São Paulo/ SP e implicações sobre os sistemas de drenagem urbana. 2014. Dissertação (Mestrado) - Escola Politécnica da Universidade de São Paulo, São Paulo, 2014.

CONSELHO BRASILEIRO DE CONSTRUÇÃO SUSTENTÁVEL. Quota Ambiental da Cidade de São Paulo (minuta). São Paulo: CBCS, 2015.

COUTO, C.G. Negociação, decisão e governo: padrões interativos na relação executivo-legislativo e o caso paulistano. In: ANDRADE, R.C. (org.). Processo de governo no município e no estado: uma análise a partir de São Paulo. São Paulo: Edusp, 1998.

CREDER, H. Instalações hidráulicas e sanitárias. 3.ed. Rio de Janeiro: LTC, 1984.

CRUZ, M.C.; TUCCI, C.E.M.; DA SILVEIRA, A.L.L. Controle do escoamento com detenção em lotes urbanos. Revista Brasileira de Recursos Hídricos, v. 3, n.4, p.19-31, out./ dez. 1998.

; TUCCI, C.E.M.; DA SILVEIRA, A.L.L. Controle do escoamento em lotes urbanos com detenção. In: TUCCI, C.E.M.; MARQUES, D.M.L.M. (org.) Avaliação e controle da drenagem urbana. Porto Alegre: ABRH, 2000.

CULLETON, A. Ockham e a lei natural. Florianópolis: Editora da UFSC, 2011.

CUNHA, J.C.C.B. Adoecimento e afastamento do trabalho de servidores públicos estaduais de Santa Catarina. 2007. Dissertação (Mestrado em Saúde Pública) - Programa de Pós-Graduação em Saúde Pública, Universidade Federal de Santa Catarina, Florianópolis.

DA COSTA, L.J. Diversidade de espécies, diversidade funcional e estoque de biomassa no sub-bosque de florestas nativas e monoculturas arbóreas. 2009. Dissertação (Mestrado) - Universidade do Vale do Rio dos Sinos, São Leopoldo, RS.

DA MOTTA, R.S. Water quality and policy in Brazil: estimates of health costs associated to sanitation services and simulation of pollution. Rio de Janeiro: IPEA, 1995. (Seminários IPEA n.8/95).

DA SILVEIRA, A.L.; LOUZADA, J.A.; BELTRAME, L.F. Infiltração e armazenamento no solo. In: TUCCI, C.E.M. (org.). Hidrologia: ciência e aplicação. Porto Alegre: Ed. da Universidade/ ABRH; São Paulo: Edusp, 1993. (Coleção ABRH de Recursos Hídricos, v.4). p.335-72.

DA VEIGA, A.H.; RODRIGUES, B.S.; PIVA, M.F.; SZPOGANICZ, M.V. Bioferramentas construtivas. Monografia (Graduação) - Departamento de Arquitetura e Urbanismo, Centro Tecnológico, Universidade Federal de Santa Catarina, 2013, Florianópolis. 22p.

DE ALVARENGA, A.T. et al. Histórico, fundamentos filosóficos e teórico-metodológicos da interdisciplinaridade. In: PHILIPPI, A.; SILVA NETO, A.J. (org.). Interdisciplinaridade em ciência, tecnologia \& inovação. São Paulo: Manole, 2011.

DE AMORIM, S.V.; PEREIRA, D.J.A. Estudo comparativo dos métodos de dimensionamento para reservatórios utilizados em aproveitamento de água pluvial. Ambiente Construído, Porto Alegre, v.8, n.2, p.53-66, abr./ jun. 2008.

DE CAMARGO, A.P.; DE CAMARGO, M.B.P. Uma revisão analítica da evapotranspiração potencial. Bragantia, Campinas, v.59, n.2, p.125-37, 2000.

DE CARVALHO, J.P. A tipologia dos edifícios de apartamentos e sua relação com o tecido urbano da cidade - um estudo das suas transformações nos últimos 40 anos. 2008. Dissertação (Mestrado em planejamento urbano e regional) - Faculdade de Arquitetura e Urbanismo, Universidade de São Paulo, São Paulo.

DE FREITAS, L. O bacharelismo no Brasil e o atual fenômeno da bacharelice: uma análise sócio-histórica. Quaestio, Sorocaba, v.12, p.81-91, nov. 2010. 
DE LIMA, E.K. Administração de conflitos, espaço público e cidadania: uma perspectiva comparada. Civitas - Revista de Ciências Sociais, ano 1, n.2, p.11-6, dez. 2001.

Sensibilidades jurídicas, saber e poder: bases culturais de alguns aspectos do direito brasileiro em uma perspectiva comparada. Anuário Antropológico 2009, v.2, p.25-51, 2010.

DE MELLO, L.G.F.S. Drenagem vertical para sobreadensamento dos solos argilosos. In: HACHICH, W. et al. (org.). Fundações: teoria e prática. 2.ed. São Paulo: Pini, 1998. p.596-602.

DE MENEZES, A.W.N.C. O fenômeno do bacharelismo à luz de Gilberto Freyre. Revista Inter-Legere: Revista Semestral do Programa de Pós-Graduação em Ciências Sociais - UFRN, n.5, p.95-107, 2009.

DE MORAES; T.P.B.; MILANI, F.S. Altruísmo como uma via evolutivamente sustentável: uma revisão sobre a evolução do altruísmo. Revista do Instituto de Direito Brasileiro, Lisboa, v.2, n.14, p.17281-305, 2013.

DE MOURA, C.A.R. Nietzsche: civilização e cultura. São Paulo: Martins Fontes, 2005. (Coleção tópicos).

DE PURY, D.G.G.; FARQUHAR, G.D.F. Simple scaling of photosynthesis from leaves to canopies without the errors of bigleaf models. Plant, Cell and Environment, v.20, p.537-57, 1997.

DE VIRGILIS, A.L.C. Procedimentos de projeto e execução de pavimentos permeáveis visando retenção e amortecimento de picos de cheias. 2009. Dissertação (mestrado em engenharia civil) - Departamento de Engenharia de Transportes, Escola Politécnica, Universidade de São Paulo, São Paulo.

DE WIT, R. Do all ecosystems maximize their distance with respect to thermodynamic equilibrium? A comment on the "Ecological Law of Thermodynamics" (ELT) proposed by Sven Erik Jørgensen. Scientia Marina, v.69, n.3, p.427-34, 2005.

DEUTSCHLAND (BUNDESREPUBLIK). Umweltbundesamt (UBA). Bundesanstalt für Straßenwesen (BASt).

Bundesforschungsanstalt für Landeskunde und Raumordnung (BfLR). Flächenhafte Verkehrsberuhigung: Folgerungen für die Praxis. Bonn, 1992. Döldissen et al.

DEVECCHI, A.M. Reformar não é construir: a reabilitação de edifícios verticais: novas formas de morar em São Paulo no século XXI. São Paulo: Editora Senac São Paulo, 2014.

DEWULF, J. et al. Exergy: its potential and limitations in environmental science and technology. Environmental Science Techn., v.42, n.7, p. 2221-32, Febr. 2008.

Illustration of the confusion on the informational exergy concept and on the difference between informational storage and information entropy, 2008b. Disponivel em: <pubs.acs.org>.

DIAS, M.A.F.S. et al. Changes in extreme daily rainfall for São Paulo, Brazil. Climatic Change, v.116, n.3-4, p.705-22, 2013.

D’OCA, F.R.M. Política, direito e relações internacionais em Francisco de Vitoria. Revista Opinião Filosófica, Porto Alegre, v.3, n.1, p.172-90, 2012.

DOMINONI, C.M.B. Análise de estabilidade e compressibilidade de um aterro sobre solo mole no porto de Suape, Região Metropolitana do Recife. 2011. Projeto de Graduação (graduação em engenharia civil) - Escola Politécnica, Universidade Federal do Rio de Janeiro, Rio de Janeiro.

DOMON, G.; GARIÉPY, M.; BOUCHARD, A. La planification écologique: analyse critique et mise en relation avec la planification environnementale. Cahiers de Geographie du Québec, v.31, n.B2, avril 1987, p.5-21.

DOS SANTOS, R.F. Planejamento ambiental: teoria e prática. São Paulo: Oficina de Textos, 2004.

DOSTAL, P. et al. Quantifying the human thermal-heat-stress in central European cities with BOTworld and on site-interviews as analyzing tool to estimate the thermal sensation of pedestrians. INTERNATIONAL CONFERENCE ON URBAN CLIMATE, 7., 2009, Yokohama. Proceedings...

DIAZ, G.; DOUGLAS, C.R. Etimologia grega do vocabulário científico. São Paulo: Robe, 1993.

DRAGANOVIC, V. et al. Sustainability assessment of salmonid feed using energy, classical exergy and eco-exergy analysis. Ecological Indicators, v.34, p.277-89, 2013.

DREXLER, J.Z.; DE FONTAINE, C.S.; DEVEREL, S.J. The legacy of wetland drainage on the remaining peat in the Sacramento - San Joaquin delta, California, USA. Wetlands, v.29, n.1, p.372-86, March 2009.

DUARTE, D.H.S. Variáveis urbanísticas e microclimas urbanos: modelo empírico e proposta de um indicador. Forum Patrimônio: amb. constr. e patr. sust., Belo Horizonte, v.3, n.2, jul./ dez. 2010.

ECO, U. La búsqueda de la lengua perfecta. Barcelona: Crítica, 1994. (La Construcción de Europa). 
EDDY, S.R. Non-coding RNA genes and the modern RNA world. Nat. Rev. Genet., v.2, n.12, p.919-29, Dec. 2001.

EDWARDS, E.J.; SMITH, S.A. Phylogenetic analyses reveal the shady history of $\mathrm{C}_{4}$ grasses. PNAS, v.107, n.6, p.2532-7, Febr. 2010.

EHRMAN, B.D. Como Jesus se tornou Deus. São Paulo: LeYa, 2014.

EISBERG, R.M.; LERNER, L.S. Física: fundamentos e aplicações, 2. São Paulo: McGraw-Hill, 1982.

EISBERG, R.M.; LERNER, L.S. Física: fundamentos e aplicações, 4. São Paulo: McGraw-Hill, 1983.

ELIADE, M. Mitos, sueños y misterios. Barcelona: Kairós, 2001.

EMBRAPA; ESALQ. Banco de dados climáticos do Brasil. Disponível em:

<http://www.bdclima.cnpm.embrapa.br/resultados/balanco.php?UF=\&COD=454>. Acesso em: 2 mar. 2016.

EMERIQUE, L.B. Controle judicial das políticas públicas de direitos sociais. Âmbito Jurídico, Rio Grande, v.14, n.89, jun. 2011.

ESMER, Ö. Information theory, entropy and urban spatial structure. 2005. Thesis (Doctorate in Urban and Regional Planning) - The Graduate School of Natural and Applied Sciences, Middle-East Technical University, Ankara.

FABIAN, A.J.; OTTONI FILHO, T.B. Determinação da capacidade de campo "in situ" através de equações de regressão. Pesq. Agropec. Bras., Brasília, v.35, n.5, p.1029-36, maio 2000.

FABIANO, M. et al. Temporal and spatial change of exergy and ascendency in different benthic marine ecosystems. Energy, n.29, p. 1697-712, 2004.

FATH, B.D. et al. Ecosystem growth and development. BioSystems, n.77, p.213-28, 2004.

FATH, B.D.; PATTEN, B.C.; CHOI, J.S. Complementarity of ecological goal functions. J. Theor. Biol., n.208, p.493-506, 2001

FEHR\&PEERS TRANSPORTATION CONSULTANTS. Traffic calming. Disponível em <http://trafficcalming.org/>. Acesso em: 23 nov. 2015.

FERRARI, C. Curso de planejamento municipal integrado. 4.ed. São Paulo: Pioneira, 1984.

FERREIRA, A.B.H. Novo Dicionário da Língua Portuguesa. 2.ed. rev. e aum. Rio de Janeiro: Nova Fronteira, 1986.

Novo Aurélio século XXI: o dicionário da língua portuguesa. 3.ed. Rio de Janeiro: Nova Fronteira, 1999.

FEYERABEND, P. Contra o método. 2.ed. São Paulo: Editora UNESP, 2011.

FIGUEIREDO, M.F.; FERREIRA, L.A. Olhos de Caim: a inveja sob as lentes da linguística e da psicanálise. In: FIGUEIREDO, M.F.; MENDONÇA, M.C.; ABRIATA, V.L.R. (org.). Sentidos em movimento: identidade e argumentação. Franca: Unifran, 2008. (Coleção Mestrado em Lingüística, 3). p.181-97.

FISCHHOFF, B. Standard-setting standards: a systematic approach to managing public health and safety risks. In: COVELLO, V.T. (ed.). Environmental impact assessment, technology assessment and risk analysis. Berlin: Sprenger, 1985. (NATO ASI Series v.64).

FISHBURN, P.C. Arrow's impossibility theorem: concise proof and infinite voters. Journal of Economic Theory, v.2, p.103$6,1970$.

FLUSSER, V. Fenomenologia do brasileiro: em busca de um novo homem. Rio de Janeiro: Eduerj, 1998.

FONSECA, J.C. et al. Estimation of ecological exergy using weighing parameters determined from DNA contents of organisms: a case study. Hydrobiology, n.475/ 476, p.79-90, 2002.

FORSTER, H.W.; MELO, A.C.G. Biomassa aérea e de raízes em árvores de reflorestamentos heterogêneos no vale do Paranapanema. IF Sér. Reg., n.31, p.153-7, jul. 2007.

FORTE, B. Nos caminos do uno: metafísica e teología. São Paulo: Paulinas, 2005. (Coleção espaço filosófico).

FOX; R.W.; MCDONALD, A.T. Introdução à mecânica dos fluidos. 2.ed. Rio de Janeiro: Guanabara Dois, 1981.

FRANCISS, F.O. Hidráulica de meios permeáveis: escoamento em meios porosos. Rio de Janeiro: Interciência; São Paulo: Edusp, 1980.

FREUD, S. Por que existe a guerra? In: MEGARGEE, E.I.; HAHANSON, J.E. (org.). A dinâmica da agressão: análise de 
indivíduos, grupos e nações. São Paulo: EPU/EDUSP, 1976. p.13-26.

FREYRE, G. Casa-Grande \& Senzala: formação da familia brasileira sob o regime da economia patriarcal. São Paulo: Global, 2007.

FRIEND, A.D. Modelling canopy $\mathrm{CO}_{2}$ fluxes: are 'big-leaf' simplifications justified? Global Ecology \& Biogeography, v.10, p.603-19, 2001.

FUGITA, O. et al. Drenagem urbana: manual de projeto. São Paulo: CETESB/ ASCETESB, 1986.

FUSCO, P.B. Estruturas de concreto: fundamentos do projeto estrutural. São Paulo: Edusp/ McGraw-Hill, 1976.

GARCIA, R.J.F. Subsídios para a revisão participativa da lei de parcelamento, uso e ocupação do solo (SMDU, 2014). São Paulo, 2014.

GARTLAND, L. Ilhas de calor: como mitigar zonas de calor em áreas urbanas. São Paulo: Oficina de Textos, 2010.

GEANAKOPLOS, J. Three brief proofs of Arrow's Impossibility Theorem. Economic Theory, v.26, p.211-5, 2005.

GENZ, F.; TUCCI, C.E.M. Controle do impacto da urbanização. In: TUCCI, C.E.M.; PORTO, R.L. (org.). Drenagem urbana. Porto Alegre: Ed. UFRGS/ ABRH, 1995. (Col. ABRH de Recursos Hídricos volume 5).

GERAQUE, E. 'Cota verde' para prédio de SP deve ter efeito limitado. Folha de S. Paulo, São Paulo, 25 jun. 2015. B8.

GILSON, É. O espírito da Filosofia Medieval. Trad. Eduardo Brandão. São Paulo: Martins Fontes, 2006. (Paidéia).

GLAZIER, D.S. Metabolic level and size scalling of rates of respiration and growth in unicellular organisms. Functional Ecology, v.23, p.963-8, 2009.

GOMES, A.G.; VARRIALE, M.C. Modelagem de ecossistemas: uma introdução. 2.ed. Santa Maria: Ed. UFSM, 2004.

GORGUlHO, G.S.; STORNiOlO, I; ANDERSON, A.F. (coord.). A Bíblia de Jerusalém. Nova ed., rev. São Paulo: Paulinas, 1985.

GRAHAM, A. et al. Sustainable drainage systems: maximising the potential for people and wildlife: a guide for local authorities and developers. [London]: RSPB/ WWT, 2012.

GRANDIS, I. Rebaixamento do lençol d’água. In: HACHICH, W. et al. (org.). Fundações: teoria e prática. 2.ed. São Paulo: Pini, 1998. p.581-95.

GRIMM, J.; GRIMM, W. Deutsches Wörterbuch von Jacob Grimm und Wilhelm Grimm. Disponível em: $<$ http://woerterbuchnetz.de/>.

GSPALTL, M.; STERBA, H. An approach to generalized non-destructive leaf area allometry for Norway spruce and European beech. Centralblatt für das gesamte Forstwesen, v.128, n.4, p.219-250, 2011.

GUARULHOS (CIDADE). Lei n 5.617, de 9 de novembro de 2000. Código de Obras do Município de Guarulhos. Disponível em: 〈http://leis.guarulhos.sp.gov.br/06_prefeitura/leis/leis_download/05617lei.pdf〉. Acesso em: 9 fev. 2016.

HANNS, L.A. Dicionário comentado do alemão de Freud. Rio de Janeiro: Imago, 1996. (Série Analytica).

HANDY, C. Deuses da administração: transformando as organizações. São Paulo: Vértice/ Editora dos Tribunais, 1987.

HAWLEY, P.H.; LITTLE, T.D.; CARD, N.A. The myth of the alpha male: a new look at dominance-related beliefs and behaviors among adolescent males and females. International Journal of Behavioral Development, v.32, n.1, p.76-88, 2008.

HEARNSHAW, E.I.S.; CULLEN, R.; HUGUEY, K.F.D. Ecosystem health demystified: an ecological concept determined by economic means.

HERRINGTON, S. The nature of Ian McHarg's science. Landscape Journal, v.29, p.1-10, 2010.

HESÍODO. Os trabalhos e os dias. Trad. Alessandro Rolim de Moura. Curitiba: Segesta, 2012. (Raízes do pensamento econômico; 2).

HIGASHI, M.; NAKAJIMA, H. Indirect effects in ecological interaction networks, I: the chain rule approach. Mathematical Biosciences, v.130, p.99-128, 1995.

HIGUCHI, N. et al. Biomassa da parte aérea da vegetação da floresta tropical-úmida de terra-firme da Amazônia Brasileira. Acta Amazonica, v.28, n.2, p.153-66, 1998.

HIGUERAS GARCIA, E. et al. Buenas prácticas en arquitectura y urbanismo para Madrid: critérios bioclimáticos y de 
eficiencia energética. Madrid: Área de Gobierno de Urbanismo y Vivienda del Ayuntamiento de Madrid, 2009.

HINZEN, A. et al. Umweltschutz in der Flächennutzungsplanung. Wiesbaden: Bauverl., 1995.

HIRATA, R.C.A.; FERREIRA, L.M.R. Os aqǘferos da bacia hidrográfica do Alto Tietê: disponibilidade hídrica e vulnerabilidade à poluição. Revista Brasileira de Geociências, v.31, p.43-50, mar. 2001.

HIRST, J.; MORLEY, J.; BANG, K. Functional landscapes: assessing elements of Seattle Green Factor. Seattle: The Berger Partnerships, 2008.

HOBBES, T. Leviatã ou matéria, forma e poder de um estado eclesiástico e civil. 4.ed. Trad. João Paulo Monteiro e Maria Beatriz Nizza da Silva. São Paulo: Nova Cultural, 1988. (Os pensadores).

HOBBS, R. Future landscapes and the future of landscape ecology. Landscape and Urban Planning, n.37, p.1-9, 1997.

HOGGAN, D. H. Computer-assisted floodplain hydrology and hydraulics. New York: McGraw-Hill, 1989.

HOLLING, C.S. Understanding the complexity of economic, ecological, and social systems. Ecosystems, v.4, p.390-404, 2001.

HORN, J.F.C.; TAMIOSSO, M.F.; DA SILVEIRA, G.L.; CRUZ, J.C.; SANAGIOTTO, D.G.; PADILHA, D.G.; MAZIERO, E.; DA SILVA, R.L.L. Coeficientes de escoamento superficial: estudo comparativo entre dados observados e literatura. In: SIMPÓSIO BRASILEIRO DE RECURSOS HÍDRICOS, 19., 2011, Alagoas. Anais...

HOUAISS, A.; VILLAR, M.S. Dicionário Houaiss da Língua Portuguesa. Rio de Janeiro: Objetiva, 2001.

HUTTNER, S. Further development and application of the 3-D microclimate simulation ENVI-met. 2012. Dissertation (Doktorat in Naturwissenschaften im Promotionsfach Geographie am Fachbereich Chemie, Pharmazie und Geowissenschaften) - Johannes Gutenberg-Universität, Mainz, 2012.

et al. Strategies for mitigating thermal heat stress in central European cities: the project KLIMES. JAPANESEGERMAN MEETING ON URBAN CLIMATOLOGY, 7., 2009, Yokohama. Proceedings...

; BRUSE, M.; DOSTAL, P. Using ENVI-met to simulate the impact of global warming on the microclimate in central European cities. JAPANESE-GERMAN MEETING ON URBAN CLIMATOLOGY, 5., 2008, Freiburg. Akte... Freiburg: Meteorologische Institut der Albert-Ludwigs-Universität Freiburg, 2008. (Berichte Nr. 18). p.307-12.

; BRUSE, M. Numerical modeling of the urban climate: a preview of ENVImet 4.0. JAPANESE-GERMAN MEETING ON URBAN CLIMATOLOGY, 7., 2009, Yokohama. Proceedings...

IMAÑA-ENCINAS, J.; DA SILVA, G.F.; PINTO, J.R.R. Idade e crescimento das árvores. Brasília: Universidade de Brasília, 2005. (Comunicações técnicas florestais, v.7, n.1).

IPCC. 2006 IPCC guidelines for national greenhouse gas inventories, 4: agriculture, forestry and other land use. Hayama, Kanagawa: IGES, 2006. (IPCC National Greenhouse Gas Inventories Programme). Eggleston, S. et al. (ed.).

I-TREE. i-Tree. Disponível em: <https://www.itreetools.org/>. Acesso em: 26 nov. 2015.

JAMDADE, M. et al. Library classification and its development: a study. Review of Research, v.1, n.12, p.1-4, Sept. 2012.

JAUHIAINEN, J. et al. Heterotrophic respiration on drained tropical peat is greatly affected by temperature - a passive ecosystem cooling experiment. Environ. Res. Lett., v.9, p.1-18, 2014.

JAYNES, E.T. Information theory and statistical mechanics. The Physical Review, v.106, n.4, p.620-30, May 1957.

Information theory and statistical mechanics. In: FORD, K.W. (ed.). Brandeis University Summer Institute lectures in theoretical physics: 1962 lectures, 3. [Waltham, MA]: Brandeis University, 1962.

The minimum entropy production principle. Ann. Rev. Phys. Chem., v.31, p.579-601, 1980.

JOLY, A.B. Estudo fitogeográfico dos campos de Butantan (São Paulo). Boletim da Faculdade de Filosofia, Ciências e Letras da Universidade de São Paulo Botânica, São Paulo, v.8, p.5-67, 1950.

JØRGENSEN, S.E. Integration of ecosystem theories: a pattern. Dordrecht: Kluwer Academic Publishers, 1992. (Ecology \& Environment Volume 1).

Application of exergy and specific exergy as ecological indicators of coastal areas. Aquatic Ecosystem Health \& Management, n.3, p.419-30, 2000.

Application of holistic thermodynamic indicators. Ecological Indicators, n.6, p.24-9, 2006.

Description of aquatic ecosystem's development by eco-exergy and exergy destruction. Ecological Modelling, v.204, 
p.22-8, 2007.

Ecosystem services, sustainability, and thermodynamic indicators. Ecological Complexity, v.7, p.311-3, 2010.

et al. Calculations of exergy for organisms. Ecological Modelling, n.185, p.165-75, 2005.

; LUDOVISI, A.; NIELSEN, S.N. The free energy and information embodied in the amino acid chains of organisms. Ecological Modelling, v.221, p.2388-92, 2010.

; MARQUES, J.; NIELSEN, S.N. Structural changes in an estuary, described by models and using exergy as indicator. Ecological Modelling, v.158, p.233-40, 2002.

; NIELSEN, S.N. Application of exergy as thermodynamic indicator in ecology. Energy, v.32, p.673-85, 2007. 109,1995

NIELSEN, S.N.; MEJER, H. Energy, environ, exergy and ecological modelling. Ecological Modelling, n.77, p.99-

; PATTEN, B.C.; STRAŠKRABA, M. Ecosystem emerging: 4. growth. Ecological Modelling, v.126, p.259-84, 2000.

KAPLAN, W. Cálculo avançado, 1. São Paulo: Edgard Blücher, 1972.

KANT, I. Crítica da razão pura. São Paulo: Abril, 1974. (Os pensadores).

KAY, J.J. A nonequilibrium thermodynamic framework for discussing ecosystem integrity. Environmental Management, v.15, n.4, p.483-95, 1991.

Ecosystems as self-organizing holarchic open systems: narratives and the Second Law of Thermodynamics. In: JØRGENSEN, S.E. MÜLLER, F. (ed.). Handbook of ecosystem theories and management. [S.1.]: CRC/ Lewis, 2000. p.135-50.

About some common slipups in applying Prigogine's minimum entropy production principle to living systems. [S.l.]: [s.n.], 2002. 1999.

et al. An ecosystem approach for sustainability: addressing the challenge of complexity. Futures, n.31, p.721-42,

KAZEMIAN, S. et al. A state of art review of peat: geotechnical engineering perspective. International Journal of the Physical Sciences, v.6, n.8, p.1974-81, April 2011.

KEELEY, M. The Green Area Ratio: an urban site sustainability metric. Journal of Environmental Planning and Management, v.54, n.7, p.937-58, Sept. 2011.

KHOURY, F. History of the Manning formula. [San Diego]: San Diego State University, 2005.

KIBLER, D.F. Desk-top methods for urban stormwater calculations. In: (ed.). Urban stormwater hydrology. Washington: AGU, 1982

KOGURE, K. An analytical prediction of consolidation settlement of fibrous peat deposit under loading. In: INTERNATIONAL CONFERENCE ON CASE HISTORIES IN GEOTECHNICAL ENGINEERING, 3., 1993, St. Louis, Missouri. Proceedings...

KRUUSE, A. The green space factor and the green points system. London: Town and Country Planning Association, 2011. (Green and Blue Space Adaptation for Urban Areas and Eco Towns (GRaBS) Expert Paper 6).

KUHN, T.S. A estrutura das revoluções científicas. 7.ed. Tradução de Beatriz Vianna Boeira e Nelson Boeira. São Paulo: Perspectiva, 2003.

KUICHLING, E. Gaugings of the discharge of sewer in Rochester, N.Y., during rainstorms, and the application of the results to the proposed trunk sewer. In: Report on the proposed trunk sewer for the east side of the City of Rochester, N.Y. Rochester: Union and Advertisers, 1889. p.158-89.

KUTNER, A.S. Análise geológica e caracterização dos solos da bacia do Alto Tietê para avaliação de escoamento superficial. São Paulo: DAEE/ Consórcio Enger-Promon-CKC, 1998.

LALANDE, A. Vocabulario técnico y crítico de la filosofia. 2.ed. Buenos Aires: El Ateneo, 1966.

LANDSCHAFT PLANEN \& BAUEN; BECKER GISEKE MOHREN RICHARD. Der Biotopflächenfaktor als ökologischer Kennwert: Grundlagen zur Ermittlung und Zielgrößenbestimmung. Berlin: Senatsverwaltung für Umweltsschutz und Stadtentwicklung, 1990.

LEE, S.; OH, K.; JUNG, S. The carrying capacity assessment framework for ubiquitous-ecological cities in Korea. [Seoul], 
[s.d.].

LEITE, A.; SIMON, S. Werner Heisenberg e a Interpretação de Copenhague: a filosofia platônica e a consolidação da teoria quântica. SCIENTI/E STUDIA, São Paulo, v.8, n.2, p.213-41, 2010.

LEITHOLD, L. O cálculo com geometria analítica, 2. São Paulo: Harper \& Row, 1977.

LENCASTRE, A. Manual de hidráulica geral. São Paulo: Edgard Blücher; Edusp, 1972.

; FRANCO, A.M. Lições de hidrologia. Lisboa: Universidade Nova de Lisboa, 1984.

LÉVI-STRAUSS, C. Tristes trópicos. São Paulo: Companhia das Letras, 1996. pensadores)

Raça e história. Trad. Inácia Canelas. In:

Lévi-Strauss. São Paulo: Abril Cultural, 1980, p.45-87. (Os

LIBRALATO, S.; TORRICELLI, P.; PRANOVI, F. Exergy as ecosystem indicator: as application to the recovery process of marine benthic communities. Ecological Modelling, n.192, p.571-85, 2006.

LIMA, J.A.S. Estimativas da biomassa acima do solo de florestas secundárias da área de proteção ambiental rio Macaco (RJ). Rio de Janeiro: Embrapa Solos, 2010.

LINDLEY, D.V. On a measure of the information provided by an experiment. In: CHAPEL HILL AND BERKELEY MEETINGS OF THE INSTITUTE OF MATHEMATICAL STATISTICS, 1955, [S.1.]. Proceedings...p...986-1005

LOCKE, J. Segundo tratado sobre o governo civil. São Paulo: IBRASA, 1963.

LÖFVENHAFT, K.; BJÖRN, C.; IHSE, M. Biotope patterns in urban areas: a conceptual model integrating biodiversity issues in spatial planning. Landscape and Urban Planning, n.58, p.223-40, 2002.

LORENZINI NETO, F.; TASSI, R.; TASSINARI, L.; BASSO, R. Calibração e simulação hidrológica de um telhado verde utilizando o método da curva-número do SCS. In: SIMPÓSIO BRASILEIRO DE RECURSOS HIIDRICOS, 20., 2013, Bento Gonçalves. Anais...Porto Alegre: ABRH, 2013.

LORMAND, J.R. The effects of urban vegetation on stormwater runoff in an arid environment. 1988. Dissertation (Master's Degree) - School of Renewable Natural Resources, The University of Arizona, [S.1.].

LU, H.F. et al. Emergy and eco-exergy evaluation of four forest restoration modes. Ecological Engineering, n.37, p.277-85, 2011.

LUDEMAN, K.; ERLANDSON, E. Coaching the alpha male. Harvard Business Review, May 2004.

LUDOVISI, A.; et al. Use of thermodynamic indices as ecological indicators of the development state of lake ecosystems. Ecological Modelling, n.159, p.223-38, 2003.

MACINTYRE, A.J. Instalações hidráulicas e prediais. 2.ed. Rio de Janeiro: Guanabara Dois, 1987.

MALLMANN, C.S. et al. Fatores associados à síndrome de burnout em funcionários públicos municipais. Psicologia: Teoria e Prática, São Paulo, v.11, n.2, p.69-82, 2009.

MANSUROGLU, S.; ORTACESME, V.; KARAGUZEL, O. Biotope mapping in an urban environment and its implications for urban management in Turkey. Journal of Environmental Mangement, v.81, p.175-87, 2006.

MARCELLI, M. Sinistros na construção civil: causas e soluções para danos e prejuízos em obras. São Paulo: Pini, 2007.

MARCHI, M. et al. Dynamic model of Lake Chozas (León, NW Spain): decrease in eco-exergy from clear to turbid phase due to introduction of exotic crayfish. Ecological Modelling, v.222, p.3002-10, 2011.

MARQUES, J.C. et al. Analysis of the properties of exergy and biodiversity along an estuarine gradient of eutrophication. Ecological Modelling, n.102, p.155-67, 1997.

MARTINS, J.A. Infiltração. In: PINTO, N.S. et al. (org.). Hidrologia básica. São Paulo: Edgard Blücher, 1976. p.44-55.

; GUKOVAS, M.; SALEMI FILHO, A. Construções hidráulicas. São Paulo, 1978. Notas de aula à disciplina PHD-501 - Escola Politécnica da Universidade de São Paulo.

MARTYUSHEV, L.M. Entropy and entropy production: old misconceptions and new breakthroughs. Entropy, n.15, p.115270, 2013.

MARUAYAMA, M. Mindscapes and science theories. Current Anthropology, v.21, n.5, p.589-608, Oct. 1980. 
MASCARÓ, J.J.; MASCARÓ, L. Densidades, ambiência e infra-estrutura urbana. Arquitextos, São Paulo, ano 2, n.017.08, out. 2001.

MASKIN, E. The Arrow impossibility theorem: where do we go from here? In: ARROW LECTURES, 2., 2009, New York. Proceedings...

MATTICK, J.S. Challenging the dogma: the hidden layer of non-protein-coding RNAs in complex organisms. BioEssays, n.25, p.930-9, 2003.

MAY, S. Estudo da viabilidade do aproveitamento de água de chuva para consumo não potável em edificações. 2004. Dissertação (Mestrado em engenharia civil) - Escola Politécnica, Universidade de São Paulo, São Paulo.

McPHEARSON, P.T.; KREMER, P.; HAMSTEAD, Z. Urban ecosystems services in New York City: a social-ecological multicriteria approach. In: ISEE CONFERENCE, 2012, Rio de Janeiro. Proceedings...

McSHEA, D.W. Metazoan complexity and evolution: is there a trend? International Journal of Organic Evolution, v.50, n.2, p.477-92, April 1996.

MEDEIROS, A.V.M. Estudo da evapotranspiração de referência a partir da equação de Penman-Monteith de medidas lisimétricas e de equações empíricas, em Paraipaba, CE. 2002. Tese (Doutorado) - Escola Superior de Agricultura "Luiz de Queiroz", Universidade de São Paulo, Piracicaba.

MEIRELLES, H.L. Direito administrativo brasileiro. 20.ed. São Paulo: Malheiros, 1995.

MIANA, A.C. Adensamento e forma urbana: inserção de parâmetros ambientais no processo de projeto. 2010. Tese (Doutorado) - Faculdade de Arquitetura e Urbanismo, Universidade de São Paulo, São Paulo.

MICHAELIS: moderno dicionário da língua portuguesa. São Paulo: Melhoramentos, 1998. (Dicionários Michaelis).

MIERZWA, J.C. et al. Águas pluviais: método de cálculo do reservatório e conceitos para um aproveitamento adequado. REGA, v.4, n.1, p.29-37, jan./ jun. 2007.

MILITITSKY, J.; CONSOLI, N.C.; SCHNAID, F. Patologia das fundações. São Paulo: Oficina de Textos, 2008.

MILL, J.S. Three essays on religion. 3.ed. London: Longmans, 1874.

MOLOZZI, J. et al. Thermodynamic oriented ecological indicators: application of Eco-Exergy and Specific Eco-Exergy in capturing environmental changes between disturbed and non-disturbed tropical reservoirs. Ecological Indicators, v.24, p.54351,2013.

MORARESKUL, N.N.; BRONIN, V.N. Consolidation of peat soils. Fundamenty i Mekhanika Gruntov, n.1, p.31-3, Jan./ Febr. 1974.

MORELLI, D.D.O. Paredes verdes: vegetação como qualidade ambiental no espaço construído. 2009. Dissertação (Mestrado) - Faculdade de Engenharia Civil, Universidade Estadual de Campinas, Campinas.

MORUZZI, R. B.; DE MOURA, C. C.; BARBASSA, A. P. Avaliação do efeito da inclinação e umidade antecedente na qualidade e quantidade das parcelas escoadas, percoladas e armazenadas em telhado verde extensivo. Ambiente Construído, Porto Alegre, v.14, n.3, p.59-73, jul./ set. 2014.

MOSS, M.R. Interdisciplinarity, landscape ecology and the 'Transformation of Agricultural Landscapes'. Landscape Ecology, n.15, p.303-11, 2000.

MOUHEBATI, N. Analysis of visual impacts in compact city's form. International Journal of Architecture and Urban Development, v.2, n.3, 2012.

MOURA, A.R.C. et al. Evapotranspiração de referência baseada em métodos empíricos em bacia experimental no estado de Pernambuco- Brasil. Revista Brasileira de Meteorologia, São Paulo, v.28, n.2, p.181-91, jun. 2013.

MOURA, T.A.M. Estudo experimental de superfícies permeáveis para o controle de escoamento superficial em ambientes urbanos. 2005. Dissertação (Mestrado) - Departamento de Engenharia Civil e Ambiental, Faculdade de Tecnologia, Universidade Nacional de Brasília, Brasília. 117p.

MOTTA, F.C.P. Revista de Administração de Empresas, São Paulo, v.31, n.2., p.100-2, jun. 91. Resenha de: HANDY, C. Deuses da administração: transformando as organizações. São Paulo: Vértice; Editora dos Tribunais, 1987.

MUKAI, T. Direito ambiental sistematizado. 2.ed. Rio de Janeiro: São Paulo: Forense Universitária, 1994.

MURRAY, R.B.; JACOBSON, M.Q. An evaluation of dimension analysis for predicting shrub biomass. Journal of Range Management, v.35, n.4, p.451-4, July 1982. 
NEHRING, S.; ALBRECHT, U. Biotop, Habitat, Mikrohabitat: ein Diskussionsbeitrag zur Begriffsdefinition. Lauterbornia Internationale Zeitschrift für Faunistik und Floristik des Süßwassers, n.38, p.75-84, 2000.

NELSON, B.W. et al. Allometric regressions for improved estimate of secondary forest biomass in the central Amazon. Forest Ecology and Management, n.117, p.149-67, 1999.

NIETZSCHE, F. A disputa de Homero. In: Cinco prefácios para cinco livros não escritos. Trad. Pedro Süssekind. 2.ed. Rio de Janeiro: 7Letras, 1996.

Obras incompletas. Trad. Rubens Rodrigues Torres Filho. In: Nietzsche. São Paulo: Nova Cultural, 1999. (Os pensadores)

NIJKAMP, P. Environmental policy analysis. Chichester: John Wiley \& Sons, 1980.

NOBEL, P.S. Physicochemical and environmental plant physiology. 3.ed. London: Academic Press, 2005.

NOBRE, C.; MARTIN, I.; LIMA, P. Quota Ambiental: o desafio de ser simples em território complexo. São Paulo: observaSP, 14 out. 2015. Disponível em: 〈https://observasp.wordpress.com/>. Acesso em: 21 out. 2015.

NOGUEIRA, E.M. et al. Estimates of forest biomass in the Brazilian Amazon: new allometric equations and adjustments to biomass from wood-volume inventories. Forest Ecology, v.256, p.1853-67, 2008.

NOVAES, A.G. Modelos em planejamento urbano, regional e de transportes. São Paulo: Edgard Blücher, 1981.

Sistemas de transportes, 1: análise da demanda. São Paulo: Edgard Blücher, 1986.

NOWAK, A.G. Estimating leaf area and leaf biomass of open-grown decidous urban trees. Forest Science, v.42, n.4, p.504-7, Nov. 1996.

NOWAK, D.J. Urban forest structure: the state of Chigago's urban forest. In: McPHERSON, E.G.; NOWAK, D.J.; ROWNTREE, R.A. (ed.). Chicago's urban forest ecosystem: results of the Chicago Urban Forest Climate Project. Radnor, Pennsylvania: U.S. Department of Agiculture/ Forest Service/ Northeastern Forest Experiment Station, 1994. p.3-18.

et al. A ground-based method of assessing urban forest structure and ecosystem services. Arboriculture $\&$ Urban

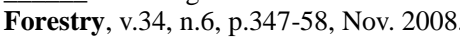

NUCCI, J.C. Qualidade ambiental e adensamento urbano: um estudo de ecologia e planejamento da paisagem aplicado ao distrito de Santa Cecília (MSP). 2.ed. Curitiba: O Autor, 2008.

NUNES, A.V.L.; LINS, S.L.B. Servidores públicos federais: uma análise do prazer e sofrimento no trabalho. Revista Psicologia Organizações e Trabalho, Brasília, v.9, n.1, p.51-67, jan./ jun. 2009.

NUNES, R.A.C. História da educação na idade média. São Paulo: Edusp, 1979.

OBSERVASP. Entre a utopia e o plausível: conversa com Silvio Macedo. São Paulo, 2015. Disponível em: <https://observasp.wordpress.com/2015/01/14/entre-a-utopia-e-o-plausivel-conversa-com-silvio-macedo/>. Acesso em: 9 dez. 2015. Entrevista concedida a Pedro Lima e Paula Santoro.

$\mathrm{OH}, \mathrm{K}$. et al. Determining sustainable development density using the urban carrying capacity assessment system London: Centre for Advanced Spatial Analysis, [s.d.]. (CASA Working Paper Series 78).

OLENIN, S; DUCROTOY, J.-P. The concept of biotope in marine ecology and coastal management. Marine Pollution Bulletin, n.53, p.20-9, 2006

OMETTO, J.C. Bioclimatologia vegetal. São Paulo: Ceres, 1981.

ONG. B.L. Green plot ratio: an ecological measure for architecture and urban planning. Landscape and Urban Planning, v.63, p.197-211, 2003

ONSAGER, L. Reciprocal relations in irreversible processes. I. Physical Review, v.37, p.405-426, Febr. 1931.

ORTOLANO, L. Environmental planning and decision making. New York: John Wiley \& Sons, 1984.

OSBORNE, C.P.; BEERLING, D.J. Nature's green revolution: the remarkable evolutionary rise of $\mathrm{C}_{4}$ plants. Philosophical Transactions of the Royal Society B: Biological Sciences, v.361, n.1465, p.173-94, 2006.

OUZOUNIAN, A.M.; ZELAZNY, J. Design-construction process. In: RATAY, R.T. (ed.). Forensic structural engineering handbook. New York: McGraw-Hill, 2000. (McGraw-Hill handbooks).

PALAZZO, L.S.; CARLOTTO, M.S.; AERTS, D.R.G.C. Síndrome de burnout: estudo de base populacional com servidores do poder público. Revista de Saúde Pública, São Paulo, v.46, n.6, p.1066-73, 2012. 
PARANÁ (ESTADO). Governo do Estado do Paraná. Secretaria de Estado do Meio Ambiente e Recursos Hídricos. Superintendência de Desenvolvimento de Recursos Hídricos e Saneamento Ambiental. Plano de drenagem para a bacia do rio Iguaçu na Região Metropolitana de Curitiba. Manual de Drenagem Urbana: Região Metropolitana de Curitiba - PR. Versão 1.0. Curitiba, dez. 2002. CH2MHill.

PAVITCH, M. (PAVIĆ, M.). O dicionário kazar: romance-enciclopédia em 100.000 palavras: edição feminina. São Paulo: Marco Zero, 1989.

PEREIRA, A.R. Como selecionar plantas para áreas degradadas e controle de erosão. 2.ed. Belo Horizonte: FAPI, 2008.

PEREIRA-SILVA, E.F.L.; JOLY, C.A.; AIDAR, M.P.M. Relações entre precipitação, pulso de nitrogênio no solo e o transporte e uso do nitrato por espécies arbóreas de floresta ombrófila densa submontana, Parque Estadual de Carlos Botelho, SP. In: CONGRESSO DE ECOLOGIA DO BRASIL, 7., 2007, Caxambu. Anais...

PEREIRA-SILVA, E.F.L. et al. Sucessão ecológica e usos do nitrogênio em florestas tropicais. Interciência \& Sociedade, Mogi Guaçu, v.1, n.1, p.149-59, 2012.

PEIXOTO; WILLMERSDORF (org.). Modelo de valoração econômica dos impactos ambientais em unidades de conservação. Brasília: IBAMA, 2002.

PELE, D.T. About the impossibility theorem for indicators aggregation. Journal of Applied Quantitative Methods, v.4, n.1, Spring 2009.

PERISSÉ, G. Para ler um outro mundo. Língua, São Paulo, n.1, p.10-3, jan. 2006.

PINTO, C.S. Propriedades dos solos. In: HACHICH, W. et al. (org.). Fundações: teoria e prática. 2.ed. São Paulo: Pini, 1998. p.51-118.

PIPES, L.A. Matemáticas aplicadas para ingenieros y físicos. Madrid: Ediciones del Castillo, 1963.

PISKUNOV, N. Calculo diferencial y integral, 2. Moscu: Mir, 1969.

Differential and integral calculus. Moscow: Peace Publishers (Mir), [s.d.].

POBLOTH, S. Die Entwicklung der Landschaftsplanung in Berlin im Zeitraum 1979 bis 2004 unter besonderer Berücksichtung der Stadtökologie. 2008. Dissertation (Doktorat Ingenieurwissenschaft) - Fakultät VI Planen Bauen Umwelt der Technischen Universität Berlin, Berlin.

POPPER, K.R. A lógica da pesquisa científica. São Paulo: Cultrix, 1993.

PORTO, M.F.A. Estabelecimento de parâmetros de controle da poluição. In: PORTO, R.L. et al. (org.). Hidrologia ambiental. São Paulo: Edusp; [Porto Alegre]: ABRH, 1991. (Coleção ABRH de Recursos Hídricos, v.3). p.375-90.

PORTO, R.L. et al. Drenagem urbana. In: TUCCI, C.E.M. (org.). Hidrologia: ciência e aplicação. Porto Alegre: Ed. da Universidade/ ABRH; São Paulo: Edusp, 1993. (Coleção ABRH de Recursos Hídricos; v.4). p.805-47.

PORTO, R.M. Hidráulica básica. 3.ed. São Carlos: EESC-USP, 2004.

PORTO ALEGRE (CIDADE). Prefeitura Municipal de Porto Alegre. Departamento de Esgotos Pluviais. Plano Diretor de Drenagem Urbana, 6: Manual de drenagem urbana. Porto Alegre: Prefeitura Municipal de Porto Alegre, 2005. Instituto de Pesquisas Hidráulicas, Universidade Federal do Rio Grande do Sul.

PRALON, E.M.; FERREIRA, G.N. Centralidade da Câmara Municipal de São Paulo no Processo Decisório. In: ANDRADE, R.C. (org.). Processo de governo no município e no estado: uma análise a partir de São Paulo. São Paulo: Edusp, 1998.

PREVEDELLO, C.L. Estimativas da profundidade da frente de molhamento a partir da curva de infiltração. Revista Brasileira de Recursos Hídricos, v.4, n.3, p.17-21, jul./ set. 1999.

PUSCEDDU, A.; DANOVARO, R. Exergy, ecosystem functioning and efficiency in a coastal lagoon: the role of auxiliary energy. Estuarine, Coastal and Shelf Science, n.84, p.227-36, 2009.

QIU, L. A methodological study of biotope mapping in nature conservation. Urban Forestry \& Urban Greening, v.9, p.1616,2010 .

RANT, Z. Exergie, ein neues Wert für “Technische Arbeitsfähigkeit”. Forsch. Ing. Wes., n.22, p.36-7, 1956.

RICARD, J. What do we mean by biological complexity? Science de la Vie, v. 326, p.133-40, 2003.

RIGHETTO, A.M. Hidrologia e recursos hídricos. São Carlos: EESC -USP, 1998. (Projeto REENGE). 
ROSA, G. Grande sertão: veredas. 19.ed. Rio de Janeiro: Nova Fronteira, 2001.

ROSADO, B.H.P. et al. Fine root biomass and root length density in a lowland and a montane tropical rain forest, SP, Brazil. Biota Neotrop., Campinas, v.11, n.3, p.203-9, Sept. 2011.

ROGERS, R. et al. Towards a strong urban renaissance: an independent report by members of the Urban Task Force chaired by Lord Rogers of Riverside. [S.1.]: Urban Task Force, 2005.

ROSSMAN, L.A. Stormwater management model: user's manual: version 5.0. Cincinnati, OH: EPA, 2010.

ROUCHE, M. Alta idade média ocidental. In: VEYNE, P. (org.). História da vida privada, 1: do Império Romano ao ano mil. Trad. Hildegard Feist. Versão de bolso. São Paulo: Companhia das Letras, 2009. p.408-532.

ROUSSEAU, J.-J. Ensaio sobre a origem das línguas no qual se fala da melodia e da imitação musical. Trad. Lourdes Gomes Machado. In: Rousseau. São Paulo: Abril Cultural, 1973. (Os pensadores).

RUEDA, S. et al. Plan especial de indicadores de sostenibilidad de la actividad urbanística de Sevilla. Barcelona: Ayuntamiento de Sevilla, 2008.

RUSSELL, B. História do pensamento ocidental: a aventura dos pré-socráticos a Wittgenstein. Trad. Laura Alves; Aurélio Rebello. [Ed. Especial]. Rio de Janeiro: Nova Fronteira, 2013. (Saraiva de bolso).

SALAS, F. et al. Application of the exergy index as ecological indicator of organically enrichment areas in the Mar Menor lagoon (south-eastern Spain). Energy, n.30, p.2505-22, 2005.

SAMMIS, T.W.; WANG, J.; MILLER, P.R. The transition of the Blaney-Criddle formula to the Penman-Monteith equation in the western United States. Journal of Service Climatology, v.5, n.1 p.1-11, 2011.

SANDERS, R.A. Urban vegetation impacts on the hydrology of Dayton, Ohio. Urban Ecology, v.9, p.361-76, 1986.

SANTOS, D.M.; CASIMIRO, A.P.B.S. Memória e direito: as origens do bacharelismo liberal no Brasil Império (1922-1889). Educação, Gestão e Sociedade: revista da Faculdade Eça de Queirós, ano2, n.5, mar. 2012.

SANTOS, L.R.; DOS SANTOS, E.A.; FERREIRA, E.J.L. Estimativa da capacidade de biomassa e carbono da vegetação arbórea de um fragmento do parque Tucumã, em Rio Branco, Acre. Enciclopédia Biosfera, Goiânia, v.9, n.7, p.1305-21, 2013.

SÃO PAULO (CIDADE). Lei no 8.989, de 29 de outubro de 1979. Dispõe sobre o Estatuto dos Funcionários Públicos do Município de São Paulo e dá outras providências. Disponível em:

<http://www.prefeitura.sp.gov.br/cidade/secretarias/upload/chamadas/Servidores\%20-\%20Estatuto_1265987442.pdf>. Acesso em: 23 out. 2015.

Lei ${ }^{\circ} 10.365$, de 22 de setembro de 1987. Disciplina o corte e a poda de vegetação de porte arbóreo existente no Município de São Paulo, e dá outras providências. Disponível em: <http://www.prefeitura.sp.gov.br/cidade/secretarias/subprefeituras/upload/pinheiros/arquivos/LEI_10365.pdf>. Acesso em: 5 nov. 2015

Lei Orgânica do Município de São Paulo. 4 abr. 1990. Disponível em:

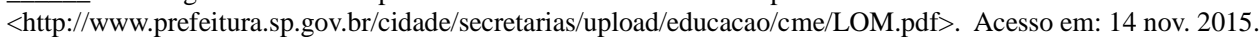

Lei $n^{\circ} 11.228 / 92 a$. Dispõe sobre as regras gerais e específicas a serem obedecidas no projeto, licenciamento, execução, manutenção e utilização de obras e edificações, dentro dos limites dos imóveis; revoga a Lei n ${ }^{\circ} 8.266$, de 20 de junho de 1975, com as alterações adotadas por leis posteriores, e dá outras providências. Disponível em:

<http://www.prefeitura.sp.gov.br/cidade/secretarias/subprefeituras/upload/pinheiros/arquivos/COE_1253646799.pdf〉. Acesso em: 5 nov. 2015.

Decreto n 32.329, de 23 de setembro de 1992b. Regulamenta a Lei 11.228, de 25 de junho de 1992 - Código de Obras e Edificações, e dá outras providências. Disponível em:

<http://www.prefeitura.sp.gov.br/cidade/secretarias/subprefeituras/upload/santo_amaro/acesso_a_informacao/Perguntas\%20freq uentes/DECRETO32329_COE_pref_Sao_paulo.pdf>. Acesso em: 5 nov. 2015.

Prefeitura do Município de São Paulo. Relatório final do Grupo de Trabalho de Detalhamento da Carta Geotécnica do Município de São Paulo, criado pela Portaria 12, de 14 de janeiro de 1992, do Gabinete do Prefeito. São Paulo, 1992c.

Prefeitura do Município de São Paulo. Carta Geoténica do Município de São Paulo. São Paulo, 1992d. Disponível

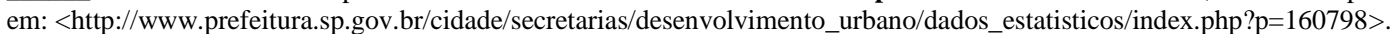
Acesso em: 28 fev.2016 
Prefeitura do Município de São Paulo. Secretaria de Vias Públicas. Suprintendência de Projetos e Obras. Diretrizes de projeto de hidráulica e drenagem urbana. Diretrizes de projeto para estudos hidrológicos - equação de chuvas: DP-H02. São Paulo, 1999a. (PMSP Secretaria de Vias Públicas, Documentos de Circulação Externa, volume 4).

Prefeitura do Município de São Paulo. Diretrizes básicas para projetos de drenagem urbana no município de São Paulo. São Paulo: PMSP, 1999b. FCTH.

Lei $n^{\circ} 13.276$, de 4 de janeiro de 2002. Torna obrigatória a execução de reservatório para as águas coletadas por coberturas e pavimentos nos lotes edificados ou não, que tenham área impermeabilizada superior a 500,00m² (quinhentos metros quadrados). Disponível em:

<http://www.leispaulistanas.com.br/sites/default/files/ReservatorioDeAgua/LEI\%2013276.PDF>. Acesso em: 15 nov. 2015.

Lei $n^{\circ}$ 13.430, de 13 de setembro de 2002b. Plano Diretor Estratégico. Disponível em:

<http://www.prefeitura.sp.gov.br/cidade/secretarias/upload/infraestrutura/sp_obras/arquivos/plano_diretor_estrategico.pdf>. Acesso em: 28 fev. 2016.

Atlas Ambiental do Município de São Paulo. São Paulo: SVMA/ SEMPLA, 2002c. Dissponível em: <http://atlasambiental.prefeitura.sp.gov.br/>. Acesso em: 29 fev. 2002c

Câmara Municipal de São Paulo. Projeto de Lei 01-822/2003 do Vereador Goulart (2003a). Dispõe sobre a proibição de rebaixamento do lençol freático, da lavagem da via pública por particulares, da proibição do uso do subsolo para ancoragens, e dá outras providências. Disponível em: <http://documentacao.camara.sp.gov.br/iah/fulltext/projeto/PL0822-2003.pdf>. Acesso em: 20 nov. 2015.

Lei ${ }^{\circ}$ 13.558, de 14.4.2003b. Dispõe sobre a regularização de edificações e dá outras providências. Disponível em: <http://www3.prefeitura.sp.gov.br/cadlem/secretarias/negocios_juridicos/cadlem/integra.asp?alt=24072004L\%20138760000>. Acesso em: 11 fev. 2016

GEO Cidade de São Paulo: panorama do meio ambiente urbano. São Paulo: SVMA/ IPT; Brasília: PNUMA, 2004.

Prefeitura do Município de São Paulo. Secretaria Municipal do Verde e do Meio Ambiente. Manual técnico de arborização urbana. 2.ed. São Paulo: SVMA, 2005a

Lei ${ }^{\circ} 14.023$, de 8 de julho de 2005b. Dispõe sobre a obrigatoriedade de tornar subterrâneo todo o cabeamento ora instalado no Município de São Paulo. Disponível em:

<http://www3.prefeitura.sp.gov.br/cadlem/secretarias/negocios_juridicos/cadlem/integra.asp?alt=09072005L\%20140230000>. Acesso em: 12 fev. 2016

Lei ${ }^{\circ}$ 14.933, de 5 de junho de 2005c. Institui a Política de Mudança do Clima no Município de São Paulo. Disponível em:

<http://www3.prefeitura.sp.gov.br/cadlem/secretarias/negocios_juridicos/cadlem/integra.asp?alt=06062009L\%20149330000 > Acesso em: 12 fev. 2016.

Decreto ${ }^{\circ} 47.817$, de 26 de outubro de 2006. Disponível em:

<http://www3.prefeitura.sp.gov.br/cadlem/secretarias/negocios_juridicos/cadlem/integra.asp?alt=27102006D\%20478170000>. Acesso em: 12 fev. 2016

Curso municipal de jardinagem. São Paulo: SVMA - Divisão Técnica Escola Municipal de Jardinagem, [2008a]

Indicadores ambientais e gestão urbana: desafios para a construção da sustentabilidade na cidade de São Paulo. São Paulo: SVMA/ Centro de Estudos da Metrópole, 2008b.

Lei ${ }^{\circ}{ }^{\circ}$ 4.933, de 5 de junho de 2009. Institui a Política de Mudança do Clima no Município de São Paulo. Disponível em:

<http://www.prefeitura.sp.gov.br/cidade/secretarias/meio_ambiente/comite_do_clima/legislacao/leis/index.php?p=15115>.

Acesso em: 1 nov. 2015

Prefeitura do Município de São Paulo. Secretaria Municipal de Desenvolvimento Urbano. Manual de drenagem e manejo de águas pluviais, 2: aspectos tecnológicos: fundamentos. São Paulo: SMDU, 2012a. Fundação Centro Tecnológico de Hidráulica.

Prefeitura do Município de São Paulo. Secretaria Municipal de Desenvolvimento Urbano. Manual de drenagem e manejo de águas pluviais, 3: aspectos tecnológicos: diretrizes para projetos. São Paulo: SMDU, 2012b. Fundação Centro Tecnológico de Hidráulica.

Prefeitura do Município de São Paulo. Curso de Treinamento PCSWMM. São Paulo: LabSid/ FCTH, 2012c.

Prefeitura do Município de São Paulo. Secretaria Municipal de Desenvolvimento Urbano. Manual de drenagem e manejo de águas pluviais, 1: gerenciamento do sistema de drenagem urbana. São Paulo: SMDU, 2012d. Fundação Centro Tecnológico de Hidráulica 
Prefeitura do Município de São Paulo. Gabinete do Prefeito. Portaria 171/12-PREF, de 13 de fevereiro de 2012e. Disponível em:

<http://www3.prefeitura.sp.gov.br/cadlem/secretarias/negocios_juridicos/cadlem/integra.asp?alt=14022012P\%20001712012PR EF\%20\%20\%20\%20\%20\%20\%20\%20\&secr=14\&depto=0\&descr_tipo=PORTARIA>. Acesso em: 20 nov. 2015.

Prefeitura do Município de São Paulo. Secretaria Municipal do Verde e do Meio Ambiente. Departamento de Educação Ambiental e Universidade Aberta do Meio Ambiente e da Cultura da Paz. Divisão Técnica Escola Municipal de Jardinagem. Curso Municipal de Recursos Paisagísticos. São Paulo, 2012f.

Prefeitura do Município de São Paulo. Secretaria Municipal do Verde e do Meio Ambiente. Departamento de Educação Ambiental e Universidade Aberta do Meio Ambiente e da Cultura da Paz. Guia de permacultura para administradores de parques. São Paulo, 2012g.

Prefeitura do Município de São Paulo. Secretaria Municipal de Infraestrutura Urbana. ETS-03/2013: pavimentos permeáveis com revestimento asfáltico poroso - CPA. São Paulo: SIURB, 2013a.

Prefeitura do Município de São Paulo. Secretaria Municipal do Verde e do Meio Ambiente. Portaria 130/13b SVMA. Disponível em:

$<$ http://www3.prefeitura.sp.gov.br/cadlem/secretarias/negocios_juridicos/cadlem/integra.asp?alt=12102013P\%20001302013SV MA>. Acesso em: 25 nov. 2015.

. Decreto $\mathrm{n}^{\circ} 54.421$, de 3 de outubro de $2013 \mathrm{c}$. Confere nova regulamentação ao procedimento de fiscalização ambiental no Município de São Paulo; revoga o Decreto no 42.833, de 6 de fevereiro de 2003. Disponível em: $<\mathrm{http} / / / \mathrm{www} 3$. prefeitura.sp.gov.br/cadlem/secretarias/negocios_juridicos/cadlem/integra.asp?alt=04102013D\%20544210000>.

Prefeitura do Município de São Paulo. Secretaria Municipal de Infraestrutura Urbana. Estudos de drenagem e manejo de águas pluviais no âmbito do contrato 008-SIURB/2014. São Paulo: SIURB, 2014a. FCTH.

Lei no 16.050, de 31 de julho de 2014b. Aprova a Política de Desenvolvimento Urbano e o Plano Diretor Estratégico do Município de São Paulo e revoga a Lei no 13.430/2002. Disponível em:

<http://www.prefeitura.sp.gov.br/cidade/secretarias/upload/chamadas/2014-07-31_-_lei_16050_-

_plano_diretor_estratgico_1428507821.pdf>. Acesso em: 23 out. 2015.

Prefeitura do Município de São Paulo. Oficina técnica da Quota Ambiental: texto de referência para discussão. São Paulo, 2014c. Paulo Mantey Domingues Caetano, Patrícia Marra Sepe, Hélia Maria Santa Bárbara Pereira e Lara Cavalcanti Ribeiro de Figueiredo.

Prefeitura do Município de São Paulo. Secretaria Municipal do Verde e do Meio Ambiente. Departamento de Controle da Qualidade Ambiental. Portaria 1/14d - DECONT-SVMA. Disponível em:

$<$ http://www3.prefeitura.sp.gov.br/cadlem/secretarias/negocios_juridicos/cadlem/integra.asp?alt=14012014P\%20000012014SV MA\%20\%20DECONT>

RESOLUÇÃO 170/14 CADES/SVMA, de 05 de dezembro de 2014e. Disponível em:

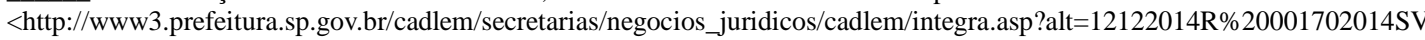
MA\% $20 \% 20$ CADES>.

Projeto de lei nº 272/2015a, referente à revisão da lei de parcelamento, uso e ocupação do solo. Disponível em:

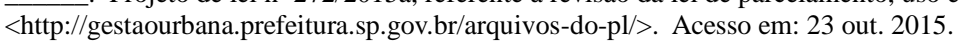

Lei ${ }^{\circ} 16.277$, de 5 de outubro de 2015b. Dispõe sobre a obrigatoriedade da instalação de „Telhado Verde“ nos locais que especifica e dá outras providências. Disponível em:

$\langle$ http://www3.prefeitura.sp.gov.br/cadlem/secretarias/negocios_juridicos/cadlem/integra.asp?alt=06102015L\%20162770000〉. Acesso em: 6 dez. 2015.

Decreto $\mathrm{n}^{\circ} 55.994$, de 10 de março de 2015 c. Introduz alterações no artigo $4^{\circ}$ do Decreto $\mathrm{n}^{\circ}$ 53.889, de 8 de maio de 2013, que regulamenta o Termo de Compromisso Ambiental - TCA. Disponível em:

<http://www3.prefeitura.sp.gov.br/cadlem/secretarias/negocios_juridicos/cadlem/integra.asp?alt=11032015D\%20559940000>. Acesso em: 6 dez. 2015.

Prefeitura do Município de São Paulo. Secretaria Municipal do Verde e do Meio Ambiente. Manual Técnico de Arborização Urbana. 3.ed.rev.ampl. São Paulo, 2015d.

SÃO PAULO (ESTADO). Carta de aptidão física ao assentamento urbano: guia de utilização. São Paulo: CDHU/ SCTDE/ EMPLASA/ IPT: 1990.

Lei no 7.663, de 30 de dezembro de 1991. Estabelece normas de orientação à Política Estadual de Recursos Hídricos bem como ao Sistema Integrado de Gerenciamento de Recursos Hídricos. Disponível em:

$\langle$ http://www.cetesb.sp.gov.br/licenciamento/documentos/1991_Lei_Est_7663.pdf〉. Acesso em: 8 set.2015. 
Lei ${ }^{\circ} 12.526$, de 2 de janeiro de 2007. Estabelece normas para a contenção de enchentes e destinação de águas pluviais. Disponível em: <http://www.al.sp.gov.br/repositorio/legislacao/lei/2007/lei-12526-02.01.2007.html>. Acesso em: 15 nov. 2015.

Governo do Estado de São Paulo. Secretaria de Estado do Meio Ambiente. Fundo Estadual de Recursos Hídricos. Novos procedimentos para drenagem de estruturas subterrâneas: relatório final. São Paulo: FCTH, 2012.

Deliberação CONSEMA Normativa 01/2014, de 23 de abril de 2014. Fixa tipologia para o exercício da competência municipal, no âmbito do licenciamento ambiental, dos empreendimentos e atividades de potencial impacto local, nos termos do Art. 9, inciso XIV, alínea “a”, da Lei Complementar Federal 140/2011. Disponível em: < http://www.ambiente.sp.gov.br/consema/files/2014/01/DelNormativa01.pdf >.

SCHLINDWEIN, V.L.C.; MORAIS, P.R. Prevalência de transtornos mentais e comportamentais nas instituições públicas federais. Cadernos de Psicologia Social do Trabalho, São Paulo, v.17, n.1, p.117-27, 2014.

SCHNEIDER, E.D.; KAY, J.J. Life as manifestation of Second Law of Thermodynamics. Mathl. Comput. Modelling, v.19, n. $6-8$, p. $25-48,1994$.

Order from disorder: the thermodynamics of complexity in biology. In: MURPHY, M.P.; O’NEILL, L.A. (ed.). What is life: the next fifty years: reflections of the future of biology. Cambridge: Cambridge University Press, 1995. p.161-72.

Ordem a partir da desordem: a termodinâmica da complexidade biológica. In: MURPHY, M;P.; O’NEILL, L.A. (org.). "O que é vida?" 50 anos depois: especulações sobre o futuro da biologia. São Paulo: Ed. UNESP, 1997. (UNESP/ Cambridge). p.187-201. Tradução da obra acima.

SCIUBBA, E.; WALL, G. A brief commented history of exergy from the beginnings to 2004. International Journal of Thermodynamics, v.10, n.1, p.1-26, March 2007.

SEARLE, J.R. What is an institution? Journal of Institutional Economics, v.1, n.1, p.1-22, 2005.

SHANNON, C.E. A mathematical theory of communication. The Bell System Technical Journal, v.27, p.379-423 e 623-56, Jul./ Oct. 1948.

SHEAFFER, J. R. Urban storm drainage management. NewYork: Marcel Dekker, 1982.

SILOW, E.A. Exergy changes in lakes around the world under pressure from global change. Archives des Sciences, v.65, p.209-14, 2012.

; MOKRY, A.V. Exergy as a tool for ecosystem health assessment. Entropy, n.12, p.902-25, 2010.

; MOKRY, A.V.; JØRGENSEN, S.E. Some applications of Thermodynamics for ecological systems. In: MORENO,

J.C. (ed.). Thermodynamics: interaction studies: solids, liquids and gases. Rijeka, Croatia: InTech, $2011 \mathrm{a}$.

; MOKRY, A.V.; JØRGENSEN, S.E. Eco-exergy use for ecosystem health assessment. In: INTERNATIONAL JOURNEY OF EXERGY, 2011b, Paris. Proceedings...

et al. Case studies of eco-exergy use for ecosystem health assessment. In: INTERNATIONAL JOURNEY OF EXERGY, 2011c, Paris. Proceedings...

SILVA, E.B.F. et al. Transtornos mentais e comportamentais: perfil dos afastamentos de servidores públicos estaduais em Alagoas, 2009. Epidemiol. Serv. Saúde, Brasília, v.21, n.3, p.505-14, jul./ set. 2012.

SILVEIRA, E.A. et al. O estado da arte na estimativa de biomassa e carbono em formações florestais. Floresta, Curitiba, v.38, n.1, p.185-206, jan./ mar. 2008

SILVEIRA, M.M.; DE BRITO, A.N. O papel da empatia e das emoções nas distinções sociais. Natureza Humana - Revista Internacional de Filosofia e Psicanálise, São Paulo, v.15, n.2, p.140-59, 2014.

SILVA, L.D.B.; GUIMARÃES, A.J.A.; CARVALHO, D.F. Saneamento Básico. Seropédica, RJ, 2007. Notas de aula do curso IT 179 Saneamento Básico - Instituto de Tecnologia da Universidade Rural do Rio de Janeiro. Disponível em: <http://www.ufrrj.br/institutos/it/deng/leonardo/downloads/APOSTILA/Apostila\%20IT\%20179/Cap\%201.pdf>. Acesso em: 8 set. 2015.

SIMON, M.; BENOIT, A. Judaísmo e cristianismo antigo: de Antíoco Epifânio a Constantino. São Paulo: Pioneira/ Edusp, 1987.

SKÄRBÄCK, E. Landscape planning to promote well being: studies and examples from Sweden. Environmental Practice, v.9, n.3, p. 206-17, Sept. 2007.

SKROBACKI, Z. Selected methods for the estimation of the logistic function parameters. Eksploatacja, n.3, p.52-6, 2007. 
SLACK, C.R.; HATCH, M.D. Comparative studies on the activity of carboxylase and other enzymes in relation to the new pathway of photosynthetic carbon dioxide fixation on tropical grasses. Biochemical Journal, v.103, p.660-5, 1967.

SOARES, A.R. et al. Calibração do software ENVI-met ao clima de João Pessoa - PB: aplicação do campus João Pessoa do IFPB. SEMANA DE CIÊNCIA E TECNOLOGIA DO IFPB, 7., 2011, João Pessoa. Anais... João Pessoa: IFPB, 2011.

SPANGENBERG, J. et al. Simulation of the influence of vegetation on microclimate and thermal comfort in the city of São Paulo. Revista da Sociedade Brasileira de Arborização Urbana, Piracicaba, v.3, n.2, p.1-19, jun. 2008.

Retro-innovating nature in megacities: São Paulo/ Brazil: a case study. 2010. Dissertation (Doktorat) - Fakultät Architektur der Bauhaus-Universität Weimar, Weimar.

SPIRN, A.W. The authority of nature: conflict and confusion in landscape architecture. In: BULMAHN, J. (ed.). Nature and ideology. Washington, D.C.: Wolschke-Dumbarton Oaks, 1997, p.249-6.

STEENHUIS, T.S. et al. SCS runoff equation revisited for variable source runoff areas. Journal of Irrigation and Drainage Engineering, p.234-8, May/ June 1995.

STENNING, E. An assessment of the Seattle Green Factor: increasing and improving the quality of urban green structure. 2008. Thesis (Mastery Urban Planning) - Department of Urban Design and Planning, University of Washington, [s.1.].

STREETER, V.L.; WYLIE. E.B. Mecânica dos Fluidos. 7.ed. São Paulo: McGraw-Hill, 1982

SUKOPP, H.; WEILER, S. Biotope mapping and nature conservation strategies in urban areas of the Federal Republic of Germany. Landscape and Urban Planning, n.15, p.39-58, 1988.

SVIREZHEV, Y.M. Thermodynamics and ecology. Ecological Modelling, n.132, p.11-22, 2000

; STEINBORN, W.H. Exergy of solar radiation: information approach. Ecological Modelling, v.145, issues 2-3, p.10110, Nov. 2001

TAKÁCS, A.; KISS, M.; GULYÁS, Á. Some aspects of indicator development for mapping microclimate regulation ecosystem for urban tree stands. ACTA CLIMATOLOGICA ET CHOROLOGICA Universitatis Szegediensis, Szeged, Hungary, v.4748, p.99-108, 1999.

TAKIYA, H. Estudo da sedimentação neogênico-quaternária no município de São Paulo: caracterização dos depósitos e suas implicações na geologia urbana. 1997. Tese (Doutorado em Geologia Sedimentar) - Instituto de Geociências, Universidade de São Paulo, São Paulo.

TAUBE, O.L.S. Revista Uningá, n.1, p.59-62, jun. 2004. Resenha de: BAZZO, E.F. Algumas considerações sobre a saúde mental dos funcionários públicos. Psicologia Ciência e Profissão, v.17, n.1, p.41-4, 1997.

TERZAGHI, K.; PECK, R.B. Mecánica de suelos en la ingeniería práctica. 2.ed. Buenos Aires: El Ateneo, 1958.

THADANI, D.A. The language of towns \& cities. New York: Rizzoli, 2010

TOBIN, B. et al. Assessment of allometric algorithms for estimating leaf biomass, leaf area index and litter fall in differentaged Sitka spruce forests. Forestry, v.79, n.4, p.453-65, 2006.

TOMAZ, P. Detenção em lotes em Guarulhos. [Guarulhos], 2001.

Cálculos hidrológicos e hidráulicos para obras municipais. [S.1.]: Navegar, 2002.

Reservatórios para múltiplas finalidades. [Guarulhos], 2003.

Aproveitamento de águas de chuva para áreas urbanas e fins não potáveis. São Paulo: Navegar, 2004.

Poluição difusa. São Paulo: Navegar, 2006.

TRIGO, T.R.; TENG, C.T., HALLAK, J.E.C. Síndrome de burnout ou estafa profissional e os transtornos psiquiátricos. Revista de Psiquiatria Clínica, São Paulo, v.34, n.5, p.223-33, 2007.

TSCHEBOTARIOFF, G.P. Foundations, retaining and earth structures: the art of design and construction and its scientific basis in soil mechanics. 2.ed. McGraw-Hill Kogakusha: Tokyo, 1973.

TUCCI, C.E.M. Modelos determinísticos. In: BARTH, F.T. et al. Modelos para gerenciamento de recursos hídricos. São Paulo: Nobel/ ABRH, 1987. (Coleção ABRH de recursos hídricos, n.1). p.211-324. 
Intercepção. In: (org.). Hidrologia: ciência e aplicação. Porto Alegre: Editora da UFRGS; São Paulo: Edusp, 1993. (Coleção ABRH de Recursos Hídricos v.4). p.243-52.

Coeficiente de escoamento e vazão máxima de bacias urbanas. Revista Brasileira de Recursos Hídricos, v.5, n.1,

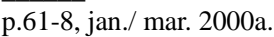

Estimativa do volume para controle da drenagem urbana. In: TUCCI, C.E.M.; MARQUES, D.M.L.M. (org.)

Avaliação e controle da drenagem urbana. Porto Alegre: ABRH, 2000b.

Elementos para o controle da drenagem urbana. Artigo em elaboração para submeter à RBRH.

; BELTRAME, L.F.S. Evaporação e evapotranspiração. In: TUCCI, C.E.M. (org.). Hidrologia: ciência e aplicação. Porto Alegre: Editora da UFRGS; São Paulo: Edusp, 1993. (Coleção ABRH de Recursos Hídricos v.4). p.253-83.

TULLOCK, G. The general irrelevance of the general impossibility theorem. The Quarterly Journal of Economics, v.81, n.2, p.256-70, May 1967

TUNICK, A. Critical assessment of selected of urban microclimate model frameworks. Adelfi: Army Research Laboratory, 2005.

TURNER, D.P. et al. Assessing alternative allometric algorithms for estimating leaf area of Douglas-fir trees and stands. Forest Ecology and Management, v.126, p.61-76, 2000

UHL, C.; BUSCHBACHER, R.; SERRÃO, E.A.S. Abandoned pastures in eastern Amazon, I: patterns of plant succession. Journal of Ecology, Oxford, v.76, p.663-81, 1988

ULANOWICZ, R.E.; JØRGENSEN, S.E., FATH, B.D. Exergy, information and aggradation: an ecosystem reconciliation. Ecological Modelling, n.198, p.520-4, 2006.

ULEN, T.S. The Arrow impossibility theorem. Law and Economics, Fall 2004.

UNITED KINGDOM OF GREAT BRITAIN AND NORTHERN IRELAND. Northern Ireland. Department of the Environment. The Planning Service. Planning and flood risk. Belfast, 2006. (Planning Policy Statement 15).

Northern Ireland Assembly. Research and Library Service. Sustainable urban drainage: policy and legislation in NI. [S.1.], 2010. (Research and Library Service paper 109/10 NIAR 398-10). Suzie Cave.

Department for Environment, Food and Rural Affairs (DEFRA). National Standards for sustainable drainage systems: designing, constructing, operating and mantaining drainage for surface runoff. London: DEFRA, 2011.

URBONAS, B.; STAHRE, P. Stormwater: best management practices and detention for water quaility, drainage, and CSO management. Englewood Cliffs: Prentice-Hall, 1993.

URTADO, M.C. Transplante de árvores: verificação e análise da sobrevivência de exemplares arbóreos transplantados em terrenos edificados no município de São Paulo. 2008. Dissertação (Mestrado em Tecnologia Ambiental) - Instituto de Pesquisa Tecnológica do Estado de São Paulo, São Paulo.

UTAH COOPERATIVE EXTENSION SERVICE. Salt Lake County named urban forestry research area. Tree Leaves, v.9, n.2, p.1-2, 1985 .

VALESAN, M. Percepção ambiental de moradores de edificações residenciais com pele-verde em Porto Alegre. 2009. Dissertação (Mestrado) - Escola de Engenharia, Universidade Federal do Rio Grande do Sul, Porto Alegre.

VAN WYLEN, G.J.; SONNTAG, R.E. Fundamentos da termodinâmica clássica. 2.ed. São Paulo: Edgard Blücher, 1976.

VASKOVIĆ, S. et al. A new approach at the selection of optimal variant of energy upply chain based on biomass. [Sarajevo]: s.n., 2015.

VARGAS, M. Metodologia da pesquisa tecnológica. Rio de Janeiro: Globo, 1985.

VASSALO, P. et al. Assessing the health of coastal marine ecosystems: a holistic approach based on sediment micro and meiobenthic measures. Ecological Indicators, n.6, p.525-42, 2006.

VON SPERLING, M. Princípios básicos do tratamento de esgotos. Belo Horizonte: DESA-UFMG, 1996.

WALL, G. Exergetics. Bucaramanga: [s.n.], 2009. 45, 2001.

GONG, M. On exergy and sustainable development - Part 1: conditions and concepts. Exergy Int. J., v.1, n.3, p.128-

WATTS JR, J.M. Systems concepts for building fire safety. In: COTE, A.E. et al. (ed.). Fire Protection Handbook. 18.ed. 
Quincy, Massachussetts: NFPA, 1997.

WESTPHAL, M.; PINHEIRO, T.C. A epistemologia de Mario Bunge e sua contribuição para o ensino de Ciências. Ciência \& Educação, v.10, n.3, p.585-96, 2004.

WIEDIJK, F. Arrow's impossibility theorem. Formalized Mathematics, v.15, n.4, p.171-4, 2007.

WILKEN, P.S. Engenharia de drenagem superficial. São Paulo: CETESB, 1978.

WILLIAMS, B.P. et al. Phenotypic landscape inference reveals multiple evolutionary paths to $\mathrm{C}_{4}$ photosynthesis. eLife, 2013.

WILSON, A.G. Entropy in urban and regional modeling. London: Pion, 1970.

WOOD JR. Uma nação de videotas. Carta Capital, ano 21, n. 872, p.41, 21 out. 2015.

XU, F. et al. Modeling the effects of ecological engineering on ecosystem health of a shallow eutrophic Chinese lake (Lake Chao). Ecological Modelling, n.117, p.239-60, 1999.

; TAO, S. On the study of ecosystem health. Journal of Environmental Science, v.12, n.1, p.33-8, 2000.

et al. Marine coastal ecosystem health assessment: a case study of the Tolo Harbour, Hong Kong, China. Ecological Modelling, n.173, p.355-70, 2004.

et al. An ecosystem health index methodology (EHIM) for lake ecosystem health assessment. Ecological Modelling, n.188, p. $327-39,2005$.

et al. Ecosystem health assessment of the plant-dominated Bayangdian Lake based on eco-exergy. Ecological Modelling, n.222, p.201-9, 2011.

et al. Ecosystem health assessment of Bayangdian Lake based on thermodynamics indicators. Procedia Environmental Sciences, n.13, p.2402-13, 2012.

; JØRGENSEN, S.E.; TAO. S. Ecological indicators for assessing freshwater ecosystem health. Ecological Modelling, n.116, p.77-106, 1999.

YIN, R.K. Estudo de caso: planejamento e métodos. 2.ed. Porto Alegre: Bookman, 2001.

ZHANG, L.L. et al. Integrated ecosystem health assessment of a macrophyte-dominated lake. Ecological Modelling. n.252, p.141-52, 2013.

ZIMERMAN, D.E. Vocabulário contemporâneo de psicanálise. Porto Alegre: Artmed, 2008.

Etimologia de termos psicanalíticos. Porto Alegre: Artmed, 2012. 
ANEXOS 


\section{ANEXO 1 JUSTIFICATIVA DA EXPRESSÃO DE ECOEXERGIA DE JØRGENSEN}

Como vimos, BENDORICCHIO e JØRGENSEN apud DEWULF et al. (2008, p.2223-4) $)^{216}$ apresentam cálculo do conteúdo de exergia de um componente de ecossistema como a probabilidade de produzir o componente considerado no equilíbrio termodinâmico. Para os componentes biológicos de um ecossistema, ela consiste na probabilidade de produzir a matéria orgânica (termo clássico da exergia) e na probabilidade de encontrar o código genético, isto é, a sequência correta de nucleotídeos do DNA (termo da exergia informacional), sendo obtida uma expressão relacionando ambos os termos. Assim, a exergia de organismos e de ecossistemas pode ser estimada por (SILOW, MOKRY e JØRGENSEN, 2011a e 2011b):

$$
\mathrm{Ex} / \mathrm{RT}=\Sigma_{\mathrm{i}=1, \mathrm{n}} \mathrm{c}_{\mathrm{i}} \cdot \beta_{\mathrm{i}} \quad\left[\mathrm{g} \text { detritus. } \mathrm{m}^{-3}\right]^{217}
$$

sendo Ex: ecoexergia total do sistema, em J; R: constante universal dos gases, no valor de 8,31 J.Mol ${ }^{-1} \cdot \mathrm{K}^{-1}$; T: temperatura absoluta do ambiente, em $\mathrm{K}$; $\mathrm{c}_{\mathrm{i}}$ : concentração da biomassa, em g.m-3; $\beta_{\mathrm{i}}$ : fator de conversão ecoexergia-biomassa, que reflete a quantidade de informação armazenada no organismo ou no ecossistema.

Neste anexo é apresentada a justificativa da expressão acima, além de comentar a respeito dos procedimentos para compilar listas de $\beta \mathrm{s}$. Embora ela esteja disponível nas referências apresentadas, sua discussão aqui proporcionará a explicitação de pressupostos e o aclaramento de pontos que, de outra forma, permaneceriam não visíveis. Além disso, esforçamo-nos por integrar distintas referências bibliográficas e, na medida do possível, torná-las mais palatáveis.

Nesse âmbito teórico, seres vivos e ecossistemas, do ponto de vista termodinâmico, realizam seus processos distantes do equilíbrio com o meio, situando-se em níveis mais altos de ordem e informação. É necessário, assim, para descrevê-los, recorrer à termodinâmica distante do equilíbrio. Um tratamento desse tipo é encontrado em SVIREZHEV (2000).

\footnotetext{
${ }^{216}$ As referências relativas a este anexo estão apresentadas no item 18 do texto principal. ${ }^{217}$ A respeito das unidades de volume, v. discussão mais adiante.
} 
Consideremos inicialmente a taxa de produção de entropia, ou taxa de dissipação de energia, a assim chamada função dissipativa $\beta$ (não confundir com o fator de conversão exergia-biomassa) ${ }^{218}$ Três questões se colocam: a) como calcular $\beta$ referente a um sistema distante do equilíbrio se não conhecemos as equações cinéticas apropriadas? b) nesse caso, o que se pode calcular?; c) que espécie de afirmações "termodinâmicas" podem ser formuladas nesse caso?

Suponhamos que a cinética de um sistema biológico seja descrita pelo seguinte sistema de equações diferenciais ordinárias:

$$
\mathrm{dC}_{\mathrm{i}} / \mathrm{dt}=\mathrm{f}_{\mathrm{i}}\left(\mathrm{C}_{1}, \ldots, \mathrm{C}_{\mathrm{n}}\right) \quad \mathrm{i}=1, \ldots, \mathrm{n} \quad \mathrm{C}_{\mathrm{i}} \in \mathrm{P}^{\mathrm{n}}
$$

sendo $\mathbf{C}=\left\{\mathrm{C}_{\mathrm{i}}\right\}$ um vetor de variáveis de estado e $\mathrm{P}^{\mathrm{n}}$ um ortante positivo.

Imponhamos ao sistema um único ponto estável de equilíbrio $\mathbf{C}^{*}$ :

$$
\mathbf{C}^{*}=\left\{\mathrm{C}_{\mathrm{i}} *\right\} \in \mathrm{P}^{\mathrm{n}}
$$

tal que $\mathbf{C} \rightarrow \mathbf{C}^{*}$ quando $\mathrm{t} \rightarrow \infty$ para qualquer $\mathrm{C} \in \mathrm{P}^{\mathrm{n}}$.

A forma exata de tais equações é frequentemente desconhecida. Na melhor das hipóteses dispomos de uma série temporal de observações registradas no curso de transições do estado inicial $\mathbf{C}^{0}=\left\{\mathrm{C}_{\mathrm{i}}^{0}\right\}$ em direção ao estado de equilíbrio $\mathbf{C}^{*}=$ $\left\{\mathrm{C}_{\mathrm{i}}{ }^{*}\right\}$. Ela corresponde à solução seguinte desconhecida (por nós) do sistema básico de equações diferenciais:

$$
\mathbf{C}=\mathbf{C}\left(\mathrm{C}^{0}, \mathrm{t}\right)
$$

De qualquer forma, é possível calcular a quantidade total de energia dissipada L:

$$
\mathrm{L}=\int_{\mathrm{t}, \infty} \beta(\mathrm{t}) \mathrm{dt}
$$

para a transição $\mathbf{C}\left(\mathrm{t}_{0}\right)=\mathbf{C}^{0} \rightarrow \mathbf{C}^{*}(\infty)$ em um caso especial.

Suponhamos que a dinâmica do sistema seja um movimento dentro de um campo potencial com os potenciais químicos:

$$
\mu_{\mathrm{i}}=\mu_{\mathrm{i} 0}+\mathrm{RT} \ln \mathrm{C}_{\mathrm{i}} \quad \mathrm{i}=1, \ldots, \mathrm{n}
$$

sendo $\mu_{\mathrm{i}}$ o potencial químico do componente $\mathrm{i}, \mu_{\mathrm{i} 0} \mathrm{o}$ potencial químico do componente i no estado de equilíbrio com o meio, $\mathrm{C}_{\mathrm{i}}$ as concentrações molares da substância i, R a constante universal dos gases e T a temperatura absoluta.

Suponhamos que todos os componentes do sistema sejam substâncias de

\footnotetext{
${ }^{218} \mathrm{O}$ autor iguala $\beta$ à derivada da entropia em relação ao tempo: $\beta=\mathrm{dS} / \mathrm{dt}$. Queremos crer, no entanto, que mais adequado seria $\beta=\mathrm{d}(\mathrm{S} . \mathrm{T}) / \mathrm{dt}$
} 
origem idêntica, ou pelo menos similar, de tal forma que:

$$
\mu_{10}=\mu_{20}=\ldots=\mu_{n}
$$

Os valores iniciais são arbitrários, de forma que podemos considerar qualquer ponto $\mathbf{C}(\mathrm{t})$, exceto $\mathbf{C}^{*}$, como um ponto inicial.

Uma vez que a afinidade para a reação (transição) $\mathrm{C}_{\mathrm{i}} \rightarrow \mathrm{C}_{\mathrm{i}}$ * é igual a:

$$
\mathrm{A}_{\mathrm{i}, \mathrm{i}}{ }^{*}=\mathrm{RT} \ln \left(\mathrm{C}_{\mathrm{i}} / \mathrm{C}_{\mathrm{i}}^{*}\right)
$$

decorre que:

$$
\begin{gathered}
\mathrm{L}=\int_{\mathrm{t} 0, \infty} \beta(\mathrm{t}) \mathrm{dt}=\int_{\mathrm{t} 0, \infty} \sum_{\mathrm{i}=1, \mathrm{n}} \beta_{\mathrm{i}}(\mathrm{t}) \mathrm{dt}=\mathrm{RT} \sum_{\mathrm{i}=1, \mathrm{n}} \int_{\mathrm{t} 0, \infty} \ln \left(\mathrm{C}_{\mathrm{i}}(\mathrm{t}) / \mathrm{C}_{\mathrm{i}} *\right) \mathrm{d} \mathrm{C}_{\mathrm{i}} / \mathrm{dt} \mathrm{dt}= \\
=\mathrm{RT} \sum_{\mathrm{i}=1, \mathrm{n}} \int_{\mathrm{Ci}(\mathrm{t}), \mathrm{Ci}(\infty)}\left(\ln \mathrm{C}_{\mathrm{i}}-\ln \mathrm{nC}_{\mathrm{i}}{ }^{*}\right) \mathrm{dC}_{\mathrm{i}}=\mathrm{RT} \sum_{\mathrm{i}=1, \mathrm{n}}\left[-\mathrm{C}_{\mathrm{i}} \ln \left(\mathrm{C}_{\mathrm{i}} / \mathrm{C}_{\mathrm{i}}^{*}\right)+\left(\mathrm{C}_{\mathrm{i}}-\mathrm{C}_{\mathrm{i}}{ }^{*}\right)\right]= \\
\mathrm{L}=\sum_{\mathrm{i}=1, \mathrm{n}} \mathrm{L}_{\mathrm{i}}=-\mathrm{RT} \sum_{\mathrm{i}=1, \mathrm{n}}\left[\mathrm{C}_{\mathrm{i}} \ln \left(\mathrm{C}_{\mathrm{i}} / \mathrm{C}_{\mathrm{i}}^{*}\right)-\left(\mathrm{C}_{\mathrm{i}}-\mathrm{C}_{\mathrm{i}}{ }^{*}\right)\right]
\end{gathered}
$$

Podemos ver que $\mathrm{L}<0 \mathrm{p} /$ qq $\mathrm{C}_{\mathrm{i}}>0$ (exceto $\mathrm{C}_{\mathrm{i}}=\mathrm{C}_{\mathrm{i}}$, , quando $\mathrm{L}=0$ ). Nas palavras de Svirezhev:

Isso significa que, para qualquer sistema aberto distante do equilíbrio termodinâmico (quando o sistema se move de um estado não estacionário para um equilíbrio dinâmico estável), a variação total de entropia é negativa. Além disso, esse valor não depende das características da transição. Por outro lado, processos espontâneos (quando o sistema fechado se afasta em direção a um equilíbrio dinâmico estável a partir de pequenas flutuações internas) são acompanhados pelo aumento de entropia. No nosso caso, a transição $\mathrm{C} \rightarrow \mathrm{C}^{*}$ não é espontânea, mas forçada, uma vez que depende da interação entre o sistema e o seu ambiente. É óbvio que a diminuição de entropia (em processos de transição similares) é o resultado de consumo (pelo sistema) de energia livre proveniente do ambiente. Por sua vez, isso é um resultado de processos de troca, que dão uma contribuição negativa à produção de entropia. (SVIREZHEV, 2000, p.19).

A partir da definição de $\beta$, podemos escrever ${ }^{219}$ :

$\beta=d S / d t=d_{e} S / d t+d_{i} S / d t$

sendo $\beta_{\mathrm{e}}=\mathrm{d}_{\mathrm{e}} \mathrm{S} / \mathrm{dt}$ um resultado de trocas entre o sistema e o seu ambiente e $\beta_{\mathrm{i}}=\mathrm{d}_{\mathrm{i}} \mathrm{S} / \mathrm{dt}$ um resultado de processos espontâneos irreversíveis dentro do sistema. Retornando a Svirezhev:

Para sistemas em "quasi-equilibrium" (o domínio da termodinâmica linear, o "mundo de Prigogine"), $\beta^{*}$ (e $\left|\beta_{\mathrm{e}}^{*}\right|$ ) é mínimo. Portanto, em sistemas abertos similares, quando todos os processos de transição tiverem terminado e um estado quase estacionário, um estado de "quasiequilibrium", tiver sido estabelecido, o "armazenamento total de energia" deve ser mínimo. No nosso caso, para sistemas abertos distantes do equilíbrio termodinâmico, o "armazenamento total de energia" aumenta a expensas de trocas entre o sistema e seu ambiente no curso de uma transição forçada em direção a um equilíbrio dinâmico estável, de maneira que $\mathrm{L}<0$. (SVIREZHEV, 2000, p.19).

${ }^{219}$ V. nota anterior. 
Suponhamos agora que o lado direito de (1) dependa de alguns parâmetros $\alpha_{1}$, $\ldots, \alpha_{\mathrm{m}}$ de tal maneira que:

$$
\mathrm{dC}_{\mathrm{i}} / \mathrm{dt}=\mathrm{f}_{\mathrm{i}}\left(\mathrm{C}_{1}, \ldots, \mathrm{C}_{\mathrm{n}} ; \alpha_{1}, \ldots, \alpha_{\mathrm{m}}\right)
$$

$\mathrm{O}$ vetor de parâmetros $\boldsymbol{\alpha}$ descreve um estado do ambiente. É óbvio que o equilíbrio $\mathbf{C}^{*}$ depende de $\boldsymbol{\alpha}$. Svirezhev se propõe a realizar um Gedankenexperiment (experimento mental), segundo o qual:

a) o estado corrente do ambiente é descrito por um vetor $\boldsymbol{\alpha}_{1}$, do que decorre $\mathbf{C}^{*}=\mathbf{C} *\left(\alpha_{1}\right)$

b) altera-se o meio do estado $\boldsymbol{\alpha}_{1}$ ao estado $\boldsymbol{\alpha}_{2} \mathrm{em}$ um intervalo de tempo rápido em comparação com a ordem de grandeza de tempo associada ao sistema;

c) gasta-se energia (trabalho) $\mathrm{E}_{1,2}$ para fazer essa transição;

d) após essa mudança, o estado $\mathbf{C}^{*}\left(\boldsymbol{\alpha}_{1}\right)$ deixa de ser um estado estacionário e o sistema começa a evoluir em direção a um novo estado estacionário $\mathbf{C}^{*}\left(\boldsymbol{\alpha}_{2}\right)$.

Calculando a energia "dissipativa" dessa transição, teríamos:

$$
\mathrm{L}_{1,2}=-\mathrm{RT} \sum_{\mathrm{i}=1, \mathrm{n}}\left\{\left[\mathrm{C}_{\mathrm{i}}^{*}\left(\alpha_{1}\right) \ln \left[\mathrm{C}_{\mathrm{i}}^{*}\left(\alpha_{1}\right) / \mathrm{C}_{\mathrm{i}}^{*}\left(\alpha_{2}\right)\right]-\left[\mathrm{C}_{\mathrm{i}}^{*}\left(\alpha_{1}\right)-\mathrm{C}_{\mathrm{i}}^{*}\left(\alpha_{2}\right)\right]\right\}\right.
$$

Da Segunda Lei da Termodinâmica, $E_{1,2} \geq-\mathrm{L}_{1,2}$. O mínimo de $\mathrm{E}_{1,2}$ corresponde $\mathrm{a}-\mathrm{L}_{1,2}$. Consideremos o caso extremo e assumamos que $\mathrm{E}_{1,2}=-\mathrm{L}_{1,2}$.

Seja o vetor $\boldsymbol{\alpha}_{1}$ como o estado atual do ambiente (de uma maneira geral, a biosfera), o vetor $\boldsymbol{\alpha}_{2}$ como algum ambiente pré-biológico e $\mathbf{C}^{*}\left(\boldsymbol{\alpha}_{2}\right)=\mathbf{C}^{\mathbf{0}}$ como equivalente às concentrações de elementos biogênicos em algumas estruturas prébiológicas. Concluímos imediatamente que $\mathrm{E}_{1,2}$ corresponde à equação proposta por MEJER e JØRGENSEN (1979)220 apud BENDORICCHIO e JØRGENSEN (1997) como expressão da exergia de ecossistemas:

$$
\mathrm{Ex}=\mathrm{RT} \sum_{\mathrm{i}=1, \mathrm{n}}\left[\mathrm{c}_{\mathrm{i}} \cdot \ln \left[\mathrm{c}_{\mathrm{i}} / \mathrm{c}_{\mathrm{ieq}}\right)-\left(\mathrm{c}_{\mathrm{i}}-\mathrm{c}_{\mathrm{ieq}}\right)\right]
$$

sendo Ex: exergia; R: constante universal dos gases; $\mathrm{c}_{\mathrm{i}}$ : concentração do i-ésimo componente do ecossistema; c cieq: concentração do i-ésimo componente do ecossistema na situação de equilíbrio termodinâmico com o meio (no caso, mesma pressão e temperatura, uma vez que podem ser desconsiderados outros termos como velocidade e altura).

${ }^{220}$ MEJER, H.F.; JØRGENSEN, S.E. Energy and ecological buffer capacity. In: CONFERENCE ON ECOLOGICAL MODELLING, Copenhagen, 1978. Proceedings... JØRGENSEN, S.E. (ed.). State of art of ecological modelling: environmental sciences and applications. Copenhagen: International Society for Ecological Modelling, 1979. p.829-46. 
É necessária uma consideração especial em relação aos índices i da equação. $\mathrm{O}$ índice 0 trata dos componentes inorgânicos do sistema. $\mathrm{O}$ índice 1 refere-se aos componentes orgânicos do sistema não associados a seres vivos; como matéria morta, chamados de detritus ${ }^{221}$. Os índices seguintes (a partir de n=2) referem-se cada um aos diferentes componentes vivos considerados no ecossistema.

Svirezhev conclui:

Vamos lembrar que a exergia é igual ao trabalho necessário para tal transformação do ambiente do ecossistema, de forma que nesse novo ambiente o sistema evolui em direção a um estado pré-biológico. Ele pode ser considerado como um equilíbrio termodinâmico, isto é, corresponde à morte do sistema. Em outras palavras, a exergia é uma energia necessária para matar o sistema, para destruí-lo. Note (isso é muito importante) que o trabalho não pode ser feito diretamente no sistema, devendo sê-lo no seu ambiente, ou seja, não podemos matar o sistema diretamente. Para fazê-lo, devemos mudar o sistema em um caminho hostil (para o sistema). Portanto, o princípio de máxima exergia de Jørgensen postula que esse trabalho deve ser máximo. (SVIREZHEV, 2000, p.20).

Para fins de modelagem e avaliação de sistemas, foi proposto, como já vimos, que a ecoexergia fosse estimada pela equação seguinte:

$\mathrm{Ex} / \mathrm{RT}=\sum_{\mathrm{i}=1, \mathrm{n}}\left(\beta_{\mathrm{i}} \cdot \mathrm{c}_{\mathrm{i}}\right)$

sendo $\beta_{\mathrm{i}}$ um coeficiente de correlação ecoexergia-biomassa de um determinado compartimento i do ecossistema.

BENDORICCHIO e JØRGENSEN (1997) apresentaram a justificativa da equação (14), que passamos a acompanhar agora ${ }^{222}$.

Consideremos a probabilidade $\mathrm{P}_{\mathrm{i}}$ de produzir o componente i no equilíbrio termodinâmico. Ela pode ser expressa por:

$$
\mathrm{P}_{\mathrm{i}}=\mathrm{c}_{\mathrm{ieq}} / \sum_{\mathrm{i}=\mathrm{o}, \mathrm{n}} \mathrm{c}_{\mathrm{ieq}}
$$

${ }^{221}$ Detritus, neste contexto, corresponde a elementos orgânicos abióticos de um ecossistema, na forma, por exemplo, de carboidratos, lipídios e protídeos. Uma vez que no nosso idioma a palavra detrito dá ideia de resto, sobra, rejeito, ou, mais explicitamente, o resultado de um processo de desintegração, sendo proveniente do latim detritus, a,um "retirado, suprimido, rejeitado", particípio passado do verbo latino detere "tirar esfregando, gastar, enfraquecer", sendo etimologicamente associado a trépano, tritura, atrito, tribulação, trigo (porque triturado), detrimento, contrição, deterioração (HOUAISS e VILLAR, 2001), não havendo, ao que parece, o sentido de "matéria orgânica sem vida" ou "partículas de matéria orgânica", a não ser eventualmente por estrangeirismo, pareceu-nos mais adequado ao longo desta tese manter a forma do latim, que é a que comparece em inglês no original, sendo por isso necessário manter a palavra em negrito. Não é esse o entendimento, por exemplo, de GOMES e VARRIALE (2004, p.172) que, no âmbito da teoria de ecoexergia de Jørgensen, usam simplesmente a palavra "detrito".

222 Devemos notar que tal justificativa está alicerçada em probabilidades de produção dos componentes do ecossistema, sendo que no caso de componentes bióticos tal probabilidade está associada à obtenção da informação incorporada nos genes. 
Uma vez que o componente inorgânico $c_{o}$ é muito determinante no equilíbrio termodinâmico ${ }^{223}$, temos:

$$
\mathrm{P}_{\mathrm{i}} \approx \mathrm{c}_{\mathrm{ieq}} / \mathrm{c}_{\mathrm{oeq}}
$$

$\mathrm{ou}^{224}$ :

$$
\mathrm{c}_{\mathrm{ieq}} \approx \mathrm{P}_{\mathrm{i}} \text {. } \mathrm{c}_{\mathrm{oeq}}
$$

Para a matéria orgânica morta (correspondente ao índice 1, enquanto o índice 0 refere-se ao componente inorgânico), temos, da termodinâmica clássica:

$$
\mu_{1}=\mu_{1 \text { eq }}+\mathrm{RT} \ell \mathrm{n}\left(\mathrm{c}_{1} / \mathrm{c}_{1 \mathrm{eq}}\right)
$$

sendo $\mu_{1}$ o potencial químico do detritus e $\mu_{\text {leq }}$ o potencial químico do detritus no equilíbrio com o meio ${ }^{225}$. De (16), temos, para o componente $\mathrm{i}=1$ :

$$
\mathrm{c}_{1} / \mathrm{c}_{1 \mathrm{eq}}=\exp \left[\left(\mu_{1}-\mu_{1 \mathrm{eq}}\right) / \mathrm{RT}\right]
$$

De (16) e (19), obtemos:

$$
\mathrm{P}_{1} \approx\left(\mathrm{c}_{1} / \mathrm{c}_{0 \mathrm{eq}}\right) \cdot \exp \left[-\left(\mu_{1}-\mu_{1 \mathrm{eq}}\right) / \mathrm{RT}\right]
$$

Para os componentes biológicos do ecossistema $(i=2,3, \ldots, n)$, a probabilidade $\mathrm{P}_{\mathrm{i}}$ consiste na probabilidade de produzir matéria orgânica (detritus), ou seja, $\mathrm{P}_{1}$, e a probabilidade $\mathrm{P}_{\mathrm{ia}}$ de obter a informação incorporada nos genes. Considerando ambos

\footnotetext{
${ }^{223}$ Para evitar confusão, o índice " 0 " refere-se a partir de agora não mais ao estado de equilíbrio com o meio, mas aos componentes inorgânicos do ecossistema, cabendo a "eq" indicar o estado de equilíbrio com o meio.

${ }^{224}$ Para tornar a demonstração mais clara, ressaltamos que c é a concentração molar (molaridade) referida não necessariamente a litros, mas a uma unidade de volume considerada mais adequada. Assim, temos moles por unidade de volume considerada mais conveniente.

${ }^{225}$ Segundo CASTELLAN (1983, p.222 e 240-1), o potencial químico da substância i numa mistura corresponde a $\left(\partial \mathrm{G} / \partial \mathrm{n}_{\mathrm{i}}\right)_{\mathrm{T}, \mathrm{P}, \mathrm{nj}}$ sendo $\mathrm{G}$ a energia livre ou função de Gibbs (definida como G $\equiv \mathrm{H}-\mathrm{T} . \mathrm{S}$, sendo $\mathrm{H}$ a entalpia do sistema, $\mathrm{T}$ sua temperatura absoluta e $\mathrm{S}$ sua entropia) e $\mathrm{n}_{\mathrm{i}}$ o número de moles da substância i nessa mistura, estando constantes a temperatura absoluta $\mathrm{T}$, a pressão $\mathrm{P}$ e o número de moles $n_{j}$ de todas as outras substâncias presentes na mistura. Ou seja, o potencial químico de uma substância i em uma mistura corresponde ao aumento da energia livre do sistema decorrente da adição infinitesimal de moles dessa substância. A quantidade adicionada é restrita a uma quantidade infinitesimal, de tal modo que a composição da mistura e, portanto, o valor de $\mu$ não variem. Sendo o potencial químico a derivada de uma variável extensiva em relação a outra, é uma propriedade intensiva do sistema, tendo o mesmo valor em todos os pontos de um sistema que esteja em equilíbrio Porém, estritamente falando, o potencial químico corresponde a $\left(\partial \mathrm{G} / \partial \mathrm{m}_{\mathrm{i}}\right)_{\mathrm{T}, \mathrm{P}, \mathrm{m}}$, sendo $\mathrm{m}_{\mathrm{i}}$ a massa da iésima substância do sistema e $m_{\mathrm{j}}$ todas as outras massas dos diferentes componentes do sistema. Assim, o potencial químico corresponde, estritamente falando, ao aumento da energia livre que advém da adição infinitesimal da massa da substância i estando T, P e a massa de todas as outras substâncias constantes. Não há dificuldade em usar a primeira definição na medida em que uma variação da massa molecular for tratada como um equilíbrio químico. VAN WYLEN e SONNTAG (1976, p.328-35), comparando as derivadas parciais de energia interna, função de Gibbs, entalpia e função de Helmholtz em relação ao número de moles de uma substância $\mathrm{i}$, conclui que somente a expressão $\left(\partial \mathrm{G} / \partial \mathrm{n}_{\mathrm{i}}\right)_{\mathrm{T}, \mathrm{P}, \mathrm{nj}}$ satisfaz a definição de propriedade molar parcial; assim, define-se $\mu_{\mathrm{i}}=\left(\partial \mathrm{G} / \partial \mathrm{n}_{\mathrm{i}}\right)_{\mathrm{T}, \mathrm{P}, \mathrm{ni}}$ como a função de Gibbs molar parcial do componente i.
} 
os eventos como independentes, temos:

$$
\mathrm{P}_{\mathrm{i}}=\mathrm{P}_{1} \cdot \mathrm{P}_{\mathrm{ia}} \quad(\mathrm{i} \geq 2)
$$

Como podemos expressar $\mathrm{P}_{\mathrm{ia}}$ ? A argumentação apresentada consiste no seguinte: organismos vivos utilizam 20 diferentes aminoácidos; cada gene determina a sequência de em média 700 aminoácidos. $\mathrm{P}_{\text {ia }}$ pode ser obtida a partir do número de possíveis permutações de aminoácidos $\left(20^{700}\right)$. A probabilidade associada a um único gene é de $(1 / 20)^{700}$. Se se tratar de um ser unicelular, sendo g o número de genes, temos:

$$
\mathrm{P}_{\mathrm{ia}}=\prod_{\mathrm{g}}(1 / 20)^{700}=20^{-700 \mathrm{~g}}
$$

Para seres pluricelulares, e sendo nc o seu número de células, temos:

$$
\mathrm{P}_{\mathrm{ia}}=20^{-700 \mathrm{~g} / \mathrm{nc}}
$$

Voltando ao desenvolvimento principal, e de (17) e (13), obtemos ${ }^{226}$ :

$$
\mathrm{Ex} \approx \mathrm{R} T \sum_{\mathrm{i}=0, \mathrm{n}}\left\{\mathrm{c}_{\mathrm{i} \cdot} \cdot\left[\ln \left(1 / \mathrm{P}_{\mathrm{i}}\right)-\ln \left(\mathrm{c}_{\text {oeq }} / \mathrm{c}_{\mathrm{i}}\right)\right]-\left(\mathrm{c}_{\mathrm{i}}-\mathrm{P}_{\mathrm{i}} \cdot \mathrm{c}_{\text {oeq }}\right)\right\}
$$

Uma vez que $c_{i} \gg c_{i e q}$, temos:

$$
\left(1 / \mathrm{P}_{\mathrm{i}}\right) \approx \mathrm{c}_{\mathrm{oeq}} / \mathrm{c}_{\mathrm{ieq}}>>\mathrm{c}_{\mathrm{oeq}} / \mathrm{c}_{\mathrm{i}}
$$

Em assim sendo, temos que:

$$
\left|\ln \left(1 / \mathrm{P}_{\mathrm{i}}\right)\right|>>\left|\ln \left(\mathrm{c}_{\mathrm{oeq}} / \mathrm{c}_{\mathrm{i}}\right)\right|
$$

Daí decorre que:

$$
\mathrm{Ex} \approx \mathrm{RT} \sum \mathrm{i}_{\mathrm{i}=0, \mathrm{n}}\left\{\mathrm{c}_{\mathrm{i}} \cdot\left[\ell \mathrm{n}\left(1 / \mathrm{P}_{\mathrm{i}}\right)-1\right]+\mathrm{P}_{\mathrm{i}} \cdot \mathrm{c}_{\mathrm{oeq}}\right\}
$$

Mas $1 \ll \ell$ n $\left(1 / \mathrm{P}_{\mathrm{i}}\right)$. Além disso, considerando (22), $\mathrm{P}_{\mathrm{i}} \cdot \mathrm{c}_{\mathrm{oeq}}$ é quase igual a zero. Daí decorre que:

$$
\mathrm{Ex} \approx-\mathrm{RT} \sum_{\mathrm{i}=1, \mathrm{n}} \mathrm{c}_{\mathrm{i}} \cdot \ln \mathrm{P}_{\mathrm{i}}
$$

De (28), (20) e (21), obtemos:

$$
\mathrm{Ex} / \mathrm{RT}=-\sum_{\mathrm{i}=1, \mathrm{n}}\left[\mathrm{c}_{\mathrm{i}} \cdot \ln \left(\mathrm{c}_{1} / \mathrm{c}_{\mathrm{oeq}}\right)\right]+\left[\left(\mu_{1}-\mu_{1 \mathrm{eq}}\right) / \mathrm{RT}\right] \cdot \sum_{\mathrm{i}=1, \mathrm{n}} \mathrm{c}_{\mathrm{i}}-\sum_{\mathrm{i}=2, \mathrm{n}}\left[\mathrm{c}_{\mathrm{i}} \cdot \ln \left(\mathrm{P}_{\mathrm{ia}}\right)\right]
$$

A primeira parcela da equação acima é uma constante que pode ser desconsiderada porque ela afeta todos os valores da exergia do mesmo modo. Ficamos, então, com:

$$
\mathrm{Ex} / \mathrm{RT}=\left[\left(\mu_{1}-\mu_{1 \mathrm{eq}}\right) / \mathrm{RT}\right] \cdot \sum_{\mathrm{i}=1, \mathrm{n}} \mathrm{c}_{\mathrm{i}}-\sum_{\mathrm{i}=2, \mathrm{n}}\left[\mathrm{c}_{\mathrm{i}} \cdot \ln \left(\mathrm{P}_{\mathrm{ia}}\right)\right]
$$

Consideremos agora apenas o detritus $(\mathrm{n}=1)$. Nessa situação, temos apenas:

\footnotetext{
${ }^{226}$ É possível demonstrar que a exergia (ou disponibilidade), definida como o máximo trabalho reversível que pode ser realizado por um sistema para atingir o estado de equilíbrio com o meio, corresponde à variação da energia livre, ou variação da função de Gibbs, ocorrida nesse processo (v. VAN WYLEN e SONNTAG, 1976, p.205-14).
} 
$\mathrm{Ex} / \mathrm{RT}=\left[\left(\mu_{1}-\mu_{1 \mathrm{eq}}\right) / \mathrm{RT}\right] \cdot \mathrm{c}_{1}$

Os autores fazem as seguintes afirmações:

a) sabe-se que a energia livre liberada por grama de matéria orgânica é de cerca de $18,5 \mathrm{~kJ} / \mathrm{g}^{227}$

b) assume-se que a massa molecular média de detritus é de $10^{5} \mathrm{~g} / \mathrm{Mol}^{228,229}$;

c) admite-se uma temperatura de $300 \mathrm{~K}$.

Concluem os autores daí que a exergia de detritus é:

$\mathrm{Ex} /(\mathrm{RT})=18500(\mathrm{~J} / \mathrm{g}) /[(8,31 \mathrm{~J} . \mathrm{Mol} / \mathrm{K}) \cdot 300 \mathrm{~K}] \cdot 10^{5} \mathrm{~g} / \mathrm{Mol} . \mathrm{c}_{1}=7,34 \cdot 10^{5} . \mathrm{c}_{1}$

Os autores atribuem ao resultado final dessa conta a unidade $[\mathrm{g} / \ell]^{230}$.

Pode vir a mostrar-se mais útil usar diretamente $E x /(R T)=\Sigma_{i=1, n} c_{i} \cdot \beta_{i}$, que Jørgensen denominou densidade de ecoexergia. Para o cálculo da ecoexergia por unidade de área utilizando diretamente a densidade de ecoexergia teríamos:

$$
\operatorname{Ex}\left(\mathrm{kJ} / \mathrm{m}^{2}\right)=\Sigma_{\mathrm{i}=1, \mathrm{n}} \mathrm{c}_{\mathrm{i}}\left(\mathrm{g} / \mathrm{m}^{2}\right) \cdot \beta_{\mathrm{i}} \cdot 18,7 \mathrm{~kJ} / \mathrm{g}
$$

Consideremos agora um um típico fitoplâncton unicelular, que pode ser assumido como tendo 850 genes. De (23) temos:

$$
-\ln \left(\mathrm{P}_{\mathrm{fit}, \mathrm{a}}\right)=-\ln \left(20^{-700.850}\right)=17,2.10^{5}
$$

Zooplâncton tem aproximadamente $10^{5}$ células e 50.000 genes por célula. Portanto:

$$
-\ln \left(\mathrm{P}_{\text {zoo,a }}\right)=-\ln \left(20^{-700.50000} \cdot 10^{-5}\right) \approx 1049.10^{5}
$$

É possível verificar que a contribuição relativa ao número de células $\left(\ell \mathrm{n} 10^{-5}\right)$ é desprezível.

No caso de peixes, podemos adotar g=120.000, e, independentemente do número de células dos peixes, temos:

$$
-\ln \left(\mathrm{P}_{\text {pei,a }}\right)=-\ln \left(20^{-700.120000}\right) \approx 2517.10^{5}
$$

\footnotetext{
${ }^{227}$ Observar que aqui se tem a energia livre definida como $\left(\partial \mathrm{G} / \partial \mathrm{m}_{\mathrm{i}}\right)_{\mathrm{T}, \mathrm{P}, \mathrm{mj}}$ e não $\left(\partial \mathrm{G} / \partial \mathrm{n}_{\mathrm{i}}\right)_{\mathrm{T}, \mathrm{P}, \mathrm{n} \text {. }}$. ${ }^{228}$ Segundo MOROWITZ (1968) apud JØRGENSEN e NIELSEN (2006), o processo que descreve a decomposição aeróbica de matéria orgânica pode ser assim descrito aproximadamente: $\mathrm{C}_{3500} \mathrm{H}_{6000} \mathrm{O}_{2800} \mathrm{~N}_{600}+4350 \mathrm{O}_{2} \rightarrow 3500 \mathrm{CO}_{2}+2700 \mathrm{H}_{2} \mathrm{O}+600 \mathrm{NO}_{3}{ }^{-}+600 \mathrm{H}^{+}$

A referência apresenta $\mathrm{C}_{3500} \mathrm{H}_{6000} \mathrm{O}_{3000} \mathrm{~N}_{600}$. No entanto, com essa formulação o balanceamento para o oxigênio se apresenta incorreto, sendo necessário substituir para $\mathrm{C}_{3500} \mathrm{H}_{6000} \mathrm{O}_{2800} \mathrm{~N}_{600}$. Daí temos que a sua massa molecular é $101.200 \mathrm{~g}$, contra $104.400 \mathrm{~g}$ na formulação original.

V. tb. JØRGENSEN, LUDOVISI e NIELSEN (2010).

${ }^{229}$ SILOW, MOKRY e JØRGENSEN (2011 a e 2011b) apresentam-na como de 105g/Mol, provavelmente devido a um erro de impressão.

${ }^{230}$ Nada impede que seja utilizada a unidade $\left[\mathrm{g} / \mathrm{m}^{3}\right]$ como fizeram, por exemplo, SILOW, MOKRY e JØRGENSEN (2011a e 2011b). O essencial é que a unidade de concentração seja gramas por uma unidade de volume (no caso, de água) considerada adequada.
} 
Se considerarmos, sem perda de generalidade, um modelo com compartimentos de fitoplâncton, zooplâncton, peixes e detritus, teremos, aplicando as equações acima:

$\mathrm{Ex} / \mathrm{RT}=\left(\mathrm{c}_{1}+\mathrm{c}_{\mathrm{fit}}+\mathrm{c}_{\mathrm{zoo}}+\mathrm{c}_{\mathrm{pei}} \cdot\right) \cdot 7,34 \cdot 10^{5}+\mathrm{c}_{\mathrm{fit}} \cdot 17,2 \cdot 10^{5}+\mathrm{c}_{\mathrm{zoo}} \cdot 1049 \cdot 10^{5}+\mathrm{c}_{\mathrm{pei}} \cdot 2517 \cdot 10^{5}(\mathrm{~g} / \ell)$

Devemos ter em mente que a primeira parcela do lado direito da equação constitui-se no termo clássico da exergia ${ }^{231}$. As parcelas restantes constituem-se no termo informacional da exergia, constituindo-se na essência da teoria de Jørgensen.

A toda a massa orgânica, biótica ou abiótica, foi atribuído o mesmo valor $\left(7,34.10^{5}\right)$, o que parece adequado para a definição de $\beta$ e coerente com o grau de incerteza envolvido. Por outro lado, SZARGUT, MORRIS e STEWARD (1988) ${ }^{232}$ apud DRAGANOVIC et al. (2013) (trabalho no qual consta Jørgensen como coautor) calcularam as exergias químicas intrínsecas, em $\mathrm{kJ} / \mathrm{kg}$, de trigo, legumes, oleaginosas, peixes frescos, krill e algas a partir de seu poder calorífico inferior

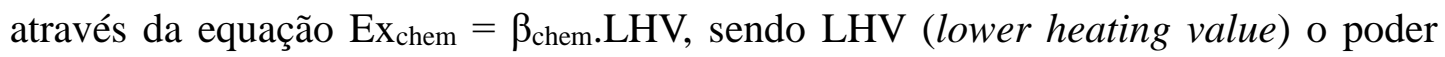

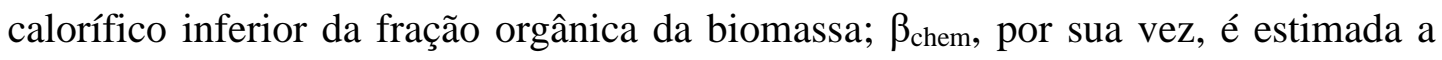
partir de correlações estatísticas desenvolvidas por SZARGUT e STYRYLSKA $(1964)^{233}$ apud DRAGANOVIC et al. (2013), tendo sido utilizada, por exemplo, a seguinte correlação para combustíveis sólidos:

$$
\beta_{\text {chem }}=\{1,044+0,0160 \mathrm{H} / \mathrm{C}-0,3493 \mathrm{O} / \mathrm{C}[1+0,0531 \mathrm{H} / \mathrm{C}]+0,0493 \mathrm{~N} / \mathrm{C}\} /[1-0,4124 / \mathrm{C}]
$$

sendo $\mathrm{H} / \mathrm{C}, \mathrm{O} / \mathrm{C}$ e N/C as relações atômicas do combustível. A exergia química da soma dos componentes foi ponderada por sua fração em massa na biomassa, de maneira a fornecer a exergia química da biomassa através de: $\operatorname{Ex}_{c h e m, i}=\sum E x_{c h e m, i} \cdot x_{i}$, sendo $x_{i}$ a fração em massa $(\mathrm{kg} / \mathrm{kg})$.

O objetivo agora é normalizar os valores de exergia para que eles tenham como referência não o estado de equilíbrio termodinâmico com o meio, mas a quantidade de detritus. Assim, a equação (36) pode ser convertida de g/ $\ell$ para $g$ detritus/ $\ell$ dividindo-a por $7,34.10^{5}$ e fazendo os rearranjos necessários: ${ }^{234}$

\footnotetext{
${ }^{231}$ Por esse motivo foram incluídas as concentrações de fitoplâncton, zooplâncton e peixes. 232 SZARGUT, L.; MORRIS, D.R.; STEWARD, F.R. Exergy analysis of thermal, chemical, and metallurgical processes. New York: Hemisphere, 1988.

${ }^{233}$ SZARGUT, L.; STYRYLSKA, T. Angenäherte Bestimmung des Exergie von Brennstoffen. Brennstoff-Wärme-Kraft, v.16, n.12, p.589-96, 1964.

${ }^{234}$ Seria um preciosismo desnecessário colocar o lado esquerdo da equação 37 como: $(\mathrm{Ex} / \mathrm{RT}) / 7,34 \cdot 10^{5}$.
} 
$\mathrm{Ex} / \mathrm{RT}=\mathrm{c}_{1}+\mathrm{c}_{\mathrm{fit}} .3,3+\mathrm{c}_{\mathrm{zoo}} .144+\mathrm{c}_{\mathrm{pei}} .344 \quad[\mathrm{~g} \text { detritus } / \ell]^{235}$

Houve-se por bem denominar de ecoexergia a exergia assim calculada, pelo fato de ser referida a detritus e por conter termos informacionais.

Os coeficientes 1, 3,3, 144 e 344 podem ser considerados fatores para o cálculo de exergia de um determinado ecossistema, bastando multiplicar as concentrações de cada compartimento por esses fatores. Constituem-se, portanto, nos fatores $\beta$ referidos na equação (14). Assim, temos:

$$
\beta=1-\ln \mathrm{P}_{\mathrm{ia}} / 7,34.10^{5}
$$

o que, combinado com (22), conduz a:

$$
\beta=1+(700 \mathrm{~g} \cdot \ln 20) /\left(7,34 \cdot 10^{5}\right)
$$

Um melhoramento, apresentado em JØRGENSEN et al. (2005), é baseado no raciocínio seguinte. Como vimos, organismos vivos utilizam 20 diferentes tipos de aminoácidos. Considerando os sequenciamentos de genoma, que conduziram à avaliação do tamanho dos genomas em $\mathrm{Mb}$ e a porcentagem de sequências repetidas, e que 3 nucleotídeos ( 1 códon) determinam um aminoácido, podemos estimar:

$\mathrm{P}_{\mathrm{ia}}=20^{-[\text {número de nucleotídeos(1-número de genes repetidos)/3] }}$

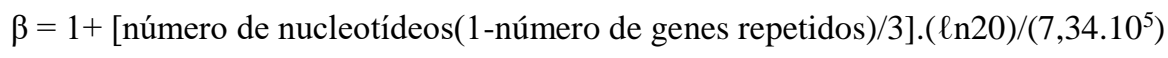

Uma vez que $\ln 20 \approx 3$, temos:

$\beta \approx 1+[$ número de nucleotídeos(1-número de genes repetidos)]/(7,34.1055)

Posteriormente o rol de betas disponíveis foi ajustado ou aumentado através de correlações constantes da tabela A1-1.

${ }^{235}$ No original aparece incorretamente grafado Ex/RT $=\mathrm{c}_{1}+\mathrm{c}_{\mathrm{fit}} \cdot 2,3+\mathrm{c}_{\mathrm{zoo}} \cdot 144+\mathrm{c}_{\mathrm{pei}} \cdot 344$ 
Tabela A1-1 - Correlações entre beta e outras medidas de complexidade usadas para ajustar ou encontrar novos valores de beta.

\begin{tabular}{lcc}
\hline \multicolumn{1}{c}{ conceito } & Correlação & $\mathbf{R}$ \\
\hline NCT & $\beta=10,9 . \mathrm{NCT}-9,06$ & 0,83 \\
\hline r-DNA & $\ln \beta=5,44 . r-\mathrm{DNA}+1,62$ & 0,83 \\
\hline min-DNA & $\beta=12,0+1000$. min-DNA & 0,80 \\
\hline idade & $\beta=2601-385 . \ell$ n idade & 0,84 \\
\hline$\beta$-Fon & $\beta=84,8+1,19 . \beta$-Fon & 0,92 \\
\hline
\end{tabular}

Fonte: LADEGAARD et al. (submetido) apud JØRGENSEN et al. (2005)

Notas:

NCT: número de tipos de células (number of cell types);

r-DNA: razão entre non-coding DNA e DNA total;

min-DNA: o DNA total mínimo em um grupo de espécies;

idade: a idade (age) das espécies;

$\beta$-Fon: valores de beta encontrados por FONSECA et al. (2000) baseados na determinação do DNA nuclear total.

Com relação ao min-DNA, deve ser observado que a quantidade total de DNA nuclear (valor C) é muito mais fácil de ser medida do que o número de genes de cada espécie, dada a menor disponibilidade desta informaação. No entanto, empiricamente não se observa correlação entre a complexidade estrutural dos organismos e os valores $\mathrm{C}$ (o que é chamado de paradoxo do valor $\mathrm{C}$ ) ${ }^{236}$, dada a existência dos assim chamados junk genes. RICARD (2001) $)^{237}$ apud JØRGENSEN et al. (2005) mostrou que a informação sequencial armazenda nos cromossomos não representa a informação completa das células. Mostrou-se também que a informação pode ser transferida de proteína a proteína. O dogma central da genética passou a ser contestado (EDDY, 2001; MATTICK, 2003), constatando-se que muitos genes escondidos trabalham por meio do RNA e que alguns deles desempenham um

\footnotetext{
236 "Nos estudos iniciais da complexidade associada ao DNA, assumia-se que os organismos mais 'avançados' (tais como os humanos) eram mais complexos, em algum sentido não especificado, e a expectativa era que a geração de maiores complexidades requereria mais genes e genomas maiores (Britten e Davidson, 1969; Sparrow et al., 1972). Na maior parte das vezes, essas expectativas foram frustradas. Baseados em dados limitados (Cavalier-Smith, 1985; Szathmáry e Maynard Smith, 1995), a correlação entre 'avanço' e tamanho do genoma (também chamado de valor C) é fraca. A correlação com número de genes é melhor, mas as estimativas disponíveis colocam humanos na mesma posição de peixes pulmonados (Szathmáry e Maynard Smith, 1995). O comportamento rebelde dessas variáveis foi chamado de 'paradoxo do valor C', mas para a complexidade tal paradoxo não existe. De fato, a ausência de uma correlação entre estrutura e mecanismo de geração não é surpreendente, especialmente ao longo da enorme fenda de escala que separa moléculas de DNA e a morfologia do organismo inteiro". (McSHEA, 1996, p.482).

${ }^{237}$ RICARD, J. Binding energy and the information content of some elementary biological process. Science de la Vie, v.324, p.297-304, 2001.
} 
importante papel no controle, manutenção e desenvolvimento dos organismos. Disso decorre, segundo JØRGENSEN et al. (2005), que o conteúdo de informação da rede metabólica é muito maior do que o conteúdo de informação do genoma e, portanto, a informação total da célula não pode ser identificada somente com a informação genética, mas com a informação armazenada nas redes biológicas, desde a célula e o organismo até o ecossistema. RICARD (2003) argumenta que se duas propriedades distintas de uma rede forem expressas por duas variáveis discretas, o princípio de subaditividade da teoria da informação de Shannon se aplica quando todos os nós da rede estiverem associados a essas propriedades. Caso contrário, esse princípio pode não se aplicar. Esta situação é frequentemente encontrada em redes enzimáticas e metabólicas, sendo precisamente o que ocorre quando uma enzima liga aleatoriamente seus dois substratos. Isso implica que uma enzima, ou uma rede metabólica, pode mostrar uma entropia conjunta igual, menor ou maior do que a correspondente soma das entropias individuais dos subsistemas. No primeiro caso, as propriedades coletivas das redes podem ser reduzidas às propriedades individuais de seus componentes. Mais do que isso, a rede nesse caso é desprovida de informação. No segundo caso, o sistema apresenta um fenômeno de integração de seus componentes em um todo coerente e tem informação positiva. Se, finalmente, a rede possuir uma entropia conjunta superior à soma das entropias individuais de seus componentes, a rede pode ser considerada complexa e apresenta propriedades emergentes em relação às de seus componentes. A informação da rede possui nesse caso um sinal negativo. Numerosas reações enzimáticas e redes metabólicas certamente se encaixam nos dois últimos casos. Se a rede não existir senão em um estado de quasi-equilíbrio, em condições de estado estacionário, ela se comporta como um sistema termodinâmico aberto, no qual o fluxo de matéria que percorre o sistema cria as propriedades emergentes. Se a rede evoluir de seu estado inicial de quasi-equilíbrio em direção a um novo estado estacionário através do aumento da constante catalítica da reação, a informação do sistema torna-se cada vez mais negativa. Observa-se essa situação mesmo que no estado inicial de quasi-equilíbrio o sistema não possua nenhuma informação. A evolução de um sistema enzimático em direção a um estado de não equilíbrio termodinâmico engendra a complexidade. A noção de complexidade é assim totalmente distinta daquele de complicação 
(complication).

McShea, comentando a respeito da tese tradicional segundo a qual a complexidade aumenta com a evolução, conclui que

[em tal matéria] é tentador tomar partido tanto a favor como contra a visão tradicional. E se uma escolha tiver que ser feita agora, teríamos que concluir, acredito, que a média e os máximos para pelo menos alguns tipos de complexidade dos metazoários aumentou ao longo do Fanerozoico, apesar de não consistentemente e em alguns talvez não recentemente. (...) Minha visão pessoal está em que os dados a respeito de tipos celulares são muito esparsos e muito ambíguos e as amostras de subgrupos de metazoários estudadas, muito pequenas para justificar tanto a aceitação como a rejeição da visão tradicional - em relação a qualquer tipo de complexidade. (...) A evidência até agora sustenta apenas um agnosticismo, na verdade um enfático agnosticismo. (McSHEA, 1996, p.489).

Não obstante, na busca de aprimorar e complementar a lista de correlações ecoexergia-biomassa, tentou-se visualizar árvores evolutivas dos diferentes grupos taxonômicos. Assim, espécies, grupos de espécies ou famílias que estão mais de perto relacionadas em termos de filogenia do que os valores de beta indicavam foram aglomeradas em grupo, e valores médios dos betas foram adotados de forma a representar os organismos então incluídos no mesmo grupo. O número de betas mais do que dobrou em compração com a listagem anterior. 


\section{ANEXO 2 RELAÇÕES ENTRE INFORMAÇÃO, EXERGIA E ECOEXERGIA}

\section{A2.1 INTRODUÇÃO}

Um aspecto fascinante da Termodinâmica está em suas relações com a Teoria da Informação. Apresentaremos neste anexo algumas relações básicas entre informação, exergia e ecoexergia.

\section{A2.2 EXERGIA E INFORMAÇÃO}

Para tratar das relações entre exergia e informação, é necessária uma rápida menção à entropia no âmbito da mecânica estatística. Nesta disciplina temos:

$$
\mathrm{S} \equiv \mathrm{k} . \ln \Omega
$$

sendo S: entropia de um macroestado contendo $\Omega$ microestados $\left[\mathrm{M} \cdot \mathrm{L}^{2} \cdot \mathrm{t}^{-2} \cdot \mathrm{T}^{-1}\right]$; $\mathrm{k}$ : constante de Boltzmann $\left(1,38.10^{-23} \mathrm{~J} / \mathrm{K}\right)^{238} ; \Omega$ : número de microestados associados ao macroestado. EISBERG e LERNER (1982, p.478) ${ }^{239}$ informam que frequentemente a entropia de um macroestado de um sistema é chamada simplesmente de entropia do sistema.

NOVAES (1981, p.62-78, referência acima) apresenta o desenvolvimento seguinte. A partir da análise combinatória, verifica-se que o número de microestados associados a um determinado macroestado corresponde a:

$$
\Omega=\mathrm{N} ! /\left(\mathrm{N}_{1} ! \cdot \mathrm{N}_{2} ! \ldots \mathrm{N}_{\mathrm{m}} !\right)
$$

${ }^{238}$ Extraído de EISBERG e LERNER (1982, p.572).

${ }^{239}$ As referências relativas a este anexo estão apresentadas no item 18 do texto principal. 
sendo $\mathrm{N}=\sum_{\mathrm{j}} \mathrm{N}_{\mathrm{j}}$; $\mathrm{N}_{\mathrm{j}}$ : número de vezes em que diversos microestados intermediários podem ocorrer $^{240}$.

Para valores elevados de $\mathrm{N}_{\mathrm{j}}$, é válida a fórmula de Stirling:

$$
\ln \mathrm{N} ! \approx \mathrm{N} \ell \mathrm{n} \mathrm{N}-\mathrm{N}
$$

Aplicando a fórmula de Stirling aos fatorais da expressão de $\Omega$, obtém-se:

$$
\ln \Omega=\mathrm{N} \ell \mathrm{n} N-\mathrm{N}-\sum_{\mathrm{j}} \ln \mathrm{N}_{\mathrm{j}}+\sum_{\mathrm{j}} \mathrm{N}_{\mathrm{j}}=-\sum_{\mathrm{j}} \ln \left(\mathrm{N}_{\mathrm{j}} / \mathrm{N}\right)
$$

Sendo $\mathrm{p}_{\mathrm{j}}$ a frequência relativa associada à ocorrência do microestado $\mathrm{N}_{\mathrm{j}}$, temse:

$$
\ln \Omega=-\mathrm{N} \sum_{\mathrm{j}}\left(\mathrm{N}_{\mathrm{j}} / \mathrm{N}\right) \ln \left(\mathrm{N}_{\mathrm{j}} / \mathrm{N}\right)=-\mathrm{N} \sum_{\mathrm{j}} \mathrm{p}_{\mathrm{j}} \ln \mathrm{p}_{\mathrm{j}}
$$

Assim sendo, o número de microestados associados a um macroestado pode ter a seguinte formulação:

$$
\Omega=-\mathrm{k} . \mathrm{N} \cdot \mathrm{H}
$$

sendo $\mathrm{H}$ a função de Boltzmann:

$$
\mathrm{H}=\sum_{\mathrm{j}} \mathrm{p}_{\mathrm{j}} \ell \mathrm{n} \mathrm{p}_{\mathrm{j}}
$$

Dividindo-se $\Omega=$ - K.N.H por N obtém-se a entropia média do sistema (-k.H).

SHANNON (1948) definiu a informação contida em uma mensagem como:

$$
\mathrm{I} \equiv-\log _{2} \mathrm{p}
$$

sendo $\mathrm{p}$ a probabilidade de ocorrência de um evento. A essa grandeza foi conferida unidade denominada bit ( $\underline{\text { binary }}$ unit ), embora seja uma grandeza adimensional. Caso se utilizasse na definição acima o logaritmo neperiano, ou natural, a unidade seria nat.

Se um processo de transmissão de mensagens se repetir por $\mathrm{N}$ vezes, cada uma das mensagens $\mathrm{M}_{1}, \mathrm{M}_{2}, \ldots, \mathrm{M}_{\mathrm{m}}$ tem associada a si uma probabilidade $\mathrm{p}_{1}, \mathrm{p}_{2}, \ldots$, $\mathrm{p}_{\mathrm{m}}$. Uma mensagem $\mathrm{M}_{\mathrm{j}}$ qualquer apresenta informação igual a $-\log _{2} \mathrm{p}_{\mathrm{j}}$. Somando as informações das N.p. mensagens de tipo $M_{j}$, tem-se $-N \cdot p_{j} \cdot \log _{2} p_{j}$. Somando-se as informações correspondentes às mensagens $\mathrm{M}_{1}, \mathrm{M}_{2}, \ldots, \mathrm{M}_{\mathrm{m}}$, tem-se:

$$
\mathrm{I}_{\text {total }}=-\mathrm{N} \sum_{\mathrm{j}} \mathrm{p}_{\mathrm{j}} \log _{2} \mathrm{p}_{\mathrm{j}}
$$

Tendo sido transmitidas $\mathrm{N}$ mensagens, a informação média $\mathrm{I}_{\text {média }}$ por mensagem corresponde a:

$$
I_{\text {média }}=-\sum_{j} p_{j} \log _{2} p_{j}
$$

${ }^{240}$ V., p. ex., CASTELLAN (1983, p.205-17). 
Por analogia à mecânica estatística, Shannon denominou "entropia", ou, mais precisamente, entropia da distribuição de probabilidade $\mathrm{p}_{\mathrm{j}}$, a seguinte expressão:

$$
\mathrm{H} \equiv-\sum_{\mathrm{j}} \mathrm{p}_{\mathrm{j}} \log _{2} \mathrm{p}_{\mathrm{j}}
$$

Assim, na teoria da informação de Shannon a entropia representa a informação média por mensagem ou por evento, fornecendo uma magnitude da indeterminação de uma distribuição de probabilidade.

WALL (2009, p.70-7) relaciona a quantidade de informação com a de exergia física.

Sendo $\Omega$ o número de microestados de um sistema, tem-se que sua entropia $S$ pode ser calculada por:

$$
\mathrm{S}=-\mathrm{k} \sum_{\mathrm{j}=1, \Omega} \mathrm{p}_{\mathrm{j}} \ln \mathrm{p}_{\mathrm{j}}
$$

As probabilidades $\mathrm{p}_{\mathrm{j}}{ }^{0}$ no equilíbrio são tais que maximizam a entropia do sistema, independentemente de outras restrições:

$$
\mathrm{S}_{\mathrm{eq}}=\mathrm{S}_{\max }=-\mathrm{k} \sum_{\mathrm{j}=1, \Omega} \mathrm{p}_{\mathrm{j}}^{0} \ln \mathrm{p}_{\mathrm{j}}^{0}
$$

Assim, a neguentropia disponível do sistema corresponde a:

$$
\text { - }\left(\mathrm{S}-\mathrm{S}_{\mathrm{eq}}\right)=\mathrm{S}_{\mathrm{eq}}-\mathrm{S}=\mathrm{k}\left(\sum_{\mathrm{j}=1, \Omega} \mathrm{p}_{\mathrm{j}} \ln \mathrm{p}_{\mathrm{j}}-\sum_{\mathrm{j}=1, \Omega} \mathrm{p}_{\mathrm{j}}^{0} \ell \mathrm{n} \mathrm{p}_{\mathrm{j}}^{0}\right)
$$

Ora, pela teoria da informação tem-se que a informação, em bits, é:

$$
\mathrm{I}=(1 / \ell \mathrm{n} 2) .\left(\sum_{\mathrm{j}=1, \Omega} \mathrm{p}_{\mathrm{j}} \ell \mathrm{n} \mathrm{p}_{\mathrm{j}}-\sum_{\mathrm{j}=1, \Omega} \mathrm{p}_{\mathrm{j}}^{0} \ell \mathrm{n} \mathrm{p}_{\mathrm{j}}{ }^{0}\right)
$$

Se um sistema tiver $\mathrm{N}$ partículas com 2 possíveis estados cada um ( 0 ou 1$)$, então $\Omega=2^{\mathrm{N}}$. Se não houver nenhuma outra restrição, para todos os $\mathrm{p}_{\mathrm{j}}^{0}$ tem-se que $\mathrm{p}_{\mathrm{j}}{ }^{0}=2^{-\mathrm{N}}$. A informação total $\mathrm{I}$ do sistema (com um dos $\mathrm{p}_{\mathrm{j}}$ sendo igual à unidade $\mathrm{e}$ todos os outros iguais a zero) corresponde a:

$$
\mathrm{I}=(1 / \ell \mathrm{n} 2) \cdot\left(0-\sum_{\mathrm{j}=1,2^{\mathrm{N}}} 2^{-\mathrm{N}} \ln 2^{-\mathrm{N}}\right)=(1 / \ell \mathrm{n} 2) \cdot\left[-2^{\mathrm{N}} \cdot\left(1 / 2^{\mathrm{N}}\right) \cdot(-\mathrm{N}) \cdot(\ln 2)\right]=\mathrm{N}
$$

Sendo $\mathrm{I}=\mathrm{N}$, a cada partícula há informação correspondendo às respostas "sim" ou "não" a uma questão específica. Cada resposta corresponde a 1bit de informação.

É possível agora correlacionar a neguentropia com a informação:

$$
\mathrm{S}_{\text {eq }}-\mathrm{S}=\mathrm{k}^{\prime} . \mathrm{I}
$$

sendo $\mathrm{k}^{\prime}=\mathrm{k} . \ln 2 \approx 1,0.10^{-23} \mathrm{~J} / \mathrm{K}$.

Assim, 1bit de informação corresponde a $1,0.10^{-23} \mathrm{~J} / \mathrm{K}$ de neguentropia.

A relação entre neguentropia e exergia é dada por:

$$
\mathrm{E}=\mathrm{T}_{0} \cdot\left(\mathrm{S}_{\mathrm{eq}}-\mathrm{S}\right)=\mathrm{k}^{\prime} \cdot \mathrm{T}_{0} \cdot \mathrm{I}
$$


sendo E: exergia $\left[\mathrm{M}_{\mathrm{L}} \mathrm{L}^{2} \cdot \mathrm{t}^{-2}\right] ; \mathrm{T}_{0}$ : temperatura absoluta do ambiente $[\mathrm{T}] .^{241}$

Sendo à temperatura ambiente $\mathrm{k}^{\prime} \cdot \mathrm{T}_{0} \approx 2,9.10^{-21} \mathrm{~J}$, temos que 1 bit de informação à temperatura ambiente corresponde a uma quantidade de exergia de $\mathrm{k}^{\prime} \cdot \mathrm{T}_{0} \approx 2,9.10^{-21} \mathrm{~J}$.

Essa relação fundamental entre exergia e informação pode fornecer algumas considerações interessantes. Assim, o fluxo líquido de informação do Sol à Terra pode ser estimado como $4.10^{37}$ bits/s. Desses, a humanidade utiliza apenas, segundo a referência, $5.10^{13}$ bits/s. Essa baixa utilização decorre, segundo o autor, do fato de a transmissão de informação por via genética necessitar de alta redundância para a garantia de certo grau de segurança nessa transmissão, o que demanda gasto de energia para deixá-la suficientemente irreversível (segura), ainda que erros na transferência de informação (mutações) sejam essenciais para a viabilização do processo de variabilidade e, portanto, de evolução.

A tabela A2-1 fornece alguns exemplos de taxas de exergia por unidade de informação para diversos processos de transferência de informação. Quanto menor o valor, maior a eficiência na transmissão de informação.

Tabela A2-1 - Taxas de exergia por unidade de informação para diversos processos de transferência de informação.

\begin{tabular}{lc}
\hline \multicolumn{1}{c}{ Processo } & $\begin{array}{c}\text { Exergia por unidade de informação } \\
(\mathbf{J} / \mathbf{b i t})\end{array}$ \\
\hline Máquina de escrever elétrica & 1 \\
Receptor de rádio & $5.10^{-4}$ \\
Televisão & $2.10^{-5}$ \\
Memória de computador & $10^{-12}$ \\
Fala humana & $10^{-16}$ \\
Ouvido humano & $10^{-17}$ \\
Olho humano & $5.10^{-18}$ \\
Síntese proteica em uma célula & $4,6.10^{-21}$ \\
\hline
\end{tabular}

Fonte: WALL (2009)

\footnotetext{
${ }^{241}$ A correlação mostrada acima entre neguentropia e exergia exige que consideremos que o processo termodinâmico entre o sistema e o reservatório ocorra sem troca de trabalho (v. GOMES e VARRIALE, 2004, p.113).
} 


\section{A2.3 ECOEXERGIA E INFORMAÇÃO}

SVIREZHEV (2000 e 2001) oferece interessantes comentários acerca das relações entre a ecoexergia e a teoria da informação.

Como vimos no anexo 1, a exergia de um ecossistema consistindo de $n$ componentes pode ser dada por:

$$
\mathrm{Ex}=\mathrm{RT} \sum_{\mathrm{i}=1, \mathrm{n}}\left[\mathrm{C}_{\mathrm{i}} \cdot \ln \left(\mathrm{C}_{\mathrm{i}} / \mathrm{C}_{\mathrm{i} 0}\right)-\left(\mathrm{C}_{\mathrm{i}}-\mathrm{C}_{\mathrm{i} 0}\right)\right]
$$

sendo Ex: exergia; R: constante universal dos gases $\left(8,31.10^{3} \mathrm{~J} /(\mathrm{kmol} . \mathrm{K})\right)^{242} ; \mathrm{C}_{\mathrm{i}}$ : concentração do i-ésimo componente do ecossistema; $\mathrm{C}_{\mathrm{i} 0}$ : concentração do i-ésimo componente do ecossistema na situação de equilíbrio termodinâmico com o meio (no caso, mesma pressão e temperatura, uma vez que podem ser desconsiderados outros termos como velocidade e altura).

Sejam as três novas variáveis seguintes introduzidas:

a) $\mathrm{p}_{\mathrm{i}}=\mathrm{C}_{\mathrm{i}} / \sum_{\mathrm{i}=1, \mathrm{n}} \mathrm{C}_{\mathrm{i}}$ descrevendo o vetor $\mathbf{p}=\left\{\mathrm{p}_{1}, \ldots, \mathrm{p}_{\mathrm{n}}\right\}$ a estrutura do sistema

b) $\mathrm{A}=\sum_{\mathrm{i}=1, \mathrm{n}} \mathrm{C}_{\mathrm{i}}$ (quantidade total de matéria no sistema)

c) $\mathrm{A}_{0}=\sum_{\mathrm{i}=1, \mathrm{n}} \mathrm{C}_{\mathrm{i} 0}$

Com elas, a expressão acima pode ser reescrita como:

$$
\mathrm{Ex} /(\mathrm{RT})=\mathrm{A} \cdot \sum_{\mathrm{i}=1, \mathrm{n}} \mathrm{p}_{\mathrm{i}} \ln \left(\mathrm{p}_{\mathrm{i}} / \mathrm{p}_{\mathrm{i} 0}\right)+\left[\mathrm{A} \cdot \ln \left(\mathrm{A} / \mathrm{A}_{0}\right)-\left(\mathrm{A}-\mathrm{A}_{0}\right)\right]
$$

A expressão $\mathrm{K}=\sum_{\mathrm{i}=1, \mathrm{n}} \mathrm{p}_{\mathrm{i}} \ell \mathrm{n}\left(\mathrm{p}_{\mathrm{i}} / \mathrm{p}_{\mathrm{i} 0}\right) \geq 0$ é denominada medida de Kullback, sendo assim conceituada: seja uma distribuição inicial po conhecida; se o sistema passar dessa distribuição po para uma distribuição $\mathbf{p}$, então $K=K\left(\mathbf{p}, \mathbf{p}_{\mathbf{0}}\right)$ é uma medida da informação adicional incorrida nessa passagem. Então A.K se constitui em medida da quantidade total de informação para o sistema como um todo que foi acumulada no processo de transição de algum estado de referência correspondente ao equilíbrio termodinâmico, isto é, um estado pré-vital, para o estado corrente de matéria viva.

A ecoexergia pode ser decomposta em duas parcelas, uma resultado de mudanças estruturais no sistema (Exinf) e outra causada por mudanças na massa total do sistema $\left(\right.$ Ex $\left._{\text {mat }}\right)$ :

\footnotetext{
${ }^{242}$ Extraído de EISBERG e LERNER (1982, p.572).
} 


$$
\begin{gathered}
E x=E x_{i n f}+E x_{m a t} \\
E_{\text {inf }}=\text { R.T.A.K }\left(\mathbf{p}, \mathbf{p}_{0}\right) \geq 0 \\
\text { Ex }_{\text {mat }}=\text { R.T. }\left[\text { A. } \ln \left(A / A_{0}\right)-\left(A-A_{0}\right)\right] \geq 0
\end{gathered}
$$

Se aceitarmos como válido o princípio de máxima exergia de Jørgensen, podemos postular que a exergia deve aumentar durante a evolução do sistema:

$$
\mathrm{dEx} / \mathrm{dt} \geq 0
$$

Então:

$$
\begin{aligned}
& \left.\mathrm{dEx} / \mathrm{dt}=\mathrm{dEx} \mathrm{xinf} / \mathrm{dt}+\mathrm{dEx} x_{\mathrm{mat}} / \mathrm{dt}=\text { R.T.[A. }(\mathrm{dK} / \mathrm{dt})+\mathrm{K} .(\mathrm{dA} / \mathrm{dt})+\ell \mathrm{n}(\mathrm{A} / \mathrm{A} 0) .(\mathrm{dA} / \mathrm{dt})\right] \\
& \mathrm{dEx} / \mathrm{dt}=\mathrm{R} \cdot \mathrm{T} \cdot \mathrm{A} \cdot\left[\mathrm{dK} / \mathrm{dt}+\left[\mathrm{K}+\ln \left(\mathrm{A} / \mathrm{A}_{0}\right)\right] \cdot(1 / \mathrm{A}) \cdot(\mathrm{dA} / \mathrm{dt})\right]
\end{aligned}
$$

Se definirmos $\ell \mathrm{n}\left(\mathrm{A} / \mathrm{A}_{0}\right) \equiv \xi$ e tendo $\mathrm{A}>0$, temos como critério evolutivo:

$$
\mathrm{dK} / \mathrm{dt}+(\mathrm{K}+\xi) \cdot \mathrm{d} \xi / \mathrm{dt} \geq 0
$$

Isso embasa alguns comentários:

a) se $d \xi / d t \geq 0$ significa um aumento da biomassa total no curso da evolução, $d K / d t \geq 0$ pode ser interpretado como um aumento da informação contida por unidade de biomassa, o que pode, por sua vez, ser interpretado como um aumento da complexidade da estrutura do sistema.

b) se $\mathrm{d} \xi / \mathrm{dt}=0$, o que significa que a biomassa não se alterou, então o sistema pode evoluir somente com aumento da complexidade da estrutura do sistema;

c) se a estrutura for simplificada $(\mathrm{dK} / \mathrm{dt}<0)$ e se a biomassa crescer de modo suficientemente rápido ( $\mathrm{d} \xi / \mathrm{dt}>>1)$, então a exergia aumenta e o sistema evolui;

d) se a biomassa diminuir, o sistema evolui somente se a estrutura se tornar mais complexa de modo suficientemente rápido;

e) uma situação paradoxal ocorre se a exergia aumenta enquanto a biomassa total diminui e a estrutura se simplifica:

$$
\begin{gathered}
\text { se } \mathrm{A}<\mathrm{A}_{0} \rightarrow \xi<0 \rightarrow \xi .(\mathrm{d} \xi / \mathrm{dt})>0 \\
\xi .(\mathrm{d} \xi / \mathrm{dt}) \geq|\mathrm{dK} / \mathrm{dt}|+\mathrm{K} .|\mathrm{d} \xi / \mathrm{dt}|
\end{gathered}
$$

Essa inequação só se verifica se

$$
|\xi|>>\mathrm{K} \text { e }|\mathrm{dK} / \mathrm{dt}|<<1
$$

ou seja, se o sistema for suficientemente simples $(K<<1)$ e o processo de simplificação adicional for muito lento; 
f) nas vizinhanças do equilíbrio termodinâmico e no estágio inicial de sua evolução, temos que $\xi \approx 0$, do que decorre que $\mathrm{dK} / \mathrm{dt}>0$, ou seja, no estágio inicial de sua evolução o sistema deve tornar mais complexa sua estrutura para evoluir. 


\section{ANEXO 3 CONTROVÉRSIA JØRGENSEN/ SCHNEIDER-KAY}

\section{A3.1 INTRODUÇÃO}

Como verificamos, a saúde ecossistêmica poderia ser bem descrita pelo indicador ecoexergia, devido a Jørgensen, que também postula que ecossistemas podem ser descritos por um princípio de maximização da ecoexergia armazenada nesse ecossistema. Além disso, verificamos que a integridade ecossistêmica poderia ser bem descrita pelo princípio de maximização da degradação de exergia devido a Schneider e Kay. Argumentamos que um bom indicador para microclima seria a evapotranspiração e abraçamos argumentação segundo a qual ela se inscreveria na teoria de Schneider e Kay. Nosso desejo era obter uma equivalência entre o princípio de maximização de armazenamento de ecoexergia e o princípio de maximização de degradação de exergia. Provada a equivalência entre os dois princípios, poder-se-ia sugerir que tanto a qualidade ecossistêmica, medida por meio da ecoexergia, como o microclima poderiam ser bem descritos pelo mesmo indicador.

$* * *$
É importante retomar algumas considerações no texto referente à terminologia para prosseguir. De fato, Jaynes assevera que:

As principais dificuldades que retardaram o progresso em um século [em termos de desenvolvimento de teorias relacionadas a princípios variacionais em dissipação de energia] não são de ordem matemática, mas conceitual; e estas, por sua vez, constituem-se principalmente em artefatos da semântica. As palavras "irreversível", "entropia", "probabilidade" são usadas indicrimidadamente com sentidos muito diversos, e o fato de a mesma palavra ser usada dificulta a muitos ver que os significados são diferentes. Assim, uma frase comum tal como "o paradoxo de como reconciliar a irreversibilidade da segunda lei com a reversibilidade das equações de movimento" registra não um paradoxo, mas um abuso de linguagem. É impossível pensar em se comunicar racionalmente esses problemas a menos que usemos diferentes palavras e símbolos para transmitir ideias diferentes. De longe, a palavra que mais sofre abuso é "entropia". Confusões a respeito dos diferentes significados da palavra, já sérios há 35 anos atrás, atingiram proporções desastrosas com o advento da teoria da informação de Shannon em 1948, que não só se apropriou da mesma palavra para um novo 
conjunto de significados, mas, ainda pior, provou ser altamente relevante para a mecânica estatística. (JAYNES, 1980, p.583) ${ }^{243}$.

Tentemos, pois, definir com clareza, pelo menos para o âmbito do presente trabalho, alguns conceitos. Regime permanente, segundo KAY (2002, referências acima), significa que certas variáveis de estado do sistema não se alteram com o tempo ${ }^{244}$. Na maior parte do tempo isso corresponde à igualdade entre insumos e respostas ao sistema. Esse conceito é interessante porque usualmente se postula que os ecossistemas tendam a certos estados nos quais, atingidos, o ecossistema opera em regime permanente ${ }^{245}$. O equilíbrio (interno) de um sistema, também segundo KAY (2002), está relacionado a variações espaciais de variáveis intensivas do sistema ${ }^{246}$; existindo tal variação, um gradiente existe e o sistema não está em equilíbrio. $\mathrm{O}$ equilíbrio de um sistema com o meio ${ }^{247}$ ocorre, segundo VAN WYLEN e SONNTAG (1976, p.206), quando não há variações espaciais de variáveis intensivas do sistema com o meio (em especial, sistema com a mesma pressão e temperatura do meio; o sistema também deve ter velocidade zero e energia potencial mínima, além de estar em equilíbrio químico com o meio, o que implica não ocorrer nenhuma reação). É necessário ainda distinguir entre irreversibilidades e dissipação. KAY (2002) observa que os dois conceitos são muitas vezes usados como equivalentes. Segundo VAN WYLEN e SONNTAG (1976, p. 132), a irreversibilidade de um ciclo termodinâmico está relacionada à impossibilidade de realizar tal ciclo sem que uma parcela de calor seja transmitida ao meio. Já a dissipação corresponde a fluxos de saída do ecossistema ${ }^{248}$. Sistema corresponde a uma quantidade limitada de matéria.

\footnotetext{
${ }^{243}$ As referências relativas a este anexo estão apresentadas no item 18 do texto principal.

${ }^{244}$ Estritamente falando, isso implica que qualquer derivada, parcial ou total, em relação ao tempo nas equações que regem o funcionamento de um sistema ou de um volume de controle é necessariamente nula.

${ }^{245}$ A respeito de consequências teóricas da hipótese segundo a qual os sistemas passam a regime permanente quando o tempo tende ao infinito, v. BRUERS (2007).

${ }^{246}$ As variáveis macroscópicas que descrevem o estado de um sistema termodinâmico, segundo VAN WYLEN e SONNTAG (1976, p.16), podem ser intensivas (aquelas que independem da massa; p.ex.: temperatura, pressão e densidade) ou extensivas (p.ex.: massa e volume). Se uma quantidade de matéria for dividida em duas porções iguais, o valor numérico de suas propriedades intensivas permanece o mesmo e o das propriedades extensivas é dividido por dois.

${ }^{247}$ Nas referências, denominado também equilíbrio termodinâmico (com o meio).

${ }^{248}$ SCHNEIDER e KAY (1994, p.34) apresentam uma diferença entre dissipação e degradação. Para eles, dissipação de energia significa mover energia através do sistema, o que pode ou não destruir gradientes. Degradação de energia significa destruir a habilidade de a energia estabelecer gradientes. Assim, degradação de energia significa destruição de exergia, ou seja, a degradação da habilidade de a
} 
É uma contradição em termos falar em fluxos de matéria em sistemas, ainda que tal seja comum em trabalhos de ecologia e físico-química (v., p.ex., CASTELLAN, 1983, p.109). Volume de controle corresponde a uma região definida de maneira tal que facilite o tratamento matemático de fenômenos; assim, nesse volume de controle pode haver fluxos de entrada ou de saída através da fronteira do volume de controle. As leis que governam sistemas (leis zero, primeira e segunda da termodinâmica, princípio de conservação da massa) são válidas também para volumes de controle, mas a formulação é diferente, sendo necessário recorrer ao teorema de transporte de Reynolds para sair da formulação relativa a sistemas para chegar a formulações para volumes de controle. Muito da termodinâmica clássica é por excelência a ciência dos sistemas em equilíbrio (interno). Assim, conceitos termodinâmicos há que são definidos somente para sistemas em equilíbrio.

Como dissemos, é padrão nas teorias de modelagem ecossistêmica utilizar o conceito de sistema aberto, no qual pode haver tanto fluxos de energia em sua fronteira como fluxos de massa, o que, segundo a aparato conceitual usual da mecânica dos fluidos e da termodinâmica clássica, não faria sentido, a menos que se recorresse ao teorema de transpote de Reynolds, tomando o cuidado de transformar a descrição lagrangiana (apta a descrever sistemas) em descrição euleriana (apta a descrever volumes de controle e superfícies de controle). A tradição de utilizar o conceito de sistema aberto conduz, a nosso ver, a dificuldades desnecessárias.

Para demonstrá-lo, tomemos, por exemplo, um extrato de texto de Schneider e Kay, autores que, ressaltamos, têm grande preocupação com o rigor nos conceitos utilizados:

Uma classe de fenômenos mais interessante pertence à terceira categoria de sistemas, os quais
estão abertos ao fluxo de energia e/ ou matéria e encontram-se em estados quase-estáveis a
uma certa distância do equilíbrio (Nicolis \& Prigogine, 1977/ 1989). Sistemas organizados não
vivos (como células de convecção, tornados e lasers) e sistemas vivos (desde as células aos
ecossistemas) dependem de fluxos energéticos externos para manter sua organização e
dissipam gradientes de energia para realizar esses processos de auto-organização. Tal
organização é mantida à custa de aumentar a entropia do sistema "global" maior em que a
estrutura está imersa. Nesses sistemas dissipativos, a mudança total de entropia é a soma da
produção interna de entropia no sistema (que é sempre maior ou igual a zero) e a troca de
entropia com o ambiente, que pode ser positiva, negativa ou zero. Para que o sistema se energia produzir gradientes capazes de realizar trabalho. Estruturas dissipativas são dissipadoras de gradientes e degradadoras de exergia. 
mantenha em um estado constante de não-equilíbrio, a troca de entropia precisa ser positiva e igual à entropia gerada por processos internos, como o metabolismo. (SCHNEIDER e KAY, 1997, p.190-1).

Queremos crer que uma maneira muito mais fácil, rigorosa e compreensível da citação acima ${ }^{249}$ corresponde a recorrer ao teorema de transporte de Reynolds.

Uma aplicação do teorema de transporte de Reynolds à segunda lei da termodinâmica pode ser encontrada, por exemplo, em FOX e McDONALD (1981, p.161-2).

Uuma maneira de expressar a desigualdade de Clausius corresponde a:

$$
\mathrm{dS} / \mathrm{dt})_{\text {sistema }}=(1 / \mathrm{T}) \cdot \mathrm{Q}^{\prime} \quad 250
$$

sendo Q' o fluxo em massa de calor através da fronteira do sistema e onde a entropia total do sistema é dada por:

$$
\mathrm{S}_{\text {sistema }}=\int_{\text {massa (sistema) }} \mathrm{s} \mathrm{dm}=\int_{\mathrm{V}^{*}(\text { sistema) }} \text { s. } \rho \mathrm{dV}^{*}
$$

sendo s a entropia específica, dm o diferencial de massa, $V^{*}$ o volume ${ }^{251}, \rho$ a densidade do fluido e $\mathrm{dV}^{*}$ o diferencial de volume.

A aplicação do teorema de transporte de Reynolds à desigualdade de Clausius formulada acima conduz a:

$$
\partial / \partial \mathrm{t} \int_{\mathrm{VC}} \text { s. } \rho \mathrm{dV}^{*}+\int_{\mathrm{Sc}} \text { s. } \rho \mathbf{V} \cdot \mathrm{d} \mathbf{A} \geq \int_{\mathrm{sc}}(1 / \mathrm{T})\left(\mathrm{Q}^{\prime} / \mathrm{A}\right) \mathrm{dA}
$$

sendo VC um volume de controle, SC a superfície de controle que envolve esse volume de controle, $\mathbf{V}$ a velocidade do fluido ao atravessar a superfície de controle, dA o vetor unitário normal à superfície de controle, A a área da superfície de controle de maneira a indicar (Q'/A) como o fluxo de calor por unidade de área através da superfície de controle.

Queremos crer que, no texto acima, os autores, ao se referirem à produção interna de entropia dentro do sistema, referiam-se na verdade à primeira parcela da

\footnotetext{
249 “A justificativa para um tratamento [matemático] rigoroso é pedagógica; torna o assunto mais simples. (...) Algumas das deduções 'simplificadas' não são propriamente difíceis, mas sim impossíveis. Estas deduções são nebulosas e dão ao estudante a impressão de que é necessário um sexto sentido para compreendê-las, e realmente o é. "(CASTELLAN, 1983, p.VII-VIII).

${ }^{250} \mathrm{O}$ modo usual de expressar o fluxo de massa de calor através da fronteira do sistema corresponde a um ponto superposto à letra Q. Infelizmente, por não disponibilização desse símbolo no processador de texto, usamos Q'.

${ }^{251}$ Para que não se confunda velocidade com volume, o modo usual em mecânica dos fluidos de referir volume corresponde à letra $\mathrm{V}$ com um traço médio. Na falta desse símbolo no processador de texto, usamos $\mathrm{V}^{*}$.
} 
esquerda da desigualdade acima; que, ao informar que ela é sempre maior ou igual a zero, na realidade postularam que assim fosse; que a troca de entropia do sistema a que se referem os autores acima corresponda à segunda parcela à esquerda da desigualdade acima; que ao informar que "para que o sistema se mantenha em um estado constante de não-equilíbrio, a troca de entropia precisa ser positiva e igual à entropia gerada por processos internos", e sendo a convenção do cálculo que o vetor unitário tangente à superfície de controle seja orientado para fora da superfície de controle $^{252}$, temos que a segunda parcela do lado esquerdo da desigualdade acima seja necessariamente positiva. A título de ilustração, nessa condição de estado constante de não-equilíbrio, no qual a troca de entropia é positiva e igual à gerada por processos internos, temos:

$$
\partial / \partial \mathrm{t} \int_{\mathrm{VC}} \text { s.p } \mathrm{dV}^{*}=\int_{\mathrm{SC}} \text { s. } \rho \text { V.dA }
$$

Apicando o teorema de Ostrogradsky-Gauss (v. PISKUNOV, s.d., p.699), temos que:

$$
\operatorname{div}(\text { s. } \rho \mathbf{V})=\partial / \partial \mathrm{t}(\mathrm{s} . \rho) \quad \text { ou } \quad \operatorname{div}(\text { s. } \rho \mathbf{V})-\partial / \partial \mathrm{t}(\mathrm{s} . \rho)=0
$$

Assim, o texto acima pode ser traduzido em três asserções (sendo uma delas um postulado) e um corolário:

a) em processos dissipativos, a quantidade de entropia produzida dentro de um volume de controle é sempre maior do que zero, ou seja:

$$
\partial / \partial \mathrm{t} \int_{\mathrm{VC}} \mathrm{s} . \rho \mathrm{dV}^{*}>0
$$

b) para que o sistema dissipativo se mantenha em um estado constante de nãoequilíbrio, o fluxo de entropia através da superfície de controle precisa ser positivo, ou seja:

$$
\int_{\text {SC }} \text { s.p V.dA }>0
$$

c) para que o sistema dissipativo se mantenha em um estado constante de nãoequilíbrio, o fluxo de entropia através da superfície de controle precisa ser igual à quantidade de entropia produzida dentro de um volume de controle, ou seja:

\footnotetext{
${ }^{252}$ Isso porque o vetor normal à superfície corresponde ao vetor gradiente dessa superfície, tendo ele necessariamente o sentido para fora da superfície (v. KAPLAN, 1972, p.114-7, LEITHOLD, 1977, p.751-2).
} 


$$
\partial / \partial \mathrm{t} \int_{\mathrm{VC}} \operatorname{s.\rho } \mathrm{dV}^{*}=\int_{\mathrm{SC}} \operatorname{s.\rho } \mathbf{V} \cdot \mathrm{d} \mathbf{A}
$$

d) da asserção anterior decorre:

$$
\operatorname{div}(\text { s. } \rho \mathbf{V})=\partial / \partial \mathrm{t}(\mathrm{s} . \rho)
$$

As asserções acima podem, devido à sua formulação matemática, parecer mais obscuras. Na realidade, não o são. Pelo contrário, dão mais clareza e segurança ao raciocínio.

Retomando a argumentação, temos que há aparente incoerência entre o princípio de maximização de ecoexergia e o princípio de maximização de dissipação. Um corresponde a um princípio de máximo armazenamento e outro a de máxima dissipação. Um trata de armazenamento no sistema e outro de fluxos de através do ecossistema. A essa aparente incoerência chamaremos aqui de controvérsia Jørgensen/ Schneider-Kay. O objetivo de nossa argumentação é nos autorizar a postular, em certas condições, a equivalência entre os indicadores de qualidade ecossistêmica e de microclima.

Papel central nessa argumentação desempenha a demonstração de FATH, PATTEN e CHOI (2001), segundo a qual há consistência e complementaridade entre esses dois princípios. Estando ela disponível na bibliografia, por que retomá-la aqui? Podemos listar algumas razões. Em primeiro lugar, é nossa intenção que a tese esteja formalmente completa. Em segundo lugar, sendo a demonstração relativamente longa, propondo-nos aqui a "mastigá-la" para torná-la (assim esperamos) mais palatável. Em terceiro lugar, a apresentação da demonstração permitirá que se retomem os principais conceitos envolvidos na descrição de ecossistemas, esboçando-se, de forma algo pretensiosa, uma micro-história dessas teorias. Finalmente, assim o fazendo, teremos oportunidade demostrar confrontação e complementação de alguns trabalhos.

Porém, antes de nos dedicarmos à controvérsia Jørgensen/ Schneider-Kay, é necessário nos determos rapidamente no que chamamos aqui de controvérsia Prigogine/ Kay. 


\section{A3.2 A CONTROVÉRSIA PRIGOGINE/ KAY}

Para tratar da controvérsia Prigogine/ Kay, há necessidade de uma curtíssima apreciação do conceito de entropia.

No âmbito da termodinâmica clássica, há inúmeras expressões da segunda lei da termodinâmica. Assim, por exemplo, uma redação consistiria em afirmar ser impossível que um mecanismo termodinâmico que extraia calor de um reservatório quente realize trabalho sem que transmita calor a um reservatório frio ${ }^{253}$. A desigualdade de Clausius, uma maneira mais familiar de expressar a segunda lei, introduz o conceito de entropia. Esta é retomada e redefinida na mecânica estatística por Bolzmann por meio da expressão seguinte:

$$
\mathrm{S} \equiv \mathrm{k} \cdot \ln \Omega
$$

sendo S: entropia $\left[\mathrm{M} \cdot \mathrm{L}^{2} \cdot \mathrm{t}^{-2} \cdot \mathrm{T}^{-1}\right]$; $\mathrm{k}$ : constante de Boltzmann $\left(1,38 \cdot 10^{-23} \mathrm{~J} / \mathrm{K}\right)^{254} ; \Omega$ : número de microestados que compõem determinado macroestado. Assim, a entropia $\mathrm{S}$ de um macroestado contendo $\Omega$ microestados tem o valor da expressão acima. Frequentemente, a entropia de um macroestado de um sistema é chamada de entropia desse sistema (EISBERG e LERNER, 1982, p.478).

MARTYUSSHEV (2013) não se cansa de lamentar sobre os equívocos introduzidos ao relacionar entropia a desordem. Segundo ele, trata-se de uma confusão aparecida no início do século XX e ainda encontrada principalmente em trabalhos de filósofos e biólogos, além de na literatura popular. Ele cita exemplos. MARTYUSHEV e SALNIKOVA (2004) ${ }^{255}$ apud MARTYUSHEV (2013) fornecem dados segundo os quais, por exemplo, a entropia de um quilograma de madeira (pinho ou carvalho) é de $2,8 \mathrm{~kJ} / \mathrm{K}$, em condições normais, enquanto a entropia do quartzo é de $0,7 \mathrm{~kJ} / \mathrm{K}$, o que causa à primeira vista estranheza porque se tende a considerar organismos possuindo entropia menor do que a de matéria inanimada.

\footnotetext{
${ }^{253}$ Talvez o enunciado da Segunda Lei da Termodinâmica devido a Kelvin, proposto em 1850, seja mais adequado: "É impossível para um sistema operando em um ciclo e acoplado a um único reservatório de calor produzir uma quantidade positiva de trabalho nas vizinhanças" (CASTELLAN, 1983, p.166).

${ }^{254}$ Extraído de EISBERG e LERNER (1982, p.572).

${ }^{255}$ MARTYUSHEV, L.M.; SALNIKOVA, E.M. Desenvolvimento de ecossistemas e moderna termodinâmica (em russo). Moscou: Izhevsk, 2004.
} 
BLUMMENFELD (1981) ${ }^{256}$ apud MARTYUSHEV (2013) avaliou de maneira aproximada a variação de entropia durante a construção de um organismo a partir de células, de células a partir de biopolímeros e de biopolímeros a partir de monômeros, tendo concluído que as chamadas "tendências antientrópicas" da evolução biológica e sobre a ordem da matéria animada são baseadas em mal-entendidos, sendo qualquer sistema biológico não mais ordenado do que um pedaço de rocha de mesmo peso.

McShea tem algo a dizer a respeito das palavras "ordem" e "organização":

\begin{abstract}
Essas palavras têm sido usadas despreocupadamente (casually) em biologia e intercambiavelmente com [a palavra] complexidade, criando muita confusão. A ordem é especialmente problemática porque se diz que sistemas simples como cristais e complexos como organismos são altamente ordenados. Há quem tenha sugerido que a organização deveria denotar grau de funcionalidade, independentemente da complexidade, mas esse uso não é geralmente aceito. (...) Um agrupamento composto é entrópico na medida em que um grande número de microestados (combinações e configurações possíveis de partes) corresponda ao mesmo macroestado (o mesmo agrupamento composto). Chamar complexo um agrupamento composto seria um erro categórico. Entropia é uma relação entre microestados e macroestado, enquanto complexidade é uma propriedade de um único microestado, de uma composição e de uma configuração específica, e assim não envolve tal relação. (...) Em biologia, uma noção comum está em que a complexidade de um organismo consiste no conteúdo de informação de seu DNA, o que é assumido como uma espécie de mecanismo de geração. Um problema está em que muito da informação acerca do desenvolvimento é citoplasmática e não presente no DNA. Outro está em que sistemas simples podem ter mecanismos complexos de geração e vice-versa. (McSHEA, 1996, p.479 e 481).
\end{abstract}

A entropia constitui-se em conceito bastante profícuo, encontrando aplicações em diversas áreas do conhecimento: a) termodinâmica clássica (VAN WYLEN e SONNTAG, 1976, p.125-82); b) mecânica estatística (EISBERG e LERNER, 1982, p.416-83); c) entropia de Jaynes (JAYNES, 1957 e 1962; WILSON, 1970, p.8-9); d) entropia de Lindley (LINDLEY, 1955; WILSON, 1970, p.9-11); e) modelagem urbana e de transportes (NOVAES, 1981, p.198-206 e 183-4); f) teoria da informação (SHANNON, 1948; NOVAES, 1981, p.62-81). Além disso, pode-se demonstrar que os modelos seguintes são equivalentes ao princípio de maximização de entropia: a) maximização de utilidade (WILSON, 1970, p.100-5); b) modelo logit multinomial (NOVAES, 1986, p.74-8; NOVAES, 1981, p.108-18); c) modelo de oportunidades intervenientes (NOVAES, 1981, p.143-64; BRUTON, 1979, p.99-102;

${ }^{256}$ BLUMENFELD, L.A. Problems of biological physics. Berlin: Springer, 1981. 
FERRARI，1984，p.498-9; WILSON，1970, p.151-5); d) modelo gravitacional (NOVAES, 1986, p.33-44; NOVAES, 1981, p.121-2; WILSON, 1970, p.16-7 e 19). A respeito de todas essas possibilidades da entropia, pode-se ler com bastante proveito ESMER (2005).

Podemos agora nos dedicar à controvérsia Prigogine/ Kay.

KAY (2002) faz uma crítica a algumas conclusões alcançadas por Prigogine. Seja $d S_{i}$ a produção de entropia no sistema devido a processos irreversíveis e $\mathrm{dS}_{\mathrm{e}} \mathrm{o}$ fluxo de entropia devido a trocas entre o sistema e o meio. A variação total de entropia dS é dada por $\mathrm{dS}_{\mathrm{i}}+\mathrm{d} \mathrm{S}_{\mathrm{e}}$. A segunda lei da termodinâmica, segundo Kay, assevera que $d S_{i} \geq 0{ }^{257}$. Mas se um fluxo de entropia suficientemente baixa entrar no sistema, então $d S_{e} \leq 0$, sendo possível, portanto, que $\left|d S_{e}\right|>\left|d S_{\mathrm{i}}\right|$. É possível também que o sistema atinja regime permanente $(\mathrm{d} S=0)$. Esse é o processo estudado por Prigogine.

Prigogine se valeu das chamadas relações de reciprocidade de ONSAGER (1931), além de obras diversas, embasando a chamada termodinâmica linear de não equilíbrio (v. tb. MARTYUSHEV, 2013). Onsager generalizou leis empíricas tais como a lei de Ohm, a de Fourier e a de Fick ${ }^{258}$, que apresentamos da maneira seguinte, todas associadas a leis de conservação, resultando em equações de Fourier:

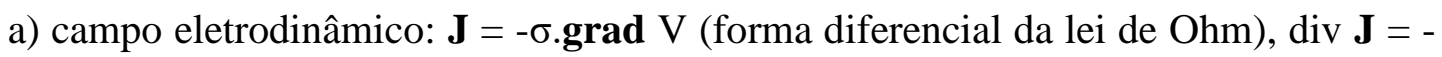
C. $\partial \mathrm{V} / \partial \mathrm{t}$ (forma diferencial da lei de conservação das cargas elétricas ou primeira lei

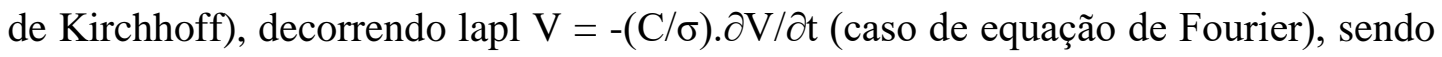
J a densidade de corrente elétrica, $\sigma$ a condutividade elétrica, $\mathrm{C}$ a capacitância elétrica;

b) condução de calor: $\mathbf{q}=-k \cdot g r a d ~ T$ (lei de Fourier), div $\mathbf{q}=\rho \cdot C_{\mathrm{v}} \cdot(\partial \mathrm{T} / \partial \mathrm{t}$ ) (forma diferencial da lei de conservação de energia), resultando em lapl $\mathrm{T}=-\left(\rho \cdot \mathrm{C}_{\mathrm{v}} / \mathrm{k}\right) .(\partial \mathrm{T} / \partial \mathrm{t})$ (caso de equação de Fourier, desde que não haja fonte ou sorvedouro de calor), sendo q o vetor fluxo de calor, $\mathrm{k}$ a condutibilidade térmica do material, $\mathrm{T}$ a temperatura absoluta, $\rho$ a densidade de massa do material, $\mathrm{C}_{\mathrm{v}} \mathrm{o}$ calor específico do material a volume constante;

\footnotetext{
${ }^{257}$ Evidentemente isso é válido apenas para sistemas isolados, uma vez que a segunda lei trata do aumento da entropia do universo (sistema + meio) e não apenas do sistema. V. observações anteriores. ${ }^{258}$ No trabalho de Onsager fica claro que são consideradas apenas as leis relacionadas diretamente a processos irreversíveis.
} 
c) difusão molecular: $\mathbf{J}=-$ D.grad c (lei de Fick), $\operatorname{div} \mathbf{J}=-\partial \mathrm{c} / \partial \mathrm{t}$ (forma da lei de conservação da massa), resultando em lapl $\mathrm{c}=(1 / \mathrm{D}) . \partial \mathrm{c} / \partial \mathrm{t}$ (caso de equação de Fourier), sendo $\mathbf{J}$ o vetor fluxo de massa, c a concentração, D o coeficiente de difusão ${ }^{259}$.

Onsager postulou que entre fluxos $\mathrm{J}_{\mathrm{i}}$ e forças termodinâmicas $\mathrm{X}_{\mathrm{i}}$ existe uma relação linear $\mathrm{J}_{\mathrm{i}}=\sum_{\mathrm{k}} \mathrm{L}_{\mathrm{ik}}$. $\mathrm{X}_{\mathrm{k}}$ havendo relação recíproca $\mathrm{L}_{\mathrm{ik}}=\mathrm{L}_{\mathrm{ki}}$. A mudança da entropia $\mathrm{S}$ ou da entropia específica s com o tempo t corresponde à soma da geração (produção) de entropia $\Sigma$ em um corpo (ou a produção de entropia $\sigma$ por unidade de volume) e o fluxo de entropia $\mathbf{J}_{\mathbf{s}}$ entrando ou saindo da fronteira (П) do corpo considerado (MARTYUSHEV, 2013):

$$
\mathrm{dS} / \mathrm{dt}=\Sigma-\int_{\Pi} \mathrm{d} \Pi
$$

ou:

$$
\mathrm{ds} / \mathrm{dt}=\sigma-\operatorname{div} \mathbf{J}_{\mathrm{s}}
$$

Demonstra-se que:

$$
\sigma=\sum_{\mathrm{i}} \mathrm{X}_{\mathrm{i}} . \mathrm{J}_{\mathrm{i}}
$$

Uma vez que $\mathrm{J}_{\mathrm{i}}=\sum_{\mathrm{k}} \mathrm{L}_{\mathrm{ik}} \cdot \mathrm{X}_{\mathrm{k}}$, temos que:

$$
\sigma=\sum_{\mathrm{i}} \sum_{\mathrm{k}} \mathrm{L}_{\mathrm{ik}} \cdot \mathrm{X}_{\mathrm{k}} \cdot \mathrm{X}_{\mathrm{i}} \quad 260
$$

KAY (2002) informa que Prigogine, partindo de $\mathrm{P}=\mathrm{d} \mathrm{S}_{\mathrm{i}} / \mathrm{dt}=\int \sigma \mathrm{dV} \geq 0$, sendo $\sigma$ a produção local de entropia, usando as relações de reciprocidade de Onsager, fazendo

\footnotetext{
${ }^{259}$ Na realidade, a lei de Fick é um caso particular de uma equação mais ampla que, conjugada à equação da continuidade, fornece a forma geral para a equação da dinâmica de massas. Assim, o que chamaremos aqui de lei de Fick ampliada para um constituinte i corresponderia a

$\mathbf{J}_{\mathrm{i}}=-\sum_{\mathrm{j}} \mathrm{D}_{\mathrm{ij}} \operatorname{grad} \rho_{\mathrm{i}}$-DgradT, sendo $\mathbf{J}_{\mathrm{i}}$ o vetor fluxo de massa do constituinte $\mathrm{i}, \mathrm{D}_{\mathrm{ij}}$ a matriz de difusão, $\underline{\rho}_{\mathrm{i}}$ a densidade do constituinte $\mathrm{i}, \underline{\mathrm{D}}$ o coeficiente de difusão térmica e $\mathrm{T}$ a temperatura absoluta. Essa equação, quando combinada à equação da continuidade, fornece $\partial / \partial \mathrm{t} \rho_{\mathrm{i}}=\operatorname{div}\left(\sum_{\mathrm{j}} \mathrm{D}_{\mathrm{ij}} \operatorname{grad} \rho_{\mathrm{i}}+\operatorname{DgradT}\right)$. Combinada à advecção, fornece $\partial / \partial \mathrm{t} \rho_{\mathrm{i}}=\operatorname{div}\left(-\rho_{\mathrm{i}} \cdot \mathbf{v}+\sum_{\mathrm{j}} \mathrm{D}_{\mathrm{ij}} \operatorname{grad} \rho_{\mathrm{i}}+\underline{\operatorname{ggrad} T}\right)$, sendo $\mathbf{v}$ a velocidade do fluido (GOMES e VARRIALE, 2004, p.115-6). Uma variação interessante da lei de Fick corresponde à equação de Turing: $\partial \mathbf{c} / \partial \mathrm{t}=\mathbf{f}(\mathbf{c})+\mathbf{D}$.laplc, sendo $\mathbf{c}=\mathbf{c}(\mathbf{r}, \mathrm{t})$ um vetor de $\mathrm{n}$ concentrações dependentes da posição $\mathbf{r}$ e do tempo $t, \mathbf{f}(\mathbf{c})$ uma função vetorial que contém a dinâmica associada às reações químicas e D uma matriz diagonal de coeficientes de difusão. A proposta de Turing é que, sob condições bem específicas, os produtos químicos podem reagir de tal forma a produzir espaços estacionários espacialmente não homogêneos. No caso de duas espécies químicas $\mathrm{A}(\mathbf{r}, \mathrm{t})$ e $\mathrm{B}(\mathbf{r}, \mathrm{t})$ e em algumas condições, desenvolve-se um padrão ou motivo, induzido por uma instabilidade associada ao caso $\mathrm{D}_{\mathrm{A}} \neq \mathrm{D}_{\mathrm{B}}$ (GOMES e VARRIALE, 2004, p.37-51).

${ }^{260}$ Jaynes (1980, p.589) informa que nos anos 1940 e 1950 foram feitas algumas tentativas de generalizar o tratamento de Onsager através de uma teoria de contínuo macroscópico baseada nas noções de equilíbrio local e taxa local de produção de entropia. Essa abordagem postula a existência de uma densidade local de entropia $\mathrm{s}(\mathrm{x}, \mathrm{t})$ que desempenha o papel de uma variável de campo. Há também uma taxa de fluxo $\mathbf{J}_{\mathrm{s}}$ e uma força de fonte $\sigma(\mathrm{x}, \mathrm{t}) \geq 0$ de maneira a obedecer uma equação de campo $\dot{\mathrm{s}}+\boldsymbol{\nabla} . \mathrm{J}_{\mathrm{s}}=\sigma(\mathrm{x}, \mathrm{t})$ (que corresponde a uma equação de continuidade). Assim, a entropia é concebida como uma espécie de fluido que, uma vez criado, é conservado para sempre.
} 
diversas assunções acerca de forças e diferenciando com relação ao tempo, concluiu que $\mathrm{dP} / \mathrm{dt}<0$ longe do regime permanente e $\mathrm{dP} / \mathrm{dt}=0$ no regime permanente, o que se constitui na Regra de Mínima Produção de Entropia, e que, por sua vez, governaria o comportamento de estruturas dissipativas em regime permanente. É possível mostrar que essa regra garante a estabilidade de estados de não-equilíbrio em regime permanente. Em outras palavras, a taxa com que um sistema estável em regime permanente e fora do equilíbrio produz entropia é mínima ${ }^{261}$. Prigogine postulou que estruturas dissipativas se auto-organizam frente a pequenas flutuações.

KAY (2002) identificou na derivação dessa regra sete assunções: a) o sistema deve ser bem comportado o suficiente de forma que se verifique equilíbrio local; b) os fluxos são expressos através de combinações lineares por meio da Relação de Reciprocidade de Onsager; c) $\mathrm{L}_{\mathrm{ij}}$ deve ser independente do tempo; d) o meio deve ser isotrópico; e) as condições de contorno impostas ao sistema devem ser independentes do tempo; f) o sistema deve ser isotérmico; g) o sistema deve estar em equilíbrio mecânico e térmico, havendo apenas fluxos de massa na sua fronteira ${ }^{262}$. Kay observa que essas hipóteses são tão restritivas que não se pode falar em uma termodinâmica distante do equilíbrio ou em uma teoria de auto-organização. Além disso, a hipótese de equilíbrio local é bastante duvidosa para sistemas vivos. Acrescente-se que essa hipótese corresponde a um critério suficiente para regime permanente, mas não necessário. Finamente, sistemas vivos não estão em equilíbrio, embora possam estar em regime permanente. Kay afirma ainda que o princípio de mínima produção de entropia específica (entropia por unidade de massa do sistema)

\footnotetext{
261 JAYNES (1980, p.581) assim resumiu o argumento de Prigogine (“o inteiro conteúdo do seu teorema"): é postulada a existência de fluxos $\mathrm{J}_{\mathrm{i}}$ e forças $\mathrm{X}_{\mathrm{i}}$ conectadas por relações fenomenológicas $\mathrm{J}_{\mathrm{i}}=\mathrm{L}_{\mathrm{ij}} \cdot \mathrm{X}_{\mathrm{i}}$, definidas de tal maneira que a taxa de produção de entropia é $\dot{\mathrm{S}}=\mathrm{J}_{\mathrm{i}} \cdot \mathrm{X}_{\mathrm{i}}=\mathrm{L}_{\mathrm{ij}} \cdot \mathrm{X}_{\mathrm{i}} \cdot \mathrm{X}_{\mathrm{j}}$.

Considerando algumas das forças como fixas e outras livres, a condição de mínima taxa $\dot{\mathrm{S}}$ com respeito a uma variável livre $\mathrm{X}_{\mathrm{m}}$ é $\partial \dot{\mathrm{S}} / \partial \mathrm{X}_{\mathrm{m}}=\left(\mathrm{L}_{\mathrm{mj}}+\mathrm{L}_{\mathrm{jm}}\right) \cdot \mathrm{X}_{\mathrm{j}}=0$ se os $\mathrm{L}_{\mathrm{ij}}$ forem constantes. Mas se forem válidas relações recíprocas $\mathrm{L}_{\mathrm{ij}}=\mathrm{L}_{\mathrm{ji}}$, isso é o mesmo que $\mathrm{J}_{\mathrm{m}}=0$, o que é considerado sinônimo de "estado estacionário".

262 GOMES e VARRIOLE (2004, p.125-30) apresentam a dedução da Regra de Mínima Produção de Entropia, informando ainda a respeito de outras restrições: são desprezíveis os efeitos de convecção (preferiríamos falar advecção) e $\partial \rho_{\mathrm{k}} / \partial \mathrm{t}=0$ sobre a superfície, ou seja, a contribuição de produção de entropia associada à superfície é zero, ou, ainda, não há fluxos de massa através da fronteira. Os autores deduzem também uma regra no âmbito da termodinâmica não linear, concluindo que, "para uma escolha arbitrária de expressões fenomenológicas não lineares", $\mathrm{dP} / \mathrm{dt} \leq 0$ (nulo no caso de estado estacionário). Eles informam que, pela sua generalidade, tal desigualdade tem sido denominada Critério de Evolução Universal.
} 
de Prigogine é mais geral, mas ainda restritivo. BRUERS (2007), no entanto, mostra que o princípio de Ziegler só vale em sistemas em regime de resposta linear ou em alguns casos excepcionais altamente restritos.

GOMES e VARRIOLE (2004, p.130-3) estudaram as estruturas dissipativas considerando duas situações distintas: a primeira corresponde à estabilidade assintótica do estado de equilíbrio, enquanto a segunda trata de introduzir um processo sistemático de desvio do equilíbrio através de sua submissão a uma perturbação. Para tanto, eles tomam como exemplo a existência de um parâmetro de controle externo $\lambda$. Concluem então que estados de equilíbrio termodinâmico podem tornar-se instáveis quando o parâmetro for superior a um valor crítico $\lambda_{\mathrm{c}}$, perdendo o ramo termodinâmico a estabilidade através de uma bifurcação.

MARTYUSHEV (2013) queixa-se de que, não obstante as fraquezas do modelo e sua virtual inaplicabilidade a sistemas vivos, o princípio de mínima produção de entropia ainda atrai muita atenção, especialmente entre biólogos e filósofos. Isso se deve, de um lado, à grande reputação de Prigogine e à popularização de sua atividade, e, por outro, à errônea concepção segundo a qual a entropia é uma medida de desordem. Como resultado, há uma assunção errônea de que um sistema em não equilíbrio termodinâmico tende à mínima produção de desordem, o que é condizente com algumas ideias relacionadas à evolução biológica e social. Martyushev observa que, se esse princípio se aplicasse, a meta principal do desenvolvimento de um ser animado seria a morte mais breve possível, quando a produção de entropia atinge seu valor mínimo, a saber, zero.

Martyushev observa ainda que o mesmo aparato matemático poderia conduzir a uma conclusão aparentemente oposta, denominada princípio de Ziegler: se as forças termodinâmicas $X_{i}$ corresponderem a um conjunto previamente dado, então os verdadeiros fluxos $\mathrm{J}_{\mathrm{i}}$ satisfazendo à condição $\sigma=\sum_{\mathrm{i}} \mathrm{X}_{\mathrm{i}} . \mathrm{J}_{\mathrm{i}}$ fornecem o valor máximo (e não o mínimo) da produção de densidade de entropia $\sigma(J)$. Demonstra-se que o princípio de Prigogine corresponde a um caso particular do mais abrangente princípio de Ziegler, podendo ser observada uma hierarquia de processos: para pequenos intervalos de tempo o sistema maximiza a produção de entropia com as forças fixas e, como resultado, as relações lineares entre os fluxos e as forças tornam- 
se válidas; para uma escala de tempo maior, o sistema varia as forças termodinâmicas livres de maneira a reduzir a produção de entropia. ${ }^{263}$

SCHNEIDER e KAY (1994, 1995 e 1997) informam que em 1908 a termodinâmica deu um passo à frente quando Carathéodory ${ }^{264}$ demonstrou que "a entropia cresce" não é a formulação mais geral da segunda lei, mas: "Na vizinhança de qualquer dado estado de qualquer sistema fechado, existem estados inacessíves a ele por qualquer caminho adiabático reversível ou não". Tal formulação não depende, assim, da natureza do sistema nem de conceitos como entropia ou temperatura. Além disso, eles foram beber na chamada Lei do Equilíbrio Estável, de HATSOPOULOS e KEENAN (1965) ${ }^{265}$ apud SCHNEIDER e KAY (1994 e 1995) ou Princípio Unificado da Termodinâmica, de KESTIN (1966) ${ }^{266}$ apud SCHNEIDER e KAY (1994 e 1995). O enunciado desse princípio ou lei unifica as leis zero, primeira e segunda da termodinâmica. Sua redação é a seguinte: "Quando um sistema isolado realiza um processo a partir da remoção de uma série de restrições internas, ele atingirá um único estado de equilíbrio: esse estado de equilíbrio é independente da ordem com que as restrições foram removidas”. Segundo os autores, a importância desse princípio estaria em que ele determina uma direção e um estado final para todo processo real. Schneider e Kay demonstraram a partir desse princípio um corolário: "O princípio termodinâmico que governa o comportamento de sistemas é tal que, à medida que eles se afastam do equilíbrio, utilizarão todos os caminhos disponíveis para se contrapor aos gradientes aplicados. À medida que os gradientes aplicados aumentam, aumenta também a habilidade do sistema a se opor a movimentos mais distantes do equilíbrio".

Em síntese muito apertada, o princípio de estruturas dissipativas de Schneider e Kay consiste no seguinte (KAY, 1999): um sistema exposto a um fluxo de exergia do exterior será deslocado do equilíbrio. A resposta do sistema será organizar-se de

\footnotetext{
${ }^{263}$ Lembramos que em estudos de uso do solo e transportes que fazem uso do conceito de entropia (v. acima), admite-se a maximização de entropia.

${ }^{264}$ CARATHÉODORY, C. Investigations into the foundations of thermodynamics. In: KESTIN, J. (1976). The second law of thermodynamics: benchmark papers on energy, 5. New York: Dowden, Hutchinson \& Ross, 1976. p.229-56.

${ }^{265}$ HATSOPOULOS, G.; KEENAN, J. Principles of General Thermodynamics. New York: John Wiley, 1965.

${ }^{266}$ KESTIN, J. A course in thermodynamics. Waltham: Blaisdell, 1966.
} 
maneira a degradar a exergia de modo tão completo quanto as circunstâncias permitirem, assim limitando o grau em relação ao qual o sistema é movido do equilíbrio termodinâmico. Além disso, quanto mais o sistema é movido além do equilíbrio, maior o número de oportunidades organizacionais (dissipativas) que se tornarão acessíveis a ele e, consequentemente, mais efetivo se tornará na degradação de exergia. Aplicando o raciocínio a ecossistemas, tem-se que o sol fornece energia de alta qualidade (alta exergia) aos sistemas biológicos. Essa exergia produz gradientes no sistema que atuam no sentido de deslocar o ecossistema do equilíbrio termodinâmico. O ecossistema, então, procura reagir à mudança do estado de equilíbrio, e o faz na forma de estruturas dissipativas emergentes que cada vez melhor dissipam o gradiente externo. Cria-se assim uma estrutura auto-organizativa coerente que resiste e dissipa externamente gradientes aplicados que moveriam o sistema do equilíbrio. Assim, a vida pode ser visualizada como uma estrutura dissipativa distante do equilíbrio que mantém seu nível local de organização às expensas da degradação da exergia recebida do sol. Em assim sendo, a vida corresponde a uma das maneiras de dissipar o gradiente solar induzido, em um contínuo que passa pelo âmbito físico, pelo químico autocatalítico e pelo dos sistemas vivos.

\section{A3.3 UMA MÍNIMA HISTÓRIA DAS TEORIAS ECOSSISTÊMICAS}

Uma micro-história das teorias ecossistêmicas é necessária para o entendimento da demonstração apresentada no item seguinte, não somente para a apresentação de certos elementos teóricos, mas também para situá-los no contexto do desenvolvimento de teorias ecossistêmicas. Baseamo-nos quase que integralmente em HEARNSHAW, CULLEN e HUGHEY (s.d.), embora não tenha sido a intenção desses autores apresentar uma micro-história.

As principais teorias, princípios e paradigmas serão apresentados muito resumidamente a seguir em ordem aproximadamente cronológica e conceitual: 


\section{Reducionismo}

Todos os fenômenos ecossistêmicos podem ser explicados a partir da consideração das ciências moleculares.

\section{Princípio de máxima potência}

Ecossistemas são ciclos de energia e fluxos de materiais que têm diferentes propriedades autocatalíticas. O "princípio de máxima potência” (maximum power principle) assevera que os ecossistemas tendem a aumentar seus fluxos de matéria e energia, tornando-os mais eficientes na utilização de energia.

\section{Teoria da sucessão ecológica}

Uma sequência sucessional altamente ordenada de comunidades dominadas por espécies pequenas de rápido crescimento denominadas estrategistas-r faz $o$ ecossistema convergir dinamicamente de modo linear em direção a um clímax sustentável, com propriedades homeostáticas, determinístico (e frequentemente previsível) e dominado por espécies grandes e de crescimento lento denominadas estrategistas-K.

\section{Ecossistemas com dinâmica não linear e múltiplos estados de equilíbrio}

Existem múltiplos estados de equilíbrio, sendo os ecossistemas apenas localmente, mas não globalmente, estáveis. Para tal, foi necessário introduzir o conceito de resiliência ecológica, relacionado às noções de estabilidade e elasticidade locais do estado do sistema. Resiliência e estabilidade enquanto tal se diferenciam porque esta é relevante quando o sistema está próximo ao seu equilíbrio, enquanto a primeira trata da investigação de condições não lineares distantes do regime permanente, ou seja, a magnitude de distúrbio que um sistema em particular pode absorver sem transicionar para um estado alternativo. 


\section{Modelo diversidade-estabilidade}

A conectância (número de conexões) engendra a estabilidade de um ecossistema. Sendo a biodiversidade um indicador da conectância, quanto maior a biodiversidade de um ecossistema, mais estável tende a rede do sistema a ser e mais provável que as diversas funções ecossistêmicas sejam mantidas.

\section{Hipótese das espécies diretoras}

Espécies ditas diretoras controlam a resiliência do sistema, enquanto espécies ditas passageiras pouco fazem para manter o sistema em um estado particular.

\section{Auto-organização, emergência e funções-objetivo}

O desenvolvimento e o comportamento de sistemas dinâmicos não lineares baseiamse no princípio da auto-organização, pelo qual sistemas tendem a se conduzir de um processo que vai de baixos a altos níveis de organização ao mesmo tempo em que é mantido em certos limites. Ocorre a emergência de estruturas em redes altamente complexas. Um sistema se comporta como se ele estivesse sendo "atraído" em direção a um domínio, daí o conceito de "atrator". A auto-organização é função em grande parte da causalidade interna e tudo se passa como se o sistema fosse dominado por circuitos de retroalimentação não newtonianos positivos e negativos. Tais circuitos permitem ao sistema manter-se perto de um atrator a despeito de mudanças externas no ambiente. É essa capacidade de se organizar em torno de um atrator e manter-se que demonstra o caráter auto-organizativo de um sistema. Isso implica a existência de funções-objetivo (similares ao clímax no modelo de sucessão ecológica) através das quais mecanismos internos causais direcionam o ecossistema em direção ao atrator. 


\section{Sistemas dissipativos}

Sistemas auto-organizantes são dissipativos, ou seja, energia com grande quantidade de informação (exergia) sempre se dissipa em um sistema auto-organizante. Uma vez que um processo dissipativo emerja, o sistema tem uma alta propensão a mover-se para fora do equilíbrio termodinâmico, atingindo uma distância crítica desse equilíbrio a partir da qual o sistema responde com a emergência espontânea de comportamentos organizados que usam o fluxo de exergia para manifestar-se e organizar-se como uma estrutura complexa. Com mais exergia obtida por esse sistema, um ecossistema finalmente emerge. Assim, um ecossistema, de acordo com a perspectiva de sistemas dinâmicos não lineares, pode ser descrito como uma constelação de processos disssipativos auto-organizantes e estruturas organizadas em torno de um conjunto particular de exergia, materiais e informação inserido no ambiente. Uma vez que a estrutura do ecossistema esteja estabelecida, o crescimento do ecossistema é proporcionado pelo armazenamento de exergia em estruturas ordenadas de biomassa. Esse crescimento desenvolve organização e estrutura adicionais e continua a permitir que o sistema se mova contra o gradiente. Se a esse sistema for oferecido mais de um caminho para se distanciar do equilíbrio, a organização que comportar maior crescimento ou exergia será selecionada. Para que os ecossistemas e suas espécies continuem a crescer, eles devem se adaptar e se especializar no ambiente circundante, o que é feito por meio do armazenamento de mais informação no sistema. $\mathrm{O}$ processo de diversificação, adaptação e especialização aumenta a estrutura emergente enquanto permite ao sistema ser mais eficiente na utilização de seus recursos, bem como ser mais efetivo na construção de mais estrutura e mais adaptado às condições prevalecentes do ambiente, o que aumenta ainda mais a capacidade adaptativa do ecossistema. Em um sistema maduro, a maior parte da exergia capturada é usada para a manutenção de sua estrutura e somente uma pequena parte para crescimento adicional, cessando o crescimento quando um fator limitante se tornar escasso. Há diversas funções-objetivo. Por exemplo, tem-se funções-objetivo associadas a emergia (a quantidade de energia necessária para criar a estrutura de um ecossistema), a ascedência (indicador que 
estima não só a quantidade de espécies que estão no ecossistema, mas também como tais espécies estão nele organizadas coletivamente) ou a exergia.

\section{Ponto ótimo, integridade, janela de vitalidade, ordem, caos, complexidade}

O ponto no qual as forças desorganizantes do ambiente e as forças organizantes do sistema estão equilibradas corresponde a um ótimo de operação do sistema. Sistemas complexos auto-organizantes buscam não um máximo, mas um ótimo, havendo limites superiores e inferiores. Isso está relacionado à integridade do ecossistema, ou seja, à capacidade de o ecossistema manter-se dentro desses limites. Existe, portanto, uma janela de vitalidade entre cujos limites a auto-organização pode ocorrer e a emergência ser mantida. Estados possíveis entre o mínimo e o máximo correspondem a estados de complexidade, os únicos nos quais é possível produzir emergência e auto-organização. Abaixo do ponto de mínimo, existem estados de ordem, com nenhuma ou poucas conexões; correspondem a estados nos quais a coerência e a estabilidade de informação do sistema são maximizadas, mas arranjos possíveis tendem a ser improváveis. Acima do ponto de máximo, existem estados de caos, ocorrendo o oposto, o que ocasiona uma grande quantidade de oportunidades, mas com baixa probabilidade de desencadear alguma que seja viável.

\section{Modelo de ciclo adaptativo}

KAY (2000) apresentou como narrativa de um ecossistema o modelo de ciclo adaptativo de HOLLING (2001), resumido na figura A3-1. O primeiro ramo, que vai da "exploração" para a "conservação" corresponde à sucessão. Há dois atratores, o máximo consumo de exergia e o equilíbrio local com o meio. $\mathrm{Na}$ "conservação" (clímax autótrofo), há um equilíbrio, mais ou menos instável, entre esses dois atratores. A superconectividade do ecossistema nesse estado o torna frágil, sendo que inevitáveis distúrbios, como fogo, tempestades, etc. podem provocar uma súbita descarga ("liberação"). Nessa fase, o sistema tende a se reconstituir, sendo a fonte de energia a exergia armazenda na biomassa. Aparece um segundo ramo do ciclo, no qual o ecossistema caminha para o estado de "reorganização", sendo esse ramo 
chamado de destruição criativa. Esse ramo contém considerável incerteza, tendendo a um clímax heterótrofo. Se o ecossistema dispuser de condições ambientais adequadas, de suficientes nutrientes e de informação biológica disponível (nesse ponto a biodiversidade é crucial), ele pode retornar à exploração.

HOLLING (2001) e HEARNSHAW, CULLEN e HUGHEY (s.d.) ressaltam a inclusão de uma terceira variável, a resiliência. Teríamos, assim, na "exploração" e na "reorganização" alta resiliência, enquanto na "conservação" e "liberação", baixa resiliência.

Figura A3-1 - Modelo de quatro caixas de Holling.

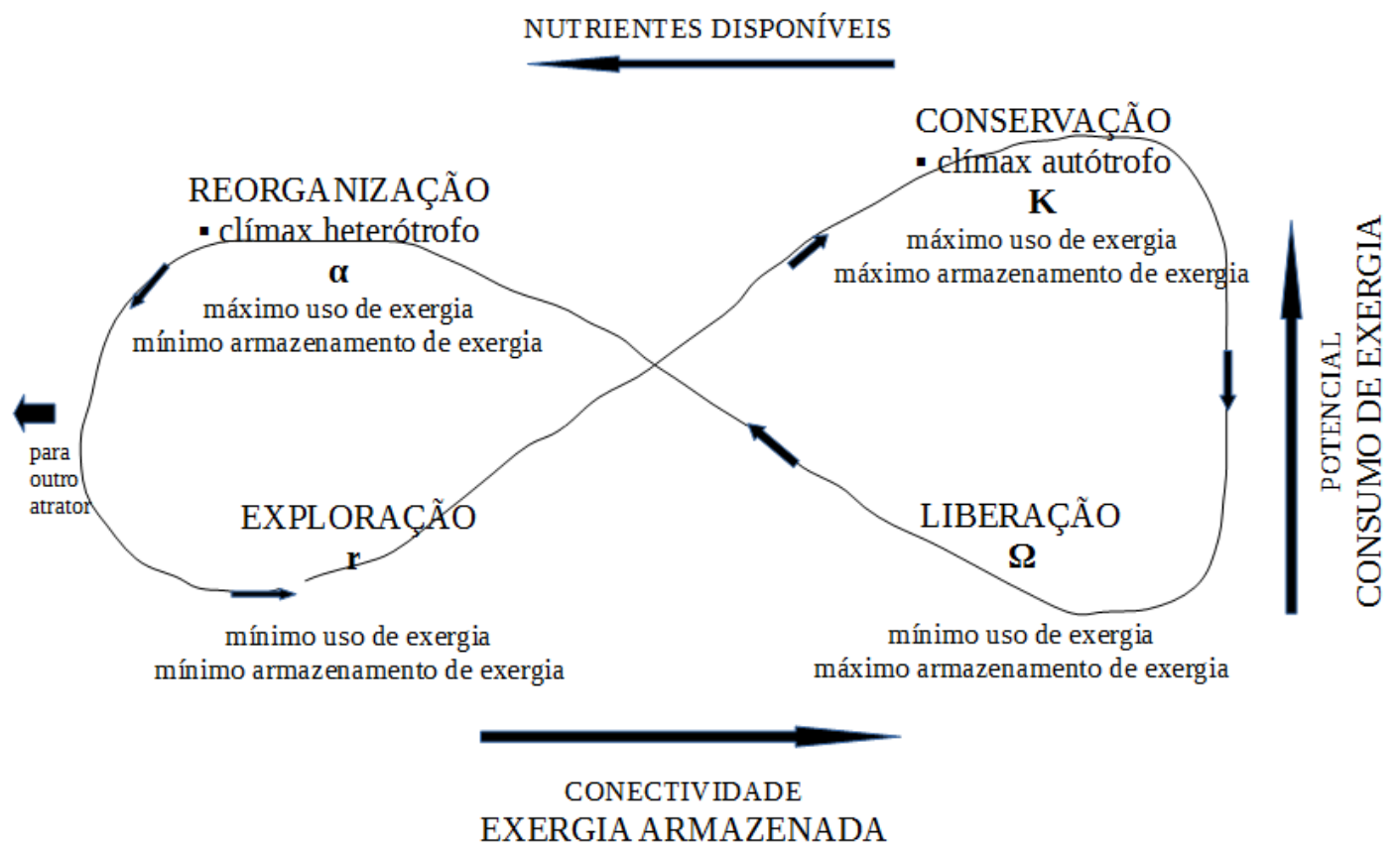

Fonte: HOLLING (2001) e KAY (2000), mod.

\section{Catástrofes, bifurcações e incertezas}

As mudanças de atração dos sistemas são modeladas frequentemente tanto pela teoria de catástrofe como pela teoria de bifurcação. A primeira trata de transições de estado nas quais a trajetória do sistema ao longo de uma superfície plana apresenta combinações de impossibilidade em certos pontos, representadas por dobras, o que o 
faz saltar ao se aproximar desses pontos (catástrofe) ${ }^{267}$. Pela teoria de bifurcação, a dinâmica de um sistema pode ser usada para explicar a existências de pontos críticos através dos quais a trajetória de um sistema é dividida em novos possíveis caminhos. O comportamento de um sistema em uma bifurcação tem elementos de incerteza extremamente imprevisíveis e que não podem ser reduzidos a estimativas probabilísticas, não importa de quanta informação se disponha e de quão sofisticados sejam os modelos de simulação.

\section{A3.4 DEMONSTRAÇÃO SEGUNDO FATH, PATTEN, CHOI E HIGASHI DA COMPLEMENTARIDADE E CONSISTÊNCIA INTERNA DE FUNÇÕES-OBJETIVO ECOLÓGICAS}

Apresentaremos aqui uma versão, que cremos simplificada e "mastigada", da demonstração apresentada em FATH, PATTEN e CHOI (2001). O nome de Higashi foi incluído em virtude de uma nota dos autores segundo a qual, estando ele falecido havia pouco tempo quando da redação do artigo, seu trabalho anterior perpassava todo o artigo e muitas das pesquisas prévias dos autores.

Os autores utilizaram um modelo conceitual denominado na bibliografia de modelo (ou análise) de rede.

Os autores apresentam algumas definições:

TST (total system throughflow): fluxo total do sistema;

TSS (total system storage): armazenamento total do sistema;

TSE (total system export): exportação total do sistema;

TSC (total systema cycling): ciclagem total do sistema;

EMP (empower): empoderamento;

\footnotetext{
${ }^{267}$ É interessante observar que em Resistência dos Materiais (caso particular da Mecânica dos Sólidos, no qual o material é elástico, linear, homogêneo e isotrópico e as estruturas são formadas por barras), a instabilidade ocorre quando mais de um estado de equilíbrio existe, sendo pelo menos um deles instável. No caso de barras comprimidas, uma vez que os estados estáveis de equilíbrio implicam enorme deslocamentos, o estado instável é considerado um estado limite último.
} 
EMG (emergy): emergia ${ }^{268}$;

ASC (ascendency): ascendência;

AMI (average mutual information): informação média mútua.

O objetivo é demonstrar a complementaridade e a consistência interna de alguns princípios com os quais se pretende descrever ecossistemas. Os autores traduziram cada princípio segundo as definições acima:

a) maximização de potência: $\max (\mathrm{TST})$;

b) maximização de armazenamento: $\max (\mathrm{TSS})$;

c) maximização de empoderamento: $\max (\mathrm{EMP})$;

d) maximização de emergia: $\max (\mathrm{EMG})$;

e) maximização de ascendência: $\max (\mathrm{ASC})$;

f) maximização de dissipação: $\max (\mathrm{TSE})$;

g) maximização de ciclagem: $\max (\mathrm{TSC})$;

h) maximização de tempo de residência: $\max (\mathrm{TSS} / \mathrm{TST})$;

i) minimização de dissipação específica: $\min (\mathrm{TSE} / \mathrm{TSS})$;

j) minimização da razão entre empoderamento e exergia: $\min (\mathrm{TST} / \mathrm{TSS})$.

Iniciemos, pois, a demonstração. Em primeiro lugar trataremos de fluxos, passando depois a armazenamento.

Seja uma matriz quadrada $F\left(f_{i j}\right)$ de $n$ linhas e colunas na qual cada elemento $f_{i j}$ descreve um fluxo dos compartimentos das colunas j para compartimentos das linhas i. A matriz $\mathrm{F}$ linearizada corresponde à matriz $\mathrm{G}\left(\mathrm{g}_{\mathrm{ij}}\right)$.

Um ecossistema apresenta diversos caminhos através dos quais as intensidades de fluxo são propagadas dos compartimentos de origem $\mathrm{j}$ para os compartimentos de destino i. Uma maneira de simbolizar matematicamente as possibilidades associadas à grande quantidade de caminhos possíveis, de comprimento $\mathrm{m}$, corresponde a obter potências $\mathrm{G}^{\mathrm{m}}$ e somá-las conforme $\sum_{\mathrm{m}=0, \infty} \mathrm{G}^{\mathrm{m}}$, obtendo dessa forma a matriz $\mathrm{N}$ :

$$
\mathrm{N}=\sum_{\mathrm{m}=0, \infty} \mathrm{G}^{\mathrm{m}}=\mathrm{I}+\mathrm{G}+\mathrm{G}^{2}+\mathrm{G}^{3}+\ldots+\mathrm{G}^{\mathrm{m}}+\ldots
$$

sendo I a matriz unitária correspondente a $\mathrm{G}^{0}$.

${ }^{268}$ Para uma comparação entre exergia e emergia v. JøRGENSEN, NIELSEN e MEJER (1995). 
Essa somatória converge uma vez que, devido à dissipação, os fluxos tendem a zero à medida que $\mathrm{m} \rightarrow \infty$. Nessas condições, a série acima converge para:

$$
\mathrm{N}=\sum \mathrm{m}=0, \infty \mathrm{G}^{\mathrm{m}}=\mathrm{I}+\mathrm{G}+\mathrm{G}^{2}+\mathrm{G}^{3}+\ldots+\mathrm{G}^{\mathrm{m}}+\ldots=(\mathrm{I}-\mathrm{G})^{-1}
$$

Seja agora um vetor coluna $\mathrm{z}\left(\mathrm{Z}_{\mathrm{n}}\right)$ de insumos (inputs) correspondente aos fluxos de entrada de fronteira externa do sistema em regime permanente ${ }^{269}$. Definese o vetor $\mathrm{T}\left(\mathrm{t}_{\mathrm{n}}\right)$ por meio de:

\section{$\mathrm{T} \equiv \mathrm{N} . \mathrm{z}$}

$\mathrm{O}$ significado de $\mathrm{T}$ está relacionado ao seguinte. O fluxo total do sistema no regime permanente (distante do equilíbrio) consiste em contribuições de fluxos chegando a cada compartimento terminal i originando-se de diversos compartimentos fonte $\mathrm{j}$ e sendo transferidos através de todos os caminhos de todos os tipos e comprimentos $\mathrm{m}$. Ou seja, os fluxos em regime permanente são quantidades distribuídas não só com respeito aos fluxos que se adicionam diretamente a eles, mas também às histórias, curtas ou longas, diretas ou indiretas, desses fluxos ao longo do ecossistema. Dado que $\mathrm{f}_{\mathrm{ij}}=\mathrm{g}_{\mathrm{ij}} \cdot \mathrm{T}_{\mathrm{j}}$, tem-se:

$$
\mathrm{T}_{\mathrm{j}} \equiv \mathrm{T}_{\mathrm{j}}{ }^{(\text {out })}=\sum \mathrm{i}(\neq \mathrm{j})=0, \mathrm{n} \mathrm{T}_{\mathrm{ij}}
$$

em que cada elemento de distribuição $T_{\mathrm{ij}}$ é derivado historicamente dos insumos de fronteira $\mathrm{z}_{\mathrm{j}}$ :

$$
\mathrm{T}_{\mathrm{ij}}=\mathrm{n}_{\mathrm{ij}} \cdot \mathrm{Z}_{\mathrm{j}}=\sum \mathrm{m}=0, \infty \mathrm{g}_{\mathrm{ij}}^{(\mathrm{m})} \cdot \mathrm{Z}_{\mathrm{j}}
$$

É interessante observar que nesse ponto da argumentação o vetor se transforma em uma matriz quadrada. O motivo ficará claro mais adiante.

Temos:

$$
T_{i j}=\left(g_{i j}^{(0)}+g_{i j}^{(1)}+g_{i j}^{(2)}+g_{i j}^{(3)}+\ldots+g_{i j}^{(m)}+\ldots\right) \cdot z_{j}
$$

Disso resulta:

$$
\mathrm{f}_{\mathrm{ij}}=\mathrm{g}_{\mathrm{ij}} \cdot\left[\sum_{\mathrm{i}(\neq \mathrm{j})=0, \mathrm{n}} \sum_{\mathrm{m}=0, \infty} \mathrm{g}_{\mathrm{ij}}^{(\mathrm{m})} \cdot \mathrm{z}_{\mathrm{j}}\right]
$$

É necessário definir três níveis de fluxos (e de armazenamento, conforme veremos a seguir):

1) interações por par: a contribuição de qualquer $\mathrm{j}$ para qualquer $\mathrm{i}(\mathrm{i}, \mathrm{j}=0,1, \ldots, n)$;

2) nível de compartimento: a contribuição total de todos os j para um i $(i, j=0,1, \ldots, n)$;

3) contribuição total em nível de sistema de todos os j para todos os $i(i, j=0,1, \ldots, n)$.

\footnotetext{
${ }^{269}$ Os autores de teoria ecossistêmica parecem supor que os ecossistemas tendem a regime permanente. V. nota anterior a esse respeito.
} 
Assumindo que esses níveis são aditivos, $\mathrm{T}_{\mathrm{i}}=\sum \mathrm{T}_{\mathrm{ij}}$ e $\mathrm{TST}=\sum \mathrm{T}_{\mathrm{i}}$, levando a fluxos duplamente distribuídos: $\mathrm{TST}=\sum \mathrm{T}_{\mathrm{i}}=\sum \sum \mathrm{T}_{\mathrm{ij}}$. A distinção de modo indica que o fluxo total é dividido em porções de insumo (vetor) (0), de primeira passagem (matriz) (1) e cíclicas (matriz) (2).

A notação associada a esses conceitos corresponde a:

a) contribuição de qualquer j para qualquer i mais insumos de fronteira (0):

$$
\mathrm{T}_{\mathrm{ij}}=\mathrm{f}_{\mathrm{i} 0}{ }^{(0)}+\mathrm{f}_{\mathrm{ij}}^{(1)}+\mathrm{f}_{\mathrm{ij}}^{(2)}
$$

b) contribuição de todos os $\mathrm{j}$ para determinado $\mathrm{i}$ mais insumos de fronteira (compartimentalizado):

$$
\mathrm{T}_{\mathrm{i}}=\mathrm{f}_{\mathrm{i} 0}^{(0)}+\sum_{\mathrm{j}=1, \mathrm{n}}\left(\mathrm{f}_{\mathrm{ij}}^{(1)}+\mathrm{f}_{\mathrm{ij}}^{(2)}\right)
$$

c) contribuição total em nível de sistema: a contribuição de todos os j para todos os i mais insumos de fronteira (para todo o sistema):

$$
\mathrm{TST}=\sum_{\mathrm{i}=1, \mathrm{n}} \mathrm{f}_{\mathrm{i} 0}{ }^{(0)}+\sum_{\mathrm{i}=1, \mathrm{n}} \sum_{\mathrm{j}=1, \mathrm{n}}\left(\mathrm{f}_{\mathrm{ij}}{ }^{(1)}+\mathrm{f}_{\mathrm{ij}}{ }^{(2)}\right)
$$

Os fluxos podem ser particiondos em cinco modos $(0,1,2,3,4)$, correspondentes aos apresentados acima. A única novidade é que agora é adicionado um modo 3. Assim:

a) o modo 0 corresponde aos insumos obtidos na fronteira externa do sistema;

b) o modo 1, a todos os fluxos em que uma substância se move do nó j para o nó terminal i pela primeira vez somente;

c) o modo 2, aos fluxos ciclados nos nós terminais i para cada par (i,j). Observar que quando a porção ciclada $\mathrm{n}_{\mathrm{ii}}-1$ for ponderada pelo primeiro fluxo de passagem, $\left(\mathrm{n}_{\mathrm{ij}} / \mathrm{n}_{\mathrm{ii}}\right) \mathrm{z}_{\mathrm{j}}$, tem-se a ciclagem total;

d) o modo 3, aos fluxos dissipativos, no sentido de que se sai do nó i para nunca retornar a esse nó;

d) modo 4, aos produtos (outputs) na fronteira externa de i consistindo sistematicamente em fluxos dissipativos saindo do sistema.

A formalização aparece na segunda e na terceira colunas da tabela A3-1. 
Tabela A3-1 - Representação de partições de fluxos e armazenamentos em cinco modos para cada par $(\mathrm{i}, \mathrm{j})$ em um sistema.

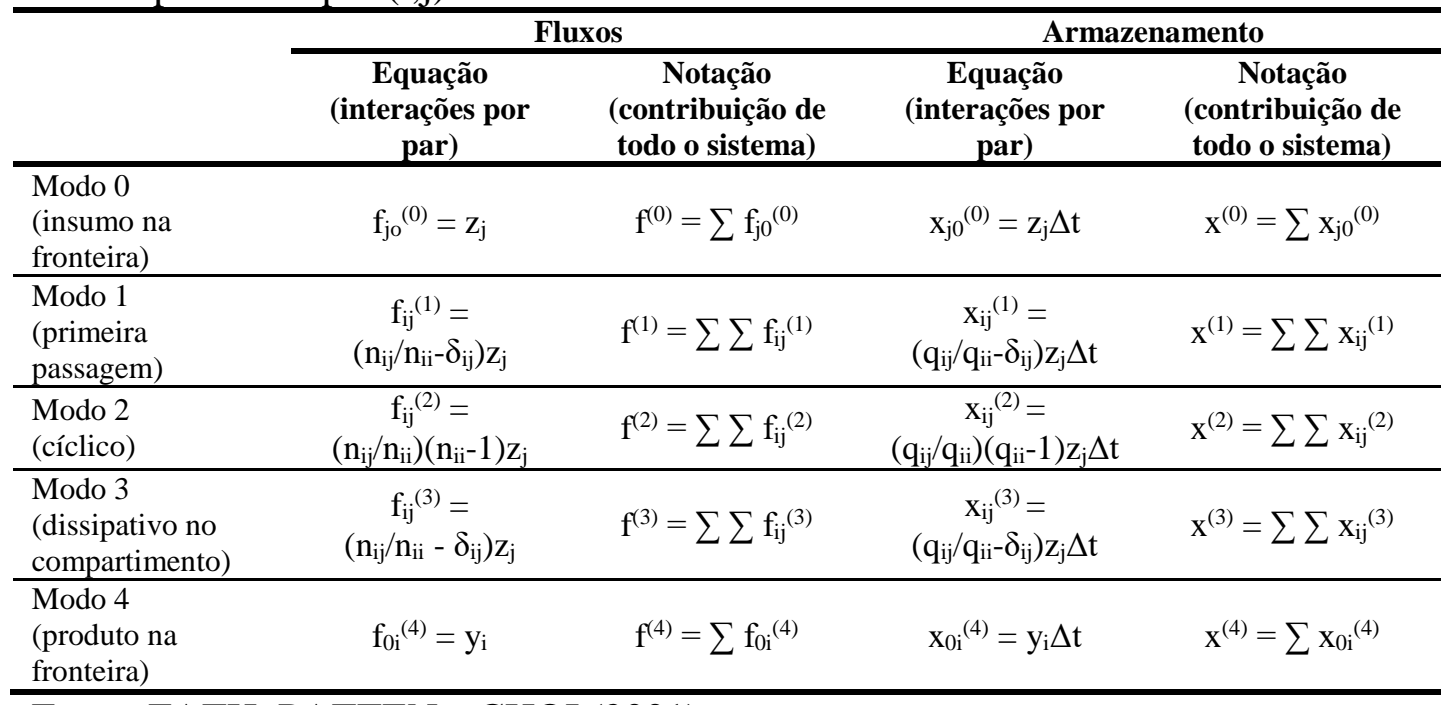

Fonte: FATH, PATTEN e CHOI (2001)

Nota:

$\delta_{\mathrm{ij}}$ é o delta de Kronecker, definido por $\delta_{\mathrm{ij}}=1$ para $\mathrm{i}=\mathrm{j}$ e $\delta_{\mathrm{ij}}=0$ para $\mathrm{i} \neq \mathrm{j}^{270}$;

$\mathrm{n}_{\mathrm{ii}}$ : número total de vezes que um recurso deixará um comportimento em particular.

Passemos agora ao armazenamento. Seja um vetor $\mathrm{x}\left(\mathrm{x}_{\mathrm{j}}\right)$ correspondente aos valores de armazenamento no regime permanente. Dele é possível obter uma matriz $\mathrm{C}\left(\mathrm{c}_{\mathrm{ij}}\right)$, definida por:

$$
c_{i j}=f_{i j} / x_{j}
$$

e

$$
\mathrm{c}_{\mathrm{ii}}=-\sum_{\mathrm{k}(\neq \mathrm{fi})=0, \mathrm{n}} \mathrm{c}_{\mathrm{ki}}=-\tau_{\mathrm{i}}^{-1}
$$

sendo $\tau_{\mathrm{i}}$ o tempo de rotatividade (turnover time) e $\tau_{\mathrm{i}}^{-1}$, a taxa de rotatividade (turnover rate).

$\mathrm{C}$ deve agora ser desdimensionalizada, obtendo-se a matriz $\mathrm{P}\left(\mathrm{p}_{\mathrm{ij}}\right)$. Isso é feito através de intervalos de tempo discretos:

$$
\mathrm{P}=\mathrm{I}+\mathrm{C} . \Delta \mathrm{t} \text {, tal que } 0 \leq \mathrm{p}_{\mathrm{ij}}<1 \text {, para qualquer } \mathrm{i}, \mathrm{j}
$$

Especificamente, os elementos da diagonal de $\mathrm{P}$ correspondem a:

$$
\mathrm{p}_{\mathrm{ii}}=1+\mathrm{c}_{\mathrm{ii}} \cdot \Delta \mathrm{t}=1-\tau_{\mathrm{i}}^{-1} \cdot \Delta \mathrm{t}
$$

A matriz $\mathrm{P}$ corresponde à probabilidade de que uma substância em $\mathrm{j}$ no tempo t esteja em i após o intervalo de tempo $\Delta \mathrm{t}$.

${ }^{270}$ O delta de Kronecker pode ser entendido como um tensor misto de segunda ordem (PIPES, 1963, p.476). 
Analogamente a $\mathrm{G}$, pode ser obtida uma série infinita, que define a matriz $\mathrm{Q}$ :

$$
\mathrm{Q}=\mathrm{I}+\mathrm{P}+\mathrm{P}^{2}+\mathrm{P}^{3}+\ldots+\mathrm{P}^{\mathrm{m}}+\ldots
$$

Essa série converge desde que a somas das colunas de $\mathrm{P}$ sejam menores do que a unidade. Uma vez que os ecossistemas são energética e materialmente abertos, a condição de convergência pode ser obtida fazendo-se $\Delta$ t suficientemente pequeno. Dessa forma, obtém-se:

$$
\mathrm{Q}=\mathrm{I}+\mathrm{P}+\mathrm{P}^{2}+\mathrm{P}^{3}+\ldots+\mathrm{P}^{\mathrm{m}}+\ldots=(\mathrm{I}-\mathrm{P})^{-1}
$$

Tem-se, então, que:

$$
\mathrm{x}=\mathrm{Q}(\mathrm{z} \Delta \mathrm{t})=\left(\mathrm{I}+\mathrm{P}+\mathrm{P}^{2}+\mathrm{P}^{3}+\ldots+\mathrm{P}^{\mathrm{m}}+\ldots\right) \mathrm{z} \Delta \mathrm{t}
$$

Temos:

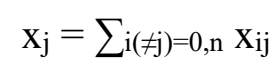

sendo:

$$
\mathrm{x}_{\mathrm{ij}}=\mathrm{q}_{\mathrm{ij}}\left(\mathrm{Zj}_{\mathrm{j}} \Delta \mathrm{t}\right)=\sum \mathrm{m}=0, \infty \mathrm{p}_{\mathrm{ij}}^{(\mathrm{m})} \mathrm{Zj}_{\mathrm{j}} \Delta \mathrm{t}
$$

de forma que:

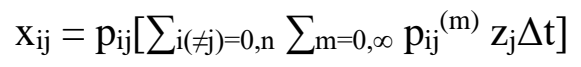

Assumindo que os níveis são aditivos, $\mathrm{x}_{\mathrm{i}}=\sum \mathrm{x}_{\mathrm{ij}}$ e TSS $=\sum \mathrm{x}_{\mathrm{i}}$, levando a fluxos duplamente distribuídos: $\mathrm{TSS}=\sum \mathrm{x}_{\mathrm{i}}=\sum \sum \mathrm{x}_{\mathrm{ij}}$. A distinção de modo indica que o fluxo total é dividido em porções de insumo (vetor) (0), de primeira passagem (matriz) (1) e cíclicas (matriz) (2).

A notação associada a esses conceitos corresponde a:

a) contribuição de qualquer j para qualquer i mais insumos de fronteira (0):

$$
\mathrm{x}_{\mathrm{ij}}=\mathrm{x}_{\mathrm{i} 0^{(0)}}+\mathrm{x}_{\mathrm{ij}}^{(1)}+\mathrm{x}_{\mathrm{ij}}^{(2)}
$$

b) contribuição de todos os $\mathrm{j}$ para determinado $\mathrm{i}$ mais insumos de fronteira (compartimentalizado):

$$
\mathrm{X}_{\mathrm{i}}=\mathrm{x}_{\mathrm{i} 0}{ }^{(0)}+\sum_{\mathrm{j}=1, \mathrm{n}}\left(\mathrm{x}_{\mathrm{ij}}{ }^{(1)}+\mathrm{x}_{\mathrm{ij}}{ }^{(2)}\right)
$$

c) contribuição total em nível de sistema: a contribuição de todos os j para todos os i mais insumos de fronteira (para todo o sistema):

$$
\mathrm{TSS}=\sum_{\mathrm{i}=1, \mathrm{n}} \mathrm{x}_{\mathrm{i} 0}{ }^{(0)}+\sum_{\mathrm{i}=1, \mathrm{n}} \sum_{\mathrm{j}=1, \mathrm{n}}\left(\mathrm{x}_{\mathrm{ij}}{ }^{(1)}+\mathrm{x}_{\mathrm{ij}}^{(2)}\right)
$$

Os armazenamentos também podem ser particiondos em cinco modos $(0,1,2,3,4)$, analogamente aos fluxos.

A formalização aparece na quarta e na quinta colunas da tabela A3-1. 
Talvez um caso particular e simplificado apresentado na figura A3-2 possa ajudar a melhor visualizar a notação e clarificar alguns conceitos.

Figura A3-2 - Esquema gráfico dos conceitos da análise de rede.

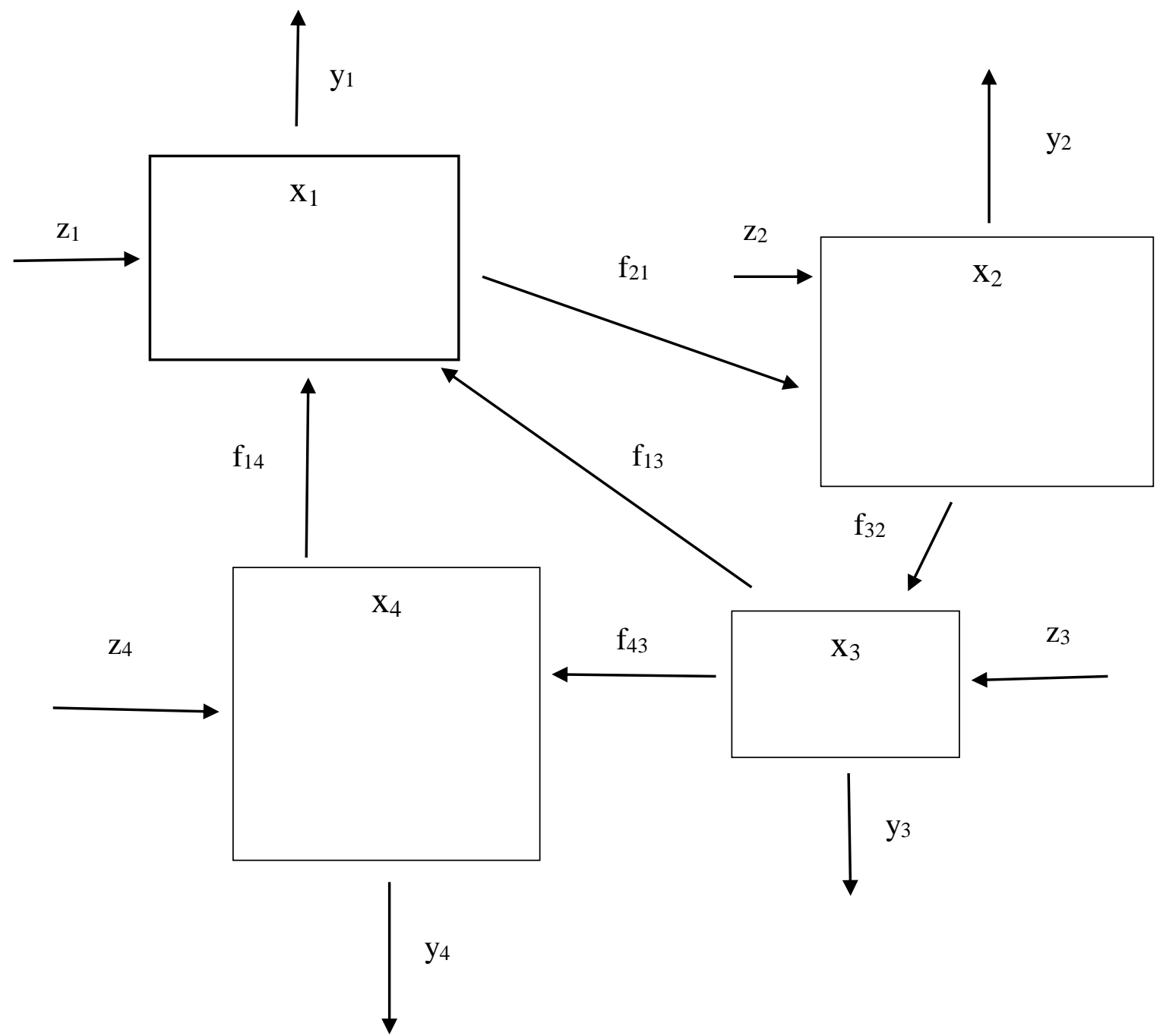

Fonte: FATH et al. (2004) mod.

Nota:

$\mathrm{f}_{14}$ corresponde ao modo 2 (ciclagem)

Finalmente estamos em condição de alinhar aos princípios e sua tradução as definições propostas pelos autores, conforme apresentado no início do item, com parâmetros e formulações desenvolvidos ao longo da demonstração, o que é apresentado na tabela A3-2. 
Tabela A3-2 - Princípios extremos de descrição de ecossistemas associados à representação de partições de fluxos e armazenamentos em cinco modos para todo o sistema.

\begin{tabular}{|c|c|c|c|}
\hline Princípio & Princípio extremo & $\begin{array}{c}\text { Parâmetro } \\
\text { (nível de sistema) }\end{array}$ & $\begin{array}{c}\text { Formulação em análise de } \\
\text { rede }\end{array}$ \\
\hline Maximização de potência & $\max (\mathrm{TST})$ & $\mathrm{TST}=\mathrm{f}^{(0)}+\mathrm{f}^{(1)}+\mathrm{f}^{(2)}$ & $\mathrm{TST}=\sum \sum\left(\mathrm{n}_{\mathrm{ij}}\right) \mathrm{z}_{\mathrm{j}}$ \\
\hline $\begin{array}{l}\text { Maximização de } \\
\text { armazenamento }\end{array}$ & $\max (\mathrm{TSS})$ & $\mathrm{TSS}=\mathrm{x}^{(0)}+\mathrm{x}^{(1)}+\mathrm{x}^{(2)}$ & $\mathrm{TSS}=\sum \sum \tau_{\mathrm{i}}\left(\mathrm{n}_{\mathrm{ij}}\right) \mathrm{z}_{\mathrm{j}}$ \\
\hline $\begin{array}{l}\text { Maximização de } \\
\text { empoderamento }\end{array}$ & $\max (\mathrm{EMP})$ & $E M P=f^{(0)}+f^{(1)}+f^{(2)}$ & $\mathrm{EMP}=\sum \sum\left(\mathrm{n}_{\mathrm{ij}}{ }^{*}\right) \mathrm{z}_{\mathrm{j}}$ \\
\hline Maximização de emergia & $\max (\mathrm{EMG})$ & $\mathrm{EMG}=\mathrm{x}^{(0)}+\mathrm{x}^{(1)}+\mathrm{x}^{(2)}$ & $\mathrm{EMG}=\sum \sum \tau_{\mathrm{i}}\left(\mathrm{n}_{\mathrm{ij}}{ }^{*}\right) \mathrm{z}_{\mathrm{j}}$ \\
\hline $\begin{array}{l}\text { Maximização de } \\
\text { ascendência }\end{array}$ & $\max (\mathrm{ASC})$ & $\mathrm{ASC}=\mathrm{AMI} \cdot\left[\mathrm{f}^{(0)}+\mathrm{f}^{(1)}+\mathrm{f}^{(2)}\right]$ & $\mathrm{ASC}=\mathrm{AMI} \sum \sum\left(\mathrm{n}_{\mathrm{ij}}\right) \mathrm{z}_{\mathrm{j}}$ \\
\hline $\begin{array}{l}\text { Maximização de } \\
\text { dissipação }\end{array}$ & $\max (\mathrm{TSE})$ & $\mathrm{TSE}=\mathrm{f}^{(4)}$ & $\mathrm{TSE}=\sum \sum \varepsilon_{\mathrm{i}}\left(\mathrm{n}_{\mathrm{ij}}\right) \mathrm{z}_{\mathrm{j}}$ \\
\hline Maximização de ciclagem & $\max (\mathrm{TSC})$ & $\mathrm{TSC}=\mathrm{f}^{(2)}$ & $\mathrm{TSC}=\sum \sum\left(\mathrm{n}_{\mathrm{ij}} / \mathrm{n}_{\mathrm{ii}}\right)\left(\mathrm{n}_{\mathrm{ii}}-1\right) \mathrm{z}_{\mathrm{j}}$ \\
\hline $\begin{array}{l}\text { Maximização de tempo de } \\
\text { residência }\end{array}$ & $\max (\mathrm{TSS} / \mathrm{TST})$ & $\mathrm{TSS} / \mathrm{TST}=\tau$ & $\mathrm{TSS} / \mathrm{TST}=\sum \sum \tau_{\mathrm{i}}\left(\mathrm{n}_{\mathrm{ij}}\right) \mathrm{z}_{\mathrm{j}} /\left(\left(\mathrm{n}_{\mathrm{ij}}\right) \mathrm{z}_{\mathrm{j}}\right)=\sum \tau_{\mathrm{i}}$ \\
\hline $\begin{array}{l}\text { Minimização de dissipação } \\
\text { específica }\end{array}$ & $\min (\mathrm{TSE} / \mathrm{TSS})$ & TSE/TSS $=\mathrm{f}^{(4)} /\left[\mathrm{x}^{(0)}+\mathrm{x}^{(1)}+\mathrm{x}^{(2)}\right]$ & $\begin{array}{c}\mathrm{TSE} / \mathrm{TSS}=\sum \sum \varepsilon_{\mathrm{i}}\left(\mathrm{n}_{\mathrm{ij}}\right) \mathrm{z}_{\mathrm{j}} /\left(\tau_{\mathrm{i}}\left(\mathrm{n}_{\mathrm{ij}}\right) \mathrm{z}_{\mathrm{j}}\right)= \\
\sum \sum \varepsilon_{\mathrm{i}} / \tau_{\mathrm{i}}\end{array}$ \\
\hline $\begin{array}{l}\text { Minimização da razão } \\
\text { entre empoderamento e } \\
\text { exergia }\end{array}$ & $\min (\mathrm{TST} / \mathrm{TSS})$ & $\mathrm{TST} / \mathrm{TSS}=1 / \tau$ & $\begin{array}{c}\mathrm{TST} / \mathrm{TSS}=\sum \sum\left(\mathrm{n}_{\mathrm{ij}}{ }^{*}\right) \mathrm{z}_{\mathrm{j}} / \tau_{\mathrm{i}}\left(\mathrm{n}_{\mathrm{ij}}\right) \mathrm{z}_{\mathrm{j}}= \\
\sum \sum\left(\mathrm{n}_{\mathrm{ij}}{ }^{*}\right) / \tau_{\mathrm{i}}\left(\mathrm{n}_{\mathrm{ij}}\right)\end{array}$ \\
\hline
\end{tabular}

Fonte: FATH, PATTEN e CHOI (2001)

Nota:

$\mathrm{n}_{\mathrm{ij}}$ * denota transformidades (transformities) que convertem fluxos de energia e de armazenamento em empoderamento e emergia;

AMI: informação média mútua; $\varepsilon_{\mathrm{i}}$ : frações específicas para cada compartimento do fluxo em i derivado de cada insumo $\mathrm{j}$.

Na tabela A3-2 a definição de tempo de rotatividade como o armazenamento dividido pelo fluxo de fronteira externa de todo o sistema é usada para compor fluxos de fronteira externa em armazenamentos: $\mathrm{x}_{\mathrm{ij}}=\tau_{\mathrm{i}} \mathrm{T}_{\mathrm{i}}=\tau_{\mathrm{i}} \mathrm{n}_{\mathrm{i}} \mathrm{Z}_{\mathrm{j}}$.

Passemos à avaliação de cada princípio à luz da tabela A3-2:

a) maximização de potência: tendo esta sido associada à maximização do fluxo de todo o sistema (TST), tem-se que por definição TST $=\mathrm{f}^{(0)}+\mathrm{f}^{(1)}+\mathrm{f}^{(2)}$, que, como visto na tabela A3-1, corresponde à somatória dos produtos de intensidades de fluxo, $\mathrm{n}_{\mathrm{ij}}$, por insumos, $\mathrm{z}_{\mathrm{j}}$;

b) maximização de armazenamento: por definição $\mathrm{TSS}=\mathrm{x}^{(0)}+\mathrm{x}^{(1)}+\mathrm{x}^{(2)}$. Porém, $\mathrm{x}_{\mathrm{ij}}=\tau_{\mathrm{i}} \mathrm{n}_{\mathrm{j} j} \mathrm{Z}_{\mathrm{j}}$. Daí decorre que o armazenamento é igual à potência multiplicada pelo fator de tempo de rotatividade, $\tau_{i}$, para cada compartimento; 
c) maximização de empoderamento e emergia: a menos da diferença entre $\mathrm{n}_{\mathrm{ij}}$ e $\mathrm{n}_{\mathrm{ij}}{ }^{*}$, a maximização de empoderamento e a maximização de emergia têm formulações idênticas a TST e TSS, respectivamente;

d) maximização de ascendência: a ascendência é definida pelo produto de TST pela informação média mútua (AMI). Porém, observa-se que TST domina o cálculo de ascendência;

e) maximização da dissipação: a dissipação corresponde à exportação total do sistema (TSE), e, portanto, a $\mathrm{f}^{(4)}$. A dissipação é expressa aqui como frações, $\varepsilon_{\mathrm{i}}$, específicas para cada compartimento do fluxo em i derivado de cada insumo $z_{j}$, ou seja, $\mathrm{TSE}=\sum \varepsilon_{\mathrm{i}} \mathrm{T}_{\mathrm{i}}=\sum \sum \varepsilon_{\mathrm{i}} \mathrm{n}_{\mathrm{ijj}} \mathrm{Z}_{\mathrm{j}}$, uma vez que no regime permanente a exportação total do sistema iguala-se à importação total do sistema $\left(\mathrm{f}^{(4)}=\mathrm{f}^{(0)}\right)$. Daí decorre que a maximização da dissipação é equivalente à maximização dos insumos, que correspondem a um componente do fluxo total do sistema. Assim, a maximização dos insumos contribui para a maximização da potência;

f) maximização da ciclagem: $\mathrm{f}^{(2)}$ ocorre quando a porção do modo 2 do TST aumenta. O fluxo ciclado contribui para o TST de maneira separada do fluxo de insumos ou de primeira passagem. Os elementos da diagonal $\mathrm{n}_{\mathrm{ii}}$ de $\mathrm{N}$ dão o número total de vezes que um recurso deixará um compartimento em particular. Quando a porção ciclada, $\mathrm{n}_{\mathrm{ii}}-1$, é ponderada pelo fluxo da primeira passagem, $\left(\mathrm{n}_{\mathrm{ij}} / \mathrm{n}_{\mathrm{ii}}\right) \mathrm{Z}_{\mathrm{j}}$, obtémse a ciclagem total do sistema. Aparentemente há uma contradição entre a maximização da ciclagem e a maximização da dissipação porque parece que a dissipação é limitada pela ciclagem. Se TST fosse fixado, ou seja, fosse de soma zero, então haveria um tradeoff entre o modo 4 (dissipação de fronteira), o modo 2 (ciclagem) e o modo 1 (fluxo de primeira passagem). No entanto, TST não é fixo, mas está se automaximizando. Assim, maximizar a ciclagem é consistente com a maximização da potência uma vez que TST é abrangido tanto pela dissipação como pela ciclagem;

g) maximização do tempo de residência: $\tau=\mathrm{TSS} / \mathrm{TST}$ é consistente com a maximização do armazenamento;

h) minimização da dissipação específica: $\mathrm{f}^{(4)} /\left[\mathrm{x}^{(0)}+\mathrm{x}^{(1)}+\mathrm{x}^{(2)}\right]$ pode ser simplificado para $\varepsilon_{\mathrm{i}} / \tau_{\mathrm{i}}$. O tempo de rotatividade é gerado a partir das eficiências de transferência

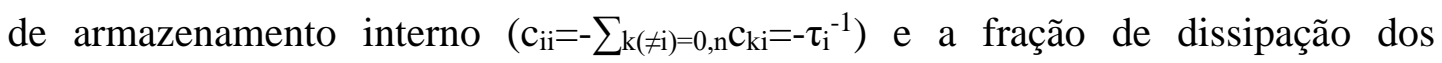


insumos. Portanto, o princípio de minimização da dissipação específica captura duas propriedades básicas de sistemas, sendo que para otimizá-la o tempo de residência deve aumentar;

i) minimização da razão entre empoderamento e exergia: $\min (\mathrm{TST} / \mathrm{TSS})$ pode ser simplificado para a minimização da taxa de rotatividade, que é equivalente à maximização do tempo de residência. Essa função-objetivo combina ambas as condições de referência e mede a eficiência do sistema na manutenção da estrutura. À medida que a transformidade, $\mathrm{N}^{*}$, se aproxima da matriz de fluxo integral, $\mathrm{N}$, essa razão se aproxima do princípio de maximização do tempo de residência.

Conclui-se, portanto, que os princípios de maximização do armazenamento e da dissipação são complementares e consistentes.

\section{A3.5 FUNÇÕES-OBJETIVO AO LONGO DO DESENVOLVIMENTO DO ECOSSISTEMA}

Como visto acima, FATH, PATH e CHOI (2001) mostraram que dez funções-objetivo que pretendem descrever ecossistemas podem ser consideradas complementares e mutuamente consistentes. Seria interessante ver como se comportam funções-objetivo ao longo do desenvolvimento de ecossistemas.

FATH et al. (2004) propuseram um modelo de crescimento de ecossistemas que separa a sucessão em quatro estágios:

a) estágio 0: o crescimento da fronteira traz insumos materiais de baixa entropia para dentro do sistema;

b) estágio 1: o crescimento estrutural ocorre quando a quantidade física de biomassa no sistema aumenta, frequentemente como resultado do aumento de quantidade, número e tamanho de seus componentes. $\mathrm{O}$ crescimento estrutural consiste em retroalimentação positiva porque a biomassa adicional torna possível ao sistema capturar mais energia solar, embora também mais energia seja requerida para a manutenção; 
c) estágio 2: o crescimento da rede corresponde a crescimento em conectividade através de interações adicionais de energia-matéria, o que resulta na proliferação de caminhos e em mais ciclagem de matéria e energia;

d) estágio 3: o crescimento de informação consiste em crescimento qualitativo no comportamento do sistema partindo de padrões de exploração para padrões mais conservativos, que são energeticamente mais eficientes.

Os autores compararam as seguintes funções-objetivo: a) mínima dissipação específica; b) máximo fluxo de energia; c) máxima dissipação de exergia; d) máximo armazenamento de exergia; e) máximo tempo de retenção.

Para comparar essas funções-objetivo, foram utilizadas três abordagens: a) um modelo ecossistêmico; b) evidência de campo; c) modelo de rede.

Duas das conclusões que emergiram foram as seguintes:

a) das cinco funções-objetivo comparadas, somente a maximização do fluxo de energia e a maximização do armazenamento de exergia são válidas nos quatro estágios de sucessão descritos acima;

b) a dissipação de exergia aumenta durante os estágios 0 e 1 , tendendo rapidamente ao máximo nos estágios 2 e 3.

Essas duas constatações já constavam de FATH et al. (2001), que observaram que a dissipação do sistema aumenta rapidamente em direção a um valor próximo do máximo teórico no crescimento inicial, enquanto o armazenamento de exergia continua a aumentar indefinidamente nos estágios médio e tardio do desenvolvimento. Eles atribuem essa tendência de o armazenamento aumentar mais rapidamente do que a dissipação à relação $\mathrm{R} \alpha \mathrm{B}^{3 / 4}$, sendo $\mathrm{R}$ a taxa de respiração $\mathrm{e} \mathrm{B} \mathrm{o}$ tamanho do organismo 271 .

\footnotetext{
${ }^{271}$ GLAZIER (2009) informa que essa relação é denominada "lei da potência dos 3/4", que R pode se referir à taxa de diversos processos metabólicos, e não apenas à respiração, que "análises tanto de organismos uni quanto multicelulares mostram que não existe uma relação de escala metabólica universal, e que a variação de tais relações é sistemática e possivelmente universalmente relacionada ao nível metabólico".
} 


\section{A3.6 UMA MÉTRICA COMUM À ECOEXERGIA E À DEGRADAÇÃO DE EXERGIA}

Se formos capazes de indicar, entre ecoexergia e degradação de exergia, não uma igualdade, porque uma se refere a armazenamento e outra, a fluxos, mas uma proporcionalidade, teremos condições de afirmar que ambos se equivalem e que a unidade ambiental, definida como a concentração superficial de detritus equivalente por metro quadrado de área de terreno dividida por 1000 corresponde a um indicador razoável não apenas da qualidade ecossistêmica, mas também do microclima.

Verificamos no item anterior que a degradação e o armazenamento de exergia não são proporcionais em todas as fases do desenvolvimento ecossistêmico. De fato, há base empírica para tal afirmação, conforme apresentado na figura A3-3. A figura apresenta uma relação observada entre a porcentagem de radiação solar degradada (que podemos associar à exergia degradada) ${ }^{272}$ e o armazenamento de exergia. A porcentagem de radiação solar degradada foi estimada por SCHNEIDER e KAY (1994) para diversos ecossistemas a partir de intensidades de radiação de onda longa reirradiada obtidas por satélite. A exergia armazenada foi estimada por FATH et al. (2004) (v. tabela 3) a partir de dados disponíveis em SCHNEIDER e KAY (1994). Todos esses dados se encaixaram bem em uma equação do tipo Michaelis-Menten obtida por nós: $\mathrm{DIS}=64 . \mathrm{ST} /(0,2+\mathrm{ST})$, sendo DIS a porcentagem de radiação solar degradada em processos não-radioativos (\%), e ST o armazenamento de exergia $\left(\mathrm{MJ} / \mathrm{m}^{2}\right)$. Ora, uma característica marcante das equações do tipo Michaelis-Menten, ou de Monod (VON SPERLING, 1996, p.110-2) é que para baixos valores da abscissa a função é linear, como se pode verificar na figura. De fato, FATH et al. (2004), a partir dos dados que subsidiaram a confecção dessa figura, informam que a dissipação de exergia apresenta uma relação linear com a exergia armazenada nos ecossistemas menos desenvolvidos.

\footnotetext{
${ }^{272}$ A exergia degradada é quase igual à exergia capturada pelo ecossistema na medida em que a maior parte da exergia é utilizada para manutenção, evaporação e respiração dos organismos do ecossistema (v. JØRGENSEN, 2007, p.24).
} 
JØRGENSEN, PATTEN e STRAŠKRABA (2000) propuseram um modelo de crescimento de ecossistemas que esclarece a sucessão em cinco estágios: (0) condição inicial; (I) sucessão inicial a média; (II) sucessão média a tardia; (III) atrator de clímax; (IV) senescência e destruição criativa. FATH et al. (2004) denominavam os quatro primeiros como crescimentos de fronteira, estrutural, de rede e de informação. A destruição criativa está associada ao modelo de quatro caixas de HOLLING (2001), que pode ser visualizado na figura A3-1. A relação entre a exergia específica degradada ${ }^{273}$ e a exergia armazenada no contexto dos estágios de crescimento dos ecossistemas pode ser visualizada na figura A3-4. Alguém poderia argumentar que no trecho inicial a ecoexergia estaria relacionada apenas ao termo clássico da exergia e que no trecho constante a ecoexergia estaria relacionada apenas ao termo da exergia informacional. Não procederia, no entanto, essa argumentação; em ambos os trechos são considerados os dois termos da ecoexergia, haja vista, por exemplo, a simulação apresentada em FATH et al. (2004), trabalho do qual Jørgensen é um dos coautores.

O cerne da nossa argumentação reside no fato de que os biótopos no lote, em sua maioria esmagadora, estão em fases iniciais de seu desenvolvimento. Disso concluímos que há uma relação linear entre a exergia degradada e a exergia armazenada, ou seja, ambas são proporcionais. Sendo proporcionais, ambas se sujeitam a ser descritas pelo mesmo indicador. Conforme a argumentação apresentada, então a qualidade ecossistêmica e o impacto da vegetação no microclima podem ter o mesmo valor numérico, que pode ser chamado, como ocorre no texto legal relaciondo à Quota Ambiental, de indicador de vegetação.

Como curiosidade, podemos concluir que se impusermos hipótese segundo a qual em cada estágio do desenvolvimento de um ecossistema é válido um regime quase semipermanente, então, utilizando as notações do modelo de rede, temos que, sendo a dissipação dada por $\mathrm{TSE}=\sum \varepsilon_{\mathrm{i}} \mathrm{T}_{\mathrm{i}}=\sum \sum \varepsilon_{\mathrm{i}} \mathrm{n}_{\mathrm{ij}} \mathrm{Z}_{\mathrm{j}}$ e $\mathrm{o}$ armazenamento por $\mathrm{TSS}=\sum \sum \tau_{\mathrm{i}}\left(\mathrm{n}_{\mathrm{ij}}\right) \mathrm{z}_{\mathrm{j}}$, tudo se passa como se nos primeiros estágios de desenvolvimento do ecossistema tivéssemos para cada compartimento $\varepsilon_{\mathrm{i}}=\tau_{\mathrm{i}}$.

\footnotetext{
${ }^{273}$ Para um estudo empírico da correlação entre ecoexergia e ecoexergia específica de diferentes ecossistemas aquáticos, v. JØRGENSEN (2007).
} 
Figura A3-3 - Relação entre exergia degradada e exergia armazenada em diversos ecossistemas.

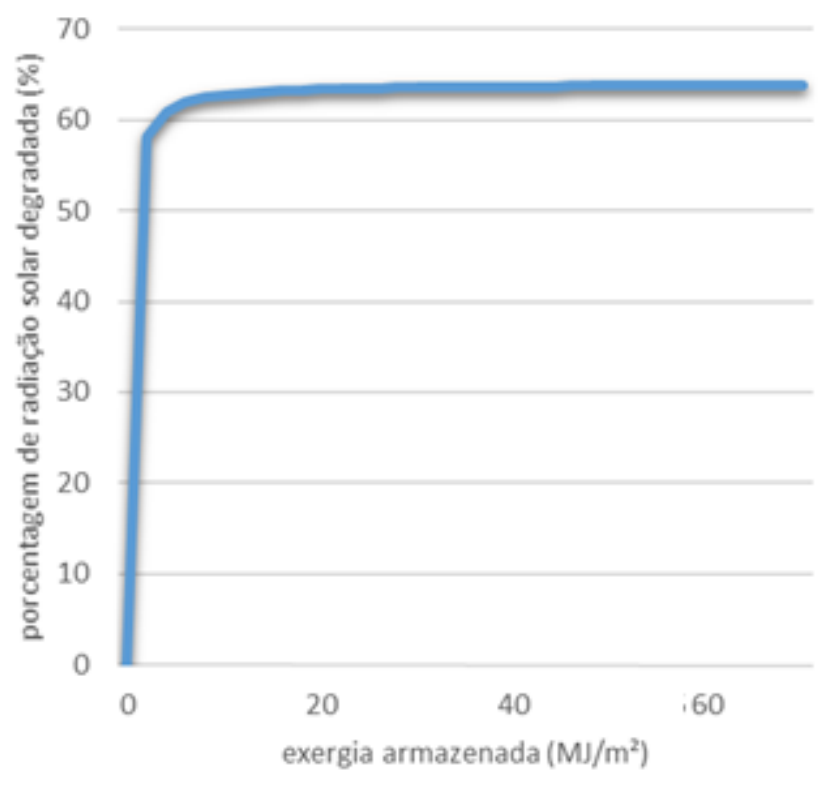

Fonte: produção própria a partir de dados de SCHNEIDER e KAY (1994) e FATH et al. (2004)

Notas:

a) a exergia degradada é correlacionada com a porcentagem de radiação solar degradada em processos não-radioativos;

b) a porcentagem de radiação solar degradada foi estimada por SCHNEIDER e KAY (1994) em diversos ecossistemas a partir de intensidades de radiação de onda longa reirradiada obtidas por satélite;

c) a exergia armazenada foi estimada por FATH et al. (2004) (v. tabela 3) a partir de dados disponíveis em SCHNEIDER e KAY (1994);

d) a partir dos dados acima realizamos regressão para equação de Michaelis-Menten, tendo obtido:

$$
\mathrm{DIS}=64 . \mathrm{ST} /(0,2+\mathrm{ST})
$$

sendo DIS: porcentagem de radiação solar degradada em processos não-radioativos (\%); ST: armazenamento de exergia $\left(\mathrm{MJ} / \mathrm{m}^{2}\right)$. 
Figura A3-4 - Relação entre a exergia específica degradada e a exergia armazenada no contexto dos estágios de crescimento dos ecossistemas.

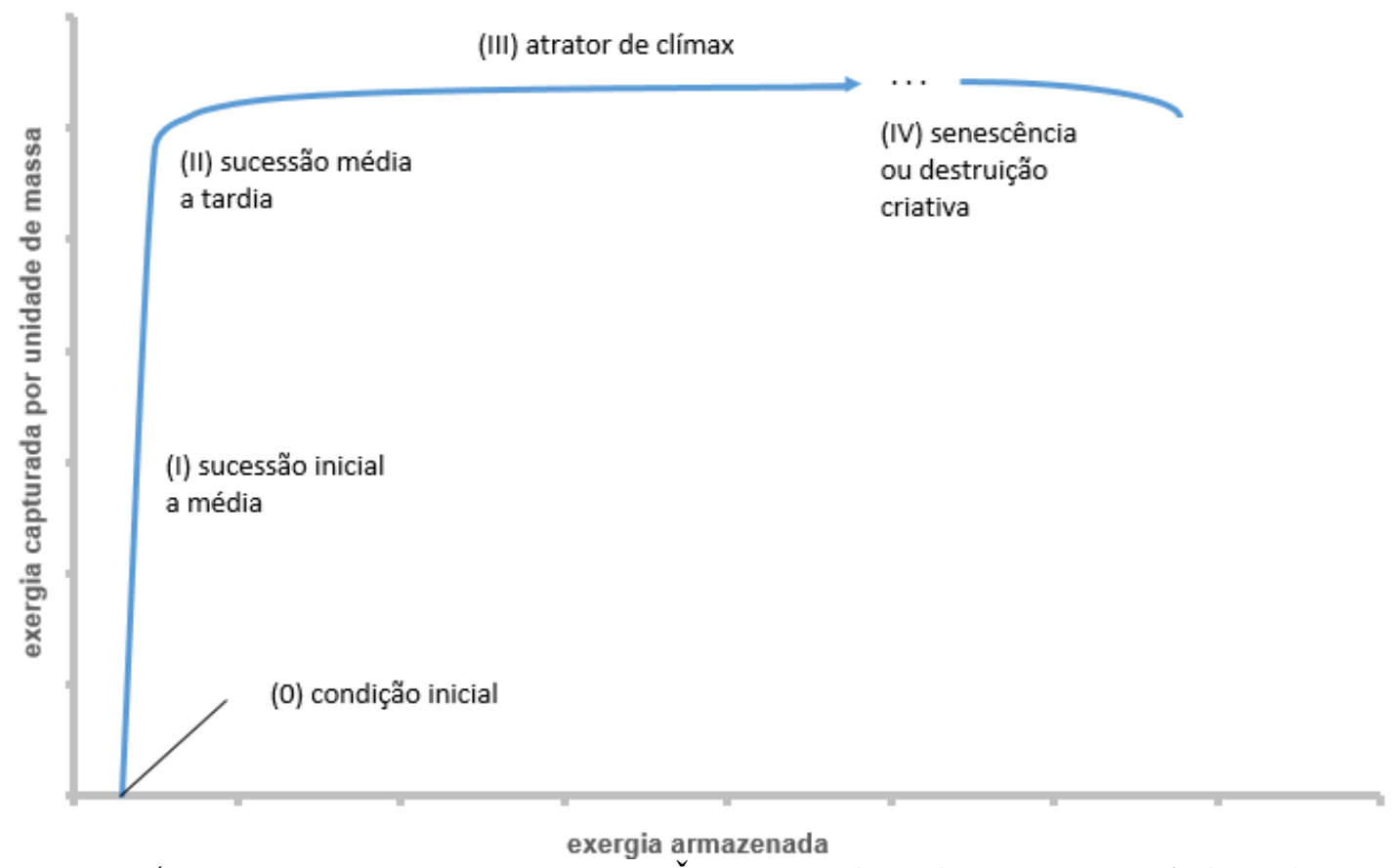

Fonte: JØRGENSEN, PATTEN e STRAŠKRABA (2000) e FATH et al. (2004) 


\section{$\underline{\text { Resumo acadêmico-profissional }}$}

Paulo Mantey Domingues Caetano nasceu em 1966 em São Paulo - SP.

Cursou o primeiro e o segundo graus de 1973 a 1983 no Colégio Arquidiocesano de São Paulo, hoje Colégio Marista Arquidiocesano. No período de 1974 a 1983 frequentou a Pró-Música Escola de Arte, período durante o qual a escola era denominada Conservatório Gomes Cardim.

Graduou-se em engenharia civil pela Escola Politécnica da Universidade de São Paulo em 1988.

Recebeu em 1999 o título de "mestre em engenharia civil” também pela Escola Politécnica da Universidade de São Paulo.

Participou em 1996 e 1997 de Fortbildungsprogramm sobre o tema Städtisch-Industrieller Umweltschutz (Proteção Ambiental Urbano-Industrial), promovido pelo Bundesministerium für Wirtschaftliche Zusammenarbeit und Entwicklung (Ministério Federal de Cooperação Econômica e Desenvolvimento da República Federal da Alemanha) e pela contratada Carl Duisberg Gesellschaft, tendo como parceira a Technische Universität Berlin.

Concluiu em 1999 no Instituto Mauá de Tecnologia o MBA Administração para Engenheiros.

Concluiu em 2008 também no Instituto Mauá de Tecnologia o MBA Gestão Estratégica em Meio Ambiente.

Desde 2012 é doutorando na Faculdade de Saúde Pública da Universidade de São Paulo.

Trabalha desde 1991 como engenheiro civil na Prefeitura do Município de São Paulo, tendo estado lotado na maior parte desse tempo no Departamento de Planejamento Ambiental (antigo Departamento de Educação Ambiental e Planejamento e Coordenadoria de Planejamento Ambiental e Ações Descentralizadas) da Secretaria Municipal do Verde e do Meio Ambiente. Tem participado de planos, programas e projetos relacionados a meio ambiente, urbanismo e recursos hídricos, além de vir redigindo pareceres e manifestações diversos. 